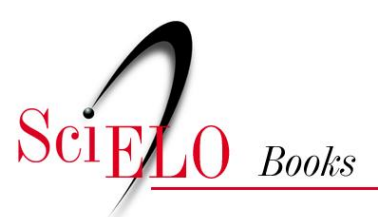

\title{
Catálogo dos estágios iniciais de desenvolvimento dos peixes da bacia de Campos
}

\author{
Ana Cristina Teixeira Bonecker \\ Claudia Akemi Pereira Namiki \\ Márcia Salustiano de Castro \\ Paula Nepomuceno Campos
}

\section{SciELO Books / SciELO Livros / SciELO Libros}

BONECKER, ACT., et al. Catalogo dos estágios iniciais de desenvolvimento dos peixes da bacia de Campos [online]. Curitiba: Sociedade Brasileira de Zoologia, 2014, 295 p. Zoologia: guias e manuais de identificação series. ISBN 978-85-98203-10-2. Available from SciELO Books

$<\underline{\text { http://books.scielo.org }>\text {. }}$

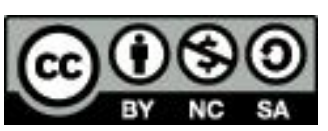

All the contents of this chapter, except where otherwise noted, is licensed under a Creative Commons Attribution-Non Commercial-ShareAlike 3.0 Unported.

Todo o conteúdo deste capítulo, exceto quando houver ressalva, é publicado sob a licença Creative Commons Atribuição Uso Não Comercial - Partilha nos Mesmos Termos 3.0 Não adaptada.

Todo el contenido de este capítulo, excepto donde se indique lo contrario, está bajo licencia de la licencia Creative Commons Reconocimento-NoComercial-CompartirIgual 3.0 Unported. 


\section{Série 7oologia \\ GUIAS E MANUAIS}

Catálogo dos estágios

iniciais de desenvolvimento

dos peixes da bacia de Campos

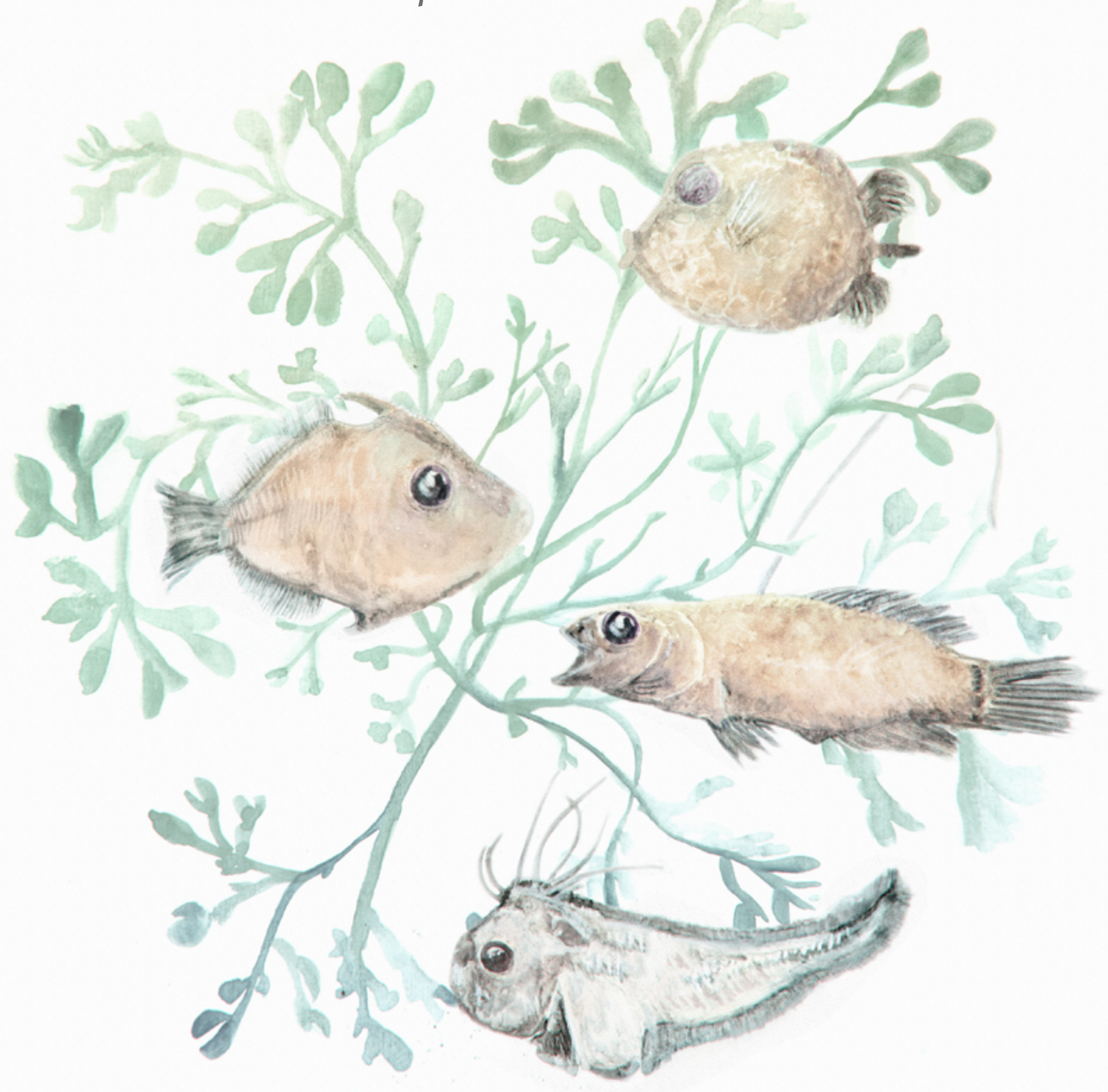

Ana Cristina Teixeira Bonecker - Claudia Akemi Pereira Namiki Márcia Salustiano de Castro - Paula Nepomuceno Campos 


\section{Catálogo dos estágios iniciais de desenvolvimento dos peixes da bacia de Campos}

Ana Cristina Teixeira Bonecker - Claudia Akemi Pereira Namiki Márcia Salustiano de Castro - Paula Nepomuceno Campos

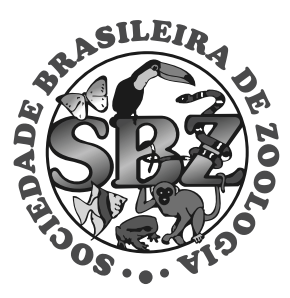

$\frac{\text { Série Zoologia }}{\frac{\text { GUIAS E MANUAIS }}{\text { DE IDENTIFICAÇÃO }}}$

Curitiba, 2014 
Autores

Ana Cristina Teixeira Bonecker ${ }^{1}$

$\checkmark$ ana@biologia.ufrj.br

Claudia Akemi Pereira Namiki²

$\square$ claunamiki@gmail.com

Márcia Salustiano de Castro ${ }^{1}$

$\square$ mscastro@biologia.ufrj.br

Paula Nepomuceno Campos

$\square$ polinhacampos@yahoo.com.br

Universidade Federal do Rio de Janeiro ${ }^{1}$

Instituto de Biologia, Departamento de Zoologia

CCS, Bloco A, Ilha do Fundão,

CEP 21941-590 - Rio de Janeiro, RJ

Universidade de São Paulo ${ }^{2}$

Instituto Oceanográfico,

Departamento de Oceanografia Biológica

Praça do Oceanográfico, 191, Butantan

CEP. CEP 05508-120 - São Paulo, SP

Secretaria de Estado de Meio Ambiente do Pará ${ }^{3}$

Travessa Lomas Valentinas, 2717

Diretoria de Licenciamento Ambiental

Gerência de Projetos Minerários

CEP 66.095-770 - Belém, PA
Sociedade Brasileira de Zoologia (SBZ)

Departamento de Zoologia, UFPR

Caixa Postal 19020, 81531-980

Curitiba/PR

$\checkmark$ secretaria@sbzoologia.org.br

(C) (41) 3266.6823

Coordenação

Rosana Moreira da Rocha

$\checkmark$ rmrocha@ufpr.br

Sionei Ricardo Bonatto

$\checkmark$ sbz@sbzoologia.org.br

Projeto Gráfico e-Book/ ilustração capa

Trillo Comunicação e Design

www.agenciatrillo.com.br

$\square$ bernardo@agenciatrillo.com.br

Universidade Federal do Paraná

Sistema de Bibliotecas

ISBN 978-85-98203-10-2

Catalogo dos estágios iniciais de desenvolvimento dos peixes da bacia de Campos [recurso eletrônico] / Ana Cristina Teixeira Bonecker, Claudia Akemi Pereira Namiki, Márcia Salustiano de Castro, Paula Nepomuceno Campos - Curitiba : Sociedade Brasileira de Zoologia, 2014.

1 recurso eletrônico ; (296p.) - (Série Zoologia : guias e manuais de identificação / Sociedade Brasileira de Zoologia)

Modo de acesso: World Wide Web. URL: http://books.scielo.org/id/q7vqn

1. Peixe - Larva. 2.Peixe - Campos, Bacia de (RJ). 3. Livros eletrônicos I. Bonecker, Ana Cristina Teixeira. II. Namiki, Claudia Akemi Pereira. III. Castro, Márcia Salustiano de. IV. Campos, Paula Nepomuceno. V. Sociedade Brasileira de Zoologia. Série Zoologia : guias e manuais de identificação.

CDD (20. ed.) 597 


\section{Sumário}

PREFÁCIO

INTRODUÇÃO

METODOLOGIA

RESULTADOS

ORDEM ANGUILLIFORMES

Família Chlopsidae

Família Muraenidae

Família Ophichthidae

Família Congridae

Família Nemichthyidae

Família Nettastomatidae

ORDEM CLUPEIFORMES

Família Engraulidae

ORDEM STOMIIFORMES

Família Gonostomatidae

Família Sternoptychidae

Família Phosichthyidae

Família Stomiidae

ORDEM AULOPIFORMES

Família Scopelarchidae

Família Notosudidae

Família Synodontidae

Família Paralepididae

Família Anotopteridae

Família Evermannellidae

ORDEM MYCTOPHIFORMES

Família Myctophidae

ORDEM LAMPRIFORMES

Família Trachipteridae

ORDEM GADIFORMES

Família Bregmacerotidae

Família Macrouridae

Família Phycidae

\section{ORDEM OPHIDIIFORMES}

Família Ophidiidae

Família Carapidae

Família Aphyonidae

ORDEM LOPHIIFORMES

Família Antennariidae

Família Gigantactinidae

Ordem Beloniformes

Família Scomberesocidae

Família Hemiramphidae

Família Exocoetidae

Ordem Stephanoberyciformes

Família Melamphaidae
ORDEM BERYCIFORMES

Família Holocentridae 166

ORDEM SYNGNATHIFORMES 169

Família Fistulariidae $\quad 170$

Família Syngnathidae $\quad 172$

ORDEM SCORPAENIFORMES 175

Família Scorpaenidae 176

ORDEM PERCIFORMES $\mathbf{1 8 0}$

Família Acropomatidae 181

Família Serranidae 183

Família Symphysanodontidae $\quad 189$

Família Apogonidae 191

Família Pomatomidae 194

Família Carangidae 196

Família Coryphaenidae 203

Família Bramidae 205

Família Lutjanidae 207

Família Gerreidae 209

Família Mullidae 211

Família Chaetodontidae 213

Família Pomacanthidae $\quad 215$

Família Cirrhitidae 218

Família Mugilidae $\quad 220$

Família Pomacentridae 222

Família Labridae $\quad 226$

Família Scaridae $\quad 229$

Família Chiasmodontidae $\quad 235$

Família Callionymidae $\quad 237$

Família Gobiidae $\quad 239$

Família Microdesmidae $\quad 246$

Família Acanthuridae $\quad 249$

Família Sphyraenidae 251

Família Gempylidae 253

Família Scombridae $\quad 259$

Família Nomeidae 263

ORDEM PLEURONECTIFORMES 266

Família Paralichthyidae $\quad 267$

Família Bothidae $\quad 270$

Família Cynoglossidae $\quad 274$

ORDEM TETRAODONTIFORMES 276

Família Monacanthidae 277

Família Ostraciidae $\quad 279$

Família Tetraodontidae $\quad 281$

AGRADECIMENTOS 284

Glossário 285

REFERÊNCIAS 286 


\section{PREFÁCIO}

A identificação de espécies de larvas de peixes de uma determinada área é de grande importância para os estudos de levantamentos dos recursos pesqueiros existentes. A maioria dos peixes teleósteos marinhos possui estágio larval, passando parte do seu ciclo de vida no plâncton. Sendo assim, o potencial de explotação desses recursos depende diretamente do que ocorre durante essa fase da vida.

O "Catálogo dos estágios iniciais de desenvolvimento dos peixes da bacia de Campos" foi elaborado pensando em estudantes que querem iniciar seus conhecimentos nessa área e também para auxiliar ictioplanctólogos tornando as informações mais acessíveis.

O material ictioplanctônico utilizado para elaboração deste catálogo é proveniente de coletas realizadas na região oceânica da bacia de Campos. A Petrobras em convênio com o Instituto de Biologia realizou amostragens até $1.000 \mathrm{~m}$ de profundidade, possibilitando um melhor conhecimento da comunidade de larvas de peixes de regiões profundas, uma vez que ainda são escassos os estudos de ictioplâncton nessa região. De maneira geral, esses estudos revelaram uma grande variabilidade de larvas de peixes, algumas sendo até mesmo coletadas e identificadas pela primeira vez no Brasil.

Foram identificadas 17 ordens, 68 famílias e 158 espécies de peixes. Ao todo foram identificados 4.490 exemplares de larvas e juvenis de peixes. O catálogo contem as informações gerais das ordens e famílias identificadas. Foram incluídas fotografias de diferentes estágios de desenvolvimento (quando possível), descrição das principais características para identificação da espécie, georreferenciamento das amostras utilizadas, habitat da espécie, nome vulgar (quando existente) e as referências utilizadas para a identificação. 


\section{INTRODUÇÃO}

A caracterização da comunidade ictioplanctônica da região oceânica da bacia de Campos teve início em outubro de 2001, com realização de coletas de plâncton no campo de Roncador. Esse estudo teve continuidade, ainda em 2001, no campo de Marlim Sul e no ano de 2002 nos campos de Albacora Leste e Barracuda-Caratinga, dentro da campanha intitulada Albacar. Os estudos de Roncador e Albacar pertencem ao Projeto de Caracterização Ambiental de Águas Profundas da Bacia de Campos, coordenado pelo CENPES/PETROBRAS.

Ainda em 2002 teve início o projeto Oceano Profundo (Ocean Prof), que abrangeu os campos de Roncador e Albacora Leste, ao norte da Bacia de Campos; e Barracuda-Caratinga, Marlim Sul e Marlim Leste, na área sul. Além da caracterização da comunidade de larvas de peixes, esse projeto também objetivou verificar a existência de diferenças nas composições específicas nas áreas norte e sul da Bacia de Campos, e analisar as variações sazonais dessas espécies.

A realização desses estudos possibilitou um melhor conhecimento da comunidade de larvas de peixes da região da bacia de Campos, uma vez que ainda são escassos os estudos de ictioplâncton nessa região. De maneira geral, esses projetos revelaram uma grande variabilidade de larvas de peixes, algumas sendo até mesmo coletadas e identificadas pela primeira vez no Brasil.

A identificação das larvas de peixes no Brasil atualmente é baseada no Atlas de Larvas de Peixes da Região Central da Zona Econômica Exclusiva brasileira (Bonecker \& Castro, 2006), no conhecimento de peixes adultos da região e em manuais de outras áreas do mundo (Nafpaktitis et al., 1977; Leis \& Rennis, 1983; Moser, 1996; Richards, 2006; Fahay, 2007, entre outros). Estudos sobre ictioplâncton desenvolvidos ao longo da costa brasileira também auxiliam na identificação, uma vez que fornecem uma lista das espécies registradas (Bonecker et al., 2013). Outra ferramenta importante para a identificação das larvas de peixes em nível taxonômico de espécie é o intercâmbio de conhecimento entre os pesquisadores do Brasil e do exterior.

Dessa forma, as larvas de peixes coletadas durante o Projeto de Caracterização Ambiental de Águas Profundas foram reunidas em um catálogo para auxiliar a identificação dos estágios iniciais dos peixes que ocorrem na região da bacia de Campos. 


\section{METODOLOGIA}

As larvas de peixes identificadas nesse catálogo foram coletadas durante seis campanhas realizadas nas áreas norte e sul da bacia de Campos. A metodologia empregada para a coleta de ictioplâncton variou de acordo com os objetivos específicos em cada campanha. Os dados sobre as redes utilizadas, a malhagem, o tipo e a profundidade do arrasto são apresentados para cada espécie identificada (georreferenciamento).

Em laboratório, as larvas de peixes foram totalmente triadas sob microscópio estereoscópio e identificadas utilizando bibliografia especializada como Nafpaktitis et al. (1977), Moser (1996), Bonecker \& Castro (2006), Richards (2006), Fahay (2007), Santos \& Figueiredo (2008), entre outras. A classificação das larvas de peixes foi baseada em Eschmeyer (2014). Informações sobre o número de gêneros e espécies de cada família, habitat e a distribuição das espécies também foram obtidas em Nelson (2006), Fahay (2007) e Froese \& Pauly (2014). O comprimento padrão (CP) das larvas identificadas foi medido com uma lâmina milimetrada de 0,1 mm de precisão.

A identificação foi baseada nas características morfométricas e merísticas. A terminologia adotada para os diferentes estágios de desenvolvimento larval seguiu as propostas de Kendall et al. (1984) e Moser (1996):

Larva - este estágio divide-se em três subestágios de acordo com o estado de flexão da notocorda durante a formação da nadadeira caudal:

- Pré-flexão - a partir do final da absorção do saco vitelino até o início da flexão da notocorda;

- Flexão - desde o início da flexão da notocorda até a formação dos ossos hipurais;

- Pós-flexão: após a completa flexão da notocorda.

Larva em estágio de transformação - período em que há mudanças na forma geral e estrutural; começam a ter caracteres dos adultos e vão perdendo as características de larvas. Há mudanças nas proporções (migração das nadadeiras), aumento da pigmentação, da altura do corpo, do comprimento da cabeça, etc.

Estágio juvenil - é aquele em que a transformação se completa e o espécime é morfologicamente similar ao adulto com nadadeiras e escamação completamente formados.

Todas as larvas identificadas foram tombadas na coleção de ictioplâncton do Laboratório Integrado de Zooplâncton e Ictioplâncton, da Universidade Federal do Rio de Janeiro (DZUFRJ).

As espécies identificadas foram fotografadas, incluindo os diferentes estágios de desenvolvimento, quando possível. Todas as fotos foram tiradas pelo biólogo Pedro Freitas de Carvalho com o auxílio de um microscópio estereoscópio Olympus SZX12 utilizando o software de captura de imagem Image-Pro Plus 6.1. Em alguns casos, foram selecionados indivíduos da coleção, que estivessem no mesmo estágio de desenvolvimento, por evidenciarem melhor as características para identificação. Além das fotos, foi incluída a descrição das principais características utilizadas na identificação de cada espécie. O georreferenciamento está associado aos dados do tombo da coleção de ictioplâncton do Laboratório Integrado de Zooplâncton e Ictioplâncton, da Universidade 
Federal do Rio de Janeiro (DZUFRJ). São fornecidas as seguintes informações: coordenadas, data da coleta, tipo de arrasto, profundidade de coleta, rede e malha utilizadas e número de indivíduos encontrados. Além destes dados, o catálogo apresenta também o habitat, o nome vulgar e as referências utilizadas para a identificação. As referências utilizadas para os nomes vulgares das espécies foram Szpilman (2000) e Freire \& Carvalho Filho (2009). 


\section{RESULTADOS}

Foram identificados 4.490 indivíduos incluindo 17 ordens, 68 famílias e 158 espécies de larvas de peixes (Tabela 1). Para cada ordem e família contempladas no catálogo foram elaborados textos contendo informações gerais para auxiliar na separação nesses níveis taxonômicos e o número de espécies já identificadas para costa brasileira.

Tabela 1: Relação taxonômica das larvas e juvenis de peixes encontrados nas áreas norte e sul da Bacia de Campos

\section{ORDEM ANGUILLIFORMES Família Chlopsidae \\ Chlopsis dentatus \\ Kaupichthys hyoproroides \\ Kaupichthys nuchalis \\ Família Muraenidae \\ Gymnothorax ocellatus}

Família Ophichthidae

Bascanichthyini sp.

Myrichthys ocellatus

Família Congridae

Ariosoma balearicum

Conger triporiceps

Congridae sp. 1

Congridae sp. 2

Família Nemichthyidae

Nemichthys sp.

Família Nettastomatidae

Facciolella sp.

Saurenchelys sp.

\section{ORDEM CLUPEIFORMES}

Família Engraulidae

Engraulis anchoita

\section{ORDEM STOMIIFORMES}

Família Gonostomatidae

Cyclothone acclinidens

Cyclothone alba

Cyclothone braueri

Cyclothone pseudopallida

Diplophos taenia

Margrethia obtusirostra

Gonostoma elongatum

Família Sternoptychidae

Argyropelecus aculeatus

Argyropelecus hemigymnus

Argyropelecus sladeni

Maurolicus stehmanni
Sternoptyx sp.

Sternoptyx diaphana

Valenciennellus tripunculatus

Família Phosichthyidae

Ichthyococcus ovatus

Pollichthys mauli

Vinciguerria nimbaria

Família Stomiidae

Chauliodus sloani

Eustomias sp.

Melanostomias sp.

Stomias affinis

ORDEM AULOPIFORMES

Família Scopelarchidae

Benthalbella infans

Scopelarchus sp.

Família Notosudidae

Scopelosaurus herwigi

Scopelosaurus smithii

Família Synodontidae

Saurida sp.

Synodus synodus

Trachinocephalus myops

Família Paralepididae

Lestidiops affinis

Lestidium atlanticum

Lestrolepis intermedia

Magnisudis atlantica

Stemonosudis sp.

Stemonosudis rothschildi

Sudis atrox

Uncisudis advena

Família Anotopteridae

Anotopterus pharao

Família Evermannellidae

Coccorella atlantica

Evermannella balbo

Evermannella melanoderma
ORDEM MYCTOPHIFORMES

Família Myctophidae

Benthosema suborbitale

Bolinichthys distofax

Centrobranchus nigroocelatus

Ceratoscopelus warmingii

Diaphus anderseni

Diaphus dumerilii

Diaphus mollis

Diaphus splendidus

Hygophum hygomii

Hygophum reinhardtii

Hygophum taaningi

Lampadena sp. 1

Lampadena sp. 2

Lampanyctus alatus

Lepidophanes gaussi

Lepidophanes guentheri

Lobianchia gemellarii

Myctophum affine

Myctophum nitidulum

Myctophum obtusirostre

Notolychnus valdiviae

Notoscopelus caudispinosus

Symbolophorus rufinus

\section{ORDEM LAMPRIFORMES}

Família Trachipteridae

Zu cristatus

\section{ORDEM GADIFORMES}

Família Bregmacerotidae

Bregmaceros atlanticus

Bregmaceros n sp.

Família Macrouridae

Coryphaenoides armatus

Família Phycidae

Urophycis cirrata 
ORDEM OPHIDIIFORMES

Família Ophidiidae

Ophidion nocomis

Família Carapidae

Echiodon dawsoni

Snyderidia canina

Família Aphyonidae

Aphyonidae sp. 1

\section{ORDEM LOPHIIFORMES}

Família Antennariidae

Histrio histrio

Família Gigantactinidae

Gigantactis sp.

ORDEM BELONIFORMES

Família Scomberesocidae

Scomberesox sp.

Família Hemiramphidae

Euleptorhamphus velox

Hyporhamphus unifasciatus

Família Exocoetidae

Hirundichthys rondeletti

\section{ORDEM}

STEPHANOBERYCIFORMES

Família Melamphaidae

Melamphaes simus

Poromitra capito

\section{ORDEM BERYCIFORMES}

Família Holocentridae

Holocentrus sp.

Sargocentron bullisi

\section{ORDEM SYNGNATHIFORMES}

Família Fistulariidae

Fistularia tabacaria

Família Syngnathidae

Micrognathus crinitus

Micrognathus erugatus

\section{ORDEM SCORPAENIFORMES}

Família Scorpaenidae

Scorpaena sp.

Scorpaenodes sp.
ORDEM PERCIFORMES

Família Acropomatidae

Synagrops spinosus

Família Serranidae

Dules auriga

Liopropoma carmabi

Pseudogramma gregoryi

Família Symphysanodontidae

Symphysanodon sp.

Família Apogonidae

Apogon sp.

Astrapogon sp.

Família Pomatomidae

Pomatomus saltatrix

Família Carangidae

Caranx sp.

Decapterus punctatus

Selar crumenophthalmus

Seriola dumerili

Trachurus lathami

Família Coryphaenidae

Coryphaena hippurus

Família Bramidae

Brama dussumieri

Família Lutjanidae

Lutjanus sp.

Família Gerreidae

Eucinostomus sp.

Família Mullidae

Upeneus parvus

Família Chaetodontidae

Chaetodon sedentarius

Família Pomacanthidae

Centropyge aurantonotus

Família Cirrhitidae

Amblycirrhitus pinos

Família Mugilidae

Mugil curema

Família Pomacentridae

Abudefduf saxatilis

Microspathodon chrysurus

Stegastes leucostictus

Família Labridae

Halichoeres maculipinna

Thalassoma noronhanum

Família Scaridae

Cryptotomus roseus

Scarus sp.

Sparisoma sp.
Família Chiasmodontidae

Chiasmodon niger

Família Callionymidae

Callionymus bairdi

Família Gobiidae

Bathygobius soporator

Ctenogobius sp.

Gnatholepis thompsoni

Gobiidae sp. 1

Gobionellus sp. 1

Gobionellus sp. 2

Família Microdesmidae

Ptereleotris randalli

Família Acanthuridae

Acanthurus sp.

Família Sphyraenidae

Sphyraena guachancho

Família Gempylidae

Diplospinus multistriatus

Gempylus serpens

Lepidocybium flavobrunneum

Nesiarchus nasutus

Família Scombridae

Auxis thazard

Euthynnus alletteratus

Scomber colias

Família Nomeidae

Psenes cyanophrys

ORDEM PLEURONECTIFORMES

Família Paralichthyidae

Citharichthys sp.

Syacium papillosum

Família Bothidae

Bothus ocellatus

Chascanopsetta lugubris

Família Cynoglossidae

Symphurus kyaropterygium

ORDEM TETRAODONTIFORMES

Família Monacanthidae

Monacanthus ciliatus

Família Ostraciidae

Acanthostracion sp.

Família Tetraodontidae

Canthigaster rostrata

Lagocephalus lagocephalus 


\section{ORDEM ANGUILLIFORMES}

A ordem Anguilliformes é composta por 15 famílias com aproximadamente 791 espécies. Essa ordem compreende as enguias e moreias, que durante os estágios iniciais de desenvolvimento possuem larvas denominadas leptocephalus. Essas larvas possuem cabeça diminuta e corpo lateralmente comprimido e transparente, permitindo a visualização dos miômeros. As leptocephali dessa ordem podem variar de exemplares pequenos a muito grandes. Possuem nadadeira caudal pequena e contínua com as nadadeiras dorsal e anal. Não possuem nadadeiras pélvicas. As nadadeiras peitorais podem ser presentes ou ausentes, sendo de tamanho reduzido em alguns casos.

Nesse estudo a ordem Anguilliformes é representada pelas famílias Chlopsidae, Muraenidae, Ophichthidae, Congridae, Nemichthyidae e Nettastomatidae. 


\section{Família Chlopsidae}

A família Chlopsidae é marinha e ocorre nas regiões tropicais e subtropicais dos oceanos Atlântico, Índico e Pacífico. Compreende oito gêneros com 18 espécies. As larvas podem alcançar até $100 \mathrm{~mm}$ de comprimento e possuem corpo alto e cauda arredondada. O intestino é reto e curto, chegando a menos da metade do corpo. A nadadeira dorsal é longa começando no primeiro quinto do corpo.

No Brasil já foram identificadas seis espécies nas fases de larva e adulto: Nesse estudo são contempladas as espécies Chlopsis dentatus, Kaupichthys hyoproroides e Kaupichthys nuchalis. 


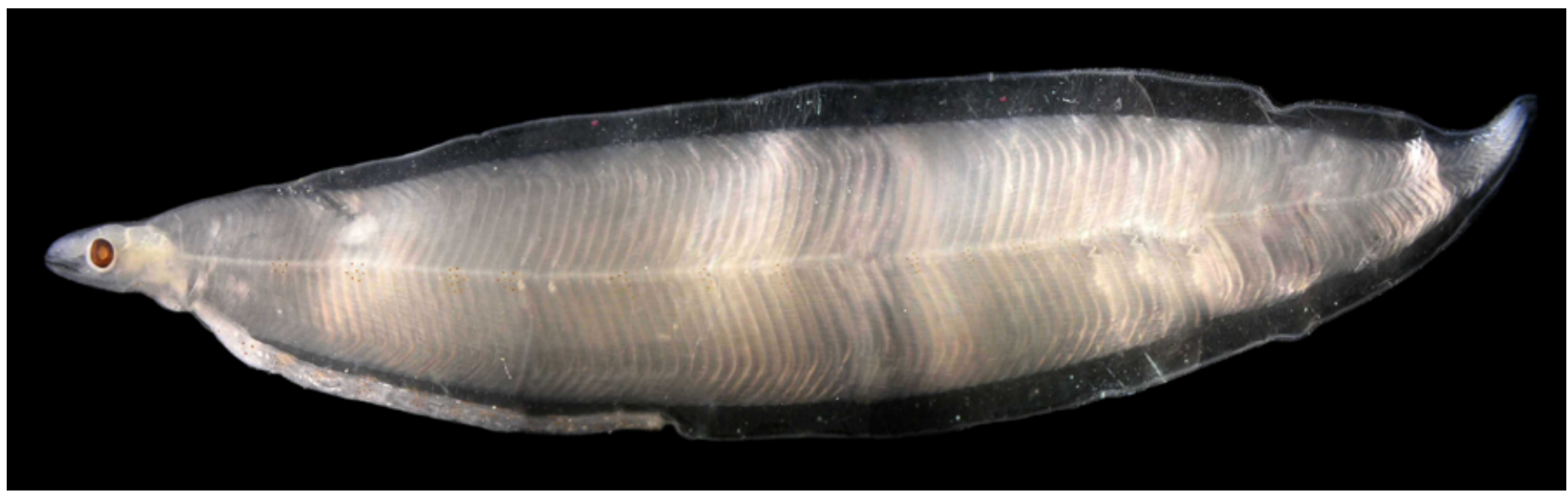

Figura 1 - A: DZUFRJ 22079; CP 52,0 mm. Vista geral

\section{Chlopsis dentatus (Seale, 1917)}

A principal característica para identificação dessa espécie é a presença de grupos de pequenos melanóforos ao longo da linha lateral, desde logo depois da cabeça até o final da cauda. Presença de melanóforos na margem superior do intestino. O intestino é curto alcançando aproximadamente $42 \%$ do comprimento total do corpo. Número total de miômeros: 114-119.

Habitat: espécie marinha e demersal. Ocorre entre 64 e $366 \mathrm{~m}$ de profundidade.

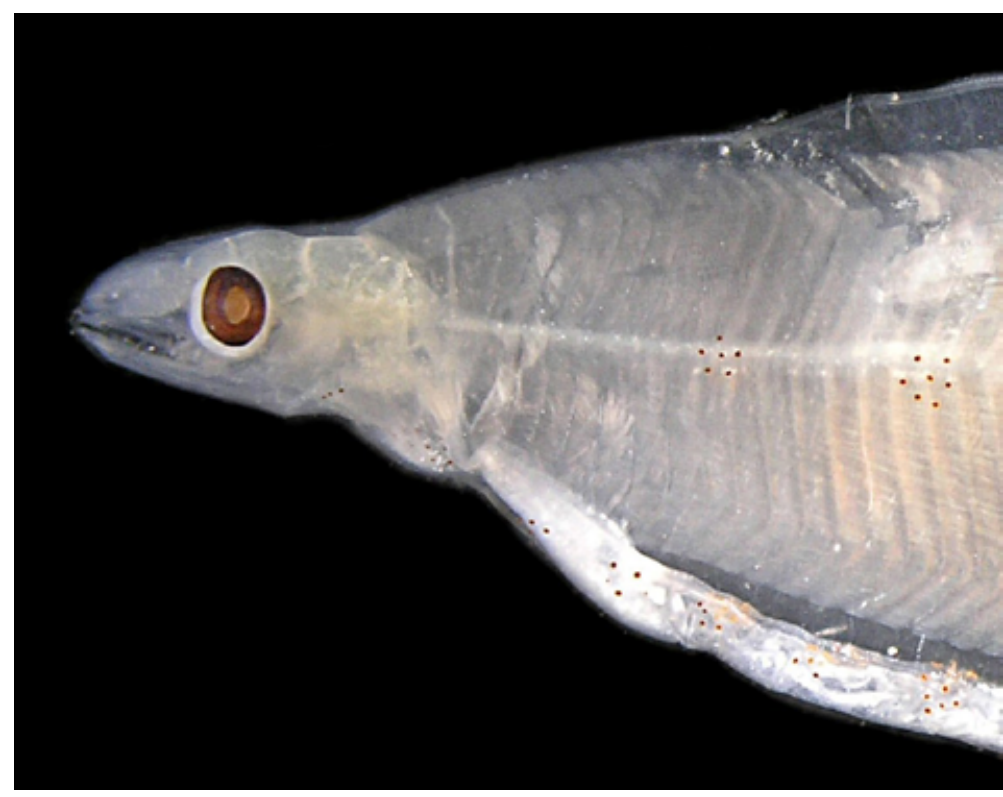

Figura 1 - B: Destaque dos grupos de pequenos melanóforos ao longo da linha lateral.

\section{Georreferencimento}

\begin{tabular}{|l|l|l|l|l|l|l|l|l|}
\hline DZUFRJ & Latitude (S) & Longitude (W) & Data & $\begin{array}{l}\text { Tipo de } \\
\text { arrasto }\end{array}$ & $\begin{array}{l}\text { Profundidade } \\
\text { de coleta }\end{array}$ & Rede & $\begin{array}{l}\text { Malha } \\
\text { ( } \boldsymbol{\mu m})\end{array}$ & $\begin{array}{l}\mathbf{N}^{\circ} \text {. de } \\
\text { inds. }\end{array}$ \\
\hline 22079 & $22^{\circ} 31^{\prime} 40,9^{\prime \prime}$ & $040^{\circ} 02^{\prime} 39,6^{\prime \prime}$ & $07 / 11 / 2001$ & oblíquo & $1.000 \mathrm{~m}$ & $\begin{array}{l}\text { cilíndrico- } \\
\text { cônica }\end{array}$ & 500 & 1 \\
\hline
\end{tabular}

Referências: Smith, 1989a. 


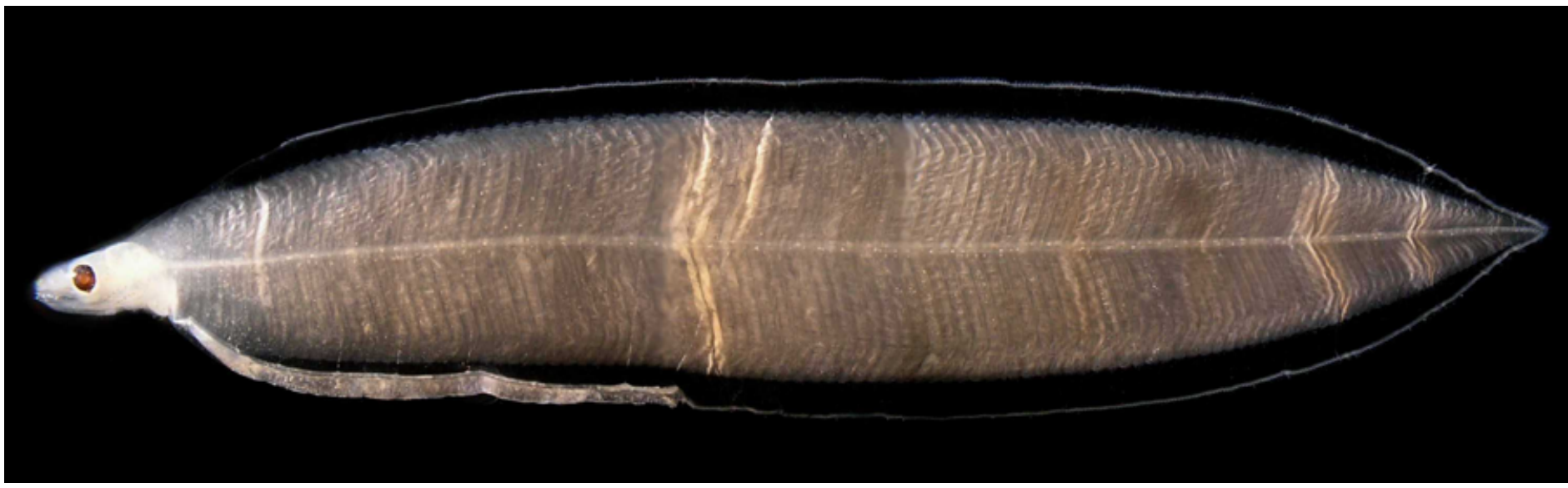

Figura 2 - A: Kaupichthys hyoproroides DZUFRJ 22078; CP 55,0 mm. Vista geral.

\section{Kaupichthys hyoproroides (Strömman, 1896)}

As principais características para identificação dessa espécie são: intestino curto (menos de $50 \%$ do comprimento total) e presença de melanóforos espalhados por todo o corpo. Apresenta uma mancha de pigmentos, no formato de meia-lua, abaixo do olho. Número total de miômeros: 113-120.

Habitat: espécie marinha, associada a formações coralinas. Vive em águas subtropicais em profundidades de até $95 \mathrm{~m}$.

Nome vulgar: Falsa moreia marrom.

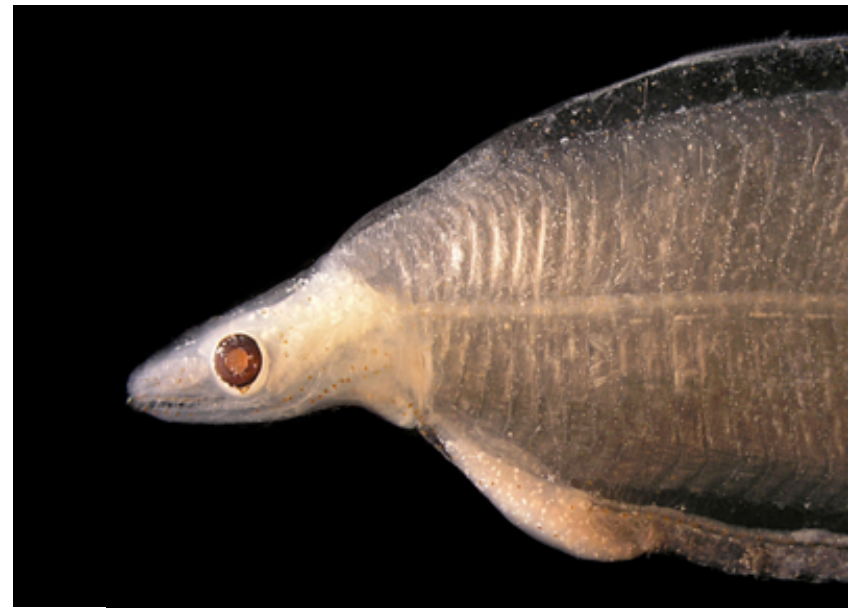

Figura 2 - B: Melanóforos espalhados pelo corpo.

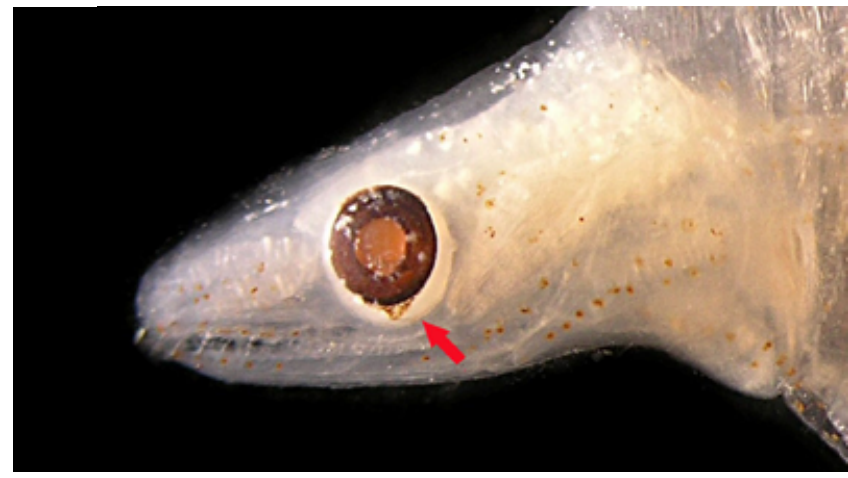

Figura 2 - C: Detalhe da cabeça com mancha de pigmentos no formato de meia-lua abaixo do olho.

Georreferenciamento

\begin{tabular}{|c|c|c|c|c|c|c|c|c|}
\hline DZUFR & Latitude (S) & Longitude (W) & Data & $\begin{array}{c}\text { Tipo de } \\
\text { arrasto }\end{array}$ & $\begin{array}{c}\text { Profundidade } \\
\text { de coleta }\end{array}$ & Rede & $\begin{array}{c}\text { Malha } \\
\text { ( } \begin{array}{c}\boldsymbol{N}^{\circ} \text { ) } \\
\text { inds. }\end{array}\end{array}$ \\
\hline 408 & $22^{\circ} 33^{\prime} 47,7^{\prime \prime}$ & $040^{\circ} 12^{\prime} 20,5^{\prime \prime}$ & $17 / 05 / 2002$ & oblíquo & $50 \mathrm{~m}$ & bongô & 330 & 1 \\
\hline 1290 & $22^{\circ} 02^{\prime} 30,0^{\prime \prime}$ & $039^{\circ} 49^{\prime} 41,2^{\prime \prime}$ & $12 / 05 / 2002$ & oblíquo & até a termoclina & bongô & 500 & 1 \\
\hline 7591 & $22^{\circ} 31^{\prime} 40,9^{\prime \prime}$ & $040^{\circ} 02^{\prime} 39,6^{\prime \prime}$ & $07 / 11 / 2001$ & oblíquo & $1.000 \mathrm{~m}$ & cilíndrico-cônica & 500 & 1 \\
\hline 22078 & $22^{\circ} 32^{\prime} 50,0^{\prime \prime}$ & $040^{\circ} 04^{\prime} 09,9^{\prime \prime}$ & $06 / 11 / 2001$ & oblíquo & $1.000 \mathrm{~m}$ & cilíndrico-cônica & 500 & 2 \\
\hline
\end{tabular}

Referências: Smith, 1989a; Castro \& Bonecker, 2005; Castro \& Bonecker, 2006a. 


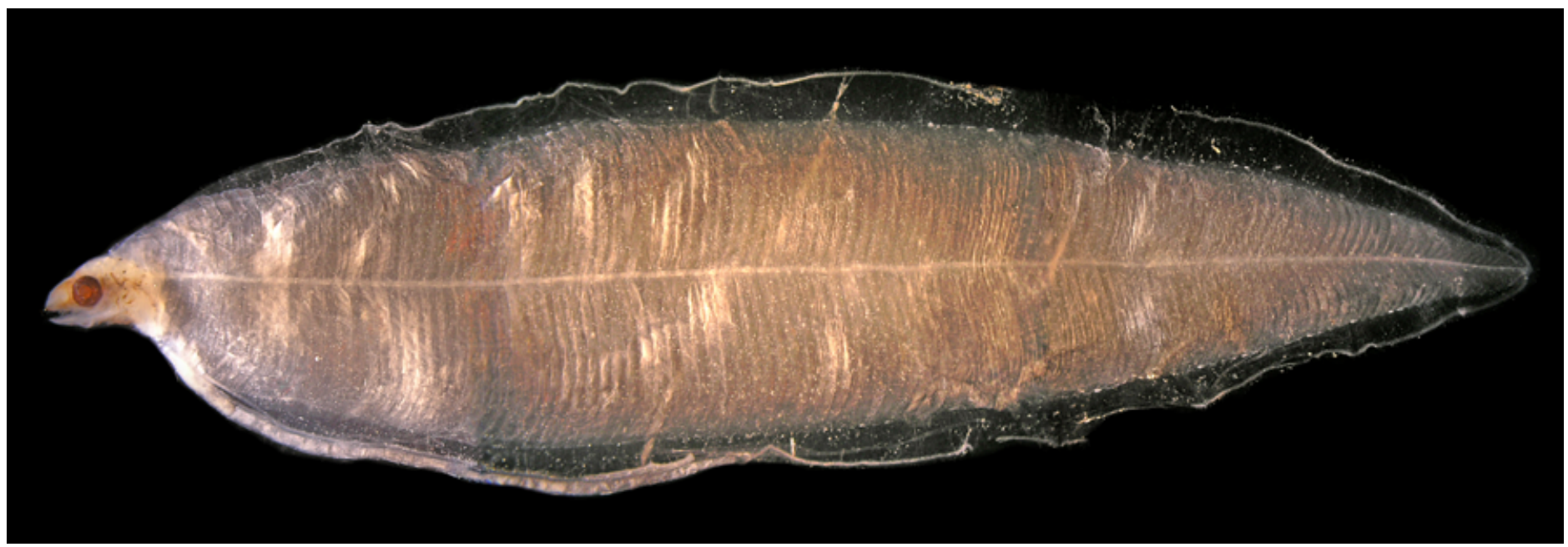

Figura 3 - A: Kaupichthys nuchalis DZUFRJ 21541; CP 52,0 mm. Vista geral.

\section{Kaupichthys nuchalis Böhlke, 1967}

A principal característica para separar essa espécie dos outros representantes da família é que o nefros termina um pouco antes do ânus. Possui melanóforos muito pequenos na região da linha lateral, desde o ânus até a cauda, a cada dois ou três miômeros. Os melanóforos também estão presentes na cabeça, na frente e atrás do olho. Número total de miômeros: 121-125.

Habitat: espécie marinha, associada a formações coralinas. Vive em águas tropicais em profundidades de até $77 \mathrm{~m}$, mas já foi capturada entre 604-732 m. Ainda não havia sido registrada para o Brasil.

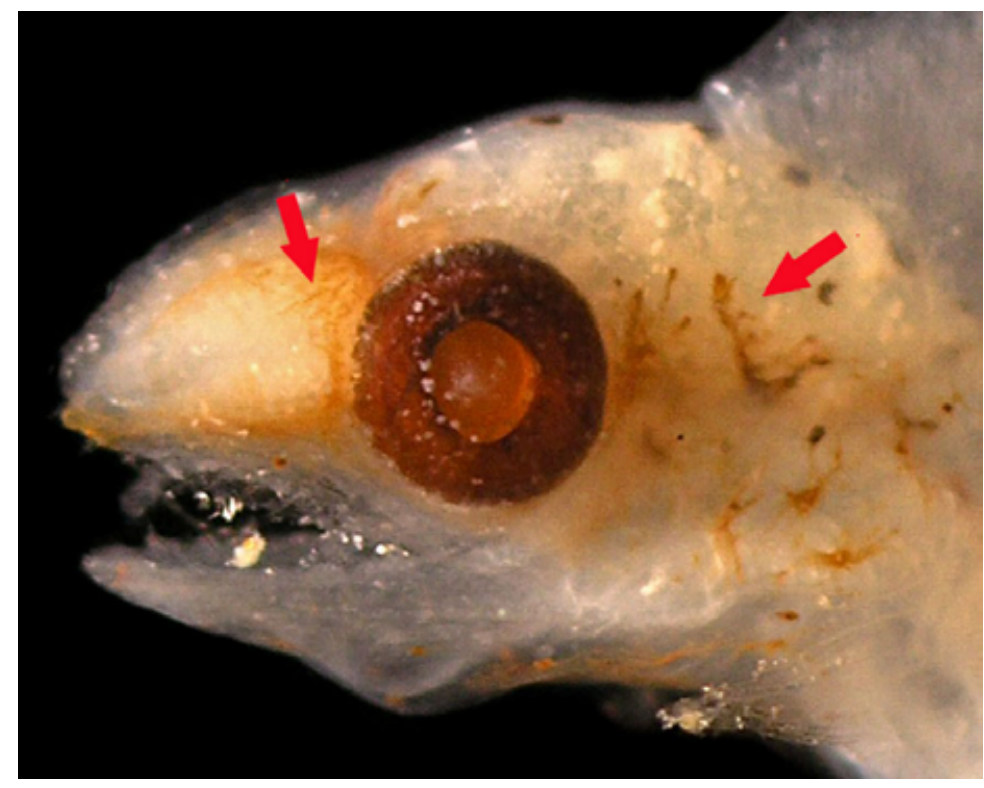

Figura 3 - B: Detalhe da cabeça com melanóforos na frente e atrás do olho.

\section{Georreferenciamento}

\begin{tabular}{|c|c|c|c|c|c|c|c|c|}
\hline DZUFRJ & Latitude (S) & Longitude (W) & Data & $\begin{array}{c}\text { Tipo de } \\
\text { arrasto }\end{array}$ & $\begin{array}{c}\text { Profundidade } \\
\text { de coleta }\end{array}$ & Rede & $\begin{array}{c}\text { Malha } \\
\text { ( } \boldsymbol{\mu m} \text { ) }\end{array}$ & $\begin{array}{c}\mathbf{N}^{\circ} \text {. de } \\
\text { inds. }\end{array}$ \\
\hline 21541 & $22^{\circ} 31^{\prime} 58,9^{\prime \prime}$ & $040^{\circ} 02^{\prime} 53,4^{\prime \prime}$ & $07 / 11 / 2001$ & oblíquo & $1.000 \mathrm{~m}$ & $\begin{array}{c}\text { cilíndrico- } \\
\text { cônica }\end{array}$ & 500 & 1 \\
\hline
\end{tabular}

Referências: Smith, 1989a. 


\section{Família Muraenidae}

A família Muraenidae é marinha, mas algumas espécies ocasionalmente podem entrar em ambientes de água doce. Ocorre nos oceanos tropicais e temperados. Compreende 15 gêneros com 185 espécies. As larvas geralmente chegam no máximo a $100 \mathrm{~mm}$ de comprimento e o corpo é moderadamente alto. A cauda é arredondada e o intestino é um tubo reto alcançando a metade ou $3 / 4$ do comprimento padrão. Uma característica importante para a identificação é a nadadeira peitoral reduzida. Os gêneros e as espécies podem ser separados principalmente pela pigmentação e pela posição das nadadeiras dorsal e anal.

No Brasil já foram identificadas 19 espécies nas fases de larva e adulto. Nesse estudo é contemplada apenas a espécie Gymnothorax ocellatus. 


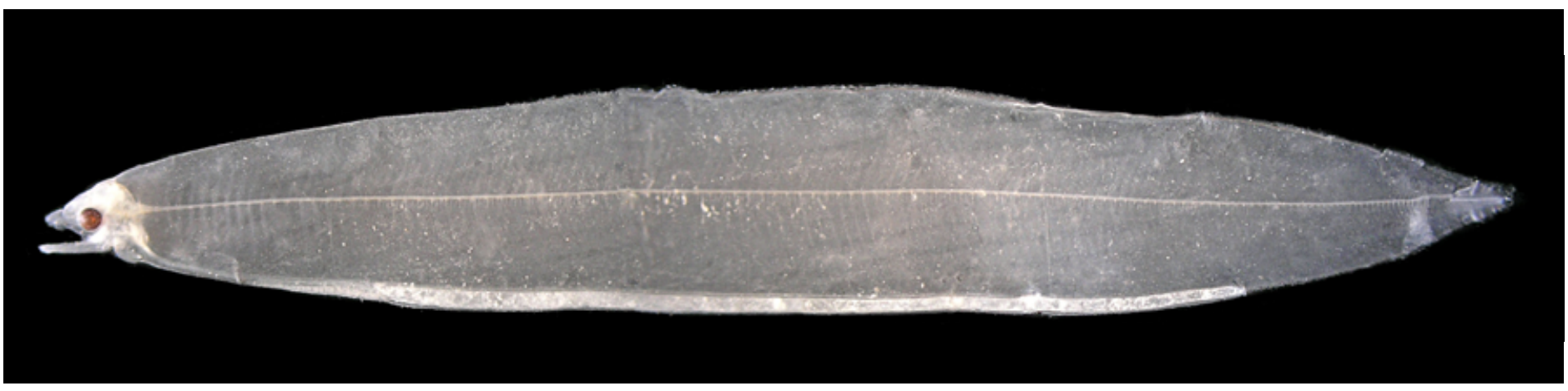

Figura 4: Gymnothorax ocellatus DZUFRJ 13694; CP 36,0 mm.

\section{Gymnothorax ocellatus Agassiz, 1831}

A nadadeira dorsal começa muito antes do ânus, entre os miômeros 22 e 32. Apresenta pigmentos nas regiões dorsal e ventral do intestino, nas bases das nadadeiras dorsal, anal, e caudal, e melanóforos na região dorsal, desde o miômero oito até o início da nadadeira dorsal. Número total de miômeros: 136-145.

Habitat: espécie marinha, associada a formações coralinas. Vive em águas tropicais até a profundidade de $160 \mathrm{~m}$. É muito comum no litoral brasileiro.

Nome vulgar: Moreia de areia.

\section{Georreferenciamento}

\begin{tabular}{|c|c|c|c|c|c|c|c|c|}
\hline DZUFRJ & Latitude (S) & Longitude (W) & Data & $\begin{array}{c}\text { Tipo de } \\
\text { arrasto }\end{array}$ & $\begin{array}{c}\text { Profundidade } \\
\text { de coleta }\end{array}$ & Rede & $\begin{array}{c}\text { Malha } \\
\text { ( } \boldsymbol{\mu m} \text { ) }\end{array}$ & $\begin{array}{c}\mathbf{N}^{\circ} \text {. de } \\
\text { inds. }\end{array}$ \\
\hline 494 & $22^{\circ} 31^{\prime} 27,0^{\prime \prime}$ & $040^{\circ} 16^{\prime} 56,0^{\prime \prime}$ & $17 / 05 / 2002$ & oblíquo & $600 \mathrm{~m}$ & $\begin{array}{c}\text { cilíndrico- } \\
\text { cônica }\end{array}$ & 500 & 1 \\
\hline 22077 & $22^{\circ} 33^{\prime} 37,0^{\prime \prime}$ & $040^{\circ} 19^{\prime} 10,0^{\prime \prime}$ & $17 / 05 / 2002$ & oblíquo & $50 \mathrm{~m}$ & bongô & 500 & 1 \\
\hline
\end{tabular}

Referências: Smith, 1989b; Castro \& Bonecker, 2005; Castro \& Bonecker, 2006a. 


\section{Família Ophichthidae}

A família Ophichthidae é marinha, mas algumas espécies ocasionalmente podem entrar em ambientes de água doce. Ocorre nos oceanos tropicais e temperados quentes. Compreende 52 gêneros com 290 espécies. As larvas são alongadas e frequentemente chegam no máximo a 100 $\mathrm{mm}$. Possuem no mínimo duas voltas no intestino, fígado dividido em dois ou três lóbulos com a vesícula gasosa presente no último lóbulo. Uma característica importante é que o nefros termina até 15 miômeros antes do ânus.

No Brasil já foram identificadas 29 espécies nas fases de larva e adulto. Nesse estudo foi contemplado o morfotipo Bascanichthyini sp. e a espécie Myrichthys ocellatus. 


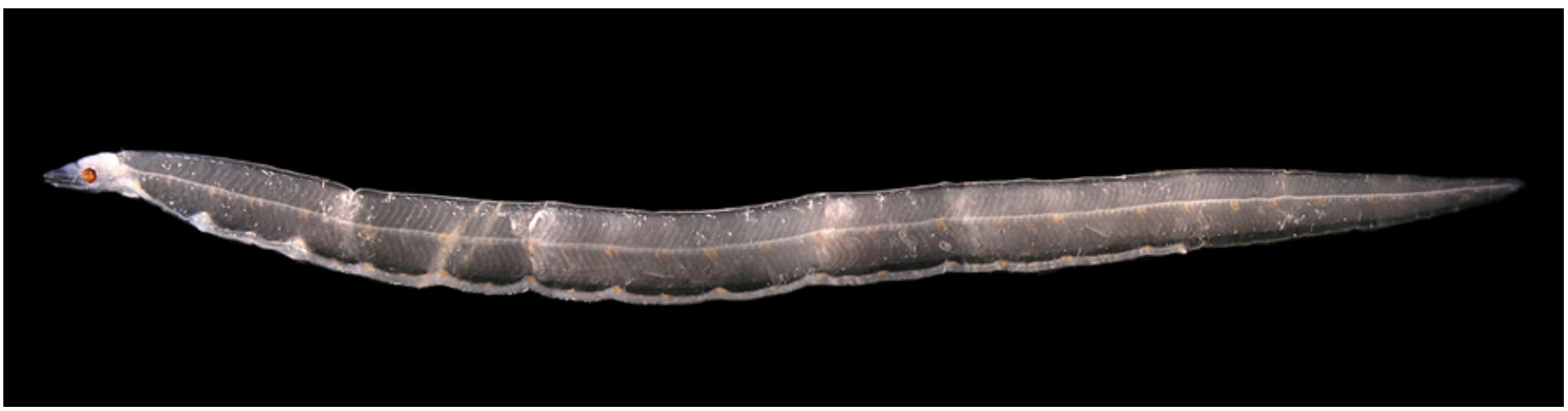

Figura 5: Bascanichthyini sp. DZUFRJ 592; CP 49,2 mm.

\section{Bascanichthyini sp.}

Os indivíduos da tribo Bascanichthyni têm o intestino e o nefros relativamente longos. A maioria das espécies desse grupo possui o intestino com voltas moderadas ou não pronunciadas. A pigmentação observada é pouco útil na identificação das espécies. No exemplar coletado nesse estudo, o nefros termina na última volta do intestino, junto com o ânus. Possui aproximadamente 37 grupos de pigmentos na região da linha lateral desde a cabeça até a cauda. Número total de miômeros: 220; número de miômeros pré-anal: 145.

Habitat: a maioria das espécies dessa tribo é marinha.

\section{Georreferenciamento}

\begin{tabular}{|c|c|c|c|c|c|c|c|c|}
\hline DZUFR & Latitude (S) & Longitude (W) & Data & $\begin{array}{c}\text { Tipo de } \\
\text { arrasto }\end{array}$ & $\begin{array}{c}\text { Profundidade } \\
\text { de coleta }\end{array}$ & Rede & $\begin{array}{c}\text { Malha } \\
\text { ( } \boldsymbol{\mu m})\end{array}$ & $\begin{array}{c}\mathbf{N} \text {. de } \\
\text { inds. }\end{array}$ \\
\hline 592 & $22^{\circ} 33^{\prime} 45,8^{\prime \prime}$ & $040^{\circ} 13^{\prime} 22,9^{\prime \prime}$ & $17 / 05 / 2002$ & oblíquo & $800 \mathrm{~m}$ & cilíndrico-cônica & 500 & 1 \\
\hline
\end{tabular}

Referências: Leiby, 1989. 


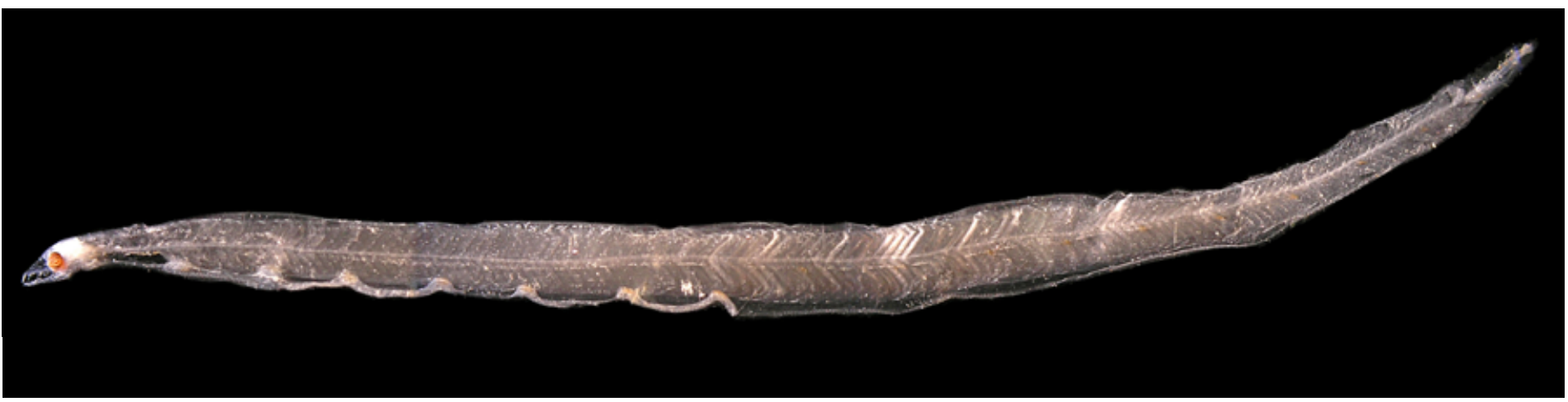

Figura 6: Myrychthys ocellatus DZUFRJ 21616; CP ca 58,0 mm.

\section{Myrychthys ocellatus (Lesueur, 1825)}

Possui sete voltas do intestino bem pronunciadas, com o nefros terminando na última volta. A origem da nadadeira dorsal está situada na altura da primeira volta do intestino em larvas com aproximadamente $80 \mathrm{~mm}$ de comprimento. A pigmentação varia de acordo com o estágio de desenvolvimento da larva. Nos exemplares coletados a pigmentação consiste em linhas oblíquas de pigmentos em alguns miosseptos; 10 a 11 manchas de pigmento na cauda abaixo da notocorda e pequenos melanóforos estrelados em cada volta do intestino. Número total de miômeros: 168; número de miômeros pré-anal: 62-67.

Habitat: espécie marinha, associada a formações coralinas. Vive em águas tropicais.

Nome vulgar: Mututuca.

\section{Georreferenciamento}

\begin{tabular}{|c|c|c|c|c|c|c|c|c|}
\hline DZUFRJ & Latitude (S) & Longitude (W) & Data & $\begin{array}{c}\text { Tipo de } \\
\text { arrasto }\end{array}$ & $\begin{array}{c}\text { Profundidade } \\
\text { de coleta }\end{array}$ & Rede & $\begin{array}{c}\text { Malha } \\
\text { ( } \boldsymbol{\mu m} \text { ) }\end{array}$ & $\begin{array}{c}\mathbf{N} \text {. de } \\
\text { inds. }\end{array}$ \\
\hline 21616 & $22^{\circ} 31^{\prime} 58,9^{\prime \prime}$ & $040^{\circ} 02^{\prime} 53,4^{\prime \prime}$ & $07 / 11 / 2001$ & oblíquo & $1.000 \mathrm{~m}$ & $\begin{array}{c}\text { cilíndrico- } \\
\text { cônica }\end{array}$ & 500 & 1 \\
\hline
\end{tabular}

Referências: Leiby, 1989; Castro \& Bonecker, 2005; Castro \& Bonecker, 2006a. 


\section{Família Congridae}

A família Congridae é marinha e ocorre nas regiões tropicais e temperadas dos oceanos Atlântico, Índico e Pacífico. Compreende 32 gêneros com 160 espécies. As larvas possuem corpo alongado e podem medir entre 90 e $300 \mathrm{~mm}$ de comprimento. As leptocephali dessa família variam muito quanto as principais características de identificação tais como comprimento do intestino e da nadadeira dorsal. A pigmentação ventral está sempre presente, enquanto que a lateral pode ser ausente. Uma característica importante é que o nefros termina a mais de 15 miômeros antes do ânus.

No Brasil já foram identificadas 27 espécies nas fases de larva e adulto. Nesse estudo são contempladas as espécies Ariosoma balearicum, Conger triporiceps e os morfotipos Congridae sp. 1, Congridae sp. 2. 


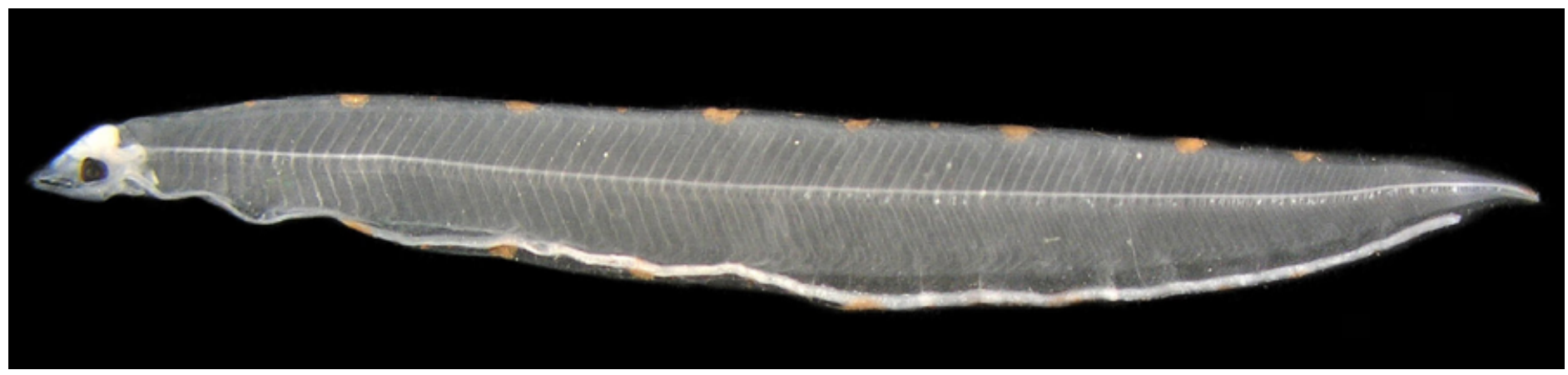

Figura 7 - A: Ariosoma balearicum DZUFRJ 31403; CP 22,7 mm. Vista geral.

\section{Ariosoma balearicum (Delaroche, 1809)}

As larvas com aproximadamente $11 \mathrm{~mm}$ de comprimento possuem sete manchas de pigmentos na margem dorsal do corpo, pigmentos na região ventral do intestino e as linhas oblíquas de pigmentos em cada miossepto já são visíveis. Os exemplares maiores apresentam intestino muito longo, que alcança quase a totalidade do corpo. As nadadeiras dorsal e anal são curtas e estão limitadas à extremidade posterior do corpo. A pigmentação consiste de linhas oblíquas em cada miossepto, desde a cabeça até a cauda; uma série de pequenos melanóforos no esôfago, intestino até o ânus; e uma série de melanóforos pequenos em toda a região dorsal. Número total de miômeros: 126.

Habitat: espécie marinha, associada a formações coralinas. Vive em águas subtropicais e pode ser coletada até $732 \mathrm{~m}$ de profundidade, mas ocorre principalmente até $100 \mathrm{~m}$.

Nome vulgar: Congro das baleares.

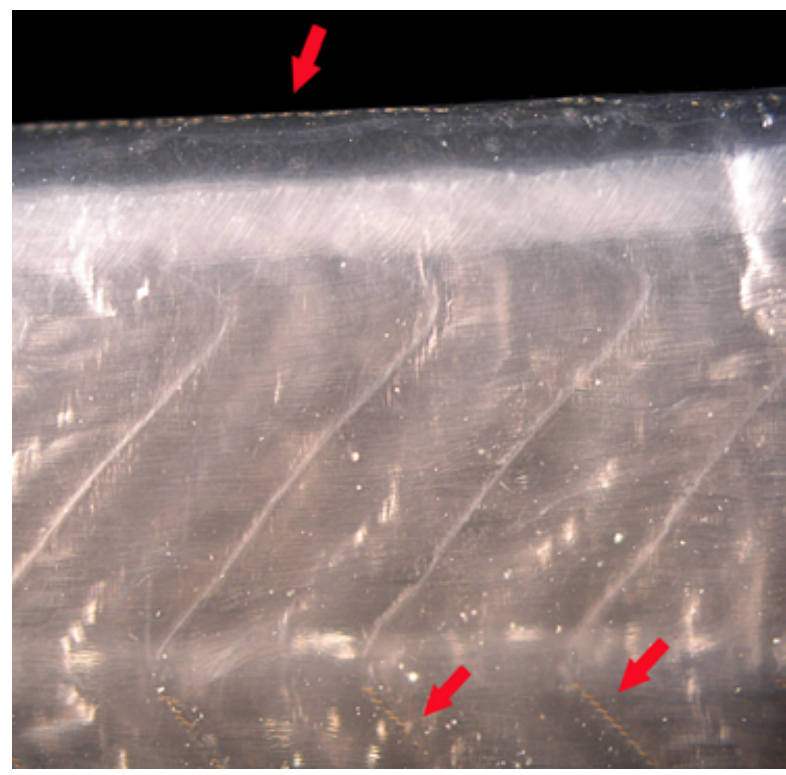

Figura 7 - B: Série de pequenos melanóforos em toda a margem dorsal e nos miosseptos.

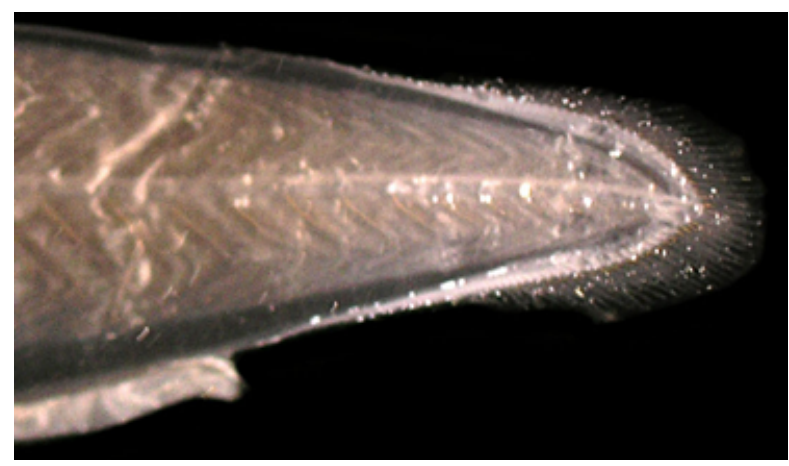

Figura 7 - C: Nadadeiras dorsal e anal.

\section{Georreferenciamento}

\begin{tabular}{|c|c|c|c|c|c|c|c|c|}
\hline DZUFRJ & Latitude (S) & Longitude (W) & Data & $\begin{array}{l}\text { Tipo de } \\
\text { arrasto }\end{array}$ & $\begin{array}{c}\text { Profundidade } \\
\text { de coleta }\end{array}$ & Rede & $\begin{array}{l}\text { Malha } \\
(\mu \mathrm{m})\end{array}$ & $\begin{array}{l}N^{\circ} \text {. de } \\
\text { inds. }\end{array}$ \\
\hline 7517 & $21^{\circ} 57^{\prime} 10,5^{\prime \prime}$ & $039^{\circ} 43^{\prime} 33,3^{\prime \prime}$ & 09/10/2001 & oblíquo & $1.000 \mathrm{~m}$ & cilíndrico-cônica & 500 & 1 \\
\hline 7548 & $21^{\circ} 57^{\prime} 10,5^{\prime \prime}$ & $039^{\circ} 43^{\prime} 33,3^{\prime \prime}$ & 09/10/2001 & oblíquo & $1.000 \mathrm{~m}$ & cilíndrico-cônica & 500 & 1 \\
\hline 7550 & $21^{\circ} 58^{\prime} 31,0^{\prime \prime}$ & $039^{\circ} 50^{\prime} 29,7^{\prime \prime}$ & $11 / 10 / 2001$ & oblíquo & $1.000 \mathrm{~m}$ & cilíndrico-cônica & 500 & 1 \\
\hline
\end{tabular}

Referências: Smith, 1989c; Castro \& Bonecker, 2005; Castro \& Bonecker, 2006a. 


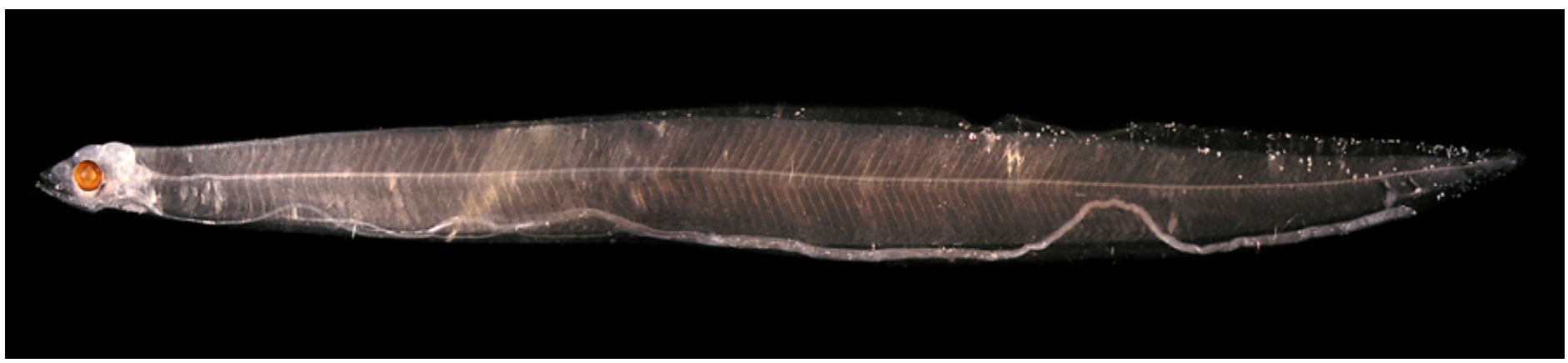

Figura 8: Conger triporiceps DZUFRJ 21611; CP 36,3 mm.

\section{Conger triporiceps Kanazawa, 1958}

Essa espécie não apresenta pigmentos na lateral do corpo e possui uma mancha de pigmentos abaixo do olho. Apresenta pequenos melanóforos ao longo do intestino. Número total de miômeros: 153-156.

Habitat: espécie marinha, associada a formações coralinas. Vive em águas tropicais até a profundidade de $55 \mathrm{~m}$.

Nome vulgar: Congro dentão.

\section{Georreferenciamento}

\begin{tabular}{|c|c|c|c|c|c|c|c|c|}
\hline DZUFRJ & Latitude (S) & Longitude (W) & Data & $\begin{array}{c}\text { Tipo de } \\
\text { arrasto }\end{array}$ & $\begin{array}{c}\text { Profundidade } \\
\text { de coleta }\end{array}$ & Rede & $\begin{array}{c}\text { Malha } \\
\text { ( } \boldsymbol{\mu m} \text { ) }\end{array}$ & $\begin{array}{c}\mathbf{N}^{\circ} \text {. de } \\
\text { inds. }\end{array}$ \\
\hline 21611 & $22^{\circ} 32^{\prime} 49,0^{\prime \prime}$ & $040^{\circ} 04^{\prime} 20,9^{\prime \prime}$ & $07 / 11 / 2001$ & oblíquo & $1.000 \mathrm{~m}$ & $\begin{array}{c}\text { cilíndrico- } \\
\text { cônica }\end{array}$ & 500 & 1 \\
\hline
\end{tabular}

Referências: Smith, 1989c; Castro \& Bonecker, 2005; Castro \& Bonecker, 2006a. 


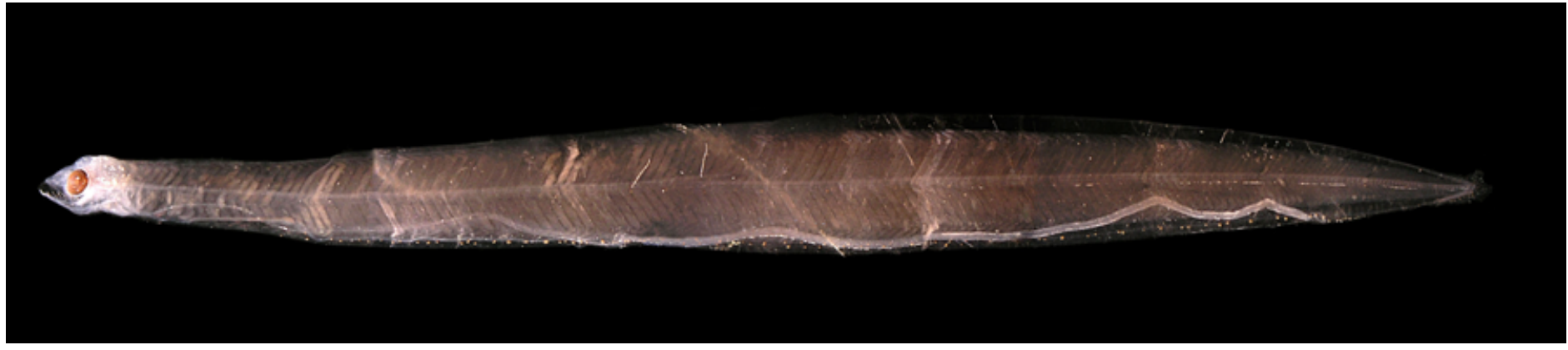

Figura 9 - A: Congridae sp. 1 DZUFRJ 7546; CP 58,5 mm. Vista geral.

\section{Congridae sp. 1}

Apresenta uma mancha de pigmentos abaixo do olho e pigmentos nos raios da nadadeira caudal. Possui pigmentos pequenos abaixo da linha lateral a cada 5-8 miômeros e pigmentos maiores na margem ventral do intestino. Número de miômeros pré-anais: 124. Número total de miômeros: 155-157.

Habitat: todas as espécies da família Congridae são marinhas.

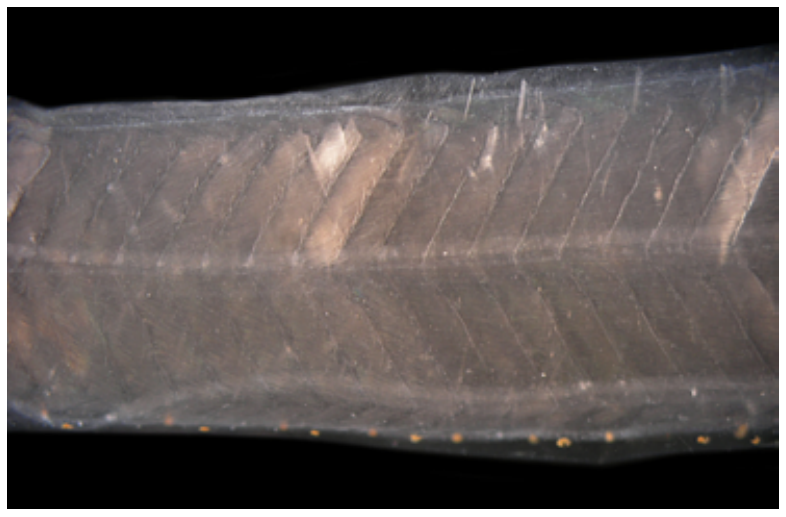

Figura 9 - C: Pigmentos maiores na margem ventral do intestino.

\section{Georreferenciamento}

\begin{tabular}{|c|c|c|c|c|c|c|c|c|}
\hline DZUFR & Latitude (S) & Longitude (W) & Data & $\begin{array}{c}\text { Tipo de } \\
\text { arrasto }\end{array}$ & $\begin{array}{c}\text { Profundidade } \\
\text { de coleta }\end{array}$ & Rede & $\begin{array}{c}\text { Malha } \\
(\boldsymbol{\mu m})\end{array}$ & $\begin{array}{c}\mathbf{N}^{\circ} \text {. de } \\
\text { inds. }\end{array}$ \\
\hline 5431 & $22^{\circ} 31^{\prime} 40,9^{\prime \prime}$ & $040^{\circ} 02^{\prime} 39,6^{\prime \prime}$ & $07 / 11 / 2001$ & oblíquo & $1.000 \mathrm{~m}$ & cilíndrico-cônica & 500 & 1 \\
\hline 7519 & $21^{\circ} 58^{\prime} 31,0^{\prime \prime}$ & $039^{\circ} 50^{\prime} 29,7^{\prime \prime}$ & $10 / 10 / 2001$ & oblíquo & $1.000 \mathrm{~m}$ & cilíndrico-cônica & 500 & 13 \\
\hline 7520 & $21^{\circ} 58^{\prime} 31,0^{\prime \prime}$ & $039^{\circ} 50^{\prime} 29,7^{\prime \prime}$ & $11 / 10 / 2001$ & oblíquo & $1.000 \mathrm{~m}$ & cilíndrico-cônica & 500 & 8 \\
\hline 7546 & $21^{\circ} 54^{\prime} 36,5^{\prime \prime}$ & $039^{\circ} 45^{\prime} 20,0^{\prime \prime}$ & $10 / 10 / 2001$ & oblíquo & $1.000 \mathrm{~m}$ & cilíndrico-cônica & 500 & 1 \\
\hline 21539 & $22^{\circ} 32^{\prime} 490^{\prime \prime}$ & $040^{\circ} 04^{\prime} 2 \mathbf{1}^{\prime \prime}$ & $07 / 11 / 2001$ & oblíquo & $1.000 \mathrm{~m}$ & cilíndrico-cônica & 500 & 3 \\
\hline
\end{tabular}

Referências: Smith, 1989c.

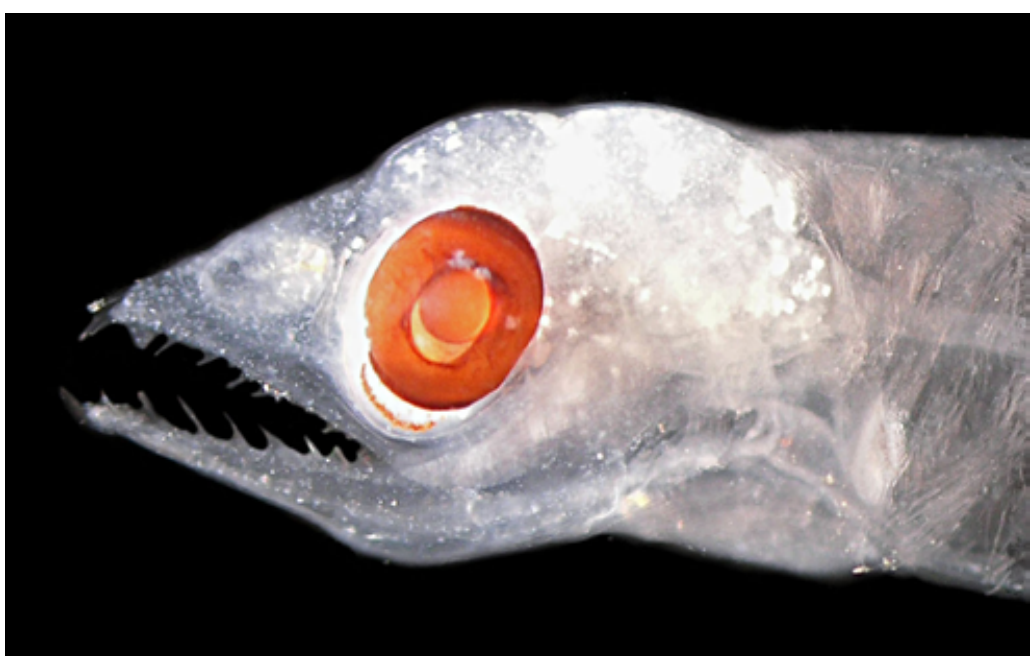

Figura 9 - B: Presença de uma mancha de pigmentos abaixo do olho.

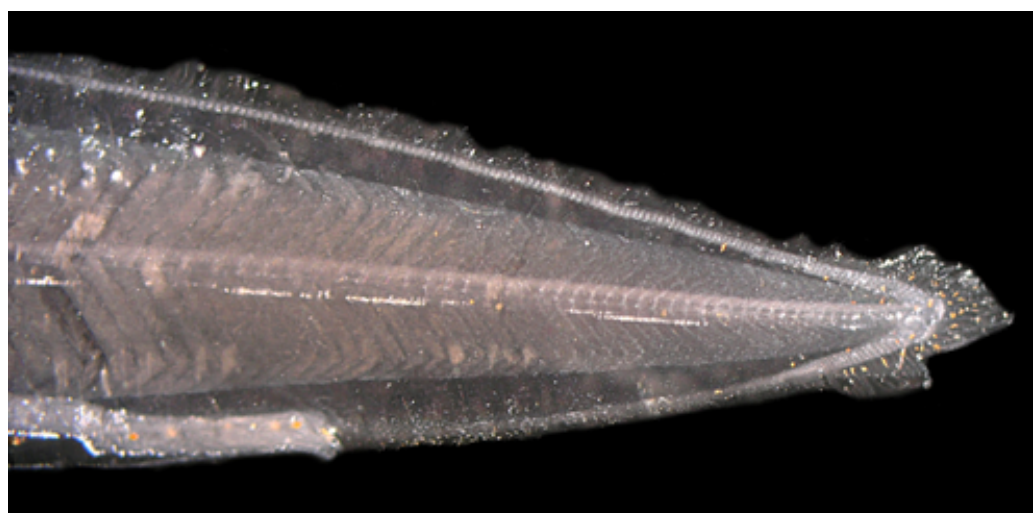

Figura 9 - D: Nadadeira caudal pigmentada. 


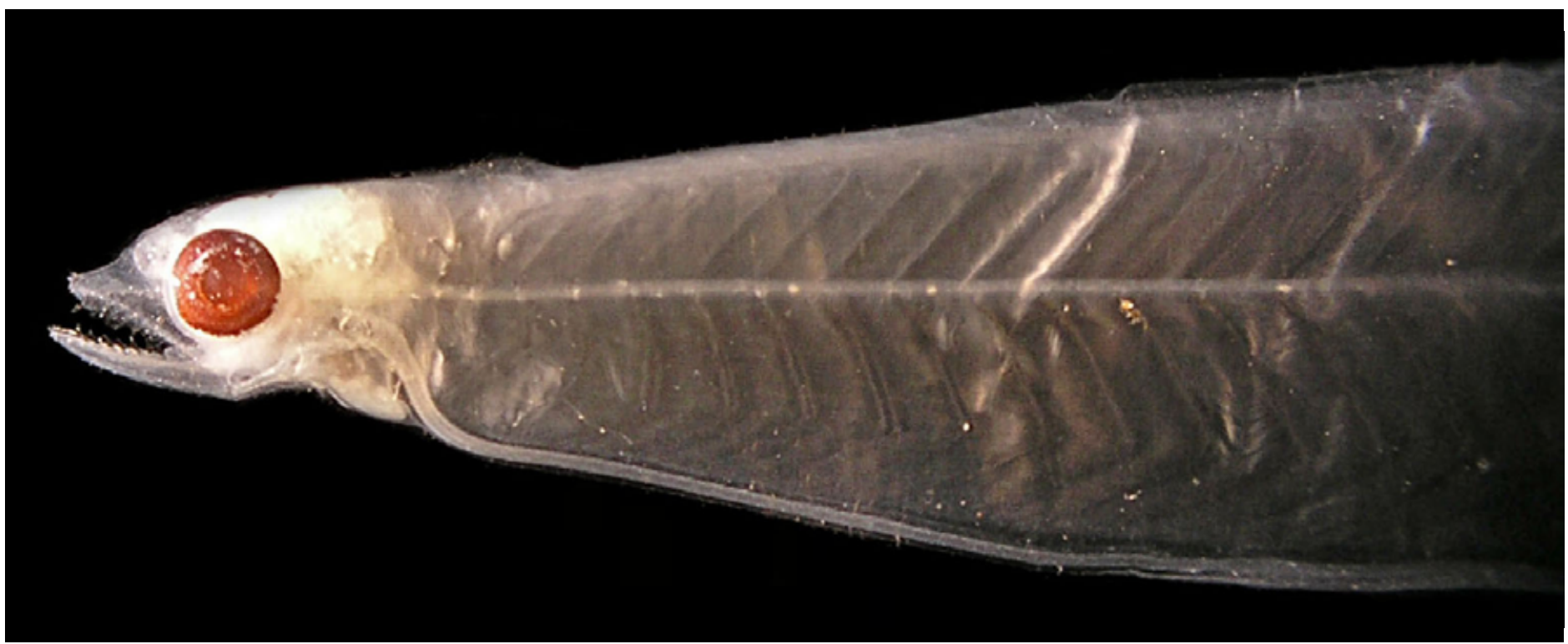

Figura 10 - A: Congridae sp. 2 DZUFRJ 21540; CP 105,0 mm. Vista geral.

\section{Congridae sp. 2}

Possui linhas diagonais de pigmentos em cada miômero logo abaixo da linha lateral. O intestino termina junto com a cauda que é muito arredondada. Número de miômeros anais: 88 . Número total de miômeros: 88.

Habitat: todas as espécies da família Congridae são marinhas.

\section{Georreferenciamento}

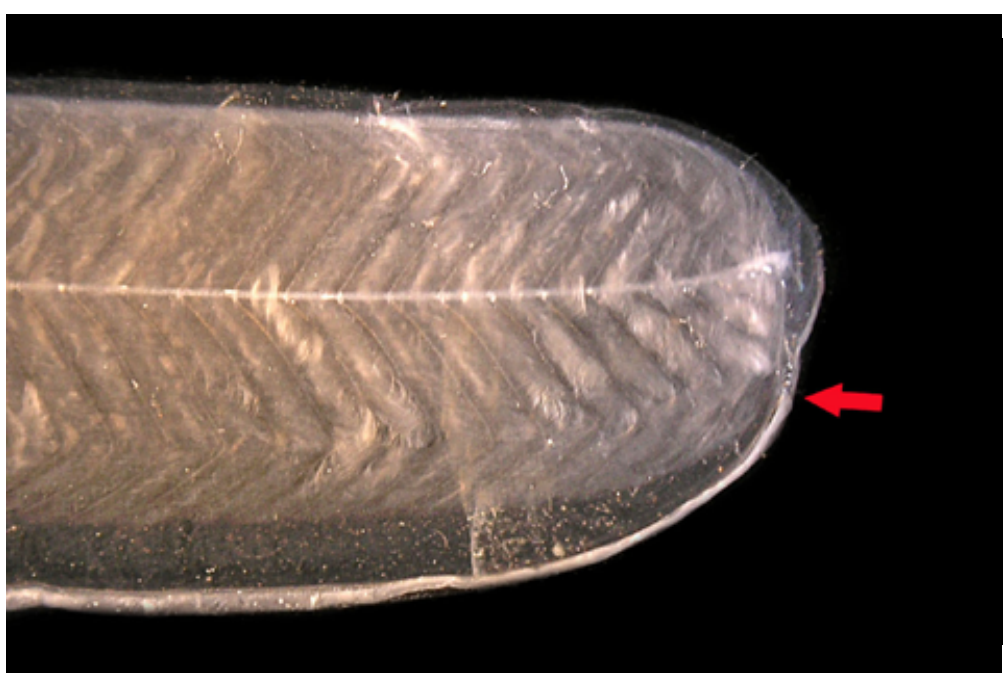

Figura 10 - B: Ânus localizado próximo a nadadeira caudal.

\begin{tabular}{|c|c|c|c|c|c|c|c|c|}
\hline DZUFRJ & Latitude (S) & Longitude (W) & Data & $\begin{array}{c}\text { Tipo de } \\
\text { arrasto }\end{array}$ & $\begin{array}{c}\text { Profundidade } \\
\text { de coleta }\end{array}$ & Rede & $\begin{array}{c}\text { Malha } \\
\text { ( } \boldsymbol{\mu m})\end{array}$ & $\begin{array}{c}\mathbf{N}^{\circ} \text {. de } \\
\text { inds. }\end{array}$ \\
\hline 21540 & $22^{\circ} 31^{\prime} 40,9^{\prime \prime}$ & $040^{\circ} 02^{\prime} 39,6^{\prime \prime}$ & $07 / 11 / 2001$ & oblíquo & $1.000 \mathrm{~m}$ & cilíndrico-cônica & 500 & 1 \\
\hline
\end{tabular}

Referências: Smith, 1989c. 


\section{Família Nemichthyidae}

A família Nemichthyidae é marinha e as espécies possuem hábitos meso e batipelágicos. Ocorre nos oceanos Atlântico, Índico e Pacífico. Compreende três gêneros com nove espécies. As larvas são grandes e finas atingindo 300-400 mm de comprimento. O intestino é longo e reto; o ânus está situado próximo ao final da cauda que é afilada. O padrão de pigmentação é variável e importante para a identificação das espécies.

No Brasil já foram identificadas cinco espécies nas fases de larva e adulto: Avocettina acuticeps (Regan, 1916); Avocettina infans (Günther, 1878); Labichthys carinatus Gill \& Ryder, 1883; Nemichthys curvirostris (Strömman, 1896) e Nemichthys scolopaceus Richardson, 1848. Nesse estudo é contemplada a espécie Nemichthys sp. 


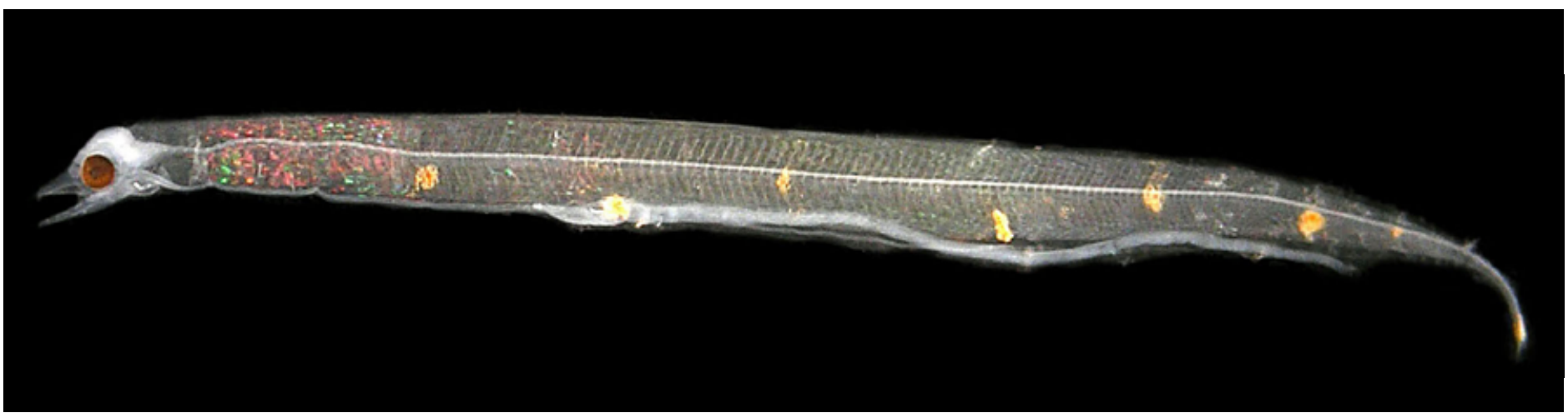

Figura 11: Nemichthys sp. DZUFRJ 7549; CP 8,5 mm.

\section{Nemichthys sp.}

Nos exemplares pequenos existem duas manchas grandes de pigmento na região ventral do corpo que são perdidas quando a larva atinge aproximadamente $60 \mathrm{~mm}$ de comprimento. As larvas de Nemichthys são muito longas e apresentam cauda filiforme. Têm mais miômeros que as demais larvas dessa família, variando entre 300 e 400 ou mais. No Brasil já foram registradas as espécies Nemichthys scolopaceus Richardson, 1848 e Nemichthys curvirostris Strömman, 1896.

Habitat: as três espécies descritas na literatura são marinhas, têm hábitos mesopelágicos e habitam grandes profundidades, até $2.000 \mathrm{~m}$.

\section{Georreferenciamento}

\begin{tabular}{|c|c|c|c|c|c|c|c|c|}
\hline DZUFR & Latitude (S) & Longitude (W) & Data & $\begin{array}{c}\text { Tipo de } \\
\text { arrasto }\end{array}$ & $\begin{array}{c}\text { Profundidade } \\
\text { de coleta }\end{array}$ & Rede & $\begin{array}{c}\text { Malha } \\
\text { ( } \boldsymbol{\mu m} \text { ) }\end{array}$ & $\begin{array}{c}\mathbf{N}^{\circ} \text {. de } \\
\text { inds. }\end{array}$ \\
\hline 7549 & $21^{\circ} 54^{\prime} 36,5^{\prime \prime}$ & $039^{\circ} 45^{\prime} 20,0^{\prime \prime}$ & $10 / 10 / 2001$ & oblíquo & $1.000 \mathrm{~m}$ & $\begin{array}{c}\text { cilíndrico- } \\
\text { cônica }\end{array}$ & 500 & 1 \\
\hline
\end{tabular}

Referências: Smith, 1989d; Castro \& Bonecker, 2005; Castro \& Bonecker, 2006a. 


\section{Família Nettastomatidae}

A família Nettastomatidae é marinha e ocorre nos oceanos Atlântico, Índico e Pacífico. Compreende seis gêneros com aproximadamente 38 espécies. As larvas podem alcançar até $200 \mathrm{~mm}$ de comprimento, possuem corpo alto ou comprido e cauda afilada. O intestino é curto com ondulações ou duas voltas distintas, alcançando menos da metade do comprimento total. A nadadeira dorsal é longa se originando logo após a cabeça.

No Brasil já foram identificadas nove espécies nas fases de larva e adulto. Nesse estudo são contempladas as espécies Facciolella sp. e Saurenchelys sp. 


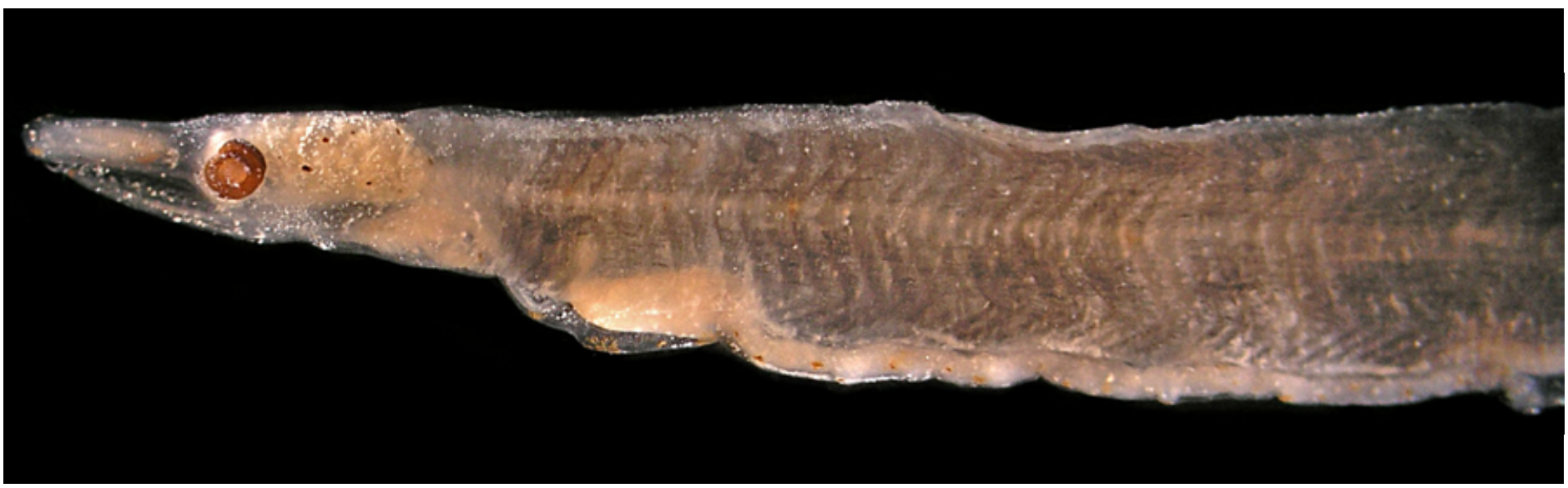

Figura 12: Facciolella sp. DZUFRJ 7518; CP 99,0 mm.

\section{Facciolella sp.}

As larvas de Facciolella possuem corpo longo e estreito, com cauda afilada. O intestino é curto, tem ondulações irregulares e uma série de melanóforos grandes. A nadadeira dorsal é longa e começa pouco depois da nadadeira peitoral. A cabeça é longa e o focinho é afilado. A pigmentação da região lateral do corpo varia entre as espécies, mas de maneira geral elas possuem pigmentos no intestino e no cérebro. O número de miômeros varia entre 240 e 264.

Habitat: as espécies de Facciolella são marinhas, algumas são demersais, batipelágicas, batidemersais ou bentopelágicas. Vivem em águas profundas e já foram registradas em 3.109 m de profundidade. Normalmente, ocorrem entre 329 e $732 \mathrm{~m}$. De acordo com a literatura, as espécies denominadas Facciolella sp. B e Facciolella sp. C já foram coletadas na região oceânica do Brasil.

\section{Georreferenciamento}

\begin{tabular}{|c|c|c|c|c|c|c|c|c|}
\hline DZUFRJ & Latitude (S) & Longitude (W) & Data & $\begin{array}{c}\text { Tipo de } \\
\text { arrasto }\end{array}$ & $\begin{array}{c}\text { Profundidade } \\
\text { de coleta }\end{array}$ & Rede & $\begin{array}{c}\text { Malha } \\
\text { ( } \boldsymbol{\mu m} \text { ) }\end{array}$ & $\begin{array}{c}\mathbf{N}^{\circ} \text {. de } \\
\text { inds. }\end{array}$ \\
\hline 7518 & $21^{\circ} 58^{\prime} 31,0^{\prime \prime}$ & $039^{\circ} 50^{\prime} 29,7^{\prime \prime}$ & $11 / 10 / 2001$ & oblíquo & $1.000 \mathrm{~m}$ & $\begin{array}{c}\text { cilíndrico- } \\
\text { cônica }\end{array}$ & 500 & 1 \\
\hline
\end{tabular}

Referências: Smith, 1989e; Castro \& Bonecker, 2005; Castro \& Bonecker, 2006a; Fahay, 2007. 


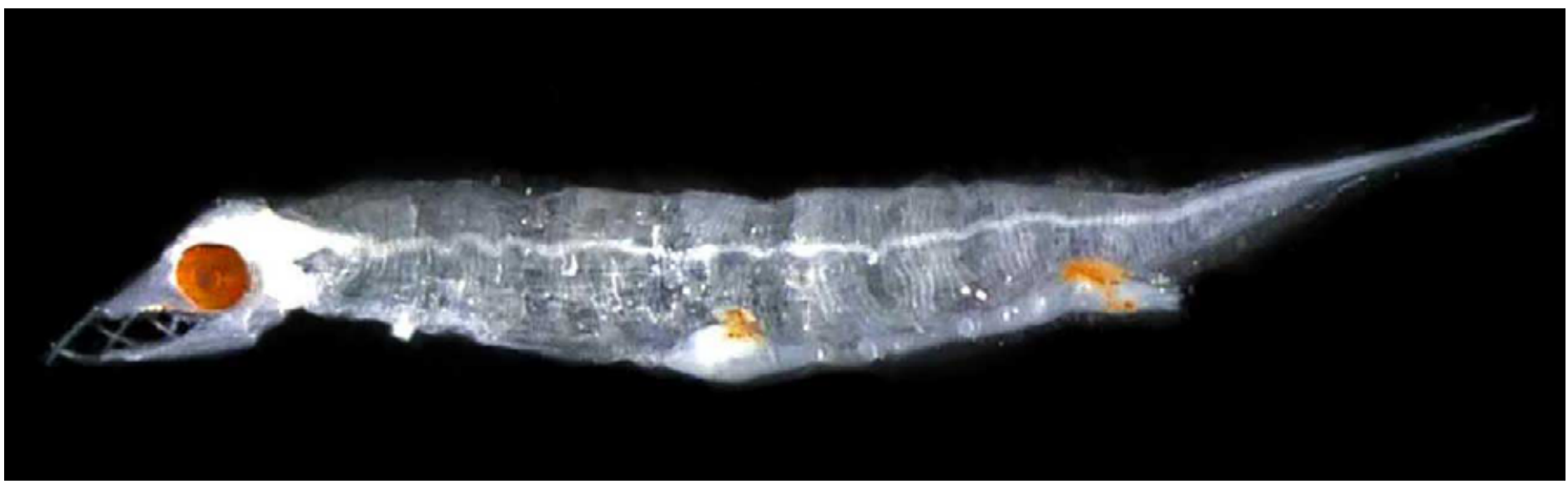

Figura 13: Saurenchelys sp. DZUFRJ 22076; CP 5,3 mm.

\section{Saurenchelys sp.}

Os exemplares pequenos possuem duas manchas grandes de pigmentos sobre as duas voltas do intestino, que continuam nos exemplares maiores, um pouco mais dispersas. As larvas de Saurenchelys são caracterizadas por apresentarem corpo longo e estreito, com cauda afilada. O intestino é relativamente curto, com duas voltas pequenas distintas. A nadadeira dorsal é longa e começa na altura da primeira volta do intestino. A pigmentação da região lateral do corpo varia entre as espécies, mas de maneira geral há uma série de melanóforos internos próximo à notocorda, na região da cauda. Possuem pigmentos sobre as voltas do intestino e no palato. O número de miômeros varia entre 192 e 276. No Brasil há registros das espécies Saurenchelys cancrivora Peters, 1864 e Saurenchelys stylura (Lea, 1913).

Habitat: todas as espécies de Saurenchelys registradas na literatura são marinhas. A maioria é demersal, ocorrendo até $700 \mathrm{~m}$ de profundidade.

\section{Georreferenciamento}

\begin{tabular}{|c|c|c|c|c|c|c|c|c|}
\hline DZUFRJ & Latitude (S) & Longitude (W) & Data & $\begin{array}{c}\text { Tipo de } \\
\text { arrasto }\end{array}$ & $\begin{array}{c}\text { Profundidade } \\
\text { de coleta }\end{array}$ & Rede & $\begin{array}{c}\text { Malha } \\
\text { ( } \boldsymbol{\mu m} \text { ) }\end{array}$ & $\begin{array}{c}\mathbf{N}^{\circ} \text {. de } \\
\text { inds. }\end{array}$ \\
\hline 21612 & $22^{\circ} 34^{\prime} 05,0^{\prime \prime}$ & $040^{\circ} 19^{\prime} 40,0^{\prime \prime}$ & $17 / 05 / 2002$ & oblíquo & $600 \mathrm{~m}$ & $\begin{array}{c}\text { cilíndrico- } \\
\text { cônica }\end{array}$ & 500 & 2 \\
\hline 22076 & $22^{\circ} 38^{\prime} 25,0^{\prime \prime}$ & $040^{\circ} 17^{\prime} 41,0^{\prime \prime}$ & $19 / 05 / 2002$ & oblíquo & $40 \mathrm{~m}$ & bongô & 500 & 1 \\
\hline
\end{tabular}

Referências: Smith \& Castle, 1982; Smith, 1989e; Castro \& Bonecker, 2005; Castro \& Bonecker, 2006a. 


\section{ORDEM CLUPEIFORMES}

A ordem Clupeiformes é composta por cinco famílias e aproximadamente 364 espécies. As características comuns da ordem são: corpo alongado e fino, intestino reto e estriado, distância pré-anal entre 50 e 95\% do comprimento do corpo, olho redondo, número de vértebras 38 a 54.

Nesse estudo a ordem Clupeiformes é representada pela família Engraulidae. 


\section{Família Engraulidae}

A família Engraulidae é pelágica e costeira. Ocorre nos oceanos Atlântico, Índico e Pacífico. Compreende duas subfamílias e 16 gêneros com 139 espécies. Dezessete espécies ocorrem em água doce, algumas são estuarinas e a maioria é marinha. As larvas de Engraulidae são alongadas e possuem vesícula gasosa proeminente. As principais características para separar as larvas de Engraulidae das larvas das famílias Clupeidae, Argentinidae, Bathylagidae e Phosichthyidae, que são muito semelhantes, são a distância pré-anal, a posição das nadadeiras dorsal e anal e o formato dos olhos. Nos engraulídeos o intestino alcança $75 \%$ do comprimento padrão, a origem da nadadeira anal e o final da nadadeira dorsal se sobrepõem e os olhos são redondos.

No Brasil já foram identificadas 17 espécies marinhas nas fases de larva e adulto. Nesse estudo é contemplada a espécie Engraulis anchoita. 


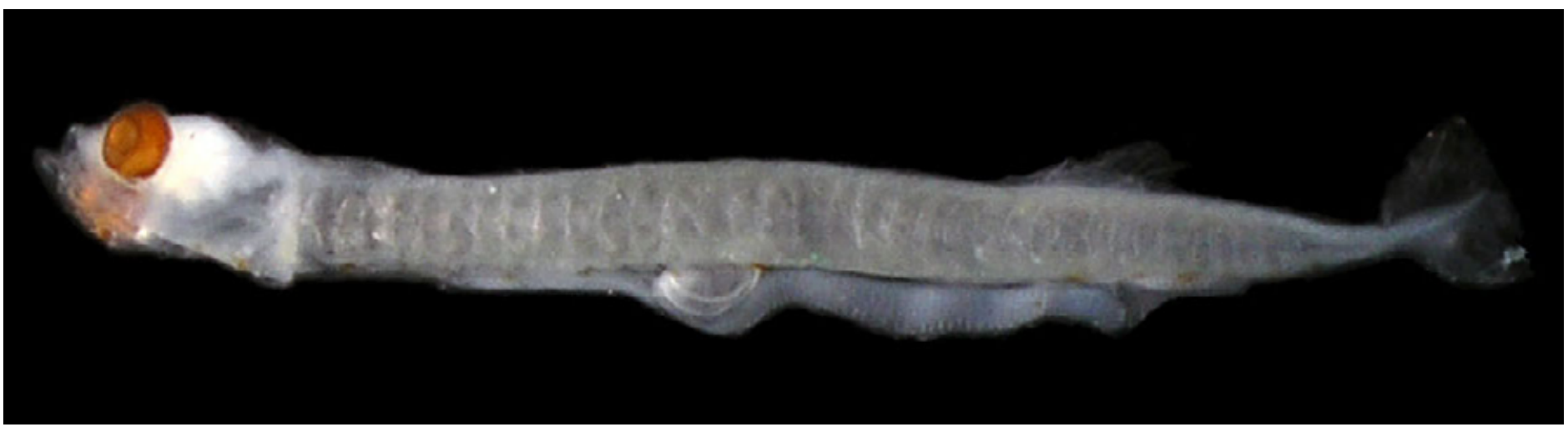

Figura 14: Engraulis anchoita DZUFRJ 31311; Pré-flexão; CP 5,5 mm.

\section{Engraulis anchoita Hubbs \& Marini, 1935}

Possui o corpo muito alongado e fino. O intestino é estriado e longo alcançando aproximadamente $75 \%$ do corpo. Apresenta um melanóforo no cleitro e logo acima da base da nadadeira peitoral. Possui melanóforos na região ventral anterior do corpo e na extremidade posterior da notocorda. O número de vértebras varia entre 44 e 48.

Tamanho: pré-flexão: 4,5-6,5 mm.

Habitat: espécie marinha e pelágica. Ocorre em profundidades entre 30 e $200 \mathrm{~m}$.

Nome vulgar: Anchoita.

\section{Georreferenciamento}

\begin{tabular}{|c|c|c|c|c|c|c|c|c|}
\hline DZUFRJ & Latitude (S) & Longitude (W) & Data & $\begin{array}{c}\text { Tipo de } \\
\text { arrasto }\end{array}$ & $\begin{array}{c}\text { Profundidade } \\
\text { de coleta }\end{array}$ & Rede & $\begin{array}{c}\text { Malha } \\
\text { ( } \boldsymbol{\mu m} \text { ) }\end{array}$ & $\begin{array}{c}\text { No. de } \\
\text { inds. }\end{array}$ \\
\hline 350 & $22^{\circ} 33^{\prime} 37,0^{\prime \prime}$ & $040^{\circ} 19^{\prime} 10,0^{\prime \prime}$ & $17 / 5 / 2002$ & oblíquo & $50 \mathrm{~m}$ & bongô & 330 & 2 \\
\hline 355 & $22^{\circ} 33^{\prime} 37,0^{\prime \prime}$ & $040^{\circ} 19^{\prime} 10,0^{\prime \prime}$ & $17 / 5 / 2002$ & oblíquo & $50 \mathrm{~m}$ & bongô & 500 & 2 \\
\hline 358 & $22^{\circ} 34^{\prime} 05,0^{\prime \prime}$ & $040^{\circ} 19^{\prime} 40,0^{\prime \prime}$ & $17 / 5 / 2002$ & oblíquo & $600 \mathrm{~m}$ & cilíndrico-cônica & 500 & 1 \\
\hline
\end{tabular}

Referências: Ciechomski, 1965; Phonlor, 1984. 


\section{ORDEM STOMIIFORMES}

A ordem Stomiiformes é composta por quatro famílias com aproximadamente 399 espécies. Todas as espécies são marinhas, a maioria ocorre em grandes profundidades. A principal característica das larvas em transformação e dos adultos é a presença de fotóforos.

Nesse estudo a ordem Stomiiformes é representada pelas famílias Gonostomatidae, Phosichthyidae, Sternoptychidae e Stomiidae. 


\section{Família Gonostomatidae}

A família Gonostomatidae é marinha e ocorre nos oceanos Atlântico, Índico e Pacífico. Compreende oito gêneros com 31 espécies. As larvas de Diplophos possuem o corpo muito alongado, blocos de pigmentos nas margens dorsal e ventral do corpo e nadadeira dorsal curta situada aproximadamente na metade do corpo. As larvas de Manducus possuem o corpo mais curto (63 miômeros) que as de Diplophos, têm uma membrana pronunciada em volta do intestino e uma série de pigmentos na região dorso-lateral do corpo. O padrão de pigmentação na margem dorsal do corpo é importante para separar as larvas do gênero Cyclothone. Indivíduos desse gênero que já sofreram transformação podem ser separados pelo padrão de pigmentação da membrana que cobre o cérebro (meninge).

No Brasil já foram identificadas dez espécies nas fases de larva e adulto. Nesse estudo são contempladas as espécies Cyclothone acclinidens, Cyclothone alba, Cyclothone braueri, Cyclothone pseudopallida, Diplophos taenia, Margrethia obtusirostra e Gonostoma elongatum. 


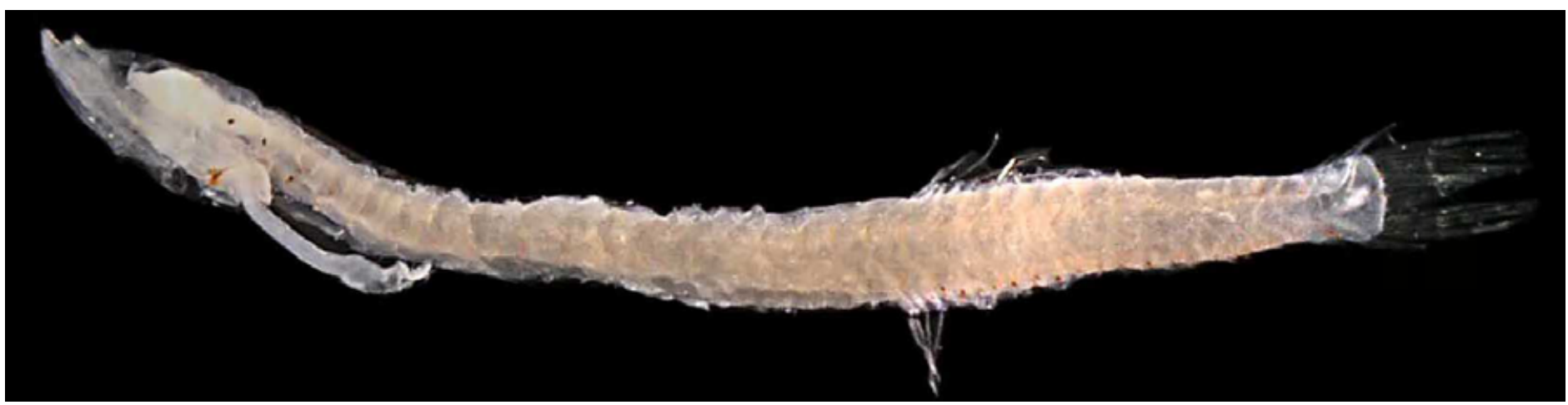

Figura 15 - A: Cyclothone acclinidens. DZUFRJ 21608; Pós-flexão; CP 11,0 mm.

\section{Cyclothone acclinidens Garman, 1899}

As larvas dessa espécie durante a flexão e a pós-flexão, apresentam uma série contínua de pigmentos na região dorsal e outra série de pigmentos na região ventral do corpo, desde a cabeça até a vesícula gasosa; e na base da nadadeira anal. Possuem também pigmento bem marcado na região ventral do pedúnculo caudal, na base da nadadeira caudal e na vesícula gasosa. O número de miômeros varia entre 30 e 32. Os espécimes que estão no estágio de transformação; ou seja, quando os fotóforos começam a se desenvolver, podem ser separados pelo número de rastros branquiais do primeiro arco: 7(6-9) + 12-14 (15-17) = 23-25 e pela pigmentação da membrana (meninge) que cobre a região dorsal do cérebro. Essa

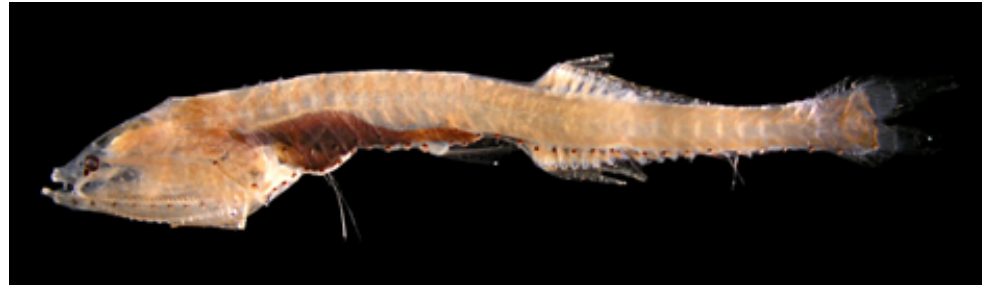

Figura 15 - B: DZUFRJ 21888; Juvenil; CP 22,5 mm.

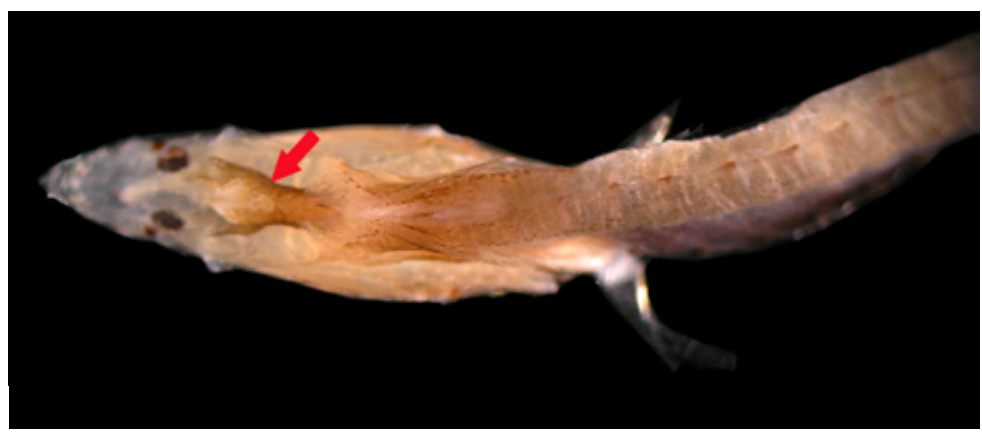

Figura 15 - C: Detalhe da cabeça e meninge com pigmentos escuros formando um "V". membrana permanece intacta, mesmo quando os espécimes estão muito danificados. No caso de $C$. acclinidens, a meninge possui pigmentos escuros na lateral do cérebro formando um " $\mathrm{V}$ ", com o vértice voltado para trás. Esse " $\mathrm{V}$ " é mais espesso que o observado em C. alba.

Tamanho: pós-flexão: 11,0-12,5 mm; juvenil: 22,5-43,2 mm.

Habitat: espécie marinha, epi-mesopelágica e batipelágica, ocorre em águas tropicais em profundidades entre 50 e $1.900 \mathrm{~m}$.

\section{Georreferenciamento}

\begin{tabular}{|c|c|c|c|c|c|c|c|c|}
\hline DZUFRJ & Latitude (S) & Longitude (W) & Data & $\begin{array}{c}\text { Tipo de } \\
\text { arrasto }\end{array}$ & $\begin{array}{c}\text { Profundidade } \\
\text { de coleta }\end{array}$ & Rede & $\begin{array}{c}\text { Malha } \\
\text { ( } \boldsymbol{\mu m} \text { ) }\end{array}$ & $\begin{array}{c}\text { No. de } \\
\text { inds. }\end{array}$ \\
\hline 21608 & $21^{\circ} 57^{\prime} 10,5^{\prime \prime}$ & $039^{\circ} 43^{\prime} 33,3^{\prime \prime}$ & $9 / 10 / 2001$ & oblíquo & $1.000 \mathrm{~m}$ & cilíndrico-cônica & 500 & 2 \\
\hline 21887 & $21^{\circ} 54^{\prime} 36,5^{\prime \prime}$ & $039^{\circ} 45^{\prime} 20,0^{\prime \prime}$ & $10 / 10 / 2001$ & oblíquo & $1.000 \mathrm{~m}$ & cilíndrico-cônica & 500 & 1 \\
\hline 21888 & $21^{\circ} 54^{\prime} 36,5^{\prime \prime}$ & $039^{\circ} 45^{\prime} 20,0^{\prime \prime}$ & $9 / 10 / 2001$ & oblíquo & $1.000 \mathrm{~m}$ & cilíndrico-cônica & 500 & 5 \\
\hline 21889 & $21^{\circ} 58^{\prime} 31,0^{\prime \prime}$ & $039^{\circ} 50^{\prime} 29,7^{\prime \prime}$ & $10 / 10 / 2001$ & oblíquo & $1.000 \mathrm{~m}$ & cilíndrico-cônica & 500 & 2 \\
\hline
\end{tabular}

Referências: Bond \& Tighe, 1974; Olivar \& Fortuño, 1991; Miya, 1994; Watson, 1996a; Bonecker et al., 2006a; Richards, 2006a; Fahay, 2007. 


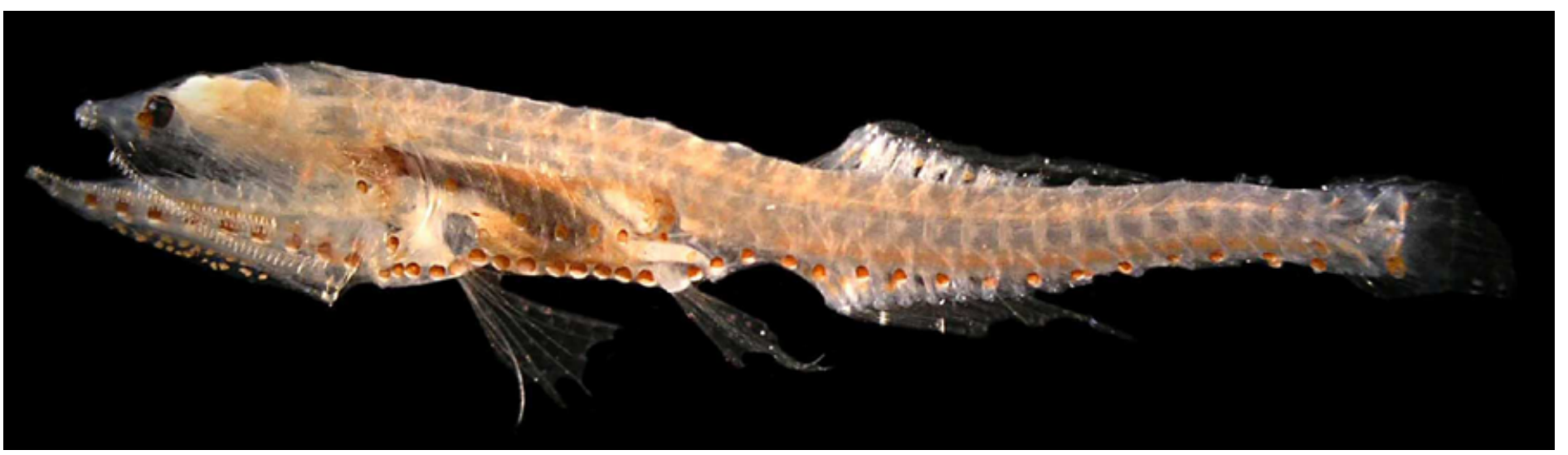

Figura 16 - A: Cyclothone alba. DZUFRJ 21971; Transformação; CP 12,5 mm.

\section{Cyclothone alba Brauer, 1906}

As larvas dessa espécie durante a flexão e a pós-flexão, apresentam uma série descontínua de pigmentos na região dorsal posterior do corpo. Há uma série de pigmento na região

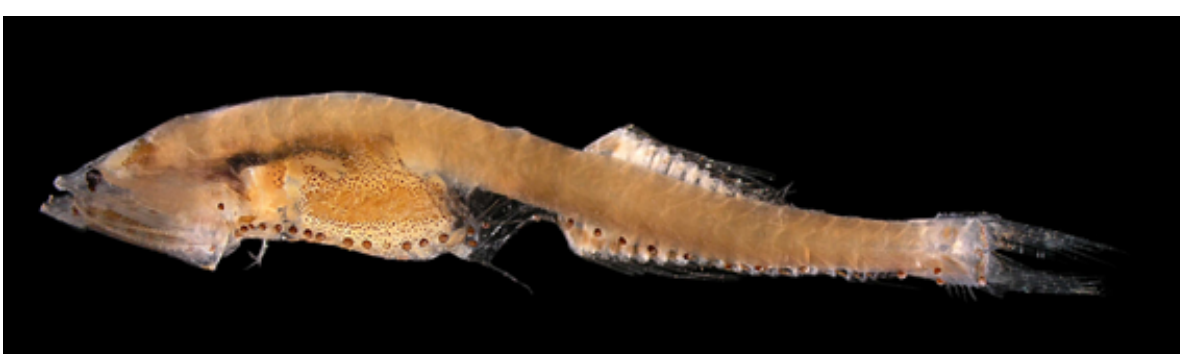

Figura 16 - B: DZUFRJ 21969; Juvenil; CP 27,5 mm. ventral do corpo, desde a cabeça até a vesícula gasosa; e na base da nadadeira anal. Possui um pigmento bem marcado na região ventral do pedúnculo caudal e na vesícula gasosa. O número de miômeros varia entre 31 e 32. Os espécimes que estão no estágio de transformação; ou seja, quando os fotóforos começam a se desenvolver, podem ser separados pelo número de rastros branquiais do primeiro arco $(4+1+9=14)$ e pela pigmentação da membrana (meninge) que cobre a região dorsal do cérebro. Essa membrana permanece intacta, mesmo quando os espécimes estão muito danificados. No caso de C. alba, a meninge possui pigmentos escuros na lateral do cérebro formando um “V”, com o vértice voltado para trás. Esse é o único pigmento da meninge dessa espécie.

Tamanho: transformação: 12,0-19,0 mm; juvenil: 22,0-50,0 mm.

Habitat: espécie marinha, mesopelágica e batipelágica, ocorre em águas tropicais e subtropicais em profundidades entre 400 e $3.000 \mathrm{~m}$.

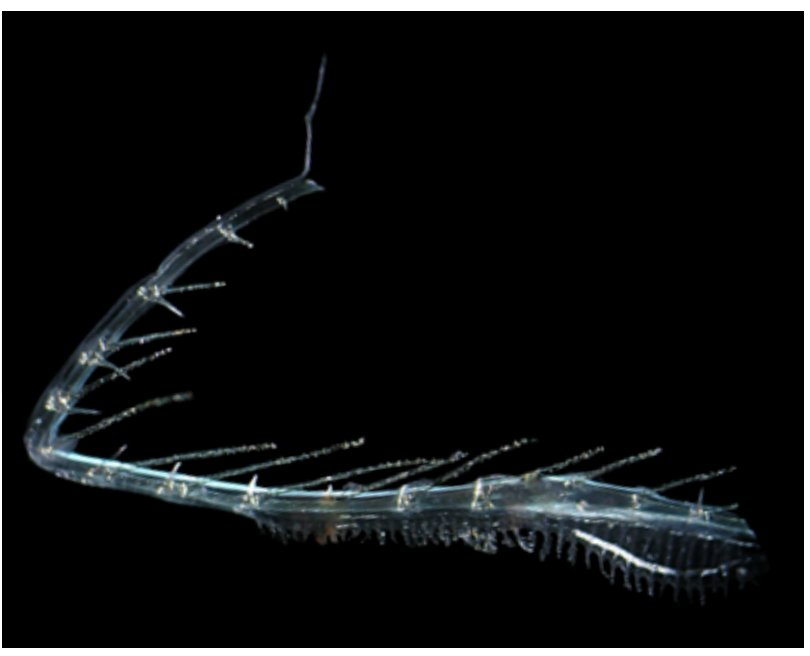

Figura 16 - C: Rastros branquiais do primeiro arco.

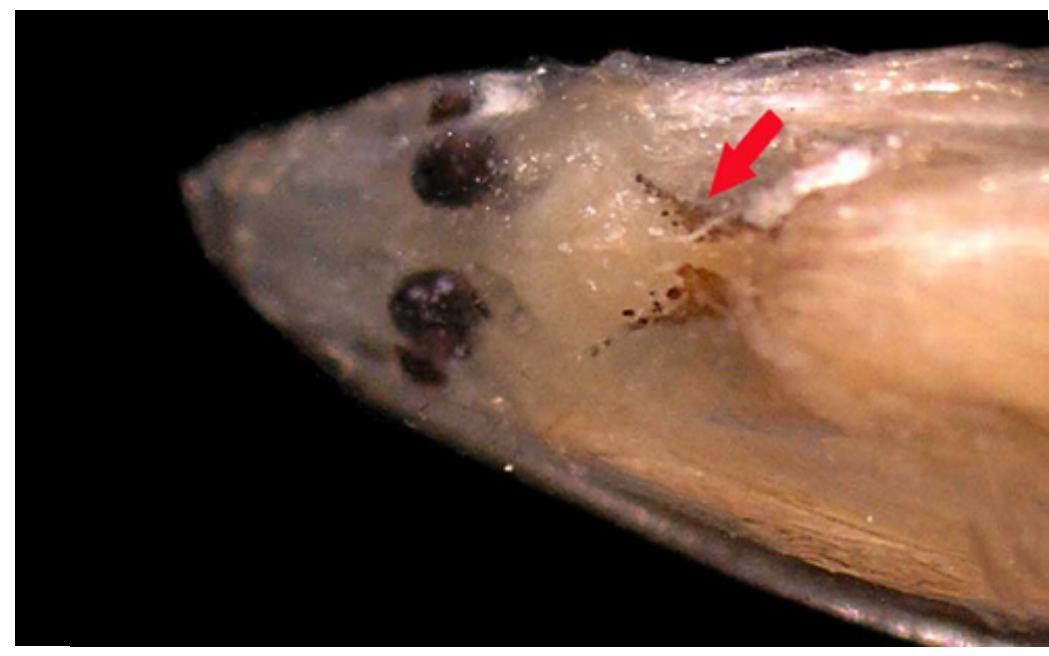

Figura 16 - D: Detalhe da cabeça e meninge com pigmentos escuros formando um "V". 


\section{Georreferenciamento}

\begin{tabular}{|c|c|c|c|c|c|c|c|c|}
\hline DZUFRJ & Latitude (S) & Longitude (W) & Data & $\begin{array}{l}\text { Tipo de } \\
\text { arrasto }\end{array}$ & $\begin{array}{l}\text { Profundidade } \\
\text { de coleta }\end{array}$ & Rede & $\begin{array}{l}\text { Malha } \\
(\mu \mathrm{m})\end{array}$ & $\begin{array}{l}N^{\circ} \text {. de } \\
\text { inds. }\end{array}$ \\
\hline 605 & $22^{\circ} 38^{\prime} 29,0^{\prime \prime}$ & $040^{\circ} 17^{\prime} 40,0^{\prime \prime}$ & 18/05/2002 & oblíquo & $800 \mathrm{~m}$ & cilíndrico-cônica & 500 & 4 \\
\hline 1197 & $22^{\circ} 06^{\prime} 52,3^{\prime \prime}$ & $039^{\circ} 48^{\prime} 46,2^{\prime \prime}$ & $11 / 05 / 2002$ & oblíquo & $1.000 \mathrm{~m}$ & cilíndrico-cônica & 500 & 15 \\
\hline 1244 & $22^{\circ} 08^{\prime} 17,5^{\prime \prime}$ & $039^{\circ} 46^{\prime} 28,5^{\prime \prime}$ & $11 / 05 / 2002$ & oblíquo & $1.000 \mathrm{~m}$ & cilíndrico-cônica & 500 & 13 \\
\hline 21575 & $22^{\circ} 31^{\prime} 40,9^{\prime \prime}$ & $040^{\circ} 02^{\prime} 39,6^{\prime \prime}$ & $07 / 11 / 2001$ & oblíquo & $1.000 \mathrm{~m}$ & cilíndrico-cônica & 500 & 1 \\
\hline 21627 & $21^{\circ} 58^{\prime} 31,0^{\prime \prime}$ & $039^{\circ} 50^{\prime 29,7 "}$ & $10 / 10 / 2001$ & oblíquo & $1.000 \mathrm{~m}$ & cilíndrico-cônica & 500 & 1 \\
\hline 21628 & $22^{\circ} 41^{\prime} 54,7^{\prime \prime}$ & $040^{\circ} 14^{\prime} 04,5^{\prime \prime}$ & $16 / 05 / 2002$ & oblíquo & $1.000 \mathrm{~m}$ & cilíndrico-cônica & 500 & 1 \\
\hline 21629 & $22^{\circ} 08,03^{\prime}$ & $039^{\circ} 50,1^{\prime}$ & $16 / 06 / 2003$ & vertical & $500-1.000 m$ & cilíndrico-cônica & 500 & 1 \\
\hline 21877 & $21^{\circ} 54^{\prime} 36,5^{\prime \prime}$ & $039^{\circ} 45^{\prime} 20,0^{\prime \prime}$ & $10 / 10 / 2001$ & oblíquo & $1.000 \mathrm{~m}$ & cilíndrico-cônica & 500 & 27 \\
\hline 21878 & $21^{\circ} 58^{\prime} 31,0^{\prime \prime}$ & $039^{\circ} 50^{\prime} 29,7^{\prime \prime}$ & $11 / 10 / 2001$ & oblíquo & $0 \mathrm{~m}$ & cilíndrico-cônica & 500 & 7 \\
\hline 21879 & $22^{\circ} 32^{\prime} 50,0^{\prime \prime}$ & $040^{\circ} 04^{\prime} 09,9^{\prime \prime}$ & $06 / 11 / 2001$ & oblíquo & $1.000 \mathrm{~m}$ & cilíndrico-cônica & 500 & 4 \\
\hline 21880 & $21^{\circ} 57^{\prime} 10,5^{\prime \prime}$ & $039^{\circ} 43^{\prime} 33,3^{\prime \prime}$ & $09 / 10 / 2001$ & oblíquo & $1.000 \mathrm{~m}$ & cilíndrico-cônica & 500 & 11 \\
\hline 21969 & $21^{\circ} 58^{\prime} 31,0^{\prime \prime}$ & $039^{\circ} 50^{\prime 29,7 "}$ & $10 / 10 / 2001$ & oblíquo & & cilíndrico-cônica & 500 & 11 \\
\hline 21970 & $21^{\circ} 54^{\prime} 36,5^{\prime \prime}$ & $039^{\circ} 45^{\prime} 20,0^{\prime \prime}$ & $10 / 10 / 2001$ & oblíquo & $1.000 \mathrm{~m}$ & cilíndrico-cônica & 500 & 2 \\
\hline 21971 & $21^{\circ} 57^{\prime} 10,5^{\prime \prime}$ & $039^{\circ} 43^{\prime} 33,3^{\prime \prime}$ & $09 / 10 / 2001$ & oblíquo & $1.000 \mathrm{~m}$ & cilíndrico-cônica & 500 & 2 \\
\hline 21972 & $21^{\circ} 53^{\prime} 10,4^{\prime \prime}$ & $039^{\circ} 45^{\prime} 49,9^{\prime \prime}$ & $10 / 10 / 2001$ & oblíquo & $1.000 \mathrm{~m}$ & cilíndrico-cônica & 500 & 25 \\
\hline 21973 & $21^{\circ} 57^{\prime} 10,5^{\prime \prime}$ & $039^{\circ} 43^{\prime} 33,3^{\prime \prime}$ & 09/10/2001 & oblíquo & $1.000 \mathrm{~m}$ & cilíndrico-cônica & 500 & 27 \\
\hline 21974 & $21^{\circ} 54^{\prime} 36,5^{\prime \prime}$ & $039^{\circ} 45^{\prime} 20,0^{\prime \prime}$ & $09 / 10 / 2001$ & oblíquo & $1.000 \mathrm{~m}$ & cilíndrico-cônica & 500 & 6 \\
\hline 21975 & $21^{\circ} 53^{\prime} 10,4^{\prime \prime}$ & $039^{\circ} 45^{\prime} 49,9^{\prime \prime}$ & $10 / 10 / 2001$ & oblíquo & $1.000 \mathrm{~m}$ & cilíndrico-cônica & 500 & 32 \\
\hline 22206 & $21^{\circ} 53^{\prime} 10,4^{\prime \prime}$ & $039^{\circ} 45^{\prime} 49,9^{\prime \prime}$ & $10 / 10 / 2001$ & oblíquo & $1.000 \mathrm{~m}$ & cilíndrico-cônica & 500 & 7 \\
\hline
\end{tabular}

Referências: Bond \& Tighe, 1974; Olivar \& Fortuño, 1991; Miya, 1994; Watson, 1996a; Bonecker et al., 2006a; Richards, 2006a; Fahay, 2007. 


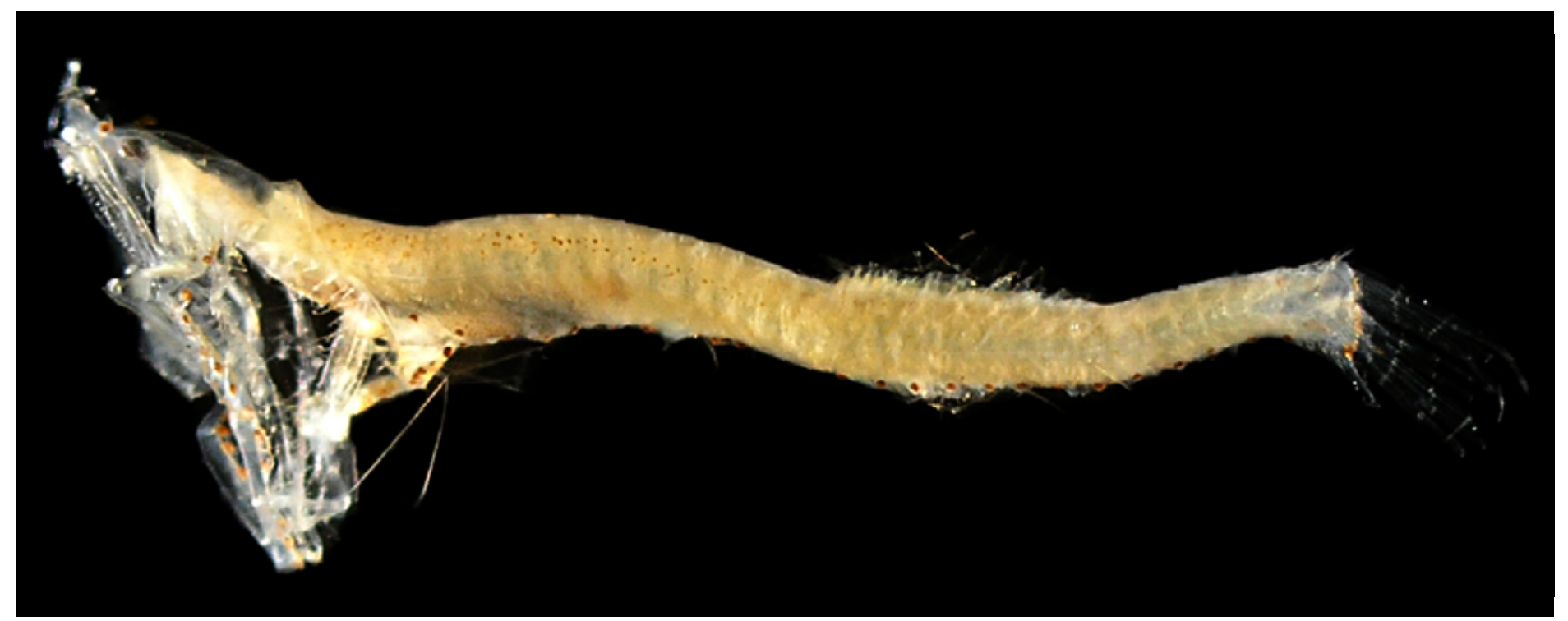

Figura 17 - A: Cyclothone braueri. DZUFRJ 22211; Pós-flexão; CP 11,5 mm.

\section{Cyclothone braueri Jespersen \& Tåning, 1926}

Desde a flexão apresenta melanóforos internos na região póstero-ventral. As larvas maiores que $8,0 \mathrm{~mm}$ CP apresentam também três melanóforos na região dorsal do pedúnculo caudal e um ventral. Possui melanóforos na porção anterior do corpo durante a pós-flexão, na vesícula gasosa e dois pigmentos no intestino. O número de miômeros varia entre 30 e 32. Os espécimes que estão no estágio de transformação; ou seja,

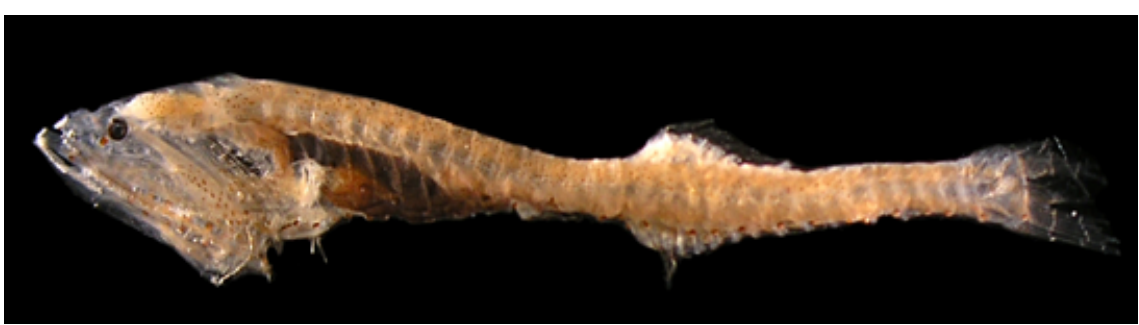

Figura 17 - B: DZUFRJ 21894; Transformação; CP 14,7 mm.

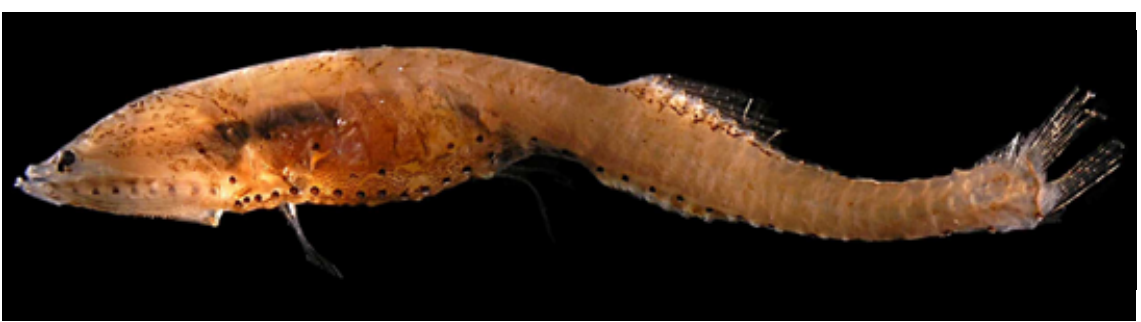

Figura 17 - C: DZUFRJ 22210; Transformação; CP 29,5 mm. quando os fotóforos começam a se desenvolver, podem ser separados pelo número de rastros branquiais do primeiro arco $(5-6+2+9-10=$ 15-17) e pela pigmentação da membrana (meninge) que cobre a região dorsal do cérebro. Essa membrana permanece intacta, mesmo quando os espécimes estão muito danificados. No caso de $C$. braueri, a meninge possui pigmentos escuros na lateral do cérebro formando um "V", com 0 vértice voltado para trás. Na membrana entre o "V" existe um ou dois melanóforos podendo ter mais de 20. Entretanto, nunca chegará a 30 melanóforos. Esses melanóforos podem estar contraídos em exemplares coletados durante o dia ou dilatados quando coletados durante a noite.

Tamanho: pós-flexão: 11,5-12,5 mm; transformação: 13,3-29,5 mm; juvenil: 47,2 $\mathrm{mm}$.

Habitat: espécie marinha, mesopelágica e batipelágica, ocorre em águas tropicais e subtropicais, desde próximo à superfície até $2.000 \mathrm{~m}$ de profundidade. 


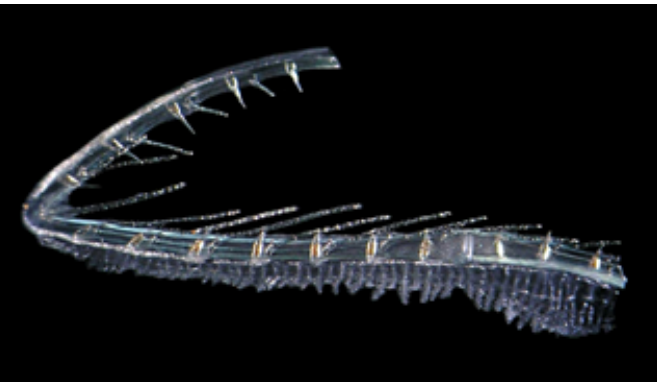

Figura 17 - D: Rastros branquiais do primeiro arco.

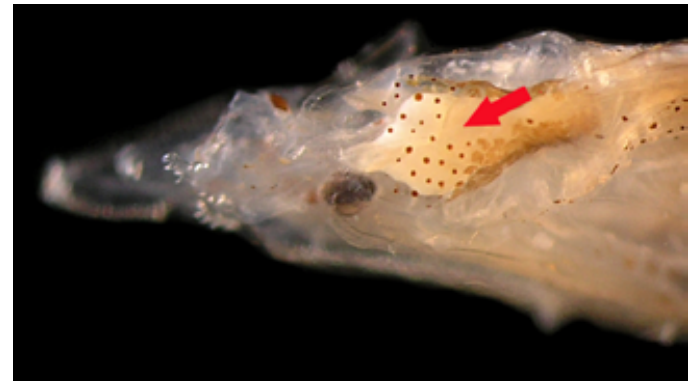

Figura 17 - E: Detalhe da cabeça com melanóforos na meninge entre o "V"

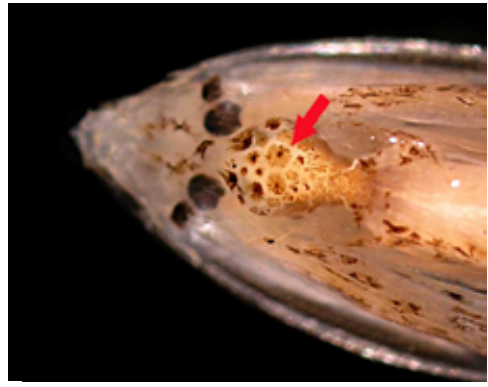

Figura 17 - F: Detalhe da cabeça com melanóforos dilatados.

\section{Georreferenciamento}

\begin{tabular}{|c|c|c|c|c|c|c|c|c|}
\hline DZUFRJ & Latitude (S) & Longitude (W) & Data & $\begin{array}{l}\text { Tipo de } \\
\text { arrasto }\end{array}$ & $\begin{array}{c}\text { Profundidade } \\
\text { de coleta }\end{array}$ & Rede & $\begin{array}{c}\text { Malha } \\
(\mu \mathrm{m})\end{array}$ & $\begin{array}{l}\text { No. de } \\
\text { inds. }\end{array}$ \\
\hline 21630 & $22^{\circ} 41^{\prime} 54,7^{\prime \prime}$ & $040^{\circ} 14^{\prime} 04,5^{\prime \prime}$ & $16 / 05 / 2002$ & oblíquo & $1.000 \mathrm{~m}$ & cilíndrico-cônica & 500 & 8 \\
\hline 21631 & $22^{\circ} 38^{\prime} 29,0^{\prime \prime}$ & $040^{\circ} 17^{\prime} 40,0^{\prime \prime}$ & $18 / 05 / 2002$ & oblíquo & $800 \mathrm{~m}$ & cilíndrico-cônica & 500 & 4 \\
\hline 21632 & $22^{\circ} 08^{\prime} 01,8^{\prime \prime}$ & $039^{\circ} 37^{\prime} 30,8^{\prime \prime}$ & $03 / 12 / 2002$ & vertical & $\begin{array}{r}1.400- \\
2.000 \mathrm{~m}\end{array}$ & cilíndrico-cônica & 200 & 3 \\
\hline 21633 & $21^{\circ} 57,12^{\prime}$ & $039^{\circ} 37,32^{\prime}$ & $16 / 06 / 2003$ & vertical & $2.000 \mathrm{~m}$ & cilíndrico-cônica & 500 & 1 \\
\hline 21634 & $22^{\circ} 28^{\prime} 40,4^{\prime \prime}$ & $039^{\circ} 55^{\prime} 44,1^{\prime \prime}$ & $06 / 12 / 2002$ & vertical & $700-1.200 \mathrm{~m}$ & cilíndrico-cônica & 200 & 2 \\
\hline 21890 & $22^{\circ} 32^{\prime} 50,0^{\prime \prime}$ & $040^{\circ} 04^{\prime} 09,9^{\prime \prime}$ & $06 / 11 / 2001$ & oblíquo & $1.000 \mathrm{~m}$ & cilíndrico-cônica & 500 & 1 \\
\hline 21892 & $21^{\circ} 57^{\prime} 10,5^{\prime \prime}$ & $039^{\circ} 43^{\prime} 33,3^{\prime \prime}$ & 09/10/2001 & oblíquo & $1.000 \mathrm{~m}$ & cilíndrico-cônica & 500 & 7 \\
\hline 21894 & $21^{\circ} 53^{\prime} 10,4^{\prime \prime}$ & $039^{\circ} 45^{\prime} 49,9^{\prime \prime}$ & $10 / 10 / 2001$ & oblíquo & $1.000 \mathrm{~m}$ & cilíndrico-cônica & 500 & 41 \\
\hline 22205 & $21^{\circ} 53^{\prime} 10,4^{\prime \prime}$ & $039^{\circ} 45^{\prime} 49,9^{\prime \prime}$ & $10 / 10 / 2001$ & oblíquo & $1.000 \mathrm{~m}$ & cilíndrico-cônica & 500 & 70 \\
\hline 22210 & $21^{\circ} 58^{\prime} 31,0^{\prime \prime}$ & $039^{\circ} 50^{\prime} 29,7^{\prime \prime}$ & $10 / 10 / 2001$ & oblíquo & $1.000 \mathrm{~m}$ & cilíndrico-cônica & 500 & 35 \\
\hline 22211 & $22^{\circ} 06^{\prime} 52,3^{\prime \prime}$ & $039^{\circ} 48^{\prime} 46,2^{\prime \prime}$ & $11 / 05 / 2002$ & oblíquo & $1.000 \mathrm{~m}$ & cilíndrico-cônica & 500 & 7 \\
\hline 22216 & $21^{\circ} 53^{\prime} 10,4^{\prime \prime}$ & $039^{\circ} 45^{\prime} 49,9^{\prime \prime}$ & $10 / 10 / 2001$ & oblíquo & $1.000 \mathrm{~m}$ & cilíndrico-cônica & 500 & 30 \\
\hline 22219 & $21^{\circ} 57^{\prime} 10,5^{\prime \prime}$ & $039^{\circ} 43^{\prime} 33,3^{\prime \prime}$ & $09 / 10 / 2001$ & oblíquo & $1.000 \mathrm{~m}$ & cilíndrico-cônica & 500 & 50 \\
\hline 22229 & $21^{\circ} 54 ' 36,5^{\prime \prime}$ & $039^{\circ} 45^{\prime} 20,0^{\prime \prime}$ & $10 / 10 / 2001$ & oblíquo & $1.000 \mathrm{~m}$ & cilíndrico-cônica & 500 & 26 \\
\hline
\end{tabular}

Referências: Bond \& Tighe, 1974; Olivar \& Fortuño, 1991; Miya, 1994; Watson, 1996a; Bonecker et al., 2006a; Richards, 2006a; Fahay, 2007. 


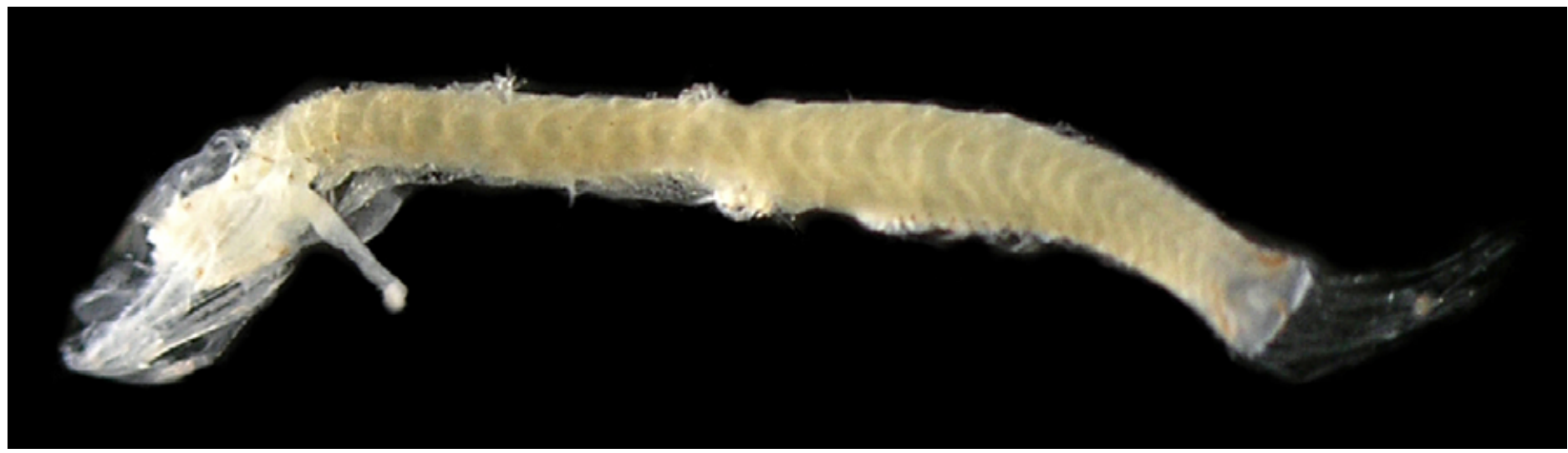

Figura 18 - A: - Cyclothone pseudopallida. DZUFRJ 1335; Flexão; CP 7,6 mm.

\section{Cyclothone pseudopallida Mukhacheva, 1964}

As larvas com menos de 7,5 mm CP apresentam série descontínua de pigmentos na região dorsal do corpo. Nas larvas maiores a série dorsal de pigmentos é contínua. Há outra série de pigmentos na região ventral e na porção anterior do corpo. Possui um pigmento bem marcado na região ventral do pedúnculo caudal, na base da nadadeira caudal e na vesícula gasosa. O número de miômeros varia entre 29 e 34 . Os espécimes que estão no estágio de transformação; ou seja, quando os fotóforos começam a se desenvolver, podem ser separados pelo número de rastros branquiais do primeiro arco (4-7 + 11-14) e pela pigmentação da membrana (meninge) que cobre a região dorsal do cérebro. Essa membrana permanece intacta, mesmo quando os espécimes estão muito danificados. No caso de $C$. pseudopallida, a meninge possui pigmentos

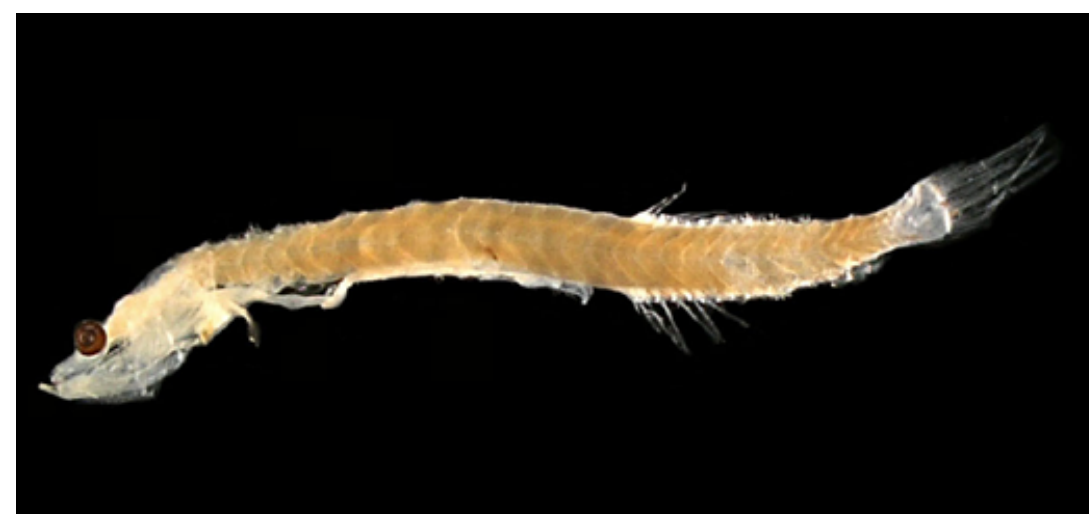

Figura 18 - B: DZUFRJ 21886; Pós-flexão; CP 9,9 mm.

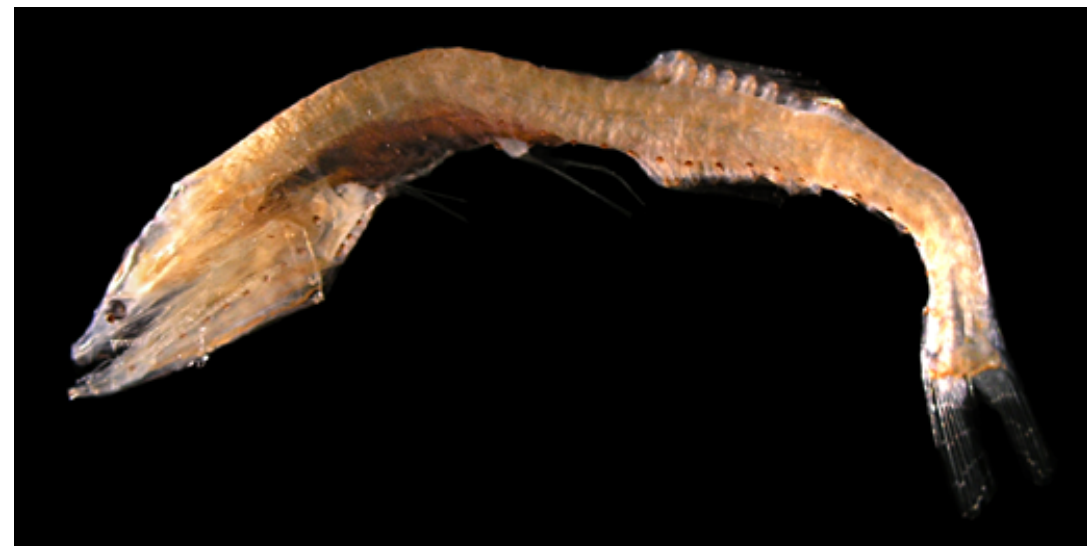

Figura 18 - C: DZUFRJ 22224; Transformação; CP 18,2 mm. escuros na lateral do cérebro formando um "V", com o vértice voltado para trás. Na membrana entre o "V" existem mais de 30 melanóforos, tipicamente entre 40 ou 50. Esses melanóforos podem estar contraídos em exemplares coletados durante o dia ou dilatados quando coletados durante a noite.

Tamanho: flexão: 6,7-7,6 mm; pós-flexão: 9,4-16,0 mm; transformação: 18,0-18,2 mm; juvenil: 25,5-29,5 mm; adulto: 61,0-68,0 mm.

Habitat: espécie marinha, mesopelágica e batipelágica, ocorre em águas tropicais e subtropicais em profundidades entre $300 \mathrm{e}$ $1.400 \mathrm{~m}$. 


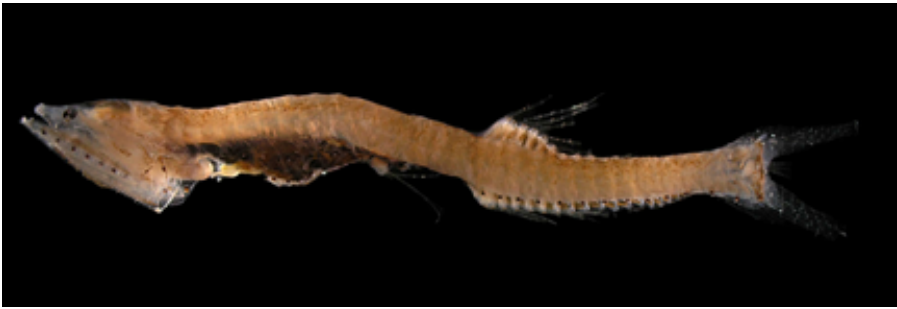

Figura 18 - D: DZUFRJ 22212; Juvenil; CP 29,0 mm.

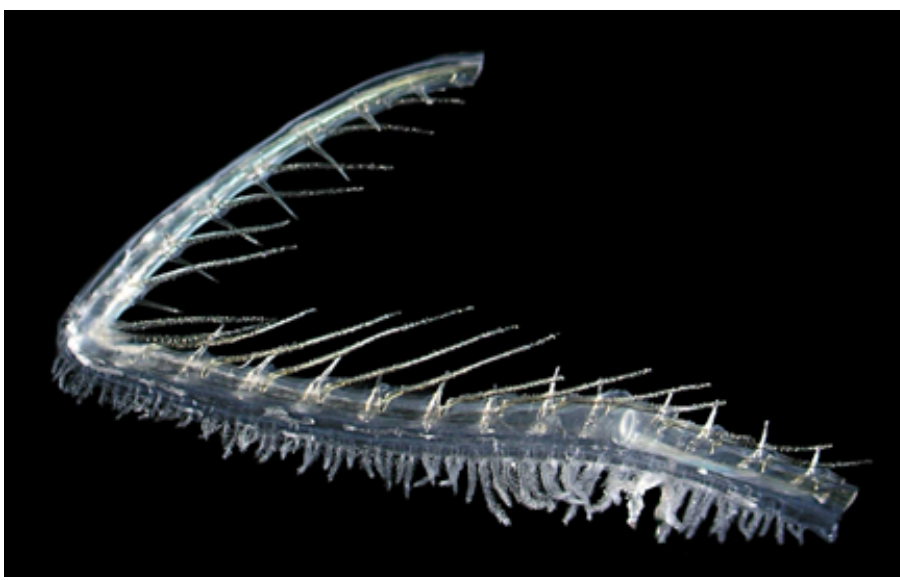

Figura 18 - F: Rastros branquiais do primeiro arco.

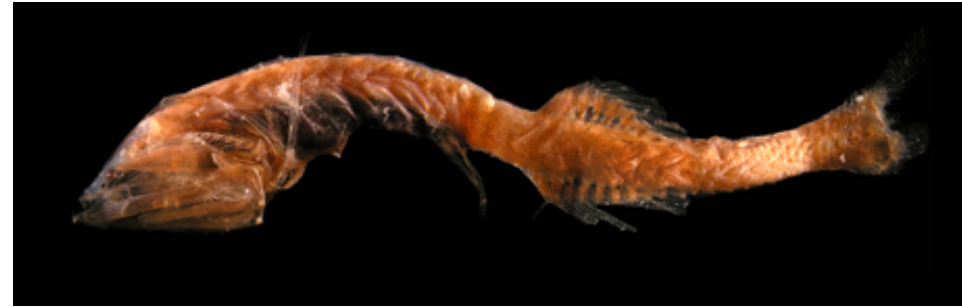

Figura 18 - E: DZUFRJ 22204; Adulto; CP 65,0 mm.

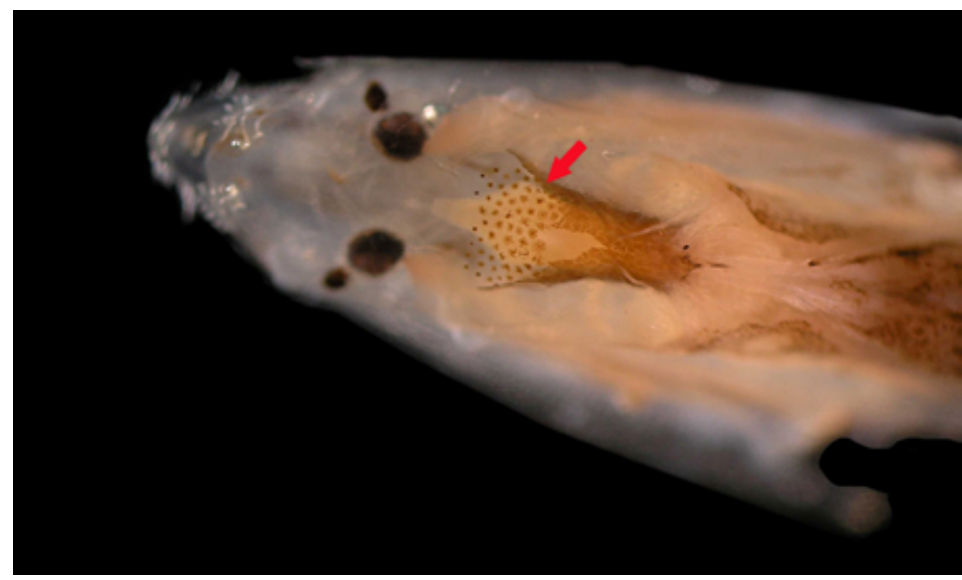

Figura 18 - G: Detalhe da cabeça com melanóforos na meninge entre 0 " $\mathrm{V}$ ".

\section{Georreferenciamento}

\begin{tabular}{|c|c|c|c|c|c|c|c|c|}
\hline DZUFRJ & Latitude (S) & Longitude (W) & Data & $\begin{array}{l}\text { Tipo de } \\
\text { arrasto }\end{array}$ & $\begin{array}{l}\text { Profundidade } \\
\text { de coleta }\end{array}$ & Rede & $\begin{array}{c}\text { Malha } \\
(\mu \mathrm{m})\end{array}$ & $\begin{array}{l}N^{\circ} \text {. de } \\
\text { inds. }\end{array}$ \\
\hline 1335 & $22^{\circ} 06^{\prime} 37,8^{\prime \prime}$ & $039^{\circ} 49^{\prime} 44,8^{\prime \prime}$ & $10 / 05 / 2002$ & oblíquo & até a termoclina & bongô & 330 & 2 \\
\hline 21574 & $22^{\circ} 31^{\prime} 40,9^{\prime \prime}$ & $040^{\circ} 02^{\prime} 39,6^{\prime \prime}$ & 07/11/2001 & oblíquo & $1.000 \mathrm{~m}$ & cilíndrico-cônica & 500 & 5 \\
\hline 21577 & $22^{\circ} 32^{\prime} 50,0^{\prime \prime}$ & $040^{\circ} 04^{\prime} 09,9^{\prime \prime}$ & 06/11/2001 & oblíquo & $1.000 \mathrm{~m}$ & cilíndrico-cônica & 500 & 12 \\
\hline 21625 & $22^{\circ} 38^{\prime} 29,0^{\prime \prime}$ & $040^{\circ} 17^{\prime} 40,0^{\prime \prime}$ & $18 / 05 / 2002$ & oblíquo & $800 \mathrm{~m}$ & cilíndrico-cônica & 500 & 4 \\
\hline 21626 & $21^{\circ} 58^{\prime} 31,0^{\prime \prime}$ & $039^{\circ} 50^{\prime} 29,7^{\prime \prime}$ & $10 / 10 / 2001$ & oblíquo & $1.000 \mathrm{~m}$ & cilíndrico-cônica & 500 & 1 \\
\hline 21635 & $21^{\circ} 57,12^{\prime}$ & $039^{\circ} 37,32^{\prime}$ & $18 / 06 / 2003$ & vertical & $500-980 m$ & cilíndrico-cônica & 500 & 1 \\
\hline 21881 & $21^{\circ} 54^{\prime} 36,5^{\prime \prime}$ & $039^{\circ} 45^{\prime} 20,0^{\prime \prime}$ & 10/10/2001 & oblíquo & $1.000 \mathrm{~m}$ & cilíndrico-cônica & 500 & 2 \\
\hline 21883 & $21^{\circ} 53^{\prime} 10,4^{\prime \prime}$ & $039^{\circ} 45^{\prime} 49,9^{\prime \prime}$ & 10/10/2001 & oblíquo & $1.000 \mathrm{~m}$ & cilíndrico-cônica & 500 & 4 \\
\hline 21885 & $21^{\circ} 57^{\prime} 10,5^{\prime \prime}$ & 03943'33,3" & 09/10/2001 & oblíquo & $1.000 \mathrm{~m}$ & cilíndrico-cônica & 500 & 3 \\
\hline 21886 & $22^{\circ} 32^{\prime} 50,0^{\prime \prime}$ & $040^{\circ} 04^{\prime} 09,9^{\prime \prime}$ & 06/11/2001 & oblíquo & $1.000 \mathrm{~m}$ & cilíndrico-cônica & 500 & 1 \\
\hline 21891 & $22^{\circ} 07^{\prime} 58,8^{\prime \prime}$ & $039^{\circ} 49^{\prime} 08,9^{\prime \prime}$ & $02 / 12 / 2002$ & vertical & $200-1.100 m$ & cilíndrico-cônica & 200 & 3 \\
\hline 22065 & $22^{\circ} 35,12^{\prime}$ & $039^{\circ} 46,24^{\prime}$ & $15 / 06 / 2003$ & vertical & $1.000-2.000 \mathrm{~m}$ & cilíndrico-cônica & 500 & 1 \\
\hline 22204 & $21^{\circ} 53^{\prime} 10,4^{\prime \prime}$ & $039^{\circ} 45^{\prime} 49,9^{\prime \prime}$ & 10/10/2001 & oblíquo & $1.000 \mathrm{~m}$ & cilíndrico-cônica & 500 & 16 \\
\hline 22212 & $21^{\circ} 58^{\prime} 31,0^{\prime \prime}$ & $039^{\circ} 50^{\prime} 29,7^{\prime \prime}$ & 10/10/2001 & oblíquo & $1.000 \mathrm{~m}$ & cilíndrico-cônica & 500 & 4 \\
\hline 22217 & $22^{\circ} 28^{\prime} 40,4^{\prime \prime}$ & $039^{\circ} 55^{\prime} 44,1^{\prime \prime}$ & $06 / 12 / 2002$ & vertical & $700-1.200 m$ & cilíndrico-cônica & 200 & 8 \\
\hline 22222 & $21^{\circ} 57^{\prime} 10,5^{\prime \prime}$ & $039^{\circ} 43^{\prime} 33,3^{\prime \prime}$ & 09/10/2001 & oblíquo & $1.000 \mathrm{~m}$ & cilíndrico-cônica & 500 & 17 \\
\hline 22224 & $21^{\circ} 54^{\prime} 36,5^{\prime \prime}$ & $039^{\circ} 45^{\prime} 20,0^{\prime \prime}$ & 09/10/2001 & oblíquo & $1.000 \mathrm{~m}$ & cilíndrico-cônica & 500 & 1 \\
\hline 22225 & $21^{\circ} 53^{\prime} 10,4^{\prime \prime}$ & $039^{\circ} 45^{\prime} 49,9^{\prime \prime}$ & 10/10/2001 & oblíquo & $1.000 \mathrm{~m}$ & cilíndrico-cônica & 500 & 26 \\
\hline 23893 & $22^{\circ} 02^{\prime} 35,2^{\prime \prime}$ & $039^{\circ} 43^{\prime} 18,2^{\prime \prime}$ & 04/12/2002 & horizontal & superfície & nêuston & 500 & 2 \\
\hline
\end{tabular}

Referências: Bond \& Tighe, 1974; Olivar \& Fortuño, 1991; Miya, 1994; Watson, 1996a; Bonecker et al., 2006a; Richards, 2006a; Fahay, 2007. 


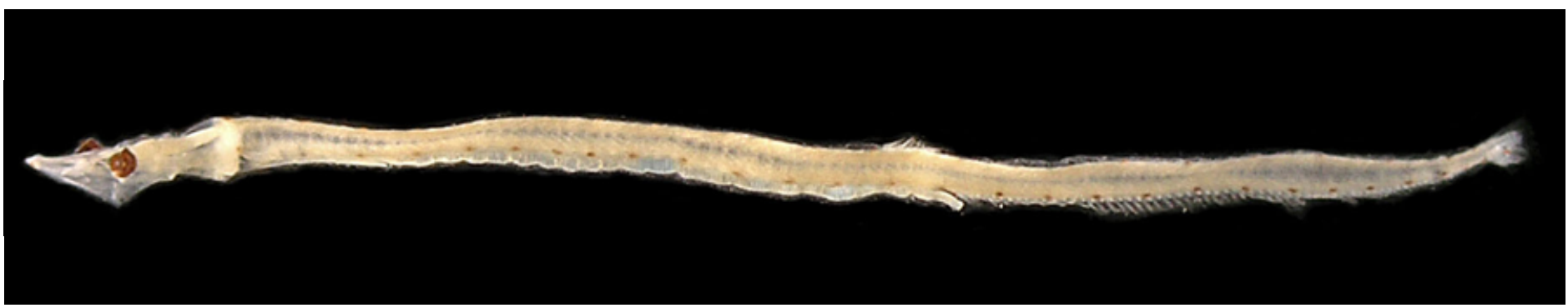

Figura 19 - A: Diplophos taenia. DZUFRJ 1348; Flexão; CP 21,0 mm.

\section{Diplophos taenia Günther, 1873}

Possui o corpo muito alongado (91-95 miômeros) e estreito, com uma série de pigmentos nas regiões dorsal e ventral, desde a cabeça até o pedúnculo caudal. Apresenta de dois a três me-

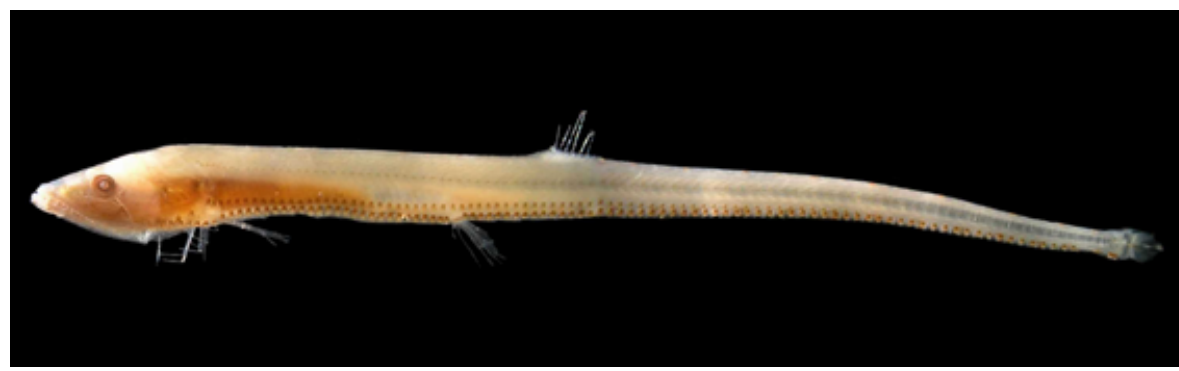

Figura 19 - B: DZUFRJ 1273; Transformação; CP 44,5 mm. lanóforos na região ventral da cabeça.

Tamanho: flexão: 20,2-21,0 mm; transformação: 44,5 mm.

Habitat: espécie marinha, mesopelágica, ocorre em águas tropicais entre 300 e $800 \mathrm{~m}$ de profundidade durante o dia. A noite pode ser encontrada nos primeiros $100 \mathrm{~m}$.

\section{Georreferenciamento}

\begin{tabular}{|c|c|c|c|c|c|c|c|c|}
\hline DZUFRJ & Latitude (S) & Longitude (W) & Data & $\begin{array}{l}\text { Tipo de } \\
\text { arrasto }\end{array}$ & $\begin{array}{l}\text { Profundidade } \\
\text { de coleta }\end{array}$ & Rede & $\begin{array}{l}\text { Malha } \\
(\mu \mathrm{m})\end{array}$ & $\begin{array}{l}N^{\circ} \text {. de } \\
\text { inds. }\end{array}$ \\
\hline 1273 & $22^{\circ} 06^{\prime} 37,8^{\prime \prime}$ & $039^{\circ} 49^{\prime} 44,8^{\prime \prime}$ & $10 / 05 / 2002$ & oblíquo & até a termoclina & bongô & 500 & 1 \\
\hline 1334 & $22^{\circ} 06^{\prime} 37,8^{\prime \prime}$ & $039^{\circ} 49^{\prime} 44,8^{\prime \prime}$ & $10 / 05 / 2002$ & oblíquo & até a termoclina & bongô & 330 & 1 \\
\hline 1348 & $22^{\circ} 06^{\prime} 52,3^{\prime \prime}$ & $039^{\circ} 48^{\prime} 46,2^{\prime \prime}$ & $11 / 05 / 2002$ & oblíquo & até a termoclina & bongô & 330 & 1 \\
\hline
\end{tabular}

Referências: Watson, 1996a; Bonecker et al., 2006a. 


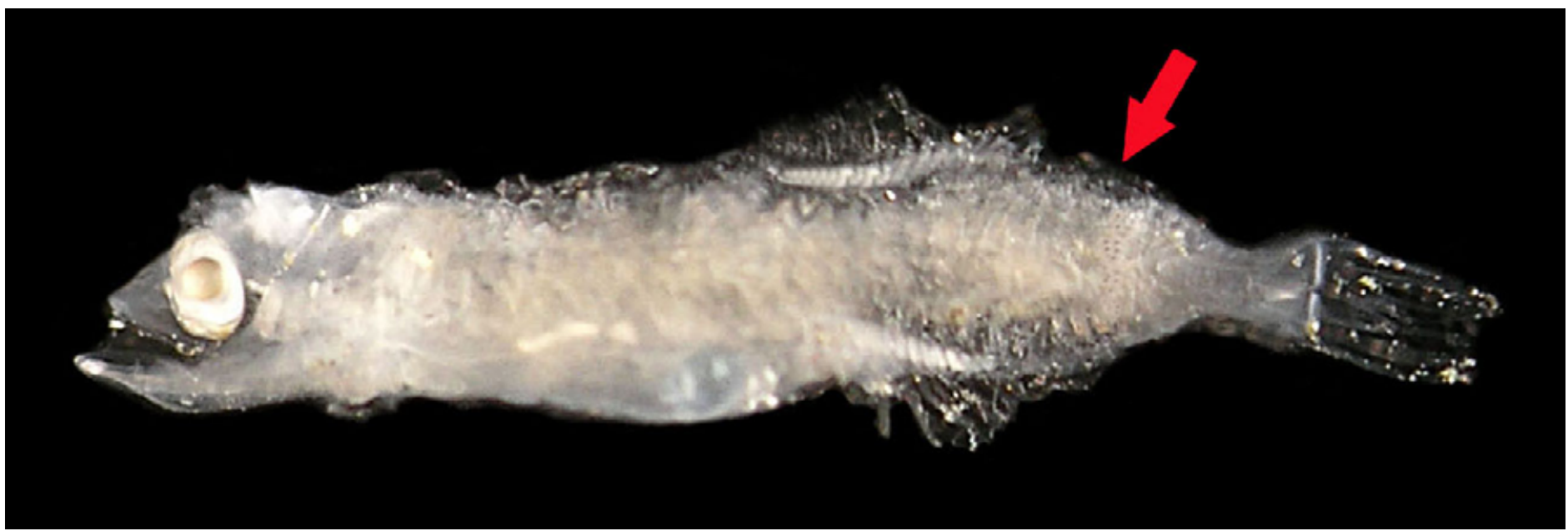

Figura 20: Margrethia obtusirostra. DZUFRJ 5541; Flexão; CP 5,5 mm.

\section{Margrethia obtusirostra Jespersen \& Täning, 1919}

Possui o corpo mais alto e menos alongado (34 miômeros) que os representantes dos outros gêneros dessa família. Os olhos são ovais nas larvas menores, ficando redondos à medida que a larva cresce. As origens das nadadeiras dorsal e anal estão aproximadamente no mesmo nível. Presença de nadadeira adiposa. As larvas em estágio de flexão possuem uma faixa vertical de pigmentos próximo ao pedúnculo caudal.

Tamanho: flexão: 5,5 mm.

Habitat: espécie marinha, mesopelágica e batipelágica, ocorre em águas tropicais e subtropicais em profundidades entre 100 e $600 \mathrm{~m}$.

\section{Georreferenciamento}

\begin{tabular}{|c|c|c|c|c|c|c|c|c|}
\hline DZUFRJ & Latitude (S) & Longitude (W) & Data & $\begin{array}{c}\text { Tipo de } \\
\text { arrasto }\end{array}$ & $\begin{array}{c}\text { Profundidade } \\
\text { de coleta }\end{array}$ & Rede & $\begin{array}{c}\text { Malha } \\
\left.\text { ( } \boldsymbol{\mu m}^{\mathbf{N}}\right)\end{array}$ & $\begin{array}{c}\mathbf{N} \text {. de } \\
\text { inds. }\end{array}$ \\
\hline 5541 & $22^{\circ} 32^{\prime} 50,0^{\prime \prime}$ & $040^{\circ} 04^{\prime} 09,9^{\prime \prime}$ & $6 / 11 / 2001$ & oblíquo & $1.000 \mathrm{~m}$ & cilíndrico-cônica & 500 & 1 \\
\hline
\end{tabular}

Referências: Watson, 1996a; Richards, 2006a; Fahay, 2007. 


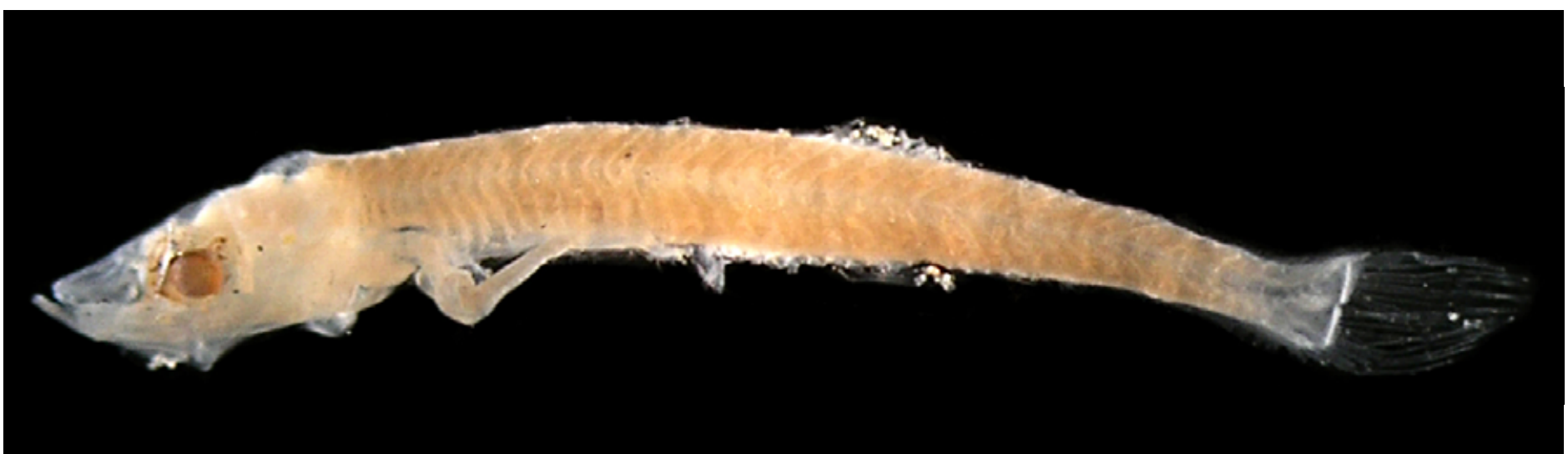

Figura 21 - A - Gonostoma elongatum. DZUFRJ 5411; Flexão, CP 7,1 mm.

\section{Gonostoma elongatum Günther, 1878}

Possui olhos elípticos e intestino que alcança menos da metade do corpo. Nos estágios de pré-flexão e de flexão não apresenta nenhum pigmento. Durante a pós-flexão tem fotóforos na região ventral do intestino e um único fotóforo próximo ao opérculo. Possui aproximadamente 39 miômeros. Exemplares em transformação e juvenis podem ser separados da outra espécie semelhante (Gonostoma atlanticum) pela presença de nadadeira adiposa.

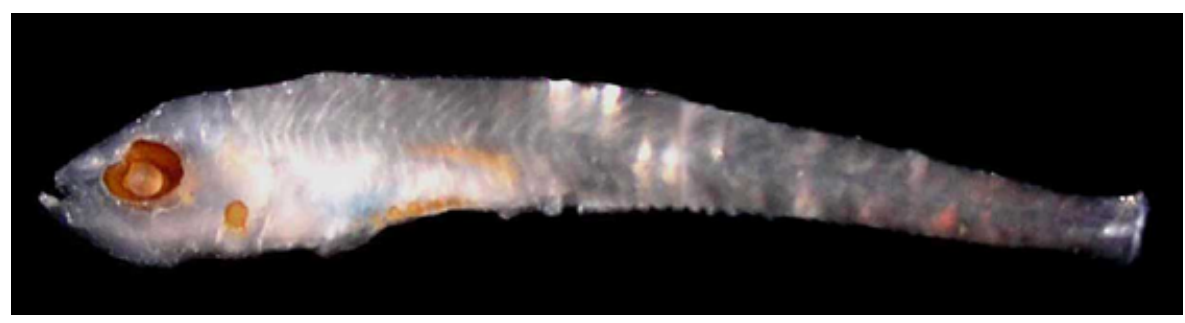

Figura 21 - B: DZUFRJ 22137; Pós-flexão; CP 11,5 mm.

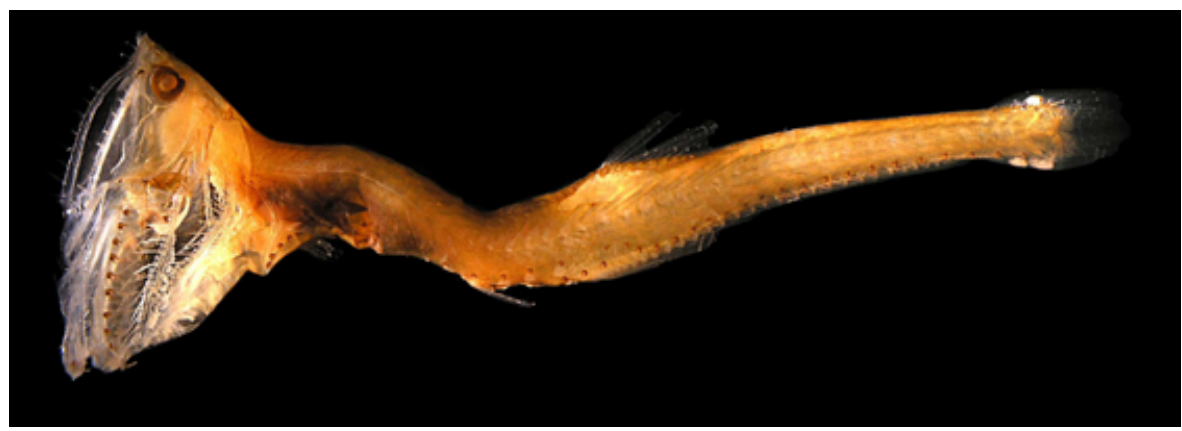

Figura 21 - C: DZUFRJ 7536; Juvenil; CP 50,0 mm.

Tamanho: pré-flexão: 4,6-4,8 mm; flexão: 5,0-9,9 mm; pós-flexão: 11,5-11,7 mm; juvenil: 50,0 mm.

Habitat: espécie marinha, mesopelágica e batipelágica, ocorre em águas tropicais e subtropicais em profundidades entre 500 e $1.200 \mathrm{~m}$. A noite pode ser encontrada entre 25 e $600 \mathrm{~m}$ de profundidade.

\section{Georreferenciamento}

\begin{tabular}{|c|c|c|c|c|c|c|c|c|}
\hline DZUFR & Latitude (S) & Longitude (W) & Data & $\begin{array}{c}\text { Tipo de } \\
\text { arrasto }\end{array}$ & $\begin{array}{c}\text { Profundidade } \\
\text { de coleta }\end{array}$ & Rede & $\begin{array}{c}\text { Malha } \\
(\boldsymbol{\mu m})\end{array}$ & $\begin{array}{c}\mathbf{N}^{\circ} \text {. de } \\
\text { inds. }\end{array}$ \\
\hline 5408 & $22^{\circ} 31^{\prime} 40,9^{\prime \prime}$ & $040^{\circ} 02^{\prime} 39,6^{\prime \prime}$ & $7 / 11 / 2001$ & oblíquo & $1.000 \mathrm{~m}$ & cilíndrico-cônica & 500 & 4 \\
\hline 5409 & $22^{\circ} 32^{\prime} 50,0^{\prime \prime}$ & $040^{\circ} 04^{\prime} 09,9^{\prime \prime}$ & $6 / 11 / 2001$ & oblíquo & $1.000 \mathrm{~m}$ & cilíndrico-cônica & 500 & 3 \\
\hline 5410 & $22^{\circ} 31^{\prime} 58,9^{\prime \prime}$ & $040^{\circ} 02^{\prime} 53,4^{\prime \prime}$ & $7 / 11 / 2001$ & oblíquo & $1.000 \mathrm{~m}$ & cilíndrico-cônica & 500 & 1 \\
\hline 5411 & $22^{\circ} 31^{\prime} 58,9^{\prime \prime}$ & $040^{\circ} 02^{\prime} 53,4^{\prime \prime}$ & $7 / 11 / 2001$ & oblíquo & $1.000 \mathrm{~m}$ & cilíndrico-cônica & 500 & 1 \\
\hline 5412 & $22^{\circ} 31^{\prime} 40,9^{\prime \prime}$ & $040^{\circ} 02^{\prime} 39,6^{\prime \prime}$ & $7 / 11 / 2001$ & oblíquo & $1.000 \mathrm{~m}$ & cilíndrico-cônica & 500 & 3 \\
\hline 5415 & $22^{\circ} 32^{\prime} 49,0^{\prime \prime}$ & $040^{\circ} 04^{\prime} 20,9^{\prime \prime}$ & $7 / 11 / 2001$ & oblíquo & $1.000 \mathrm{~m}$ & cilíndrico-cônica & 500 & 2 \\
\hline 5531 & $22^{\circ} 32^{\prime} 49,0^{\prime \prime}$ & $040^{\circ} 04^{\prime} 20,9^{\prime \prime}$ & $7 / 11 / 2001$ & oblíquo & $1.000 \mathrm{~m}$ & cilíndrico-cônica & 500 & 6 \\
\hline 5553 & $22^{\circ} 32^{\prime} 50,0^{\prime \prime}$ & $040^{\circ} \mathbf{0}^{\prime} 09,9^{\prime \prime}$ & $6 / 11 / 2001$ & oblíquo & $1.000 \mathrm{~m}$ & cilíndrico-cônica & 500 & 2 \\
\hline
\end{tabular}




\begin{tabular}{|c|c|c|c|c|c|c|c|c|}
\hline DZUFRJ & Latitude (S) & Longitude (W) & Data & $\begin{array}{l}\text { Tipo de } \\
\text { arrasto }\end{array}$ & $\begin{array}{l}\text { Profundidade } \\
\text { de coleta }\end{array}$ & Rede & $\begin{array}{l}\text { Malha } \\
(\mu \mathrm{m})\end{array}$ & $\begin{array}{l}N^{\circ} \text {. de } \\
\text { inds. }\end{array}$ \\
\hline 7434 & $21^{\circ} 54^{\prime} 36,5^{\prime \prime}$ & $039^{\circ} 45^{\prime} 20,0^{\prime \prime}$ & $10 / 10 / 2001$ & oblíquo & $1.000 \mathrm{~m}$ & cilíndrico-cônica & 500 & 6 \\
\hline 7438 & $21^{\circ} 57^{\prime} 10,5^{\prime \prime}$ & $039^{\circ} 43^{\prime} 33,3^{\prime \prime}$ & 09/10/2001 & oblíquo & $1.000 \mathrm{~m}$ & cilíndrico-cônica & 500 & 4 \\
\hline 7441 & $21^{\circ} 53^{\prime} 10,4^{\prime \prime}$ & $039^{\circ} 45^{\prime} 49,9^{\prime \prime}$ & $10 / 10 / 2001$ & oblíquo & $1.000 \mathrm{~m}$ & cilíndrico-cônica & 500 & 4 \\
\hline 7444 & $21^{\circ} 53^{\prime} 10,4^{\prime \prime}$ & $039^{\circ} 45^{\prime} 49,9^{\prime \prime}$ & 10/10/2001 & oblíquo & $1.000 \mathrm{~m}$ & cilíndrico-cônica & 500 & 1 \\
\hline 7536 & $21^{\circ} 57^{\prime} 10,5^{\prime \prime}$ & $039^{\circ} 43^{\prime} 33,3^{\prime \prime}$ & 09/10/2001 & oblíquo & $1.000 \mathrm{~m}$ & cilíndrico-cônica & 500 & 1 \\
\hline 7599 & $21^{\circ} 58^{\prime} 31,0^{\prime \prime}$ & $039^{\circ} 50^{\prime} 29,7^{\prime \prime}$ & $10 / 10 / 2001$ & oblíquo & $1.000 \mathrm{~m}$ & cilíndrico-cônica & 500 & 5 \\
\hline 7600 & $21^{\circ} 54^{\prime} 36,5^{\prime \prime}$ & $039^{\circ} 45^{\prime} 20,0^{\prime \prime}$ & $09 / 10 / 2001$ & oblíquo & $1.000 \mathrm{~m}$ & cilíndrico-cônica & 500 & 2 \\
\hline 7603 & $21^{\circ} 58^{\prime} 31,0^{\prime \prime}$ & $039^{\circ} 50^{\prime} 29,7^{\prime \prime}$ & $10 / 10 / 2001$ & oblíquo & $1.000 \mathrm{~m}$ & cilíndrico-cônica & 500 & 4 \\
\hline 21610 & $22^{\circ} 32^{\prime} 49,0^{\prime \prime}$ & $040^{\circ} 04^{\prime} 20,9^{\prime \prime}$ & $07 / 11 / 2001$ & oblíquo & $1.000 \mathrm{~m}$ & cilíndrico-cônica & 500 & 8 \\
\hline 22137 & $22^{\circ} 31^{\prime} 40,9^{\prime \prime}$ & $040^{\circ} 02^{\prime} 39,6^{\prime \prime}$ & $07 / 11 / 2001$ & oblíquo & $1.000 \mathrm{~m}$ & cilíndrico-cônica & 500 & 4 \\
\hline
\end{tabular}

Referências: Watson, 1996a; Richards, 2006a; Bonecker et al., 2006a; Fahay, 2007. 


\section{Família Sternoptychidae}

A família Sternoptychidae é marinha e ocorre nos oceanos Atlântico, Índico e Pacífico. Compreende dez gêneros com aproximadamente 67 espécies. Uma das principais características dos indivíduos em transformação é a presença de alguns fotóforos agrupados. A forma do corpo pode variar de alongado a muito alto e comprimido lateralmente.

No Brasil já foram identificadas dez espécies nas fases de larva e adulto. Nesse estudo são contempladas as espécies Argyropelecus aculeatus, Argyropelecus hemigymnus, Argyropelecus sladeni, Maurolicus stehmanni, Sternoptyx sp., Sternoptyx diaphana e Valenciennellus tripunculatus. 


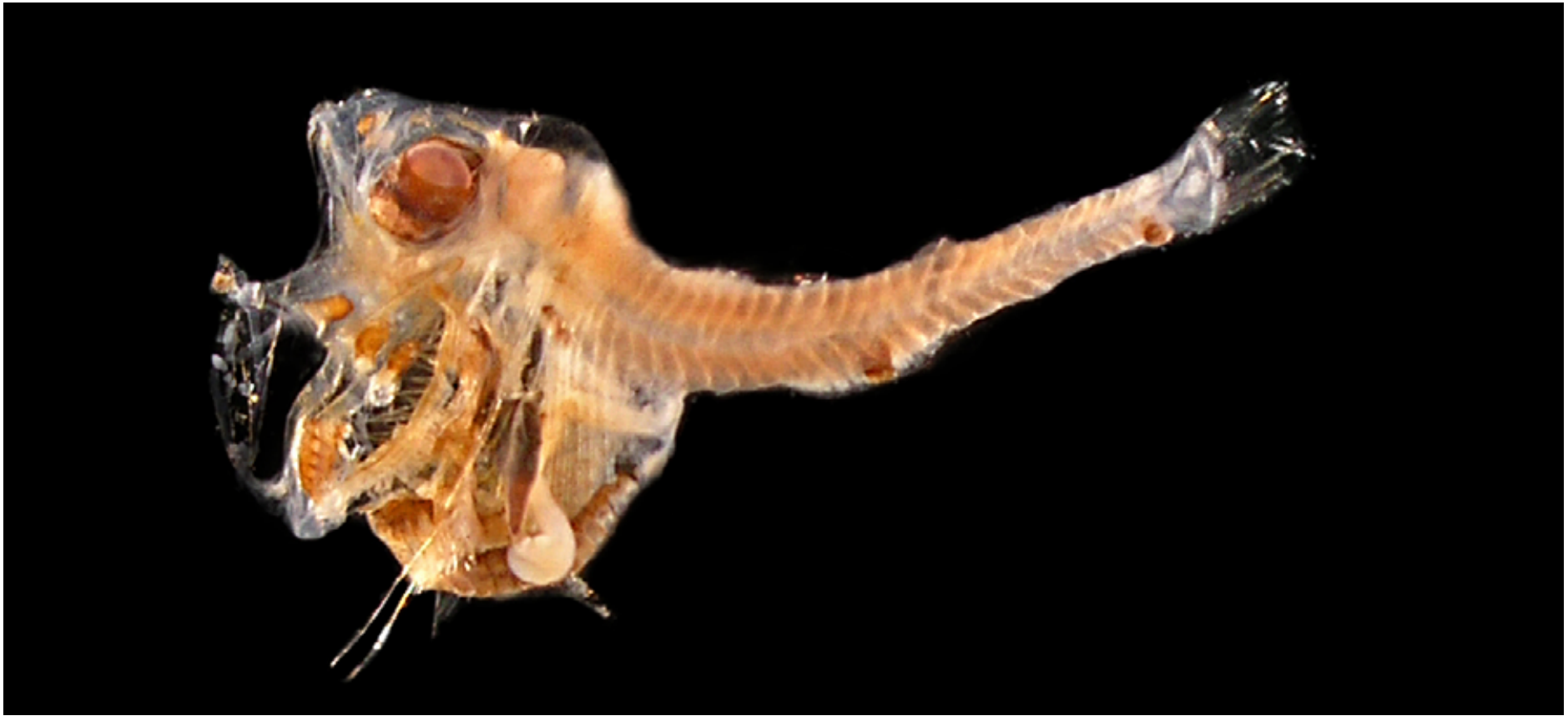

Figura 22 - A: Argyropelecus aculeatus. DZUFRJ 21870; Flexão; CP 8,0 mm.

\section{Argyropelecus aculeatus Valenciennes, 1850}

A principal característica para separar essa espécie das demais é o espinho pós-abdominal direcionado para trás. O corpo é alto e a pigmentação está mais concentrada na região da cabeça e associada aos grupos de fotóforos. O número de miômeros varia entre 34 e 36.

Tamanho: flexão: 8,0-9,3 mm; transformação: 11,714,0 mm; juvenil: 17,6 mm; adulto: 24,5-33,0 mm.

Habitat: espécie marinha, epi-mesopelágica, ocorre em águas tropicais em profundidades entre 200 e 500 m durante o dia. A noite pode ser encontrada entre 80 e $200 \mathrm{~m}$ de profundidade.

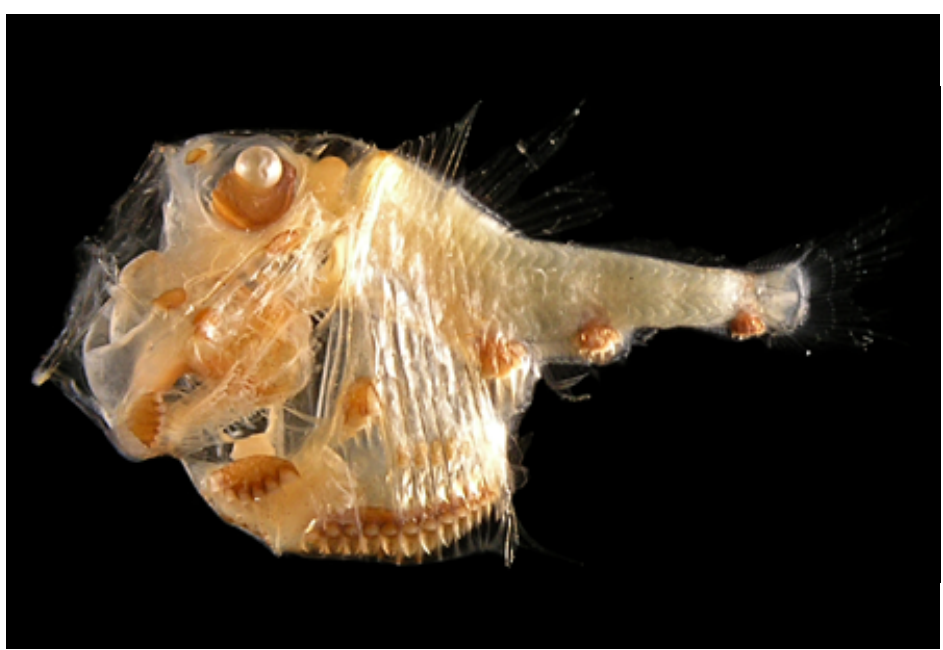

Figura 22 - B: DZUFRJ 1213; Transformação; CP 14,0 mm.

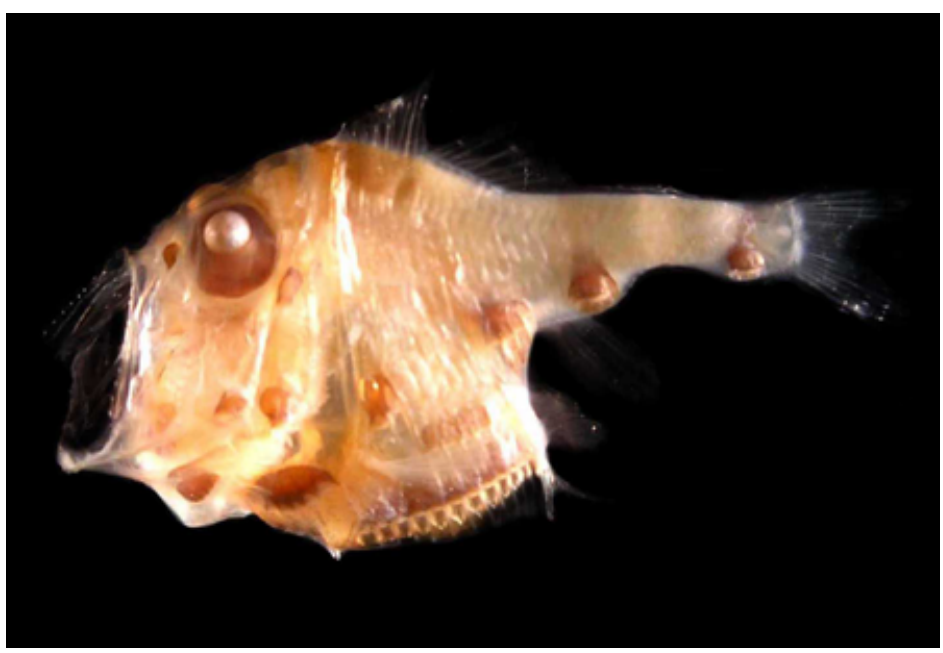

Figura 22 - C: DZUFRJ 19893; Juvenil; CP 17,6 mm. 


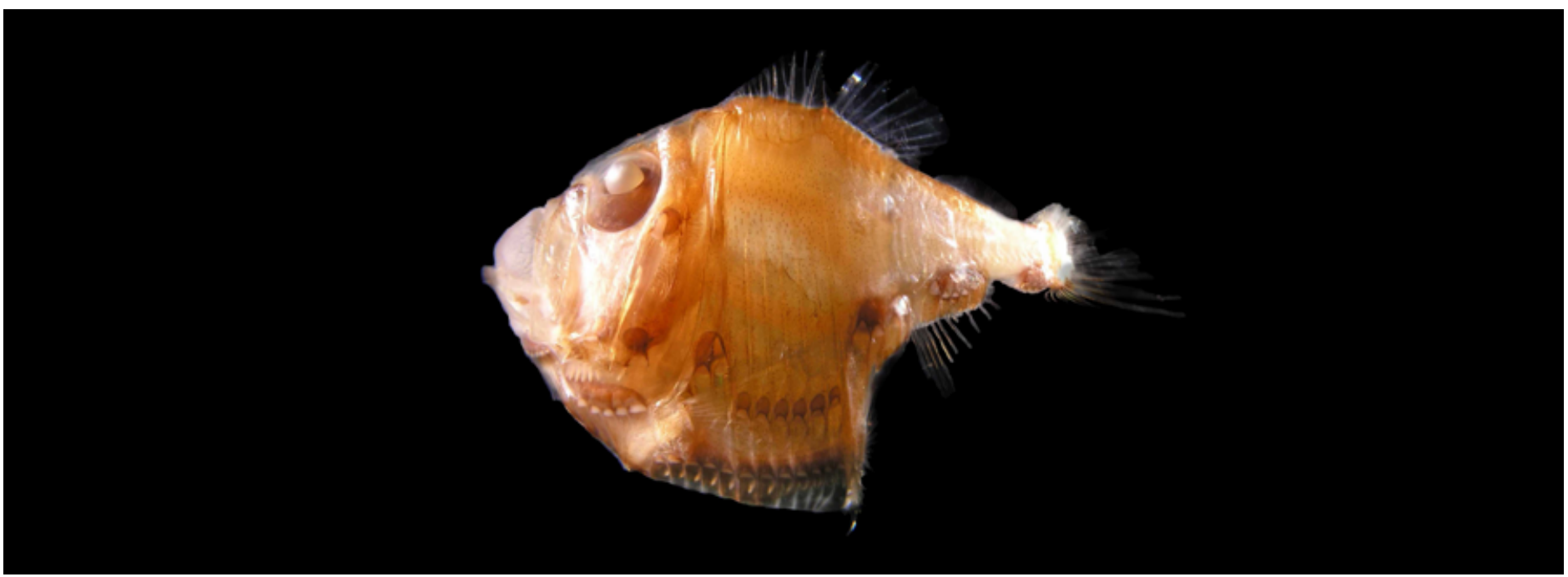

Figura 22 - D: DZUFRJ 19898; Adulto; CP 33,0 mm.

\section{Georreferenciamento}

\begin{tabular}{|c|c|c|c|c|c|c|c|c|}
\hline DZUFR J & Latitude (S) & Longitude (W) & Data & $\begin{array}{c}\text { Tipo de } \\
\text { arrasto }\end{array}$ & $\begin{array}{c}\text { Profundidade } \\
\text { de coleta }\end{array}$ & Rede & $\begin{array}{c}\text { Malha } \\
\text { ( } \boldsymbol{\mu m})\end{array}$ & $\begin{array}{c}\mathbf{N}^{\circ} \text {. de } \\
\text { inds. }\end{array}$ \\
\hline 1213 & $22^{\circ} 02^{\prime} 30,0^{\prime \prime}$ & $039^{\circ} 49^{\prime} 41,2^{\prime \prime}$ & $12 / 05 / 2002$ & oblíquo & $1.000 \mathrm{~m}$ & cilíndrico-cônica & 500 & 1 \\
\hline 1255 & $22^{\circ} 08^{\prime} 17,5^{\prime \prime}$ & $039^{\circ} 46^{\prime} 28,5^{\prime \prime}$ & $11 / 05 / 2002$ & oblíquo & $1.000 \mathrm{~m}$ & cilíndrico-cônica & 500 & 1 \\
\hline 7439 & $21^{\circ} 57^{\prime} 10,5^{\prime \prime}$ & $039^{\circ} 43^{\prime} 33,3^{\prime \prime}$ & $09 / 10 / 2001$ & oblíquo & $1.000 \mathrm{~m}$ & cilíndrico-cônica & 500 & 1 \\
\hline 19893 & $22^{\circ} 32^{\prime} 50,0^{\prime \prime}$ & $040^{\circ} 04^{\prime} 09,9^{\prime \prime}$ & $06 / 11 / 2001$ & oblíquo & $1.000 \mathrm{~m}$ & cilíndrico-cônica & 500 & 1 \\
\hline 19898 & $22^{\circ} 32^{\prime} 49,0^{\prime \prime}$ & $040^{\circ} 04^{\prime} 20,9^{\prime \prime}$ & $07 / 11 / 2001$ & oblíquo & $1.000 \mathrm{~m}$ & cilíndrico-cônica & 500 & 1 \\
\hline 19899 & $22^{\circ} 31^{\prime} 40,9^{\prime \prime}$ & $040^{\circ} 02^{\prime} 39,6^{\prime \prime}$ & $07 / 11 / 2001$ & oblíquo & $1.000 \mathrm{~m}$ & cilíndrico-cônica & 500 & 1 \\
\hline 21870 & $21^{\circ} 54^{\prime} 36,5^{\prime \prime}$ & $039^{\circ} 45^{\prime} 20,0^{\prime \prime}$ & $10 / 10 / 2001$ & oblíquo & $1.000 \mathrm{~m}$ & cilíndrico-cônica & 500 & 2 \\
\hline 21871 & $21^{\circ} 54^{\prime} 36,5^{\prime \prime}$ & $039^{\circ} 45^{\prime} 20,0^{\prime \prime}$ & $09 / 10 / 2001$ & oblíquo & $1.000 \mathrm{~m}$ & cilíndrico-cônica & 500 & 2 \\
\hline 23794 & $22^{\circ} 32^{\prime} 50,0^{\prime \prime}$ & $040^{\circ} 04^{\prime} 09,9^{\prime \prime}$ & $06 / 11 / 2001$ & oblíquo & $1.000 \mathrm{~m}$ & cilíndrico-cônica & 500 & 1 \\
\hline
\end{tabular}

Referências: Richards, 2006b; Fahay, 2007. 


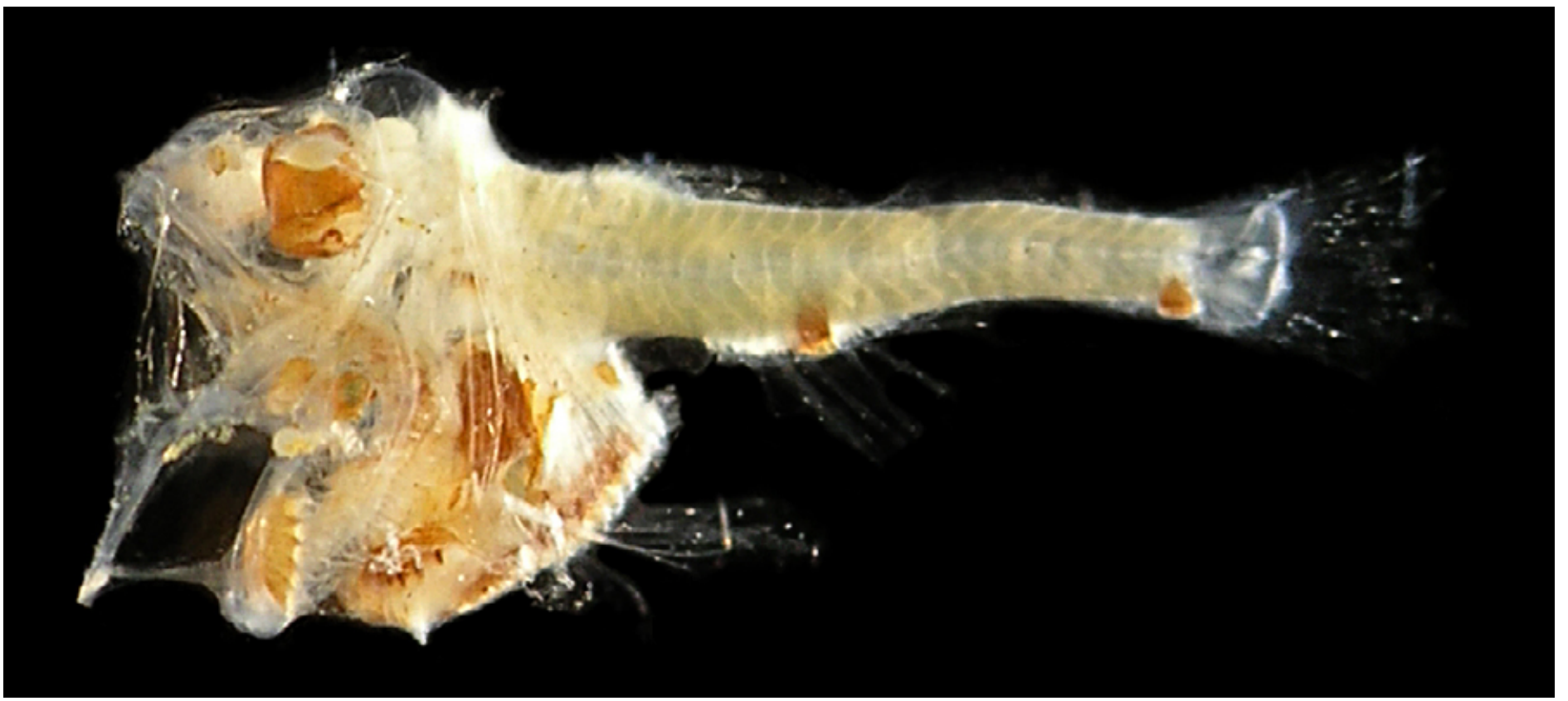

Figura 23 - A: Argyropelecus hemigymnus. DZUFRJ 22511; Pós-flexão; CP 7,5 mm.

\section{Argyropelecus hemigymnus Cocco, 1829}

Nas larvas nos estágios iniciais de desenvolvimento observa-se uma grande distância pré-anal e o olho é ovalado com tecido coroide cônico. Na nadadeira caudal forma-se um espaço no local onde os fotóforos aparecem. A principal característica que separa os juvenis dessa espécie das demais é a presença de uma faixa interrompida de pigmentos na região da linha lateral. O espinho pós-abdominal é um pouco serrilhado. O número de miômeros varia entre 38 e 39.

Tamanho: pós-flexão 7,5 mm; transformação 8,5$18,0 \mathrm{~mm}$; juvenil: 21,2-23,0 mm; adulto $34,0 \mathrm{~mm}$.

Habitat: espécie marinha, epi-mesopelágica, ocorre em águas tropicais e temperadas quentes em profundidades entre 200 e $1.000 \mathrm{~m}$ durante o dia. A noite pode ser encontrada entre 100 e $600 \mathrm{~m}$ de profundidade.

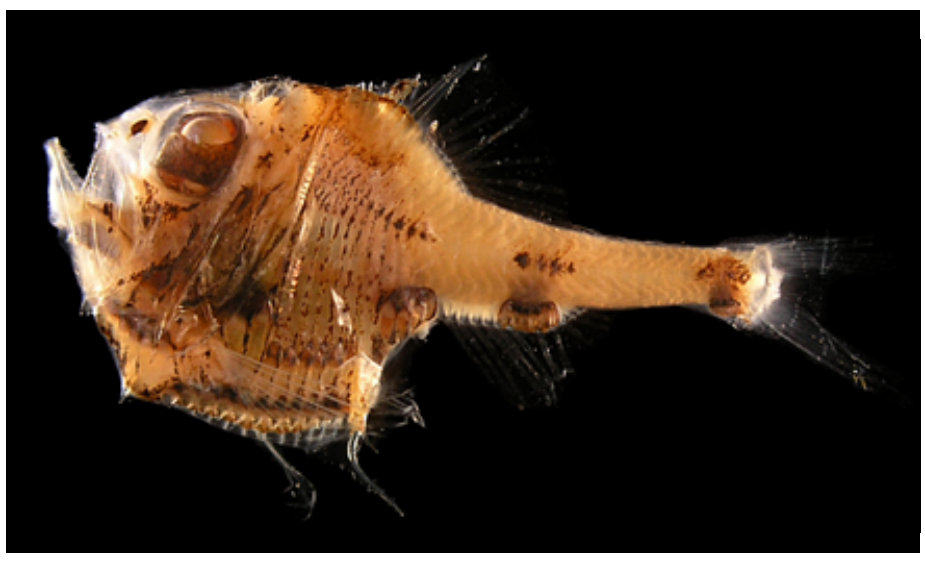

Figura 23 - B: DZUFRJ 21872; Transformação; CP 18,0 mm.

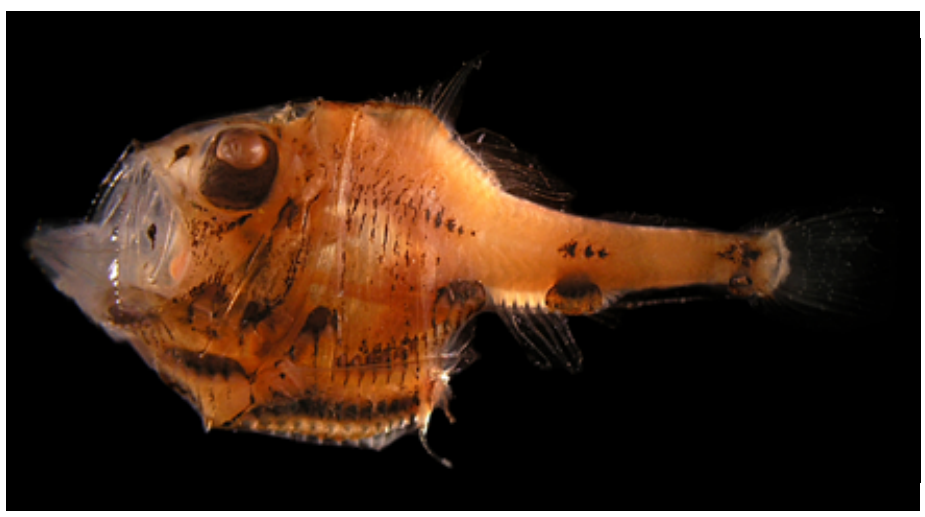

Figura 23 - C: DZUFRJ 21872; Juvenil; CP 23,0 mm. 


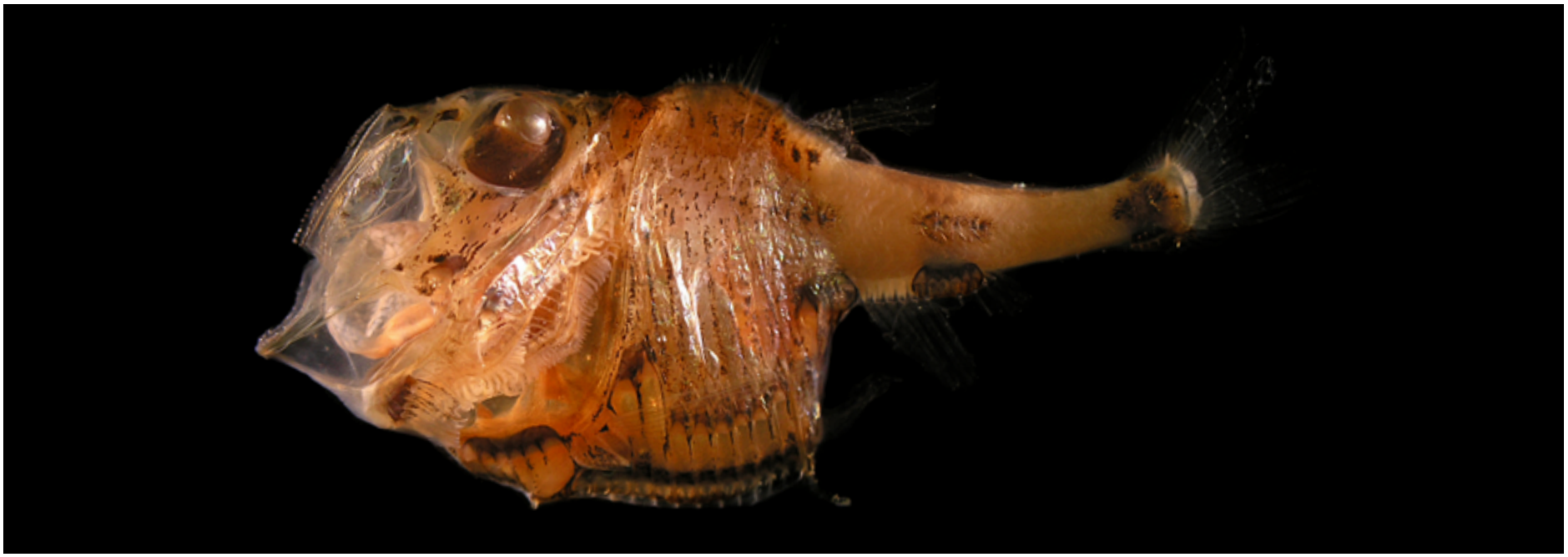

Figura 23 - D: DZUFRJ 21872; Adulto; CP 34,0 mm.

\section{Georreferenciamento}

\begin{tabular}{|c|c|c|c|c|c|c|c|c|}
\hline DZUFRJ & Latitude (S) & Longitude (W) & Data & $\begin{array}{l}\text { Tipo de } \\
\text { arrasto }\end{array}$ & $\begin{array}{l}\text { Profundidade } \\
\text { de coleta }\end{array}$ & Rede & $\begin{array}{l}\text { Malha } \\
(\mu \mathrm{m})\end{array}$ & $\begin{array}{l}N^{\circ} \text {. de } \\
\text { inds. }\end{array}$ \\
\hline 7602 & $21^{\circ} 57^{\prime} 10,5^{\prime \prime}$ & $039^{\circ} 43^{\prime} 33,3^{\prime \prime}$ & 09/10/2001 & oblíquo & $1.000 \mathrm{~m}$ & cilíndrico-cônica & 500 & 3 \\
\hline 7605 & $21^{\circ} 58^{\prime} 31,0^{\prime \prime}$ & $039^{\circ} 50^{\prime} 29,7^{\prime \prime}$ & $11 / 10 / 2001$ & oblíquo & $1.000 \mathrm{~m}$ & cilíndrico-cônica & 500 & 2 \\
\hline 19897 & $22^{\circ} 08^{\prime} 17,5^{\prime \prime}$ & $039^{\circ} 46^{\prime} 28,5^{\prime \prime}$ & $11 / 05 / 2002$ & oblíquo & $1.000 \mathrm{~m}$ & cilíndrico-cônica & 500 & 1 \\
\hline 21866 & $21^{\circ} 57^{\prime} 10,5^{\prime \prime}$ & $039^{\circ} 43^{\prime} 33,3^{\prime \prime}$ & 09/10/2001 & oblíquo & $1.000 \mathrm{~m}$ & cilíndrico-cônica & 500 & 4 \\
\hline 21869 & $21^{\circ} 53^{\prime} 10,4^{\prime \prime}$ & $039^{\circ} 45^{\prime} 49,9^{\prime \prime}$ & 10/10/2001 & oblíquo & $0 \mathrm{~m}$ & cilíndrico-cônica & 500 & 6 \\
\hline 21872 & $21^{\circ} 53^{\prime} 10,4^{\prime \prime}$ & $039^{\circ} 45^{\prime} 49,9^{\prime \prime}$ & $10 / 10 / 2001$ & oblíquo & $1.000 \mathrm{~m}$ & cilíndrico-cônica & 500 & 6 \\
\hline 21896 & $21^{\circ} 54^{\prime} 36,5^{\prime \prime}$ & $039^{\circ} 45^{\prime} 20,0^{\prime \prime}$ & 09/10/2001 & oblíquo & $1.000 \mathrm{~m}$ & cilíndrico-cônica & 500 & 1 \\
\hline 21981 & $21^{\circ} 57^{\prime} 10,5^{\prime \prime}$ & $039^{\circ} 43^{\prime} 33,3^{\prime \prime}$ & 09/10/2001 & oblíquo & $1.000 \mathrm{~m}$ & cilíndrico-cônica & 500 & 1 \\
\hline 22511 & $22^{\circ} 41^{\prime} 54,7^{\prime \prime}$ & $040^{\circ} 14^{\prime} 04,5^{\prime \prime}$ & $16 / 05 / 2002$ & oblíquo & $1.000 \mathrm{~m}$ & cilíndrico-cônica & 500 & 2 \\
\hline 22512 & $21^{\circ} 54^{\prime} 36,5^{\prime \prime}$ & $039^{\circ} 45^{\prime} 20,0^{\prime \prime}$ & $10 / 10 / 2001$ & oblíquo & $1.000 \mathrm{~m}$ & cilíndrico-cônica & 500 & 1 \\
\hline 22513 & $21^{\circ} 58^{\prime} 31,0^{\prime \prime}$ & $039^{\circ} 50^{\prime} 29,7^{\prime \prime}$ & $10 / 10 / 2001$ & oblíquo & $1.000 \mathrm{~m}$ & cilíndrico-cônica & 500 & 1 \\
\hline 22514 & $21^{\circ} 54^{\prime} 36,5^{\prime \prime}$ & $039^{\circ} 45^{\prime} 20,0^{\prime \prime}$ & $10 / 10 / 2001$ & oblíquo & $1.000 \mathrm{~m}$ & cilíndrico-cônica & 500 & 1 \\
\hline 23793 & $22^{\circ} 32^{\prime} 50,0^{\prime \prime}$ & $040^{\circ} 04^{\prime} 09,9^{\prime \prime}$ & $06 / 11 / 2001$ & oblíquo & $1.000 \mathrm{~m}$ & cilíndrico-cônica & 500 & 5 \\
\hline
\end{tabular}

Referências: Richards, 2006b; Fahay, 2007. 


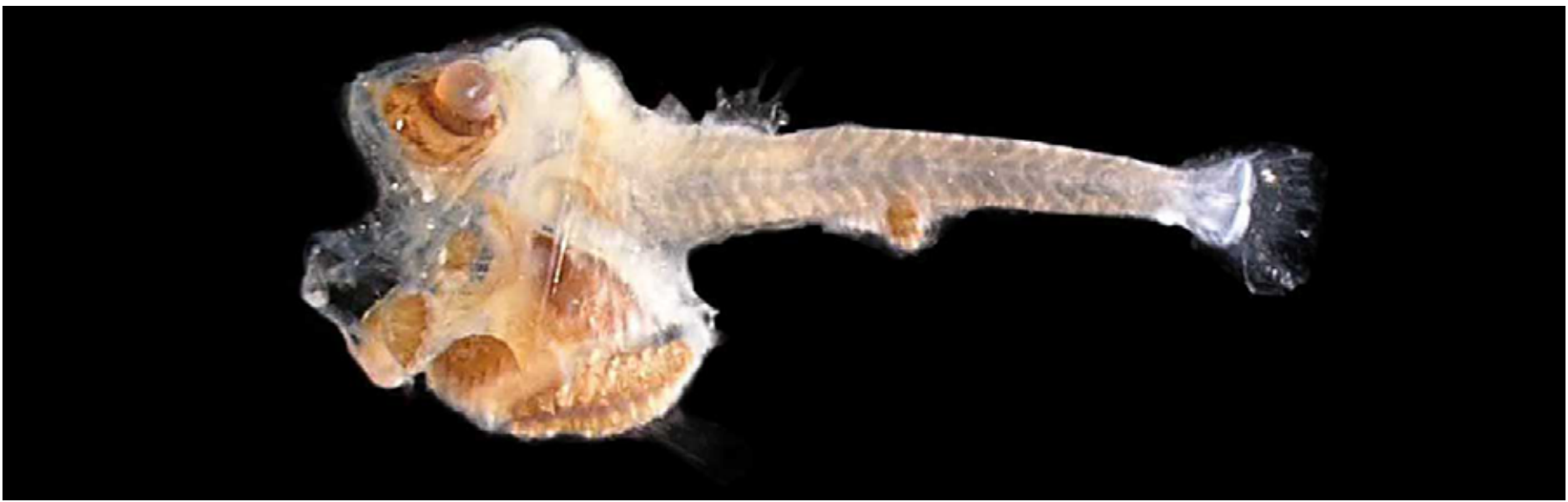

Figura 24 - A: Argyropelecus sladeni. DZUFRJ 19895; Flexão; CP 9,2 mm.

\section{Argyropelecus sladeni Regan, 1908}

Nas larvas nos estágios iniciais de desenvolvimento a distância pré-anal é curta e os olhos são ovalados. As principais características que separam os juvenis dessa espécie das demais são os dois espinhos pós-abdominais que possuem aproximadamente o mesmo tamanho e a presença de pigmentos na linha lateral na região anterior e no pedúnculo caudal. O número de miômeros varia entre 35 e 37.

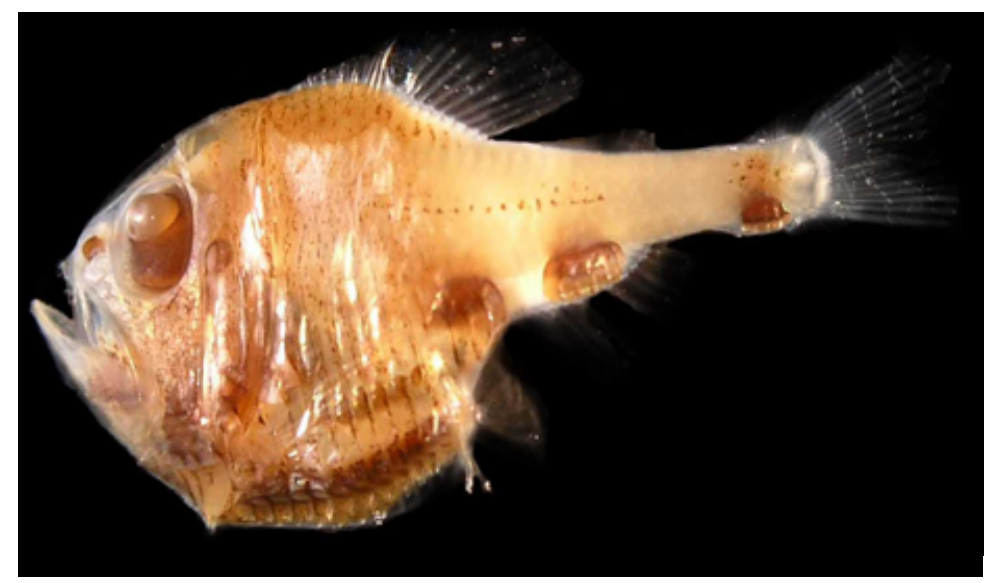

Figura 24 - B: DZUFRJ 19894; Juvenil; CP 18,3 mm.

Tamanho: flexão 7,0 mm; transformação 9,2-11,1 mm; juvenil 17,0-18,3 mm.

Habitat: espécie marinha, epi-mesopelágica, ocorre em águas tropicais e temperadas em profundidades entre 350 e 600 m durante o dia. A noite pode ser encontrada entre 100 e 375 m de profundidade.

\section{Georreferenciamento}

\begin{tabular}{|c|c|c|c|c|c|c|c|c|}
\hline DZUFRJ & Latitude (S) & Longitude (W) & Data & $\begin{array}{l}\text { Tipo de } \\
\text { arrasto }\end{array}$ & $\begin{array}{c}\text { Profundidade } \\
\text { de coleta }\end{array}$ & Rede & $\begin{array}{l}\text { Malha } \\
(\mu \mathrm{m})\end{array}$ & $\begin{array}{l}N^{\circ} \text {. de } \\
\text { inds. }\end{array}$ \\
\hline 482 & $22^{\circ} 41^{\prime} 54,7^{\prime \prime}$ & $040^{\circ} 14^{\prime} 04,5^{\prime \prime}$ & $16 / 05 / 2002$ & oblíquo & $1.000 \mathrm{~m}$ & cilíndrico-cônica & 500 & 1 \\
\hline 7431 & $21^{\circ} 58^{\prime} 31,0^{\prime \prime}$ & $039^{\circ} 50^{\prime 29,7 "}$ & $10 / 10 / 2001$ & oblíquo & $1.000 \mathrm{~m}$ & cilíndrico-cônica & 500 & 1 \\
\hline 7432 & $21^{\circ} 54^{\prime} 36,5^{\prime \prime}$ & $039^{\circ} 45^{\prime} 20,0^{\prime \prime}$ & $10 / 10 / 2001$ & oblíquo & $1.000 \mathrm{~m}$ & cilíndrico-cônica & 500 & 1 \\
\hline 7436 & $21^{\circ} 58^{\prime} 31,0^{\prime \prime}$ & $039^{\circ} 50^{\prime 2} 29,7^{\prime \prime}$ & $10 / 10 / 2001$ & oblíquo & $1.000 \mathrm{~m}$ & cilíndrico-cônica & 500 & 2 \\
\hline 7437 & $21^{\circ} 53^{\prime} 10,4^{\prime \prime}$ & $039^{\circ} 45^{\prime} 49,9^{\prime \prime}$ & $10 / 10 / 2001$ & oblíquo & $1.000 \mathrm{~m}$ & cilíndrico-cônica & 500 & 1 \\
\hline 7442 & $21^{\circ} 53^{\prime} 10,4^{\prime \prime}$ & $039^{\circ} 45^{\prime} 49,9^{\prime \prime}$ & $10 / 10 / 2001$ & oblíquo & $1.000 \mathrm{~m}$ & cilíndrico-cônica & 500 & 1 \\
\hline 7597 & $21^{\circ} 57^{\prime} 10,5^{\prime \prime}$ & $039^{\circ} 43^{\prime} 33,3^{\prime \prime}$ & 09/10/2001 & oblíquo & $1.000 \mathrm{~m}$ & cilíndrico-cônica & 500 & 1 \\
\hline 19894 & $22^{\circ} 32^{\prime} 50,0^{\prime \prime}$ & $040^{\circ} 04^{\prime} 09,9^{\prime \prime}$ & $06 / 11 / 2001$ & oblíquo & $1.000 \mathrm{~m}$ & cilíndrico-cônica & 500 & 2 \\
\hline 19895 & $22^{\circ} 31^{\prime} 40,9^{\prime \prime}$ & $040^{\circ} 02^{\prime} 39,6^{\prime \prime}$ & $07 / 11 / 2001$ & oblíquo & $1.000 \mathrm{~m}$ & cilíndrico-cônica & 500 & 1 \\
\hline 21864 & $22^{\circ} 31^{\prime} 40,9^{\prime \prime}$ & $040^{\circ} 02^{\prime} 39,6^{\prime \prime}$ & $07 / 11 / 2001$ & oblíquo & $1.000 \mathrm{~m}$ & cilíndrico-cônica & 500 & 2 \\
\hline 21865 & $22^{\circ} 32^{\prime} 49,0^{\prime \prime}$ & $040^{\circ} 04^{\prime} 20,9^{\prime \prime}$ & $07 / 11 / 2001$ & oblíquo & $1.000 \mathrm{~m}$ & cilíndrico-cônica & 500 & 1 \\
\hline 21867 & $21^{\circ} 53^{\prime} 10,4^{\prime \prime}$ & $039^{\circ} 45^{\prime} 49,9^{\prime \prime}$ & $10 / 10 / 2001$ & oblíquo & $1.000 \mathrm{~m}$ & cilíndrico-cônica & 500 & 1 \\
\hline
\end{tabular}

Referências: Richards, 2006b; Fahay, 2007. 


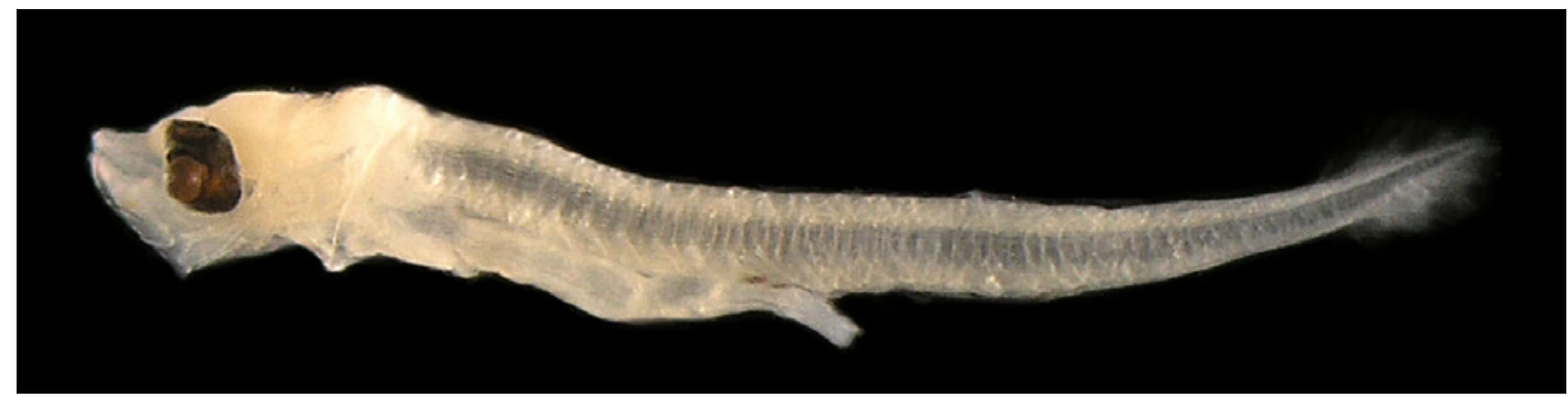

Figura 25 - A: Maurolicus stehmanni. DZUFRJ 13543; Pré-flexão; CP 4,4 mm.

\section{Maurolicus stehmanni Parin \& \\ Kobyliansky, 1993}

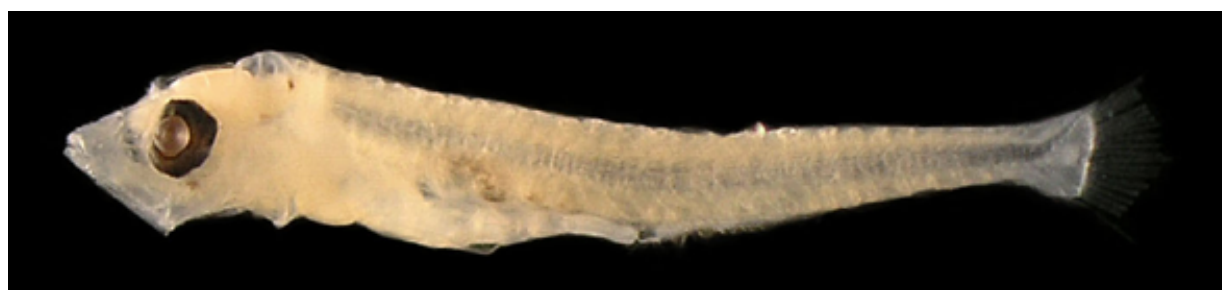

Figura 25 - B: DZUFRJ 13543; Flexão; CP 5,9 mm.

As larvas com 6,5 $\mathrm{mm}$ apresentam dois fotóforos na margem ventral do intestino. Os indivíduos com 10 $\mathrm{mm}$ já possuem os raios das nadadeiras formados, o número de fotóforos aumenta nas regiões da cabeça e do intestino e aparecem fotóforos na região caudal. As larvas

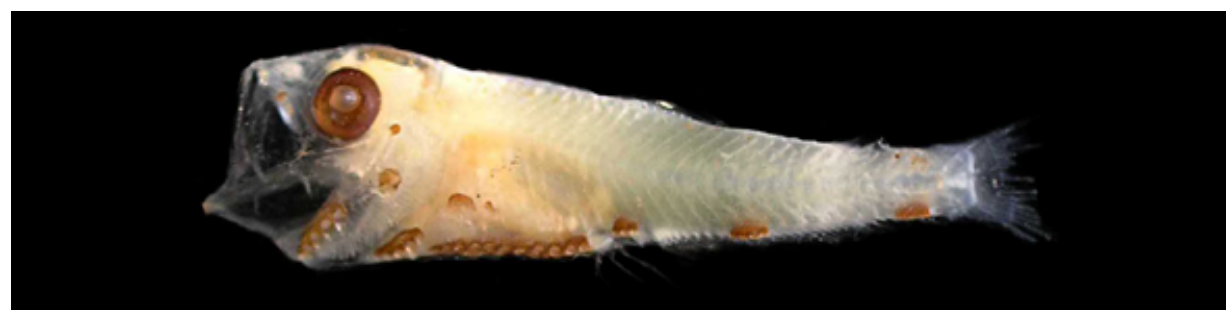

Figura 25 - C: DZUFRJ 409; Pós-flexão; CP 11,5 mm. menores podem ser confundidas com a família Myctophidae. Entretanto, larvas de $M$. stehmanni possuem o intestino liso, enquanto que larvas de Myctophidae têm intestino estriado. O número de vértebras varia entre 33 e 34 (raramente).

Tamanho: pré-flexão 2,5-5,0 mm; flexão 5,9-11,3 mm; pós-flexão 11,5-14,0 mm.

Habitat: espécie marinha e batipelágica, ocorre até $200 \mathrm{~m}$ de profundidade. Essa espécie ocorre somente no Oceano Atlântico Sudoeste.

\section{Georreferenciamento}

\begin{tabular}{|c|c|c|c|c|c|c|c|c|}
\hline DZUFR & Latitude (S) & Longitude (W) & Data & $\begin{array}{c}\text { Tipo de } \\
\text { arrasto }\end{array}$ & $\begin{array}{c}\text { Profundidade } \\
\text { de coleta }\end{array}$ & Rede & $\begin{array}{c}\text { Malha } \\
\text { ( } \boldsymbol{\mu m} \text { ) }\end{array}$ & $\begin{array}{c}\text { No. de } \\
\text { inds. }\end{array}$ \\
\hline 409 & $22^{\circ} 34^{\prime} 05,0^{\prime \prime}$ & $040^{\circ} 19^{\prime} 40,0^{\prime \prime}$ & $17 / 05 / 2002$ & oblíquo & $600 \mathrm{~m}$ & cilíndrico-cônica & 500 & 86 \\
\hline 410 & $22^{\circ} 38^{\prime} 29,0^{\prime \prime}$ & $040^{\circ} 17^{\prime} 40,0^{\prime \prime}$ & $18 / 05 / 2002$ & oblíquo & $800 \mathrm{~m}$ & cilíndrico-cônica & 500 & 36 \\
\hline 711 & $22^{\circ} 41^{\prime} 54,7^{\prime \prime}$ & $040^{\circ} 14^{\prime} 04,5^{\prime \prime}$ & $16 / 05 / 2002$ & oblíquo & $1.000 \mathrm{~m}$ & cilíndrico-cônica & 500 & 1 \\
\hline 1214 & $22^{\circ} 02^{\prime} 30,0^{\prime \prime}$ & $039^{\circ} 49^{\prime} 41,2^{\prime \prime}$ & $12 / 05 / 2002$ & oblíquo & $1.000 \mathrm{~m}$ & cilíndrico-cônica & 500 & 1 \\
\hline 5426 & $22^{\circ} 31^{\prime} 40,9^{\prime \prime}$ & $040^{\circ} 02^{\prime} 39,6^{\prime \prime}$ & $07 / 11 / 2001$ & oblíquo & $1.000 \mathrm{~m}$ & cilíndrico-cônica & 500 & 1 \\
\hline 5427 & $22^{\circ} 32^{\prime} 49,0^{\prime \prime}$ & $040^{\circ} 04^{\prime} 20,9^{\prime \prime}$ & $07 / 11 / 2001$ & oblíquo & $1.000 \mathrm{~m}$ & cilíndrico-cônica & 500 & 1 \\
\hline 5428 & $22^{\circ} 31^{\prime} 40,9^{\prime \prime}$ & $040^{\circ} 02^{\prime} 39,6^{\prime \prime}$ & $07 / 11 / 2001$ & oblíquo & $1.000 \mathrm{~m}$ & cilíndrico-cônica & 500 & 1 \\
\hline 5429 & $22^{\circ} 31^{\prime} 40,9^{\prime \prime}$ & $040^{\circ} 02^{\prime} 39,6^{\prime \prime}$ & $07 / 11 / 2001$ & oblíquo & $1.000 \mathrm{~m}$ & cilíndrico-cônica & 500 & 3 \\
\hline 5430 & $22^{\circ} 32^{\prime} 49,0^{\prime \prime}$ & $040^{\circ} 04^{\prime} 20,9^{\prime \prime}$ & $07 / 11 / 2001$ & oblíquo & $1.000 \mathrm{~m}$ & cilíndrico-cônica & 500 & 2 \\
\hline 5432 & $22^{\circ} 32^{\prime} 50,0^{\prime \prime}$ & $040^{\circ} 04^{\prime} 09,9^{\prime \prime}$ & $06 / 11 / 2001$ & oblíquo & $1.000 \mathrm{~m}$ & cilíndrico-cônica & 500 & 1 \\
\hline 5533 & $22^{\circ} 32^{\prime} 50,0^{\prime \prime}$ & $040^{\circ} 04^{\prime} 09,9^{\prime \prime}$ & $06 / 11 / 2001$ & oblíquo & $1.000 \mathrm{~m}$ & cilíndrico-cônica & 500 & 1 \\
\hline
\end{tabular}




\begin{tabular}{|c|c|c|c|c|c|c|c|c|}
\hline DZUFRJ & Latitude (S) & Longitude (W) & Data & $\begin{array}{l}\text { Tipo de } \\
\text { arrasto }\end{array}$ & $\begin{array}{c}\text { Profundidade } \\
\text { de coleta }\end{array}$ & Rede & $\begin{array}{l}\text { Malha } \\
(\mu \mathrm{m})\end{array}$ & $\begin{array}{l}N^{\circ} \text {. de } \\
\text { inds. }\end{array}$ \\
\hline 7433 & $21^{\circ} 53^{\prime} 10,4^{\prime \prime}$ & $039^{\circ} 45^{\prime} 49,9^{\prime \prime}$ & 10/10/2001 & oblíquo & $1.000 \mathrm{~m}$ & cilíndrico-cônica & 500 & 2 \\
\hline 21860 & $22^{\circ} 39,68^{\prime}$ & $040^{\circ} 03,24^{\prime}$ & $13 / 06 / 2003$ & vertical & $100-500 m$ & cilíndrico-cônica & 500 & 1 \\
\hline 21873 & $21^{\circ} 53^{\prime} 10,4^{\prime \prime}$ & $039^{\circ} 45^{\prime} 49,9^{\prime \prime}$ & $10 / 10 / 2001$ & oblíquo & $1.000 \mathrm{~m}$ & cilíndrico-cônica & 500 & 3 \\
\hline 21874 & $21^{\circ} 53^{\prime} 10,4^{\prime \prime}$ & $039^{\circ} 45^{\prime} 49,9^{\prime \prime}$ & $10 / 10 / 2001$ & oblíquo & $1.000 \mathrm{~m}$ & cilíndrico-cônica & 500 & 1 \\
\hline 21875 & $21^{\circ} 58^{\prime} 31,0^{\prime \prime}$ & $039^{\circ} 50^{\prime 29,7 "}$ & $10 / 10 / 2001$ & oblíquo & $1.000 \mathrm{~m}$ & cilíndrico-cônica & 500 & 1 \\
\hline 21876 & $21^{\circ} 58 ' 31,0^{\prime \prime}$ & $039^{\circ} 50^{\prime} 29,7^{\prime \prime}$ & $10 / 10 / 2001$ & oblíquo & $1.000 \mathrm{~m}$ & cilíndrico-cônica & 500 & 5 \\
\hline 21974 & $22^{\circ} 07^{\prime} 58,8^{\prime \prime}$ & $039^{\circ} 49^{\prime} 08,9^{\prime \prime}$ & $02 / 12 / 2002$ & vertical & $200-1.100 m$ & cilíndrico-cônica & 200 & 4 \\
\hline 21980 & $21^{\circ} 57^{\prime} 10,5^{\prime \prime}$ & $039^{\circ} 43^{\prime} 33,3^{\prime \prime}$ & $09 / 10 / 2001$ & oblíquo & $1.000 \mathrm{~m}$ & cilíndrico-cônica & 500 & 1 \\
\hline
\end{tabular}

Referências: Parin \& Kobyliansky, 1996; Almeida, 2001; Lima, 2005; Bonecker et al., 2006 


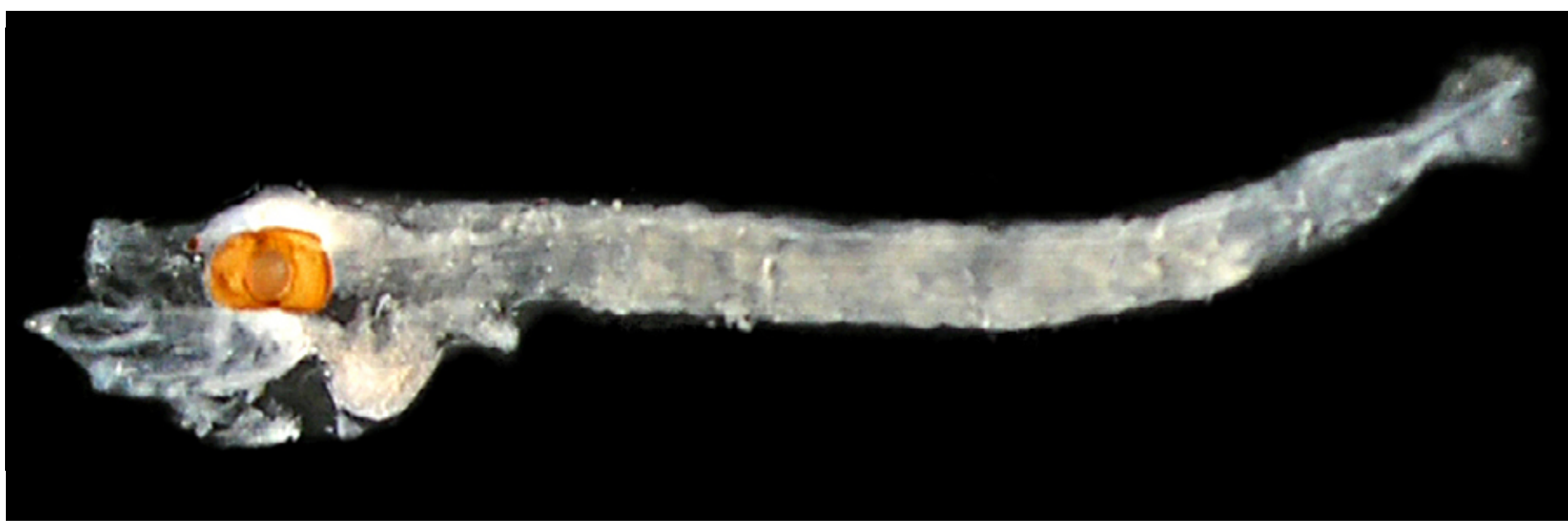

Figura 26 - A: Sternoptyx sp. DZUFRJ 5540; Pré-flexão; CP 5,9 mm.

\section{Sternoptyx sp.}

As espécies de Sternoptyx possuem intestino curto e os pigmentos surgem ao longo do desenvolvimento na cabeça, no intestino e associados aos fotóforos. Há presença de espinhos e séries de fotóforos na cabeça em larvas maiores que 7 mm CP. A identificação desse gênero é baseada no número, na forma e na localização dos fotóforos. Esses órgãos só

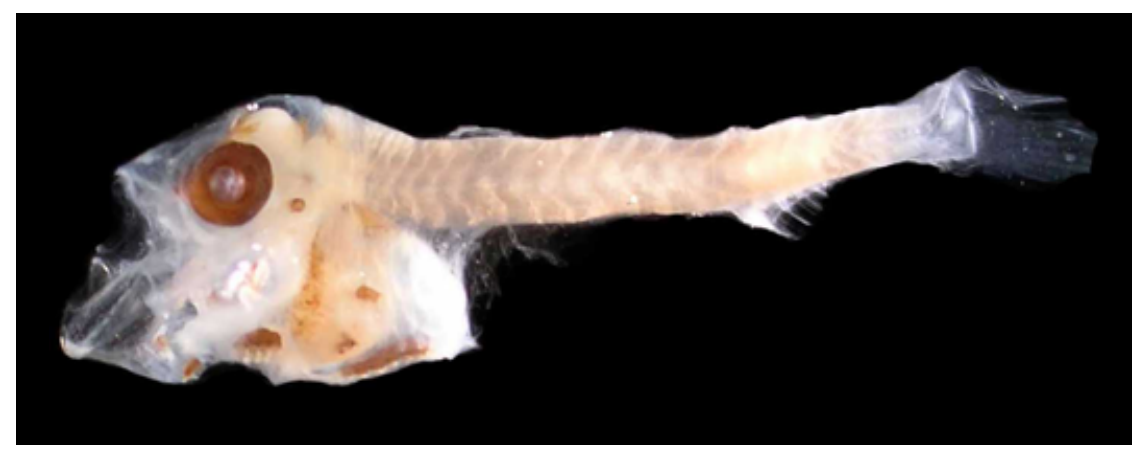

Figura 26 - B: DZUFRJ 19892; Flexão; CP 8,6 mm. estão completamente formados em indivíduos que já sofreram a transformação, com aproximadamente $11 \mathrm{~mm}$ CP. Os exemplares coletados no presente estudo ainda não apresentavam as séries de fotóforos totalmente formadas, o que impossibilitou a identificação até espécie. No Brasil já foram registradas as espécies Sternoptyx diaphana Hermann, 1781 e Sternoptyx pseudobscura Baird, 1971.

Tamanho: pré-flexão 5,5-5,9 mm; flexão 7,0-9,2 mm.

Habitat: as espécies de Sternoptyx são marinhas e batipelágicas, ocorrem até 1.500 m de profundidade.

\section{Georreferenciamento}

\begin{tabular}{|c|c|c|c|c|c|c|c|c|}
\hline DZUFR & Latitude (S) & Longitude (W) & Data & $\begin{array}{c}\text { Tipo de } \\
\text { arrasto }\end{array}$ & $\begin{array}{c}\text { Profundidade } \\
\text { de coleta }\end{array}$ & Rede & $\begin{array}{c}\text { Malha } \\
(\boldsymbol{\mu m})\end{array}$ & $\begin{array}{c}\mathbf{N}^{\circ} \text {. de } \\
\text { inds. }\end{array}$ \\
\hline 681 & $22^{\circ} 37^{\prime} 35,5^{\prime \prime}$ & $040^{\circ} 09^{\prime} 32,8^{\prime \prime}$ & $16 / 05 / 2002$ & oblíquo & $1.000 \mathrm{~m}$ & cilíndrico-cônica & 500 & 1 \\
\hline 5472 & $22^{\circ} 31^{\prime} 40,9^{\prime \prime}$ & $040^{\circ} 02^{\prime} 39,6^{\prime \prime}$ & $07 / 11 / 2001$ & oblíquo & $1.000 \mathrm{~m}$ & cilíndrico-cônica & 500 & 2 \\
\hline 5473 & $22^{\circ} 32^{\prime} 49,0^{\prime \prime}$ & $040^{\circ} 04^{\prime} 20,9^{\prime \prime}$ & $07 / 11 / 2001$ & oblíquo & $1.000 \mathrm{~m}$ & cilíndrico-cônica & 500 & 1 \\
\hline 5474 & $22^{\circ} 31^{\prime} 40,9^{\prime \prime}$ & $040^{\circ} 02^{\prime} 39,6^{\prime \prime}$ & $07 / 11 / 2001$ & oblíquo & $1.000 \mathrm{~m}$ & cilíndrico-cônica & 500 & 2 \\
\hline 5475 & $22^{\circ} 32^{\prime} 50,0^{\prime \prime}$ & $040^{\circ} 04^{\prime} 09^{\prime \prime}$ & $06 / 11 / 2001$ & oblíquo & $1.000 \mathrm{~m}$ & cilíndrico-cônica & 500 & 2 \\
\hline 5540 & $22^{\circ} 32^{\prime} 50,0^{\prime \prime}$ & $040^{\circ} 04^{\prime} 09^{\prime \prime}$ & $06 / 11 / 2001$ & oblíquo & $1.000 \mathrm{~m}$ & cilíndrico-cônica & 500 & 1 \\
\hline 7440 & $21^{\circ} 53^{\prime} 10,4^{\prime \prime}$ & $039^{\circ} 45^{\prime} 49,9^{\prime \prime}$ & $10 / 10 / 2001$ & oblíquo & $1.000 \mathrm{~m}$ & cilíndrico-cônica & 500 & 2 \\
\hline 7443 & $21^{\circ} 54^{\prime} 36,5^{\prime \prime}$ & $039^{\circ} 45^{\prime} 20,0^{\prime \prime}$ & $10 / 10 / 2001$ & oblíquo & $1.000 \mathrm{~m}$ & cilíndrico-cônica & 500 & 1 \\
\hline 19892 & $22^{\circ} 32^{\prime} 49,0^{\prime \prime}$ & $040^{\circ} 04^{\prime} 20,9^{\prime \prime}$ & $07 / 11 / 2001$ & oblíquo & $1.000 \mathrm{~m}$ & cilíndrico-cônica & 500 & 1 \\
\hline
\end{tabular}

Referências: Badcock \& Baird, 1980; Richards, 2006b; Bonecker et al., 2006a; Fahay, 2007. 


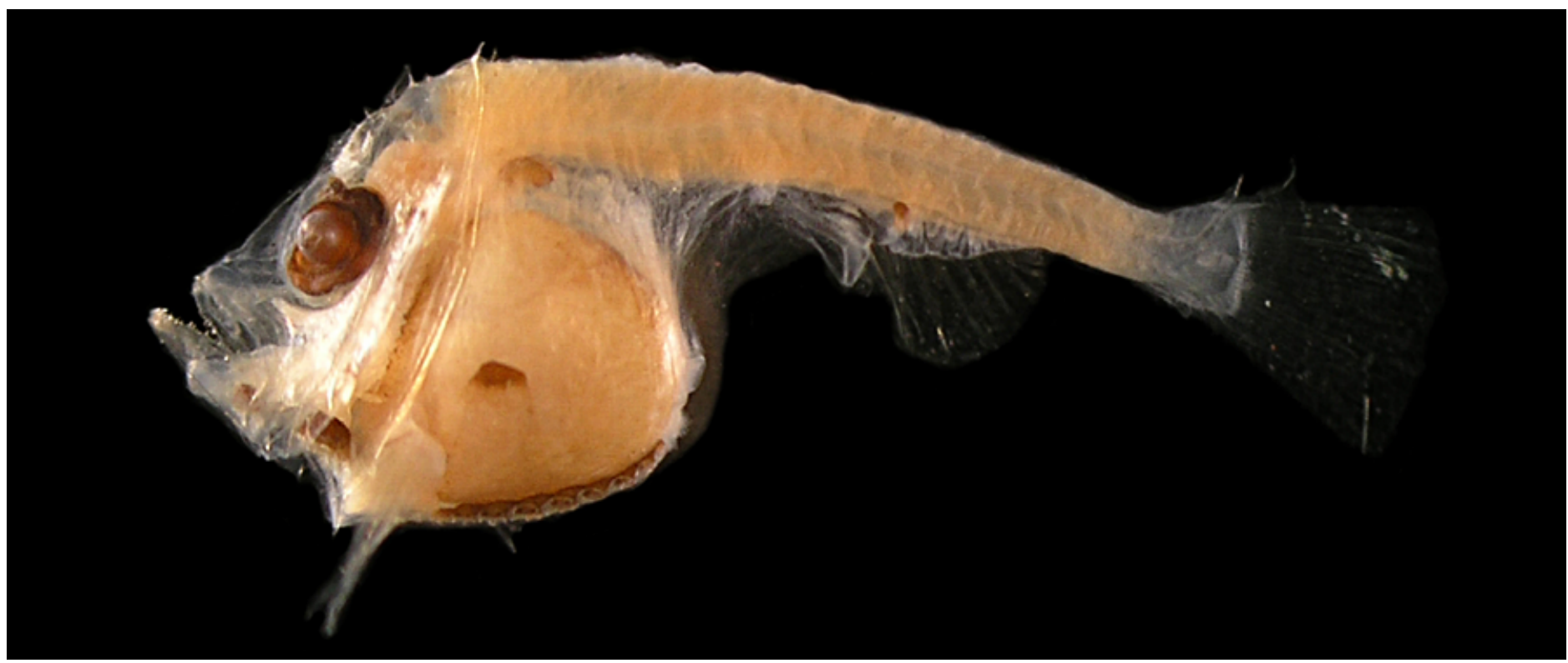

Figura 27: Sternoptyx diaphana. DZUFRJ 7598; Transformação; CP 9,3 mm.

\section{Sternoptyx diaphana Hermann, 1781}

As principais características que separam essa espécie das demais são: os pterigióforos anais posteriores são maiores do que nas outras espécies e os fotóforos da série SAN se formam logo acima dos pterigióforos anais. O meio do pedúnculo caudal pode apresentar uma mancha de pigmentos. O número de miômeros varia entre 29 e 30. Os juvenis dessa espécie se diferenciam dos de $S$. pseudobscura por apresentarem boca menor e pelo fotóforo supra-anal estar localizado logo acima dos fotóforos anais.

Tamanho: transformação 8,0-9,4 mm.

Habitat: espécie marinha, mesopelágica, ocorre em águas tropicais e temperadas em profundidades entre 300 e $1.200 \mathrm{~m}$.

\section{Georreferenciamento}

\begin{tabular}{|c|c|c|c|c|c|c|c|c|}
\hline DZUFRJ & Latitude (S) & Longitude (W) & Data & $\begin{array}{c}\text { Tipo de } \\
\text { arrasto }\end{array}$ & $\begin{array}{c}\text { Profundidade } \\
\text { de coleta }\end{array}$ & Rede & $\begin{array}{c}\text { Malha } \\
\text { ( } \boldsymbol{\mu m} \text { ) }\end{array}$ & $\begin{array}{c}\mathbf{N}^{\circ} \text {. de } \\
\text { inds. }\end{array}$ \\
\hline 7596 & $21^{\circ} 58^{\prime} 31,0^{\prime \prime}$ & $039^{\circ} 50^{\prime} 29,7^{\prime \prime}$ & $10 / 10 / 2001$ & oblíquo & $1.000 \mathrm{~m}$ & cilíndrico-cônica & 500 & 1 \\
\hline 7598 & $21^{\circ} 58^{\prime} 31,0^{\prime \prime}$ & $039^{\circ} 50^{\prime} 29,7^{\prime \prime}$ & $11 / 10 / 2001$ & oblíquo & $1.000 \mathrm{~m}$ & cilíndrico-cônica & 500 & 2 \\
\hline 7607 & $21^{\circ} 57^{\prime} 10,5^{\prime \prime}$ & $039^{\circ} 43^{\prime} 33,3^{\prime \prime}$ & $09 / 10 / 2001$ & oblíquo & $1.000 \mathrm{~m}$ & cilíndrico-cônica & 500 & 1 \\
\hline 21868 & $2^{\circ} 53^{\prime} 10,4^{\prime \prime}$ & $039^{\circ} 45^{\prime} 499^{\prime \prime}$ & $10 / 10 / 2001$ & oblíquo & $1.000 \mathrm{~m}$ & cilíndrico-cônica & 500 & 1 \\
\hline
\end{tabular}

Referências: Richards, 2006b; Fahay, 2007. 


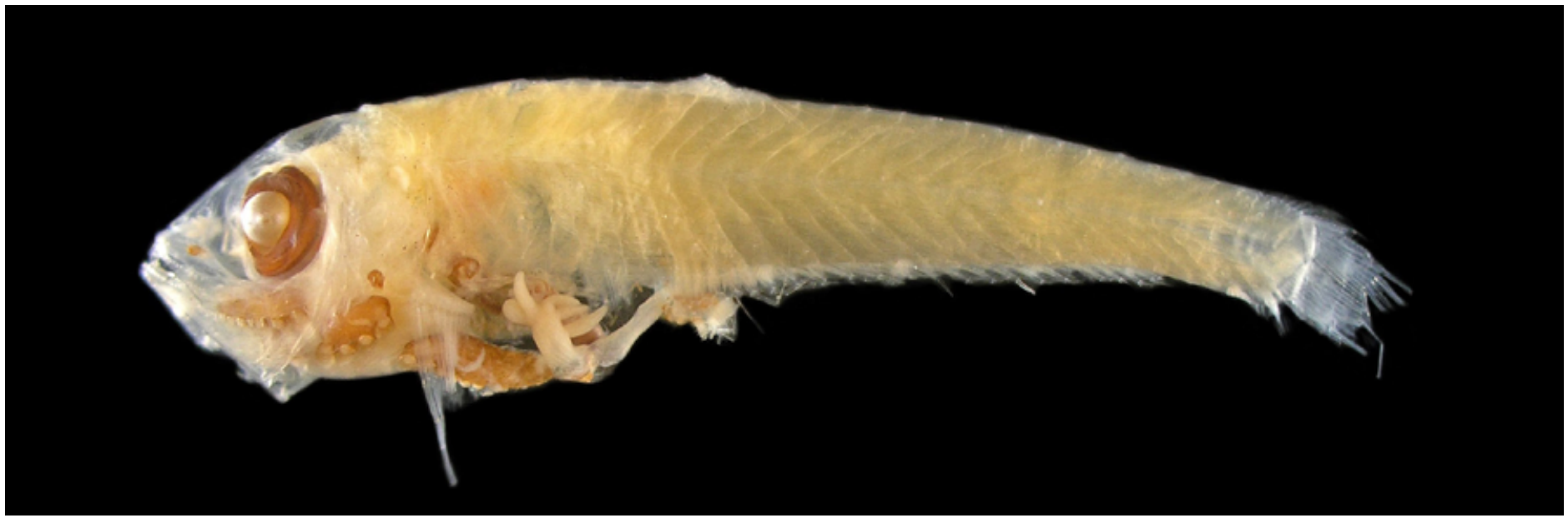

Figura 28 - A: Valenciennellus tripunculatus. A. DZUFRJ 5542; Transformação; CP 15,4 mm.

\section{Valenciennellus}

\section{tripunculatus (Esmark, 1871)}

As larvas nos estágios iniciais de desenvolvimento, antes da transformação, possuem o corpo alongado e distância pré-anal entre 55 e $60 \%$ do comprimento padrão. Presença de nadadeira adiposa e origem da nadadeira anal anterior à

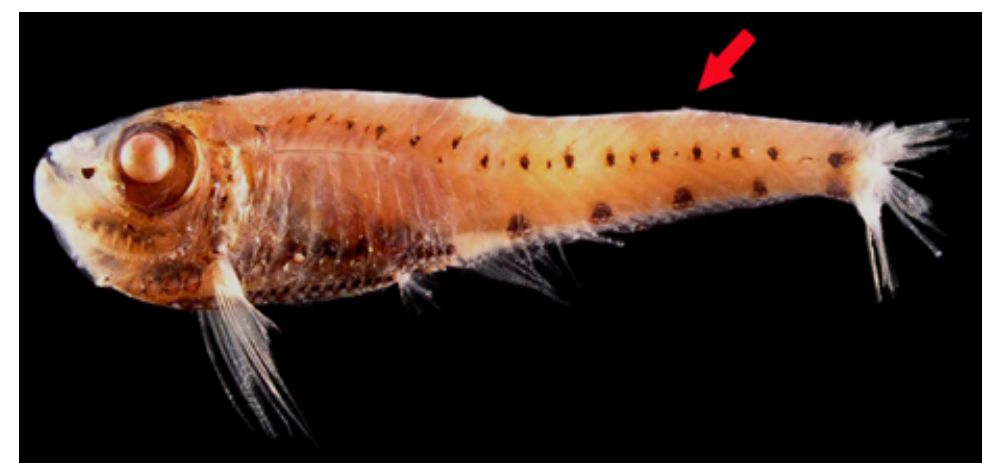

Figura 28 - B: DZUFRJ 7595; Juvenil; CP 32,5 mm. origem da nadadeira dorsal. Não possui nenhum pigmento no corpo até o estágio de transformação, quando surgem pigmentos internos sobre o trato digestório e a vesícula gasosa. O número de miômeros varia entre 32 e 35. Nos juvenis observa-se uma série de manchas de pigmentos acima da linha lateral.

Tamanho: transformação 15,3-15,8 mm; juvenil 32,5 mm.

Habitat: espécie marinha, mesopelágica e batipelágica, ocorre em águas tropicais e temperadas em profundidades entre 100 e $700 \mathrm{~m}$.

\section{Georreferenciamento}

\begin{tabular}{|c|c|c|c|c|c|c|c|c|}
\hline DZUFRJ & Latitude (S) & Longitude (W) & Data & $\begin{array}{c}\text { Tipo de } \\
\text { arrasto }\end{array}$ & $\begin{array}{c}\text { Profundidade } \\
\text { de coleta }\end{array}$ & Rede & $\begin{array}{c}\text { Malha } \\
\text { ( } \begin{array}{c|c}\mathbf{N m}^{\circ} \text {. de } \\
\text { inds. }\end{array}\end{array}$ \\
\hline 5542 & $22^{\circ} 32^{\prime} 49,0^{\prime \prime}$ & $040^{\circ} 04^{\prime} 20,9^{\prime \prime}$ & $07 / 11 / 2001$ & oblíquo & $1.000 \mathrm{~m}$ & cilíndrico-cônica & 500 & 1 \\
\hline 7595 & $21^{\circ} 54^{\prime} 36,5^{\prime \prime}$ & $039^{\circ} 45^{\prime} 20,0^{\prime \prime}$ & $10 / 10 / 2001$ & oblíquo & $1.000 \mathrm{~m}$ & cilíndrico-cônica & 500 & 1 \\
\hline 7604 & $2^{\circ} 54^{\prime} 36,5^{\prime \prime}$ & $039^{\circ} 45^{\prime} 20,0^{\prime \prime}$ & $09 / 10 / 2001$ & oblíquo & $1.000 \mathrm{~m}$ & cilíndrico-cônica & 500 & 1 \\
\hline
\end{tabular}

Referências: Richards, 2006b; Fahay, 2007. 


\section{Família Phosichthyidae}

A família Phosichthyidae é marinha e ocorre nos oceanos Atlântico, Índico e Pacífico. Compreende sete gêneros com aproximadamente 20 espécies. As larvas dessa família podem ser identificadas através da distância pré-anal, forma do olho e o padrão de pigmentação. As larvas de Pollichthys mauli possuem o intestino muito longo, alcançando $80 \%$ do comprimento padrão e não possuem pigmentos no corpo. Larvas do gênero Vinciguerria possuem intestino mais curto que de $P$. mauli, alcançando $70 \%$ do comprimento padrão, e têm um pigmento no pedúnculo caudal. As larvas de Ichthyoccocus podem ser separadas dos representantes dos outros gêneros por possuírem a extremidade do intestino solta e pelo padrão de pigmentação.

No Brasil já foram identificadas oito espécies nas fases de larva e adulto. Nesse estudo são contempladas as espécies Ichthyococcus ovatus, Pollichthys mauli e Vinciguerria nimbaria. 


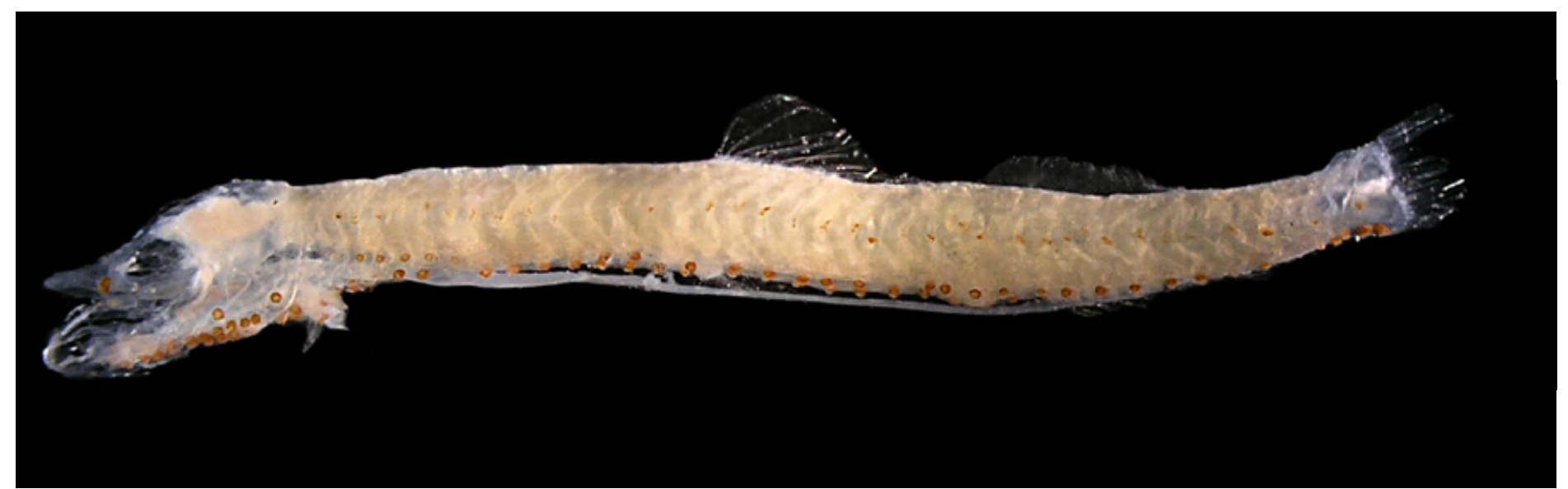

Figura 29 - Ichthyococcus ovatus. DZUFRJ 7589; Pós-flexão; CP 19,3 mm.

\section{Ichthyococcus ovatus (Cocco, 1838)}

As larvas no estágio de pré-flexão e até transformação possuem a extremidade do intestino livre e o último raio na parte inferior da nadadeira peitoral alongado. A medida que a larva cresce o intestino regride. O focinho é pontudo e o olho é oval; nadadeira adiposa presente. Nas larvas maiores a origem da nadadeira anal é bem posterior à origem da nadadeira dorsal. O número de miômeros varia entre 38 e 42 . O padrão de pigmentação é único e os pigmentos estão distribuídos nos miômeros abaixo da linha lateral. Nos indivíduos em pós-flexão começa a formação das séries de fotóforos na região ventral do corpo.

Tamanho: pré-flexão 8,5 mm; pós-flexão 19,3 m.

Habitat: espécie marinha, mesopelágica e batipelágica, ocorre em águas subtropicais em profundidades entre 200 e $500 \mathrm{~m}$.

\section{Georreferenciamento}

\begin{tabular}{|c|c|c|c|c|c|c|c|c|}
\hline DZUFR & Latitude (S) & Longitude (W) & Data & $\begin{array}{c}\text { Tipo de } \\
\text { arrasto }\end{array}$ & $\begin{array}{c}\text { Profundidade } \\
\text { de coleta }\end{array}$ & Rede & $\begin{array}{c}\text { Malha } \\
\text { ( } \boldsymbol{\mu m} \text { ) }\end{array}$ & $\begin{array}{c}\mathbf{N}^{\circ} \text {. de } \\
\text { inds. }\end{array}$ \\
\hline 5532 & $22^{\circ} 31^{\prime} 58,9^{\prime \prime}$ & $040^{\circ} 02^{\prime} 53,4^{\prime \prime}$ & $07 / 11 / 2001$ & oblíquo & $1.000 \mathrm{~m}$ & cilíndrico-cônica & 500 & 1 \\
\hline 7589 & $21^{\circ} 53^{\prime} 10,4^{\prime \prime}$ & $039^{\circ} 45^{\prime} 49,9^{\prime \prime}$ & $10 / 10 / 2001$ & oblíquo & $1.000 \mathrm{~m}$ & cilíndrico-cônica & 500 & 1 \\
\hline
\end{tabular}

Referências: Watson, 1996b; Richards, 2006c; Fahay, 2007. 


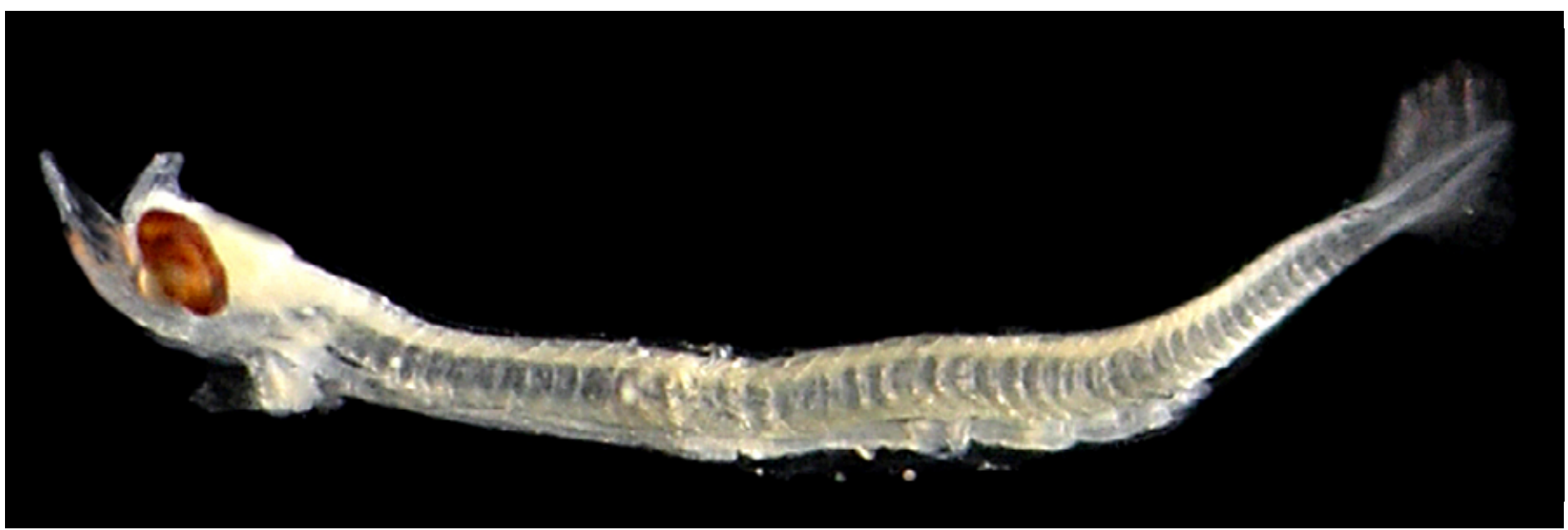

Figura 30 - A: Pollichthys mauli. A. DZUFRJ 1198; Pré-flexão; CP 3,7 mm.

\section{Pollichthys mauli (Poll, 1953)}

As larvas nos estágios de pré-flexão, flexão e pós-flexão possuem olhos elípticos com tecido coroide ventral, o focinho é pontudo e o intestino é longo (80\% do comprimento padrão). A nadadeira dorsal adiposa está presente durante a flexão e permanece nos juvenis e adultos. O número de miômeros varia entre 40 e 44 . As larvas nos estágios iniciais de desenvolvimento podem ser confundidas com Clupeiformes. Entretanto, os olhos elípticos, o intestino liso e a presença de nadadeira adiposa em $P$. mauli as separam dessa ordem. A origem da nadadeira dorsal é muito anterior à da nadadeira anal. Em espécimes com aproximadamente 16 a $18 \mathrm{~mm} \mathrm{CP}$, que estão na fase de transformação, a origem da nadadeira anal está situada abaixo dos últimos raios da nadadeira dorsal. A nadadeira anal longa (25 a 26 raios) e a cauda mais estreita separa facilmente os indivíduos dessa espécie dos demais gêneros de Phosichthyidae. Nas larvas maiores, que estão na fase de transformação, os fotóforos começam a ser formados e a ganhar pigmentação: ORB 2; OP 3; SO 1; BR 8; IV 21-23; VAV 7-9; AC 18-21.

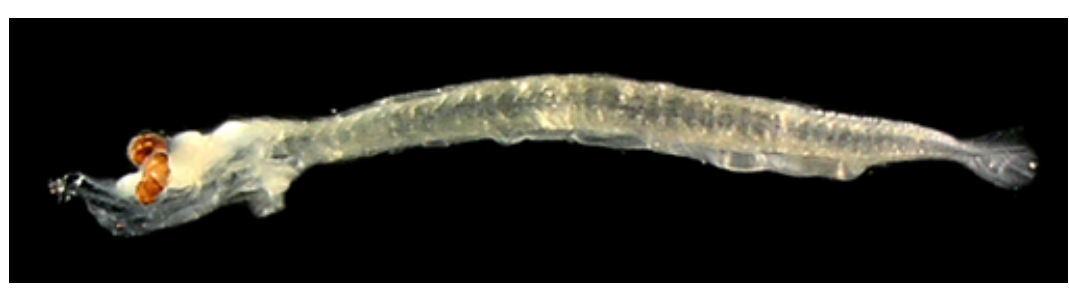

Figura 30 - B: DZUFRJ 19929; Flexão; CP 6,3 mm.

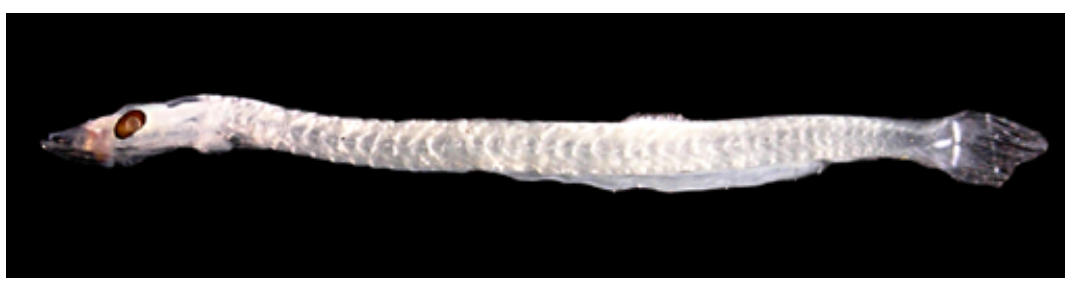

Figura 30 - C: DZUFRJ 1245; Pós-flexão; CP 12,8 mm.

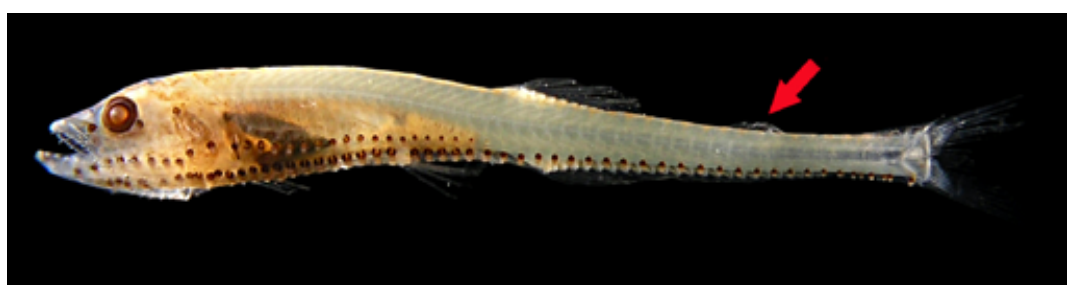

Figura 30 - D: DZUFRJ 19915; Transformação; CP 27,4 mm.

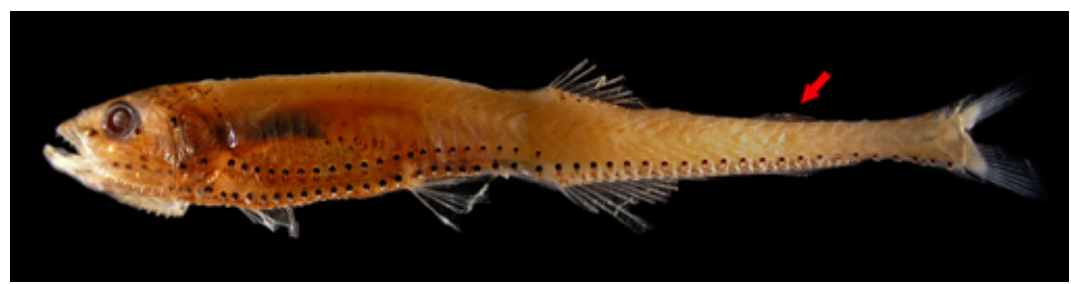

Figura 30 - E: DZUFRJ 7576; Juvenil; CP 44,5 mm.

Tamanho: pré-flexão 3,7 mm; flexão 4,6-9,0 mm; pós-flexão 10,0-17,2 mm; transformação 21,8-27,4 mm; juvenil 31,1-46,2 mm; adulto 51,0 mm.

Habitat: espécie marinha, mesopelágica e batipelágica, ocorre em águas tropicais e subtropicais em profundidades entre 200 e $500 \mathrm{~m}$ durante o dia, até o máximo de $1.000 \mathrm{~m}$. A noite pode ser encontrada entre 100 e $200 \mathrm{~m}$ de profundidade. 


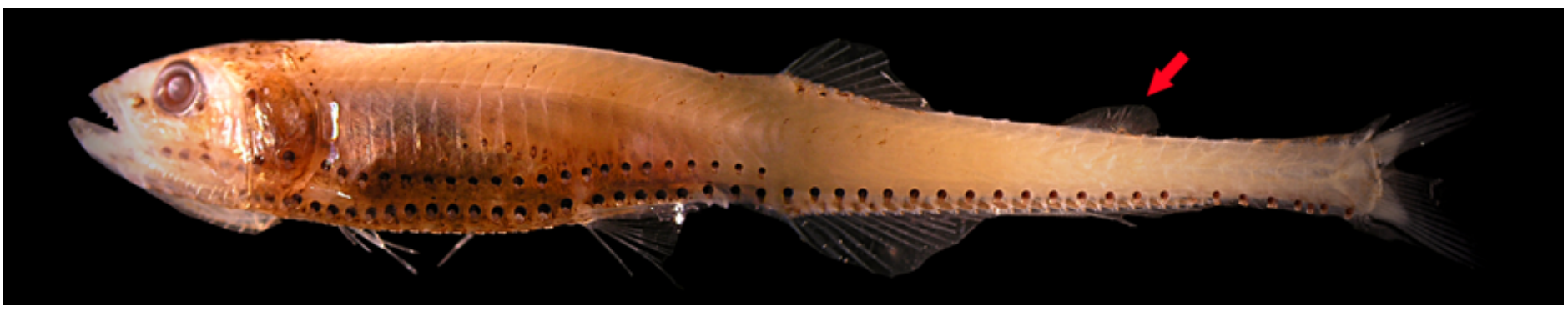

Figura 30 - F: DZUFRJ 7576; Adulto; CP 51,0 mm.

\section{Georreferenciamento}

\begin{tabular}{|c|c|c|c|c|c|c|c|c|}
\hline DZUFRJ & Latitude (S) & Longitude (W) & Data & $\begin{array}{l}\text { Tipo de } \\
\text { arrasto }\end{array}$ & $\begin{array}{l}\text { Profundidade } \\
\text { de coleta }\end{array}$ & Rede & $\begin{array}{l}\text { Malha } \\
(\mu \mathrm{m})\end{array}$ & $\begin{array}{l}N^{\circ} \text {. de } \\
\text { inds. }\end{array}$ \\
\hline 521 & $22^{\circ} 34^{\prime} 05,0^{\prime \prime}$ & $040^{\circ} 19^{\prime} 40,0^{\prime \prime}$ & $17 / 05 / 2002$ & oblíquo & $600 \mathrm{~m}$ & cilíndrico-cônica & 500 & 16 \\
\hline 608 & $22^{\circ} 38^{\prime} 29,0^{\prime \prime}$ & $040^{\circ} 17^{\prime} 40,0^{\prime \prime}$ & $18 / 05 / 2002$ & oblíquo & $800 \mathrm{~m}$ & cilíndrico-cônica & 500 & 4 \\
\hline 642 & $22^{\circ} 42^{\prime} 06,0^{\prime \prime}$ & $040^{\circ} 14^{\prime} 26,0^{\prime \prime}$ & $19 / 05 / 2002$ & oblíquo & $50 \mathrm{~m}$ & bongô & 500 & 4 \\
\hline 665 & $22^{\circ} 42^{\prime} 06,0^{\prime \prime}$ & $040^{\circ} 14 ' 26,0^{\prime \prime}$ & $19 / 05 / 2002$ & oblíquo & $50 \mathrm{~m}$ & bongô & 330 & 3 \\
\hline 667 & $22^{\circ} 33^{\prime} 47,7^{\prime \prime}$ & $040^{\circ} 12^{\prime} 20,5^{\prime \prime}$ & $17 / 05 / 2002$ & oblíquo & $50 \mathrm{~m}$ & bongô & 500 & 2 \\
\hline 703 & $22^{\circ} 41^{\prime} 54,7^{\prime \prime}$ & $040^{\circ} 14^{\prime} 04,5^{\prime \prime}$ & $16 / 05 / 2002$ & oblíquo & $1.000 \mathrm{~m}$ & cilíndrico-cônica & 500 & 3 \\
\hline 707 & $22^{\circ} 37^{\prime} 35,5^{\prime \prime}$ & $040^{\circ} 09^{\prime} 32,8^{\prime \prime}$ & $16 / 05 / 2002$ & oblíquo & $1.000 \mathrm{~m}$ & cilíndrico-cônica & 500 & 2 \\
\hline 1181 & $22^{\circ} 07^{\prime} 29,0^{\prime \prime}$ & $039^{\circ} 06^{\prime} 23,5^{\prime \prime}$ & $10 / 05 / 2002$ & oblíquo & $1.000 \mathrm{~m}$ & cilíndrico-cônica & 500 & 2 \\
\hline 1198 & $22^{\circ} 06^{\prime} 52,3^{\prime \prime}$ & $039^{\circ} 48^{\prime} 46,2^{\prime \prime}$ & $11 / 05 / 2002$ & oblíquo & $1.000 \mathrm{~m}$ & cilíndrico-cônica & 500 & 12 \\
\hline 1219 & $22^{\circ} 02^{\prime} 30,0^{\prime \prime}$ & $039^{\circ} 49^{\prime} 41,2^{\prime \prime}$ & $12 / 05 / 2002$ & oblíquo & $1.000 \mathrm{~m}$ & cilíndrico-cônica & 500 & 2 \\
\hline 1236 & $22^{\circ} 03^{\prime} 21,7^{\prime \prime}$ & $039^{\circ} 45^{\prime} 11,9^{\prime \prime}$ & $12 / 05 / 2002$ & oblíquo & $1.000 \mathrm{~m}$ & cilíndrico-cônica & 500 & 7 \\
\hline 1245 & $22^{\circ} 08^{\prime} 17,5^{\prime \prime}$ & $039^{\circ} 46^{\prime} 28,5^{\prime \prime}$ & $11 / 05 / 2002$ & oblíquo & $1.000 \mathrm{~m}$ & cilíndrico-cônica & 500 & 3 \\
\hline 7576 & $21^{\circ} 57^{\prime} 10,5^{\prime \prime}$ & $039^{\circ} 43^{\prime} 33,3^{\prime \prime}$ & 09/10/2001 & oblíquo & $1.000 \mathrm{~m}$ & cilíndrico-cônica & 500 & 4 \\
\hline 7582 & $21^{\circ} 57^{\prime} 10,5^{\prime \prime}$ & $039^{\circ} 43^{\prime} 33,3^{\prime \prime}$ & $09 / 10 / 2001$ & oblíquo & $1.000 \mathrm{~m}$ & cilíndrico-cônica & 500 & 2 \\
\hline 7584 & $21^{\circ} 54^{\prime} 36,5^{\prime \prime}$ & $039^{\circ} 45^{\prime} 20,0^{\prime \prime}$ & $09 / 10 / 2001$ & oblíquo & $1.000 \mathrm{~m}$ & cilíndrico-cônica & 500 & 3 \\
\hline 7585 & $21^{\circ} 58^{\prime} 31,0^{\prime \prime}$ & $039^{\circ} 50^{\prime} 29,7^{\prime \prime}$ & $11 / 10 / 2001$ & oblíquo & & cilíndrico-cônica & 500 & 4 \\
\hline 7590 & $21^{\circ} 58 ' 31,0^{\prime \prime}$ & $039^{\circ} 50^{\prime} 29,7^{\prime \prime}$ & $10 / 10 / 2001$ & oblíquo & $1.000 \mathrm{~m}$ & cilíndrico-cônica & 500 & 1 \\
\hline 7592 & $21^{\circ} 54^{\prime} 36,5^{\prime \prime}$ & $039^{\circ} 45^{\prime} 20,0^{\prime \prime}$ & $10 / 10 / 2001$ & oblíquo & $1.000 \mathrm{~m}$ & cilíndrico-cônica & 500 & 6 \\
\hline 19906 & $22^{\circ} 32^{\prime} 49,0^{\prime \prime}$ & $040^{\circ} 04^{\prime} 20,9^{\prime \prime}$ & $07 / 11 / 2001$ & oblíquo & $1.000 \mathrm{~m}$ & cilíndrico-cônica & 500 & 5 \\
\hline 19911 & $22^{\circ} 35^{\prime} 08,5^{\prime \prime}$ & $039^{\circ} 46^{\prime} 22,3^{\prime \prime}$ & $06 / 12 / 2002$ & vertical & $50 \mathrm{~m}$ & cilíndrico-cônica & 200 & 1 \\
\hline 19915 & $22^{\circ} 43,56^{\prime}$ & $039^{\circ} 53,25^{\prime}$ & $14 / 06 / 2003$ & vertical & $100-500 m$ & cilíndrico-cônica & 500 & 1 \\
\hline 19916 & $21^{\circ} 53^{\prime} 10,4^{\prime \prime}$ & $039^{\circ} 45^{\prime} 49,9^{\prime \prime}$ & $10 / 10 / 2001$ & oblíquo & $1.000 \mathrm{~m}$ & cilíndrico-cônica & 500 & 1 \\
\hline 19917 & $21^{\circ} 53^{\prime} 10,4^{\prime \prime}$ & $039^{\circ} 45^{\prime} 49,9^{\prime \prime}$ & $10 / 10 / 2001$ & oblíquo & $1.000 \mathrm{~m}$ & cilíndrico-cônica & 500 & 1 \\
\hline 19918 & $22^{\circ} 02,27^{\prime}$ & $039^{\circ} 43,49^{\prime}$ & $18 / 06 / 2003$ & vertical & $100-480 m$ & cilíndrico-cônica & 500 & 1 \\
\hline 19919 & $21^{\circ} 57,51^{\prime}$ & $039^{\circ} 49,57^{\prime}$ & $19 / 06 / 2003$ & vertical & $100-500 m$ & cilíndrico-cônica & 500 & 2 \\
\hline 19923 & $22^{\circ} 32^{\prime} 50,0^{\prime \prime}$ & $040^{\circ} 04^{\prime} 09,9^{\prime \prime}$ & $06 / 11 / 2001$ & oblíquo & $1.000 \mathrm{~m}$ & cilíndrico-cônica & 500 & 5 \\
\hline 19924 & $22^{\circ} 31^{\prime} 40,9^{\prime \prime}$ & $040^{\circ} 02^{\prime} 39,6^{\prime \prime}$ & $07 / 11 / 2001$ & oblíquo & $1.000 \mathrm{~m}$ & cilíndrico-cônica & 500 & 5 \\
\hline 19925 & $22^{\circ} 31^{\prime} 58,9^{\prime \prime}$ & $040^{\circ} 02^{\prime} 53,4^{\prime \prime}$ & $07 / 11 / 2001$ & oblíquo & $1.000 \mathrm{~m}$ & cilíndrico-cônica & 500 & 2 \\
\hline 19926 & $22^{\circ} 31^{\prime} 58,9^{\prime \prime}$ & $040^{\circ} 02^{\prime} 53,4^{\prime \prime}$ & $07 / 11 / 2001$ & oblíquo & $1.000 \mathrm{~m}$ & cilíndrico-cônica & 500 & 2 \\
\hline 19927 & $22^{\circ} 31^{\prime} 58,9^{\prime \prime}$ & $040^{\circ} 02^{\prime} 53,4^{\prime \prime}$ & $07 / 11 / 2001$ & oblíquo & $1.000 \mathrm{~m}$ & cilíndrico-cônica & 500 & 1 \\
\hline 19928 & $22^{\circ} 31^{\prime} 40,9^{\prime \prime}$ & $040^{\circ} 02^{\prime} 39,6^{\prime \prime}$ & $07 / 11 / 2001$ & oblíquo & $1.000 \mathrm{~m}$ & cilíndrico-cônica & 500 & 2 \\
\hline 19929 & $22^{\circ} 32^{\prime} 49,0^{\prime \prime}$ & $040^{\circ} 04^{\prime} 20,9^{\prime \prime}$ & $07 / 11 / 2001$ & oblíquo & $1.000 \mathrm{~m}$ & cilíndrico-cônica & 500 & 14 \\
\hline 19930 & $22^{\circ} 31^{\prime} 40,9^{\prime \prime}$ & $040^{\circ} 02^{\prime} 39,6^{\prime \prime}$ & $07 / 11 / 2001$ & oblíquo & $1.000 \mathrm{~m}$ & cilíndrico-cônica & 500 & 2 \\
\hline 19931 & $22^{\circ} 32^{\prime} 49,0^{\prime \prime}$ & $040^{\circ} 04^{\prime} 20,9^{\prime \prime}$ & $07 / 11 / 2001$ & oblíquo & $1.000 \mathrm{~m}$ & cilíndrico-cônica & 500 & 7 \\
\hline 19932 & $22^{\circ} 32^{\prime} 50,0^{\prime \prime}$ & $040^{\circ} 04^{\prime} 09,9^{\prime \prime}$ & $06 / 11 / 2001$ & oblíquo & $1.000 \mathrm{~m}$ & cilíndrico-cônica & 500 & 1 \\
\hline 21538 & $21^{\circ} 57^{\prime} 10,5^{\prime \prime}$ & $039^{\circ} 43^{\prime} 33,3^{\prime \prime}$ & $09 / 10 / 2001$ & oblíquo & $1.000 \mathrm{~m}$ & cilíndrico-cônica & 500 & 1 \\
\hline
\end{tabular}

Referências: Grey, 1964; Fahay, 1983; Watson, 1996b; Bonecker et al., 2006 a. 


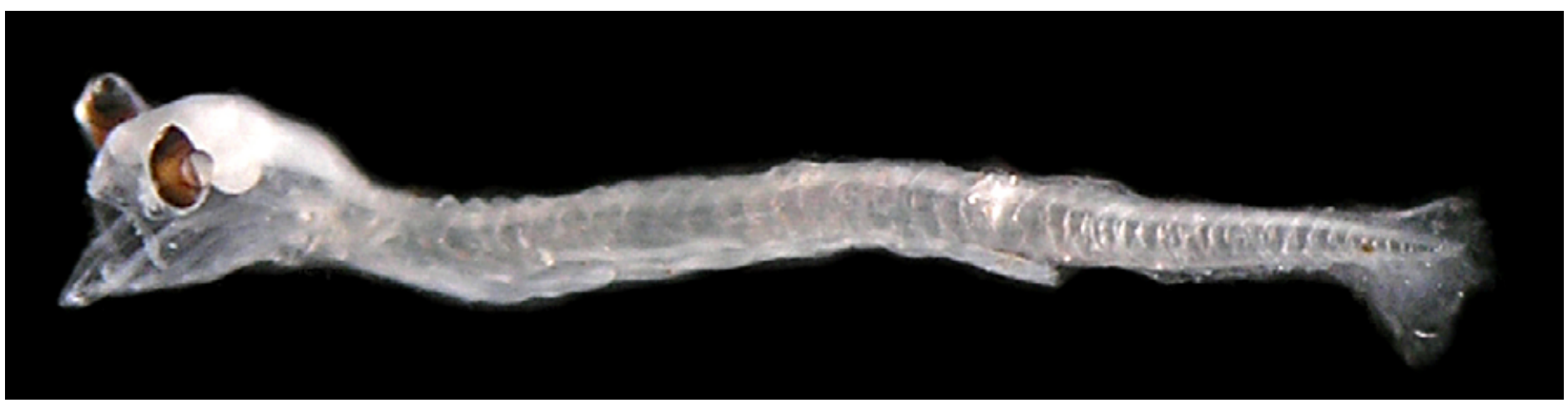

Figura 31 - A: Vinciguerria nimbaria. DZUFRJ 12034; Pré-flexão; CP 4,7 mm.

\section{Vinciguerria nimbaria (Jordan \& Williams, 1895)}

As larvas nos estágios de pré-flexão, flexão e pós-flexão possuem olhos elípticos, o focinho é pontudo e o intestino é longo (mais de 70\% do comprimento padrão). Durante o desenvolvimento a distância pré-anal diminui. A nadadeira adiposa é pequena e está presente a partir da pós-flexão. O número de miômeros varia entre 40 e 42 . A principal característica que distingue essa espécie das demais larvas do gênero Vinciguerria é a presença de um pigmento na região ventral do pedúnculo caudal. A origem da nadadeira anal está embaixo do meio da nadadeira dorsal. A nadadeira anal é mais curta (13 a 15 raios) que a de Pollichthys mauli. Nas larvas maiores, que estão na fase de transformação, os fotóforos começam a ser formados e a ganhar pigmentação: SO presente; BR 8; IV 21-24; VAV 8-11; AC 13-14; AO 23-24; IC 45-46.

Tamanho: pré-flexão 4,0-5,3 mm; flexão 5,4-10,0 mm; pós-flexão 10,7-17,6 mm; transformação 17,819,5 mm; juvenil 23,4-28,3 mm.

Habitat: espécie marinha, mesopelágica e batipelágica, ocorre em águas tropicais e temperadas em profundidades entre 200 e 400 $\mathrm{m}$ durante o dia. A noite pode ser encontrada desde próximo à superfície até $100 \mathrm{~m}$ de profundidade.

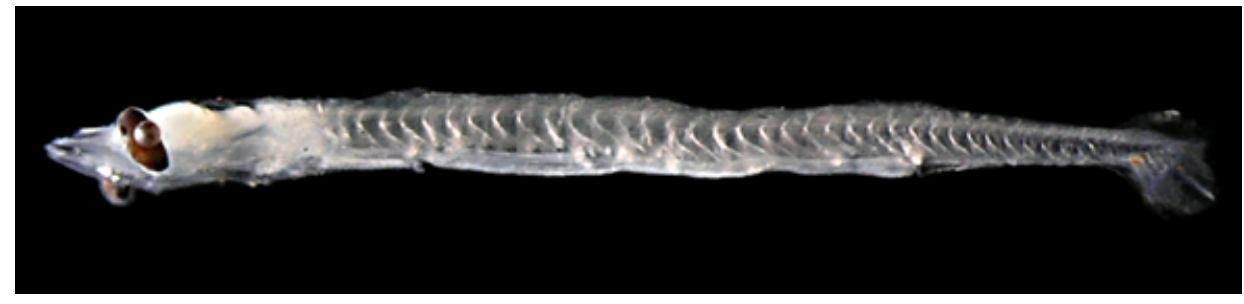

Figura 31 - B: DZUFRJ 19921; Flexão; CP 6,5 mm.

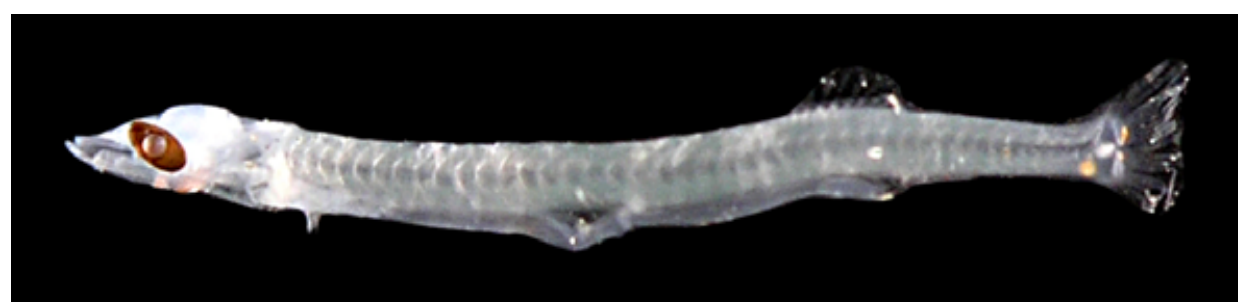

Figura 31 - C: DZUFRJ 19920; Flexão; CP 8,2 mm.

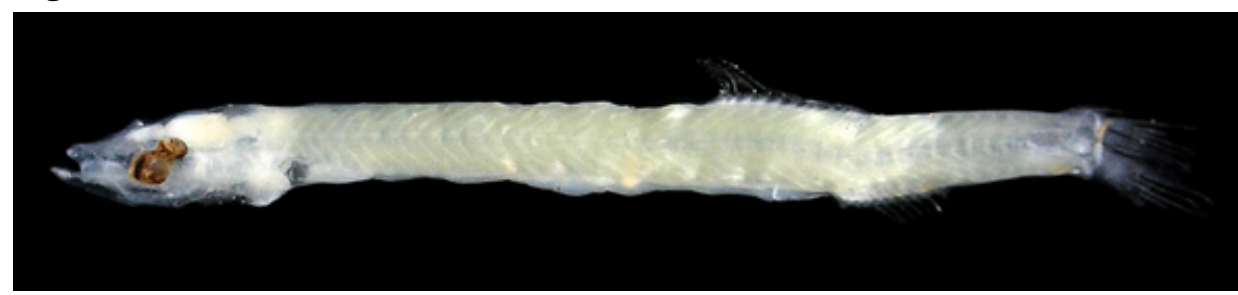

Figura 31 - D: DZUFRJ 1342; Pós-flexão; CP 13,3 mm.

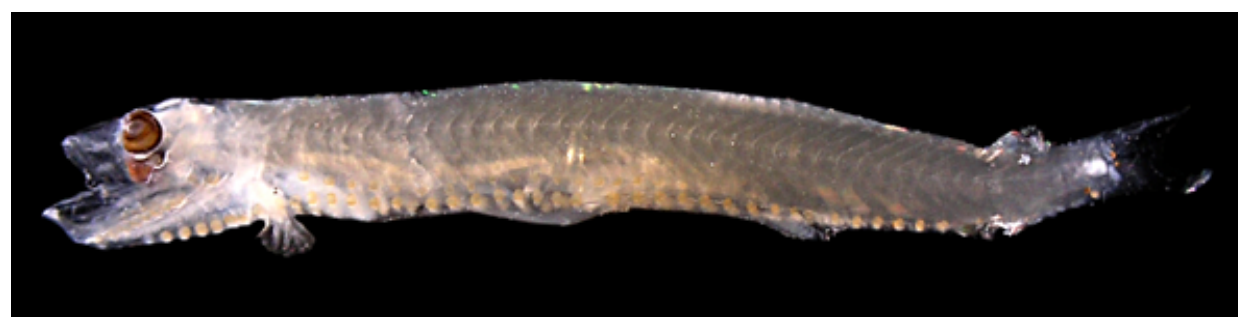

Figura 31 - E: DZUFRJ 19907; Transformação; CP 18,0 mm. 


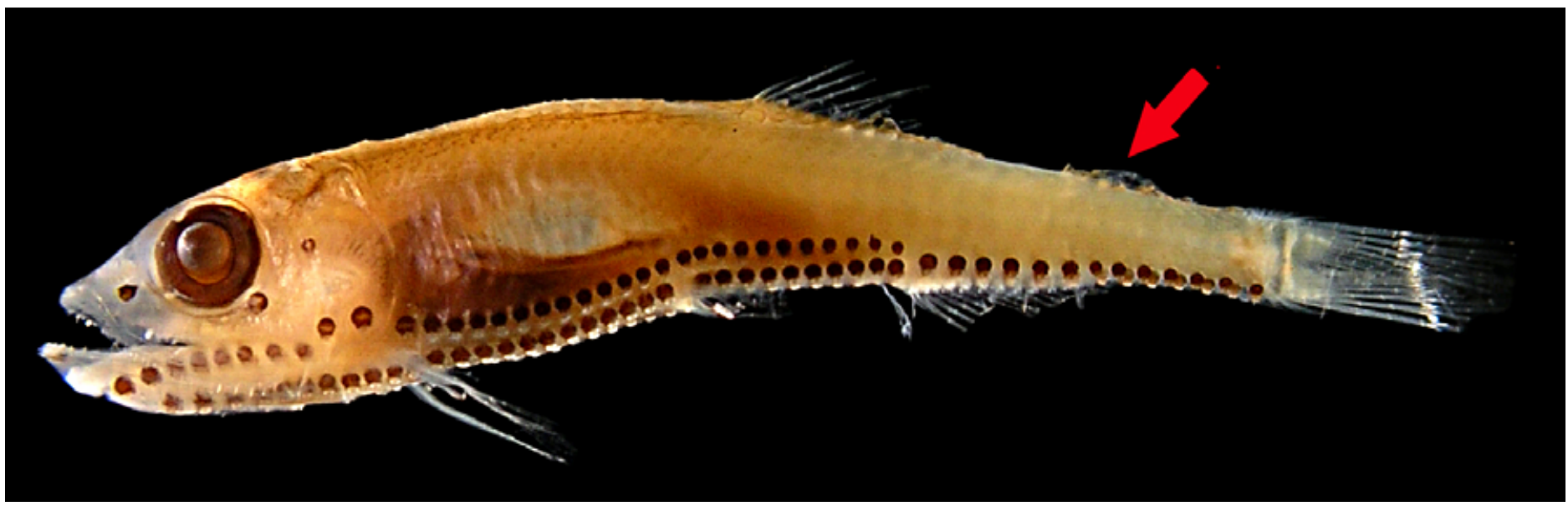

Figura 31 - F: DZUFRJ 1182; Juvenil; CP 23,4 mm.

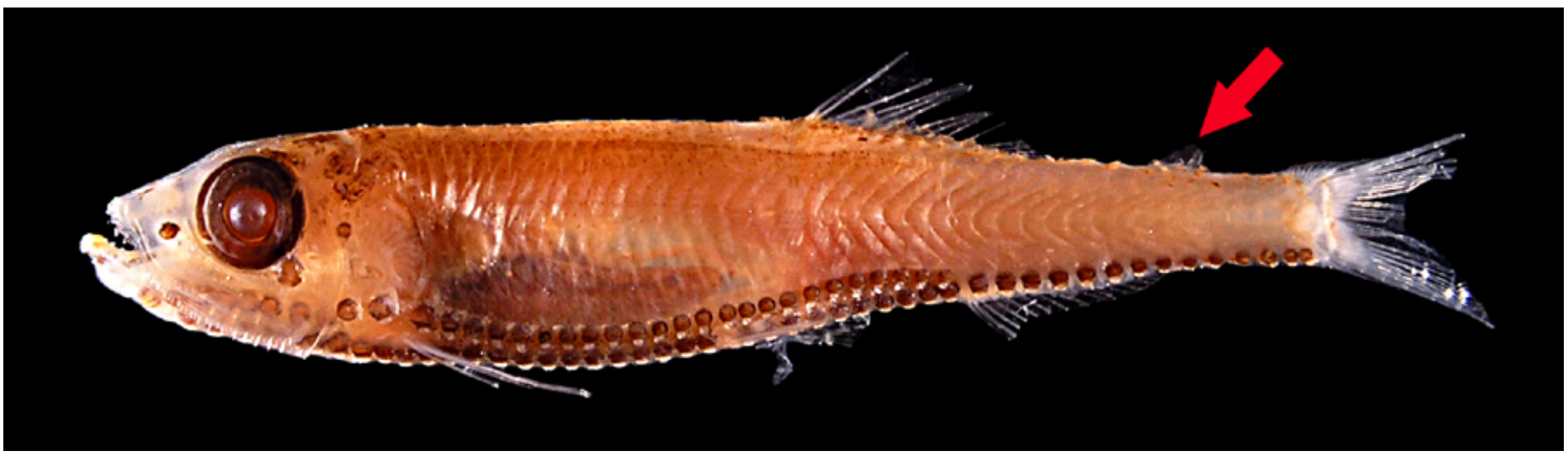

Figura 31 - G: DZUFRJ 7580; Juvenil; CP 28,3 mm.

\section{Georreferenciamento}

\begin{tabular}{|c|c|c|c|c|c|c|c|c|}
\hline DZUFRJ & Latitude (S) & Longitude (W) & Data & $\begin{array}{l}\text { Tipo de } \\
\text { arrasto }\end{array}$ & $\begin{array}{l}\text { Profundidade } \\
\text { de coleta }\end{array}$ & Rede & $\begin{array}{c}\text { Malha } \\
(\mu \mathrm{m})\end{array}$ & $\begin{array}{l}N^{\circ} \text {. de } \\
\text { inds. }\end{array}$ \\
\hline 525 & $22^{\circ} 38^{\prime} 25,0^{\prime \prime}$ & $040^{\circ} 17^{\prime} 41,0^{\prime \prime}$ & $19 / 05 / 2002$ & oblíquo & $40 \mathrm{~m}$ & bongô & 500 & 1 \\
\hline 543 & $22^{\circ} 32^{\prime} 03,0^{\prime \prime}$ & $040^{\circ} 17^{\prime} 21,0^{\prime \prime}$ & $19 / 05 / 2002$ & oblíquo & $30 \mathrm{~m}$ & bongô & 330 & 8 \\
\hline 558 & $22^{\circ} 32^{\prime} 03,0^{\prime \prime}$ & $040^{\circ} 17^{\prime} 21,0^{\prime \prime}$ & $19 / 05 / 2002$ & oblíquo & $30 \mathrm{~m}$ & bongô & 500 & 8 \\
\hline 583 & $22^{\circ} 33^{\prime} 47,7^{\prime \prime}$ & $040^{\circ} 12^{\prime} 20,5^{\prime \prime}$ & $17 / 05 / 2002$ & oblíquo & $50 \mathrm{~m}$ & bongô & 330 & 20 \\
\hline 600 & $22^{\circ} 33^{\prime} 45,8^{\prime \prime}$ & $040^{\circ} 13^{\prime} 22,9^{\prime \prime}$ & $17 / 05 / 2002$ & oblíquo & $800 \mathrm{~m}$ & cilíndrico-cônica & 500 & 14 \\
\hline 606 & $22^{\circ} 38^{\prime} 29,0^{\prime \prime}$ & $040^{\circ} 17^{\prime} 40,0^{\prime \prime}$ & $18 / 05 / 2002$ & oblíquo & $800 \mathrm{~m}$ & cilíndrico-cônica & 500 & 3 \\
\hline 615 & $22^{\circ} 36^{\prime} 54,9^{\prime \prime}$ & $040^{\circ} 09^{\prime} 19,4^{\prime \prime}$ & $16 / 05 / 2002$ & oblíquo & $50 \mathrm{~m}$ & & 500 & 6 \\
\hline 620 & $22^{\circ} 42^{\prime} 06,0^{\prime \prime}$ & $040^{\circ} 14^{\prime} 26,0^{\prime \prime}$ & $19 / 05 / 2002$ & oblíquo & $50 \mathrm{~m}$ & bongô & 500 & 3 \\
\hline 651 & $22^{\circ} 36^{\prime} 54,9^{\prime \prime}$ & $040^{\circ} 09^{\prime} 19,4^{\prime \prime}$ & $16 / 05 / 2002$ & oblíquo & $50 \mathrm{~m}$ & bongô & 330 & 14 \\
\hline 653 & $22^{\circ} 38^{\prime} 25,0^{\prime \prime}$ & $040^{\circ} 17^{\prime} 41,0^{\prime \prime}$ & $19 / 05 / 2002$ & oblíquo & $40 \mathrm{~m}$ & bongô & 330 & 3 \\
\hline 670 & $22^{\circ} 42^{\prime} 06,0^{\prime \prime}$ & $040^{\circ} 14 ' 26,0^{\prime \prime}$ & $19 / 05 / 2002$ & oblíquo & $50 \mathrm{~m}$ & bongô & 330 & 3 \\
\hline 685 & $22^{\circ} 37^{\prime} 35,5^{\prime \prime}$ & $040^{\circ} 09^{\prime} 32,8^{\prime \prime}$ & $16 / 05 / 2002$ & oblíquo & $1.000 \mathrm{~m}$ & cilíndrico-cônica & 500 & 2 \\
\hline 702 & $22^{\circ} 33^{\prime} 47,7^{\prime \prime}$ & $040^{\circ} 12^{\prime} 20,5^{\prime \prime}$ & $17 / 05 / 2002$ & oblíquo & $50 \mathrm{~m}$ & bongô & 500 & 6 \\
\hline 709 & $22^{\circ} 41^{\prime} 54,7^{\prime \prime}$ & $040^{\circ} 14^{\prime} 04,5^{\prime \prime}$ & $16 / 05 / 2002$ & oblíquo & $1.000 \mathrm{~m}$ & cilíndrico-cônica & 500 & 1 \\
\hline 1182 & $22^{\circ} 07 ' 29,0^{\prime \prime}$ & $039^{\circ} 06^{\prime} 23,5^{\prime \prime}$ & $10 / 05 / 2002$ & oblíquo & $1.000 \mathrm{~m}$ & cilíndrico-cônica & 500 & 7 \\
\hline 1199 & $22^{\circ} 06^{\prime} 52,3^{\prime \prime}$ & $039^{\circ} 48^{\prime} 46,2^{\prime \prime}$ & $11 / 05 / 2002$ & oblíquo & $1.000 \mathrm{~m}$ & cilíndrico-cônica & 500 & 4 \\
\hline 1218 & $22^{\circ} 02^{\prime} 30,0^{\prime \prime}$ & $039^{\circ} 49^{\prime} 41,2^{\prime \prime}$ & $12 / 05 / 2002$ & oblíquo & $1.000 \mathrm{~m}$ & cilíndrico-cônica & 500 & 7 \\
\hline 1235 & $22^{\circ} 03^{\prime} 21,7^{\prime \prime}$ & $039^{\circ} 45^{\prime} 11,9^{\prime \prime}$ & $12 / 05 / 2002$ & oblíquo & $1.000 \mathrm{~m}$ & cilíndrico-cônica & 500 & 3 \\
\hline
\end{tabular}




\begin{tabular}{|c|c|c|c|c|c|c|c|c|}
\hline DZUFRJ & Latitude (S) & Longitude (W) & Data & $\begin{array}{l}\text { Tipo de } \\
\text { arrasto }\end{array}$ & $\begin{array}{c}\text { Profundidade } \\
\text { de coleta }\end{array}$ & Rede & $\begin{array}{l}\text { Malha } \\
(\mu \mathrm{m})\end{array}$ & $\begin{array}{l}N^{\circ} \text {. de } \\
\text { inds. }\end{array}$ \\
\hline 1246 & $22^{\circ} 08^{\prime} 17,5^{\prime \prime}$ & $039^{\circ} 46^{\prime} 28,5^{\prime \prime}$ & $11 / 05 / 2002$ & oblíquo & $1.000 \mathrm{~m}$ & cilíndrico-cônica & 500 & 5 \\
\hline 1278 & $22^{\circ} 06^{\prime} 37,8^{\prime \prime}$ & $039^{\circ} 49^{\prime} 44,8^{\prime \prime}$ & $10 / 05 / 2002$ & oblíquo & até a termoclina & bongô & 500 & 1 \\
\hline 1282 & $22^{\circ} 06^{\prime} 52,3^{\prime \prime}$ & $039^{\circ} 48^{\prime} 46,2^{\prime \prime}$ & $11 / 05 / 2002$ & oblíquo & até a termoclina & bongô & 500 & 1 \\
\hline 1292 & $22^{\circ} 02^{\prime} 30,0^{\prime \prime}$ & $039^{\circ} 49^{\prime} 41,2^{\prime \prime}$ & $12 / 05 / 2002$ & oblíquo & até a termoclina & bongô & 500 & 6 \\
\hline 1306 & $22^{\circ} 08^{\prime} 52,5^{\prime \prime}$ & $039^{\circ} 46^{\prime} 27,9^{\prime \prime}$ & $12 / 05 / 2002$ & oblíquo & até a termoclina & bongô & 500 & 2 \\
\hline 1314 & $22^{\circ} 08^{\prime} 14,9^{\prime \prime}$ & $039^{\circ} 46^{\prime} 34,6^{\prime \prime}$ & $11 / 05 / 2002$ & oblíquo & até a termoclina & bongô & 500 & 6 \\
\hline 1324 & $22^{\circ} 03^{\prime} 03,3^{\prime \prime}$ & $039^{\circ} 50^{\prime} 39,0^{\prime \prime}$ & $10 / 05 / 2002$ & oblíquo & até a termoclina & bongô & 330 & 3 \\
\hline 1342 & $2^{\circ} 06^{\prime} 52,3^{\prime \prime}$ & $039^{\circ} 48^{\prime} 46,2^{\prime \prime}$ & $11 / 05 / 2002$ & oblíquo & até a termoclina & bongô & 330 & 6 \\
\hline 1356 & $22^{\circ} 02^{\prime} 30,0^{\prime \prime}$ & $039^{\circ} 49^{\prime} 41,2^{\prime \prime}$ & $12 / 05 / 2002$ & oblíquo & até a termoclina & bongô & 30 & 18 \\
\hline 1370 & $22^{\circ} 08^{\prime} 52,5^{\prime \prime}$ & $039^{\circ} 46^{\prime} 27,9^{\prime \prime}$ & $12 / 05 / 2002$ & oblíquo & até a termoclina & bongô & 330 & 4 \\
\hline 1379 & $22^{\circ} 08^{\prime} 14,9^{\prime \prime}$ & $039^{\circ} 46^{\prime} 34,6^{\prime \prime}$ & $11 / 05 / 2002$ & oblíquo & até a termoclina & bongô & 330 & 11 \\
\hline 7388 & & $039^{\circ} 54,39^{\prime}$ & $15 / 06 / 2003$ & horizontal & & nêuston & & 1 \\
\hline 7575 & $21^{\circ} 57^{\prime} 10,5^{\prime \prime}$ & $039^{\circ} 43^{\prime} 33,3^{\prime \prime}$ & 09/10/2001 & oblíquo & $1.000 \mathrm{~m}$ & cilíndrico-cônica & 500 & 14 \\
\hline 7577 & 158'31,0" & $039^{\circ} 50^{\prime 29,7 "}$ & $11 / 10 / 2001$ & oblíquo & $1.000 \mathrm{~m}$ & cilíndrico-cônica & 500 & 27 \\
\hline 7578 & '54'36,5" & $039^{\circ} 45^{\prime} 20,0^{\prime \prime}$ & $10 / 10 / 2001$ & & & cilíndrico-cônica & & 25 \\
\hline 7579 & $53^{\prime} 10,4^{\prime \prime}$ & $039^{\circ} 45^{\prime} 49,9^{\prime \prime}$ & $10 / 10 / 2001$ & uo & & cilíndrico-cônica & 500 & 12 \\
\hline 7580 & `58'31,0" & $039^{\circ} 50 ' 29,7^{\prime \prime}$ & $10 / 10 / 2001$ & oblíquo & 1.00 & cilíndrico-cônica & 500 & 10 \\
\hline 7581 & & $039^{\circ} 43^{\prime} 33,3^{\prime \prime}$ & $09 / 10 / 2001$ & oblíc & & cilíndrico-cônica & 50 & 20 \\
\hline 7583 & $54 ' 36,5^{\prime \prime}$ & $039^{\circ} 45^{\prime} 20,0^{\prime \prime}$ & $09 / 10 / 2001$ & & & cilíndrico-cônica & 500 & 12 \\
\hline 7587 & '58'31,0" & $039^{\circ} 50^{\prime} 29,7^{\prime \prime}$ & $10 / 10 / 2001$ & blíquo & & cilíndrico-cônica & 500 & 18 \\
\hline 7588 & & $039^{\circ} 45^{\prime} 49,9^{\prime \prime}$ & $10 / 10 / 2001$ & & & cilíndrico-cônica & 500 & 8 \\
\hline 7593 & ${ }^{\circ} 53 ' 10,4$ " & $039^{\circ} 45^{\prime} 49,9^{\prime \prime}$ & $10 / 10 / 2001$ & oblíquo & & cilíndrico-cônica & 500 & 3 \\
\hline 7594 & ${ }^{\circ} 54$ '36, 5" & $039^{\circ} 45^{\prime} 20,0^{\prime \prime}$ & $10 / 10 / 2001$ & oblíquo & $1.000 \mathrm{~m}$ & cilíndrico-cônica & 500 & 16 \\
\hline 19907 & $2^{\circ} 08^{\prime} 01,8^{\prime \prime}$ & $039^{\circ} 37^{\prime} 30,8^{\prime \prime}$ & $03 / 12 / 2002$ & vertical & $1.400-2$ & cilíndrico-cônica & 200 & 2 \\
\hline 19908 & $22^{\circ} 08^{\prime} 01,8^{\prime \prime}$ & $039^{\circ} 37^{\prime} 30,8^{\prime \prime}$ & $03 / 12 / 2002$ & vertical & $200-500 m$ & cilíndrico-cônica & 500 & 1 \\
\hline 19909 & $22^{\circ} 08^{\prime} 01,8^{\prime \prime}$ & $039^{\circ} 37^{\prime} 30,8^{\prime \prime}$ & $03 / 12 / 2002$ & vertical & & cilíndrico-cônica & 500 & 3 \\
\hline 19912 & & & $15 / 06 / 2003$ & & & cilíndrico-cônica & 50 & 2 \\
\hline 19913 & $22^{\circ} 32^{\prime} 50,0^{\prime \prime}$ & $040^{\circ} 04^{\prime} 09,9^{\prime \prime}$ & $06 / 11 / 2001$ & oblíquo & $1.000 \mathrm{~m}$ & cilíndrico-cônica & 500 & 15 \\
\hline 19914 & $22^{\circ} 31^{\prime} 40,9^{\prime \prime}$ & $040^{\circ} 02^{\prime} 39,6^{\prime \prime}$ & $07 / 11 / 2001$ & oblíquo & $1.000 \mathrm{~m}$ & cilíndrico-cônica & 50 & 29 \\
\hline 19920 & $22^{\circ} 39,68^{\prime}$ & $040^{\circ} 03,24^{\prime}$ & $13 / 06 / 2003$ & vertical & & cilíndrico-cônica & 50 & 1 \\
\hline 19921 & $22^{\circ} 02,27^{\prime}$ & $039^{\circ} 43,49^{\prime}$ & $18 / 06 / 2003$ & vertical & $90 \mathrm{~m}$ & cilíndrico-cônica & 500 & 7 \\
\hline 19933 & $22^{\circ} 32^{\prime} 49,0^{\prime \prime}$ & $040^{\circ} 04^{\prime} 20,9^{\prime \prime}$ & $07 / 11 / 2001$ & oblíquo & $1.000 \mathrm{~m}$ & cilíndrico-cônica & 500 & 7 \\
\hline 19934 & $22^{\circ} 32^{\prime} 50,0^{\prime \prime}$ & $040^{\circ} 04^{\prime} 09,9^{\prime \prime}$ & $06 / 11 / 2001$ & & & cilíndrico-cônica & 500 & 6 \\
\hline 19935 & $22^{\circ} 32^{\prime} 49,0^{\prime \prime}$ & $040^{\circ} 04^{\prime} 20,9^{\prime \prime}$ & $07 / 11 / 2001$ & oblíquo & $1.000 \mathrm{~m}$ & cilíndrico-cônica & 500 & 17 \\
\hline 19936 & $22^{\circ} 31^{\prime} 58,9^{\prime \prime}$ & $040^{\circ} 02^{\prime} 53,4^{\prime \prime}$ & $07 / 11 / 2001$ & oblíquo & $1.000 \mathrm{~m}$ & cilíndrico-cônica & 500 & 7 \\
\hline 19937 & $22^{\circ} 31^{\prime} 58,9^{\prime \prime}$ & $040^{\circ} 02^{\prime} 53,4^{\prime \prime}$ & $07 / 11 / 2001$ & & $1.000 \mathrm{~m}$ & cilíndrico-cônica & 500 & 11 \\
\hline 19938 & $22^{\circ} 32^{\prime} 50,0^{\prime \prime}$ & $040^{\circ} 04^{\prime} 09,9^{\prime \prime}$ & $06 / 11 / 2001$ & oblíquo & $1.000 \mathrm{~m}$ & cilíndrico-cônica & 500 & 2 \\
\hline 19939 & $22^{\circ} 32^{\prime} 49,0^{\prime \prime}$ & $040^{\circ} 04^{\prime} 20,9^{\prime \prime}$ & $07 / 11 / 2001$ & oblíquo & $1.000 \mathrm{~m}$ & cilíndrico-cônica & 500 & 22 \\
\hline 19940 & $22^{\circ} 31^{\prime} 40,9^{\prime \prime}$ & $040^{\circ} 02^{\prime} 39,6^{\prime \prime}$ & $07 / 11 / 2001$ & oblíquo & $1.000 \mathrm{~m}$ & cilíndrico-cônica & 500 & 22 \\
\hline 19941 & $22^{\circ} 31^{\prime} 40,9^{\prime \prime}$ & $040^{\circ} 02^{\prime} 39,6^{\prime \prime}$ & $07 / 11 / 2001$ & oblíquo & $1.000 \mathrm{~m}$ & cilíndrico-cônica & 500 & 14 \\
\hline 19942 & $22^{\circ} 31^{\prime} 58,9^{\prime \prime}$ & $040^{\circ} 02^{\prime} 53,4^{\prime \prime}$ & $07 / 11 / 2001$ & oblíquo & $1.000 \mathrm{~m}$ & cilíndrico-cônica & 500 & 6 \\
\hline 24457 & $21^{\circ} 57^{\prime} 10,5^{\prime \prime}$ & $039^{\circ} 43^{\prime} 33,3^{\prime \prime}$ & $09 / 10 / 2001$ & oblíquo & $1.000 \mathrm{~m}$ & cilíndrico-cônica & 500 & 7 \\
\hline
\end{tabular}

Referências: Grey, 1964; Fahay, 1983; Watson, 1996b; Bonecker et al., 2006a. 


\section{Família Stomiidae}

A família Stomiidae é marinha e ocorre nos oceanos Atlântico, Índico e Pacífico. Compreende 28 gêneros com aproximadamente 273 espécies. Os representantes dessa família possuem características muito variadas tais como: presença ou ausência de barbilhão e nadadeira peitoral, posição da nadadeira dorsal, comprimento do intestino, formato do olho e padrão de pigmentação.

No Brasil já foram identificadas 57 espécies nas fases de larva e adulto. Nesse estudo são contempladas as espécies Chauliodus sloani, Eustomias sp., Melanostomias sp. e Stomias affinis. 


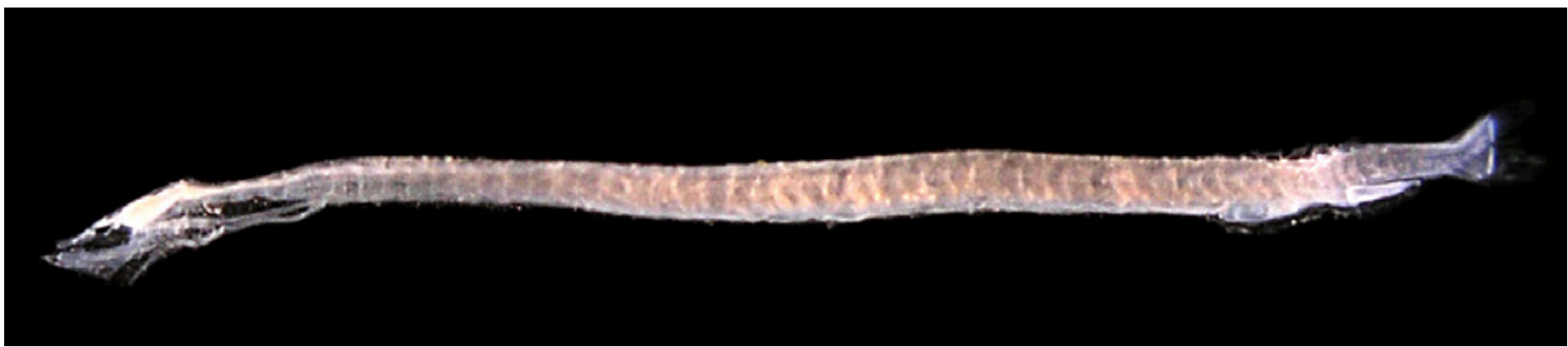

Figura 32 - A: Chauliodus sloani DZUFRJ 5537; Flexão; CP 16,9 mm.

\section{Chauliodus sloani Bloch \& \\ Schneider, 1801}

Apresenta o corpo longo e fino, o olho é oval e o focinho é pontudo. A distância pré-anal é de

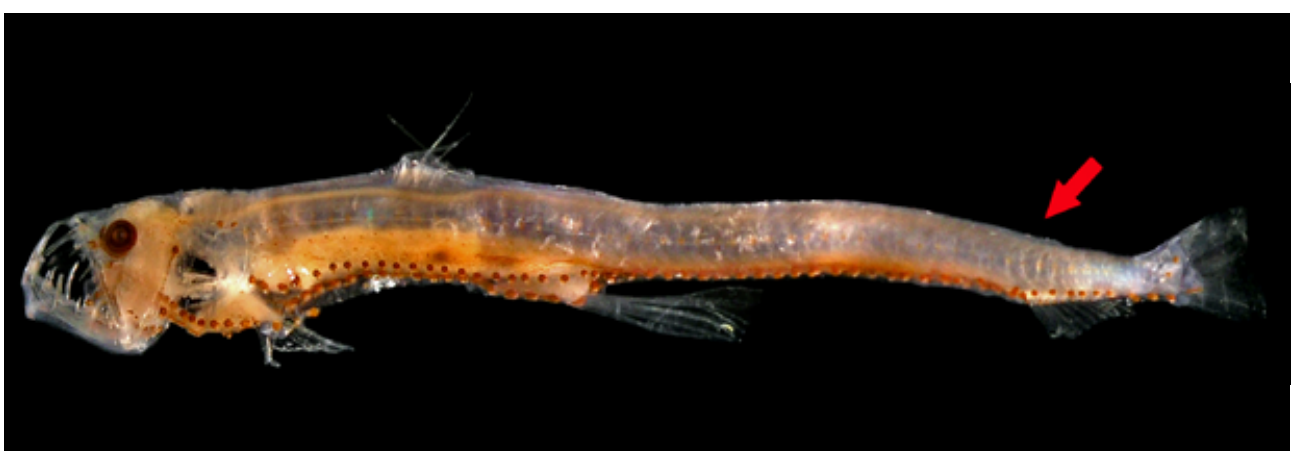

Figura 32 - B: DZUFRJ 22139; Juvenil; CP 27,5 mm. aproximadamente $90 \%$ do comprimento padrão do corpo. A nadadeira dorsal está localizada no primeiro terço do corpo, muito à frente da nadadeira anal. O primeiro raio da nadadeira dorsal é alongado como um filamento. Possui nadadeira adiposa localizada na região dorsal e uma membrana pré-anal que permanece até depois da transformação. O barbilhão é estreito, longo, flexível e geralmente está presente em espécimes com até 100 mm. O número de miômeros varia entre 54 e 62.

Tamanho: flexão 15,8-16,9 mm; juvenil 27,5-28,5 mm.

Habitat: espécie marinha com hábito batipelágico, ocorre em águas temperadas e tropicais até $1.800 \mathrm{~m}$ de profundidade.

\section{Georreferenciamento}

\begin{tabular}{|c|c|c|c|c|c|c|c|c|}
\hline DZUFR & Latitude (S) & Longitude (W) & Data & $\begin{array}{c}\text { Tipo de } \\
\text { arrasto }\end{array}$ & $\begin{array}{c}\text { Profundidade } \\
\text { de coleta }\end{array}$ & Rede & $\begin{array}{c}\text { Malha } \\
\text { ( } \boldsymbol{\mu m} \text { ) }\end{array}$ & $\begin{array}{c}\mathbf{N}^{\circ} \text {. de } \\
\text { inds. }\end{array}$ \\
\hline 5486 & $22^{\circ} 31^{\prime} 58,9^{\prime \prime}$ & $040^{\circ} 02^{\prime} 53,4^{\prime \prime}$ & $07 / 11 / 2001$ & oblíquo & $1.000 \mathrm{~m}$ & cilíndrico-cônica & 500 & 1 \\
\hline 5537 & $22^{\circ} 32^{\prime} 50,0^{\prime \prime}$ & $040^{\circ} 04^{\prime} 09,9^{\prime \prime}$ & $06 / 11 / 2001$ & oblíquo & $1.000 \mathrm{~m}$ & cilíndrico-cônica & 500 & 1 \\
\hline 7501 & $21^{\circ} 54^{\prime} 36,5^{\prime \prime}$ & $039^{\circ} 45^{\prime} 20,0^{\prime \prime}$ & $10 / 10 / 2001$ & oblíquo & $1.000 \mathrm{~m}$ & cilíndrico-cônica & 500 & 1 \\
\hline 7502 & $21^{\circ} 57^{\prime} 10,5^{\prime \prime}$ & $039^{\circ} 43^{\prime} 33,3^{\prime \prime}$ & $09 / 10 / 2001$ & oblíquo & $1.000 \mathrm{~m}$ & cilíndrico-cônica & 500 & 1 \\
\hline 22139 & $22^{\circ} 31^{\prime} 40,9^{\prime \prime}$ & $040^{\circ} 02^{\prime} 39,6^{\prime \prime}$ & $07 / 11 / 2001$ & oblíquo & $1.000 \mathrm{~m}$ & cilíndrico-cônica & 500 & 1 \\
\hline
\end{tabular}

Referências: Morrow Jr., 1964a; Moser, 1996; Bonecker et al., 2006a; Castro \& Bonecker, 2006b; Richards, 2006d. 


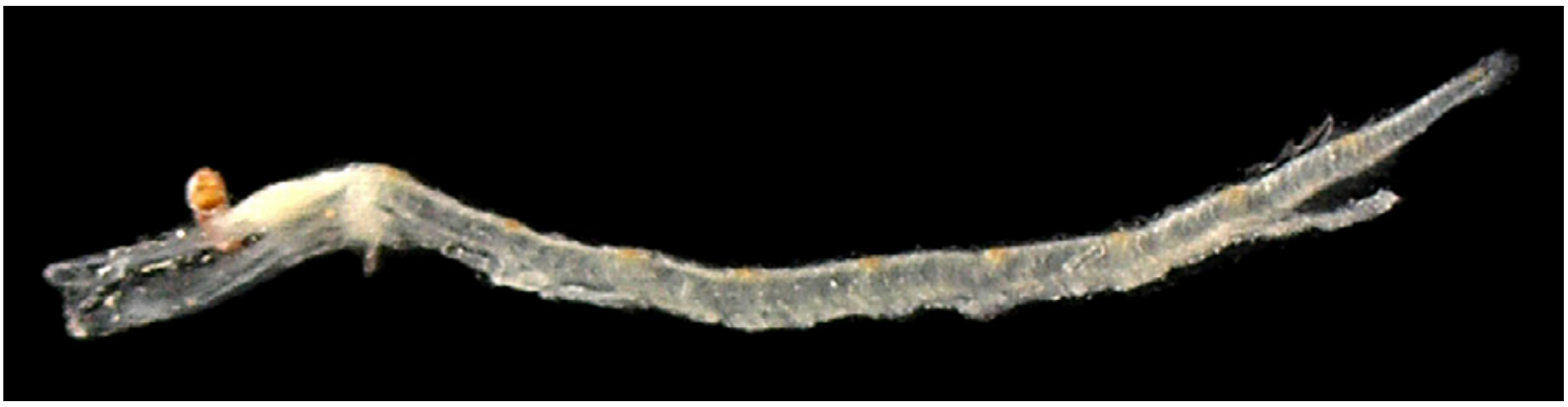

Figura 33 - A: Eustomias sp. DZUFRJ 6120; Pré-flexão; CP 11,0 mm.

\section{Eustomias sp.}

As larvas de Eustomias têm corpo muito alongado e intestino estreito e longo, com uma grande parte livre. As nadadeiras dorsal e anal estão situadas na região posterior do corpo, próximo ao

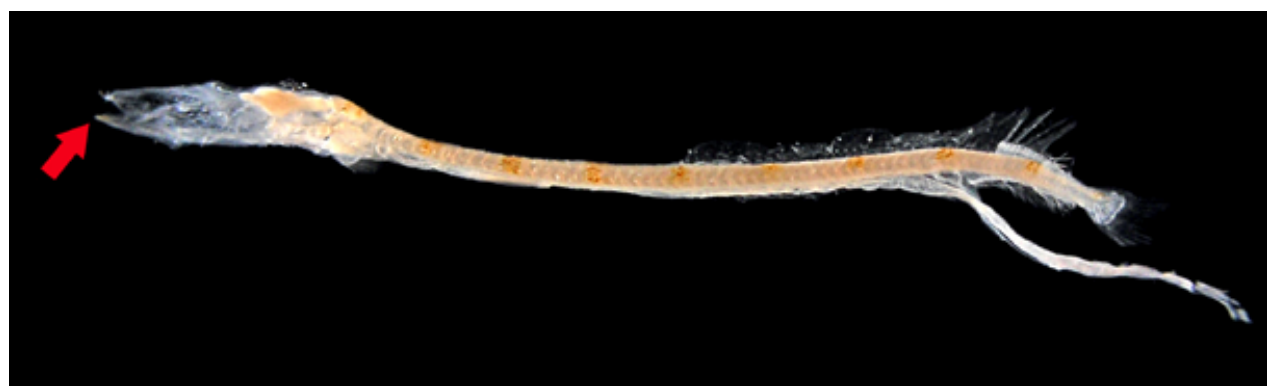

Figura 33 - B: DZUFRJ 6122; Flexão; CP 22,9 mm. pedúnculo caudal. A nadadeira anal é maior e com origem mais anterior que a dorsal. A cabeça é longa e comprimida dorsoventralmente; o olho é pequeno, pedunculado e elíptico. Apresenta uma série de sete a nove melanóforos grandes na região dorsal, desde a nadadeira pélvica até o início da dorsal, e um único melanóforo na extremidade da maxila inferior. O número de miômeros varia aproximadamente entre 56 e 71. No Brasil já foram registradas 16 espécies de Eustomias.

Tamanho: pré-flexão 11,0-15,4 mm; flexão 20,0 mm.

Habitat: todas as espécies de Eustomias registradas na literatura são marinhas. A maioria é mesopelágica e algumas são batipelágicas, ocorre desde próximo à superfície até $1.800 \mathrm{~m}$ de profundidade.

\section{Georreferenciamento}

\begin{tabular}{|c|c|c|c|c|c|c|c|c|}
\hline DZUFRJ & Latitude (S) & Longitude (W) & Data & $\begin{array}{c}\text { Tipo de } \\
\text { arrasto }\end{array}$ & $\begin{array}{c}\text { Profundidade } \\
\text { de coleta }\end{array}$ & Rede & $\begin{array}{c}\text { Malha } \\
\text { ( } \boldsymbol{\mu m})\end{array}$ & $\begin{array}{c}\mathbf{N}^{\circ} \text {. de } \\
\text { inds. }\end{array}$ \\
\hline 5489 & $22^{\circ} 32^{\prime} 50,0^{\prime \prime}$ & $040^{\circ} 04^{\prime} 09,9^{\prime \prime}$ & $06 / 11 / 2001$ & oblíquo & $1.000 \mathrm{~m}$ & cilíndrico-cônica & 500 & 2 \\
\hline 7511 & $21^{\circ} 57^{\prime} 10,5^{\prime \prime}$ & $039^{\circ} 43^{\prime} 33,3^{\prime \prime}$ & $09 / 10 / 2001$ & oblíquo & $1.000 \mathrm{~m}$ & cilíndrico-cônica & 500 & 1 \\
\hline
\end{tabular}

Referências: Moser, 1996; Bonecker et al., 2006a; Castro \& Bonecker, 2006b; Richards, 2006 e. 


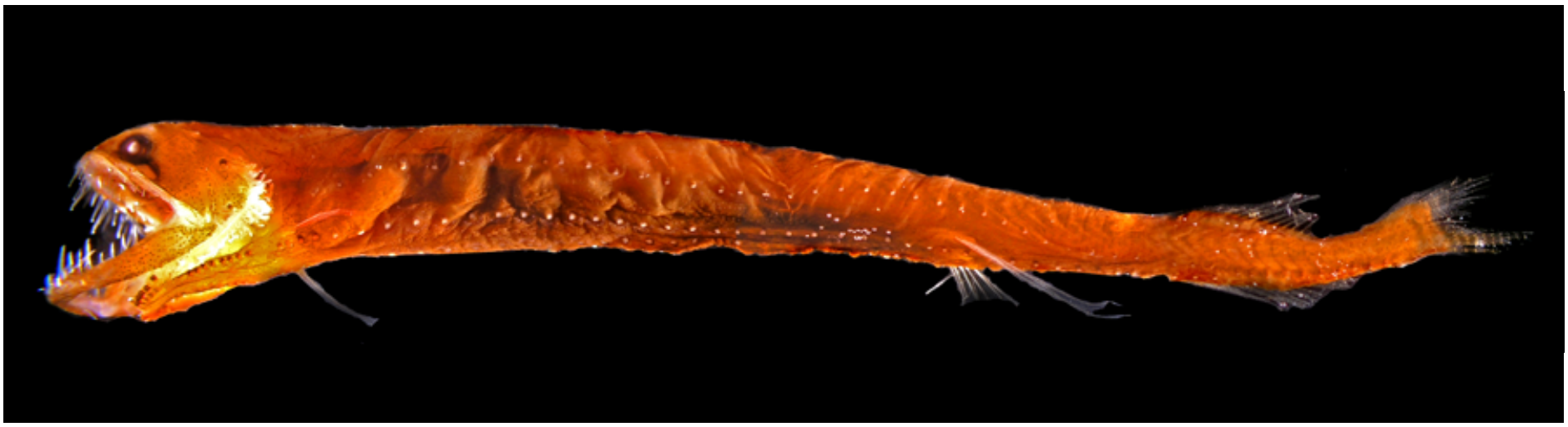

Figura 34: Melanostomias sp. DZUFRJ 22140; Juvenil; CP 57,0 mm.

\section{Melanostomias sp.}

As larvas de Melanostomias apresentam corpo alongado e intestino reto e longo com a extremidade livre. As nadadeiras dorsal e anal têm aproximadamente a mesma origem e estão situadas na região posterior do corpo, próximo ao pedúnculo caudal. A cabeça, o focinho e os olhos são pequenos. Nas larvas que não sofreram transformação o olho é elíptico, a membrana embrionária é mais larga na região dorsal do corpo e o intestino tem uma parte livre. Possui uma série descontínua de pigmentos na região dorsal do corpo e nas margens das membranas dorsal e ventral. Há uma linha de pigmentos em cada miômero da região ventral do corpo. O número de miômeros varia aproximadamente entre 50 e 55. Nos indivíduos no estágio juvenil observam-se duas séries de fotóforos abaixo da linha lateral. O exemplar coletado estava sem o barbilhão que provavelmente foi perdido. A presença da nadadeira peitoral e o número de fotóforos são características importantes para a identificação do gênero, uma vez que o barbilhão pode ser perdido. Nadadeira pélvica 7 raios; nadadeira peitoral 5 raios; nadadeira dorsal 14 raios e nadadeira anal com aproximadamente 18 raios. Possui 49 fotóforos na primeira série e cerca de 42 fotóforos na série mais ventral. No Brasil já foram registradas as espécies Melanostomias macrophotus Regan \& Trewawas, 1930; Melanostomias melanops Brauer, 1902; Melanostomias niger Gilchrist \& Von Bonde, 1924 e Melanostomias valdiviae Brauer, 1902.

Tamanho: juvenil 57,0 mm.

Habitat: todas as espécies de Melanostomias registradas na literatura são marinhas. A maioria é mesopelágica e batipelágica, ocorre em profundidades entre 45 e 1.350 m.

\section{Georreferenciamento}

\begin{tabular}{|c|c|c|c|c|c|c|c|c|}
\hline DZUFRJ & Latitude (S) & Longitude (W) & Data & $\begin{array}{c}\text { Tipo de } \\
\text { arrasto }\end{array}$ & $\begin{array}{c}\text { Profundidade } \\
\text { de coleta }\end{array}$ & Rede & $\begin{array}{c}\text { Malha } \\
\text { ( } \boldsymbol{\mu m})\end{array}$ & $\begin{array}{c}\mathbf{N}^{\circ} \text {. de } \\
\text { inds. }\end{array}$ \\
\hline 22140 & $21^{\circ} 53^{\prime} 10,4^{\prime \prime}$ & $039^{\circ} 45^{\prime} 49,9^{\prime \prime}$ & $10 / 10 / 2001$ & oblíquo & $1.000 \mathrm{~m}$ & $\begin{array}{c}\text { cilíndrico- } \\
\text { cônica }\end{array}$ & 500 & 1 \\
\hline
\end{tabular}

Referências: Morrow Jr., 1964b; Moser, 1996; Bonecker et al., 2006a; Castro \& Bonecker, 2006; Richards, 2006e. 


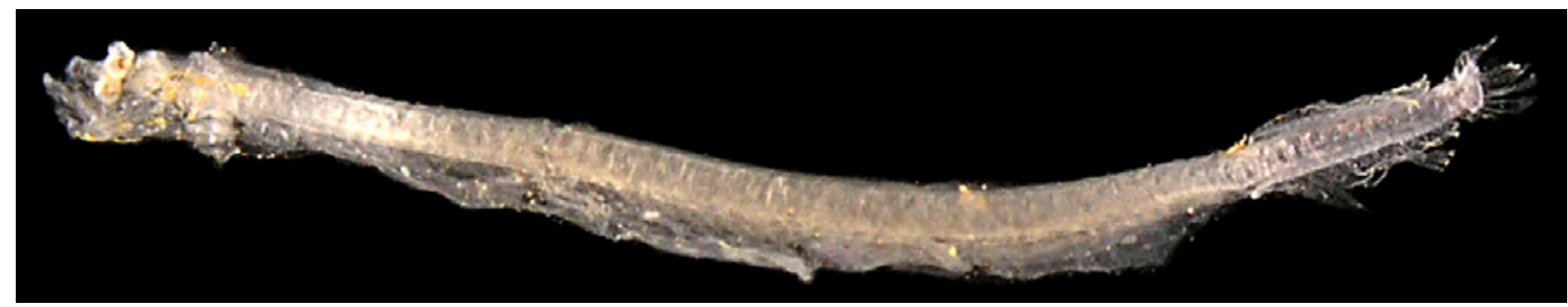

Figura 35 - A: Stomias affinis. DZUFRJ 7529; Flexão; CP 20,0 mm.

\section{Stomias affinis Günther, 1887}

Possui corpo alongado e intestino reto e longo, com a extremidade livre. As nadadeiras dorsal e anal estão situadas na região posterior do corpo, próximo ao pedúnculo caudal. A cabeça e o focinho são pequenos; o olho é pequeno e elíptico nas larvas que não sofreram transformação. Nos exemplares maiores a nadadeira pélvica está situada na porção posterior do corpo, mais próxima às nadadeiras dorsal e anal. O barbilhão é aproximadamente do tamanho da cabeça e termina em um bulbo luminoso de onde saem três filamentos finos e simples. Os órgãos luminosos estão espalhados pelo corpo arranjados em padrões de áreas pigmentadas na pele, abaixo das escamas. Nos juvenis, existem entre seis e oito fotóforos grandes ordenados em séries longitudinais. Nas três primeiras séries, existe apenas um fotóforo. Na quarta série existem de dois a três fotóforos, um sobre o outro. Na sexta série existem três fotóforos, mais ou menos ordenados em linha vertical.

Tamanho: flexão 20,0 mm; juvenil 55,0 mm; adulto 130,0 $\mathrm{mm}$.

Habitat: espécie marinha e batipelágica, ocorre até $3.182 \mathrm{~m}$ de profundidade.

\section{Georreferenciamento}

\begin{tabular}{|c|c|c|c|c|c|c|c|c|}
\hline DZUFRJ & Latitude (S) & Longitude (W) & Data & $\begin{array}{l}\text { Tipo de } \\
\text { arrasto }\end{array}$ & $\begin{array}{l}\text { Profundidade } \\
\text { de coleta }\end{array}$ & Rede & $\begin{array}{l}\text { Malha } \\
(\mu \mathrm{m})\end{array}$ & $\begin{array}{l}N^{\circ} \text {. de } \\
\text { inds. }\end{array}$ \\
\hline 1209 & $22^{\circ} 02^{\prime} 30,0^{\prime \prime}$ & $039^{\circ} 49^{\prime} 41,2^{\prime \prime}$ & $12 / 05 / 2002$ & oblíquo & $1.000 \mathrm{~m}$ & cilíndrico-cônica & 500 & 1 \\
\hline 7528 & $21^{\circ} 53^{\prime} 10,4^{\prime \prime}$ & $039^{\circ} 45^{\prime} 49,9^{\prime \prime}$ & $10 / 10 / 2001$ & oblíquo & $0 \mathrm{~m}$ & cilíndrico-cônica & 500 & 1 \\
\hline 7529 & $21^{\circ} 58^{\prime} 31,0^{\prime \prime}$ & $039^{\circ} 50^{\prime} 29,7^{\prime \prime}$ & $10 / 10 / 2001$ & oblíquo & $1.000 \mathrm{~m}$ & cilíndrico-cônica & 500 & 1 \\
\hline
\end{tabular}

Referências: Morrow Jr., 1964b; Moser, 1996; Bonecker et al., 2006a; Castro \& Bonecker, 2006; Richards, $2006 f$.

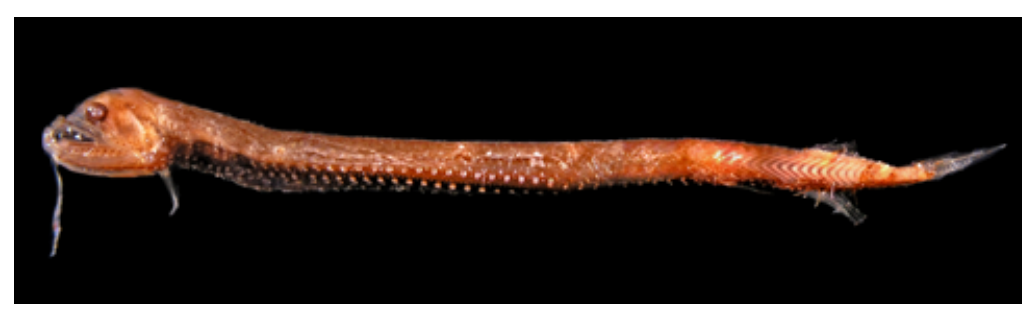

Figura 35 - B: DZUFRJ 7528; Juvenil; CP 55,0 mm.

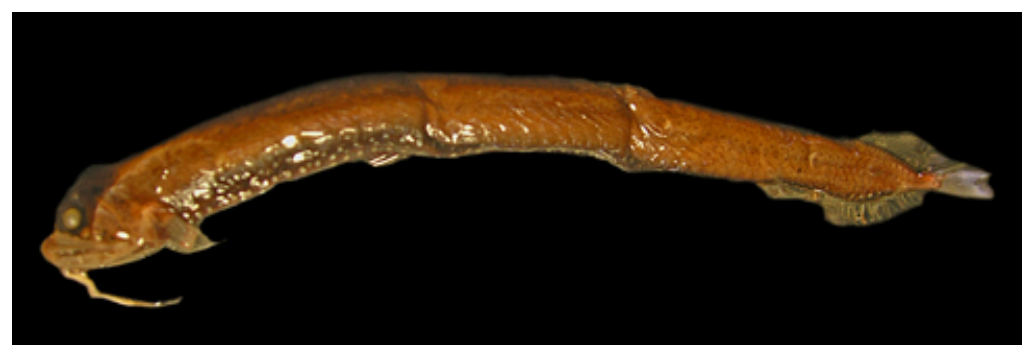

Figura 35 - C: DZUFRJ 269; Adulto; CP ca 123,0 mm.

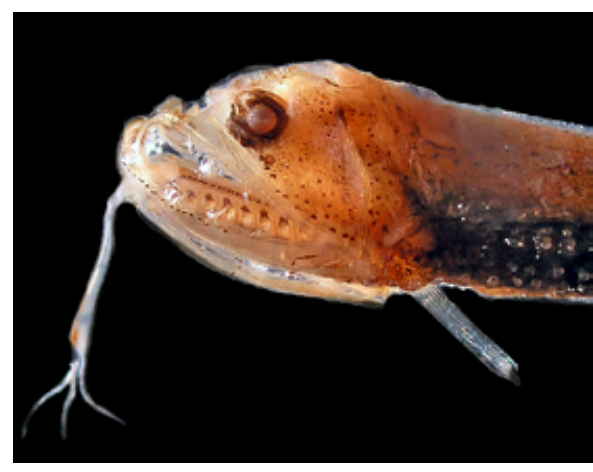

Figura 35 - D: Barbilhão.

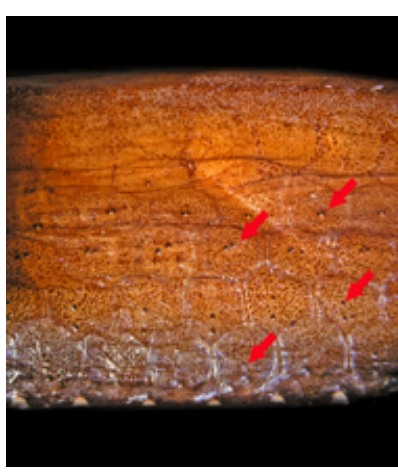

Figura 35 - E: Órgãos luminosos espalhados pelo corpo. 


\section{ORDEM AULOPIFORMES}

A ordem Aulopiformes é composta por 15 famílias e quatro subordens, com hábitos pelágicos, mesopelágicos, batipelágicos e bentônicos. A principal característica que é comum a todas as famílias dessa ordem, com exceção da família Notosudidae, é a presença de pigmentos peritoneais.

Nesse estudo a ordem Aulopiformes é representada pelas famílias Scopelarchidae, Notosudidae, Synodontidae, Paralepididae e Evermannellidae. 


\section{Família Scopelarchidae}

A família Scopelarchidae ocorre em todos os oceanos com exceção do Ártico e do Mar Mediterrâneo. Compreende quatro gêneros com 17 espécies. As larvas de Scopelarchidae podem apresentar corpo fino e alongado ou alto e curto. Possuem de 0-3 seções peritoneais, dependendo da espécie. Os olhos são elípticos e tubulares, normalmente voltados para cima. A posição das nadadeiras pélvicas ajuda na separação dos gêneros e o padrão dos pigmentos acessórios é utilizado na identificação das espécies.

No Brasil já foram identificadas seis espécies nas fases de larva e adulto. Nesse estudo são contempladas as espécies Benthalbella infans e Scopelarchus sp. 


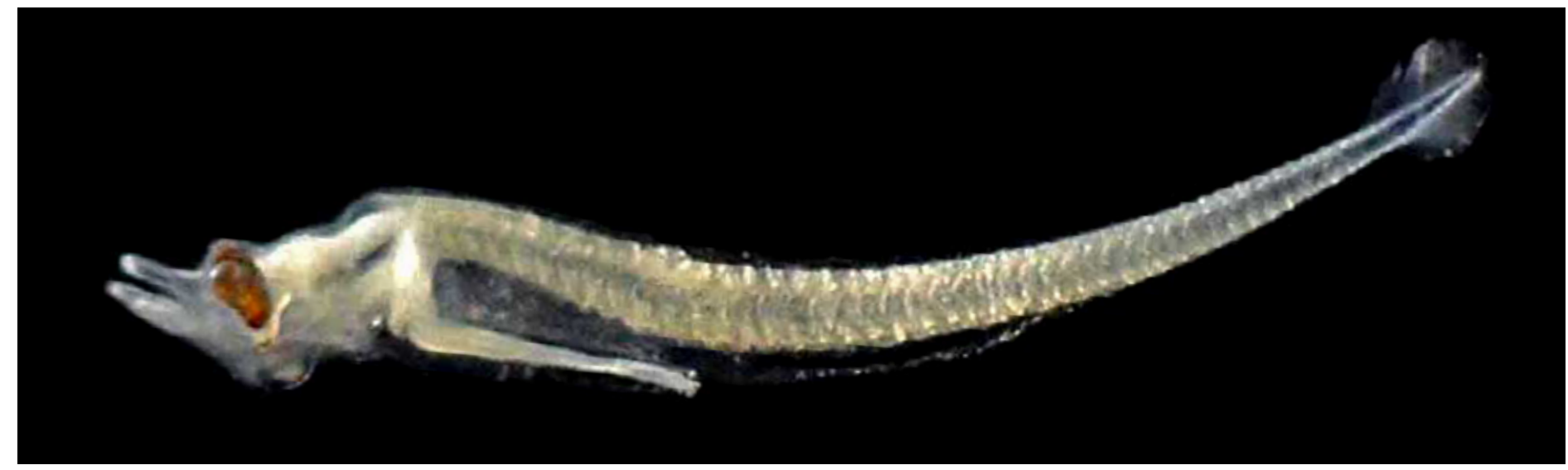

Figura 36 - A: Benthalbella infans. DZUFRJ 17630; Pré-flexão; CP 6,5 mm.

\section{Benthalbella infans Zugmayer, 1911}

As larvas do gênero Benthalbella não apresentam seção peritoneal e nenhum tipo de pigmentação no corpo. As nadadeiras pélvicas estão inseridas antes do início da nadadeira dorsal. O número de vértebras varia entre 54 e 65.

Tamanho: pré-flexão 6,5 mm; flexão 12,0-15,0 mm; pós-flexão $16,0 \mathrm{~mm}$.

Habitat: todas as espécies de Benthalbella encontradas na literatura são marinhas e batipelágicas, ocorrem até $3.400 \mathrm{~m}$ de profundidade.

\section{Georreferenciamento}

\begin{tabular}{|c|c|c|c|c|c|c|c|c|}
\hline DZUFRJ & Latitude (S) & Longitude (W) & Data & $\begin{array}{c}\text { Tipo de } \\
\text { arrasto }\end{array}$ & $\begin{array}{c}\text { Profundidade } \\
\text { de coleta }\end{array}$ & Rede & $\begin{array}{c}\text { Malha } \\
(\boldsymbol{\mu m})\end{array}$ & $\begin{array}{c}\mathbf{N}^{\circ} \text {. de } \\
\text { inds. }\end{array}$ \\
\hline 1186 & $22^{\circ} 07^{\prime} 29,0^{\prime \prime}$ & $039^{\circ} 06^{\prime} 23,5^{\prime \prime}$ & $10 / 05 / 2002$ & oblíquo & $1.000 \mathrm{~m}$ & cilíndrico-cônica & 500 & 1 \\
\hline 1223 & $22^{\circ} 02^{\prime} 30,0^{\prime \prime}$ & $039^{\circ} 49^{\prime} 41,2^{\prime \prime}$ & $12 / 05 / 2002$ & oblíquo & $1.000 \mathrm{~m}$ & cilíndrico-cônica & 500 & 1 \\
\hline 5404 & $22^{\circ} 32^{\prime} 50,0^{\prime \prime}$ & $040^{\circ} 04^{\prime} 09,9^{\prime \prime}$ & $06 / 11 / 2001$ & oblíquo & $1.000 \mathrm{~m}$ & cilíndrico-cônica & 500 & 1 \\
\hline 7497 & $21^{\circ} 58^{\prime} 31,0^{\prime \prime}$ & $039^{\circ} 50^{\prime} 29,7^{\prime \prime}$ & $11 / 10 / 2001$ & oblíquo & $1.000 \mathrm{~m}$ & cilíndrico-cônica & 500 & 1 \\
\hline 7498 & $21^{\circ} 58^{\prime} 31,0^{\prime \prime}$ & $039^{\circ} 50^{\prime} 29,7^{\prime \prime}$ & $10 / 10 / 2001$ & oblíquo & $1.000 \mathrm{~m}$ & cilíndrico-cônica & 500 & 1 \\
\hline 17624 & $22^{\circ} 31^{\prime} 40,9^{\prime \prime}$ & $040^{\circ} 02^{\prime} 39,6^{\prime \prime}$ & $07 / 11 / 2001$ & oblíquo & $1.000 \mathrm{~m}$ & cilíndrico-cônica & 500 & 1 \\
\hline 17627 & $22^{\circ} 32^{\prime} 49,0^{\prime \prime}$ & $040^{\circ} 04^{\prime} 20,9^{\prime \prime}$ & $07 / 11 / 2001$ & oblíquo & $1.000 \mathrm{~m}$ & cilíndrico-cônica & 500 & 1 \\
\hline 17629 & $22^{\circ} 08,03^{\prime}$ & $039^{\circ} 50,1^{\prime}$ & $16 / 06 / 2003$ & vertical & $500 \mathrm{~m}$ & cilíndrico-cônica & 500 & 1 \\
\hline 17630 & $22^{\circ} 02,27^{\prime}$ & $039^{\circ} 43,49^{\prime}$ & $18 / 06 / 2003$ & vertical & $100-480 \mathrm{~m}$ & cilíndrico-cônica & 500 & 1 \\
\hline 17631 & $21^{\circ} 58^{\prime} 31,0^{\prime \prime}$ & $039^{\circ} 50^{\prime} 29,7^{\prime \prime}$ & $10 / 10 / 2001$ & oblíquo & $1.000 \mathrm{~m}$ & cilíndrico-cônica & 500 & 1 \\
\hline
\end{tabular}

Referências: Johnson, 1974; Bonecker et al., 2006b; Ditty, 2006a; Fahay, 2007. 


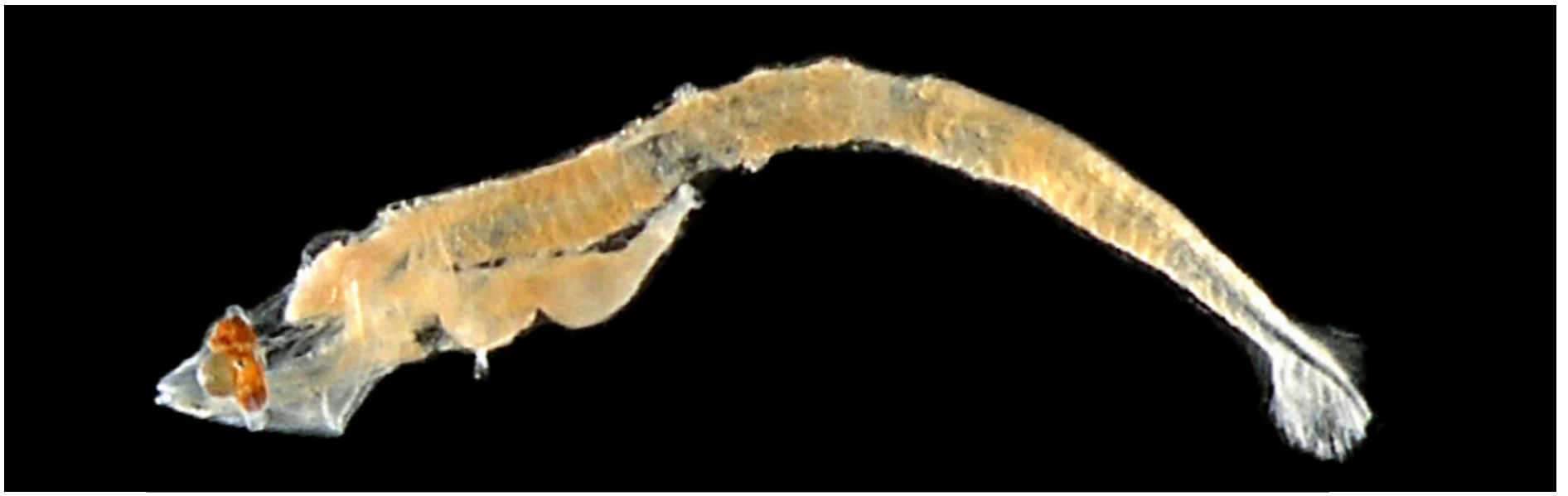

Figura 37 - A: Scopelarchus sp. DZUFRJ 5547; Pré-flexão; CP 5,3 mm.

\section{Scopelarchus sp.}

As larvas de Scopelarchus com mais de $15 \mathrm{~mm}$ de CP possuem pigmentos peritoneais. Pigmentos acessórios ausentes nas larvas menores que 10,0 mm CP. A origem das nadadeiras pélvicas é ventro-lateral, abaixo ou ao nível do intestino, localizada bem atrás da base da nadadeira dorsal. O número de vértebras varia entre 40 e 51 . No Brasil já foram coletadas as espécies Scopelarchus analis (Brauer, 1902), Scopelarchus guentheri Alcock, 1896 e Scopelarchus michaelsarsi Koefoed, 1955.

Tamanho: pré-flexão 4,0-5,3 mm; flexão 6,0-9,5 mm; pós-flexão 18,5 mm.

Habitat: todas as espécies de Scopelarchus registradas na literatura são marinhas e batipelágicas, ocorrem

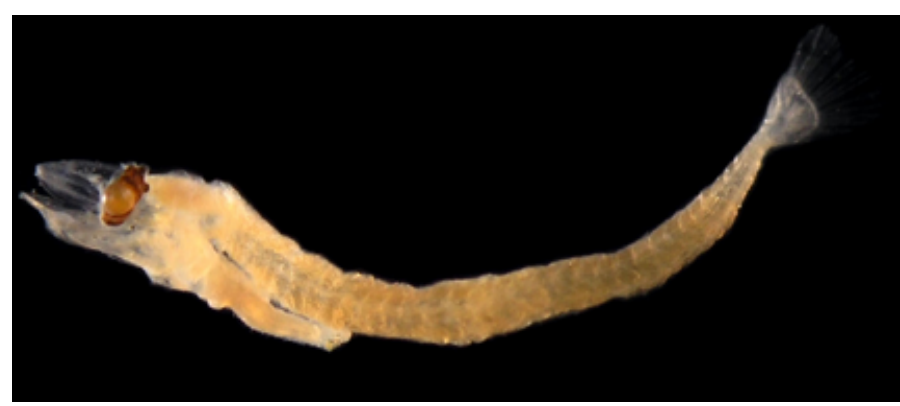

Figura 37 - B: DZUFRJ 17628; Flexão; CP 6,7 mm.

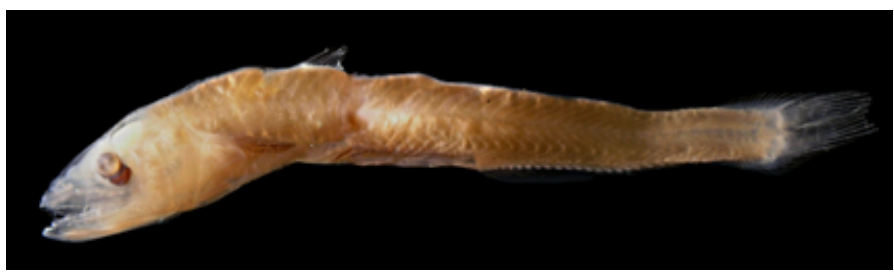

Figura 37 - C: DZUFRJ 7496; Pós-flexão; CP 18,5 mm. até $1.000 \mathrm{~m}$ de profundidade.

\section{Georreferenciamento}

\begin{tabular}{|c|c|c|c|c|c|c|c|c|}
\hline DZUFRJ & Latitude (S) & Longitude (W) & Data & $\begin{array}{l}\text { Tipo de } \\
\text { arrasto }\end{array}$ & $\begin{array}{c}\text { Profundidade } \\
\text { de coleta }\end{array}$ & Rede & $\begin{array}{l}\text { Malha } \\
(\mu \mathrm{m})\end{array}$ & $\begin{array}{l}N^{\circ} \text {. de } \\
\text { inds. }\end{array}$ \\
\hline 1212 & $22^{\circ} 02^{\prime} 30,0^{\prime \prime}$ & $039^{\circ} 49^{\prime} 41,2^{\prime \prime}$ & $12 / 05 / 2002$ & oblíquo & $1.000 \mathrm{~m}$ & cilíndrico-cônica & 500 & 1 \\
\hline 5547 & $22^{\circ} 32^{\prime} 49,0^{\prime \prime}$ & $040^{\circ} 04^{\prime} 20,9 "$ & $07 / 11 / 2001$ & oblíquo & $1.000 \mathrm{~m}$ & cilíndrico-cônica & 500 & 4 \\
\hline 7495 & $21^{\circ} 58 ' 31,0^{\prime \prime}$ & $039^{\circ} 50^{\prime} 29,7^{\prime \prime}$ & 10/10/2001 & oblíquo & $1.000 \mathrm{~m}$ & cilíndrico-cônica & 500 & 1 \\
\hline 7496 & $21^{\circ} 54 ' 36,5^{\prime \prime}$ & $039^{\circ} 45^{\prime} 20,0^{\prime \prime}$ & $10 / 10 / 2001$ & oblíquo & $1.000 \mathrm{~m}$ & cilíndrico-cônica & 500 & 1 \\
\hline 17623 & $22^{\circ} 31^{\prime} 40,9^{\prime \prime}$ & $040^{\circ} 02^{\prime} 39,6^{\prime \prime}$ & $07 / 11 / 2001$ & oblíquo & $1.000 \mathrm{~m}$ & cilíndrico-cônica & 500 & 1 \\
\hline 17625 & $22^{\circ} 31^{\prime} 40,9^{\prime \prime}$ & $040^{\circ} 02^{\prime} 39,6^{\prime \prime}$ & $07 / 11 / 2001$ & oblíquo & $1.000 \mathrm{~m}$ & cilíndrico-cônica & 500 & 1 \\
\hline 17626 & $22^{\circ} 31^{\prime} 40,9^{\prime \prime}$ & $040^{\circ} 02^{\prime} 39,6^{\prime \prime}$ & $07 / 11 / 2001$ & oblíquo & $1.000 \mathrm{~m}$ & cilíndrico-cônica & 500 & 4 \\
\hline 17628 & $22^{\circ} 32^{\prime} 49,0^{\prime \prime}$ & $040^{\circ} 04^{\prime} 20,9^{\prime \prime}$ & $07 / 11 / 2001$ & oblíquo & $1.000 \mathrm{~m}$ & cilíndrico-cônica & 500 & 2 \\
\hline
\end{tabular}

Referências: Johnson, 1974; Osawa, 1986; Bonecker et al., 2006b; Ditty, 2006a; Fahay, 2007. 


\section{Família Notosudidae}

A família Notosudidae é marinha e mesopelágica. Ocorre desde a região subártica até a subantártica. Compreende três gêneros com 19 espécies. As larvas possuem o corpo alongado e fino, com focinho longo e pontudo. Os olhos são estreitos com uma massa cônica de tecido coroide prolongada na região posterior; são um pouco pedunculados nas larvas menores. Presença de nadadeira adiposa. Na maioria das espécies o intestino é curto, alcançando aproximadamente a metade do corpo. A pigmentação ocorre primeiramente na região da cauda e é a principal característica para a identificação das espécies. Algumas espécies não possuem pigmentação no corpo e podem ser separadas pelo número de vértebras.

No Brasil já foram identificadas cinco espécies nas fases de larva e adulto: Ahliesaurus berryi Bertelsen, Krefft \& Marshall, 1976; Luciosudis normani Fraser-Brunner, 1931; Scopelosaurus argenteus (Maul, 1954); Scopelosaurus herwigi Bertelsen, Krefft \& Marshall, 1976 e Scopelosaurus smithii Bean, 1925. Nesse estudo são contempladas as espécies Scopelosaurus herwigi e Scopelosaurus smithii. 


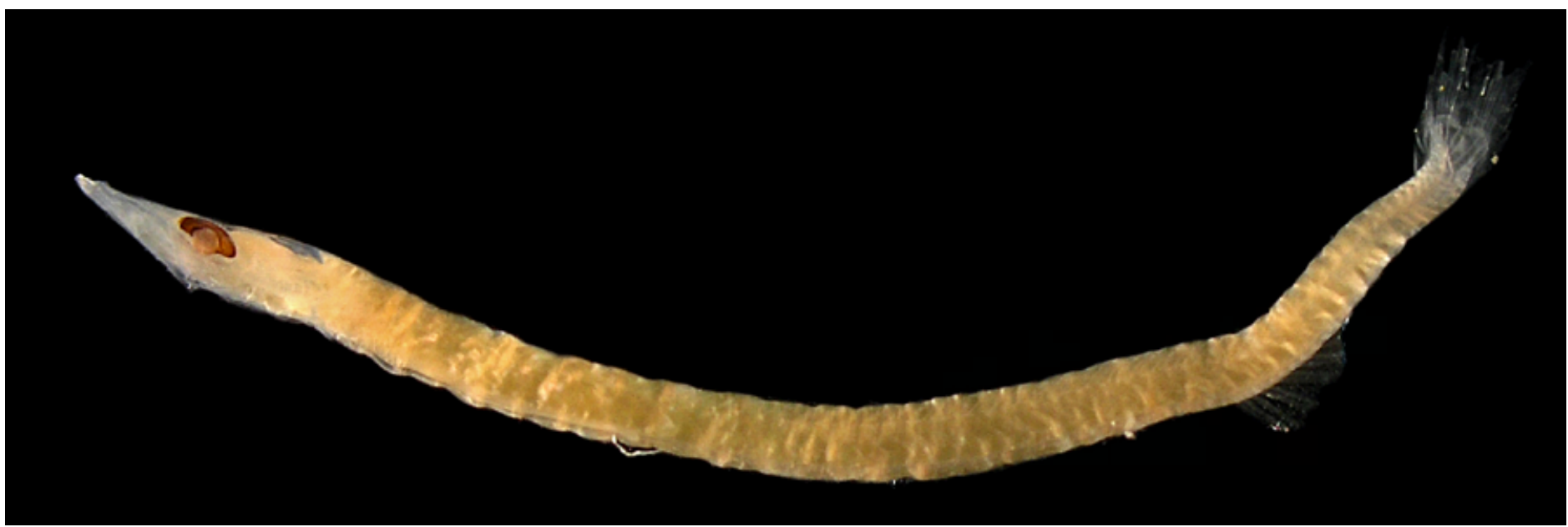

Figura 38: Scopelosaurus herwigi. DZUFRJ 7399; Pós-flexão; CP 22,0 mm.

\section{Scopelosaurus herwigi Bertelsen, Krefft \& Marshall, 1976}

A principal característica da larva dessa espécie é a ausência de pigmentos no corpo. Pode ser separada das demais espécies que também não apresentam pigmento através da contagem do número de vértebras, que nessa espécie varia entre 60 e 62.

Tamanho: flexão 10,5 mm; pós-flexão 22,0-26,0 mm.

Habitat: espécie marinha, bentopelágica, ocorre até 750 m de profundidade.

\section{Georreferenciamento}

\begin{tabular}{|c|c|c|c|c|c|c|c|c|}
\hline DZUFRJ & Latitude (S) & Longitude (W) & Data & $\begin{array}{l}\text { Tipo de } \\
\text { arrasto }\end{array}$ & $\begin{array}{l}\text { Profundidade } \\
\text { de coleta }\end{array}$ & Rede & $\begin{array}{l}\text { Malha } \\
(\mu \mathrm{m})\end{array}$ & $\begin{array}{l}\text { No. de } \\
\text { inds. }\end{array}$ \\
\hline 5385 & $22^{\circ} 31^{\prime} 58,9^{\prime \prime}$ & $040^{\circ} 02^{\prime} 53,4^{\prime \prime}$ & $07 / 11 / 2001$ & oblíquo & $1.000 \mathrm{~m}$ & cilíndrico-cônica & 500 & 1 \\
\hline 5388 & $22^{\circ} 32^{\prime} 50,0^{\prime \prime}$ & $040^{\circ} 04^{\prime} 09,9^{\prime \prime}$ & $06 / 11 / 2001$ & oblíquo & $1.000 \mathrm{~m}$ & cilíndrico-cônica & 500 & 3 \\
\hline 5389 & $22^{\circ} 32^{\prime} 49,0^{\prime \prime}$ & $040^{\circ} 04^{\prime} 20,9^{\prime \prime}$ & $07 / 11 / 2001$ & oblíquo & $1.000 \mathrm{~m}$ & cilíndrico-cônica & 500 & 2 \\
\hline 5390 & $22^{\circ} 31^{\prime} 40,9^{\prime \prime}$ & $040^{\circ} 02^{\prime} 39,6^{\prime \prime}$ & $07 / 11 / 2001$ & oblíquo & $1.000 \mathrm{~m}$ & cilíndrico-cônica & 500 & 1 \\
\hline 5391 & $22^{\circ} 31^{\prime} 58,9^{\prime \prime}$ & $040^{\circ} 02^{\prime} 53,4^{\prime \prime}$ & $07 / 11 / 2001$ & oblíquo & $1.000 \mathrm{~m}$ & cilíndrico-cônica & 500 & 1 \\
\hline 5392 & $22^{\circ} 31^{\prime} 58,9^{\prime \prime}$ & $040^{\circ} 02^{\prime} 53,4^{\prime \prime}$ & $07 / 11 / 2001$ & oblíquo & $1.000 \mathrm{~m}$ & cilíndrico-cônica & 500 & 2 \\
\hline 5394 & $22^{\circ} 31^{\prime} 40,9^{\prime \prime}$ & $040^{\circ} 02^{\prime} 39,6^{\prime \prime}$ & $07 / 11 / 2001$ & oblíquo & $1.000 \mathrm{~m}$ & cilíndrico-cônica & 500 & 5 \\
\hline 5395 & $22^{\circ} 32^{\prime} 49,0^{\prime \prime}$ & $040^{\circ} 04^{\prime} 20,9^{\prime \prime}$ & $07 / 11 / 2001$ & oblíquo & $1.000 \mathrm{~m}$ & cilíndrico-cônica & 500 & 1 \\
\hline 7399 & $21^{\circ} 54^{\prime} 36,5^{\prime \prime}$ & $039^{\circ} 45^{\prime} 20,0^{\prime \prime}$ & $10 / 10 / 2001$ & oblíquo & $1.000 \mathrm{~m}$ & cilíndrico-cônica & 500 & 1 \\
\hline 7402 & $21^{\circ} 58^{\prime} 31,0^{\prime \prime}$ & $039^{\circ} 50^{\prime} 29,7^{\prime \prime}$ & $10 / 10 / 2001$ & oblíquo & $1.000 \mathrm{~m}$ & cilíndrico-cônica & 500 & 3 \\
\hline 24180 & $21^{\circ} 54^{\prime} 36,5^{\prime \prime}$ & $039^{\circ} 45^{\prime} 20,0^{\prime \prime}$ & $09 / 10 / 2001$ & oblíquo & $1.000 \mathrm{~m}$ & cilíndrico-cônica & 500 & 1 \\
\hline 24181 & $22^{\circ} 32^{\prime} 49,0^{\prime \prime}$ & $040^{\circ} 04^{\prime} 20,9^{\prime \prime}$ & $07 / 11 / 2001$ & oblíquo & $1.000 \mathrm{~m}$ & cilíndrico-cônica & 500 & 3 \\
\hline
\end{tabular}

Referências: Bertelsen et al., 1976; Bonecker et al., 2006 b. 


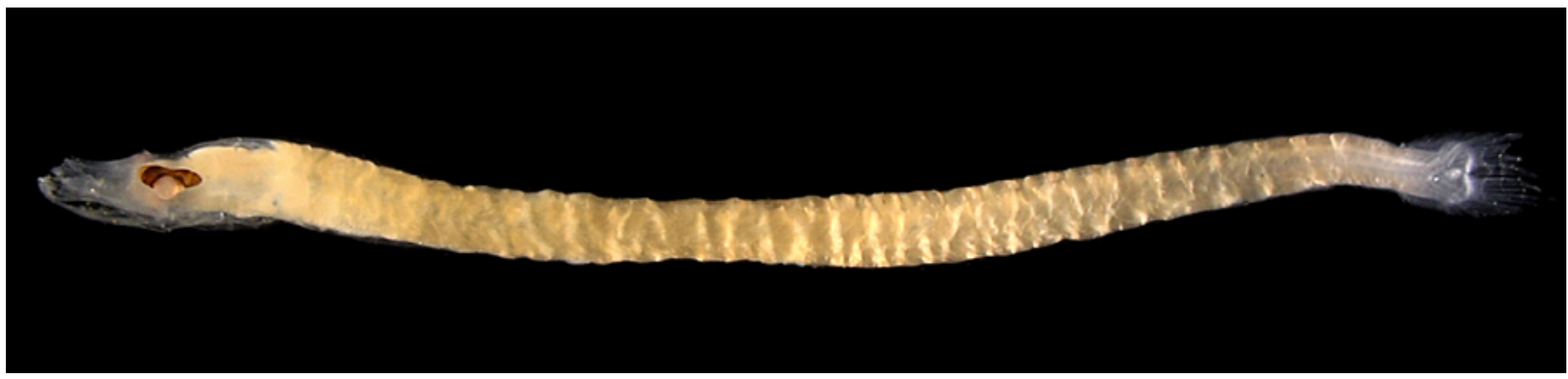

Figura 39 - A: Scopelosaurus smithii. DZUFRJ 7405; Pós-flexão; CP 14,0 mm.

\section{Scopelosaurus smithii Bean, 1925}

Tem corpo alongado e estreito, e o ânus se localiza aproximadamente a 43-45\% do comprimento padrão. A principal característica para a identificação dessa espécie é

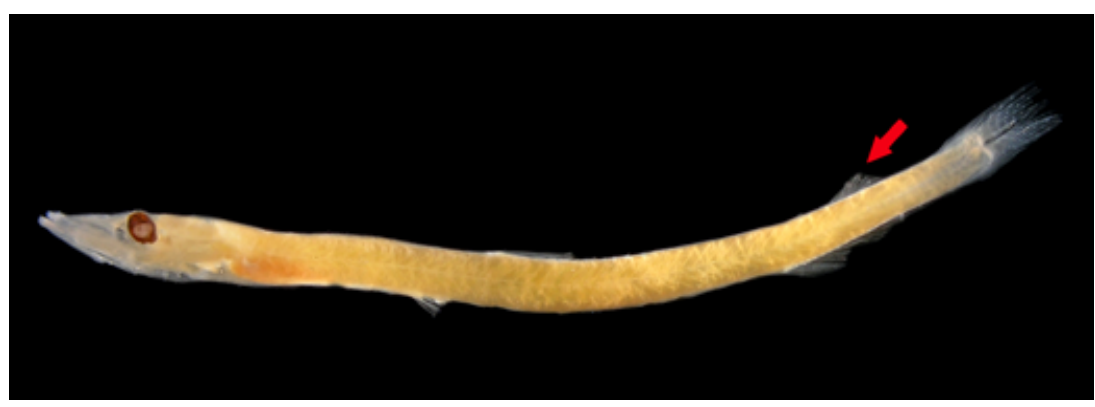

Figura 39 - B: DZUFRJ 7405; Juvenil; CP 31,0 mm. a presença de uma faixa de vários melanóforos pequenos no pedúnculo caudal. Os melanóforos também estão presentes em alguns raios da nadadeira caudal. O número de vértebras nessa espécie varia entre 53 e 56.

Tamanho: pós-flexão 14,0-24,0 mm; juvenil 31,0-33,0 mm.

Habitat: espécie marinha, ocorre em águas tropicais. As larvas são epipelágicas, os juvenis vivem entre 50 e $200 \mathrm{~m}$ de profundidade e os adultos são encontrados em profundidades superiores a $200 \mathrm{~m}$.

\section{Georreferenciamento}

\begin{tabular}{|c|c|c|c|c|c|c|c|c|}
\hline DZUFRJ & Latitude (S) & Longitude (W) & Data & $\begin{array}{l}\text { Tipo de } \\
\text { arrasto }\end{array}$ & $\begin{array}{c}\text { Profundidade } \\
\text { de coleta }\end{array}$ & Rede & $\begin{array}{c}\text { Malha } \\
(\mu \mathrm{m})\end{array}$ & $\begin{array}{l}N^{\circ} \text {. de } \\
\text { inds. }\end{array}$ \\
\hline 1251 & $22^{\circ} 08^{\prime} 17,5^{\prime \prime}$ & $039^{\circ} 46^{\prime} 28,5^{\prime \prime}$ & $11 / 05 / 2002$ & oblíquo & $1.000 \mathrm{~m}$ & cilíndrico-cônica & 500 & 1 \\
\hline 5386 & $22^{\circ} 32^{\prime} 49,0^{\prime \prime}$ & $040^{\circ} 04^{\prime} 20,9^{\prime \prime}$ & $07 / 11 / 2001$ & oblíquo & $1.000 \mathrm{~m}$ & cilíndrico-cônica & 500 & 3 \\
\hline 5387 & $22^{\circ} 32^{\prime} 50,0^{\prime \prime}$ & $040^{\circ} 04^{\prime} 09,9^{\prime \prime}$ & $06 / 11 / 2001$ & oblíquo & $1.000 \mathrm{~m}$ & cilíndrico-cônica & 500 & 1 \\
\hline 5393 & $22^{\circ} 31^{\prime} 40,9^{\prime \prime}$ & $040^{\circ} 02^{\prime} 39,6^{\prime \prime}$ & $07 / 11 / 2001$ & oblíquo & $1.000 \mathrm{~m}$ & cilíndrico-cônica & 500 & 2 \\
\hline 7398 & $21^{\circ} 54^{\prime} 36,5^{\prime \prime}$ & $039^{\circ} 45^{\prime} 20,0^{\prime \prime}$ & $09 / 10 / 2001$ & oblíquo & $1.000 \mathrm{~m}$ & cilíndrico-cônica & 500 & 2 \\
\hline 7400 & $21^{\circ} 53^{\prime} 10,4^{\prime \prime}$ & $039^{\circ} 45^{\prime} 49,9^{\prime \prime}$ & $10 / 10 / 2001$ & oblíquo & $1.000 \mathrm{~m}$ & cilíndrico-cônica & 500 & 1 \\
\hline 7401 & $21^{\circ} 57^{\prime} 10,5^{\prime \prime}$ & $039^{\circ} 43^{\prime} 33,3^{\prime \prime}$ & 09/10/2001 & oblíquo & $1.000 \mathrm{~m}$ & cilíndrico-cônica & 500 & 2 \\
\hline 7404 & $21^{\circ} 57^{\prime} 10,5^{\prime \prime}$ & $039^{\circ} 43^{\prime} 33,3^{\prime \prime}$ & 09/10/2001 & oblíquo & $1.000 \mathrm{~m}$ & cilíndrico-cônica & 500 & 1 \\
\hline 7405 & $21^{\circ} 58^{\prime} 31,0^{\prime \prime}$ & $039^{\circ} 50^{\prime} 29,7^{\prime \prime}$ & $10 / 10 / 2001$ & oblíquo & $1.000 \mathrm{~m}$ & cilíndrico-cônica & 500 & 6 \\
\hline 7406 & $21^{\circ} 53^{\prime} 10,4^{\prime \prime}$ & $039^{\circ} 45^{\prime} 49,9^{\prime \prime}$ & $10 / 10 / 2001$ & oblíquo & $1.000 \mathrm{~m}$ & cilíndrico-cônica & 500 & 5 \\
\hline 24182 & $22^{\circ} 37^{\prime} 21,9^{\prime \prime}$ & $040^{\circ} 02^{\prime} 42,5^{\prime \prime}$ & $08 / 12 / 2002$ & vertical & $200-500 m$ & cilíndrico-cônica & 200 & 1 \\
\hline
\end{tabular}

Referências: Bertelsen et al., 1976; Bonecker et al., 2006b; Richards, 2006g; Fahay, 2007. 


\section{Família Synodontidae}

A família Synodontidae é marinha e raramente ocorre em águas salobras, estando presente nos oceanos Atlântico, Índico e Pacífico. Compreende quatro gêneros com 57 espécies. O corpo é alongado e circular, possui nadadeira adiposa e as nadadeiras pélvicas são abdominais. As larvas dessa família são facilmente reconhecidas pela presença de seis a 12 manchas escuras de pigmentos peritoneais ao longo do intestino. As espécies podem ser separadas pela posição, tamanho, número e espaçamento desses pigmentos, juntamente com o número de miômeros.

No Brasil já foram identificadas 10 espécies nas fases de larva e adulto. Nesse estudo são contempladas as espécies Saurida sp., Synodus synodus e Trachinocephalus myops. 


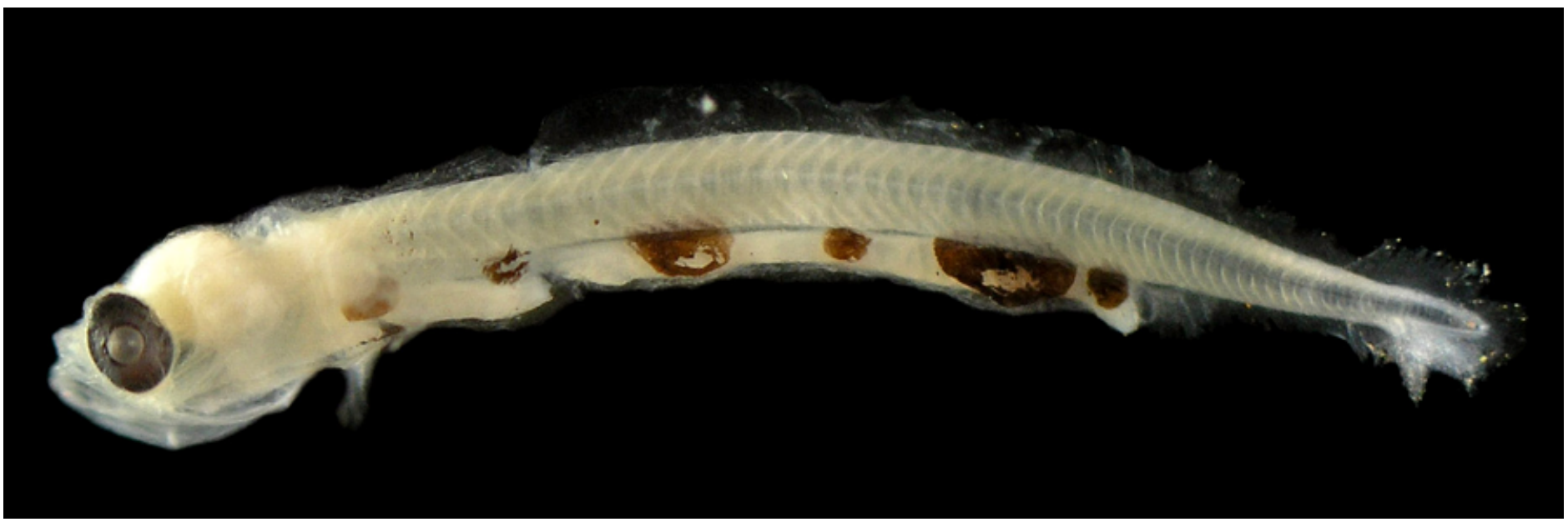

Figura 40 - A: Saurida sp. DZUFRJ 33544; Pré-flexão; CP 5,5 mm.

\section{Saurida}

\section{sp.}

Todas as larvas de Saurida apresentam seis manchas de pigmentos ao longo do intestino; o quinto pigmento é ovalado e maior. Dependendo da espécie, o número

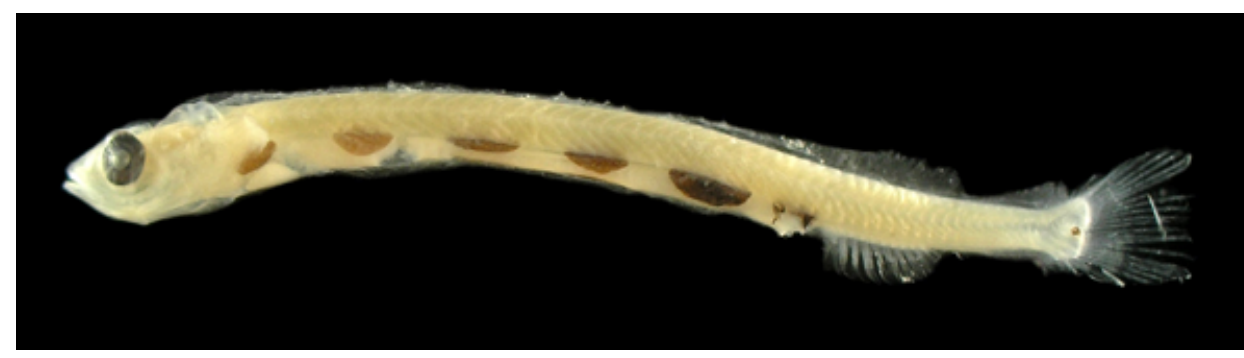

Figura 40 - B: DZUFRJ 33545; Flexão; CP 11,5 mm.

de pigmentos pós-anais pode variar. Os espécimes coletados no presente estudo apresentam um pigmento sobre a base da nadadeira anal e outro posterior a essa nadadeira. O número de miômeros varia aproximadamente entre 45 e 55. No Brasil já foram registradas as espécies Saurida brasiliensis Norman, 1935 e Saurida caribbaea Breder,1927.

Nome vulgar: Peixe-lagarto.

Tamanho: pré-flexão 3,8-5,5 mm; flexão 5,2-15,0 mm.

Habitat: todas as espécies de Saurida são marinhas e algumas podem ocorrer em águas salobras. São demersais, algumas espécies associadas a formações coralinas.

\section{Georreferenciamento}

\begin{tabular}{|c|c|c|c|c|c|c|c|c|}
\hline DZUFRJ & Latitude (S) & Longitude (W) & Data & $\begin{array}{l}\text { Tipo de } \\
\text { arrasto }\end{array}$ & $\begin{array}{c}\text { Profundidade } \\
\text { de coleta }\end{array}$ & Rede & $\begin{array}{l}\text { Malha } \\
(\mu \mathrm{m})\end{array}$ & $\begin{array}{l}N^{\circ} \text {. de } \\
\text { inds. }\end{array}$ \\
\hline 420 & $22^{\circ} 36^{\prime} 54,9^{\prime \prime}$ & $040^{\circ} 09^{\prime} 19,4^{\prime \prime}$ & $16 / 05 / 2002$ & oblíquo & $50 \mathrm{~m}$ & bongô & 330 & 2 \\
\hline 422 & $22^{\circ} 41^{\prime} 54,7 "$ & $040^{\circ} 14^{\prime} 04,5^{\prime \prime}$ & $16 / 05 / 2002$ & oblíquo & $1.000 \mathrm{~m}$ & cilíndrico-cônica & 500 & 1 \\
\hline 7445 & $21^{\circ} 57^{\prime} 10,5^{\prime \prime}$ & $039^{\circ} 43^{\prime} 33,3^{\prime \prime}$ & 09/10/2001 & oblíquo & $1.000 \mathrm{~m}$ & cilíndrico-cônica & 500 & 1 \\
\hline 7450 & $21^{\circ} 57^{\prime} 10,5^{\prime \prime}$ & $039^{\circ} 43^{\prime} 33,3^{\prime \prime}$ & 09/10/2001 & oblíquo & $1.000 \mathrm{~m}$ & cilíndrico-cônica & 500 & 1 \\
\hline
\end{tabular}

Referências: Bonecker et al., 2006b; Ditty et al., 2006a. 


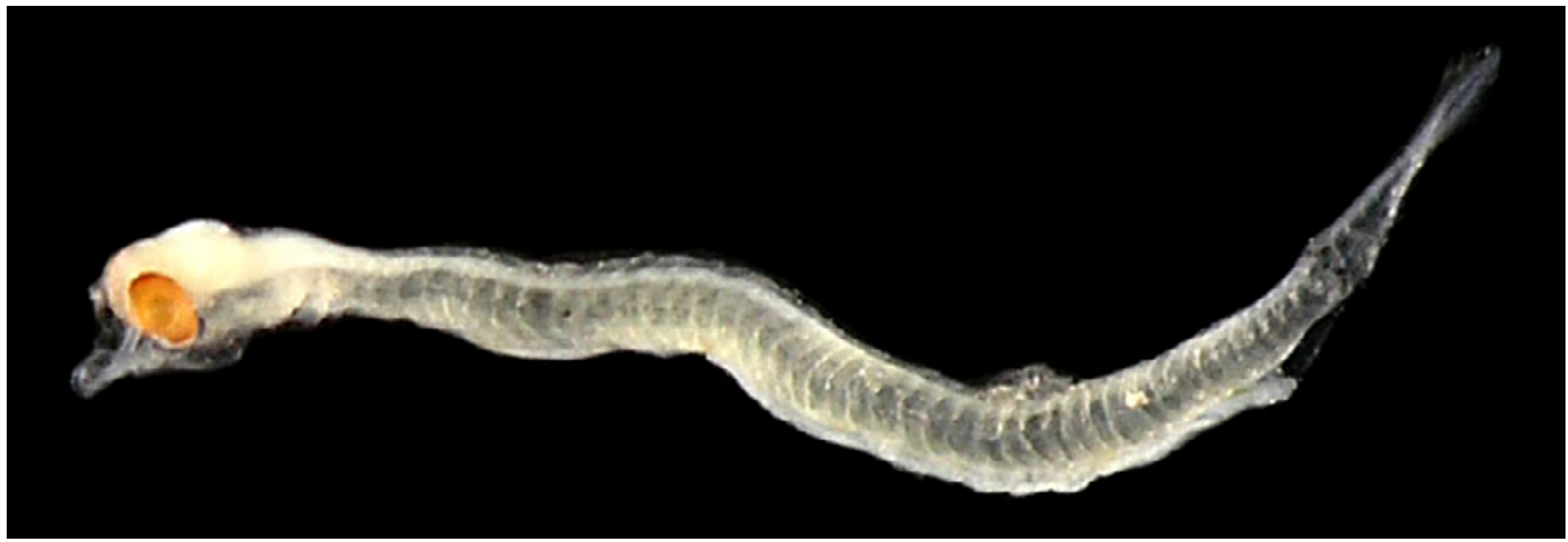

Figura 41 - A: Synodus synodus. DZUFRJ 22080; Pré-flexão; CP 4,5 mm.

\section{Synodus synodus (Linnaeus, 1758)}

Possui o corpo muito alongado e estreito. Apresenta entre doze e treze manchas de pigmentos ao longo do intestino, uma no final da base da nadadeira anal e uma na cauda entre os ossos hipurais. Os pigmentos estão visíveis desde a pré-flexão. O número de miômeros varia aproximadamente entre 56 e 58.

Tamanho: pré-flexão 4,5 mm; flexão 13,9-19,5 mm; pós-flexão 23,3 mm.

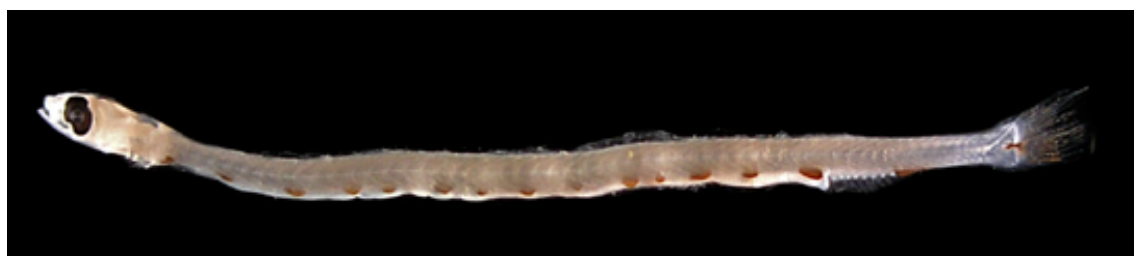

Figura 41 - B: DZUFRJ 12203; Flexão; CP 15,5 mm.

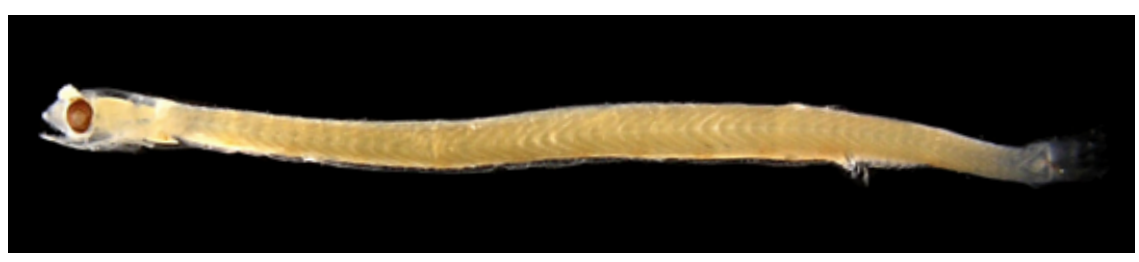

Figura 41 - C: DZUFRJ 1170; Pós-flexão; CP 23,3 mm.

Habitat: espécie marinha, demersal, associada a formações coralinas, ocorre em águas tropicais e subtropicais até $90 \mathrm{~m}$ de profundidade.

Nome vulgar: Peixe-lagarto.

\section{Georreferenciamento}

\begin{tabular}{|c|c|c|c|c|c|c|c|c|}
\hline DZUFRJ & Latitude (S) & Longitude (W) & Data & $\begin{array}{l}\text { Tipo de } \\
\text { arrasto }\end{array}$ & $\begin{array}{c}\text { Profundidade } \\
\text { de coleta }\end{array}$ & Rede & $\begin{array}{l}\text { Malha } \\
(\mu \mathrm{m})\end{array}$ & $\begin{array}{l}\text { No.de } \\
\text { inds. }\end{array}$ \\
\hline 526 & $21^{\circ} 57^{\prime} 10,5^{\prime \prime}$ & $039^{\circ} 43^{\prime} 33,3^{\prime \prime}$ & 09/10/2001 & oblíquo & $1.000 \mathrm{~m}$ & cilíndrico-cônica & 500 & 2 \\
\hline 1170 & $22^{\circ} 32^{\prime} 49,0^{\prime \prime}$ & $040^{\circ} 04^{\prime} 20,9^{\prime \prime}$ & $07 / 11 / 2001$ & oblíquo & $1.000 \mathrm{~m}$ & cilíndrico-cônica & 500 & 1 \\
\hline 7446 & $1^{\circ} 53^{\prime} 10,4^{\prime \prime}$ & $039^{\circ} 45^{\prime} 49,9^{\prime \prime}$ & $10 / 10 / 2001$ & oblíquo & $1.000 \mathrm{~m}$ & cilíndrico-cônica & 500 & 1 \\
\hline 7449 & $21^{\circ} 53^{\prime} 10,4^{\prime \prime}$ & $039^{\circ} 45^{\prime} 49,9^{\prime \prime}$ & $10 / 10 / 2001$ & & $0 \mathrm{~m}$ & cilíndrico-cônica & 500 & 1 \\
\hline 7451 & $21^{\circ} 54^{\prime} 36,5^{\prime \prime}$ & $039^{\circ} 45^{\prime} 20,0^{\prime \prime}$ & $10 / 10 / 2001$ & oblíquo & $1.000 \mathrm{~m}$ & cilíndrico-cônica & 500 & 1 \\
\hline 22080 & $22^{\circ} 41^{\prime} 54,7^{\prime \prime}$ & $040^{\circ} 14^{\prime} 04,5^{\prime \prime}$ & $16 / 05 / 2002$ & oblíquo & $1.000 \mathrm{~m}$ & cilíndrico-cônica & 500 & 1 \\
\hline
\end{tabular}

Referências: Bonecker et al., 2006b; Ditty et al., 2006a. 


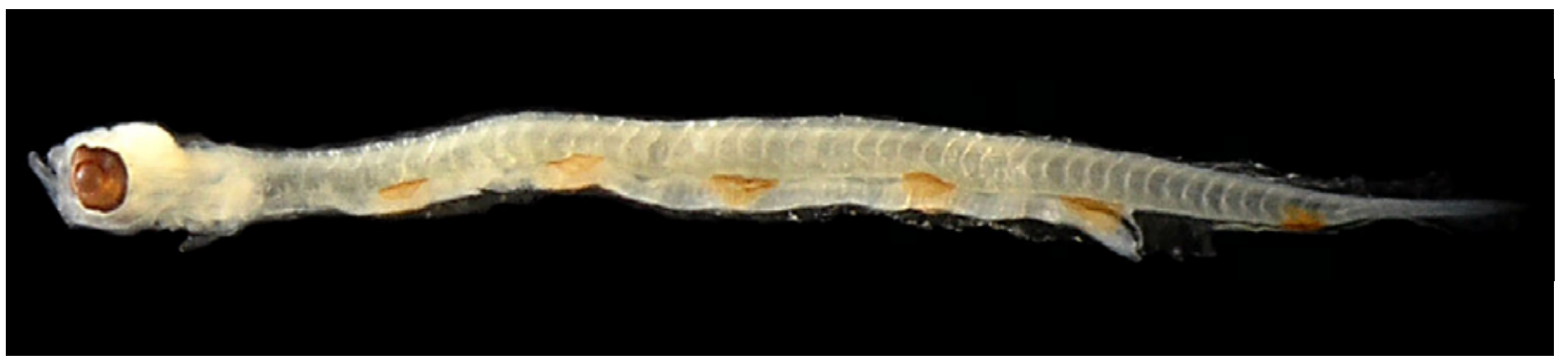

Figura 42: Trachinocephalus myops. DZUFRJ 418; Pré-flexão; CP 7,0 mm.

\section{Trachinocephalus myops (Foster, 1801)}

Apresenta seis manchas de pigmentos ao longo do intestino e uma no final da base da nadadeira anal. As larvas em estágio de pré-flexão possuem pigmentos também nas extremidades dorsal e ventral da cauda. Possui aproximadamente 55 miômeros.

Tamanho: pré-flexão 5,7-8,1 mm.

Habitat: espécie marinha, demersal, associada a formações coralinas, ocorre em águas oceânicas quentes até 387 m de pro-

fundidade.

Nome vulgar: Peixe-lagarto.

Georreferenciamento

\begin{tabular}{|c|c|c|c|c|c|c|c|c|}
\hline DZUFRJ & Latitude (S) & Longitude (W) & Data & $\begin{array}{c}\text { Tipo de } \\
\text { arrasto }\end{array}$ & $\begin{array}{c}\text { Profundidade } \\
\text { de coleta }\end{array}$ & Rede & $\begin{array}{c}\text { Malha } \\
\text { ( } \boldsymbol{\mu m}^{\prime}\end{array}$ & $\begin{array}{c}\mathbf{N}^{\circ} \text {. de } \\
\text { inds. }\end{array}$ \\
\hline 414 & $22^{\circ} 33^{\prime} 47,7^{\prime \prime}$ & $040^{\circ} 12^{\prime} 20,5^{\prime \prime}$ & $17 / 05 / 2002$ & oblíquo & $50 \mathrm{~m}$ & bongô & 330 & 1 \\
\hline 418 & $22^{\circ} 33^{\prime} 37,0^{\prime \prime}$ & $040^{\circ} 19^{\prime} 10,0^{\prime \prime}$ & $17 / 05 / 2002$ & oblíquo & $50 \mathrm{~m}$ & bongô & 500 & 1 \\
\hline 424 & $22^{\circ} 34^{\prime} 05,0^{\prime \prime}$ & $040^{\circ} 19^{\prime} 40,0^{\prime \prime}$ & $17 / 05 / 2002$ & oblíquo & $600 \mathrm{~m}$ & cilíndrico-cônica & 500 & 1 \\
\hline
\end{tabular}

Referências: Bonecker et al., 2006b; Ditty et al., 2006a. 


\section{Família Paralepididae}

A família Paralepididae ocorre em todos os oceanos incluindo o Ártico e a Antártica. Compreende 12 gêneros com aproximadamente 55 espécies. As larvas possuem corpo alongado e estreito, com exceção do gênero Sudis que possui cabeça grande e corpo curto. O número de pigmentos peritoneais e o padrão de pigmentação no corpo, especialmente do pedúnculo caudal, são características muito importantes para a identificação das espécies.

No Brasil já foram identificadas 18 espécies nas fases de larva e adulto. Nesse estudo são contempladas as espécies Lestidiops affinis, Lestidium atlanticum, Lestrolepis intermedia, Magnisudis atlantica, Stemonosudis rothschildi, Stemonosudis sp., Sudis atrox e Uncisudis advena. A espécie S. rothschildi é nova ocorrência para a costa brasileira. 


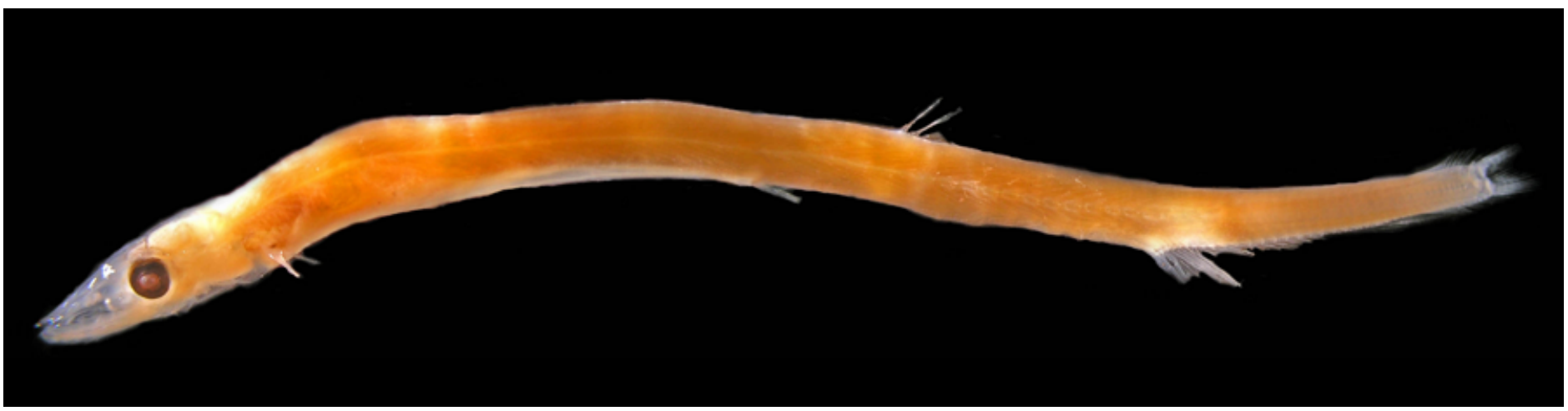

Figura 43: Lestidiops affinis. DZUFRJ 7469; Transformação; CP 48,5 mm.

\section{Lestidiops affinis (Ege, 1930)}

A principal característica das larvas dessa espécie é a presença de pares de pigmentos muito separados na margem ventral do corpo. À medida que a larva cresce aumenta o número de pigmentos na região entre o ânus e o início da nadadeira anal. Durante os estágios de pré-flexão e flexão pode ter até três pigmentos peritoneais ou nenhum. Na pós-flexão tem entre oito e nove manchas de pigmentos peritoneais. No estágio de transformação o número de pigmentos peritoneais aumenta para 11 ou 12. As larvas com mais de $35 \mathrm{~mm}$ CP apresentam pigmentos no focinho, uma série oblíqua abaixo da órbita e duas linhas no pedúnculo. O número de miômeros varia entre 75 e 85.

Tamanho: transformação 48,5 mm.

Habitat: espécie marinha, mesopelágica e batipelágica, ocorre em águas tropicais e temperadas em profundidades de até $2.000 \mathrm{~m}$, normalmente inferior a $600 \mathrm{~m}$. As larvas e os juvenis vivem em profundidades inferiores a $200 \mathrm{~m}$.

\section{Georreferenciamento}

\begin{tabular}{|c|c|c|c|c|c|c|c|c|}
\hline DZUFR & Latitude (S) & Longitude (W) & Data & $\begin{array}{c}\text { Tipo de } \\
\text { arrasto }\end{array}$ & $\begin{array}{c}\text { Profundidade } \\
\text { de coleta }\end{array}$ & Rede & $\begin{array}{c}\text { Malha } \\
(\boldsymbol{\mu m})\end{array}$ & $\begin{array}{c}\mathbf{N}^{\circ} \text {. de } \\
\text { inds. }\end{array}$ \\
\hline 7469 & $21^{\circ} 58^{\prime} 31,0^{\prime \prime}$ & $039^{\circ} 50^{\prime} 29,7^{\prime \prime}$ & $10 / 10 / 2001$ & oblíquo & $1.000 \mathrm{~m}$ & cilíndrico-cônica & 500 & 1 \\
\hline
\end{tabular}

Referências: Rofen, 1966a; Ditty, 2006b; Fahay, 2007. 


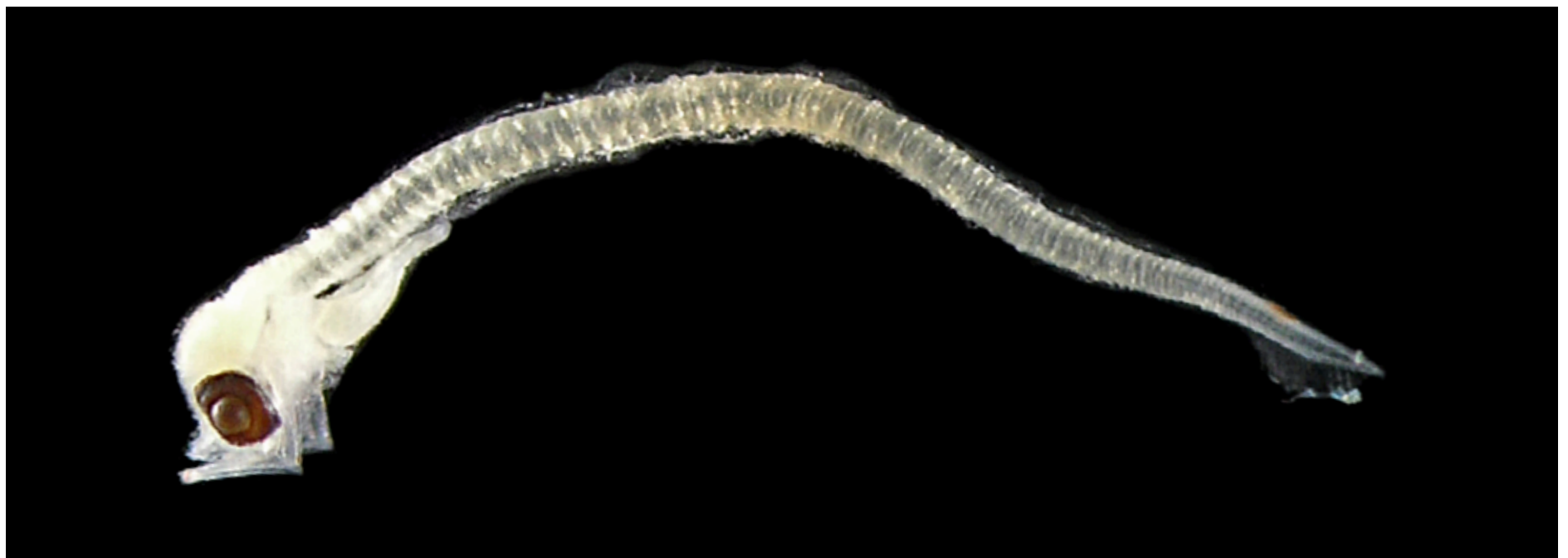

Figura 44 - A: Lestidium atlanticum. DZUFRJ 13222; Pré-flexão; CP 4,3 mm.

\section{Lestidium atlanticum Borodin, 1928}

Possui o corpo fino e alongado (80 a 83 miômeros). A principal característica das larvas com menos de $10 \mathrm{~mm}$ CP é a presença de uma única mancha de pigmento na região dorsal do pedúnculo caudal. Ausência de pigmentos na membrana dos ossos hipurais e na cauda. As larvas em flexão possuem quatro pigmentos peritoneais e começam a aparecer duas linhas de pigmentos no pedúnculo caudal. A mancha na região dorsal do pedúnculo é bem evidente. Em larvas no estágio de pós-flexão começam a aparecer pigmentos na região da cabeça. Nesse estágio, há oito manchas de pigmentos peritoneais e a mancha na região do pedúnculo ainda é evidente. Além da pigmentação da cauda, essa espécie pode ser separada de Lestrolepis e Lestidiops por ter a nadadeira pélvica abaixo da nadadeira dorsal.

Tamanho: pré-flexão 3,5-10,0 mm; flexão 11,0-15,0 mm; pós-flexão 17,3-21,5 $\mathrm{mm}$.

Habitat: espécie marinha, mesopelágica, ocorre em águas tropicais e temperadas quentes em profundidades entre 50 e $1.200 \mathrm{~m}$.

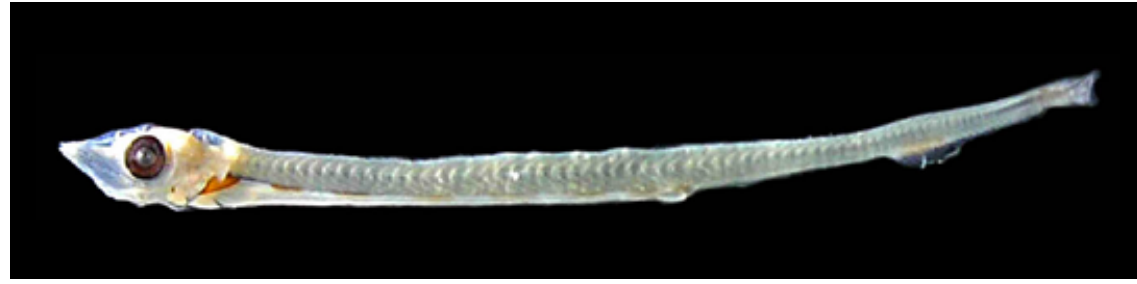

Figura 44 - B: DZUFRJ 11886; Flexão; CP 14,8 mm.

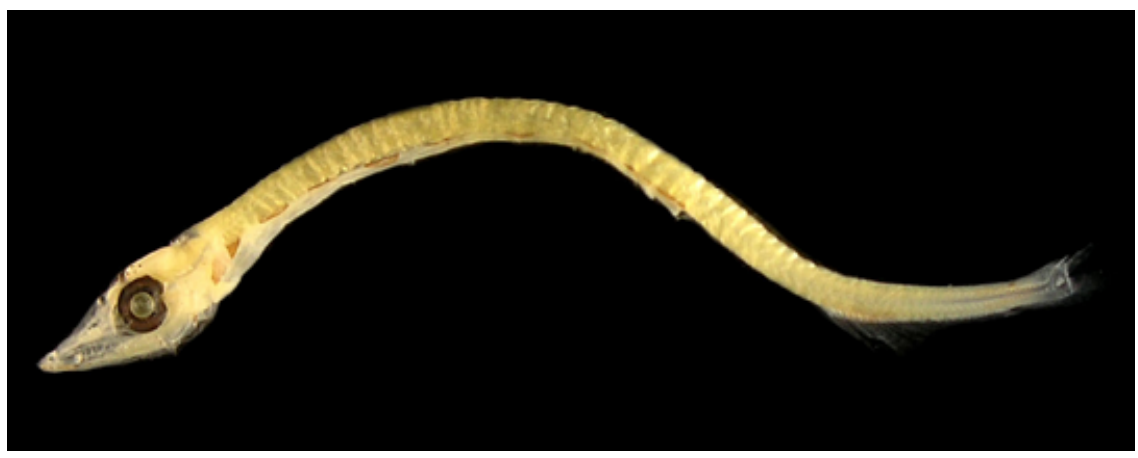

Figura 44 - C: DZUFRJ 13222; Pós-flexão; CP 17,4 mm.

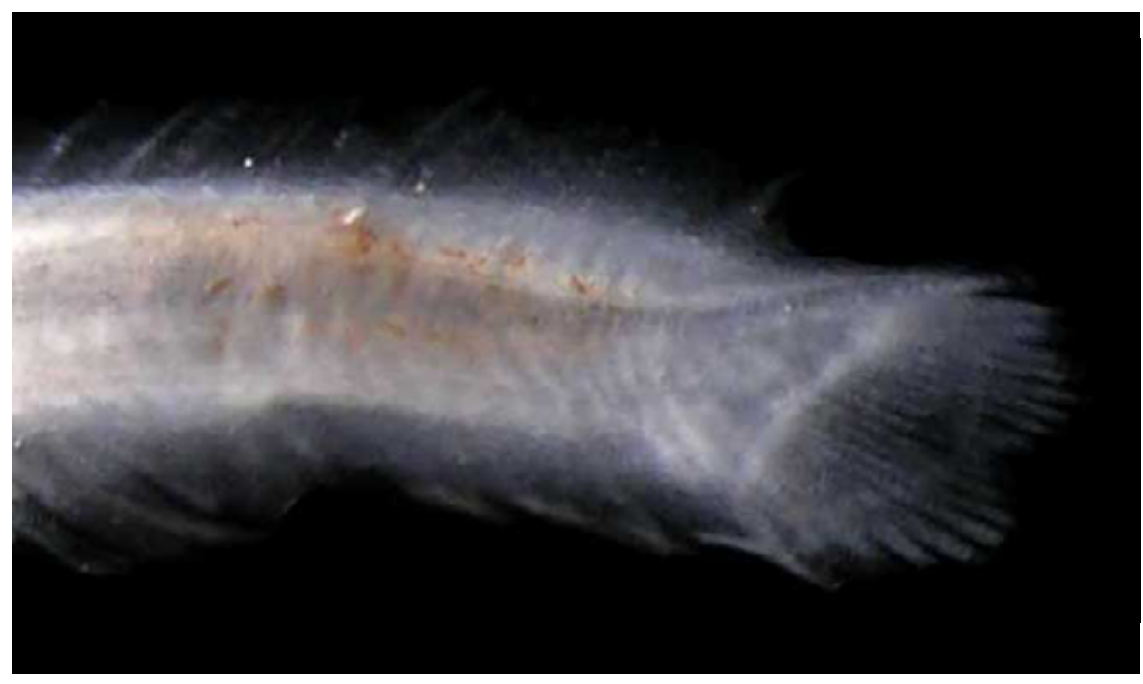

Figura 44 - D: Duas linhas de pigmentos no pedúnculo caudal. 


\section{Georreferenciamento}

\begin{tabular}{|c|c|c|c|c|c|c|c|c|}
\hline DZUFRJ & Latitude (S) & Longitude (W) & Data & $\begin{array}{l}\text { Tipo de } \\
\text { arrasto }\end{array}$ & $\begin{array}{c}\text { Profundidade } \\
\text { de coleta }\end{array}$ & Rede & $\begin{array}{l}\text { Malha } \\
(\mu \mathrm{m})\end{array}$ & $\begin{array}{l}\text { No. de } \\
\text { inds. }\end{array}$ \\
\hline 507 & $22^{\circ} 31^{\prime} 27,0^{\prime \prime}$ & $040^{\circ} 16^{\prime} 56,0^{\prime \prime}$ & $17 / 05 / 2002$ & oblíquo & $600 \mathrm{~m}$ & cilíndrico-cônica & 500 & 1 \\
\hline 560 & $22^{\circ} 32^{\prime} 03,0^{\prime \prime}$ & $040^{\circ} 17^{\prime} 21,0^{\prime \prime}$ & $19 / 05 / 2002$ & oblíquo & $30 \mathrm{~m}$ & bongô & 500 & 4 \\
\hline 584 & $22^{\circ} 33^{\prime} 45,8^{\prime \prime}$ & $040^{\circ} 13^{\prime} 22,9^{\prime \prime}$ & $17 / 05 / 2002$ & oblíquo & $800 \mathrm{~m}$ & cilíndrico-cônica & 500 & 2 \\
\hline 593 & $22^{\circ} 38^{\prime} 29,0^{\prime \prime}$ & $040^{\circ} 17^{\prime} 40,0^{\prime \prime}$ & $18 / 05 / 2002$ & oblíquo & $800 \mathrm{~m}$ & cilíndrico-cônica & 500 & 3 \\
\hline 595 & $22^{\circ} 33^{\prime} 47,7^{\prime \prime}$ & $040^{\circ} 12^{\prime} 20,5^{\prime \prime}$ & $17 / 05 / 2002$ & oblíquo & $50 \mathrm{~m}$ & bongô & 330 & 1 \\
\hline 643 & $22^{\circ} 36^{\prime} 54,9^{\prime \prime}$ & $040^{\circ} 09^{\prime} 19,4^{\prime \prime}$ & $16 / 05 / 2002$ & oblíquo & $50 \mathrm{~m}$ & bongô & 500 & 2 \\
\hline 650 & $22^{\circ} 36^{\prime} 54,9^{\prime \prime}$ & $040^{\circ} 09^{\prime} 19,4^{\prime \prime}$ & $16 / 05 / 2002$ & oblíquo & $50 \mathrm{~m}$ & bongô & 330 & 1 \\
\hline 696 & $22^{\circ} 42^{\prime} 06,0^{\prime \prime}$ & $040^{\circ} 14^{\prime} 26,0^{\prime \prime}$ & $19 / 05 / 2002$ & oblíquo & $50 \mathrm{~m}$ & bongô & 330 & 5 \\
\hline 1183 & $22^{\circ} 07^{\prime} 29,0^{\prime \prime}$ & $039^{\circ} 06^{\prime} 23,5^{\prime \prime}$ & $10 / 05 / 2002$ & oblíquo & $1.000 \mathrm{~m}$ & cilíndrico-cônica & 500 & 3 \\
\hline 1205 & $22^{\circ} 06^{\prime} 52,3^{\prime \prime}$ & $039^{\circ} 48^{\prime} 46,2^{\prime \prime}$ & $11 / 05 / 2002$ & oblíquo & $1.000 \mathrm{~m}$ & cilíndrico-cônica & 500 & 2 \\
\hline 1240 & $22^{\circ} 03^{\prime} 21,7^{\prime \prime}$ & $039^{\circ} 45^{\prime} 11,9^{\prime \prime}$ & $12 / 05 / 2002$ & oblíquo & $1.000 \mathrm{~m}$ & cilíndrico-cônica & 500 & 1 \\
\hline 1293 & $22^{\circ} 02^{\prime} 30,0^{\prime \prime}$ & $039^{\circ} 49^{\prime} 41,2^{\prime \prime}$ & $12 / 05 / 2002$ & oblíquo & até a termoclina & bongô & 500 & 3 \\
\hline 1317 & $22^{\circ} 08^{\prime} 14,9^{\prime \prime}$ & $039^{\circ} 46^{\prime} 34,6^{\prime \prime}$ & $11 / 05 / 2002$ & oblíquo & até a termoclina & bongô & 500 & 1 \\
\hline 1323 & $22^{\circ} 03^{\prime} 03,3^{\prime \prime}$ & $039^{\circ} 50^{\prime} 39,0^{\prime \prime}$ & $10 / 05 / 2002$ & oblíquo & até a termoclina & bongô & 330 & 2 \\
\hline 1343 & $22^{\circ} 06^{\prime} 52,3^{\prime \prime}$ & $039^{\circ} 48^{\prime} 46,2^{\prime \prime}$ & $11 / 05 / 2002$ & oblíquo & até a termoclina & bongô & 330 & 1 \\
\hline 1353 & $22^{\circ} 02^{\prime} 30,0^{\prime \prime}$ & $039^{\circ} 49^{\prime} 41,2^{\prime \prime}$ & $12 / 05 / 2002$ & oblíquo & até a termoclina & bongô & 330 & 2 \\
\hline 5449 & $22^{\circ} 31^{\prime} 58,9^{\prime \prime}$ & $040^{\circ} 02^{\prime} 53,4^{\prime \prime}$ & $07 / 11 / 2001$ & oblíquo & $1.000 \mathrm{~m}$ & cilíndrico-cônica & 500 & 4 \\
\hline 5450 & $22^{\circ} 32^{\prime} 49,0^{\prime \prime}$ & $040^{\circ} 04^{\prime} 20,9^{\prime \prime}$ & $07 / 11 / 2001$ & oblíquo & $1.000 \mathrm{~m}$ & cilíndrico-cônica & 500 & 2 \\
\hline 5451 & $22^{\circ} 32^{\prime} 50,0^{\prime \prime}$ & $040^{\circ} 04^{\prime} 09,9^{\prime \prime}$ & $06 / 11 / 2001$ & oblíquo & $1.000 \mathrm{~m}$ & cilíndrico-cônica & 500 & 3 \\
\hline 5453 & $22^{\circ} 32^{\prime} 49,0^{\prime \prime}$ & $040^{\circ} 04^{\prime} 20,9^{\prime \prime}$ & $07 / 11 / 2001$ & oblíquo & $1.000 \mathrm{~m}$ & cilíndrico-cônica & 500 & 6 \\
\hline 5455 & $22^{\circ} 32^{\prime} 50,0^{\prime \prime}$ & $040^{\circ} 04^{\prime} 09,9 "$ & $06 / 11 / 2001$ & oblíquo & $1.000 \mathrm{~m}$ & cilíndrico-cônica & 500 & 3 \\
\hline 5458 & $22^{\circ} 32^{\prime} 49,0^{\prime \prime}$ & $040^{\circ} 04^{\prime} 20,9^{\prime \prime}$ & $07 / 11 / 2001$ & oblíquo & $1.000 \mathrm{~m}$ & cilíndrico-cônica & 500 & 2 \\
\hline 5459 & $22^{\circ} 31^{\prime} 40,9^{\prime \prime}$ & $040^{\circ} 02^{\prime} 39,6^{\prime \prime}$ & $07 / 11 / 2001$ & oblíquo & $1.000 \mathrm{~m}$ & cilíndrico-cônica & 500 & 5 \\
\hline 5460 & $22^{\circ} 31^{\prime} 40,9^{\prime \prime}$ & $040^{\circ} 02^{\prime} 39,6^{\prime \prime}$ & $07 / 11 / 2001$ & oblíquo & $1.000 \mathrm{~m}$ & cilíndrico-cônica & 500 & 4 \\
\hline 7452 & $21^{\circ} 54^{\prime} 36,5^{\prime \prime}$ & $039^{\circ} 45^{\prime} 20,0^{\prime \prime}$ & $10 / 10 / 2001$ & oblíquo & $1.000 \mathrm{~m}$ & cilíndrico-cônica & 500 & 4 \\
\hline 7453 & $21^{\circ} 57^{\prime} 10,5^{\prime \prime}$ & $039^{\circ} 43^{\prime} 33,3^{\prime \prime}$ & $09 / 10 / 2001$ & oblíquo & $1.000 \mathrm{~m}$ & cilíndrico-cônica & 500 & 4 \\
\hline 7454 & $21^{\circ} 57^{\prime} 10,5^{\prime \prime}$ & $039^{\circ} 43^{\prime} 33,3^{\prime \prime}$ & 09/10/2001 & oblíquo & $1.000 \mathrm{~m}$ & cilíndrico-cônica & 500 & 8 \\
\hline 7456 & $21^{\circ} 58^{\prime} 31,0^{\prime \prime}$ & $039^{\circ} 50^{\prime} 29,7^{\prime \prime}$ & $11 / 10 / 2001$ & oblíquo & $1.000 \mathrm{~m}$ & cilíndrico-cônica & 500 & 10 \\
\hline 7461 & $21^{\circ} 58 ' 31,0^{\prime \prime}$ & $039^{\circ} 50^{\prime} 29,7^{\prime \prime}$ & $10 / 10 / 2001$ & oblíquo & $1.000 \mathrm{~m}$ & cilíndrico-cônica & 500 & 7 \\
\hline 7462 & $21^{\circ} 57^{\prime} 10,5^{\prime \prime}$ & $039^{\circ} 43^{\prime} 33,3^{\prime \prime}$ & 09/10/2001 & oblíquo & $1.000 \mathrm{~m}$ & cilíndrico-cônica & 500 & 5 \\
\hline 7463 & $21^{\circ} 53^{\prime} 10,4^{\prime \prime}$ & $039^{\circ} 45^{\prime} 49,9^{\prime \prime}$ & $10 / 10 / 2001$ & oblíquo & $1.000 \mathrm{~m}$ & cilíndrico-cônica & 500 & 2 \\
\hline 7466 & $21^{\circ} 54 ' 36,5^{\prime \prime}$ & $039^{\circ} 45^{\prime} 20,0^{\prime \prime}$ & 09/10/2001 & oblíquo & $1.000 \mathrm{~m}$ & cilíndrico-cônica & 500 & 7 \\
\hline 7468 & $21^{\circ} 53^{\prime} 10,4^{\prime \prime}$ & $039^{\circ} 45^{\prime} 49,9^{\prime \prime}$ & $10 / 10 / 2001$ & oblíquo & $1.000 \mathrm{~m}$ & cilíndrico-cônica & 500 & 2 \\
\hline 13752 & $21^{\circ} 53^{\prime} 10,4^{\prime \prime}$ & $039^{\circ} 45^{\prime} 49,9^{\prime \prime}$ & $10 / 10 / 2001$ & oblíquo & $1.000 \mathrm{~m}$ & cilíndrico-cônica & 500 & 1 \\
\hline 13754 & $22^{\circ} 31^{\prime} 58,9 "$ & $040^{\circ} 02^{\prime} 53,4^{\prime \prime}$ & $07 / 11 / 2001$ & oblíquo & $1.000 \mathrm{~m}$ & cilíndrico-cônica & 500 & 4 \\
\hline 13760 & $22^{\circ} 32^{\prime} 50,0^{\prime \prime}$ & $040^{\circ} 04^{\prime} 09,9^{\prime \prime}$ & $06 / 11 / 2001$ & oblíquo & $1.000 \mathrm{~m}$ & cilíndrico-cônica & 500 & 2 \\
\hline 13777 & $21^{\circ} 54 ' 36,5^{\prime \prime}$ & $039^{\circ} 45^{\prime} 20,0^{\prime \prime}$ & $10 / 10 / 2001$ & oblíquo & $1.000 \mathrm{~m}$ & cilíndrico-cônica & 500 & 17 \\
\hline 13786 & $21^{\circ} 58^{\prime} 31,0^{\prime \prime}$ & $039^{\circ} 50^{\prime 29,7 "}$ & $10 / 10 / 2001$ & oblíquo & $1.000 \mathrm{~m}$ & cilíndrico-cônica & 500 & 7 \\
\hline 13795 & $22^{\circ} 43,56^{\prime}$ & $039^{\circ} 53,25^{\prime}$ & $14 / 06 / 2003$ & vertical & $60 \mathrm{~m}$ & cilíndrico-cônica & 500 & 1 \\
\hline 13797 & $21^{\circ} 57,51^{\prime}$ & $039^{\circ} 49,57^{\prime}$ & $19 / 06 / 2003$ & vertical & $95 \mathrm{~m}$ & cilíndrico-cônica & 500 & 1 \\
\hline 13798 & $22^{\circ} 02,27^{\prime}$ & $039^{\circ} 43,49^{\prime}$ & $18 / 06 / 2003$ & vertical & $90 \mathrm{~m}$ & cilíndrico-cônica & 500 & 1 \\
\hline 14171 & $22^{\circ} 02,2865^{\prime}$ & $039^{\circ} 42,9495^{\prime}$ & $04 / 12 / 2002$ & vertical & $700-1.200 m$ & cilíndrico-cônica & 200 & 1 \\
\hline 18922 & $22^{\circ} 42^{\prime} 06,0^{\prime \prime}$ & $040^{\circ} 14^{\prime} 26,0^{\prime \prime}$ & $19 / 05 / 2002$ & oblíquo & $50 \mathrm{~m}$ & bongô & 500 & 1 \\
\hline 18923 & $22^{\circ} 41^{\prime} 54,7^{\prime \prime}$ & $040^{\circ} 14^{\prime} 04,5^{\prime \prime}$ & $16 / 05 / 2002$ & oblíquo & $1.000 \mathrm{~m}$ & cilíndrico-cônica & 500 & 1 \\
\hline 18924 & $22^{\circ} 32^{\prime} 03,0^{\prime \prime}$ & $040^{\circ} 17^{\prime} 21,0^{\prime \prime}$ & $19 / 05 / 2002$ & oblíquo & $30 \mathrm{~m}$ & bongô & 330 & 5 \\
\hline 18925 & $22^{\circ} 34^{\prime} 05,0^{\prime \prime}$ & $040^{\circ} 19^{\prime} 40,0^{\prime \prime}$ & $17 / 05 / 2002$ & oblíquo & $600 \mathrm{~m}$ & cilíndrico-cônica & 500 & 1 \\
\hline
\end{tabular}

Referências: Rofen, 1966a; Bonecker et al., 2006b; Ditty, 2006b; Fahay, 2007. 


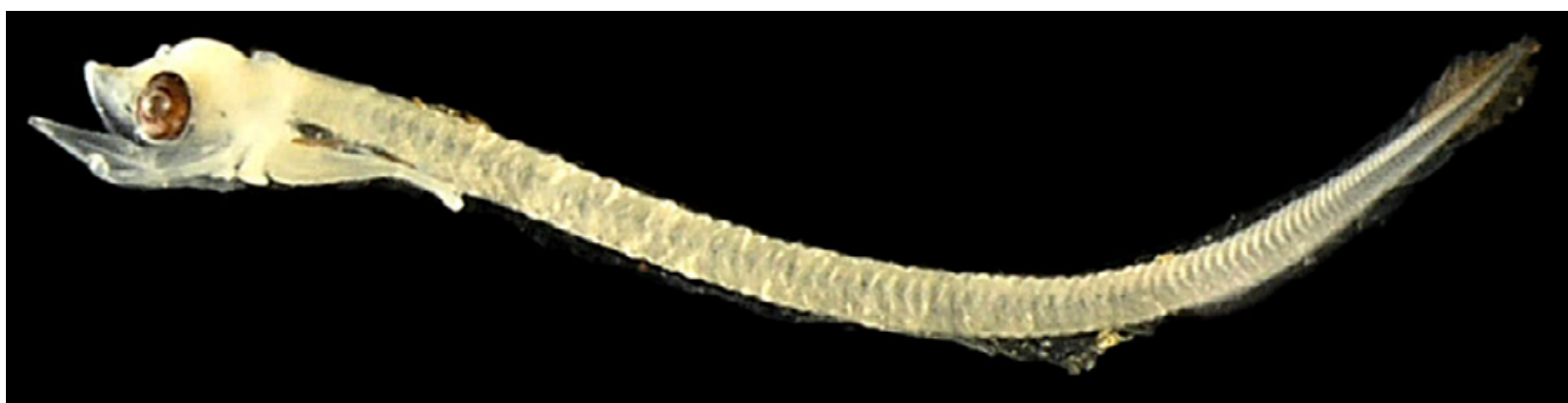

Figura 45 - A: Lestrolepis intermedia. DZUFRJ 15743; Pré-flexão; CP 8,4 mm.

\section{Lestrolepis intermedia (Poey, 1868)}

Nas larvas em estágio de pré-flexão podem ser observados pigmentos nas regiões dorsal e ventral do pedúnculo caudal e na membrana embrionária caudal. No estágio de flexão começam a aparecer quatro linhas paralelas de pigmentos na região do pedúnculo caudal. Em pré-flexão e flexão possui um a sete pigmentos peritoneais. No estágio de pós-flexão possui oito pigmentos peritoneais e um arco no cérebro. A nadadeira pélvica está localizada bem anteriormente a origem da dorsal. O número de miômeros varia entre 91 e 93.

Tamanho: pré-flexão 5,0-8,4 mm; flexão 13,5 mm.

Habitat: espécie marinha, mesopelágica, ocorre em águas tropicais e temperadas quentes em profundidades entre 400 e $1.500 \mathrm{~m}$.

\section{Georreferenciamento}

\begin{tabular}{|c|c|c|c|c|c|c|c|c|}
\hline DZUFRJ & Latitude (S) & Longitude (W) & Data & $\begin{array}{l}\text { Tipo de } \\
\text { arrasto }\end{array}$ & $\begin{array}{l}\text { Profundidade } \\
\text { de coleta }\end{array}$ & Rede & $\begin{array}{c}\text { Malha } \\
(\mu \mathrm{m})\end{array}$ & $\begin{array}{l}N^{\circ} \text {. de } \\
\text { inds. }\end{array}$ \\
\hline 532 & $22^{\circ} 34^{\prime} 05,0^{\prime \prime}$ & $040^{\circ} 19^{\prime} 40,0^{\prime \prime}$ & $17 / 05 / 2002$ & oblíquo & $600 \mathrm{~m}$ & cilíndrico-cônica & 500 & 1 \\
\hline 638 & $22^{\circ} 42^{\prime} 06,0^{\prime \prime}$ & $040^{\circ} 14^{\prime} 26,0^{\prime \prime}$ & $19 / 05 / 2002$ & oblíquo & $50 \mathrm{~m}$ & bongô & 500 & 1 \\
\hline 664 & $22^{\circ} 38^{\prime} 25,0^{\prime \prime}$ & $040^{\circ} 17^{\prime} 41,0^{\prime \prime}$ & $19 / 05 / 2002$ & oblíquo & $40 \mathrm{~m}$ & bongô & 330 & 1 \\
\hline 668 & $22^{\circ} 33^{\prime} 45,8^{\prime \prime}$ & $040^{\circ} 13^{\prime} 22,9^{\prime \prime}$ & $17 / 05 / 2002$ & oblíquo & $800 \mathrm{~m}$ & cilíndrico-cônica & 500 & 1 \\
\hline 672 & $22^{\circ} 41^{\prime} 54,7^{\prime \prime}$ & $040^{\circ} 14^{\prime} 04,5^{\prime \prime}$ & $16 / 05 / 2002$ & oblíquo & $1.000 \mathrm{~m}$ & cilíndrico-cônica & 500 & 1 \\
\hline 13750 & $22^{\circ} 06^{\prime} 52,3^{\prime \prime}$ & $039^{\circ} 48^{\prime} 46,2^{\prime \prime}$ & $11 / 05 / 2002$ & oblíquo & até a termoclina & bongô & 330 & 2 \\
\hline 13751 & $21^{\circ} 57^{\prime} 10,5^{\prime \prime}$ & $039^{\circ} 43^{\prime} 33,3^{\prime \prime}$ & 09/10/2001 & oblíquo & $1.000 \mathrm{~m}$ & cilíndrico-cônica & 500 & 1 \\
\hline 13774 & $21^{\circ} 58^{\prime} 31,0^{\prime \prime}$ & $039^{\circ} 50^{\prime 29,7 "}$ & $10 / 10 / 2001$ & oblíquo & $1.000 \mathrm{~m}$ & cilíndrico-cônica & 500 & 1 \\
\hline 13780 & $22^{\circ} 06^{\prime} 37,8^{\prime \prime}$ & $039^{\circ} 49^{\prime} 44,8^{\prime \prime}$ & $10 / 05 / 2002$ & oblíquo & até a termoclina & & 500 & 1 \\
\hline 13794 & $22^{\circ} 39,68^{\prime}$ & $040^{\circ} 03,24^{\prime}$ & $13 / 06 / 2003$ & vertical & $60 \mathrm{~m}$ & cilíndrico-cônica & 500 & 1 \\
\hline 13796 & $22^{\circ} 02,27^{\prime}$ & $039^{\circ} 43,49^{\prime}$ & $18 / 06 / 2003$ & vertical & $90 \mathrm{~m}$ & cilíndrico-cônica & 500 & 1 \\
\hline 18842 & $22^{\circ} 42^{\prime} 06,0^{\prime \prime}$ & $040^{\circ} 14^{\prime} 26,0^{\prime \prime}$ & $19 / 05 / 2002$ & oblíquo & $50 \mathrm{~m}$ & bongô & 330 & 1 \\
\hline 19078 & $22^{\circ} 32^{\prime} 03,0^{\prime \prime}$ & $040^{\circ} 17^{\prime} 21,0^{\prime \prime}$ & $19 / 05 / 2002$ & oblíquo & $30 \mathrm{~m}$ & bongô & 500 & 1 \\
\hline
\end{tabular}

Referências: Rofen, 1966a; Bonecker et al., 2006b; Ditty, 2006b; Fahay, 2007.

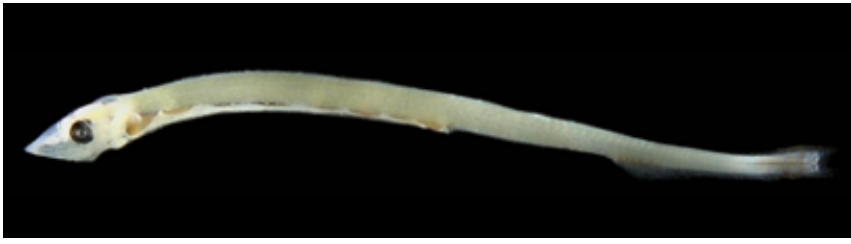

Figura 45 - B: DZUFRJ 12071; Flexão; CP 20,0 mm.

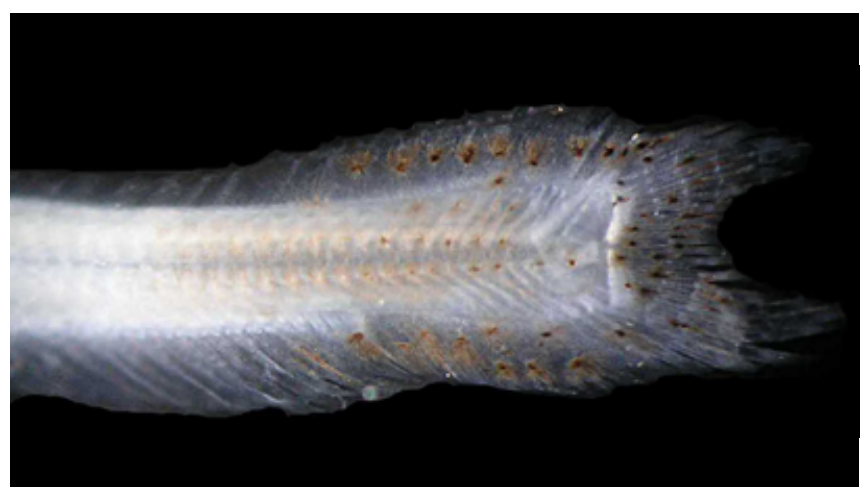

Figura 45 - C: Quatro linhas paralelas de pigmentos na região caudal. 


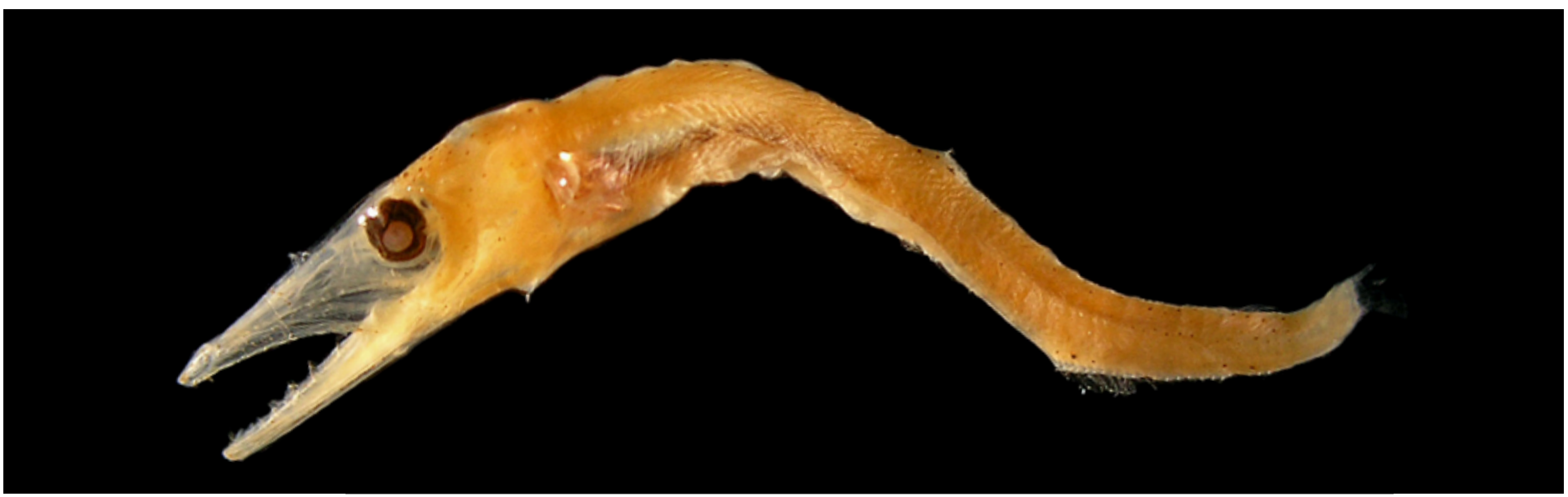

Figura 46 - A: Magnisudis atlantica. DZUFRJ 13775; Pós-flexão; CP 14,1 mm.

\section{Magnisudis atlantica (Krøyer, 1868)}

No estágio de pós-flexão possui pigmentos no focinho, acima dos olhos, na base da nadadeira dorsal e um pigmento acima e

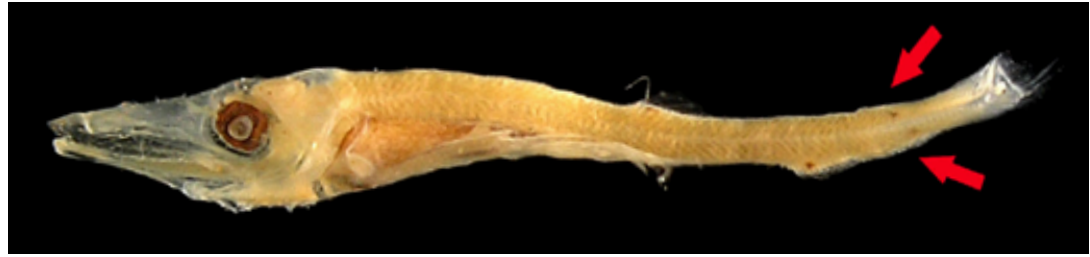

Figura 46 - B: DZUFRJ 13772; Transformação; CP 30,3 mm. abaixo da notocorda no pedúnculo caudal. Os pigmentos acima e abaixo da notocorda aumentam em número até formar uma banda vertical na direção da nadadeira adiposa, em larvas maiores que 19,0 mm CP. Possui de um a três pigmentos peritoneais. Em larvas com 13-15 mm CP o ânus alcança aproximadamente $67-72 \%$ do comprimento padrão. Nos indivíduos em transformação há pigmentos ao longo da região dorsal, na base dos raios da caudal e uma faixa larga na cauda. A nadadeira pélvica se forma abaixo da dorsal. O número de miômeros varia entre 63 e 66.

Tamanho: pós-flexão 14,1 mm; transformação 30,3 mm.

Habitat: espécie marinha, mesopelágica e batipelágica, ocorre em águas tropicais e boreais em profundidades entre 66 e 2.166, principalmente entre 230 e $1.100 \mathrm{~m}$.

\section{Georreferenciamento}

\begin{tabular}{|c|c|c|c|c|c|c|c|c|}
\hline DZUFRJ & Latitude (S) & Longitude (W) & Data & $\begin{array}{l}\text { Tipo de } \\
\text { arrasto }\end{array}$ & $\begin{array}{c}\text { Profundidade } \\
\text { de coleta }\end{array}$ & Rede & $\begin{array}{c}\text { Malha } \\
(\mu \mathrm{m})\end{array}$ & $\begin{array}{l}N^{\circ} \text {. de } \\
\text { inds. }\end{array}$ \\
\hline 13772 & $21^{\circ} 53^{\prime} 10,4^{\prime \prime}$ & $039^{\circ} 45^{\prime} 49,9^{\prime \prime}$ & $10 / 10 / 2001$ & oblíquo & $1.000 \mathrm{~m}$ & cilíndrico-cônica & 500 & 1 \\
\hline 13773 & $21^{\circ} 58^{\prime} 31,0^{\prime \prime}$ & $039^{\circ} 50^{\prime} 29,7^{\prime \prime}$ & $10 / 10 / 2001$ & oblíquo & $1.000 \mathrm{~m}$ & cilíndrico-cônica & 500 & 1 \\
\hline 13775 & $21^{\circ} 53^{\prime} 10,4^{\prime \prime}$ & $039^{\circ} 45^{\prime} 49,9^{\prime \prime}$ & $10 / 10 / 2001$ & oblíquo & $1.000 \mathrm{~m}$ & cilíndrico-cônica & 500 & 1 \\
\hline
\end{tabular}

Referências: Ditty, 2006b; Fahay, 2007. 


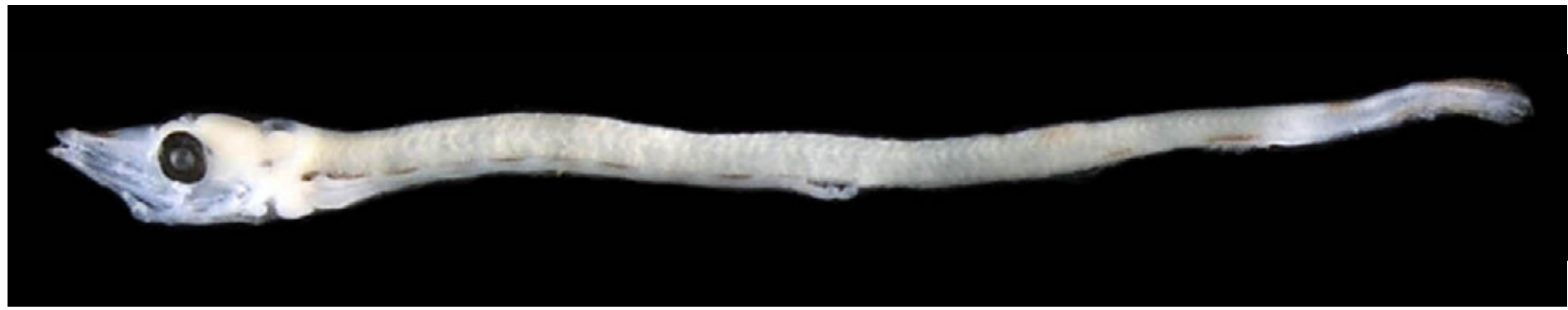

Figura 47 - A: Stemonosudis sp. DZUFRJ 12185; Pré-flexão; CP 10,7 mm.

\section{Stemonosudis}

sp.

As larvas de Stemonosudis apresentam corpo e focinho muito alongados (84 a 121 vértebras). Possuem grupos de pigmentos dorsais e ventrais alternados, e pigmentos no focinho e na cabeça. A na-

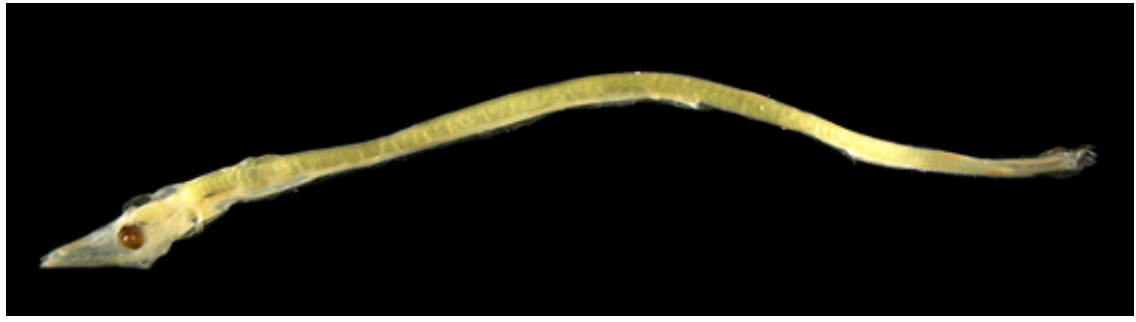

Figura 47 - B: DZUFRJ 13762; Flexão; CP 22,8 mm. dadeira pélvica está situada à frente da origem da nadadeira dorsal. Possuem entre 14 e 18 pigmentos peritoneais. Entre as espécies de Stemonosudis que ocorrem no Brasil, S. rothschildi possui menos pigmentos peritoneais e tem nadadeira dorsal precoce em comparação com S. intermedia e S. siliquiventer. Na literatura, não há descrição da larva de S. siliquiventer e portanto, não foi possível chegar ao nível específico. No Brasil já foram coletadas as espécies Stemonosudis intermedia (Ege, 1933) e Stemonosudis siliquiventer Post, 1970.

Tamanho: pré-flexão 6,4-10,7 mm; flexão 12,5-25,9 mm.

Habitat: as espécies de Stemonosudis são marinhas e batipelágicas, ocorrem em profundidades de até $2.000 \mathrm{~m}$.

\section{Georreferenciamento}

\begin{tabular}{|c|c|c|c|c|c|c|c|c|}
\hline DZUFRJ & Latitude (S) & Longitude (W) & Data & $\begin{array}{l}\text { Tipo de } \\
\text { arrasto }\end{array}$ & $\begin{array}{l}\text { Profundidade } \\
\text { de coleta }\end{array}$ & Rede & $\begin{array}{l}\text { Malha } \\
(\mu \mathrm{m})\end{array}$ & $\begin{array}{l}N^{\circ} \text {. de } \\
\text { inds. }\end{array}$ \\
\hline 1215 & $22^{\circ} 02^{\prime} 30,0^{\prime \prime}$ & $039^{\circ} 49^{\prime} 41,2^{\prime \prime}$ & $12 / 05 / 2002$ & oblíquo & $1.000 \mathrm{~m}$ & cilíndrico-cônica & 500 & 2 \\
\hline 13759 & $22^{\circ} 02^{\prime} 30,0^{\prime \prime}$ & $039^{\circ} 49^{\prime} 41,2^{\prime \prime}$ & $12 / 05 / 2002$ & oblíquo & até a termoclina & bongô & 500 & 1 \\
\hline 13761 & $22^{\circ} 31^{\prime} 40,9^{\prime \prime}$ & $040^{\circ} 02^{\prime} 39,6^{\prime \prime}$ & $07 / 11 / 2001$ & oblíquo & $1.000 \mathrm{~m}$ & cilíndrico-cônica & 500 & 1 \\
\hline 13762 & $22^{\circ} 02^{\prime} 30,0^{\prime \prime}$ & $039^{\circ} 49^{\prime} 41,2^{\prime \prime}$ & $12 / 05 / 2002$ & oblíquo & até a termoclina & bongô & 330 & 2 \\
\hline 13764 & $21^{\circ} 57^{\prime} 10,5^{\prime \prime}$ & $039^{\circ} 43^{\prime} 33,3^{\prime \prime}$ & 09/10/2001 & oblíquo & $1.000 \mathrm{~m}$ & cilíndrico-cônica & 500 & 1 \\
\hline 13785 & $21^{\circ} 58^{\prime} 31,0^{\prime \prime}$ & $039^{\circ} 50^{\prime} 29,7^{\prime \prime}$ & $10 / 10 / 2001$ & oblíquo & $1.000 \mathrm{~m}$ & cilíndrico-cônica & 500 & 1 \\
\hline
\end{tabular}

Referências: Rofen, 1966a; Bonecker et al., 2006b; Ditty, 2006b; Fahay, 2007. 


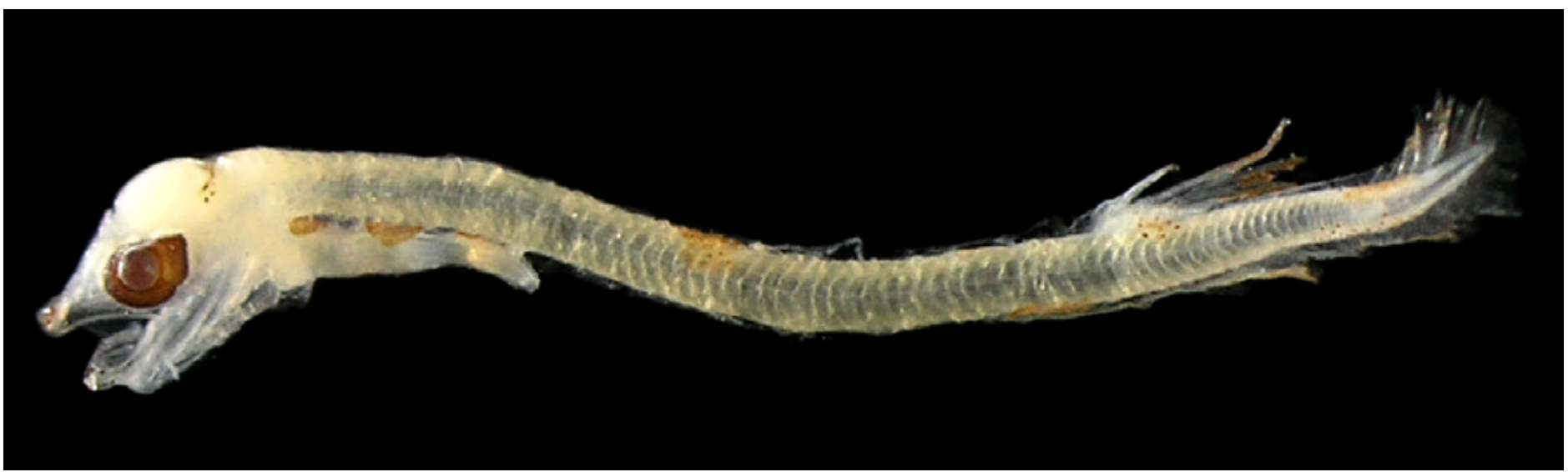

Figura 48: Stemonosudis rothschildi. DZUFRJ 13793; Pré-flexão; CP 5,2 mm.

\section{Stemonosudis rothschildi Richards, 1967}

A principal característica dessa espécie é que os raios da nadadeira dorsal são precoces. Durante o estágio de pré-flexão possui cinco grupos de pigmentos na margem dorsal e dois na margem ventral. Tem pigmentos na ponta do focinho, na região dorsal da cabeça. As larvas com menos de 7,0 mm CP tem três manchas peritoneais. O número de miômeros varia entre 92 e 95.

Tamanho: pré-flexão 6,0 mm.

Habitat: espécie marinha, mesopelágica e batipelágica, ocorre em profundidades entre 30 e $2.250 \mathrm{~m}$.

\section{Georreferenciamento}

\begin{tabular}{|c|c|c|c|c|c|c|c|c|}
\hline DZUFRJ & Latitude (S) & Longitude (W) & Data & $\begin{array}{c}\text { Tipo de } \\
\text { arrasto }\end{array}$ & $\begin{array}{c}\text { Profundidade } \\
\text { de coleta }\end{array}$ & Rede & $\begin{array}{c}\text { Malha } \\
(\boldsymbol{\mu} \text { m) }\end{array}$ & $\begin{array}{c}\text { No. de } \\
\text { inds. }\end{array}$ \\
\hline 13783 & $21^{\circ} 58^{\prime} 31,0^{\prime \prime}$ & $039^{\circ} 50^{\prime} 29,7^{\prime \prime}$ & $11 / 10 / 2001$ & oblíquo & $1.000 \mathrm{~m}$ & cilíndrico-cônica & 500 & 1 \\
\hline
\end{tabular}

Referências: Ditty, 2006b; Fahay, 2007. 


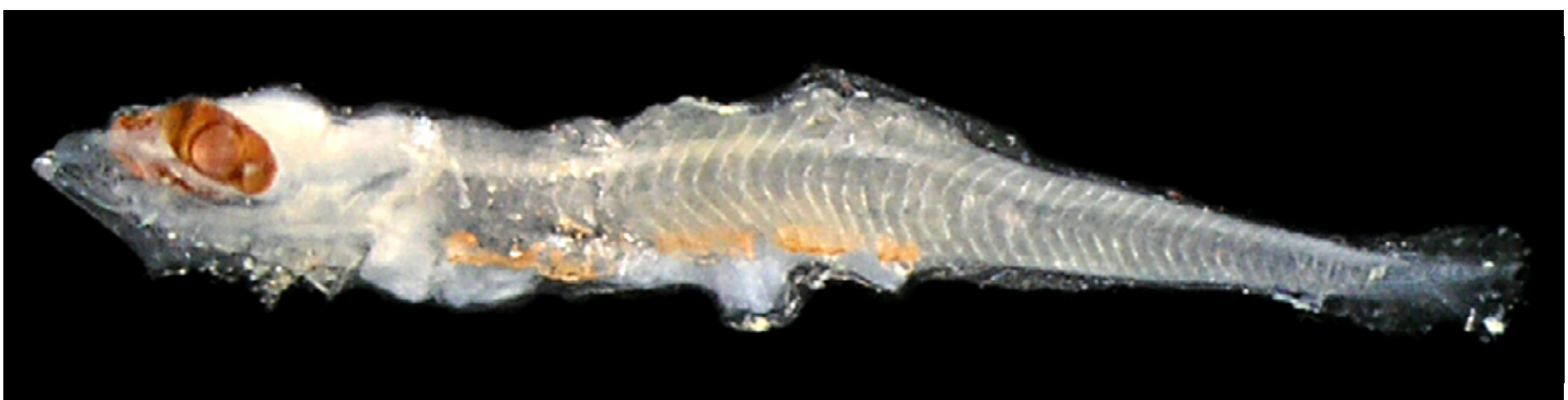

Figura 49 - A: Sudis atrox. DZUFRJ 7149; Pré-flexão; CP 4,9 mm.

\section{Sudis atrox Rofen, 1963}

Nos estágios de pré-flexão e flexão apresenta olho elíptico e o ânus situado na região mediana do corpo. Tem três espinhos pré-operculares grandes, cristas serrilhadas na cabeça, na mandíbula e no focinho. No estágio de pós-flexão, o maior espinho do pré-opérculo possui as extremidades serrilhadas e ganchos. O número de pigmentos peritoneais (três a seis) varia de acordo com o estágio de desenvolvimento larval. Em pós-flexão, apresenta pigmentos na extremidade do focinho, no espinho pré-opercular e no pedúnculo caudal. A nadadeira pélvica está situada na mesma direção da origem da nadadeira dorsal. O número de miômeros varia entre 50 e 55.

Tamanho: pré-flexão 4,1-4,9 mm; flexão 5,39,0 mm; pós-flexão 14,5 mm.

Habitat: espécie marinha, mesopelágica e batipelágica, ocorre em profundidades entre 30 e $2.250 \mathrm{~m}$.

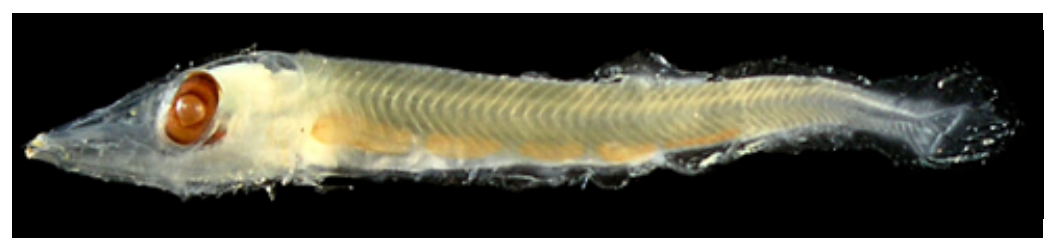

Figura 49 - B: DZUFRJ 7149; Flexão; CP 9,0 mm.

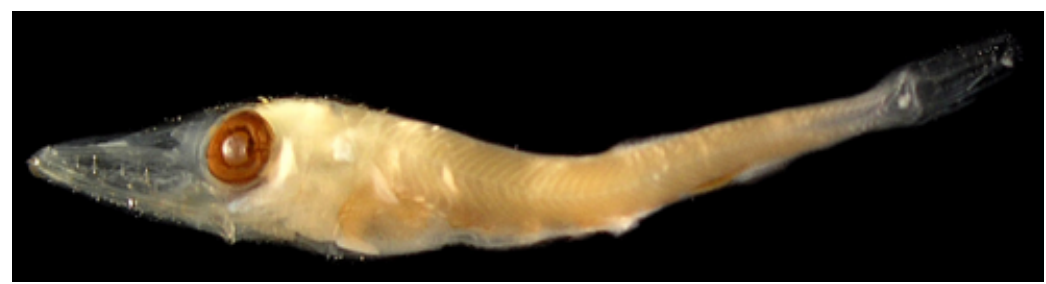

Figura 49 - C: DZUFRJ 7467; Pós-flexão; CP 14,5 mm;

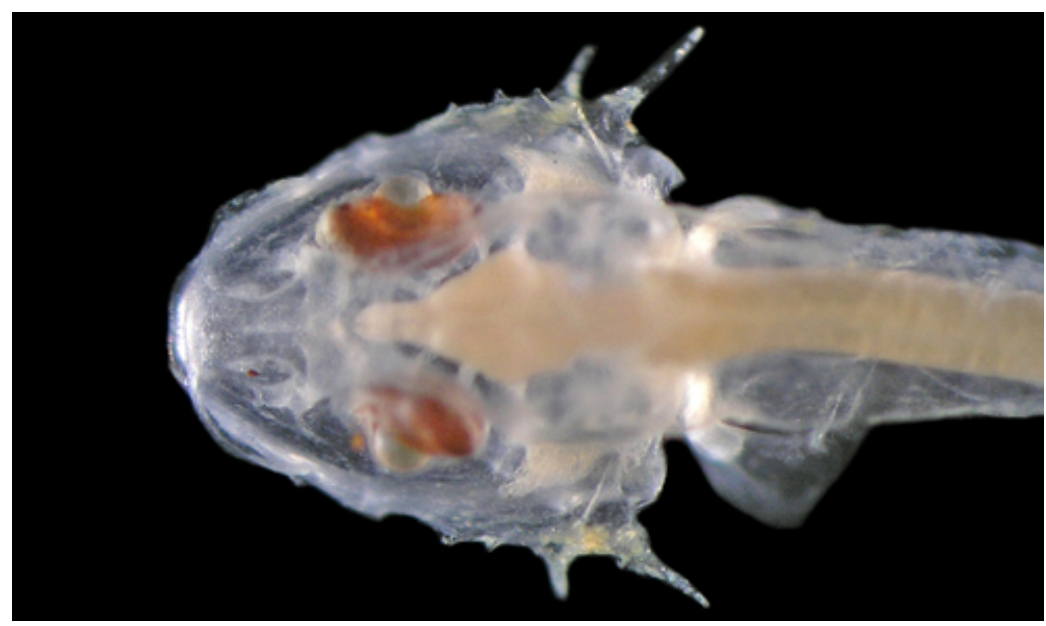

Figura 49 - D: Detalhe da cabeça durante a pré-flexão;

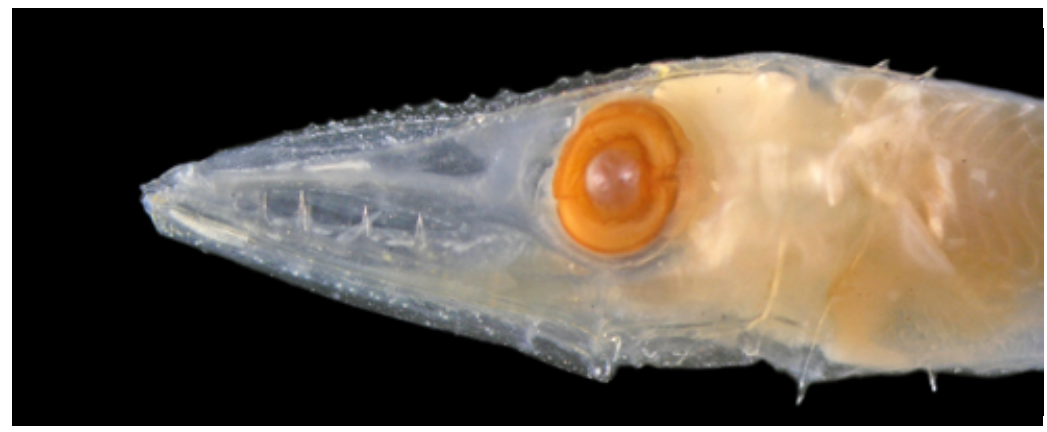

Figura 49 - E: Detalhe da cabeça durante a pós-flexão. 


\section{Georreferenciamento}

\begin{tabular}{|c|c|c|c|c|c|c|c|c|}
\hline DZUFRJ & Latitude (S) & Longitude (W) & Data & $\begin{array}{l}\text { Tipo de } \\
\text { arrasto }\end{array}$ & $\begin{array}{c}\text { Profundidade } \\
\text { de coleta }\end{array}$ & Rede & $\begin{array}{l}\text { Malha } \\
(\mu \mathrm{m})\end{array}$ & $\begin{array}{l}N^{\circ} \text {. de } \\
\text { inds. }\end{array}$ \\
\hline 1216 & $22^{\circ} 02^{\prime} 30,0^{\prime \prime}$ & $039^{\circ} 49^{\prime} 41,2^{\prime \prime}$ & $12 / 05 / 2002$ & oblíquo & $1.000 \mathrm{~m}$ & cilíndrico-cônica & 500 & 2 \\
\hline 5447 & $21^{\circ} 57^{\prime} 10,5^{\prime \prime}$ & $039^{\circ} 43^{\prime} 33,3^{\prime \prime}$ & $09 / 10 / 2001$ & oblíquo & $1.000 \mathrm{~m}$ & cilíndrico-cônica & 500 & 1 \\
\hline 5448 & $21^{\circ} 54^{\prime} 36,5^{\prime \prime}$ & $039^{\circ} 45^{\prime} 20,0^{\prime \prime}$ & 09/10/2001 & oblíquo & $1.000 \mathrm{~m}$ & cilíndrico-cônica & 500 & 1 \\
\hline 5452 & $21^{\circ} 54^{\prime} 36,5^{\prime \prime}$ & $039^{\circ} 45^{\prime} 20,0^{\prime \prime}$ & $10 / 10 / 2001$ & oblíquo & $1.000 \mathrm{~m}$ & cilíndrico-cônica & 500 & 2 \\
\hline 5454 & $21^{\circ} 54^{\prime} 36,5^{\prime \prime}$ & $039^{\circ} 45^{\prime} 20,0^{\prime \prime}$ & $10 / 10 / 2001$ & oblíquo & $1.000 \mathrm{~m}$ & cilíndrico-cônica & 500 & 1 \\
\hline 5456 & $21^{\circ} 53^{\prime} 10,4^{\prime \prime}$ & $039^{\circ} 45^{\prime} 49,9^{\prime \prime}$ & $10 / 10 / 2001$ & oblíquo & & cilíndrico-cônica & 500 & 1 \\
\hline 5461 & $21^{\circ} 58 ' 31,0^{\prime \prime}$ & $039^{\circ} 50^{\prime 29,7 "}$ & $11 / 10 / 2001$ & oblíquo & $1.000 \mathrm{~m}$ & cilíndrico-cônica & 500 & 2 \\
\hline 5462 & $22^{\circ} 32^{\prime} 50,0^{\prime \prime}$ & $040^{\circ} 04^{\prime} 09,9^{\prime \prime}$ & $06 / 11 / 2001$ & oblíquo & $1.000 \mathrm{~m}$ & cilíndrico-cônica & 500 & 4 \\
\hline 7455 & $22^{\circ} 32^{\prime} 50,0^{\prime \prime}$ & $040^{\circ} 04^{\prime} 09,9^{\prime \prime}$ & $06 / 11 / 2001$ & oblíquo & $1.000 \mathrm{~m}$ & cilíndrico-cônica & 500 & 4 \\
\hline 7457 & $22^{\circ} 32^{\prime} 50,0^{\prime \prime}$ & $040^{\circ} 04^{\prime} 09,9^{\prime \prime}$ & $06 / 11 / 2001$ & oblíquo & $1.000 \mathrm{~m}$ & cilíndrico-cônica & 500 & 4 \\
\hline 7458 & $22^{\circ} 32^{\prime} 49,0^{\prime \prime}$ & $040^{\circ} 04^{\prime} 20,9^{\prime \prime}$ & $07 / 11 / 2001$ & oblíquo & $1.000 \mathrm{~m}$ & cilíndrico-cônica & 500 & 2 \\
\hline 7464 & $22^{\circ} 32^{\prime} 49,0^{\prime \prime}$ & $040^{\circ} 04^{\prime} 20,9^{\prime \prime}$ & $07 / 11 / 2001$ & oblíquo & $1.000 \mathrm{~m}$ & cilíndrico-cônica & 500 & 2 \\
\hline 7465 & $22^{\circ} 31^{\prime} 40,9^{\prime \prime}$ & $040^{\circ} 02^{\prime} 39,6^{\prime \prime}$ & $07 / 11 / 2001$ & oblíquo & $1.000 \mathrm{~m}$ & cilíndrico-cônica & 500 & 4 \\
\hline 7467 & $22^{\circ} 31^{\prime} 40,9^{\prime \prime}$ & $040^{\circ} 02^{\prime} 39,6^{\prime \prime}$ & $07 / 11 / 2001$ & oblíquo & $1.000 \mathrm{~m}$ & cilíndrico-cônica & 500 & 1 \\
\hline
\end{tabular}

Referências: Rofen, 1966a; Ambrose, 1966a; Bonecker et al., 2006b; Ditty, 2006b; Fahay, 2007. 


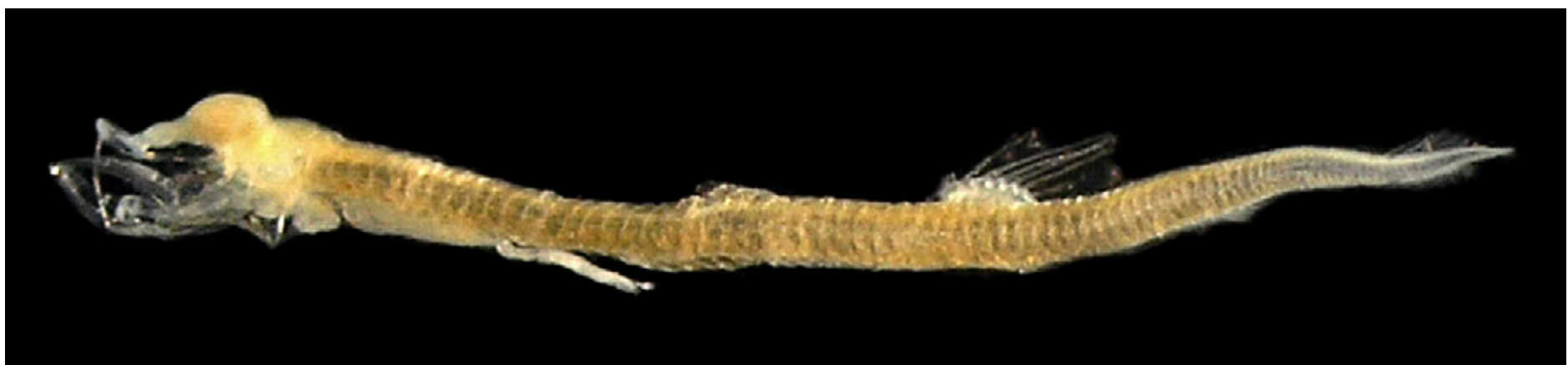

Figura 50: Uncisudis advena. DZUFRJ 13787; Pré-flexão; CP 6,6 mm.

\section{Uncisudis advena (Rofen, 1963)}

A principal característica dessa espécie é o desenvolvimento precoce das nadadeiras dorsal e pélvica. A nadadeira pélvica está situada na mesma direção da origem da nadadeira dorsal. No estágio de pré-flexão possui mancha de pigmento nas regiões dorsal e ventral da membrana embrionária caudal e cinco manchas peritoneais. Durante a flexão apresenta uma mancha na margem dorsal do pedúnculo caudal. No estágio de transformação além dessa mancha possui pigmentos na extremidade dos raios anteriores da nadadeira anal e sete manchas peritoneais. Possui aproximadamente 78 miômeros.

Tamanho: pré-flexão 6,6-8,5 mm.

Habitat: espécie marinha, mesopelágica, ocorre em profundidades entre 800 e $1.000 \mathrm{~m}$.

\section{Georreferenciamento}

\begin{tabular}{|c|c|c|c|c|c|c|c|c|}
\hline DZUFRJ & Latitude (S) & Longitude (W) & Data & $\begin{array}{l}\text { Tipo de } \\
\text { arrasto }\end{array}$ & $\begin{array}{l}\text { Profundidade } \\
\text { de coleta }\end{array}$ & Rede & $\begin{array}{l}\text { Malha } \\
(\mu \mathrm{m})\end{array}$ & $\begin{array}{l}N^{\circ} \text {. de } \\
\text { inds. }\end{array}$ \\
\hline & & & & & & & 500 & 1 \\
\hline 13787 & $21^{\circ} 58 ' 31,0^{\prime \prime}$ & $039^{\circ} 50^{\prime 29,7 "}$ & $10 / 10 / 2001$ & oblíquo & $1.000 \mathrm{~m}$ & cilíndrico-cônica & 500 & 1 \\
\hline
\end{tabular}

Referência: Rofen, 1966a; Bonecker et al., 2006b; Ditty, 2006b; Fahay, 2007. 


\section{Família Anotopteridae}

A família Anotopteridae é mono-específica representada por Anotopterus pharao. Essa espécie é mesopelágica e batipelágica, encontrada em águas temperadas e polares. 


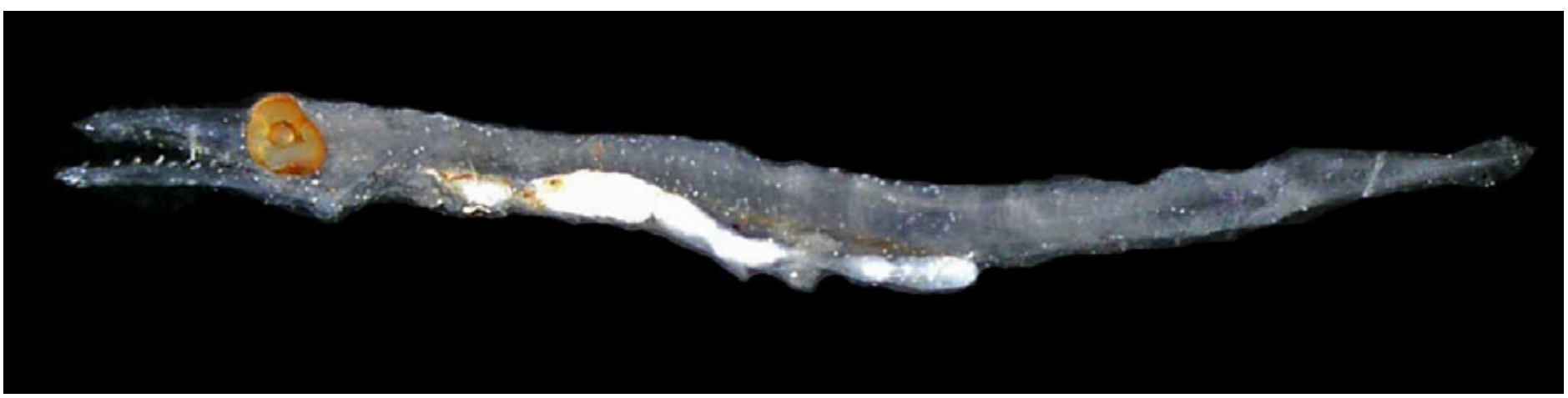

Figura 51: Anotopterus pharao. DZUFRJ 7508; Flexão; CP 11,0 mm.

\section{Anotopterus pharao Zugmayer, 1911}

Diferentemente dos demais representantes de Aulopiformes, essa espécie não possui pigmentos peritoneais. Possui o corpo fino e alongado (76 a 80 miômeros) com intestino alcançando mais da metade do comprimento padrão (no máximo $60 \%$ do CP). O focinho é alongado e possui projeções cartilaginosas nas extremidades das maxilas, com pigmento na inferior. Presença de dentes caninos em cada osso do palato, desde a pré-flexão. Ausência de nadadeira dorsal e presença de nadadeira adiposa.

Tamanho: flexão 11,0 mm.

Habitat: espécie marinha, mesopelágica e batipelágica, ocorre em profundidades entre 500 e $2.000 \mathrm{~m}$.

\section{Georreferenciamento}

\begin{tabular}{|c|c|c|c|c|c|c|c|c|}
\hline DZUFRJ & Latitude (S) & Longitude (W) & Data & $\begin{array}{c}\text { Tipo de } \\
\text { arrasto }\end{array}$ & $\begin{array}{c}\text { Profundidade } \\
\text { de coleta }\end{array}$ & Rede & $\begin{array}{c}\text { Malha } \\
\left.\text { ( } \boldsymbol{\mu m}^{\circ}\right)\end{array}$ & $\begin{array}{c}\mathbf{N}^{\circ} \text {. de } \\
\text { inds. }\end{array}$ \\
\hline 7508 & $21^{\circ} 57^{\prime} 10,5^{\prime \prime}$ & $039^{\circ} 43^{\prime} 33,3^{\prime \prime}$ & $9 / 10 / 2001$ & oblíquo & $1.000 \mathrm{~m}$ & cilíndrico-cônica & 500 & 1 \\
\hline
\end{tabular}

Referências: Ambrose, 1996b; Ditty, 2006b; Fahay, 2007. 


\section{Família Evermannellidae}

A família Evermannellidae é marinha e ocorre nos oceanos Atlântico, Índico e Pacífico. Compreende três gêneros com sete espécies. Possuem três manchas no peritôneo com exceção da espécie Odontostomops normalops que apresenta 13 a 15 manchas. Nos estágios iniciais de desenvolvimento possuem pigmentos no miossepto formando bandas descontínuas.

No Brasil já foram identificadas quatro espécies nas fases de larva e adulto: Coccorella atlantica (Parr, 1928); Evermannella balbo (Risso, 1820); Evermannella melanoderma Parr, 1928 e Odontostomops normalops (Parr, 1928). Nesse estudo são contempladas as espécies Coccorella atlantica, Evermannella balbo e Evermannella melanoderma. 


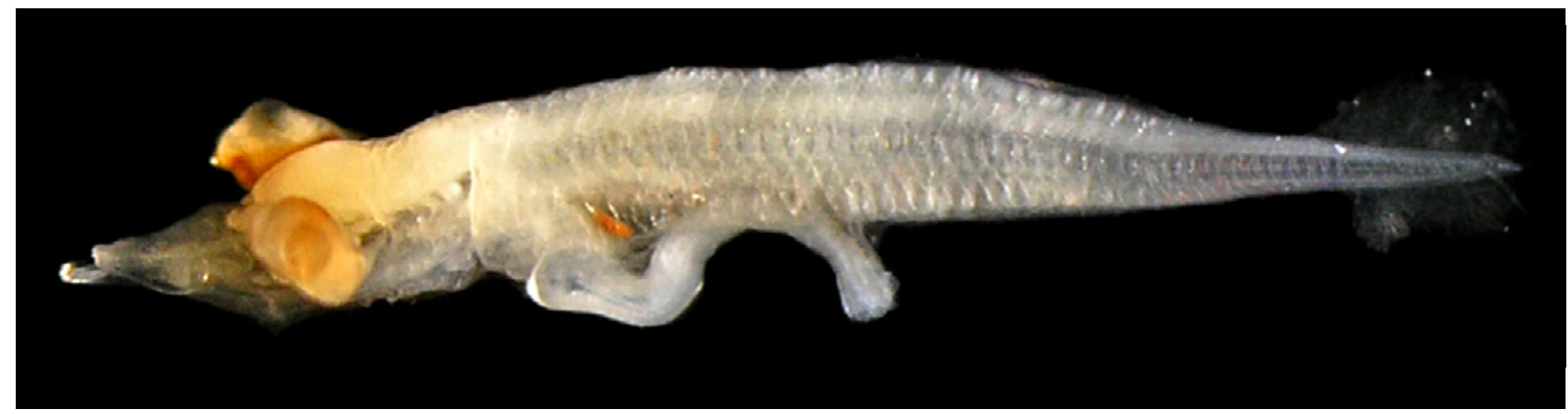

Figura 52 - A: Coccorella atlantica. DZUFRJ 13153; Pré-flexão; CP 3,5 mm.

\section{Coccorella atlantica (Parr, 1928)}

Nos estágios de pré-flexão e de flexão as larvas dessa espécie possuem três manchas peritoneais. No estágio de pós-flexão têm cinco bandas de pigmento na parte dorsal do corpo e quatro na região ventral.

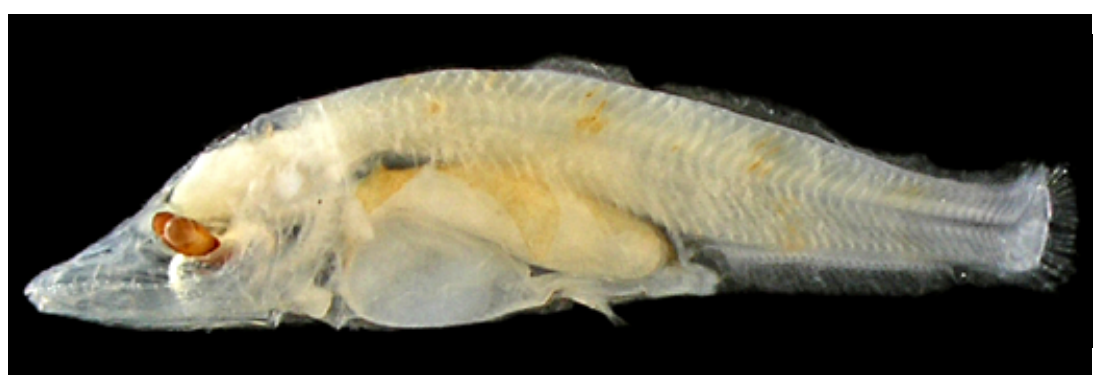

Figura 52 - B: DZUFRJ 15242; Flexão; CP 7,0 mm. O olho é elíptico, a nadadeira dorsal tem 12 raios e a anal tem 25 ou 26 raios. O número de miômeros varia entre 48 e 53. Presença de nadadeira adiposa a partir da pós-flexão.

Tamanho: pré-flexão 3,5-5,0 mm; flexão 6,5-7,0 mm.

Habitat: espécie marinha, mesopelágica, ocorre em águas tropicais e temperadas quentes em profundidades entre 100 e 500 m, principalmente entre 50 e $125 \mathrm{~m}$.

\section{Georreferenciamento}

\begin{tabular}{|c|c|c|c|c|c|c|c|c|}
\hline DZUFRJ & Latitude (S) & Longitude (W) & Data & $\begin{array}{l}\text { Tipo de } \\
\text { arrasto }\end{array}$ & $\begin{array}{l}\text { Profundidade } \\
\text { de coleta }\end{array}$ & Rede & $\begin{array}{c}\text { Malha } \\
(\mu \mathrm{m})\end{array}$ & $\begin{array}{l}N^{\circ} \text {. de } \\
\text { inds. }\end{array}$ \\
\hline 5401 & $22^{\circ} 32^{\prime} 49,0^{\prime \prime}$ & $040^{\circ} 04^{\prime} 20,9^{\prime \prime}$ & 07/11/2001 & oblíquo & $1.000 \mathrm{~m}$ & cilíndrico-cônica & 500 & 3 \\
\hline 7393 & $21^{\circ} 53^{\prime} 10,4^{\prime \prime}$ & $039^{\circ} 45^{\prime} 49,9^{\prime \prime}$ & 10/10/2001 & oblíquo & $1.000 \mathrm{~m}$ & cilíndrico-cônica & 500 & 1 \\
\hline 7396 & $21^{\circ} 58^{\prime} 31,0^{\prime \prime}$ & $039^{\circ} 50^{\prime} 29,7^{\prime \prime}$ & $10 / 10 / 2001$ & oblíquo & $1.000 \mathrm{~m}$ & cilíndrico-cônica & 500 & 5 \\
\hline 7397 & $21^{\circ} 53^{\prime} 10,4^{\prime \prime}$ & $039^{\circ} 45^{\prime} 49,9^{\prime \prime}$ & $10 / 10 / 2001$ & oblíquo & $1.000 \mathrm{~m}$ & cilíndrico-cônica & 500 & 2 \\
\hline 24176 & $21^{\circ} 58^{\prime} 31,0^{\prime \prime}$ & $039^{\circ} 50^{\prime} 29,7^{\prime \prime}$ & $11 / 10 / 2001$ & oblíquo & $1.000 \mathrm{~m}$ & cilíndrico-cônica & 500 & 1 \\
\hline 24177 & $21^{\circ} 58^{\prime} 31,0^{\prime \prime}$ & $039^{\circ} 50^{\prime} 29,7^{\prime \prime}$ & $10 / 10 / 2001$ & oblíquo & $1.000 \mathrm{~m}$ & cilíndrico-cônica & 500 & 1 \\
\hline
\end{tabular}

Referências: Rofen, 1966b; Bonecker et al., 2006b; Ditty, 2006c; Fahay, 2007. 


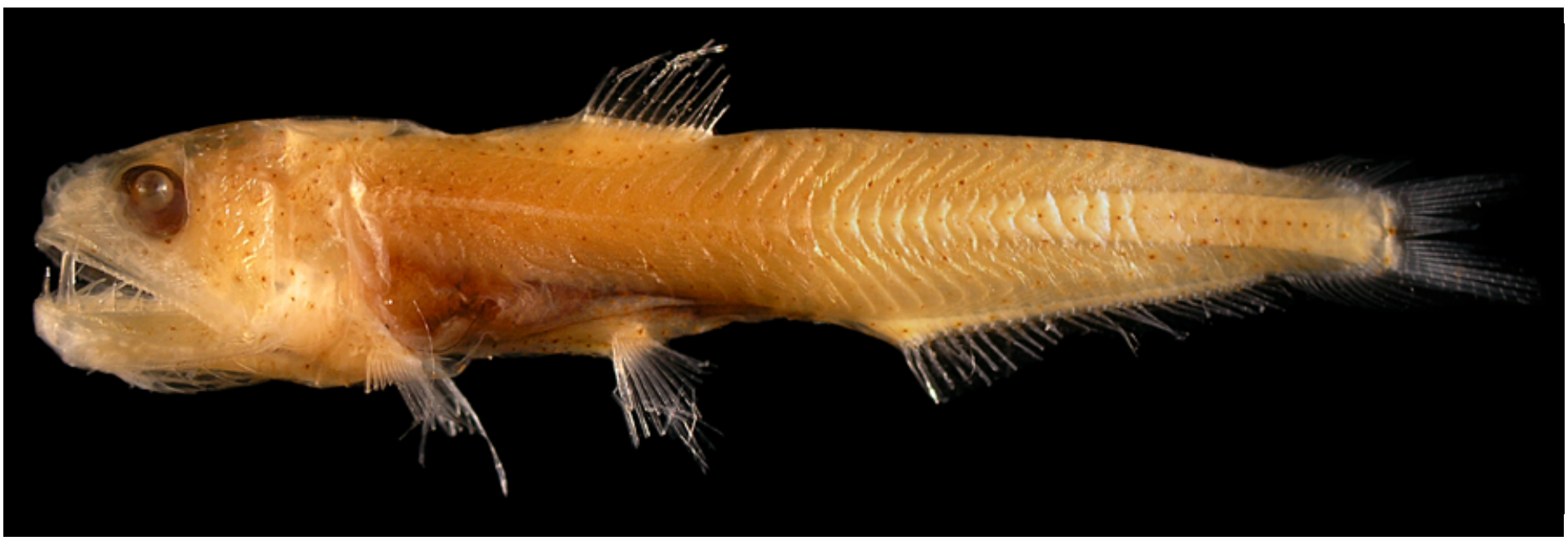

Figura 53: Evermannella balbo. DZUFRJ 5399; Juvenil; CP 28,0 mm.

\section{Evermannella balbo (Risso, 1820)}

Nos estágios de pré-flexão e de flexão possui três manchas peritoneais. Em pós-flexão as larvas têm de sete a oito bandas de pigmento na parte dorsal do corpo e de quatro a cinco na região ventral. O olho é elíptico, a nadadeira dorsal tem 12 a 13 raios e a anal tem 33 a 36 raios. Nos juvenis a cabeça fica mais arredondada e os olhos ficam menos elípticos. O número de miômeros varia entre 52 e 54. Os juvenis começam a desenvolver o padrão de pigmentação dos adultos, com melanóforos grandes alinhados em fila na região posterior do corpo. Apresentam também uma banda vertical na região do pedúnculo caudal.

Tamanho: pré-flexão 6,0 mm; juvenil 28,0 mm.

Habitat: espécie marinha, mesopelágica, ocorre em águas temperadas em profundidades entre 100 e $800 \mathrm{~m}$.

\section{Georreferenciamento}

\begin{tabular}{|c|c|c|c|c|c|c|c|c|}
\hline DZUFR & Latitude (S) & Longitude (W) & Data & $\begin{array}{c}\text { Tipo de } \\
\text { arrasto }\end{array}$ & $\begin{array}{c}\text { Profundidade } \\
\text { de coleta }\end{array}$ & Rede & $\begin{array}{c}\text { Malha } \\
\text { ( } \boldsymbol{\mu m})\end{array}$ & $\begin{array}{c}\mathbf{N}^{\circ} \text {. de } \\
\text { inds. }\end{array}$ \\
\hline 5399 & $22^{\circ} 31^{\prime} 40,9^{\prime \prime}$ & $040^{\circ} 02^{\prime} 39,6^{\prime \prime}$ & $07 / 11 / 2001$ & oblíquo & $1.000 \mathrm{~m}$ & cilíndrico-cônica & 500 & 1 \\
\hline 7394 & $21^{\circ} 58^{\prime} 31,0^{\prime \prime}$ & $039^{\circ} 50^{\prime} 29,7^{\prime \prime}$ & $11 / 10 / 2001$ & oblíquo & $1.000 \mathrm{~m}$ & cilíndrico-cônica & 500 & 1 \\
\hline
\end{tabular}

Referências: Rofen, 1966b; Bonecker et al., 2006b; Ditty, 2006c; Fahay, 2007. 


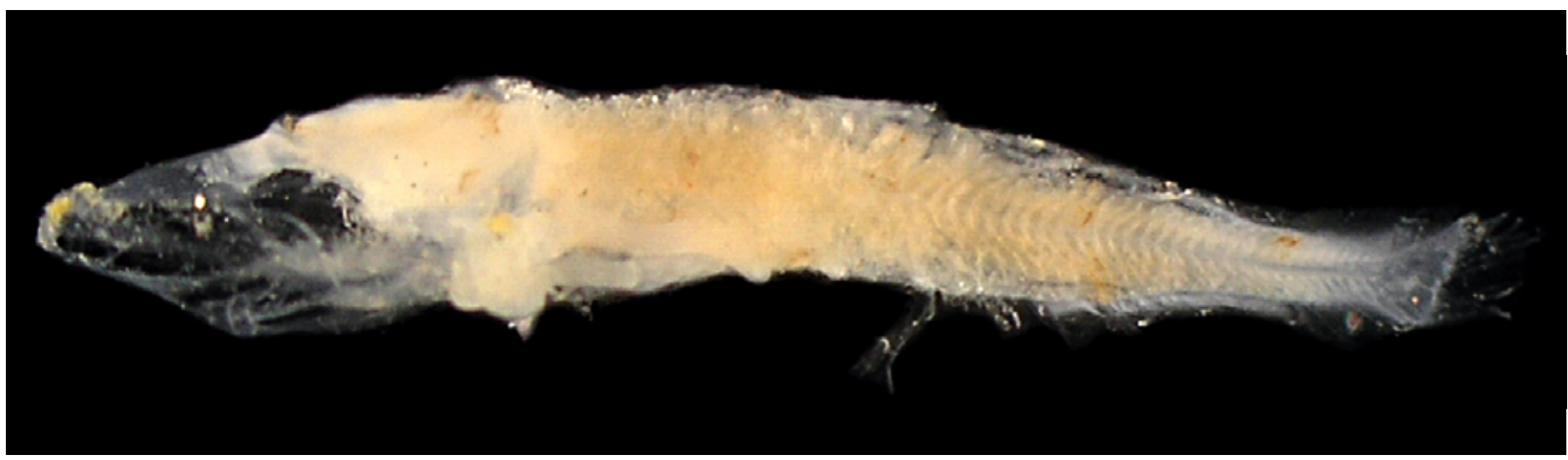

Figura 54: Evermannella melanoderma. DZUFRJ 7395; Flexão; CP 6,5 mm.

\section{Evermannella melanoderma Parr, 1928}

Nos estágios de pré-flexão e de flexão possui três manchas peritoneais. Tem duas linhas de cromatóforos ao longo do corpo, uma na região dorsal e outra na parte ventral, sobre a nadadeira anal. O olho é elíptico, a nadadeira dorsal tem 12 a 13 raios e a anal tem 27 a 31 raios. 0 número de miômeros varia entre 49 e 50.

Tamanho: flexão 6,5 mm.

Habitat: espécie marinha, mesopelágica, ocorre em águas tropicais e temperadas quentes em profundidades entre 100 e $800 \mathrm{~m}$.

\section{Georreferenciamento}

\begin{tabular}{|c|c|c|c|c|c|c|c|c|}
\hline DZUFRJ & Latitude (S) & Longitude (W) & Data & $\begin{array}{c}\text { Tipo de } \\
\text { arrasto }\end{array}$ & $\begin{array}{c}\text { Profundidade } \\
\text { de coleta }\end{array}$ & Rede & $\begin{array}{c}\text { Malha } \\
(\boldsymbol{\mu m})\end{array}$ & $\begin{array}{c}\mathbf{N}^{\circ} \text {. de } \\
\text { inds. }\end{array}$ \\
\hline 7395 & $21^{\circ} 54^{\prime} 36,5^{\prime \prime}$ & $039^{\circ} 45^{\prime} 20,0^{\prime \prime}$ & $10 / 10 / 2001$ & oblíquo & $1.000 \mathrm{~m}$ & cilíndrico-cônica & 500 & 1 \\
\hline
\end{tabular}

Referências: Rofen, 1966b; Bonecker et al., 2006b; Ditty, 2006c; Fahay, 2007. 


\section{ORDEM MYCTOPHIFORMES}

A ordem Myctophiformes é composta por duas famílias: Neoscopelidae e Myctophidae. $O$ corpo pode variar de fino e alongado a alto com cabeça grande, possuem olhos laterais, boca geralmente grande e terminal, nadadeira adiposa. Os indivíduos em transformação apresentam fotóforos, que são importantes na identificação das espécies.

Nesse estudo a ordem Myctophiformes é representada pela família Myctophidae. 


\section{Família Myctophidae}

A família Myctophidae é marinha e ocorre em todos os oceanos incluindo o Ártico e a Antártica. Compreende aproximadamente 32 gêneros com 240 espécies. Os gêneros são separados em duas subfamílias: Myctophinae (larvas com olhos elípticos) e Lampanyctinae (larvas com olhos redondos). São peixes mesopelágicos de tamanho médio, entre 3 e $35 \mathrm{~cm}$ de comprimento, com cabeça e corpo comprimidos lateralmente. Possuem uma única nadadeira dorsal seguida de nadadeira adiposa. A morfologia e o padrão de pigmentação do corpo são características muito importantes para a identificação das larvas. O número e o padrão de distribuição dos fotóforos são únicos para cada espécie, sendo fundamental para a identificação de indivíduos que já sofreram transformação. $\mathrm{Na}$ figura 56 está representado um exemplar hipotético da família Myctophidae com a denominação e posição dos fotóforos.

No Brasil já foram identificadas 80 espécies nas fases de larva e adulto. Nesse estudo são contempladas as espécies Benthosema suborbitale, Bolinichthys distofax, Centrobranchus nigroocelatus, Ceratoscopelus warmingii, Diaphus anderseni, Diaphus dumerilii, Diaphus mollis, Diaphus splendidus, Hygophum hygomii, Hygophum reinhardtii, Hygophum taaningi, Lampadena sp., Lampanyctus alatus, Lepidophanes gaussi, Lepidophanes guentheri, Lobianchia gemellarii, Myctophum affine, Myctophum nitidulum, Myctophum obtusirostre, Notolychnus valdiviae, Notoscopelus caudispinosus e Symbolophorus rufinus.

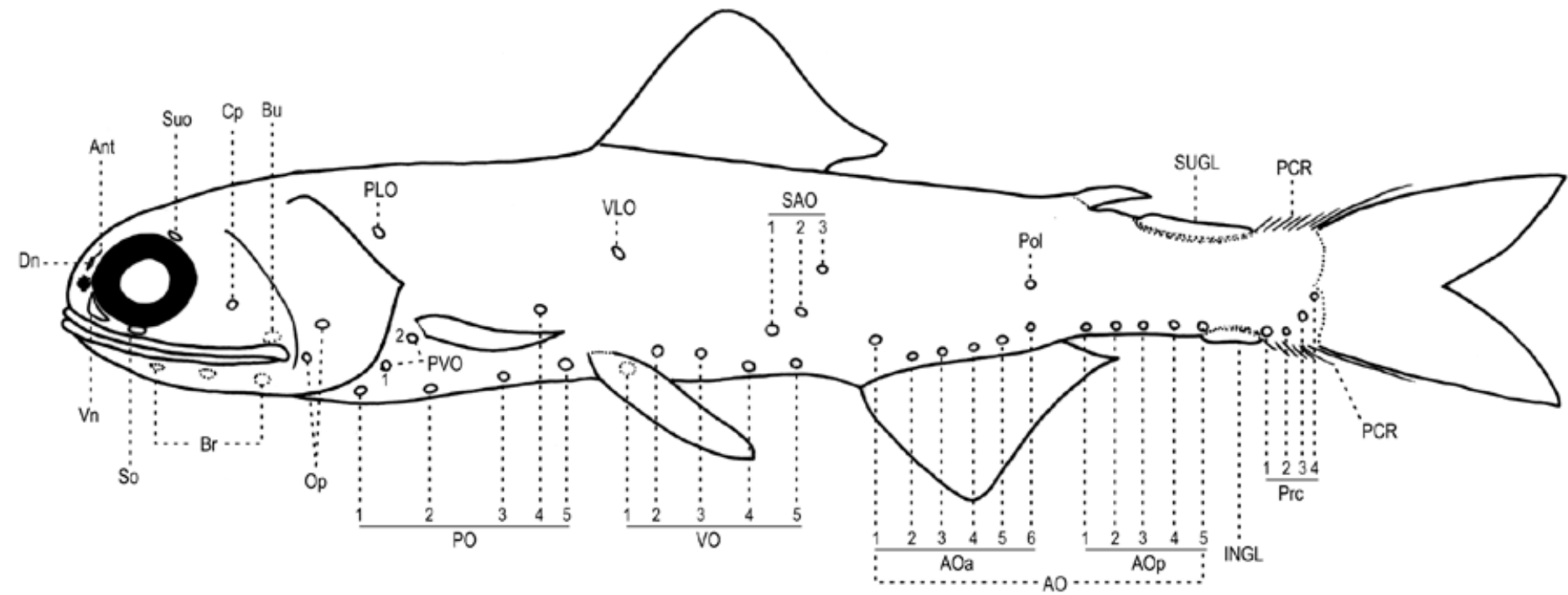

Figura 56: Padrão geral de fotóforos e terminologia utilizada para Myctophidae (modificado de Moser \& Ahlstrom, 1996). $A n t=$ fotóforo anterorbital; $A O=$ série anal; $A O a=$ fotóforos anais anteriores; $A O p=$ fotóforos anais posteriores; $B R=$ série branquiostégia; $\mathrm{Bu}$ = fotóforo bucal; $\mathrm{Cp}=$ fotóforo da face; $\mathrm{Dn}$ = fotóforo dorso-nasal; $\mathrm{INGL}=$ glândula luminosa infracaudal; $\mathrm{Op}$ = fotóforos operculares; $\mathrm{PLO}=$ fotóforo suprapeitoral; $\mathrm{PO}=$ série toráxica ou peitoral; Pol = fotóforo posterolateral; Prc = série pré-caudal; PVO = fotóforos subpeitorais; SAO = série supra-anal; So = fotóforo suborbital; SUGL = glândula luminosa supracaudal; Suo = fotóforo supraorbital; VLO = fotóforo supravental; Vn = fotóforo ventronasal; VO = série ventral. 


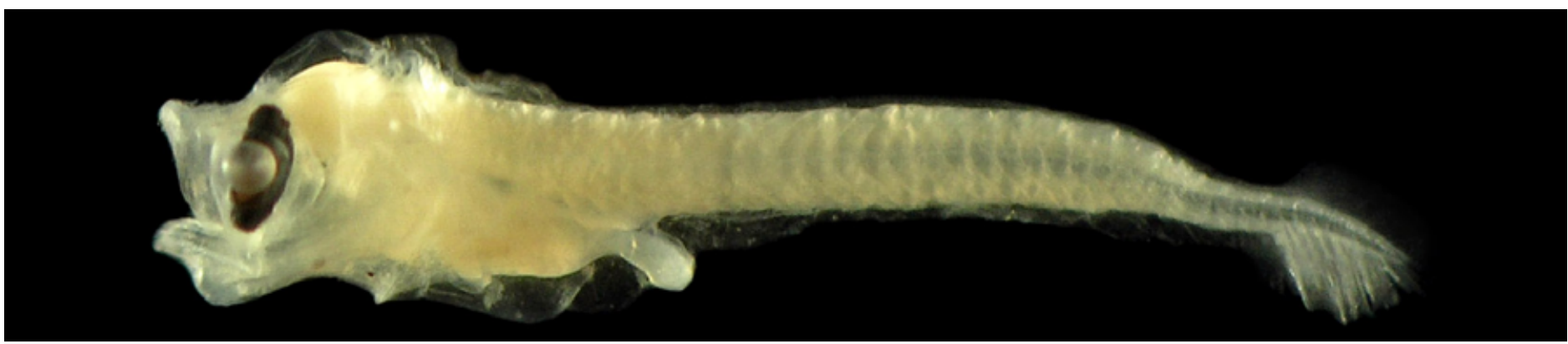

Figura 56 - A: Benthosema suborbitale. DZUFRJ 33548; Pré-flexão; CP 4,1 mm.

\section{Benthosema suborbitale (Gilbert, 1913)}

Possui olhos elípticos e intestino curto. Nos estágios de pré-flexão e flexão, a base da nadadeira anal é distante do ânus, o que separa facilmente essa espécie de algumas espécies de Hygophum que apresentam o corpo semelhante à $B$. suborbitale. Na pré-flexão possuem apenas um pigmento na região anterior à sínfise do cleitro. Na flexão surge um fotóforo na maxila inferior e manchas de melanóforos internos na região anterior a base da nadadeira peitoral. As larvas que já sofreram transformação apresentam um fotóforo suborbital; VO2 muito elevado ficando sobre ou um pouco atrás do VO1; SAO angular; 2 Prc, o segundo situado na linha lateral; $6 \mathrm{AOa}$ e 5 (4 a 6) AOp. O número de miômeros varia entre 33 e 35.

Tamanho: pré-flexão 2,7-5,0 mm; flexão 5,2-7,3 mm; pós-flexão 9,5-10,9 mm; transformação 11,5 mm.

Habitat: espécie marinha, epi-mesopelágica, ocorre em águas tropicais e subtropicais entre 375 e 750 m de profundidade durante o dia. A noite ocorre desde a superfície até $125 \mathrm{~m}$ de profundidade.

Nome vulgar: Peixe-lanterna.

\section{Georreferenciamento}

\begin{tabular}{|c|c|c|c|c|c|c|c|c|}
\hline DZUFR & Latitude (S) & Longitude (W) & Data & $\begin{array}{c}\text { Tipo de } \\
\text { arrasto }\end{array}$ & $\begin{array}{c}\text { Profundidade } \\
\text { de coleta }\end{array}$ & Rede & $\begin{array}{c}\text { Malha } \\
\text { ( } \boldsymbol{\mu m})\end{array}$ & $\begin{array}{c}\text { No. de } \\
\text { inds. }\end{array}$ \\
\hline 5518 & $22^{\circ} 31^{\prime} 58,9^{\prime \prime}$ & $040^{\circ} 02^{\prime} 53,4^{\prime \prime}$ & $07 / 11 / 2001$ & oblíquo & $1.000 \mathrm{~m}$ & cilíndrico-cônica & 500 & 1 \\
\hline 5520 & $22^{\circ} 31^{\prime} 58,9^{\prime \prime}$ & $040^{\circ} 02^{\prime} 53,4^{\prime \prime}$ & $07 / 11 / 2001$ & oblíquo & $1.000 \mathrm{~m}$ & cilíndrico-cônica & 500 & 1 \\
\hline 7390 & $21^{\circ} 54^{\prime} 36,5^{\prime \prime}$ & $039^{\circ} 45^{\prime} 20,0^{\prime \prime}$ & $10 / 10 / 2001$ & oblíquo & $1.000 \mathrm{~m}$ & cilíndrico-cônica & 500 & 1 \\
\hline 7564 & $21^{\circ} 58^{\prime} 31,0^{\prime \prime}$ & $039^{\circ} 50^{\prime} 29,7^{\prime \prime}$ & $10 / 10 / 2001$ & oblíquo & $1.000 \mathrm{~m}$ & cilíndrico-cônica & 500 & 4 \\
\hline 7568 & $21^{\circ} 53^{\prime} 10,4^{\prime \prime}$ & $039^{\circ} 45^{\prime} 49,9^{\prime \prime}$ & $10 / 10 / 2001$ & oblíquo & $1.000 \mathrm{~m}$ & cilíndrico-cônica & 500 & 2 \\
\hline 22009 & $21^{\circ} 58^{\prime} 31,0^{\prime \prime}$ & $039^{\circ} 50^{\prime} 29,7^{\prime \prime}$ & $10 / 10 / 2001$ & oblíquo & $1.000 \mathrm{~m}$ & cilíndrico-cônica & 500 & 7 \\
\hline 22052 & $22^{\circ} 07^{\prime} 29,0^{\prime \prime}$ & $039^{\circ} 06^{\prime} 23,5^{\prime \prime}$ & $10 / 05 / 2002$ & oblíquo & $1.000 \mathrm{~m}$ & cilíndrico-cônica & 500 & 1 \\
\hline 22786 & $22^{\circ} 32^{\prime} 49,0^{\prime \prime}$ & $040^{\circ} 04^{\prime} 29^{\prime \prime}$ & $07 / 11 / 2001$ & oblíquo & $1.000 \mathrm{~m}$ & cilíndrico-cônica & 500 & 1 \\
\hline
\end{tabular}

Referências: Nafpakititis et al., 1977; Moser \& Ahlstrom, 1996; Castro \& Bonecker, 2006c; Moser \& Watson, 2006; Fahay, 2007.

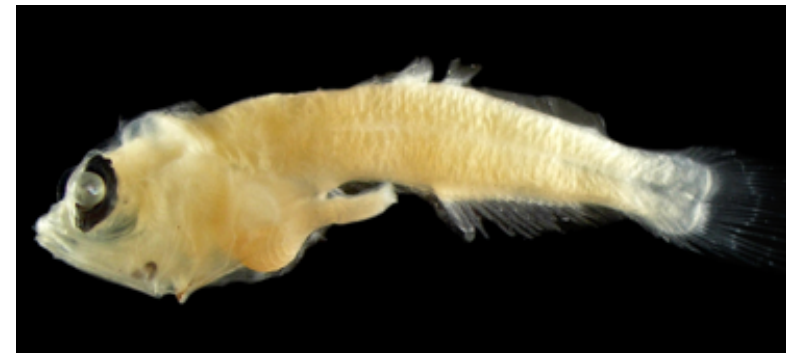

Figura 56 - B: DZUFRJ 33547; Flexão; CP 6,0 mm.

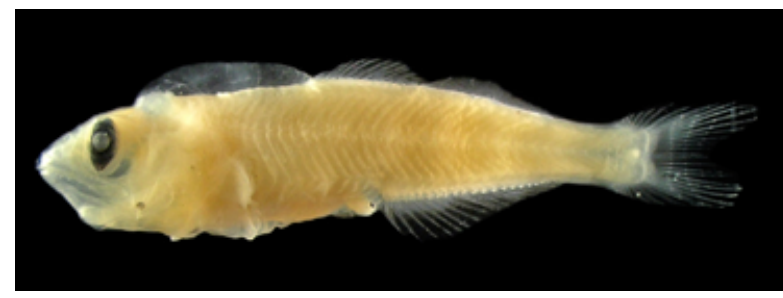

Figura 56 - C: DZUFRJ 33546; Pós-flexão; CP 10,9 mm.

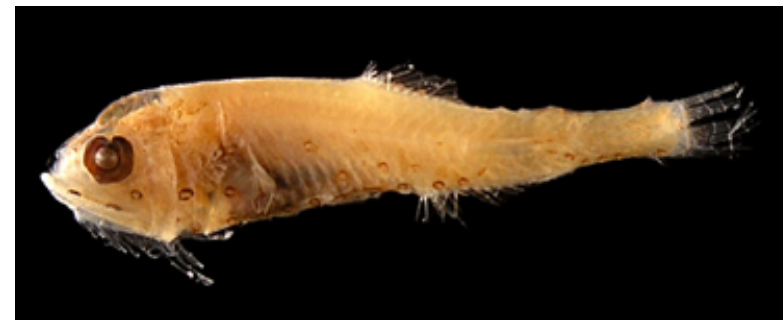

Figura 56 - D: DZUFRJ 22009; Transformação; CP $11,5 \mathrm{~mm}$. 


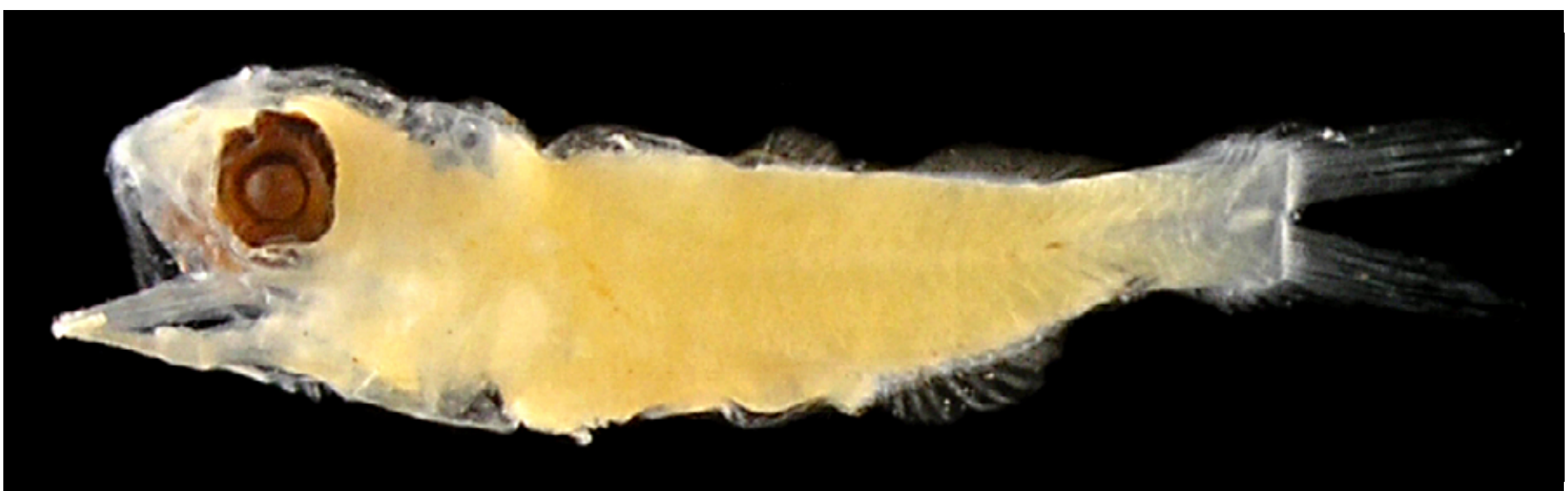

Figura 57 - A: Bolinichthys distofax. DZUFRJ 23790; Flexão; CP 5,1 mm.

\section{Bolinichthys distofax Johnson, 1975}

As larvas em estágio de flexão possuem uma série de pigmentos na região da linha lateral na cauda que é única dessa espécie. Os indivíduos que já sofreram transformação possuem o último AOa um pouco elevado e não apresentam tecido luminoso na base da nadadeira pélvica. Possui 6 (5) AOa e 4 (5) AOp; 1 Pol; 3 Prc e um total de 34 vértebras.

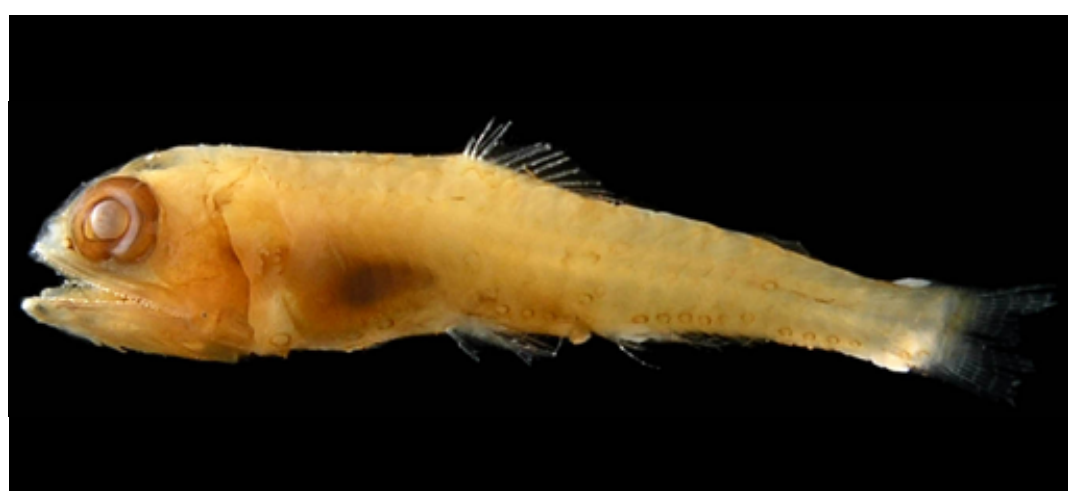

Figura 57 - B: DZUFRJ 22155; Transformação; CP 17,3 mm.

Tamanho: flexão 5,1-5,5 mm; transformação 15,5-17,3 mm.

Habitat: espécie marinha, ocorre em águas tropicais e subtropicais entre 100 e $690 \mathrm{~m}$ de profundidade.

Nome vulgar: Peixe-lanterna.

\section{Georreferenciamento}

\begin{tabular}{|c|c|c|c|c|c|c|c|c|}
\hline DZUFRJ & Latitude (S) & Longitude (W) & Data & $\begin{array}{l}\text { Tipo de } \\
\text { arrasto }\end{array}$ & $\begin{array}{l}\text { Profundidade } \\
\text { de coleta }\end{array}$ & Rede & $\begin{array}{c}\text { Malha } \\
(\mu \mathrm{m})\end{array}$ & $\begin{array}{l}N^{\circ} \text {. de } \\
\text { inds. }\end{array}$ \\
\hline 22069 & $21^{\circ} 57,51^{\prime}$ & $039^{\circ} 49,57^{\prime}$ & $19 / 06 / 2003$ & vertical & $500-1.150 \mathrm{~m}$ & cilíndrico-cônica & 500 & 1 \\
\hline 22155 & $21^{\circ} 57^{\prime} 10,5^{\prime \prime}$ & $039^{\circ} 43^{\prime} 33,3^{\prime \prime}$ & 09/10/2001 & oblíquo & $1.000 \mathrm{~m}$ & cilíndrico-cônica & 500 & 1 \\
\hline 23790 & $22^{\circ} 03^{\prime} 03,3^{\prime \prime}$ & $039^{\circ} 50^{\prime} 39,0^{\prime \prime}$ & $10 / 05 / 2002$ & oblíquo & até a termoclina & bongô & 330 & 3 \\
\hline
\end{tabular}

Referências: Nafpakititis et al., 1977; Moser \& Ahlstrom, 1996; Moser \& Watson, 2006; Santos \& Figueiredo, 2008. 


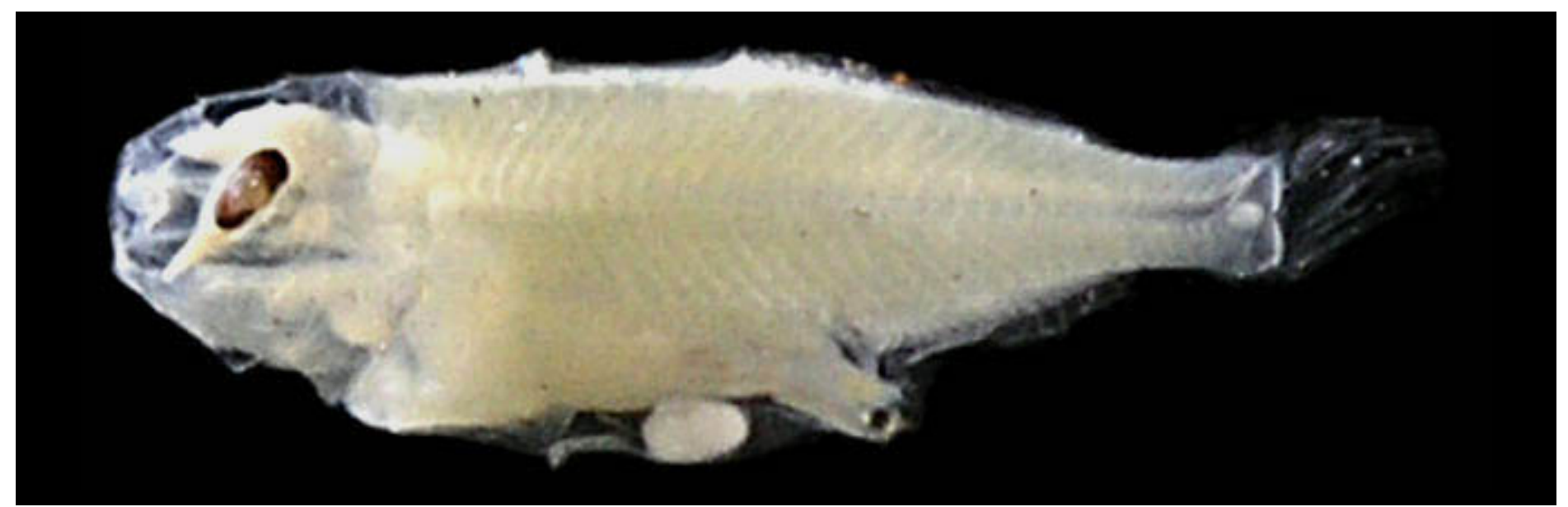

Figura 58: Centrobranchus nigroocelatus. DZUFRJ 22173; Pós-flexão; CP 7,4mm.

\section{Centrobranchus nigroocelatus (Günther, 1873)}

As larvas em pré-flexão são moderadamente alongadas, mas o corpo torna-se alto e muito comprimido ao longo do desenvolvimento. As membranas embrionárias são grandes e permanecem até a transformação. A cabeça é grande, e os olhos são estreitos e elípticos, com tecido coroide muito alongado e sem pigmento. As larvas em pós-flexão possuem pigmento na margem posterior da órbita. O número de miômeros varia entre 35 e 40.

Tamanho: pós-flexão 7,4 mm.

Habitat: espécie marinha, mesopelágica, ocorre em águas tropicais e subtropicais entre 375 e $650 \mathrm{~m}$ de profundidade durante o dia. A noite ocorre próximo à superfície.

Nome vulgar: Peixe-lanterna.

\section{Georreferenciamento}

\begin{tabular}{|c|c|c|c|c|c|c|c|c|}
\hline DZUFRJ & Latitude (S) & Longitude (W) & Data & $\begin{array}{c}\text { Tipo de } \\
\text { arrasto }\end{array}$ & $\begin{array}{c}\text { Profundidade } \\
\text { de coleta }\end{array}$ & Rede & $\begin{array}{c}\text { Malha } \\
(\boldsymbol{\mu} \text { m) }\end{array}$ & $\begin{array}{c}\text { No. de } \\
\text { inds. }\end{array}$ \\
\hline 22173 & $22^{\circ} 37^{\prime} 21,9^{\prime \prime}$ & $040^{\circ} 02^{\prime} 425^{\prime \prime}$ & $08 / 12 / 2002$ & vertical & $200-500 \mathrm{~m}$ & cilíndrico-cônica & 200 & 1 \\
\hline
\end{tabular}

Referências: Moser \& Ahlstrom, 1996; Castro \& Bonecker, 2006c; Moser \& Watson, 2006; Fahay, 2007. 


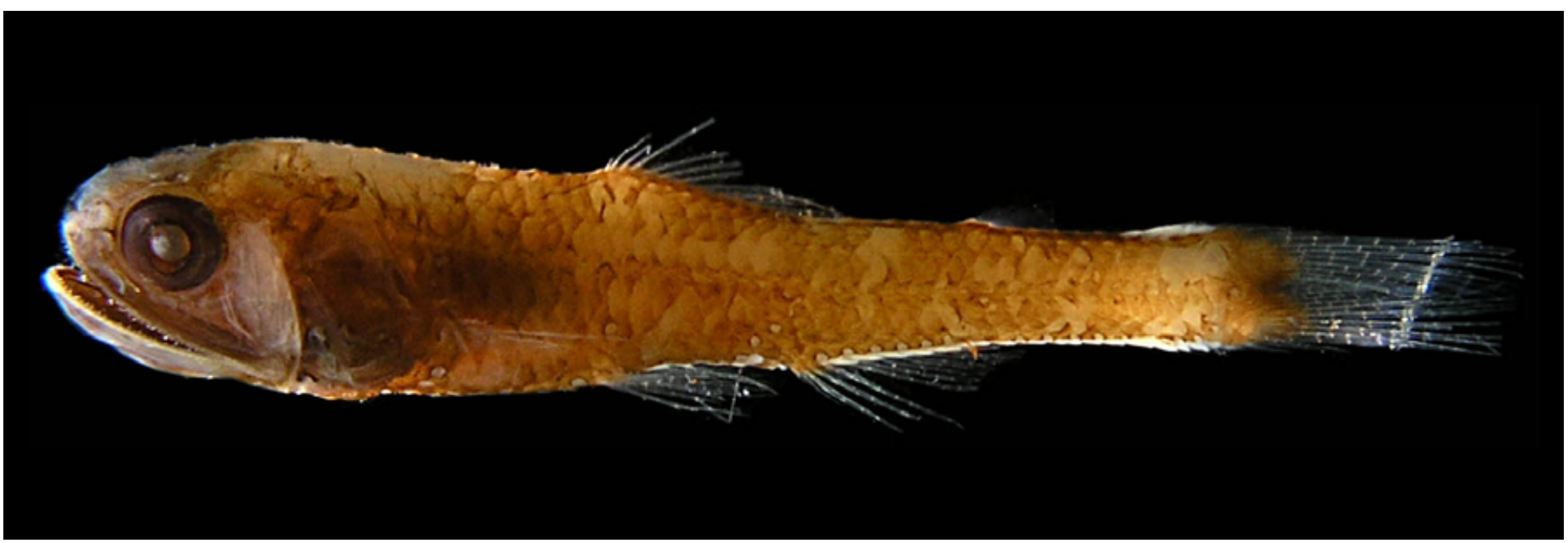

Figura 59: Ceratoscopelus warmingii. DZUFRJ 22156; Juvenil; CP 23,0 mm.

\section{Ceratoscopelus warmingii (Lütken, 1892)}

Os juvenis possuem 6 (5-7) AOa e 5 (4-6) AOp; 2 Pol; 4 Prc. Os indivíduos dessa espécie podem ser separados também pelo número de rastros branquiais 4(3) + $1+9-10(8)=14-15$ (13); pela ausência de espinhos supraorbitais e pela presença de tecido luminoso ao longo da margem ventral do corpo. O número de miômeros varia entre 35 e 36.

Tamanho: juvenil 17,0-23,0 mm.

Habitat: espécie marinha, epi-mesopelágica, ocorre em águas tropicais e subtropicais entre 425 e $1.000 \mathrm{~m}$ de profundidade durante o dia. A noite ocorre desde próximo à superfície até $125 \mathrm{~m}$ de profundidade.

Nome vulgar: Peixe-lanterna.

\section{Georreferenciamento}

\begin{tabular}{|c|c|c|c|c|c|c|c|c|}
\hline DZUFRJ & Latitude (S) & Longitude (W) & Data & $\begin{array}{l}\text { Tipo de } \\
\text { arrasto }\end{array}$ & $\begin{array}{l}\text { Profundidade } \\
\text { de coleta }\end{array}$ & Rede & $\begin{array}{c}\text { Malha } \\
(\mu \mathrm{m})\end{array}$ & $\begin{array}{l}N^{\circ} \text {. de } \\
\text { inds. }\end{array}$ \\
\hline 21982 & $21^{\circ} 58^{\prime} 31,0^{\prime \prime}$ & $039^{\circ} 50^{\prime} 29,7 "$ & $11 / 10 / 2001$ & oblíquo & $1.000 \mathrm{~m}$ & cilíndrico-cônica & 500 & 2 \\
\hline 22020 & & $0^{\prime \prime}$ & $10 / 10$ & oblíquo & $1.000 \mathrm{~m}$ & cilíndrico-cônica & 500 & 1 \\
\hline 22084 & $22^{\circ} 31^{\prime} 40,9^{\prime \prime}$ & $040^{\circ} 02^{\prime} 39,6^{\prime \prime}$ & $07 / 11 / 2001$ & oblíq & 1.0 & cilíndrico-cônica & 500 & 1 \\
\hline 22086 & $22^{\circ} 31^{\prime} 40,9^{\prime \prime}$ & $040^{\circ} 02^{\prime} 39,6^{\prime \prime}$ & $07 / 11 / 2001$ & oblíquo & $1.000 \mathrm{~m}$ & cilíndrico-cônica & 500 & 1 \\
\hline 22156 & $21^{\circ} 57^{\prime} 10,5^{\prime \prime}$ & $039^{\circ} 43^{\prime} 33,3^{\prime \prime}$ & 09/10/2001 & oblíquo & $1.000 \mathrm{~m}$ & cilíndrico-cônica & 500 & 1 \\
\hline 22711 & $21^{\circ} 54^{\prime} 36,5^{\prime \prime}$ & $039^{\circ} 45^{\prime} 20,0^{\prime \prime}$ & $10 / 10 / 2001$ & oblíquo & $1.000 \mathrm{~m}$ & cilíndrico-cônica & 500 & 2 \\
\hline
\end{tabular}

Referências: Nafpakititis et al., 1977; Castro \& Bonecker, 2006c; Santos \& Figueiredo, 2008. 


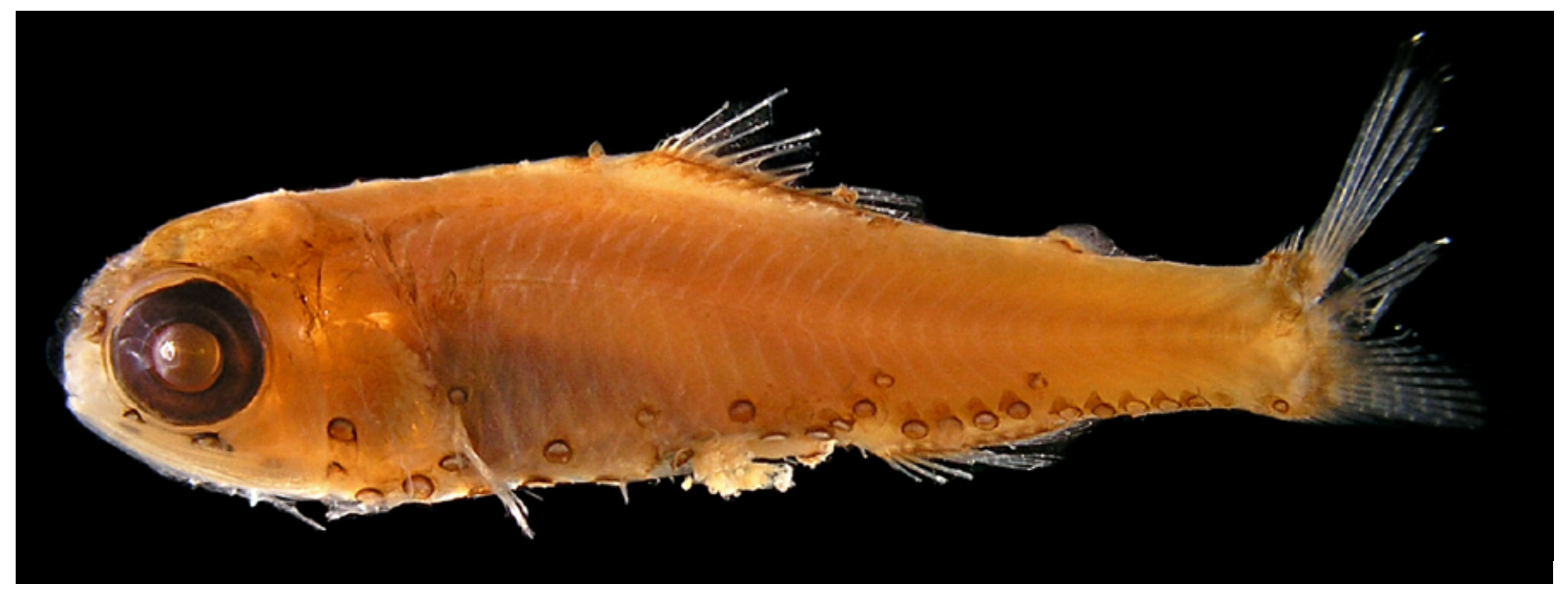

Figura 60: Diaphus anderseni. DZUFRJ 22794; Juvenil; CP 23,5 mm.

\section{Diaphus anderseni Tåning, 1932}

Os juvenis apresentam Dn, Vn e So redondos e grandes. Os fotóforos são maiores que a maioria das espécies de Diaphus. SAO está em linha reta ou um pouco angulado; 4 Prc formando um arco; 1 Pol; 4 Aoa e 4 a 5 AOp.

Tamanho: juvenil 11,7-23,5 mm.

Habitat: espécie marinha, mesopelágica, ocorrendo entre 100 e $500 \mathrm{~m}$ de profundidade.

Nome vulgar: Peixe-lanterna.

\section{Georreferenciamento}

\begin{tabular}{|c|c|c|c|c|c|c|c|c|}
\hline DZUFRJ & Latitude (S) & Longitude (W) & Data & $\begin{array}{c}\text { Tipo de } \\
\text { arrasto }\end{array}$ & $\begin{array}{c}\text { Profundidade } \\
\text { de coleta }\end{array}$ & Rede & $\begin{array}{c}\text { Malha } \\
\text { ( } \boldsymbol{\mu m})\end{array}$ & $\begin{array}{c}\mathbf{N}^{\circ} \text {. de } \\
\text { inds. }\end{array}$ \\
\hline 22794 & $21^{\circ} 58^{\prime} 31,0^{\prime \prime}$ & $039^{\circ} 50^{\prime} 29,7^{\prime \prime}$ & $11 / 10 / 2001$ & oblíquo & $1.000 \mathrm{~m}$ & cilíndrico-cônica & 500 & 1 \\
\hline 22797 & $22^{\circ} 08^{\prime} 17,5^{\prime \prime}$ & $039^{\circ} 46^{\prime} 28,5^{\prime \prime}$ & $11 / 05 / 2002$ & oblíquo & $1.000 \mathrm{~m}$ & cilíndrico-cônica & 500 & 1 \\
\hline 22800 & $22^{\circ} 02^{\prime} 30,0^{\prime \prime}$ & $09^{\circ} 49^{\prime} 41,2^{\prime \prime}$ & $12 / 05 / 2002$ & oblíquo & $1.000 \mathrm{~m}$ & cilíndrico-cônica & 500 & 1 \\
\hline
\end{tabular}

Referências: Nafpakititis et al., 1977; Castro \& Bonecker, 2006c; Santos \& Figueiredo, 2008. 


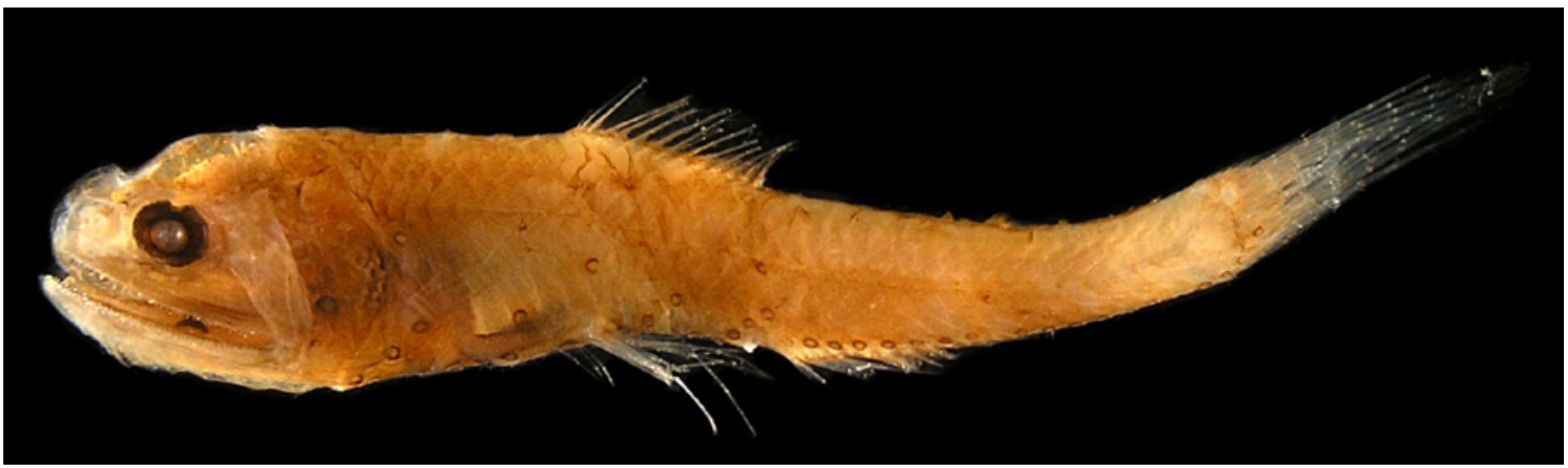

Figura 61 - A: Diaphus dumerilii. DZUFRJ 21983; Transformação; CP 16,0 mm.

\section{Diaphus dumerilii (Bleeker, 1856)}

Os indivíduos em transformação podem ser facilmente separados dos demais Diaphus por apresentarem os fotóforos $\mathrm{AOa}$ em linha reta; 7 (6 a 8) AOa e 5 (5 a 6) AOp; SAO angular; 4 Prc formando um arco; 1 Pol; Vn pequeno e situado na margem ventral anterior da pupila.

Tamanho: transformação 16,0-17,0 mm; juvenil $26,5 \mathrm{~mm}$; adulto $65,0 \mathrm{~mm}$.

Habitat: espécie marinha, mesopelágica, ocorrendo até $805 \mathrm{~m}$ de profundidade.

Nome vulgar: Peixe-lanterna.

\section{Georreferenciamento}

\begin{tabular}{|c|c|c|c|c|c|c|c|c|}
\hline DZUFRJ & Latitude & Longitude & Data & $\begin{array}{l}\text { Tipo de } \\
\text { arrasto }\end{array}$ & $\begin{array}{c}\text { Profundidade } \\
\text { de coleta }\end{array}$ & Rede & $\begin{array}{l}\text { Malha } \\
(\mu \mathrm{m})\end{array}$ & $\begin{array}{l}\text { No. de } \\
\text { inds. }\end{array}$ \\
\hline 21983 & $21^{\circ} 58 ' 31,0^{\prime \prime}$ & $039^{\circ} 50 ' 29,7^{\prime \prime}$ & $10 / 10 / 2001$ & oblíquo & $1.000 \mathrm{~m}$ & cilíndrico-cônica & 500 & 1 \\
\hline 21995 & $22^{\circ} 07^{\prime} 58,8^{\prime \prime}$ & $039^{\circ} 49^{\prime} 08,9^{\prime \prime}$ & $02 / 12 / 2002$ & vertical & $200-1.100 m$ & cilíndrico-cônica & 200 & 6 \\
\hline 22141 & $21^{\circ} 54 ' 36,5^{\prime \prime}$ & $039^{\circ} 45^{\prime} 20,0^{\prime \prime}$ & $10 / 10 / 2001$ & oblíquo & $1.000 \mathrm{~m}$ & cilíndrico-cônica & 500 & 1 \\
\hline 22149 & $21^{\circ} 53^{\prime} 10,4^{\prime \prime}$ & $039^{\circ} 45^{\prime} 49,9^{\prime \prime}$ & $10 / 10 / 2001$ & oblíquo & $1.000 \mathrm{~m}$ & cilíndrico-cônica & 500 & 1 \\
\hline
\end{tabular}

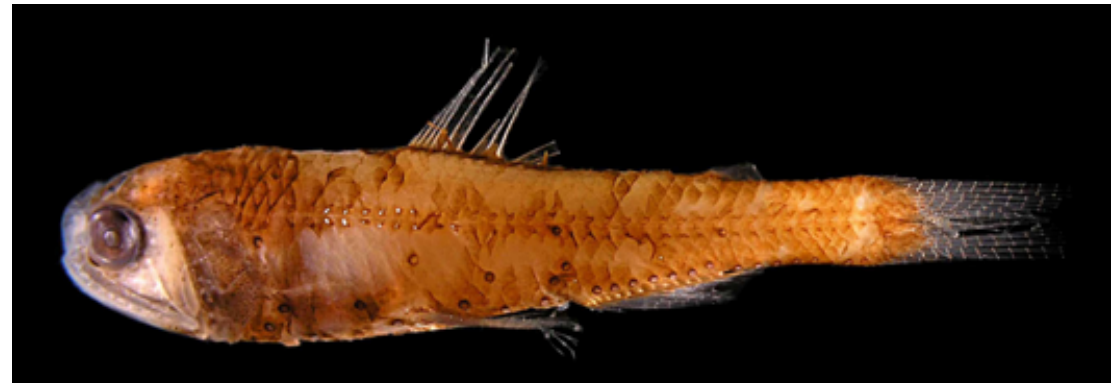

Figura 61 - B: DZUFRJ 22149; Juvenil; CP 26,5 mm.

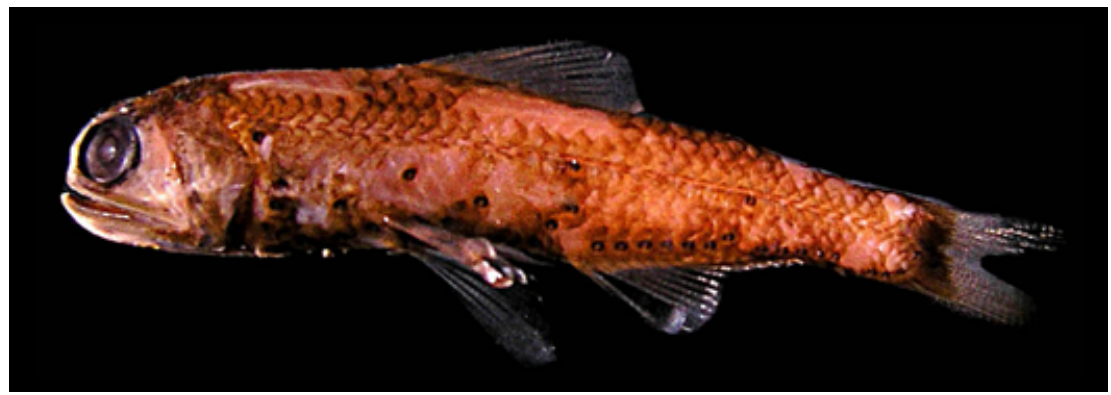

Figura 61 - C: DZUFRJ 22141; Adulto; CP 65,0 mm.

Referências: Nafpakititis et al., 1977; Castro \& Bonecker, 2006c; Santos \& Figueiredo, 2008. 


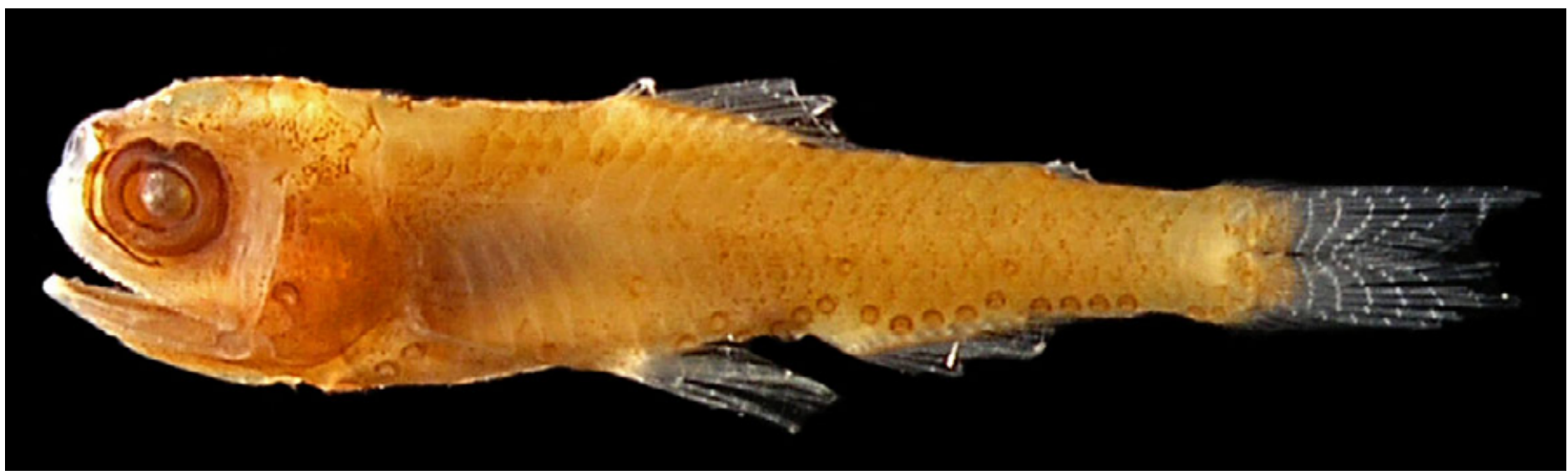

Figura 62: Diaphus mollis. DZUFRJ 22795; Transformação; CP 12,5 mm.

\section{Diaphus mollis Tåning, 1928}

Os indivíduos em transformação podem ser separados dos demais Diaphus por apresentarem o Vn alongado; SAO em ângulo obtuso e SAO1 localizado acima e atrás do VO5; 5 (4 a 6) AOa e 4 (3 a 5) AOp; AOa1 elevado e no nível do SAO2; 4 Prc formando um arco; 1 Pol. O número de miômeros varia entre 33 e 34 .

Tamanho: transformação 12,3-12,5 mm.

Habitat: espécie marinha, mesopelágica, ocorrendo entre 300 e 600 m de profundidade. Durante a noite migra para próximo da superfície.

Nome vulgar: Peixe-lanterna.

\section{Georreferenciamento}

\begin{tabular}{|c|c|c|c|c|c|c|c|c|}
\hline DZUFR & Latitude (S) & Longitude (W) & Data & $\begin{array}{c}\text { Tipo de } \\
\text { arrasto }\end{array}$ & $\begin{array}{c}\text { Profundidade } \\
\text { de coleta }\end{array}$ & Rede & $\begin{array}{c}\text { Malha } \\
\text { ( } \boldsymbol{\mu m})\end{array}$ & $\begin{array}{c}\mathbf{N}^{\circ} \text {. de } \\
\text { inds. }\end{array}$ \\
\hline 22792 & $21^{\circ} 53^{\prime} 10,4^{\prime \prime}$ & $039^{\circ} 45^{\prime} 49,9^{\prime \prime}$ & $10 / 10 / 2001$ & oblíquo & $1.000 \mathrm{~m}$ & cilíndrico-cônica & 500 & 1 \\
\hline 22795 & $22^{\circ} 06^{\prime} 52,3^{\prime \prime}$ & $039^{\circ} 48^{\prime} 46,2^{\prime \prime}$ & $11 / 05 / 2002$ & oblíquo & $1.000 \mathrm{~m}$ & cilíndrico-cônica & 500 & 1 \\
\hline
\end{tabular}

Referências: Nafpakititis et al., 1977; Fahay, 2007; Santos \& Figueiredo, 2008. 


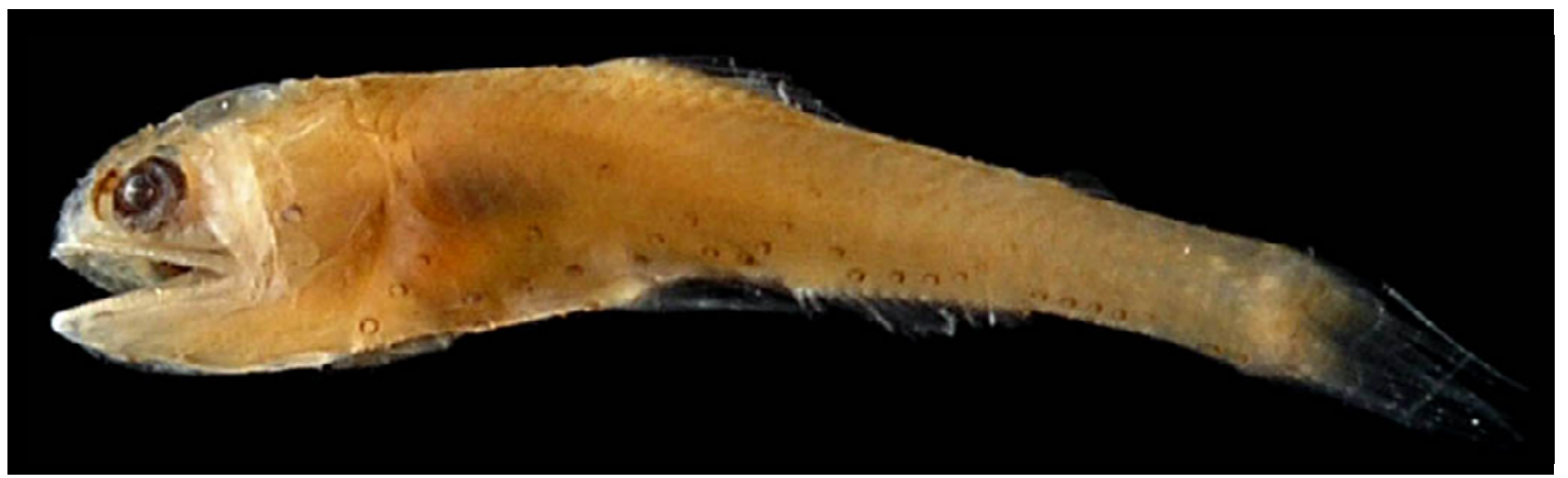

Figura 63: Diaphus splendidus. DZUFRJ 22162; Transformação; CP 12,3mm.

\section{Diaphus splendidus (Brauer, 1904)}

Os indivíduos em transformação não apresentam SO; possuem SAO em linha reta ou um pouco angulado; VLO próximo a linha lateral; 4 Prc formando um arco; 1 Pol, próximo a linha lateral; 6 (7) AOa e 6 (5) AOp. A espécie possui uma escama luminosa triangular grande no PLO e um espinho supraorbital.

Tamanho: transformação 12,3-17,0 mm.

Habitat: espécie marinha, mesopelágica, ocorrendo entre 40 e 3.872 m de profundidade.

Nome vulgar: Peixe-lanterna

\section{Georreferenciamento}

\begin{tabular}{|c|c|c|c|c|c|c|c|c|}
\hline DZUFR & Latitude (S) & Longitude (W) & Data & $\begin{array}{c}\text { Tipo de } \\
\text { arrasto }\end{array}$ & $\begin{array}{c}\text { Profundidade } \\
\text { de coleta }\end{array}$ & Rede & $\begin{array}{c}\text { Malha } \\
\text { ( } \boldsymbol{\mu m})\end{array}$ & $\begin{array}{c}\mathbf{N}^{\circ} \text {. de } \\
\text { inds. }\end{array}$ \\
\hline 22162 & $22^{\circ} 07^{\prime} 29,0^{\prime \prime}$ & $039^{\circ} 06^{\prime} 23,5^{\prime \prime}$ & $10 / 05 / 2002$ & oblíquo & $1.000 \mathrm{~m}$ & cilíndrico-cônica & 500 & 1 \\
\hline 22799 & $22^{\circ} 08^{\prime} 17,5^{\prime \prime}$ & $039^{\circ} 46^{\prime} 28,5^{\prime \prime}$ & $11 / 05 / 2002$ & oblíquo & $1.000 \mathrm{~m}$ & cilíndrico-cônica & 500 & 1 \\
\hline
\end{tabular}

Referências: Nafpakititis et al., 1977; Castro \& Bonecker, 2006c; Santos \& Figueiredo, 2008. 


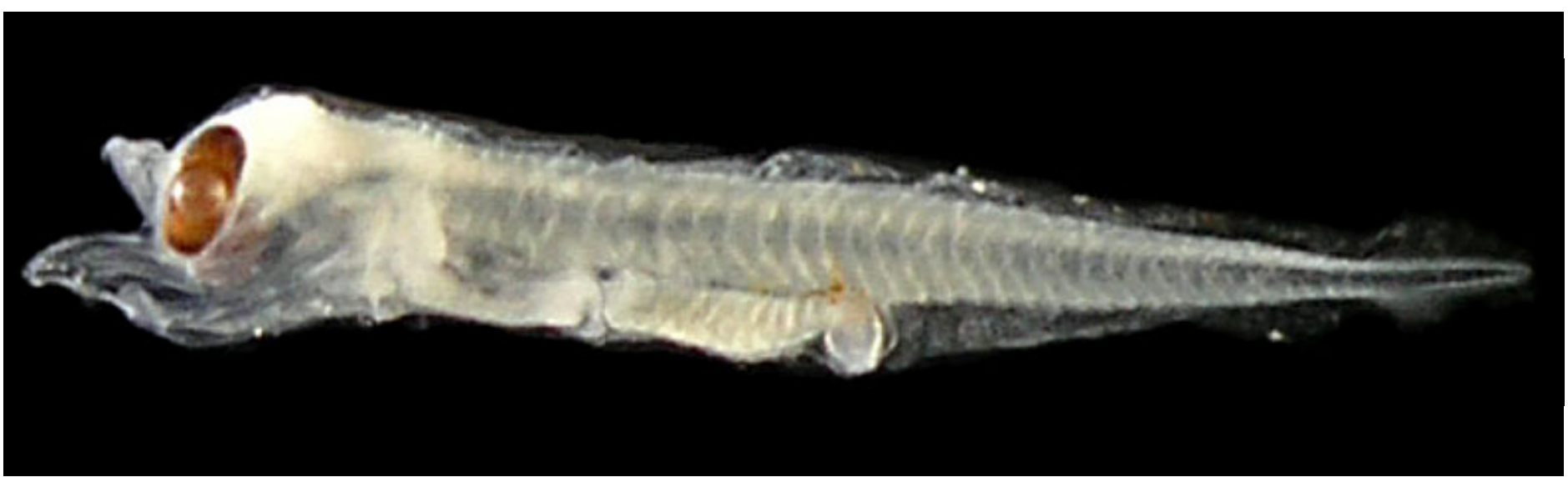

Figura 64: Hygophum hygomii. DZUFRJ 7586; Pré-flexão; CP 3,3 mm.

\section{Hygophum hygomii (Lütken, 1892)}

Possui olhos moderadamente elípticos com massa de tecido coroide amarronzado na margem ventral. A nadadeira anal começa próximo ao ânus. Apresenta um fotóforo no istmo e pigmentos no cleitro e no final do intestino, próximo ao ânus. Em alguns exemplares é possível ver melanóforos na margem da membrana dorsal. O número de miômeros varia entre 36 e 38.

Tamanho: pré-flexão 3,3 mm.

Habitat: espécie marinha, epi-mesopelágica, ocorre em águas temperadas e subtropicais entre 425 e $750 \mathrm{~m}$ de profundidade durante o dia. A noite ocorre desde próximo à superfície até $125 \mathrm{~m}$ de profundidade.

Nome vulgar: Peixe-lanterna.

\section{Georreferenciamento}

\begin{tabular}{|c|c|c|c|c|c|c|c|c|}
\hline DZUFR & Latitude (S) & Longitude (W) & Data & $\begin{array}{c}\text { Tipo de } \\
\text { arrasto }\end{array}$ & $\begin{array}{c}\text { Profundidade } \\
\text { de coleta }\end{array}$ & Rede & $\begin{array}{c}\text { Malha } \\
\text { ( } \boldsymbol{\mu m} \text { ) }\end{array}$ & $\begin{array}{c}\mathbf{N}^{\circ} \text {. de } \\
\text { inds. }\end{array}$ \\
\hline 7586 & $22^{\circ} 02,2^{\prime}$ & $039^{\circ} 43,49^{\prime}$ & $18 / 06 / 2003$ & vertical & $90 \mathrm{~m}$ & cilíndrico-cônica & 500 & 1 \\
\hline 23980 & $21^{\circ} 58^{\prime} 31,0^{\prime \prime}$ & $039^{\circ} 50^{\prime} 29,7^{\prime \prime}$ & $10 / 10 / 2001$ & oblíquo & $1.000 \mathrm{~m}$ & cilíndrico-cônica & 500 & 1 \\
\hline
\end{tabular}

Referências: Moser \& Ahlstrom, 1996; Castro \& Bonecker, 2006c; Moser \& Watson, 2006; Fahay, 2007. 


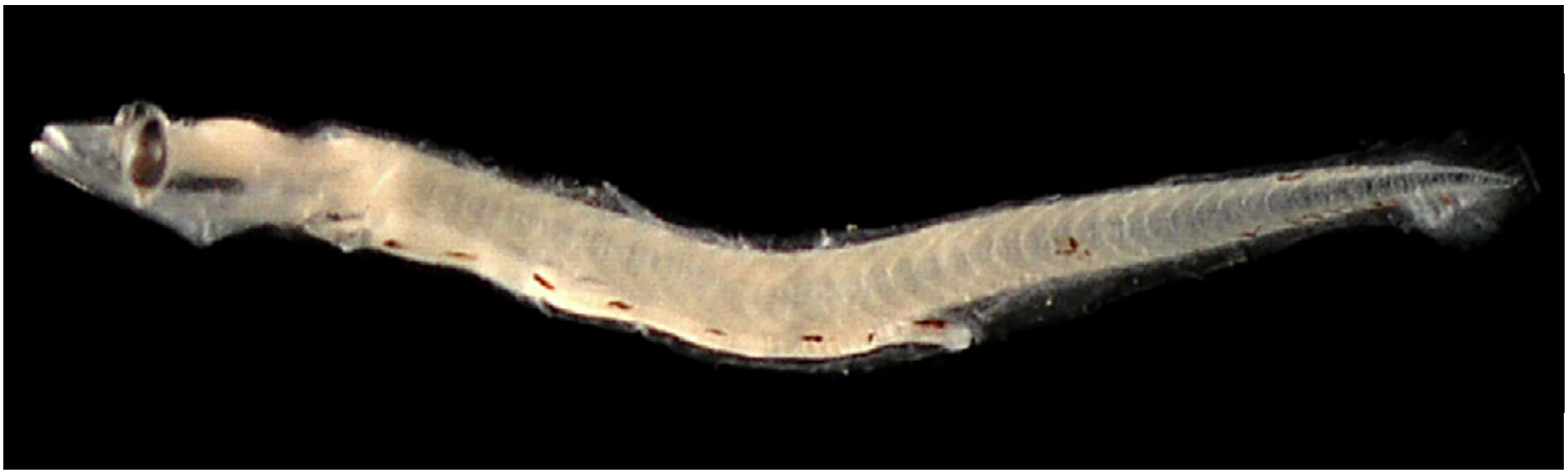

Figura 65 - A: Hygophum reinhardtii. DZUFRJ 14694; Pré-flexão; CP 6,8 mm.

\section{Hygophum reinhardtii (Lütken, 1892)}

Nos estágios de pré-flexão, flexão e pós-flexão essa espécie possui olhos muito elípticos e um pouco pedunculados, com tecido coroide cônico ventral. Tem corpo alongado e intestino longo, que alcança a metade do corpo. Durante o desenvolvimento o padrão de pigmentação varia. Na pré-flexão possui pigmentos logo após o cleitro, um par dorsal no final do intestino, dois pares na região lateral do intestino, entre outros. Durante a flexão há um pigmento no opérculo, até oito na região lateral do intestino, uma série de sete a 12 na região pós-anal começando na base da nadadeira anal. Na pós-flexão possui cinco a dez no miossepto na região pós-anal, até oito pares laterais no intestino e até 15 na base da nadadeira anal. 0 número de miômeros varia entre 38 e 40. Na transformação os fotóforos Br1, PO1, PO5, e VO4 são os primeiros que aparecem. Os indivíduos em transformação, juvenis e adultos possuem SAO1 um pouco atrás do VO2 e abaixo de uma linha reta conectando SAO2 com VLO. Possui SAO3 na direção da origem da nadadeira anal e em contato com a linha lateral; 2 Pol, o segundo à frente da base da nadadeira adiposa e em contato com a linha lateral; 2 Prc, o segundo situado na linha lateral; 7 (6 a 8) AOa e 7 (6 a 9) AOp. Nesses estágios o olho fica arredondado e há uma regressão do tecido coroide.

Tamanho: pré-flexão 3,8-8,4 mm; flexão 9,1-10,2 mm; pós-flexão 11,2$14,8 \mathrm{~mm}$; transformação 15,6-15,7 $\mathrm{mm}$; juvenil 16,0 mm; adulto 36,0 $\mathrm{mm}$.

Habitat: espécie marinha, epi-mesopelágica, ocorre em águas tropicais e subtropicais entre 475 e 850 $m$ de profundidade durante o dia. A noite ocorre desde próximo à superfície até $175 \mathrm{~m}$ de profundidade.

Nome vulgar: Peixe-lanterna.

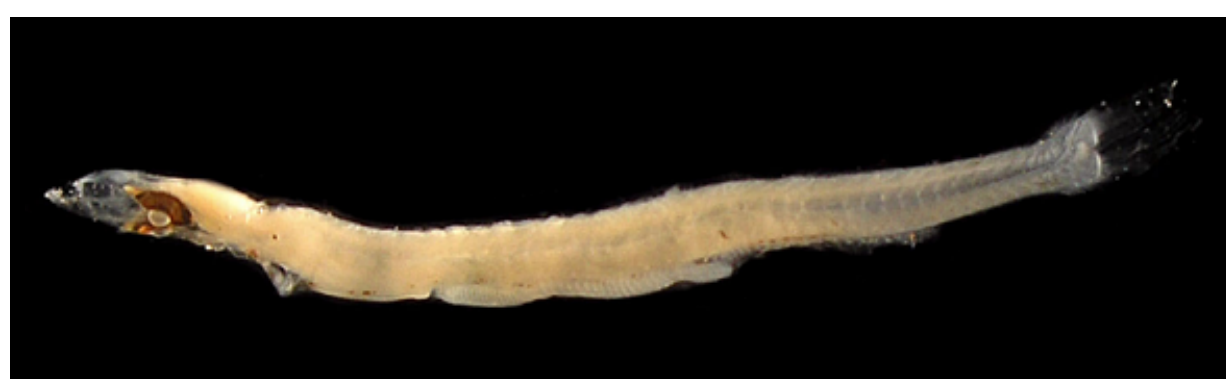

Figura 65 - B: DZUFRJ 14267; Flexão; CP 9,6 mm.

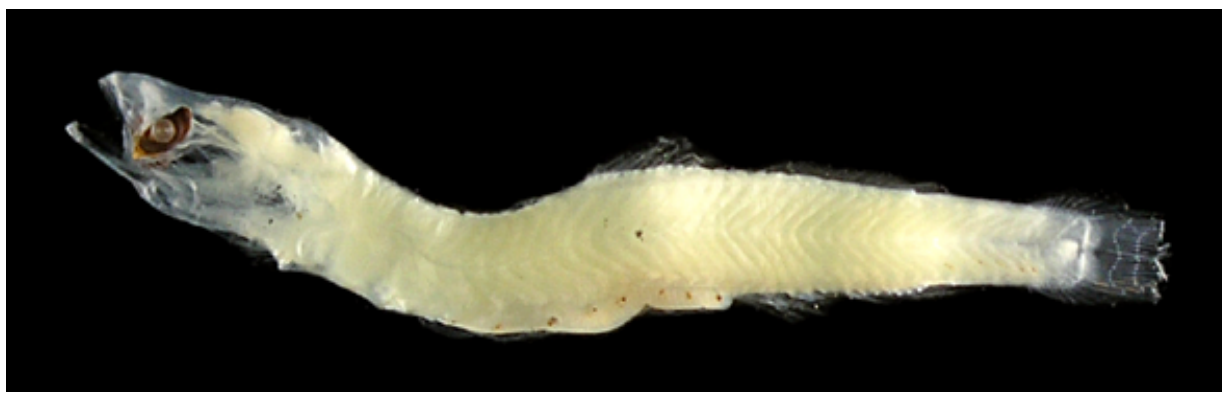

Figura 65 - C: DZUFRJ 1211; Pós-flexão; CP 14,5 mm. 


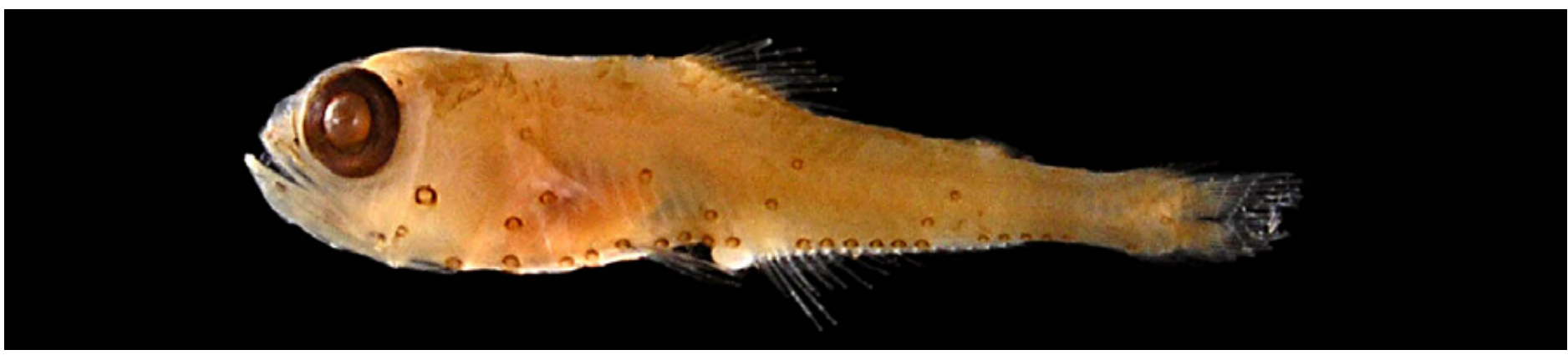

Figura 65 - D: DZUFRJ 22088; Juvenil; CP 16,0 mm.

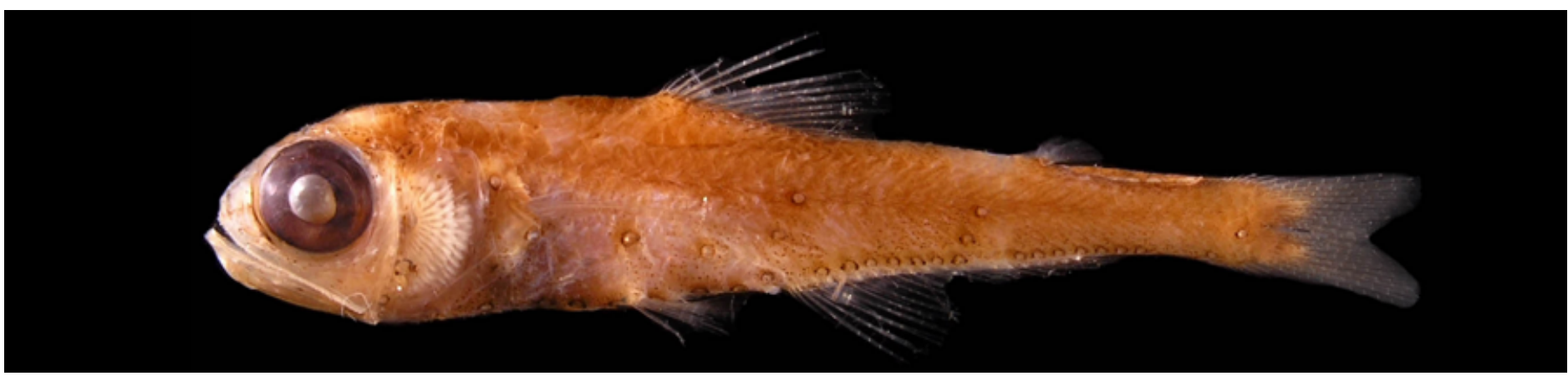

Figura 65 - E: DZUFRJ 7574; Adulto; CP 36,0 mm.

\section{Georreferenciamento}

\begin{tabular}{|c|c|c|c|c|c|c|c|c|}
\hline DZUFRJ & Latitude (S) & Longitude (W) & Data & $\begin{array}{l}\text { Tipo de } \\
\text { arrasto }\end{array}$ & $\begin{array}{l}\text { Profundidade } \\
\text { de coleta }\end{array}$ & Rede & $\begin{array}{c}\text { Malha } \\
(\mu \mathrm{m})\end{array}$ & $\begin{array}{l}N^{\circ} \text {. de } \\
\text { inds. }\end{array}$ \\
\hline 1179 & $22^{\circ} 07^{\prime} 29,0^{\prime \prime}$ & $039^{\circ} 06^{\prime} 23,5^{\prime \prime}$ & $10 / 05 / 2002$ & oblíquo & $1.000 \mathrm{~m}$ & cilíndrico-cônica & 500 & 1 \\
\hline 1211 & $22^{\circ} 02^{\prime} 30,0^{\prime \prime}$ & $039^{\circ} 49^{\prime} 41,2^{\prime \prime}$ & $12 / 05 / 2002$ & oblíquo & $1.000 \mathrm{~m}$ & cilíndrico-cônica & 500 & 2 \\
\hline 1249 & $22^{\circ} 08^{\prime} 17,5^{\prime \prime}$ & $039^{\circ} 46^{\prime} 28,5^{\prime \prime}$ & $11 / 05 / 2002$ & oblíquo & $1.000 \mathrm{~m}$ & cilíndrico-cônica & 500 & 1 \\
\hline 5519 & $22^{\circ} 31^{\prime} 58,9^{\prime \prime}$ & $040^{\circ} 02^{\prime} 53,4^{\prime \prime}$ & $07 / 11 / 2001$ & oblíquo & $1.000 \mathrm{~m}$ & cilíndrico-cônica & 500 & 2 \\
\hline 5521 & $22^{\circ} 31^{\prime} 40,9^{\prime \prime}$ & $040^{\circ} 02^{\prime} 39,6^{\prime \prime}$ & $07 / 11 / 2001$ & oblíquo & $1.000 \mathrm{~m}$ & cilíndrico-cônica & 500 & 3 \\
\hline 5525 & $22^{\circ} 31^{\prime} 58,9^{\prime \prime}$ & $040^{\circ} 02^{\prime} 53,4^{\prime \prime}$ & $07 / 11 / 2001$ & oblíquo & $1.000 \mathrm{~m}$ & cilíndrico-cônica & 500 & 1 \\
\hline 5526 & $22^{\circ} 32^{\prime} 49,0^{\prime \prime}$ & $040^{\circ} 04^{\prime} 20,9^{\prime \prime}$ & $07 / 11 / 2001$ & oblíquo & $1.000 \mathrm{~m}$ & cilíndrico-cônica & 500 & 1 \\
\hline 5527 & $22^{\circ} 32^{\prime} 49,0^{\prime \prime}$ & $040^{\circ} 04^{\prime} 20,9^{\prime \prime}$ & $07 / 11 / 2001$ & oblíquo & $1.000 \mathrm{~m}$ & cilíndrico-cônica & 500 & 3 \\
\hline 5530 & $22^{\circ} 31^{\prime} 40,9^{\prime \prime}$ & $040^{\circ} 02^{\prime} 39,6^{\prime \prime}$ & $07 / 11 / 2001$ & oblíquo & $1.000 \mathrm{~m}$ & cilíndrico-cônica & 500 & 4 \\
\hline 7381 & $21^{\circ} 58^{\prime} 31,0^{\prime \prime}$ & $039^{\circ} 50^{\prime} 29,7^{\prime \prime}$ & $10 / 10 / 2001$ & oblíquo & $1.000 \mathrm{~m}$ & cilíndrico-cônica & 500 & 10 \\
\hline 7387 & $21^{\circ} 54^{\prime} 36,5^{\prime \prime}$ & $039^{\circ} 45^{\prime} 20,0^{\prime \prime}$ & $10 / 10 / 2001$ & oblíquo & $1.000 \mathrm{~m}$ & cilíndrico-cônica & 500 & 5 \\
\hline 7389 & $21^{\circ} 54^{\prime} 36,5^{\prime \prime}$ & $039^{\circ} 45^{\prime} 20,0^{\prime \prime}$ & $09 / 10 / 2001$ & oblíquo & $1.000 \mathrm{~m}$ & cilíndrico-cônica & 500 & 2 \\
\hline 7391 & $21^{\circ} 53^{\prime} 10,4^{\prime \prime}$ & $039^{\circ} 45^{\prime} 49,9^{\prime \prime}$ & $10 / 10 / 2001$ & oblíquo & $1.000 \mathrm{~m}$ & cilíndrico-cônica & 500 & 1 \\
\hline 7563 & $21^{\circ} 54^{\prime} 36,5^{\prime \prime}$ & $039^{\circ} 45^{\prime} 20,0^{\prime \prime}$ & $10 / 10 / 2001$ & oblíquo & $1.000 \mathrm{~m}$ & cilíndrico-cônica & 500 & 8 \\
\hline 7566 & $21^{\circ} 58^{\prime} 31,0^{\prime \prime}$ & $039^{\circ} 50^{\prime} 29,7^{\prime \prime}$ & $11 / 10 / 2001$ & oblíquo & $1.000 \mathrm{~m}$ & cilíndrico-cônica & 500 & 12 \\
\hline 7570 & $21^{\circ} 58^{\prime} 31,0^{\prime \prime}$ & $039^{\circ} 50^{\prime} 29,7^{\prime \prime}$ & $10 / 10 / 2001$ & oblíquo & $1.000 \mathrm{~m}$ & cilíndrico-cônica & 500 & 5 \\
\hline 7574 & $21^{\circ} 57^{\prime} 10,5^{\prime \prime}$ & $039^{\circ} 43^{\prime} 33,3^{\prime \prime}$ & $09 / 10 / 2001$ & oblíquo & $1.000 \mathrm{~m}$ & cilíndrico-cônica & 500 & 3 \\
\hline 22063 & $22^{\circ} 02,27^{\prime}$ & $039^{\circ} 43,49^{\prime}$ & $18 / 06 / 2003$ & vertical & $90 \mathrm{~m}$ & cilíndrico-cônica & 500 & 1 \\
\hline 22087 & $22^{\circ} 32^{\prime} 50,0^{\prime \prime}$ & $040^{\circ} 04^{\prime} 09,9 "$ & $06 / 11 / 2001$ & oblíquo & $1.000 \mathrm{~m}$ & cilíndrico-cônica & 500 & 1 \\
\hline 22088 & $22^{\circ} 31^{\prime} 40,9^{\prime \prime}$ & $040^{\circ} 02^{\prime} 39,6^{\prime \prime}$ & $07 / 11 / 2001$ & oblíquo & $1.000 \mathrm{~m}$ & cilíndrico-cônica & 500 & 8 \\
\hline 22168 & $21^{\circ} 53^{\prime} 10,4^{\prime \prime}$ & $039^{\circ} 45^{\prime} 49,9^{\prime \prime}$ & $10 / 10 / 2001$ & oblíquo & $1.000 \mathrm{~m}$ & cilíndrico-cônica & 500 & 2 \\
\hline 22170 & $22^{\circ} 02,27^{\prime}$ & $039^{\circ} 43,49^{\prime}$ & $18 / 06 / 2003$ & vertical & $100-480 m$ & cilíndrico-cônica & 500 & 1 \\
\hline
\end{tabular}

Referências: Nafpakititis et al., 1977; Moser \& Ahlstrom, 1996; Castro \& Bonecker, 2006c; Moser \& Watson, 2006; Fahay, 2007; Santos \& Figueiredo, 2008. 


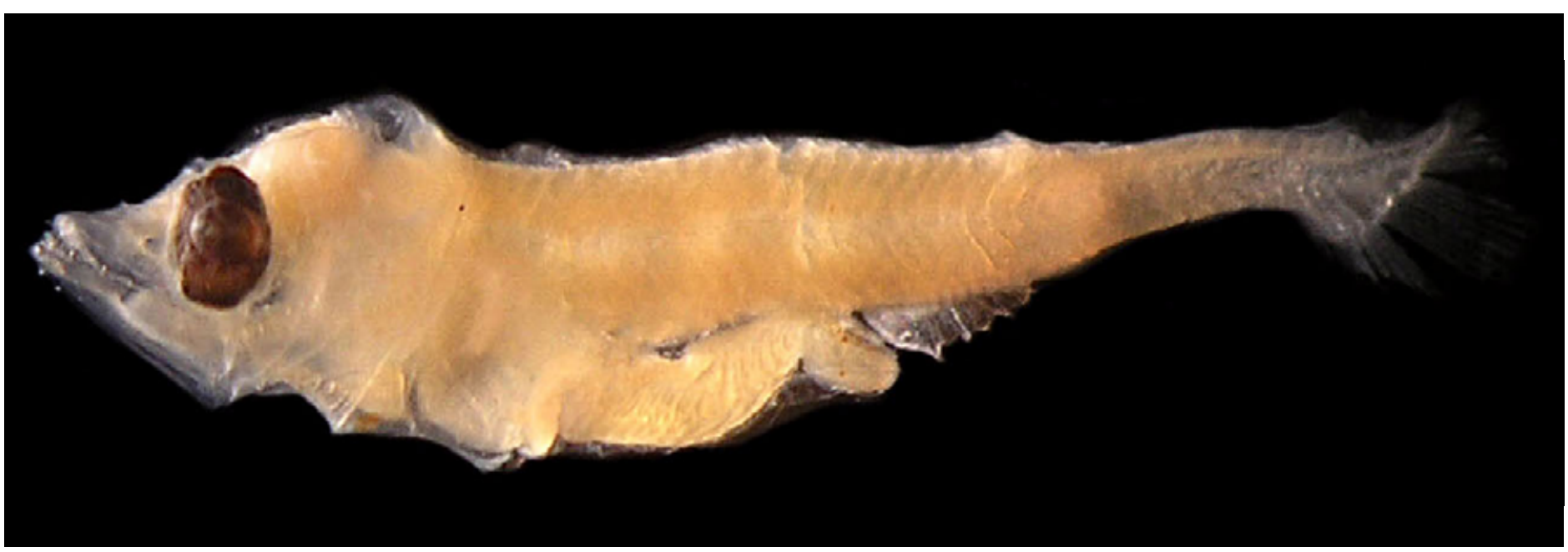

Figura 66: Hygophum taaningi. DZUFRJ 22785; Flexão; CP 5,1 mm.

\section{Hygophum taaningi Becker, 1965}

Possui olhos moderadamente elípticos sem tecido coroide, maiores e mais largos que nas outras espécies de Hygophum. O corpo é relativamente mais alto e comprimido lateralmente em comparação com outras espécies desse gênero. Durante a flexão possui um par de pigmentos na margem anterolateral da maxila inferior, um par no istmo, no cleitro e no final do intestino, próximo ao ânus. O número de miômeros varia entre 35 e 36.

Tamanho: flexão 5,1 mm.

Habitat: espécie marinha, epi-mesopelágica, ocorre em águas tropicais e subtropicais entre 475 e $1.000 \mathrm{~m}$ de profundidade durante o dia. A noite ocorre desde próximo à superfície até $125 \mathrm{~m}$ de profundidade.

Nome vulgar: Peixe-lanterna.

\section{Georreferenciamento}

\begin{tabular}{|c|c|c|c|c|c|c|c|c|}
\hline DZUFRJ & Latitude (S) & Longitude (W) & Data & $\begin{array}{c}\text { Tipo de } \\
\text { arrasto }\end{array}$ & $\begin{array}{c}\text { Profundidade } \\
\text { de coleta }\end{array}$ & Rede & $\begin{array}{c}\text { Malha } \\
(\boldsymbol{\mu m})\end{array}$ & $\begin{array}{c}\text { No. de } \\
\text { inds. }\end{array}$ \\
\hline 22785 & $22^{\circ} 07^{\prime} 29,0^{\prime \prime}$ & $039^{\circ} 06^{\prime} 235^{\prime \prime}$ & $10 / 05 / 2002$ & oblíquo & $1.000 \mathrm{~m}$ & cilíndrico-cônica & 500 & 1 \\
\hline
\end{tabular}

Referências: Moser \& Ahlstrom, 1996; Castro \& Bonecker, 2006c; Moser \& Watson, 2006; Fahay, 2007. 


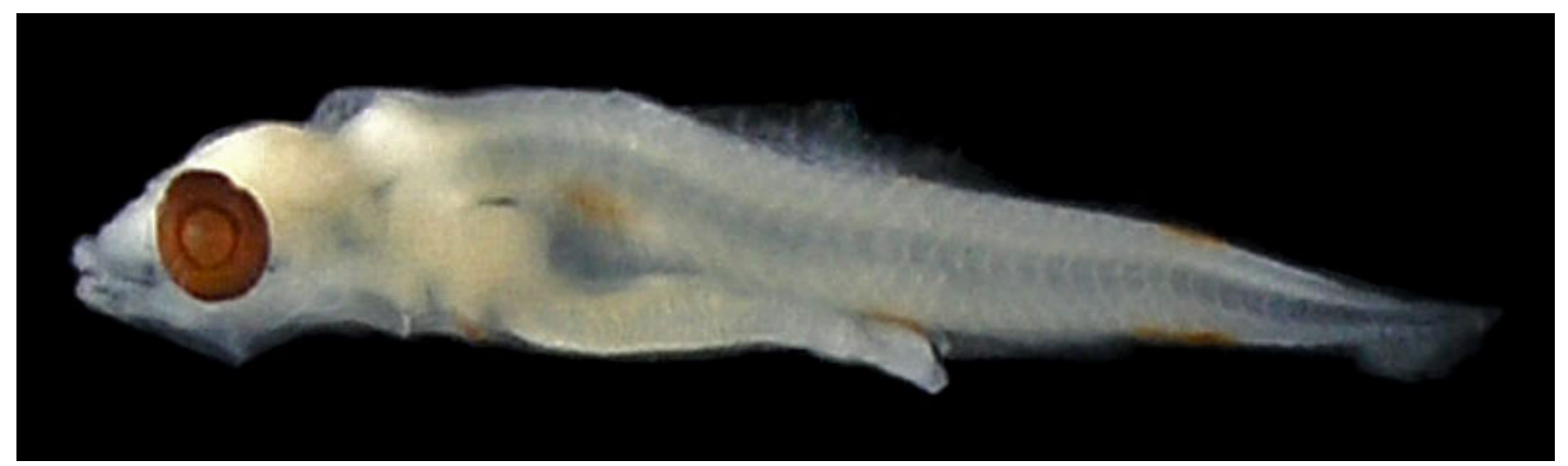

Figura 67: Lampadena sp. 1. DZUFRJ 22160; Pré-flexão; CP 5,0 mm.

\section{Lampadena sp. 1}

As larvas de Lampadena coletadas possuem, durante o período de pré-flexão, pigmentos nas margens dorsal e ventral do corpo na região da cauda; sobre a margem posterior do intestino, próximo ao ânus; na área da vesícula gasosa e um cromatóforo estrelado na margem ventral anterior do intestino. O número de miômeros varia entre 35 e 38. No Brasil já foram coletadas as espécies Lampadena anomala Parr, 1928; Lampadena chavesi Collett, 1905; Lampadena luminosa (Garman, 1899); Lampadena notialis Nafpaktitis \& Paxton, 1968 e Lampadena speculigera Goode \& Bean, 1896.

Tamanho: pré-flexão 3,5-6,1 mm.

Habitat: as espécies de Lampadena são marinhas, mesopelágicas, podendo ocorrer até $2.000 \mathrm{~m}$ de profundidade. Algumas espécies migram durante a noite para próximo da superfície.

Nome vulgar: Peixe-lanterna.

\section{Georreferenciamento}

\begin{tabular}{|c|c|c|c|c|c|c|c|c|}
\hline DZUFR & Latitude (S) & Longitude (W) & Data & $\begin{array}{c}\text { Tipo de } \\
\text { arrasto }\end{array}$ & $\begin{array}{c}\text { Profundidade } \\
\text { de coleta }\end{array}$ & Rede & $\begin{array}{c}\text { Malha } \\
(\boldsymbol{\mu m})\end{array}$ & $\begin{array}{c}\mathbf{N}^{\circ} \text {. de } \\
\text { inds. }\end{array}$ \\
\hline 22042 & $22^{\circ} 06^{\prime} 52,3^{\prime \prime}$ & $039^{\circ} 48^{\prime} 46,2^{\prime \prime}$ & $11 / 05 / 2002$ & oblíquo & até a termoclina & bongô & 500 & 1 \\
\hline 22056 & $22^{\circ} 06^{\prime} 52,3^{\prime \prime}$ & $039^{\circ} 48^{\prime} 46,2^{\prime \prime}$ & $11 / 05 / 2002$ & oblíquo & até a termoclina & bongô & 330 & 2 \\
\hline 22158 & $22^{\circ} 02^{\prime} 30,0^{\prime \prime}$ & $09^{\circ} 49^{\prime} 41,2^{\prime \prime}$ & $12 / 05 / 2002$ & oblíquo & até a termoclina & bongô & 330 & 1 \\
\hline 22160 & $22^{\circ} 02^{\prime} 30,0^{\prime \prime}$ & $039^{\circ} 49^{\prime} 41,2^{\prime \prime}$ & $12 / 05 / 2002$ & oblíquo & até a termoclina & bongô & 500 & 1 \\
\hline 22787 & $22^{\circ} 08^{\prime} 14,9^{\prime \prime}$ & $039^{\circ} 46^{\prime} 34,6^{\prime \prime}$ & $11 / 05 / 2002$ & oblíquo & até a termoclina & bongô & 330 & 1 \\
\hline
\end{tabular}

Referências: Moser \& Ahlstrom, 1996; Castro \& Bonecker, 2006c; Moser \& Watson, 2006. 


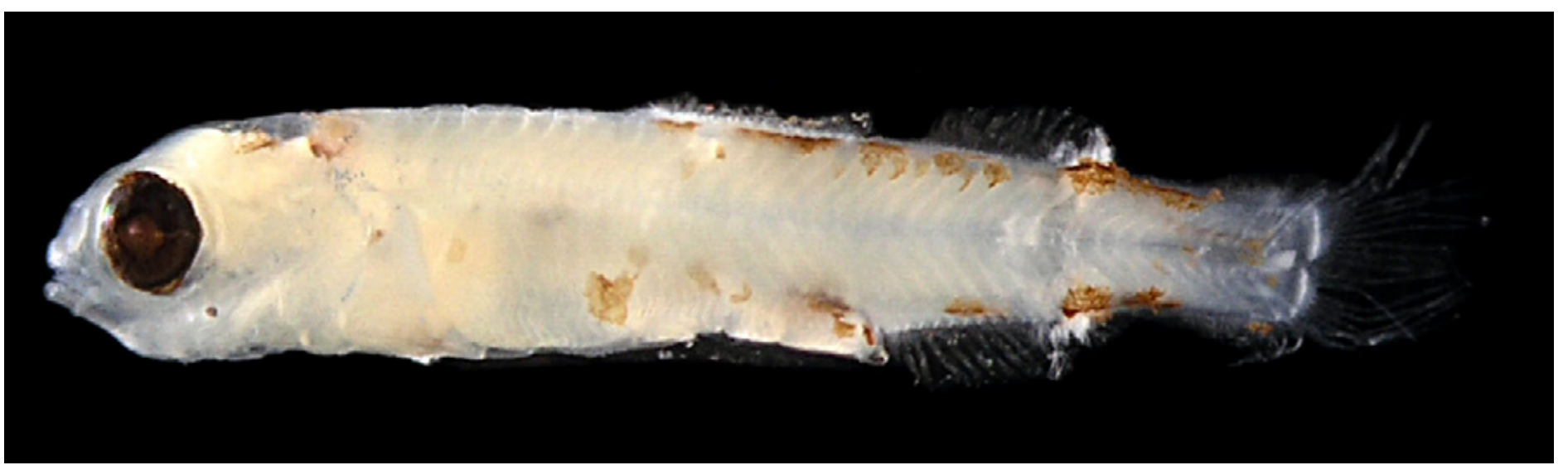

Figura 68: Lampadena sp. 2. . DZUFRJ 22167; Flexão; CP 7,6 mm.

\section{Lampadena sp. 2}

Possui fotóforo abaixo do olho na região posterior; pigmentos na cabeça, na região dorsal do corpo desde a base da nadadeira dorsal até o pedúnculo caudal. Possui ainda pigmentos na região do intestino e ânus, na base da nadadeira anal e no pedúnculo caudal. O número de miômeros varia entre 35 e 38. No Brasil já foram coletadas as espécies Lampadena anomala Parr, 1928; Lampadena chavesi Collett, 1905; Lampadena luminosa (Garman, 1899); Lampadena notialis Nafpaktitis \& Paxton, 1968 e Lampadena speculigera Goode \& Bean, 1896.

Tamanho: flexão 7,6 mm.

Habitat: as espécies de Lampadena são marinhas, mesopelágicas, podendo ocorrer até $2.000 \mathrm{~m}$ de profundidade. Algumas espécies migram durante a noite para próximo da superfície.

Nome vulgar: Peixe-lanterna.

\section{Georreferenciamento}

\begin{tabular}{|c|c|c|c|c|c|c|c|c|}
\hline DZUFRJ & Latitude (S) & Longitude (W) & Data & $\begin{array}{c}\text { Tipo de } \\
\text { arrasto }\end{array}$ & $\begin{array}{c}\text { Profundidade } \\
\text { de coleta }\end{array}$ & Rede & $\begin{array}{c}\text { Malha } \\
(\boldsymbol{\mu m})\end{array}$ & $\begin{array}{c}\mathbf{N}^{\circ} \text {. de } \\
\text { inds. }\end{array}$ \\
\hline 22167 & $2^{\circ} 57^{\prime} 5^{\prime}$ & $039^{\circ} 49,57^{\prime}$ & $19 / 06 / 2003$ & horizontal & superfície & nêuston & 500 & 1 \\
\hline
\end{tabular}

Referências: Moser \& Ahlstrom, 1996; Castro \& Bonecker, 2006c; Moser \& Watson, 2006. 


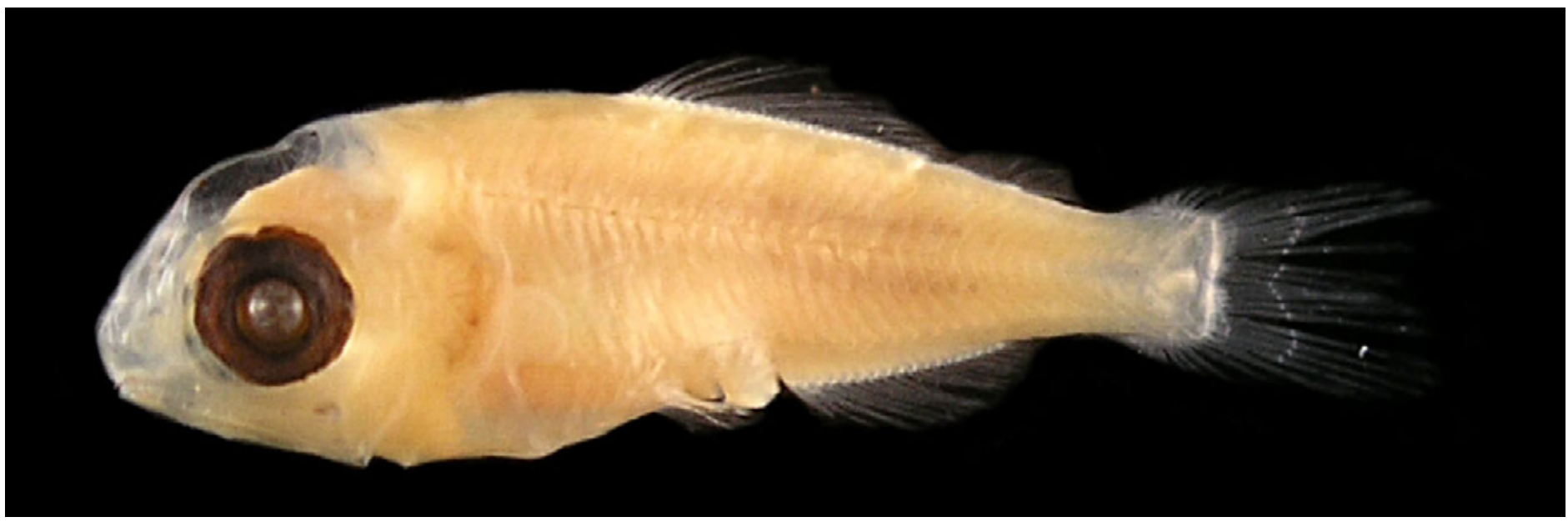

Figura 69 - A: Lampanyctus alatus. DZUFRJ 22788; Pós-flexão; CP 7,8 mm.

\section{Lampanyctus alatus Goode \& Bean, 1896}

O intestino é curto e muito flexionado, a cabeça é relativamente grande. Possui pigmentos na região dorsal da cabeça, na base da nadadeira peitoral, no intestino e

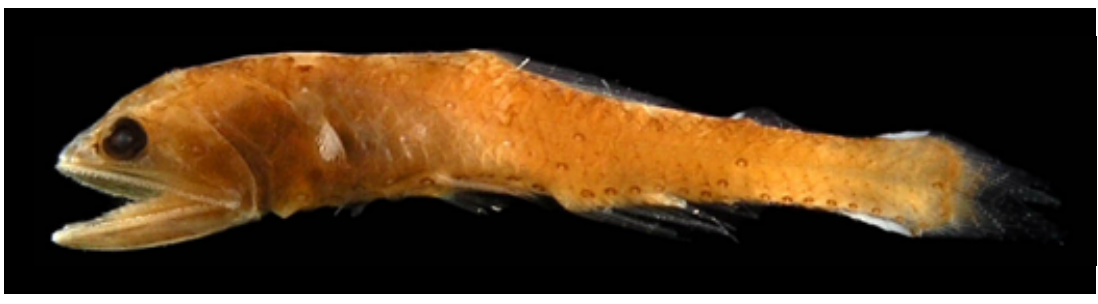

Figura 69 - B: DZUFRJ 22163; Juvenil; CP 16,5 mm. na ponta do focinho. O número de miômeros varia entre 33 e 36. Os indivíduos em transformação possuem fotóforos secundários na cabeça e na região entre a nadadeira pélvica e o pedúnculo caudal, glândula infracaudal curta e glândula luminosa na origem da nadadeira adiposa. Possui 6 (5 a 7) AOa e 5 a 7 (8) AOp; rastros branquiais do primeiro arco 4 (3) + $1+9$ (10).

Tamanho: pós-flexão 7,8 mm; juvenil 16,5 mm.

Habitat: espécie marinha, epi-mesopelágica, ocorre em águas tropicais e subtropicais entre 275 e $1.000 \mathrm{~m}$ de profundidade durante o dia. A noite ocorre entre 40 e 275 m de profundidade.

Nome vulgar: Peixe-lanterna.

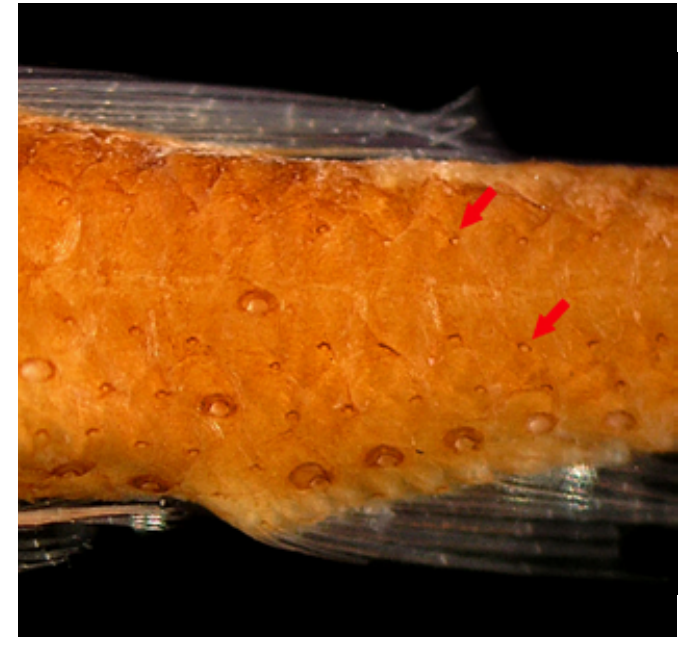

Figura 69 - C: Fotóforos secundários no tronco.

\section{Georreferenciamento}

\begin{tabular}{|c|c|c|c|c|c|c|c|c|}
\hline DZUFR & Latitude (S) & Longitude (W) & Data & $\begin{array}{c}\text { Tipo de } \\
\text { arrasto }\end{array}$ & $\begin{array}{c}\text { Profundidade } \\
\text { de coleta }\end{array}$ & Rede & $\begin{array}{c}\text { Malha } \\
\text { ( } \boldsymbol{\mu m})\end{array}$ & $\begin{array}{c}\mathbf{N}^{\circ} \text {. de } \\
\text { inds. }\end{array}$ \\
\hline 22163 & $21^{\circ} 54^{\prime} 36,5^{\prime \prime}$ & $039^{\circ} 45^{\prime} 20,0^{\prime \prime}$ & $10 / 10 / 2001$ & oblíquo & $1.000 \mathrm{~m}$ & cilíndrico-cônica & 500 & 1 \\
\hline 22788 & $21^{\circ} 58^{\prime} 31,0^{\prime \prime}$ & $039^{\circ} 50^{\prime} 29,7^{\prime \prime}$ & $10 / 10 / 2001$ & oblíquo & $1.000 \mathrm{~m}$ & cilíndrico-cônica & 500 & 1 \\
\hline
\end{tabular}

Referências: Nafpakititis et al., 1977; Moser \& Watson, 2006; Fahay, 2007; Santos \& Figueiredo, 2008. 


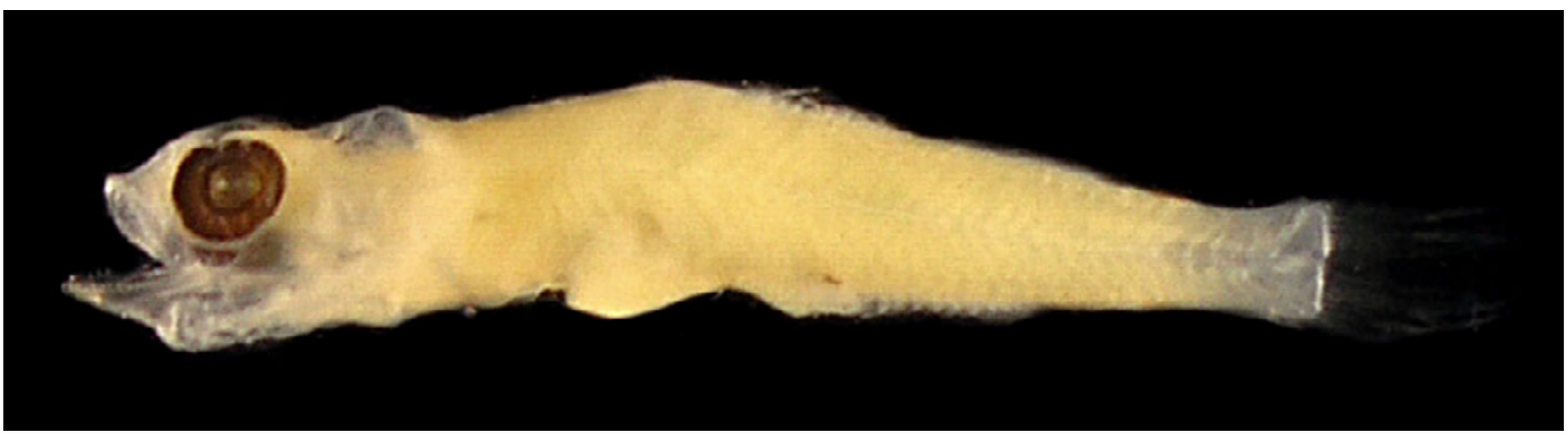

Figura 70 - A: Lepidophanes gaussi. DZUFRJ 22034; Flexão; CP 6,0 mm.

\section{Lepidophanes gaussi (Brauer, 1906)}

Possui corpo alongado (35 a 36 miômeros) e olhos redondos grandes. O intestino é longo e alcança a metade do corpo. As larvas no estágio de flexão possuem um pigmento dorsal e dois ventrais na região posterior do corpo. No estágio de pós-flexão, as larvas possuem dois pigmentos dorsais e dois ventrais na região da cauda, um no ânus, um abaixo da base da nadadeira peitoral, um na margem superior do opérculo e um na região occipital. O número de miômeros varia entre 35 e 36. Os indivíduos em transformação possuem 5 (6) AOa; 6 (5) AOp; 2 Pol; 4 Prc. A presença de tecido luminoso nas bases das nadadeiras peitoral e ventral e o número de rastros branquiais $(3+1$ + 8) separam essa espécie de L. guentheri.

Tamanho: flexão 5,6-6,7 mm; pós-flexão 7,0-9,2 mm; transformação 13,4-14,0 mm; juvenil 23,5-27,5 mm; adulto 31,5 mm.

Habitat: espécie marinha, epi-mesopelágica, ocorre em águas subtropicais entre 425 e $850 \mathrm{~m}$ de profundidade durante o dia. A noite ocorre desde próximo à superfície até $175 \mathrm{~m}$ de profundidade.

Nome vulgar: Peixe-lanterna.

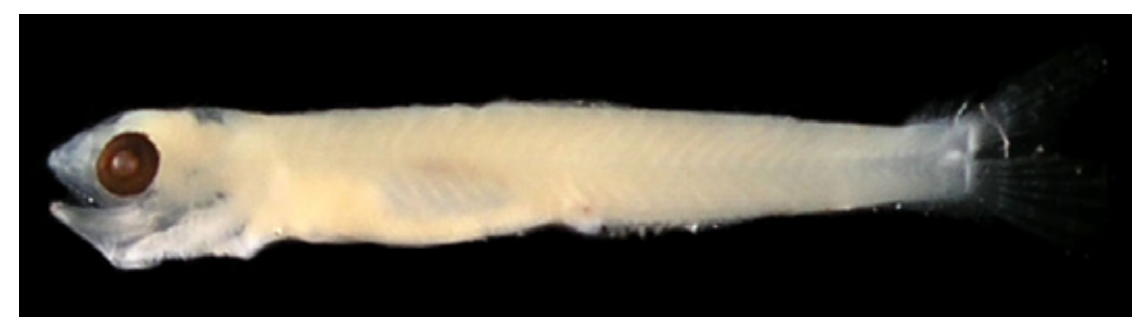

Figura 70 - B: DZUFRJ 22145; Pós-flexão; CP 9,2 mm.

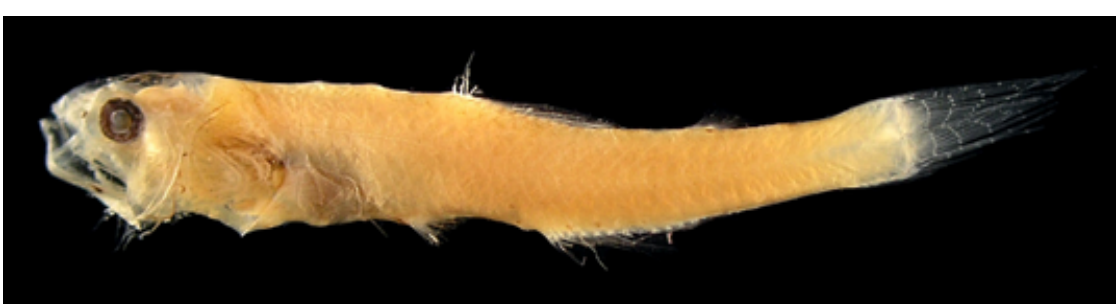

Figura 70 - C: DZUFRJ 21986; Transformação; CP 14,0 mm.

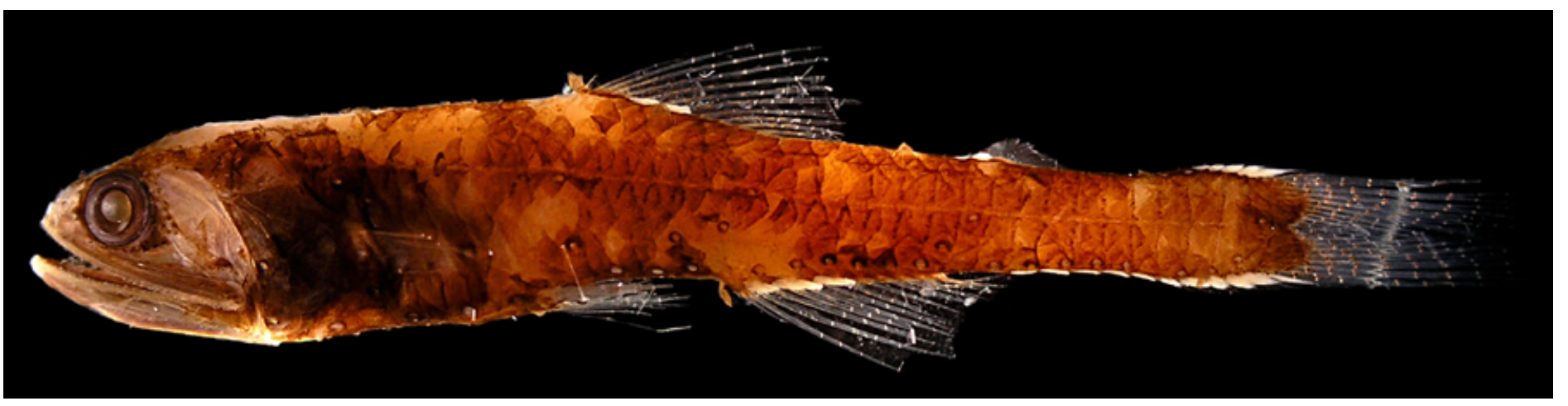

Figura 70 - D: DZUFRJ 22777; Juvenil; CP 27,5 mm. 


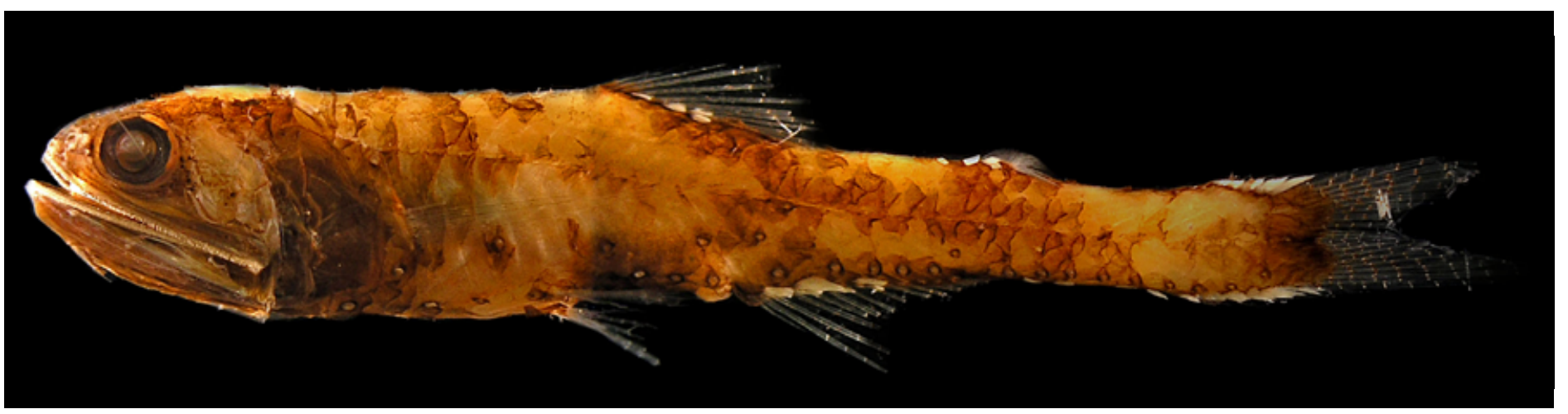

Figura 70 - E: DZUFRJ 22770; Adulto; CP 31,5 mm.

\section{Georreferenciamento}

\begin{tabular}{|c|c|c|c|c|c|c|c|c|}
\hline DZUFRJ & Latitude (S) & Longitude (W) & Data & $\begin{array}{l}\text { Tipo de } \\
\text { arrasto }\end{array}$ & $\begin{array}{c}\text { Profundidade } \\
\text { de coleta }\end{array}$ & Rede & $\begin{array}{l}\text { Malha } \\
(\mu \mathrm{m})\end{array}$ & $\begin{array}{l}N^{\circ} \text {. de } \\
\text { inds. }\end{array}$ \\
\hline 21986 & $21^{\circ} 57^{\prime} 10,5^{\prime \prime}$ & $039^{\circ} 43^{\prime} 33,3^{\prime \prime}$ & 09/10/2001 & oblíquo & $1.000 \mathrm{~m}$ & cilíndrico-cônica & 500 & 3 \\
\hline 21988 & $21^{\circ} 58^{\prime} 31,0^{\prime \prime}$ & $039^{\circ} 50^{\prime 29,7 "}$ & $10 / 10 / 2001$ & oblíquo & $1.000 \mathrm{~m}$ & cilíndrico-cônica & 500 & 1 \\
\hline 22017 & $22^{\circ} 08^{\prime} 14,9^{\prime \prime}$ & $039^{\circ} 46^{\prime} 34,6^{\prime \prime}$ & $11 / 05 / 2002$ & oblíquo & até a termoclina & bongô & 500 & 3 \\
\hline 22029 & $22^{\circ} 03^{\prime} 03,3^{\prime \prime}$ & $039^{\circ} 50^{\prime} 39,0^{\prime \prime}$ & $10 / 05 / 2002$ & oblíquo & até a termoclina & bongô & 500 & 1 \\
\hline 22032 & $22^{\circ} 06^{\prime} 37,8^{\prime \prime}$ & $039^{\circ} 49^{\prime} 44,8^{\prime \prime}$ & $10 / 05 / 2002$ & oblíquo & até a termoclina & bongô & 500 & 2 \\
\hline 22034 & $22^{\circ} 08^{\prime} 52,5^{\prime \prime}$ & $039^{\circ} 46^{\prime} 27,9^{\prime \prime}$ & $12 / 05 / 2002$ & oblíquo & até a termoclina & bongô & 500 & 1 \\
\hline 22038 & $22^{\circ} 07 ' 29,0^{\prime \prime}$ & $039^{\circ} 06^{\prime} 23,5^{\prime \prime}$ & $10 / 05 / 2002$ & oblíquo & $1.000 \mathrm{~m}$ & cilíndrico-cônica & 500 & 3 \\
\hline 22045 & $22^{\circ} 02^{\prime} 30,0^{\prime \prime}$ & $039^{\circ} 49^{\prime} 41,2^{\prime \prime}$ & $12 / 05 / 2002$ & oblíquo & até a termoclina & bongô & 500 & 2 \\
\hline 22046 & $21^{\circ} 53^{\prime} 10,4^{\prime \prime}$ & $039^{\circ} 45^{\prime} 49,9^{\prime \prime}$ & $10 / 10 / 2001$ & oblíquo & $1.000 \mathrm{~m}$ & cilíndrico-cônica & 500 & 1 \\
\hline 22094 & $22^{\circ} 37^{\prime} 35,5^{\prime \prime}$ & $040^{\circ} 09^{\prime} 32,8^{\prime \prime}$ & $16 / 05 / 2002$ & oblíquo & $1.000 \mathrm{~m}$ & cilíndrico-cônica & 500 & 2 \\
\hline 22095 & $22^{\circ} 33^{\prime} 47,7^{\prime \prime}$ & $040^{\circ} 12^{\prime} 20,5^{\prime \prime}$ & $17 / 05 / 2002$ & oblíquo & $50 \mathrm{~m}$ & bongô & 500 & 1 \\
\hline 22096 & $22^{\circ} 36^{\prime} 54,9^{\prime \prime}$ & $040^{\circ} 09^{\prime} 19,4^{\prime \prime}$ & $16 / 05 / 2002$ & oblíquo & $50 \mathrm{~m}$ & bongô & 500 & 1 \\
\hline 22097 & $22^{\circ} 31^{\prime} 58,9^{\prime \prime}$ & $040^{\circ} 02^{\prime} 53,4^{\prime \prime}$ & $07 / 11 / 2001$ & oblíquo & $1.000 \mathrm{~m}$ & cilíndrico-cônica & 500 & 1 \\
\hline 22145 & $22^{\circ} 31^{\prime} 40,9^{\prime \prime}$ & $040^{\circ} 02^{\prime} 39,6^{\prime \prime}$ & $07 / 11 / 2001$ & oblíquo & $1.000 \mathrm{~m}$ & cilíndrico-cônica & 500 & 2 \\
\hline 22770 & $21^{\circ} 53^{\prime} 10,4^{\prime \prime}$ & $039^{\circ} 45^{\prime} 49,9^{\prime \prime}$ & $10 / 10 / 2001$ & oblíquo & $1.000 \mathrm{~m}$ & cilíndrico-cônica & 500 & 1 \\
\hline 22777 & $21^{\circ} 53^{\prime} 10,4^{\prime \prime}$ & $039^{\circ} 45^{\prime} 49,9^{\prime \prime}$ & $10 / 10 / 2001$ & oblíquo & $1.000 \mathrm{~m}$ & cilíndrico-cônica & 500 & 1 \\
\hline 22782 & $21^{\circ} 58^{\prime} 31,0^{\prime \prime}$ & $039^{\circ} 50^{\prime} 29,7 "$ & $11 / 10 / 2001$ & oblíquo & $1.000 \mathrm{~m}$ & cilíndrico-cônica & 500 & 1 \\
\hline
\end{tabular}

Referências: Nafpakititis et al., 1977; Moser \& Ahlstrom, 1996; Castro \& Bonecker, 2006c; Moser \& Watson, 2006; Fahay, 2007; Santos \& Figueiredo, 2008. 


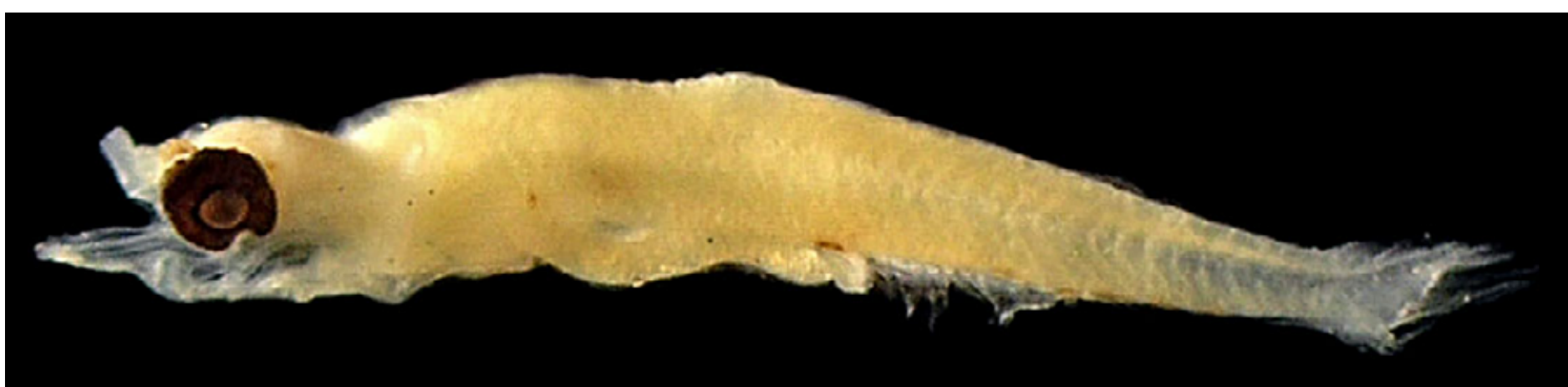

Figura 71 - A: Lepidophanes guentheri. A. DZUFRJ 22028; Flexão; CP 4,5 mm.

\section{Lepidophanes guentheri \\ (Goode \& Bean, 1896)}

Possui corpo alongado (36 miômeros) e olhos redondos grandes. O intestino é longo e alcança a metade do corpo. As larvas no estágio de flexão possuem três pigmentos dorsais e uma série ventral na região posterior do corpo. No estágio de pós-flexão as larvas possuem três pigmentos dorsais, três ventrais na região da cauda e um no ânus. Possui um fotóforo na base da nadadeira peitoral, um na região anterior e outro na região ventral do olho. Os indivíduos em transformação podem ser separadas das larvas de L. gaussi por apresentarem um número maior de rastros branquiais no primeiro arco e pela ausência de tecido luminoso na base da nadadeira peitoral. Rastros branquiais: $4+1+9$ a 10. Os juvenis possuem 2 Pol, 4 Prc formando um arco e Prc4 na altura da linha lateral, na base da nadadeira caudal; SAO bem angulado; 5 AOa (5 a 6) e 6 (5 a 7) AOp.

Tamanho: flexão 4,5-8,8 mm; pós-flexão 9,0-12,6 mm; transformação 13,4-17,3 mm; juvenil 18,0-31,5 mm; adulto 41,0-43,0 mm.

Habitat: espécie marinha, epi-mesopelágica, ocorre em águas tropicais e subtropicais entre 700 e $950 \mathrm{~m}$ de profundidade durante o dia. A noite ocorre entre 50 e $175 \mathrm{~m}$ de profundidade.

Nome vulgar: Peixe-lanterna.

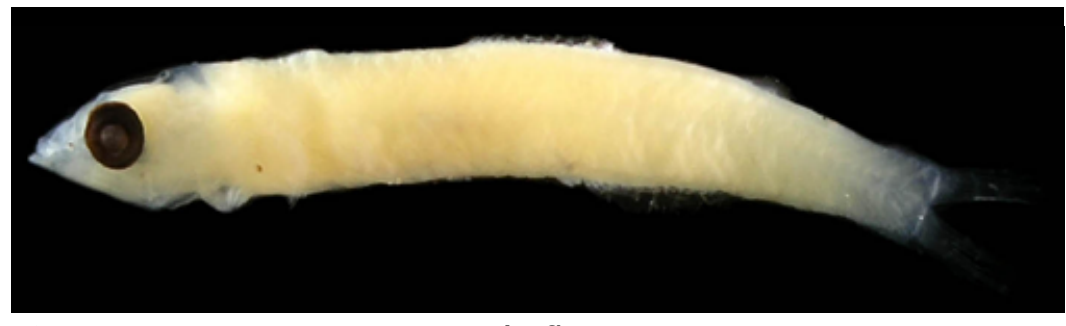

Figura 71 - B: DZUFRJ 22164; Pós-flexão; CP 11,3 mm.

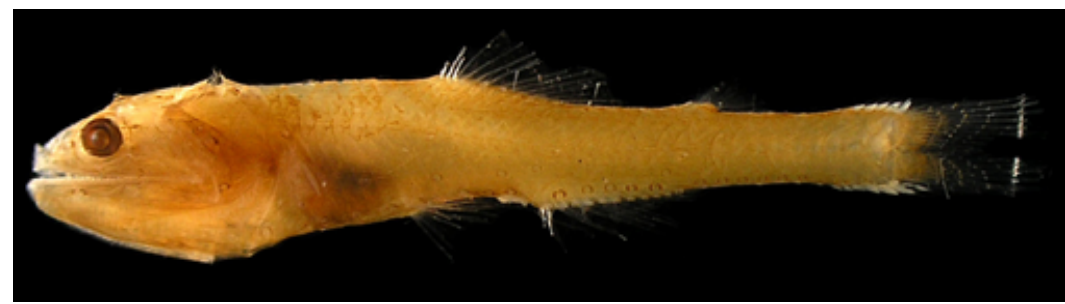

Figura 71 - C: DZUFRJ 22161; Transformação; CP 15,5 mm.

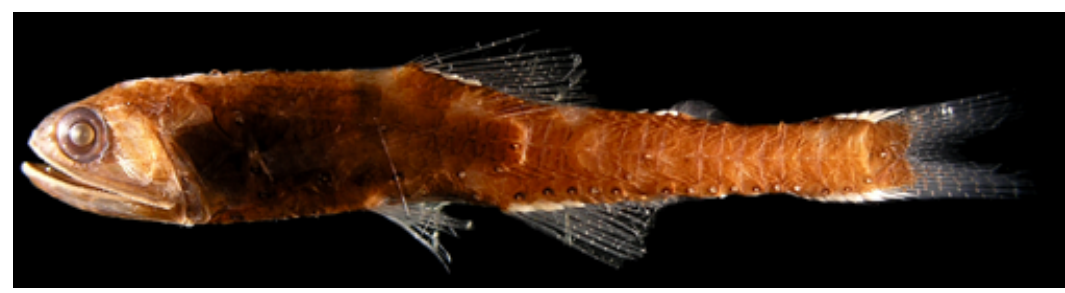

Figura 71 - D: DZUFRJ 7380; Juvenil; CP 31,5 mm.

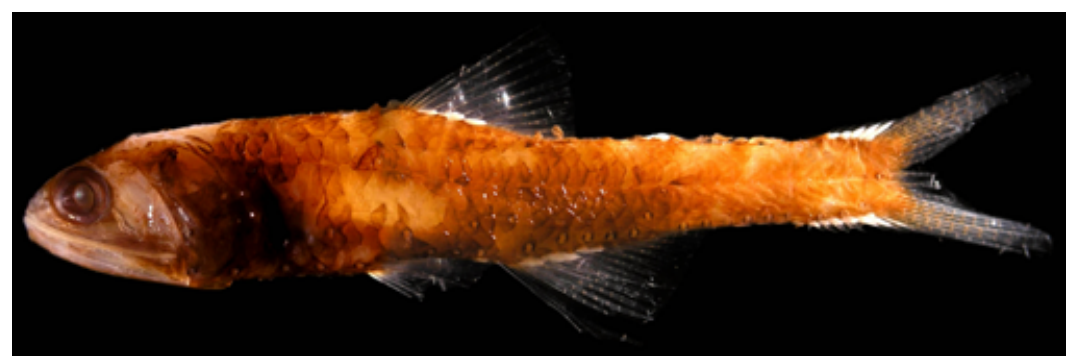

Figura 71 - E: DZUFRJ 5557; Adulto; CP 43,0 mm.

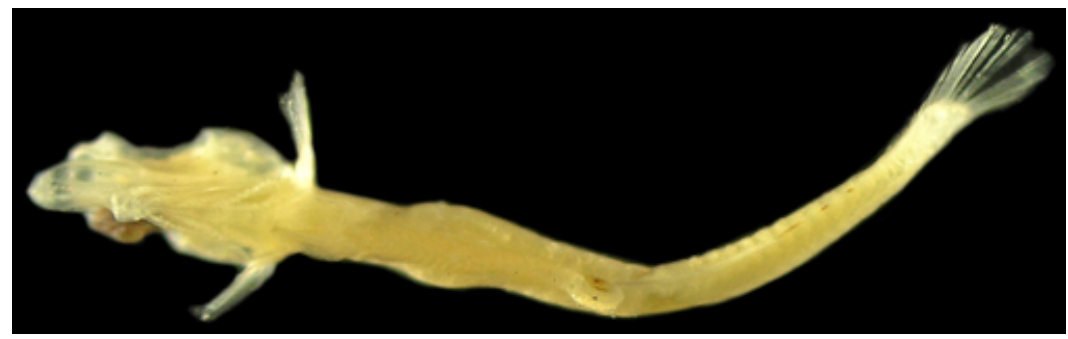

Figura 71 - F: Vista ventral durante a flexão. 


\section{Georreferenciamento}

\begin{tabular}{|c|c|c|c|c|c|c|c|}
\hline Latitude & Longitude & Data & $\begin{array}{l}\text { Tipo de } \\
\text { arrasto }\end{array}$ & $\begin{array}{l}\text { Profundidade } \\
\text { de coleta }\end{array}$ & Rede & $\begin{array}{l}\text { Malha } \\
(\mu \mathrm{m})\end{array}$ & $\begin{array}{l}\text { No. de } \\
\text { inds. }\end{array}$ \\
\hline $22^{\circ} 32^{\prime} 49,0^{\prime \prime}$ & $040^{\circ} 04^{\prime} 20,9^{\prime \prime}$ & $07 / 11 / 2001$ & oblíquo & $1.000 \mathrm{~m}$ & cilíndrico-cônica & 500 & 1 \\
\hline $22^{\circ} 31^{\prime} 40,9^{\prime \prime}$ & $040^{\circ} 02^{\prime} 39,6^{\prime \prime}$ & $07 / 11 / 2001$ & oblíquo & $1.000 \mathrm{~m}$ & cilíndrico-cônica & 500 & 2 \\
\hline $21^{\circ} 53^{\prime} 10,4^{\prime \prime}$ & $039^{\circ} 45^{\prime} 49,9^{\prime \prime}$ & $10 / 10 / 2001$ & oblíquo & $1.000 \mathrm{~m}$ & cilíndrico-cônica & 500 & 14 \\
\hline $21^{\circ} 57^{\prime} 10,5^{\prime \prime}$ & $039^{\circ} 43^{\prime} 33,3^{\prime \prime}$ & $09 / 10 / 2001$ & oblíquo & $1.000 \mathrm{~m}$ & cilíndrico-cônica & 500 & 1 \\
\hline $21^{\circ} 57^{\prime} 10,5^{\prime \prime}$ & $039^{\circ} 43^{\prime} 33,3^{\prime \prime}$ & 09/10/2001 & oblíquo & $1.000 \mathrm{~m}$ & cilíndrico-cônica & 500 & 3 \\
\hline $21^{\circ} 53^{\prime} 10,4^{\prime \prime}$ & $039^{\circ} 45^{\prime} 49,9^{\prime \prime}$ & $10 / 10 / 2001$ & oblíquo & $1.000 \mathrm{~m}$ & cilíndrico-cônica & 500 & 19 \\
\hline $21^{\circ} 57^{\prime} 10,5^{\prime \prime}$ & $039^{\circ} 43^{\prime} 33,3 "$ & 09/10/2001 & oblíquo & $1.000 \mathrm{~m}$ & cilíndrico-cônica & 500 & 7 \\
\hline $21^{\circ} 54^{\prime} 36,5^{\prime \prime}$ & $039^{\circ} 45^{\prime} 20,0^{\prime \prime}$ & 09/10/2001 & oblíquo & $1.000 \mathrm{~m}$ & cilíndrico-cônica & 500 & 4 \\
\hline $22^{\circ} 08^{\prime} 14,9^{\prime \prime}$ & $039^{\circ} 46^{\prime} 34,6^{\prime \prime}$ & $11 / 05 / 2002$ & oblíquo & até a termoclina & bongô & 330 & 14 \\
\hline $21^{\circ} 58^{\prime} 31,0^{\prime \prime}$ & $039^{\circ} 50^{\prime} 29,7^{\prime \prime}$ & $10 / 10 / 2001$ & oblíquo & $1.000 \mathrm{~m}$ & cilíndrico-cônica & 500 & 17 \\
\hline $21^{\circ} 54^{\prime} 36,5^{\prime \prime}$ & $039^{\circ} 45^{\prime} 20,0^{\prime \prime}$ & $10 / 10 / 2001$ & oblíquo & $1.000 \mathrm{~m}$ & cilíndrico-cônica & 500 & 23 \\
\hline $22^{\circ} 08^{\prime} 01,8^{\prime \prime}$ & $039^{\circ} 37^{\prime} 30,8^{\prime \prime}$ & $03 / 12 / 2002$ & vertical & $1.400-2.000 \mathrm{~m}$ & cilíndrico-cônica & 200 & 1 \\
\hline $22^{\circ} 35^{\prime} 08,5^{\prime \prime}$ & $039^{\circ} 46^{\prime} 22,3^{\prime \prime}$ & $06 / 12 / 2002$ & vertical & $50 \mathrm{~m}$ & cilíndrico-cônica & 200 & 4 \\
\hline $21^{\circ} 58^{\prime} 31,0^{\prime \prime}$ & $039^{\circ} 50^{\prime} 29,7^{\prime \prime}$ & $10 / 10 / 2001$ & oblíquo & $1.000 \mathrm{~m}$ & cilíndrico-cônica & 500 & 18 \\
\hline $21^{\circ} 58^{\prime} 31,0^{\prime \prime}$ & $039^{\circ} 50^{\prime} 29,7^{\prime \prime}$ & $11 / 10 / 2001$ & oblíquo & $1.000 \mathrm{~m}$ & cilíndrico-cônica & 500 & 7 \\
\hline $22^{\circ} 08^{\prime} 17,5^{\prime \prime}$ & $039^{\circ} 46^{\prime} 28,5^{\prime \prime}$ & $11 / 05 / 2002$ & oblíquo & $1.000 \mathrm{~m}$ & cilíndrico-cônica & 500 & 3 \\
\hline $21^{\circ} 54 ' 36,5^{\prime \prime}$ & $039^{\circ} 45^{\prime} 20,0^{\prime \prime}$ & $10 / 10 / 2001$ & oblíquo & $1.000 \mathrm{~m}$ & cilíndrico-cônica & 500 & 8 \\
\hline $21^{\circ} 53^{\prime} 10,4^{\prime \prime}$ & $039^{\circ} 45^{\prime} 49,9^{\prime \prime}$ & $10 / 10 / 2001$ & oblíquo & $1.000 \mathrm{~m}$ & cilíndrico-cônica & 500 & 8 \\
\hline $22^{\circ} 08^{\prime} 52,5^{\prime \prime}$ & $039^{\circ} 46^{\prime} 27,9^{\prime \prime}$ & $12 / 05 / 2002$ & oblíquo & até a termoclina & bongô & 500 & 2 \\
\hline $22^{\circ} 02^{\prime} 30,0^{\prime \prime}$ & $039^{\circ} 49^{\prime} 41,2^{\prime \prime}$ & $12 / 05 / 2002$ & oblíquo & até a termoclina & bongô & 330 & 43 \\
\hline $22^{\circ} 02^{\prime} 30,0^{\prime \prime}$ & $039^{\circ} 49^{\prime} 41,2^{\prime \prime}$ & $12 / 05 / 2002$ & oblíquo & $1.000 \mathrm{~m}$ & cilíndrico-cônica & 500 & 18 \\
\hline $22^{\circ} 08^{\prime} 52,5^{\prime \prime}$ & $039^{\circ} 46^{\prime} 27,9^{\prime \prime}$ & $12 / 05 / 2002$ & oblíquo & até a termoclina & bongô & 330 & 2 \\
\hline $22^{\circ} 07^{\prime} 29,0^{\prime \prime}$ & $039^{\circ} 06^{\prime} 23,5^{\prime \prime}$ & $10 / 05 / 2002$ & oblíquo & $1.000 \mathrm{~m}$ & cilíndrico-cônica & 500 & 231 \\
\hline $22^{\circ} 06^{\prime} 52,3^{\prime \prime}$ & $039^{\circ} 48^{\prime} 46,2^{\prime \prime}$ & $11 / 05 / 2002$ & oblíquo & $1.000 \mathrm{~m}$ & cilíndrico-cônica & 500 & 3 \\
\hline $22^{\circ} 08^{\prime} 14,9^{\prime \prime}$ & $039^{\circ} 46^{\prime} 34,6^{\prime \prime}$ & $11 / 05 / 2002$ & oblíquo & até a termoclina & bongô & 500 & 16 \\
\hline $22^{\circ} 03^{\prime} 03,3^{\prime \prime}$ & $039^{\circ} 50^{\prime} 39,0^{\prime \prime}$ & $10 / 05 / 2002$ & oblíquo & até a termoclina & bongô & 500 & 4 \\
\hline $22^{\circ} 06^{\prime} 52,3^{\prime \prime}$ & $039^{\circ} 48^{\prime} 46,2^{\prime \prime}$ & $11 / 05 / 2002$ & oblíquo & até a termoclina & bongô & 330 & 28 \\
\hline $22^{\circ} 43,56^{\prime}$ & $039^{\circ} 53,25^{\prime}$ & $14 / 06 / 2003$ & vertical & $60 \mathrm{~m}$ & cilíndrico-cônica & 500 & 1 \\
\hline $22^{\circ} 03^{\prime} 03,3^{\prime \prime}$ & $039^{\circ} 50^{\prime} 39,0^{\prime \prime}$ & $10 / 05 / 2002$ & oblíquo & até a termoclina & bongô & 330 & 9 \\
\hline $22^{\circ} 42^{\prime} 06,0^{\prime \prime}$ & $040^{\circ} 14 ' 26,0^{\prime \prime}$ & $19 / 05 / 2002$ & oblíquo & $50 \mathrm{~m}$ & bongô & 500 & 1 \\
\hline $22^{\circ} 38^{\prime} 29,0^{\prime \prime}$ & $040^{\circ} 17^{\prime} 40,0^{\prime \prime}$ & $18 / 05 / 2002$ & oblíquo & $800 \mathrm{~m}$ & cilíndrico-cônica & 500 & 2 \\
\hline $22^{\circ} 36^{\prime} 54,9^{\prime \prime}$ & $040^{\circ} 09^{\prime} 19,4^{\prime \prime}$ & $16 / 05 / 2002$ & oblíquo & $50 \mathrm{~m}$ & bongô & 500 & 3 \\
\hline $22^{\circ} 31^{\prime} 58,9$ & $040^{\circ} 02^{\prime} 53,4^{\prime \prime}$ & $07 / 11 / 2001$ & oblíquo & $1.000 \mathrm{~m}$ & cilíndrico-cônica & 500 & 1 \\
\hline $21^{\circ} 57,1^{\prime}$ & $039^{\circ} 37,32^{\prime}$ & $16 / 06 / 2003$ & vertical & $2.000 \mathrm{~m}$ & cilíndrico-cônica & 500 & 1 \\
\hline $22^{\circ} 02^{\prime} 35,2^{\prime \prime}$ & $039^{\circ} 43^{\prime} 18,2^{\prime \prime}$ & $04 / 12 / 2002$ & horizontal & superfície & nêuston & 500 & 2 \\
\hline $22^{\circ} 33^{\prime} 47,7^{\prime \prime}$ & $040^{\circ} 12^{\prime} 20,5^{\prime \prime}$ & $17 / 05 / 2002$ & oblíquo & $50 \mathrm{~m}$ & bongô & 500 & 6 \\
\hline $22^{\circ} 31^{\prime} 40,9^{\prime \prime}$ & $040^{\circ} 02^{\prime} 39,6^{\prime \prime}$ & $07 / 11 / 2001$ & oblíquo & $1.000 \mathrm{~m}$ & cilíndrico-cônica & 500 & 10 \\
\hline $22^{\circ} 33^{\prime} 45,8^{\prime \prime}$ & $040^{\circ} 13^{\prime} 22,9^{\prime \prime}$ & $17 / 05 / 2002$ & oblíquo & $800 \mathrm{~m}$ & cilíndrico-cônica & 500 & 11 \\
\hline $22^{\circ} 33^{\prime} 47,7^{\prime \prime}$ & $040^{\circ} 12^{\prime} 20,5^{\prime \prime}$ & $17 / 05 / 2002$ & oblíquo & $50 \mathrm{~m}$ & bongô & 330 & 13 \\
\hline $22^{\circ} 06^{\prime} 37,8^{\prime \prime}$ & $039^{\circ} 49^{\prime} 44,8^{\prime \prime}$ & $10 / 05 / 2002$ & oblíquo & até a termoclina & bongô & 330 & 84 \\
\hline $22^{\circ} 36^{\prime} 54,9^{\prime \prime}$ & $040^{\circ} 09^{\prime} 19,4^{\prime \prime}$ & $16 / 05 / 2002$ & oblíquo & $50 \mathrm{~m}$ & bongô & 330 & 24 \\
\hline $22^{\circ} 39,68^{\prime}$ & $040^{\circ} 03,24^{\prime}$ & $13 / 06 / 2003$ & vertical & $60 \mathrm{~m}$ & cilíndrico-cônica & 500 & 1 \\
\hline $22^{\circ} 31^{\prime} 40,9^{\prime \prime}$ & $040^{\circ} 02 ' 39,6^{\prime \prime}$ & 07/11/2001 & oblíquo & $1.000 \mathrm{~m}$ & cilíndrico-cônica & 500 & 2 \\
\hline $22^{\circ} 06^{\prime} 52,3^{\prime \prime}$ & $039^{\circ} 48^{\prime} 46,2^{\prime \prime}$ & $11 / 05 / 2002$ & oblíquo & até a termoclina & bongô & 500 & 4 \\
\hline $22^{\circ} 42^{\prime} 06,0^{\prime \prime}$ & $040^{\circ} 14^{\prime} 26^{\prime \prime}$ & $19 / 05 / 2002$ & oblíquo & $50 \mathrm{~m}$ & bongô & 330 & 1 \\
\hline $22^{\circ} 37^{\prime} 35,5^{\prime \prime}$ & $040^{\circ} 09^{\prime} 32,8^{\prime \prime}$ & $16 / 05 / 2002$ & oblíquo & $1.000 \mathrm{~m}$ & cilíndrico-cônica & 500 & 12 \\
\hline $22^{\circ} 31^{\prime} 58,9^{\prime \prime}$ & $040^{\circ} 02^{\prime} 53,4^{\prime \prime}$ & $07 / 11 / 2001$ & oblíquo & $1.000 \mathrm{~m}$ & cilíndrico-cônica & 500 & 5 \\
\hline $22^{\circ} 02^{\prime} 30,0^{\prime \prime}$ & $039^{\circ} 49^{\prime} 41,2^{\prime \prime}$ & $12 / 05 / 2002$ & oblíquo & até a termoclina & bongô & 500 & 19 \\
\hline $22^{\circ} 38^{\prime} 25,0^{\prime \prime}$ & $040^{\circ} 17^{\prime} 41,0^{\prime \prime}$ & $19 / 05 / 2002$ & oblíquo & $40 \mathrm{~m}$ & bongô & 330 & 2 \\
\hline $21^{\circ} 57,12^{\prime}$ & $039^{\circ} 37,32^{\prime}$ & $18 / 06 / 2003$ & vertical & $500-980 m$ & cilíndrico-cônica & 500 & 1 \\
\hline $22^{\circ} 06^{\prime} 37,8^{\prime \prime}$ & $039^{\circ} 49^{\prime} 44,8^{\prime \prime}$ & $10 / 05 / 2002$ & oblíquo & até a termoclina & bongô & 500 & 30 \\
\hline
\end{tabular}

Referências: Nafpakititis et al., 1977; Moser \& Ahlstrom, 1996; Castro \& Bonecker, 2006c; Moser \& Watson, 2006; Fahay, 2007; Santos \& Figueiredo, 2008. 


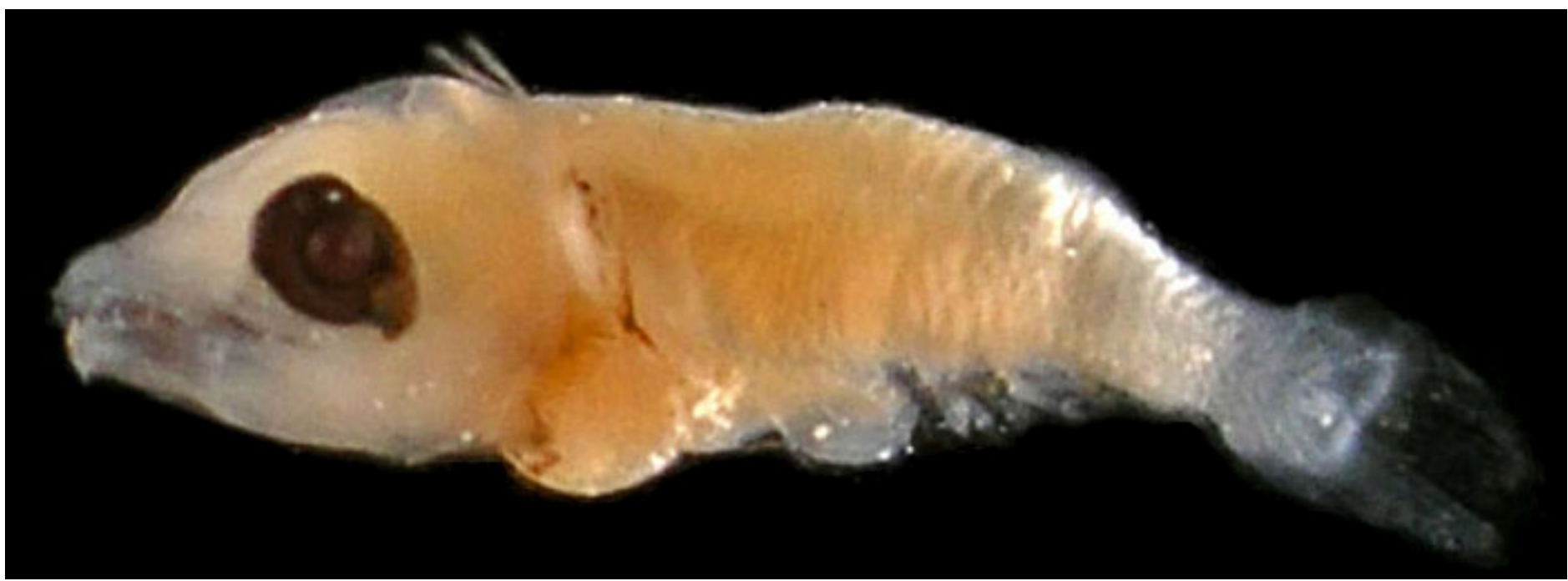

Figura 72 - A: Lobianchia gemellarii. DZUFRJ 22148; Flexão; CP 4,9 mm.

\section{Lobianchia gemellarii (Cocco, 1838)}

Possui cabeça grande e olhos ovais grandes com tecido coroide lunado ventral. A nadadeira peitoral é bilobada com os

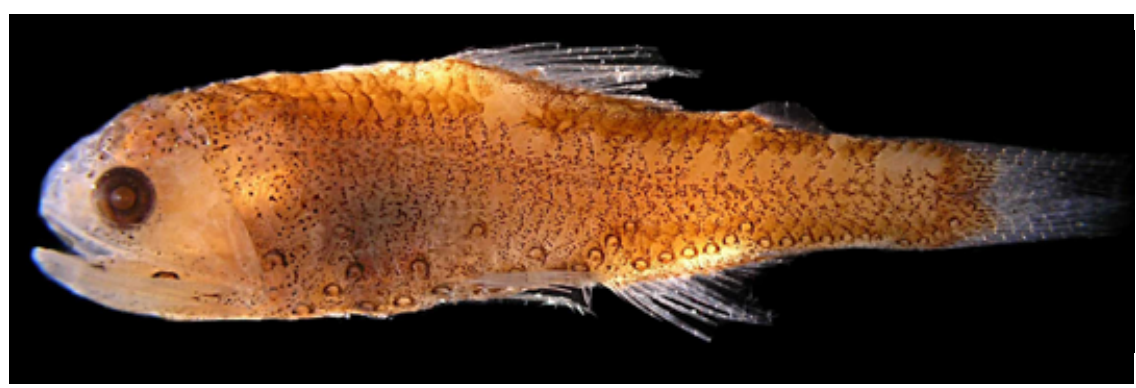

Figura 72 - B: DZUFRJ 22153; Juvenil; CP 25,0 mm. quatro raios superiores precoces mais alongados. Durante a pré-flexão e flexão possui melanóforos na base da nadadeira peitoral, anterior a base da peitoral, na parte anterior do intestino e na região do ânus. Possui pigmentos espalhados nos raios da nadadeira peitoral e pigmentos internos na vesícula gasosa. O número de miômeros varia entre 34 e 35 . Os juvenis possuem 4 Prc, 5 AOa e 6 AOp, SAO normalmente em curva.

Tamanho: flexão 4,9 mm; juvenil 25,0 mm.

Habitat: espécie marinha, epi-mesopelágica, ocorre em águas tropicais e subtropicais entre 325 e $550 \mathrm{~m}$ de profundidade durante o dia. A noite ocorre entre 40 e $175 \mathrm{~m}$ de profundidade.

Nome vulgar: Peixe-lanterna.

\section{Georreferenciamento}

\begin{tabular}{|c|c|c|c|c|c|c|c|c|}
\hline DZUFR & Latitude (S) & Longitude (W) & Data & $\begin{array}{c}\text { Tipo de } \\
\text { arrasto }\end{array}$ & $\begin{array}{c}\text { Profundidade } \\
\text { de coleta }\end{array}$ & Rede & $\begin{array}{c}\text { Malha } \\
\text { ( } \boldsymbol{\mu m} \text { ) }\end{array}$ & $\begin{array}{c}\mathbf{N}^{\circ} \text {. de } \\
\text { inds. }\end{array}$ \\
\hline 22148 & $22^{\circ} 07^{\prime} 29,0^{\prime \prime}$ & $039^{\circ} 06^{\prime} 23,5^{\prime \prime}$ & $10 / 05 / 2002$ & oblíquo & $1.000 \mathrm{~m}$ & cilíndrico-cônica & 500 & 1 \\
\hline 22153 & $21^{\circ} 53^{\prime} 10,4^{\prime \prime}$ & $039^{\circ} 45^{\prime} 49,9^{\prime \prime}$ & $10 / 10 / 2001$ & oblíquo & $1.000 \mathrm{~m}$ & cilíndrico-cônica & 500 & 1 \\
\hline
\end{tabular}

Referências: Nafpakititis et al., 1977; Moser \& Ahlstrom, 1996; Castro \& Bonecker, 2006c; Moser \& Watson, 2006; Fahay, 2007; Santos \& Figueiredo, 2008. 


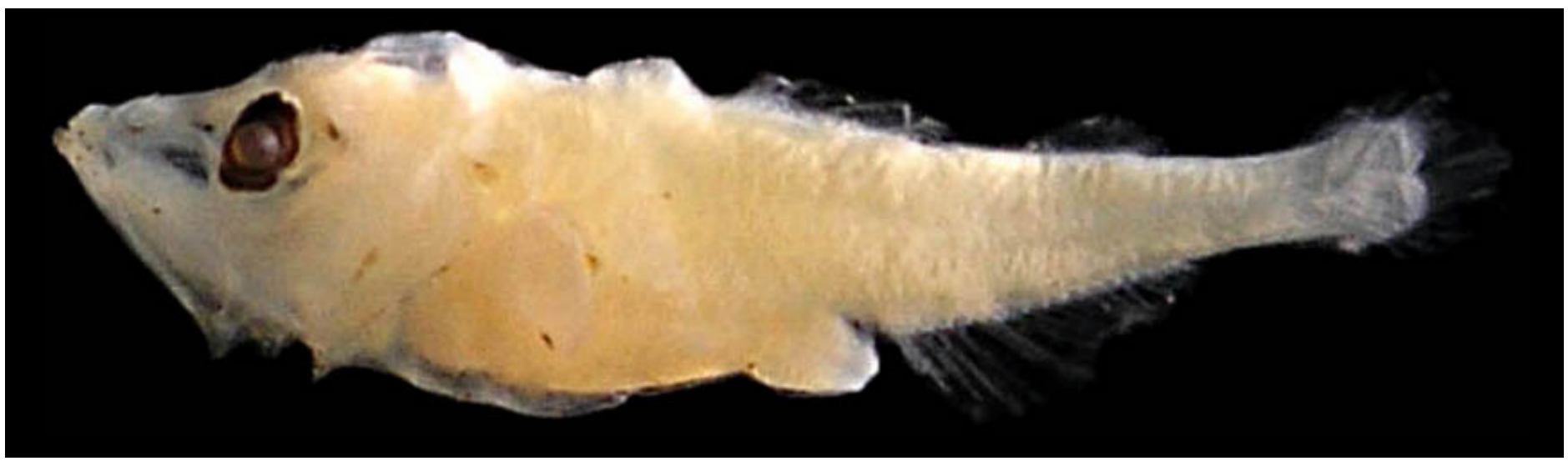

Figura 73- A: Myctophum affine. DZUFRJ 22157; Pós-flexão; CP 7,3 mm.

\section{Myctophum affine (Lütken, 1892)}

As larvas em pré-flexão, flexão e pós-flexão possuem olhos elípticos com uma pequena massa cônica ventral de tecido coroide. As nadadeiras peitorais são grandes e os raios se desenvolvem precocemente. No estágio de flexão há pigmentos nas maxilas, no cleitro, no istmo, um dorsal e um ventral na região posterior do corpo e na superfície ventral do intestino. Possui um ou dois melanóforos na parte interna da base da nadadeira peitoral, enquanto em $M$. nitidulum há vários melanóforos grandes. Na parte dorsal da cabeça existem quatro pigmentos formando um arco e mais um no centro. O número de miômeros varia entre 37 e 38 . Os indivíduos em transformação possuem SAO em linha reta com o VO3; 1 Pol; 2 Prc; 8 a 9 (7) AOa e 5 (4 a 6) AOp; AOp1 normalmente sobre o final da base da nadadeira anal. A margem póstero-dorsal do opérculo é arredondada e nos juvenis, as escamas são ctenóides.

Tamanho: pós-flexão 7,3 mm; juvenil 13,5-21,0 mm; adulto 25,5-49,5 mm.

Habitat: espécie marinha, epi-mesopelágica, ocorre em águas tropicais entre 300 e 650 m de profundidade durante o dia. A noite ocorre desde próximo à superfície até $275 \mathrm{~m}$ de profundidade.

Nome vulgar: Peixe-lanterna.

\section{Georreferenciamento}

\begin{tabular}{|c|c|c|c|c|c|c|c|c|}
\hline DZUFRJ & Latitude (S) & Longitude (W) & Data & $\begin{array}{c}\text { Tipo de } \\
\text { arrasto }\end{array}$ & $\begin{array}{c}\text { Profundidade } \\
\text { de coleta }\end{array}$ & Rede & $\begin{array}{c}\text { Malha } \\
\text { ( } \boldsymbol{\mu m} \text { ) }\end{array}$ & $\begin{array}{c}\mathbf{N}^{\circ} \text {. de } \\
\text { inds. }\end{array}$ \\
\hline 2615 & $22^{\circ} 08^{\prime} 01,8^{\prime \prime}$ & $039^{\circ} 37^{\prime} 30,8^{\prime \prime}$ & $03 / 12 / 2002$ & horizontal & superfície & nêuston & 500 & 10 \\
\hline 2617 & $22^{\circ} 35^{\prime} 08,5^{\prime \prime}$ & $039^{\circ} 46^{\prime} 22,3^{\prime \prime}$ & $07 / 12 / 2002$ & horizontal & superfície & nêuston & 500 & 4 \\
\hline 2620 & $22^{\circ} 35^{\prime} 08,5^{\prime \prime}$ & $039^{\circ} 46^{\prime} 22,3^{\prime \prime}$ & $07 / 12 / 2002$ & horizontal & superfície & nêuston & 500 & 2 \\
\hline 5554 & $22^{\circ} 32^{\prime} 49,0^{\prime \prime}$ & $040^{\circ} 04^{\prime} 20,9^{\prime \prime}$ & $07 / 11 / 2001$ & oblíquo & $1.000 \mathrm{~m}$ & cilíndrico-cônica & 500 & 1 \\
\hline 5556 & $22^{\circ} 32^{\prime} 49,0^{\prime \prime}$ & $040^{\circ} 04^{\prime} 20,9^{\prime \prime}$ & $07 / 11 / 2001$ & oblíquo & $1.000 \mathrm{~m}$ & cilíndrico-cônica & 500 & 1 \\
\hline 22018 & $22^{\circ} 08^{\prime} 14,9^{\prime \prime}$ & $039^{\circ} 46^{\prime} 34,6^{\prime \prime}$ & $11 / 05 / 2002$ & oblíquo & até a termoclina & bongô & 330 & 2 \\
\hline
\end{tabular}




\begin{tabular}{|c|c|c|c|c|c|c|c|c|}
\hline DZUFRJ & Latitude (S) & Longitude (W) & Data & $\begin{array}{l}\text { Tipo de } \\
\text { arrasto }\end{array}$ & $\begin{array}{l}\text { Profundidade } \\
\text { de coleta }\end{array}$ & Rede & $\begin{array}{l}\text { Malha } \\
(\mu \mathrm{m})\end{array}$ & $\begin{array}{l}N^{\circ} \text {. de } \\
\text { inds. }\end{array}$ \\
\hline 23130 & $22^{\circ} 08,03^{\prime}$ & $039^{\circ} 50,11^{\prime}$ & $16 / 06 / 2003$ & horizontal & superfície & nêuston & 500 & 7 \\
\hline 23131 & $22^{\circ} 08,07^{\prime}$ & $039^{\circ} 37,58^{\prime}$ & $17 / 06 / 2003$ & horizontal & superfície & nêuston & 500 & 2 \\
\hline 23135 & $21^{\circ} 57^{\prime} 08,3^{\prime \prime}$ & $039^{\circ} 49^{\prime} 05,2^{\prime \prime}$ & 05/12/2002 & horizontal & superfície & nêuston & 500 & 18 \\
\hline 23136 & $21^{\circ} 57^{\prime} 08,3^{\prime \prime}$ & $039^{\circ} 49^{\prime} 05,2^{\prime \prime}$ & $05 / 12 / 2002$ & horizontal & superfície & nêuston & 500 & 5 \\
\hline 23137 & $22^{\circ} 02^{\prime} 35,2^{\prime \prime}$ & $039^{\circ} 43^{\prime} 18,2^{\prime \prime}$ & $04 / 12 / 2002$ & horizontal & superfície & nêuston & 500 & 6 \\
\hline 23795 & $22^{\circ} 02^{\prime} 35,2^{\prime \prime}$ & $039^{\circ} 43^{\prime} 18,2^{\prime \prime}$ & 04/12/2002 & horizontal & superfície & nêuston & 500 & 1 \\
\hline 23796 & $22^{\circ} 08,03^{\prime}$ & $039^{\circ} 50,11^{\prime}$ & $16 / 06 / 2003$ & horizontal & superfície & nêuston & 500 & 8 \\
\hline 23832 & $22^{\circ} 02,27^{\prime}$ & $039^{\circ} 43,49^{\prime}$ & $18 / 06 / 2003$ & horizontal & superfície & nêuston & 500 & 1 \\
\hline 23881 & $22^{\circ} 43^{\prime} 50,4^{\prime \prime}$ & $039^{\circ} 53^{\prime} 20,5^{\prime \prime}$ & $07 / 12 / 2002$ & horizontal & superfície & nêuston & 500 & 10 \\
\hline 23892 & $22^{\circ} 43^{\prime} 50,4^{\prime \prime}$ & $039^{\circ} 53^{\prime} 20,5^{\prime \prime}$ & $07 / 12 / 2002$ & horizontal & superfície & nêuston & 500 & 4 \\
\hline
\end{tabular}

Referências: Nafpakititis et al., 1977; Moser \& Ahlstrom, 1996; Castro \& Bonecker, 2006c; Moser \& Watson, 2006; Fahay, 2007; Santos \& Figueiredo, 2008. 


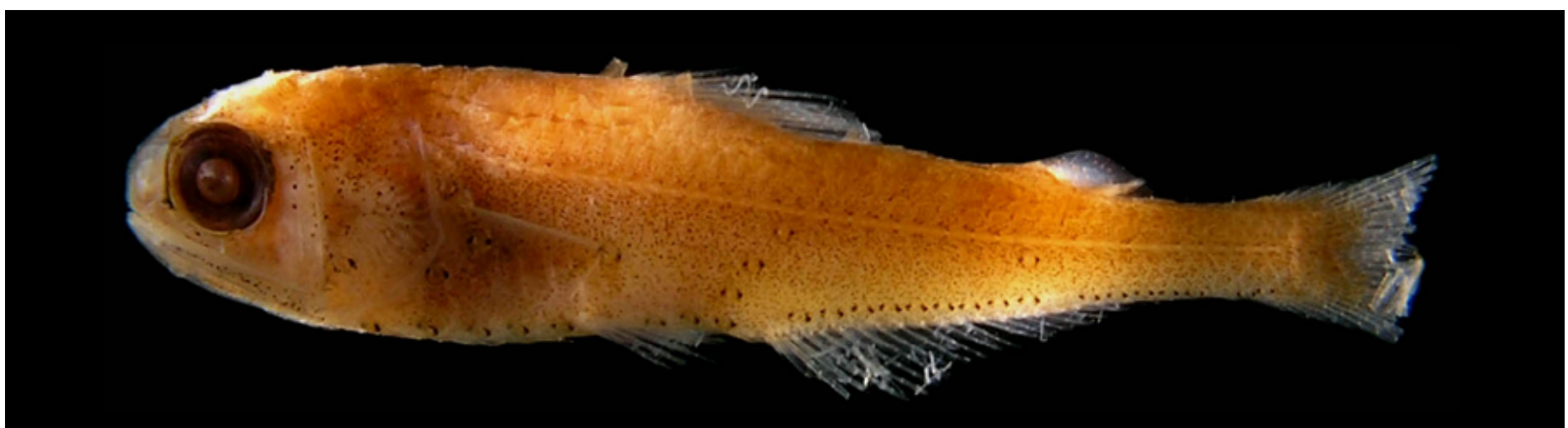

Figura 74 - A: Myctophum nitidulum. DZUFRJ 22159; Juvenil; CP 26,5 mm.

\section{Myctophum nitidulum Garman, 1899}

As larvas em pré-flexão, flexão e pós-flexão possuem olhos elípticos com uma pequena massa cônica ventral de tecido coroide. As nadadeiras peitorais são grandes e os raios se desenvolvem precocemente. No estágio de

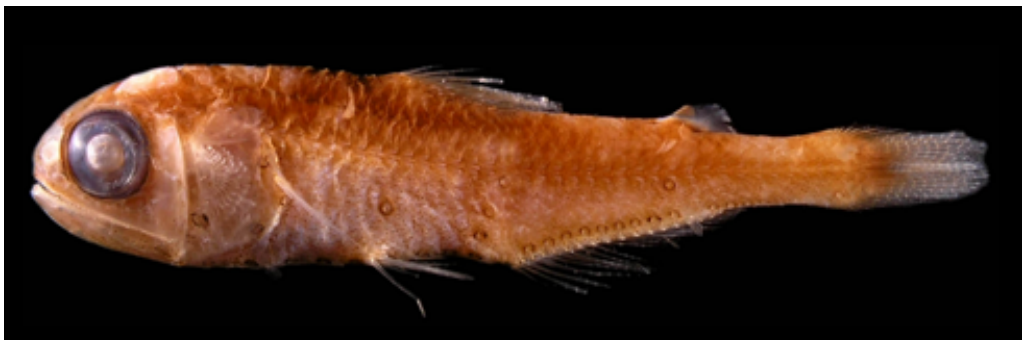

Figura 74 - B: DZUFRJ 22144; Adulto; CP 37,0 mm.

flexão há pigmentos na extremidade da maxila inferior, dois na margem dorsal e um na margem ventral do corpo, um no focinho e outros na região ventral do intestino, no opérculo e na base da nadadeira peitoral. Possui vários melanóforos grandes na parte interna da base da nadadeira peitoral, enquanto em $M$. affine há um ou dois melanóforos. Olhando a cabeça dorsalmente pode-se observar um par de pigmentos na parte lateral posterior do cérebro. O número de miômeros varia entre 36 e 39. Os indivíduos em transformação apresentam SAO em linha reta passando atrás do VO3; 2 Prc; Pol acima do último AOa; 9 (8 a 10) AOa e 5 (4 a 6) AOp; AOp1 normalmente sobre o final da base da nadadeira anal. A margem póstero-dorsal do opérculo é angular e pontuda; nos indivíduos em transformação ou juvenis, as escamas são cicloides.

Tamanho: pós-flexão 7,3 mm; juvenil 26,5 mm; adulto 37,0 mm.

Habitat: espécie marinha, epi-mesopelágica, ocorre em águas tropicais entre 475 e $850 \mathrm{~m}$ de profundidade durante o dia. A noite ocorre próximo à superfície.

Nome vulgar: Peixe-lanterna.

\section{Georreferencimento}

\begin{tabular}{|c|c|c|c|c|c|c|c|c|}
\hline DZUFR & Latitude & Longitude & Data & $\begin{array}{c}\text { Tipo de } \\
\text { arrasto }\end{array}$ & $\begin{array}{c}\text { Profundidade } \\
\text { de coleta }\end{array}$ & Rede & $\begin{array}{c}\text { Malha } \\
\text { ( } \begin{array}{c}\boldsymbol{\mu} \text { m) } \\
\text { inds. }\end{array}\end{array}$ & $\begin{array}{c}\text { No. de } \\
\text { inds. }\end{array}$ \\
\hline 22144 & $21^{\circ} 54^{\prime} 36,5^{\prime \prime}$ & $039^{\circ} 45^{\prime} 20,0^{\prime \prime}$ & $09 / 10 / 2001$ & oblíquo & $1.000 \mathrm{~m}$ & cilíndrico-cônica & 500 & 1 \\
\hline 22157 & $22^{\circ} 33^{\prime} 47,7^{\prime \prime}$ & $040^{\circ} 12^{\prime} 20,5^{\prime \prime}$ & $17 / 05 / 2002$ & oblíquo & $50 \mathrm{~m}$ & bongô & 500 & 1 \\
\hline 22159 & $22^{\circ} 31^{\prime} 40,9^{\prime \prime}$ & $040^{\circ} 02^{\prime} 39,6^{\prime \prime}$ & $07 / 11 / 2001$ & oblíquo & $1.000 \mathrm{~m}$ & cilíndrico-cônica & 500 & 1 \\
\hline
\end{tabular}

Referências: Nafpakititis et al., 1977; Moser \& Ahlstrom, 1996; Castro \& Bonecker, 2006c; Moser \& Watson, 2006; Fahay, 2007; Santos \& Figueiredo, 2008. 


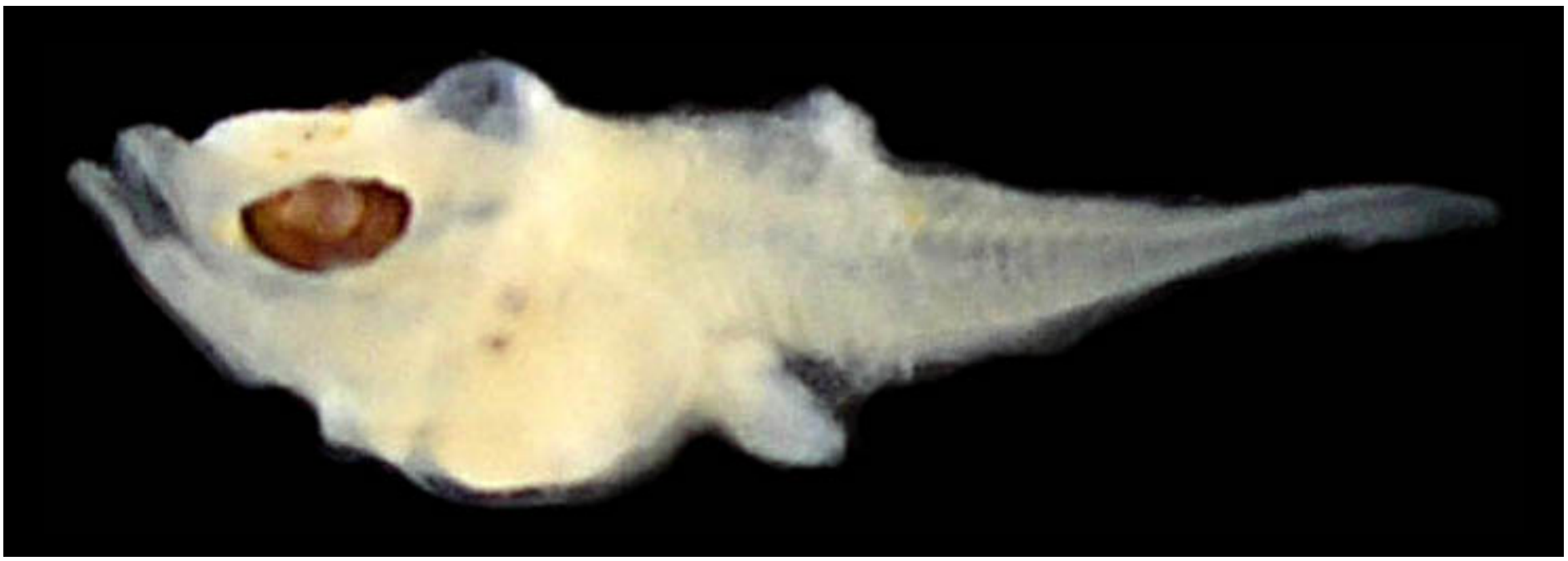

Figura 75- A: Myctophum obtusirostre. DZUFRJ 22174; Pré-flexão; CP 3,4 mm.

\section{Myctophum obtusirostre Tåning, 1928}

Na pré-flexão, flexão e pós-flexão possui o corpo alto, mandíbula grande e olhos ovais com uma pequena massa cônica ventral de tecido coroide. As larvas no estágio de flexão possuem pigmentos nas extremidades das maxilas, na região anterior do cérebro, na base da nadadeira peitoral, no intestino e no cleitro. A distância pré-anal aumenta da pré-flexão $(<50 \%)$ para a pós-flexão (>60\%). O número de miômeros varia entre 35 e 36. Os indivíduos em transformação apresentam PLO anterior à base da nadadeira peitoral, SAO um pouco curvo, SAO1 um pouco a frente do VO4; 1 Pol sobre o último AOa; 2 Prc; 7 (6 a 8) AOa e 4 (3 a 5) AOp; AOp1 normalmente sobre a base da nadadeira anal. Nos indivíduos em trans-

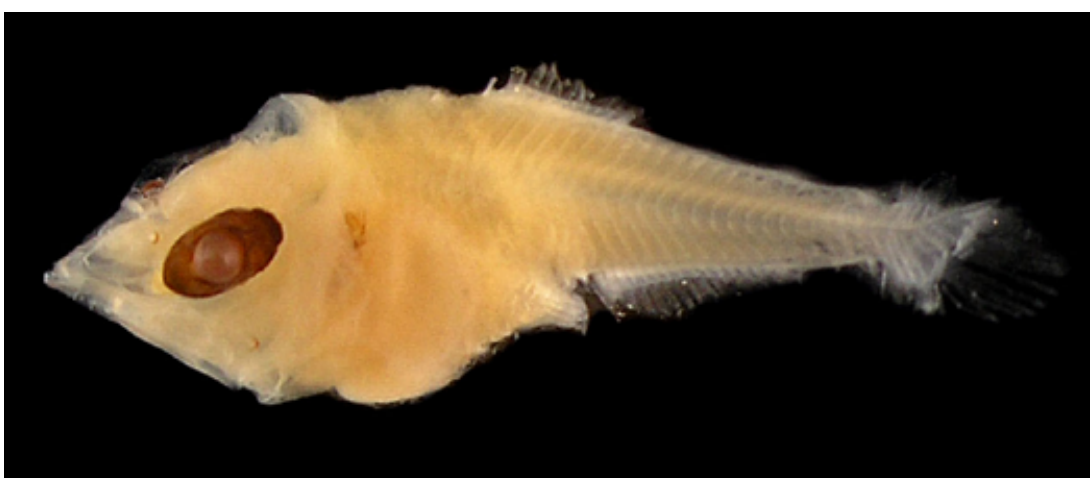

Figura 75- B: DZUFRJ 5511; Flexão; CP 5,5 mm.

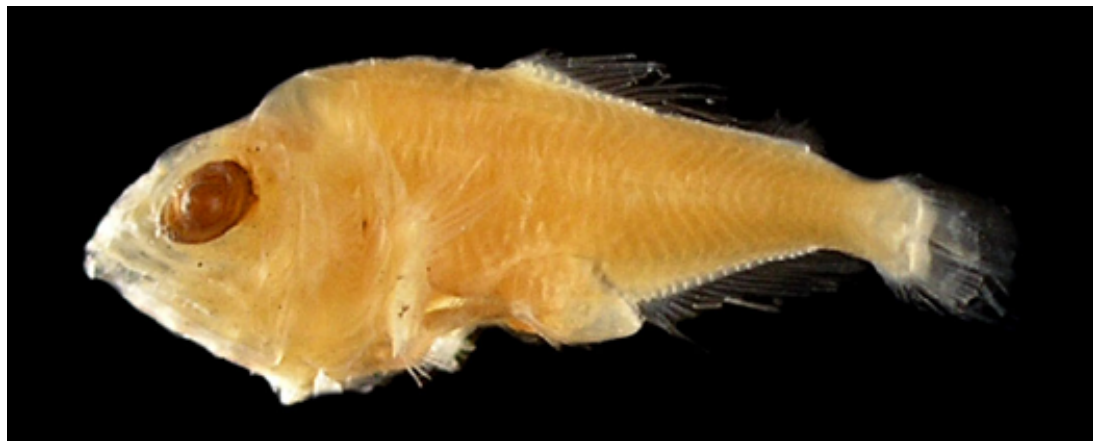

Figura 75 - C: DZUFRJ 10945; Pós-flexão; CP 7,0 mm. formação e juvenis, as escamas são cicloides.

Tamanho: pré-flexão 3,0-3,9 mm; flexão 4,0-5,9 mm; pós-flexão 6,0-7,4 mm; juvenil 15,0-17,2 $\mathrm{mm}$.

Habitat: espécie marinha, epi-mesopelágica, ocorre em águas tropicais entre 325 e $750 \mathrm{~m}$ de profundidade durante o dia. A noite ocorre próximo à superfície.

Nome vulgar: Peixe-lanterna. 


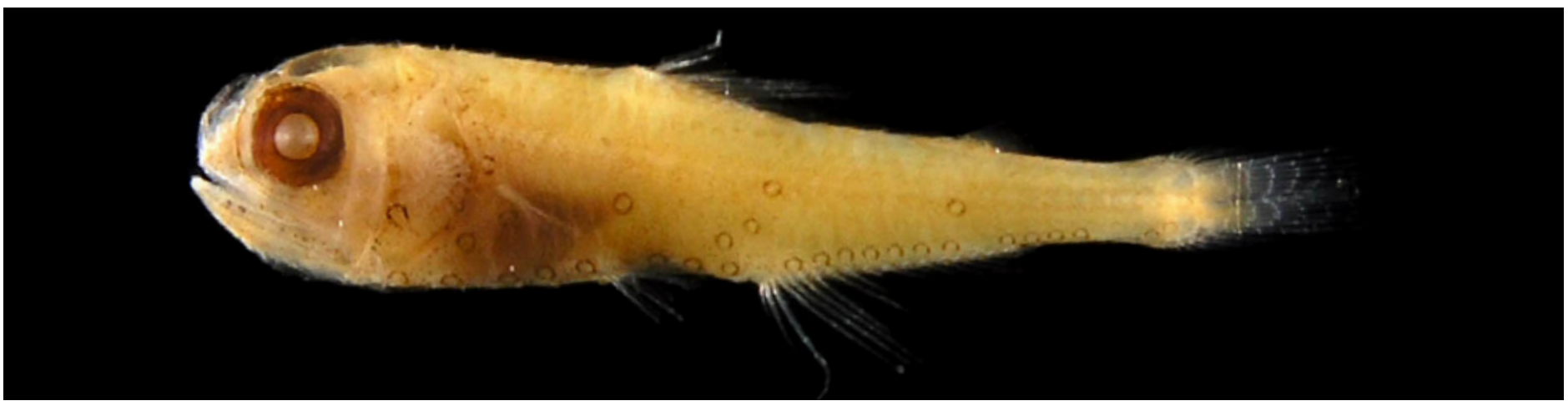

Figura 75 - D: DZUFRJ 22154; Juvenil; CP 17,0 mm.

\section{Georreferencimento}

\begin{tabular}{|c|c|c|c|c|c|c|c|c|}
\hline DZUFRJ & Latitude (S) & Longitude (W) & Data & $\begin{array}{l}\text { Tipo de } \\
\text { arrasto }\end{array}$ & $\begin{array}{l}\text { Profundidade } \\
\text { de coleta }\end{array}$ & Rede & $\begin{array}{c}\text { Malha } \\
(\mu \mathrm{m})\end{array}$ & $\begin{array}{l}N^{\circ} \text {. de } \\
\text { inds. }\end{array}$ \\
\hline 5511 & $22^{\circ} 32^{\prime} 50,0^{\prime \prime}$ & $040^{\circ} 04^{\prime} 09,9 "$ & $06 / 11 / 2001$ & oblíquo & $1.000 \mathrm{~m}$ & cilíndrico-cônica & 500 & 2 \\
\hline 7533 & $22^{\circ} 32^{\prime} 50,0^{\prime \prime}$ & $040^{\circ} 04^{\prime} 09,9^{\prime \prime}$ & 06/11/2001 & oblíquo & $1.000 \mathrm{~m}$ & cilíndrico-cônica & 500 & 1 \\
\hline 7556 & $21^{\circ} 54^{\prime} 36,5^{\prime \prime}$ & $039^{\circ} 45^{\prime} 20,0^{\prime \prime}$ & $10 / 10 / 2001$ & oblíquo & $1.000 \mathrm{~m}$ & cilíndrico-cônica & 500 & 1 \\
\hline 7569 & $21^{\circ} 53^{\prime} 10,4^{\prime \prime}$ & $039^{\circ} 45^{\prime} 49,9^{\prime \prime}$ & $10 / 10 / 2001$ & oblíquo & $1.000 \mathrm{~m}$ & cilíndrico-cônica & 500 & 1 \\
\hline 7572 & $21^{\circ} 54^{\prime} 36,5^{\prime \prime}$ & $039^{\circ} 45^{\prime} 20,0^{\prime \prime}$ & 09/10/2001 & oblíquo & $1.000 \mathrm{~m}$ & cilíndrico-cônica & 500 & 3 \\
\hline 21989 & $21^{\circ} 54^{\prime} 36,5^{\prime \prime}$ & $039^{\circ} 45^{\prime} 20,0^{\prime \prime}$ & $10 / 10 / 2001$ & oblíquo & $0 \mathrm{~m}$ & cilíndrico-cônica & 500 & 2 \\
\hline 21990 & $21^{\circ} 57^{\prime} 10,5^{\prime \prime}$ & $039^{\circ} 43^{\prime} 33,3^{\prime \prime}$ & 09/10/2001 & oblíquo & $1.000 \mathrm{~m}$ & cilíndrico-cônica & 500 & 3 \\
\hline 21992 & $21^{\circ} 58^{\prime} 31,0^{\prime \prime}$ & $039^{\circ} 50^{\prime} 29,7^{\prime \prime}$ & $11 / 10 / 2001$ & oblíquo & $1.000 \mathrm{~m}$ & cilíndrico-cônica & 500 & 3 \\
\hline 22013 & $21^{\circ} 58^{\prime} 31,0^{\prime \prime}$ & $039^{\circ} 50^{\prime} 29,7^{\prime \prime}$ & $10 / 10 / 2001$ & oblíquo & & cilíndrico-cônica & 500 & 2 \\
\hline 22024 & $21^{\circ} 53^{\prime} 10,4^{\prime \prime}$ & $039^{\circ} 45^{\prime} 49,9^{\prime \prime}$ & $10 / 10 / 2001$ & oblíquo & $1.000 \mathrm{~m}$ & cilíndrico-cônica & 500 & 1 \\
\hline 22040 & $22^{\circ} 03^{\prime} 03,3^{\prime \prime}$ & $039^{\circ} 50^{\prime} 39,0^{\prime \prime}$ & $10 / 05 / 2002$ & oblíquo & até a termoclina & bongô & 330 & 1 \\
\hline 22044 & $22^{\circ} 02^{\prime} 30,0^{\prime \prime}$ & $039^{\circ} 49^{\prime} 41,2^{\prime \prime}$ & $12 / 05 / 2002$ & oblíquo & & cilíndrico-cônica & 500 & 1 \\
\hline 22089 & $22^{\circ} 32^{\prime} 50,0^{\prime \prime}$ & $040^{\circ} 04^{\prime} 09,9^{\prime \prime}$ & $06 / 11 / 2001$ & oblíquo & $1.000 \mathrm{~m}$ & cilíndrico-cônica & 500 & 1 \\
\hline 22090 & $22^{\circ} 31^{\prime} 58,9^{\prime \prime}$ & $040^{\circ} 02^{\prime} 53,4^{\prime \prime}$ & $07 / 11 / 2001$ & oblíquo & $1.000 \mathrm{~m}$ & cilíndrico-cônica & 500 & 1 \\
\hline 22151 & $22^{\circ} 08^{\prime} 17,5^{\prime \prime}$ & $039^{\circ} 46^{\prime} 28,5^{\prime \prime}$ & $11 / 05 / 2002$ & oblíquo & $1.000 \mathrm{~m}$ & cilíndrico-cônica & 500 & 3 \\
\hline 22154 & $21^{\circ} 57^{\prime} 08,3^{\prime \prime}$ & $039^{\circ} 49^{\prime} 05,2^{\prime \prime}$ & $05 / 12 / 2002$ & horizontal & superfície & nêuston & 500 & 2 \\
\hline 22171 & $22^{\circ} 08^{\prime} 14,9^{\prime \prime}$ & $039^{\circ} 46^{\prime} 34,6^{\prime \prime}$ & $11 / 05 / 2002$ & oblíquo & até a termoclina & bongô & 500 & 1 \\
\hline 22174 & $22^{\circ} 33^{\prime} 47,7^{\prime \prime}$ & $040^{\circ} 12^{\prime} 20,5^{\prime \prime}$ & $17 / 05 / 2002$ & oblíquo & $50 \mathrm{~m}$ & bongô & 500 & 1 \\
\hline 23129 & $21^{\circ} 57^{\prime} 08,3^{\prime \prime}$ & $039^{\circ} 49^{\prime} 05,2^{\prime \prime}$ & $05 / 12 / 2002$ & horizontal & superfície & nêuston & 500 & 2 \\
\hline
\end{tabular}

Referências: Nafpakititis et al., 1977; Moser \& Ahlstrom, 1996; Castro \& Bonecker, 2006c; Moser \& Watson, 2006; Fahay, 2007; Santos \& Figueiredo, 2008. 


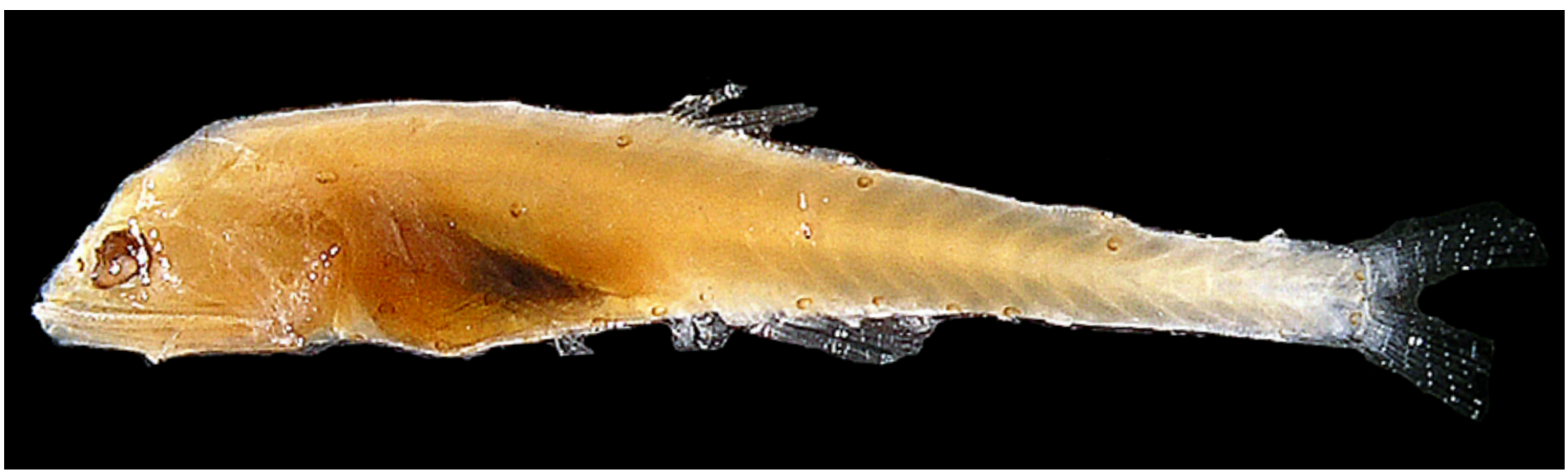

Figura 76 - A: Notolychnus valdiviae. DZUFRJ 1210; Transformação; CP 14,7 mm.

\section{Notolychnus valdiviae (Brauer, 1904)}

A principal característica dos indivíduos em transformação e dos juvenis é a posição dos fotóforos VLO, SAO3 e

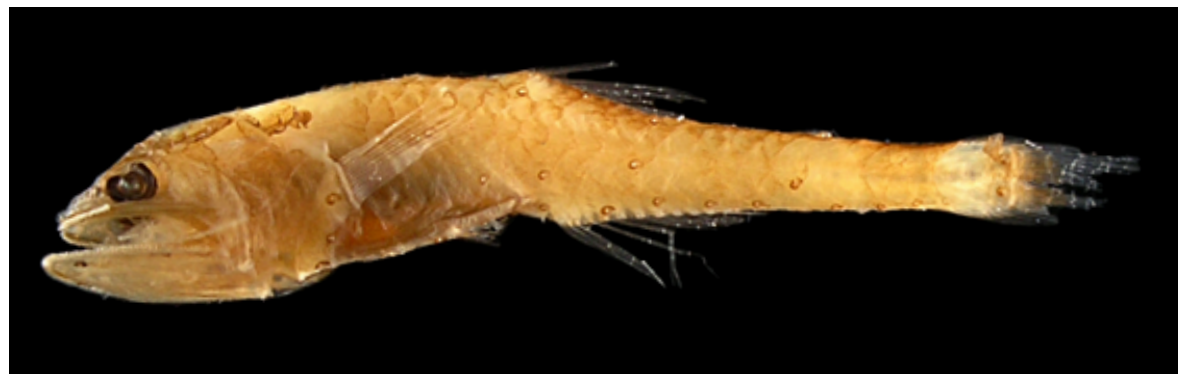

Figura 76 - B: DZUFRJ 22146; Juvenil; CP 19,2 mm. Pol2 que estão situados bem próximo à margem dorsal do corpo. Além disso, possuem um Dn pequeno; PLO bem à frente da base da nadadeira peitoral quase em contato com ela. Os fotóforos PO1, PO2 e PO5 são equidistantes formando uma linha horizontal; PO3 elevado até o nível do PVO1; PO4 muito elevado. O VO1 é elevado à frente do VO2; SAO um pouco angular, SAO3 muito próximo ao final da nadadeira dorsal; 2 Pol, Pol2 próximo à base da nadadeira adiposa; 2 Prc, o segundo situado acima do primeiro; $4 \mathrm{AOa}$ e 4 (3) AOp. O número de miômeros varia entre 27 e 31.

Tamanho: transformação 11,0-15,0 mm; juvenil 17,2-19,2 mm.

Habitat: espécie marinha, epi-mesopelágica, ocorre em águas tropicais e temperadas entre 375 e $650 \mathrm{~m}$ de profundidade durante o dia. A noite ocorre entre 40 e $125 \mathrm{~m}$ de profundidade.

Nome vulgar: Peixe-lanterna.

\section{Georreferencimento}

\begin{tabular}{|c|c|c|c|c|c|c|c|c|}
\hline DZUFR & Latitude (S) & Longitude (W) & Data & $\begin{array}{c}\text { Tipo de } \\
\text { arrasto }\end{array}$ & $\begin{array}{c}\text { Profundidade } \\
\text { de coleta }\end{array}$ & Rede & $\begin{array}{c}\text { Malha } \\
(\boldsymbol{\mu m})\end{array}$ & $\begin{array}{c}\mathbf{N}^{\circ} \text {. de } \\
\text { inds. }\end{array}$ \\
\hline 1200 & $22^{\circ} 06^{\prime} 52,3^{\prime \prime}$ & $039^{\circ} 48^{\prime} 46,2^{\prime \prime}$ & $11 / 05 / 2002$ & oblíquo & $1.000 \mathrm{~m}$ & cilíndrico-cônica & 500 & 2 \\
\hline 1210 & $22^{\circ} 02^{\prime} 30,0^{\prime \prime}$ & $039^{\circ} 49^{\prime} 41,2^{\prime \prime}$ & $12 / 05 / 2002$ & oblíquo & $1.000 \mathrm{~m}$ & cilíndrico-cônica & 500 & 3 \\
\hline 22021 & $2^{\circ} 54^{\prime} 36,5^{\prime \prime}$ & $039^{\circ} 45^{\prime} 20,0^{\prime \prime}$ & $10 / 10 / 2001$ & oblíquo & $1.000 \mathrm{~m}$ & cilíndrico-cônica & 500 & 2 \\
\hline 22025 & $21^{\circ} 58^{\prime} 31,0^{\prime \prime}$ & $039^{\circ} 50^{\prime} 29,7^{\prime \prime}$ & $10 / 10 / 2001$ & oblíquo & $1.000 \mathrm{~m}$ & cilíndrico-cônica & 500 & 2 \\
\hline 22146 & $22^{\circ} 32^{\prime} 49,0^{\prime \prime}$ & $040^{\circ} 04^{\prime} 20,9^{\prime \prime}$ & $07 / 11 / 2001$ & oblíquo & $1.000 \mathrm{~m}$ & cilíndrico-cônica & 500 & 1 \\
\hline
\end{tabular}

Referências: Nafpakititis et al., 1977; Castro \& Bonecker, 2006c; Fahay, 2007; Santos \& Figueiredo, 2008. 


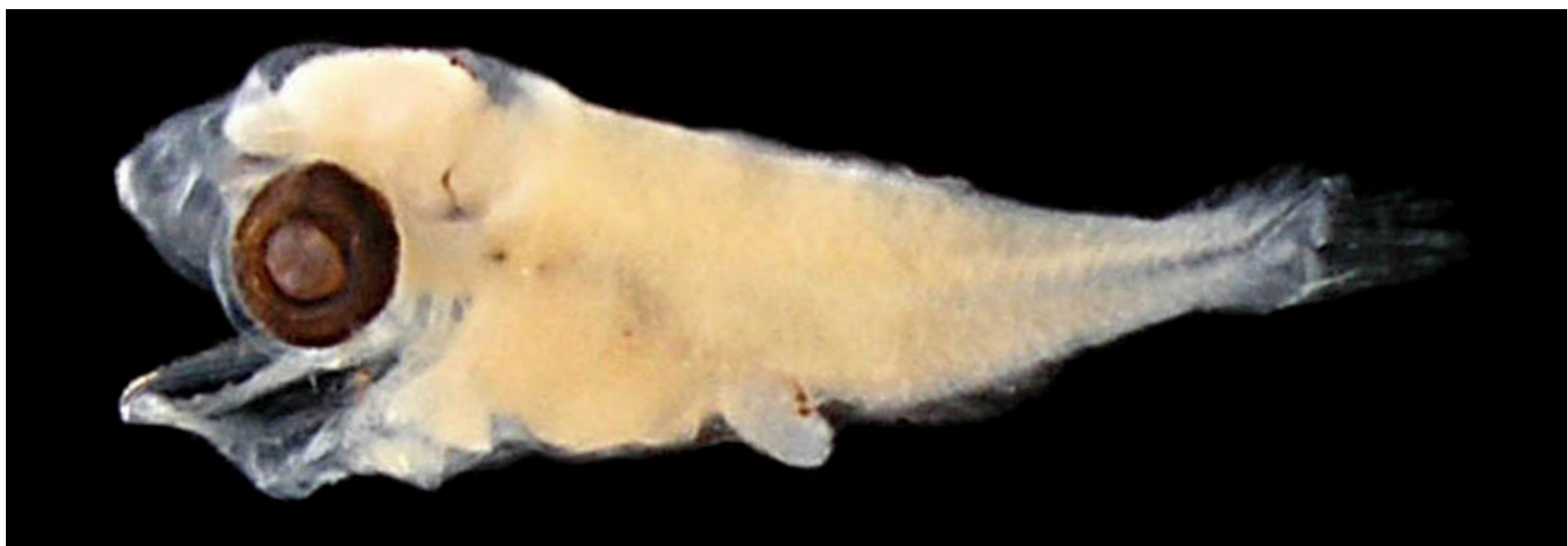

Figura 77: Notoscopelus caudispinosus. DZUFRJ 22172; Flexão; CP 5,1mm.

\section{Notoscopelus caudispinosus (Johnson, 1863)}

Possui cabeça e olhos grandes. Os dentes curvos se formam na maxila inferior no estágio de pré-flexão e o focinho é arredondado durante a flexão. O intestino é muito curto nos estágios iniciais (43\% CP), aumentando em larvas maiores (66\% CP). Possui 37 miômeros. Tem pigmentos no intestino e na cabeça na região posterior do olho. Larvas maiores (5,6 CP) tem dois melanóforos proeminentes no topo da cabeça.

Tamanho: flexão 5,1 mm.

Habitat: Espécie marinha, epi-mesopelágica, ocorre em águas tropicais e subtropicais entre 600 e $1.150 \mathrm{~m}$ de profundidade durante o dia. A noite ocorre entre 20 e $100 \mathrm{~m}$ de profundidade.

Nome vulgar: Peixe-lanterna.

Georreferencimento

\begin{tabular}{|c|c|c|c|c|c|c|c|c|}
\hline DZUFRJ & Latitude (S) & Longitude (W) & Data & $\begin{array}{c}\text { Tipo de } \\
\text { arrasto }\end{array}$ & $\begin{array}{c}\text { Profundidade } \\
\text { de coleta }\end{array}$ & Rede & $\begin{array}{c}\text { Malha } \\
(\boldsymbol{\mu m})\end{array}$ & $\begin{array}{c}\mathbf{N}^{\circ} \text {. de } \\
\text { inds. }\end{array}$ \\
\hline 22172 & $21^{\circ} 54^{\prime} 36,5^{\prime \prime}$ & $039^{\circ} 45^{\prime} 20,0^{\prime \prime}$ & $09 / 10 / 2001$ & oblíquo & $1.000 \mathrm{~m}$ & cilíndrico-cônica & 500 & 1 \\
\hline
\end{tabular}

Referências: Moser \& Ahlstrom, 1996; Moser \& Watson, 2006; Fahay, 2007. 


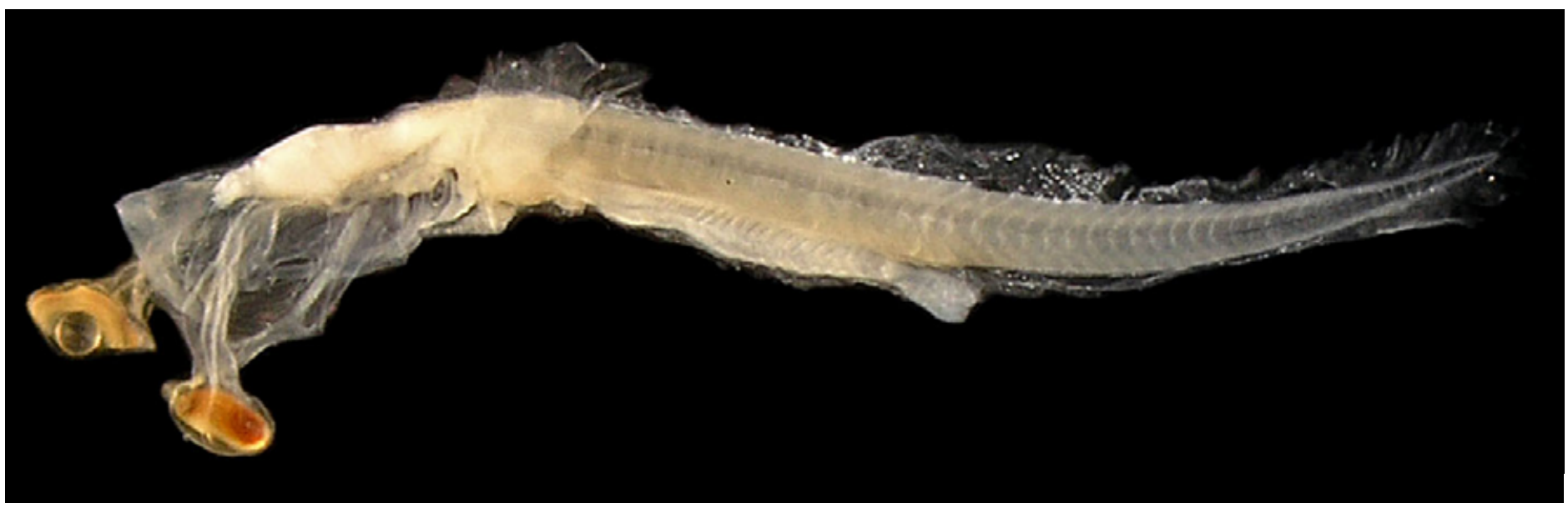

Figura 78 - A: Symbolophorus rufinus. DZUFRJ 13589; Pré-flexão; CP 6,0 mm.

\section{Symbolophorus rufinus Tåning, 1928}

Possui corpo alongado, com 37 miômeros. A cabeça é achatada e os olhos são ovais e muito pedunculados, com tecido coroide pequeno. O intestino é longo e alcança mais da metade do corpo. A

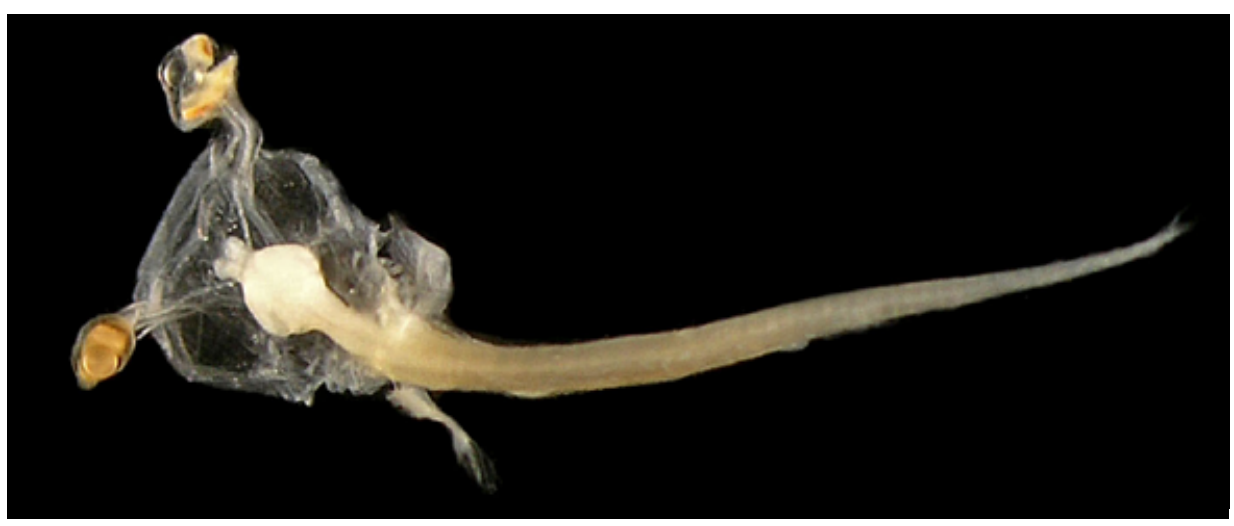

Figura 78 - B: Vista dorsal dos olhos ovais pedunculados. nadadeira peitoral se desenvolve precocemente, é grande e tem forma de asa. Tem pigmentos no istmo, na lateral do intestino, na extremidade da maxila superior e na região posterior da cabeça.

Tamanho: pré-flexão 4,0-6,0 mm.

Habitat: espécie marinha, epi-mesopelágica, ocorre em águas tropicais e subtropicais entre 425 e $850 \mathrm{~m}$ de profundidade durante o dia. A noite ocorre desde próximo à superfície até $125 \mathrm{~m}$ de profundidade.

Nome vulgar: Peixe-lanterna.

\section{Georreferencimento}

\begin{tabular}{|c|c|c|c|c|c|c|c|c|}
\hline DZUFRJ & Latitude (S) & Longitude (W) & Data & $\begin{array}{l}\text { Tipo de } \\
\text { arrasto }\end{array}$ & $\begin{array}{l}\text { Profundidade } \\
\text { de coleta }\end{array}$ & Rede & $\begin{array}{c}\text { Malha } \\
(\mu \mathrm{m})\end{array}$ & $\begin{array}{l}N^{\circ} \text {. de } \\
\text { inds. }\end{array}$ \\
\hline 5551 & $22^{\circ} 31^{\prime} 40,9^{\prime \prime}$ & $040^{\circ} 02 ' 39,6^{\prime \prime}$ & $07 / 11 / 2001$ & oblíquo & $1.000 \mathrm{~m}$ & cilíndrico-cônica & 500 & 1 \\
\hline 22085 & $22^{\circ} 31^{\prime} 40,9^{\prime \prime}$ & $040^{\circ} 02^{\prime} 39,6^{\prime \prime}$ & $07 / 11 / 2001$ & oblíquo & $1.000 \mathrm{~m}$ & cilíndrico-cônica & 500 & 1 \\
\hline 22152 & $21^{\circ} 58^{\prime} 31,0^{\prime \prime}$ & $039^{\circ} 50^{\prime 29,7 "}$ & $10 / 10 / 2001$ & oblíquo & $1.000 \mathrm{~m}$ & cilíndrico-cônica & 500 & 1 \\
\hline
\end{tabular}

Referências: Moser \& Ahlstrom, 1996; Castro \& Bonecker, 2006c; Moser \& Watson, 2006; Fahay, 2007. 


\section{ORDEM LAMPRIFORMES}

A ordem Lampriformes é composta por sete famílias com aproximadamente 21 espécies. Os peixes desta ordem apresentam maxila superior protrátil, não possuem espinhos verdadeiros nas nadadeiras e as pélvicas possuem de 0-17 raios.

Nesse estudo a ordem Lampriformes é representada pela família Trachipteridae. 


\section{Família Trachipteridae}

A família Trachipteridae é mesopelágica e ocorre em todos os oceanos. Compreende três gêneros com aproximadamente dez espécies. Possuem corpo alongado e lateralmente comprimido. As maxilas são muito protráteis. Não possuem nadadeira anal. As nadadeiras dorsal e caudal são muito longas. A nadadeira pélvica é rudimentar nos adultos de algumas espécies, mas muito conspícua nas larvas. As larvas apresentam os primeiros raios da nadadeira dorsal e os raios da nadadeira pélvica longos e ornamentados.

No Brasil já foram identificadas três espécies nas fases de larva e adulto: Desmodema polystictum (Ogilby, 1879); Trachipterus jacksonensis (Ramsay, 1881) e Zu cristatus (Bonelli, 1819). Na área de estudo é contemplada a espécie Zu cristatus. 


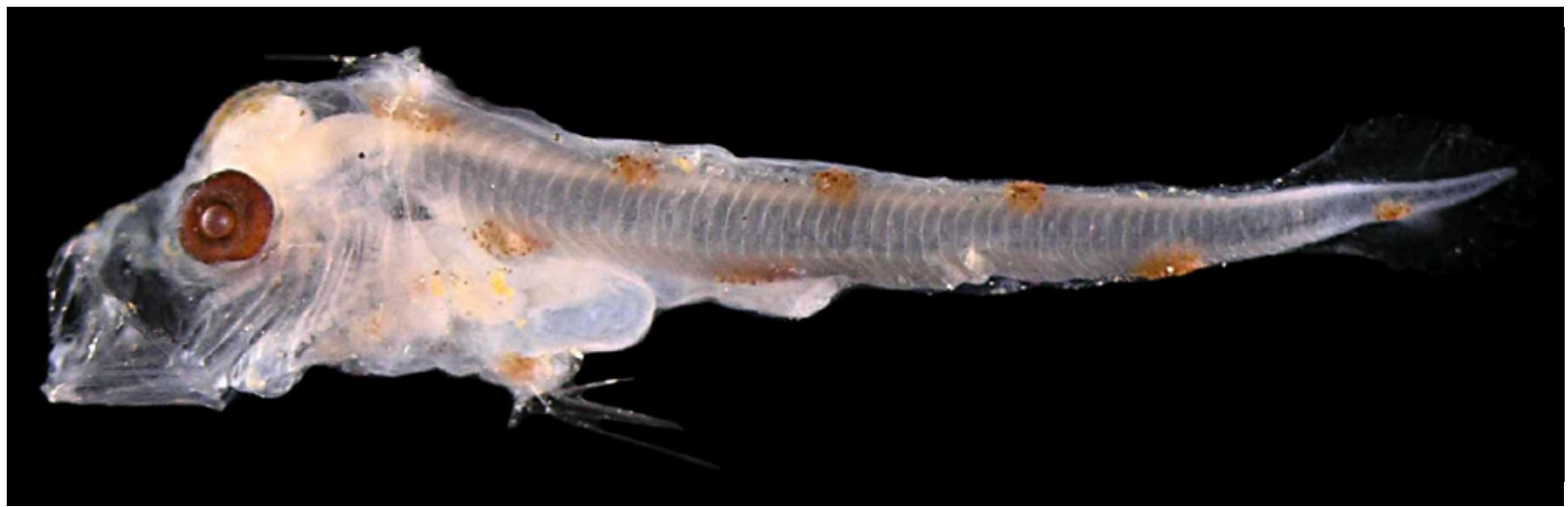

Figura 79: Zu cristatus. DZUFRJ 22487; Pré-flexão; CP 6,0 mm.

\section{Zu cristatus \\ (Bonelli, 1819)}

Desenvolvimento precoce dos primeiros raios das nadadeiras dorsal e pélvica. Não tem nadadeira anal. Série de pigmentos alternados nas margens dorsal e ventral do corpo. Pigmentos espalhados na região do crânio. Mandíbula protrátil. O número de miômeros varia aproximadamente entre 62 e 69.

Tamanho: pré-flexão 6,0 mm.

Habitat: espécie marinha, epi-mesopelágica, ocorre em águas tropicais e temperadas até $90 \mathrm{~m}$ de profundidade.

\section{Georreferenciamento}

\begin{tabular}{|c|c|c|c|c|c|c|c|c|}
\hline DZUFRJ & Latitude (S) & Longitude (W) & Data & $\begin{array}{c}\text { Tipo de } \\
\text { arrasto }\end{array}$ & $\begin{array}{c}\text { Profundidade } \\
\text { de coleta }\end{array}$ & Rede & $\begin{array}{c}\text { Malha } \\
(\boldsymbol{\mu m})\end{array}$ & $\begin{array}{c}\mathbf{N}^{\circ} \text {. de } \\
\text { inds. }\end{array}$ \\
\hline 22487 & $21^{\circ} 58^{\prime} 31,0^{\prime \prime}$ & $039^{\circ} 50^{\prime} 29,7^{\prime \prime}$ & $10 / 10 / 2001$ & oblíquo & $1.000 \mathrm{~m}$ & cilíndrico-cônica & 500 & 1 \\
\hline
\end{tabular}

Referências: Olney, 2006a; Fahay, 2007. 


\section{ORDEM GADIFORMES}

A ordem Gadiformes é formada por nove famílias com 555 espécies. As nadadeiras pélvicas, quando presentes, estão inseridas abaixo ou a frente das peitorais, com mais de 11 raios. Não possuem espinhos verdadeiros nas nadadeiras. As nadadeiras dorsal e anal são longas na maioria das espécies. As larvas costumam ser muito pigmentadas e a nadadeira caudal pode ser presente ou ausente. Muitos peixes comercialmente importantes pertencem a esta ordem e representam mais de um quarto da pesca mundial.

Nesse estudo a ordem Gadiformes é representada pelas famílias Bregmacerotidae, Macrouridae e Phycidae. 


\section{Família Bregmacerotidae}

Os peixes da família Bregmacerotidae são pequenos, possuem hábito pelágico e apresentam uma distribuição circumglobal tanto em águas costeiras quanto em regiões oceânicas. Os adultos de algumas espécies realizam migração vertical e distribuem-se desde a superfície até aproximadamente $4.000 \mathrm{~m}$ de profundidade, sendo mais comuns até $300 \mathrm{~m}$. As larvas podem ser coletadas até $600 \mathrm{~m}$ de profundidade e as espécies com distribuição mais costeira tendem a permanecer mais próximas à superfície. Esta família é composta por um único gênero (Bregmaceros) com no mínimo 15 espécies.

No Brasil já foram identificadas três espécies nas fases de larva e adulto: Bregmaceros atlanticus Goode \& Bean, 1886; Bregmaceros cantori (Milliken \& Houde, 1984) e Bregmaceros nov sp. Na área de estudo são contempladas as espécies Bregmaceros atlanticus e Bregmaceros nov sp. 


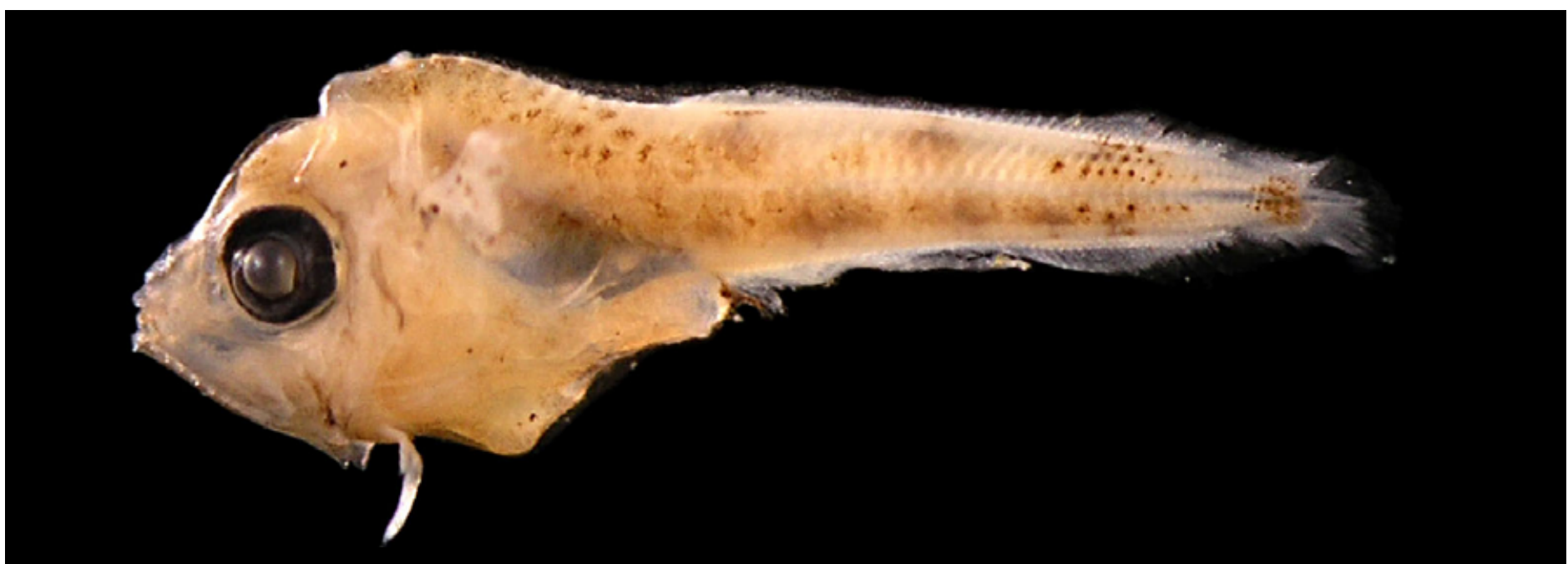

Figura 80- A: Bregmaceros atlanticus. DZUFRJ 13147; Pré-flexão; CP 4,2 mm.

\section{Bregmaceros atlanticus Goode \& Bean, 1866}

Possui intestino curto e corpo alongado (50-55 miômeros). Em larvas em pré-flexão (2,5-4,2 mm) aparecem pequenos melanóforos espalhados pela cabeça. Pigmentos na base da nadadeira, sobre a massa visceral e no lado ventral do intestino. Apresentam de dois a três melanóforos dorsais e de três a quatro melanóforos ventrais. Nadadeira anal e pedúnculo caudal começam a apresentar pigmentos. A partir de $4 \mathrm{~mm}$ os melanóforos espalhados pelo corpo se tornam mais numerosos. No estágio de flexão em diante (larvas maiores que 5,0 $\mathrm{mm}$ ) aparece um raio prolongado localizado na região superior da cabeça, denominado raio occipital.

Tamanho: pré-flexão 2,0-4,2 mm; flexão 4,4-10,0 mm; pós-flexão 12,0-17,0 mm.

Habitat: espécie marinha, epi-mesopelágica, ocorre em águas oceânicas e costeiras.

\section{Georreferencimento}

\begin{tabular}{|c|c|c|c|c|c|c|c|c|}
\hline DZUFRJ & Latitude (S) & Longitude (W) & Data & $\begin{array}{l}\text { Tipo de } \\
\text { arrasto }\end{array}$ & $\begin{array}{c}\text { Profundidade } \\
\text { de coleta }\end{array}$ & Rede & $\begin{array}{l}\text { Malha } \\
(\mu \mathrm{m})\end{array}$ & $\begin{array}{l}N^{\circ} \text {. de } \\
\text { inds. }\end{array}$ \\
\hline 1174 & $22^{\circ} 02^{\prime} 30,3^{\prime \prime}$ & $039^{\circ} 50^{\prime} 41,3^{\prime \prime}$ & $10 / 05 / 2002$ & oblíquo & $1.000 \mathrm{~m}$ & cilíndrico-cônica & 500 & 2 \\
\hline 1189 & $22^{\circ} 07^{\prime} 29,0^{\prime \prime}$ & $039^{\circ} 06^{\prime} 23,5^{\prime \prime}$ & $10 / 05 / 2002$ & oblíquo & $1.000 \mathrm{~m}$ & cilíndrico-cônica & 500 & 4 \\
\hline 1252 & $22^{\circ} 08^{\prime} 17,5^{\prime \prime}$ & $39^{\circ} 46^{\prime} 28,5^{\prime \prime}$ & $11 / 05 / 2002$ & oblíquo & $1.000 \mathrm{~m}$ & cilíndrico-cônica & 500 & 3 \\
\hline 6217 & $22^{\circ} 33^{\prime} 47,7^{\prime \prime}$ & $040^{\circ} 12^{\prime} 20,5^{\prime \prime}$ & $17 / 05 / 2002$ & oblíquo & $50 \mathrm{~m}$ & & 500 & 6 \\
\hline 533 & $22^{\circ} 34^{\prime} 05,0^{\prime \prime}$ & $040^{\circ} 19^{\prime} 40,0^{\prime \prime}$ & $17 / 05 / 2002$ & oblíquo & $600 \mathrm{~m}$ & cilíndrico-cônica & 500 & 6 \\
\hline 599 & $22^{\circ} 38^{\prime} 29,0^{\prime \prime}$ & $040^{\circ} 17^{\prime} 40,0^{\prime \prime}$ & $18 / 05 / 2002$ & oblíquo & $800 \mathrm{~m}$ & cilíndrico-cônica & 500 & 11 \\
\hline
\end{tabular}




\begin{tabular}{|c|c|c|c|c|c|c|c|c|}
\hline DZUFRJ & Latitude (S) & Longitude (W) & Data & $\begin{array}{l}\text { Tipo de } \\
\text { arrasto }\end{array}$ & $\begin{array}{c}\text { Profundidade } \\
\text { de coleta }\end{array}$ & Rede & $\begin{array}{l}\text { Malha } \\
(\mu \mathrm{m})\end{array}$ & $\begin{array}{l}N^{\circ} \text {. de } \\
\text { inds. }\end{array}$ \\
\hline 656 & $22^{\circ} 41^{\prime} 54,7 "$ & $040^{\circ} 14^{\prime} 04,5^{\prime \prime}$ & $16 / 05 / 2002$ & oblíquo & $1.000 \mathrm{~m}$ & cilíndrico-cônica & 500 & 7 \\
\hline 708 & $22^{\circ} 37^{\prime} 35,5^{\prime \prime}$ & $040^{\circ} 09^{\prime} 32,8^{\prime \prime}$ & $16 / 05 / 2002$ & oblíquo & $1.000 \mathrm{~m}$ & cilíndrico-cônica & 500 & 2 \\
\hline 7476 & $21^{\circ} 57^{\prime} 10,5^{\prime \prime}$ & $039^{\circ} 43^{\prime} 33,3^{\prime \prime}$ & 09/10/2001 & oblíquo & $1.000 \mathrm{~m}$ & cilíndrico-cônica & 500 & 1 \\
\hline 7473 & $21^{\circ} 57^{\prime} 10,5^{\prime \prime}$ & $039^{\circ} 43^{\prime} 33,3^{\prime \prime}$ & 09/10/2001 & oblíquo & $1.000 \mathrm{~m}$ & cilíndrico-cônica & 500 & 5 \\
\hline 7475 & $21^{\circ} 57^{\prime} 10,5^{\prime \prime}$ & $039^{\circ} 43^{\prime} 33,3^{\prime \prime}$ & 09/10/2001 & oblíquo & $1.000 \mathrm{~m}$ & cilíndrico-cônica & 500 & 4 \\
\hline 7479 & $21^{\circ} 54^{\prime} 36,5^{\prime \prime}$ & $039^{\circ} 45^{\prime} 20,0^{\prime \prime}$ & 09/10/2001 & oblíquo & $1.000 \mathrm{~m}$ & cilíndrico-cônica & 500 & 1 \\
\hline 7470 & $21^{\circ} 54^{\prime} 36,5^{\prime \prime}$ & $039^{\circ} 45^{\prime} 20,0^{\prime \prime}$ & $10 / 10 / 2001$ & oblíquo & $1.000 \mathrm{~m}$ & cilíndrico-cônica & 500 & 3 \\
\hline 7471 & $21^{\circ} 54^{\prime} 36,5^{\prime \prime}$ & $039^{\circ} 45^{\prime} 20,0^{\prime \prime}$ & $10 / 10 / 2001$ & oblíquo & $1.000 \mathrm{~m}$ & cilíndrico-cônica & 500 & 1 \\
\hline 7478 & $21^{\circ} 53^{\prime} 10,4^{\prime \prime}$ & $039^{\circ} 45^{\prime} 49,9^{\prime \prime}$ & $10 / 10 / 2001$ & oblíquo & $1.000 \mathrm{~m}$ & cilíndrico-cônica & 500 & 4 \\
\hline 7472 & $21^{\circ} 53^{\prime} 10,4^{\prime \prime}$ & $039^{\circ} 45^{\prime} 49,9^{\prime \prime}$ & $10 / 10 / 2001$ & oblíquo & $1.000 \mathrm{~m}$ & cilíndrico-cônica & 500 & 3 \\
\hline 7474 & $21^{\circ} 58^{\prime} 31,0^{\prime \prime}$ & $039^{\circ} 50^{\prime} 29,7^{\prime \prime}$ & $10 / 10 / 2001$ & oblíquo & $1.000 \mathrm{~m}$ & cilíndrico-cônica & 500 & 4 \\
\hline 7477 & $21^{\circ} 58 ' 31,0^{\prime \prime}$ & $039^{\circ} 50^{\prime} 29,7^{\prime \prime}$ & $10 / 10 / 2001$ & oblíquo & $1.000 \mathrm{~m}$ & cilíndrico-cônica & 500 & 3 \\
\hline 5445 & $22^{\circ} 32^{\prime} 50,0^{\prime \prime}$ & $040^{\circ} 04^{\prime} 09,9^{\prime \prime}$ & $06 / 11 / 2001$ & oblíquo & $1.000 \mathrm{~m}$ & cilíndrico-cônica & 500 & 1 \\
\hline 5444 & $22^{\circ} 32^{\prime} 50,0^{\prime \prime}$ & $040^{\circ} 04^{\prime} 09,9^{\prime \prime}$ & $06 / 11 / 2001$ & oblíquo & $1.000 \mathrm{~m}$ & cilíndrico-cônica & 500 & 1 \\
\hline 5443 & $22^{\circ} 32^{\prime} 49,0^{\prime \prime}$ & $040^{\circ} 04^{\prime} 20,9^{\prime \prime}$ & $07 / 11 / 2001$ & oblíquo & $1.000 \mathrm{~m}$ & cilíndrico-cônica & 500 & 1 \\
\hline 22203 & $22^{\circ} 31^{\prime} 58,9^{\prime \prime}$ & $040^{\circ} 02^{\prime} 53,4^{\prime \prime}$ & $07 / 11 / 2001$ & oblíquo & $1.000 \mathrm{~m}$ & cilíndrico-cônica & 500 & 1 \\
\hline 5441 & $22^{\circ} 31^{\prime} 40,9^{\prime \prime}$ & $040^{\circ} 02^{\prime} 39,6^{\prime \prime}$ & $07 / 11 / 2001$ & oblíquo & $1.000 \mathrm{~m}$ & cilíndrico-cônica & 500 & 1 \\
\hline 5442 & $22^{\circ} 31^{\prime} 40,9^{\prime \prime}$ & $040^{\circ} 02^{\prime} 39,6^{\prime \prime}$ & $07 / 11 / 2001$ & oblíquo & $1.000 \mathrm{~m}$ & cilíndrico-cônica & 500 & 1 \\
\hline 22200 & $22^{\circ} 07^{\prime} 58,8^{\prime \prime}$ & $039^{\circ} 49^{\prime} 08,9^{\prime \prime}$ & $02 / 12 / 2002$ & vertical & $200-1.100 m$ & Cilíndrico-cônica & 200 & 1 \\
\hline 22790 & $22^{\circ} 28,52^{\prime}$ & $039^{\circ} 55,47^{\prime}$ & $16 / 06 / 2003$ & vertical & $0-70 \mathrm{~m}$ & cilíndrico-cônica & 500 & 1 \\
\hline 22202 & $21^{\circ} 57,51^{\prime}$ & $039^{\circ} 49,57^{\prime}$ & $19 / 06 / 2003$ & vertical & $0-95 m$ & cilíndrico-cônica & 500 & 1 \\
\hline 22791 & $21^{\circ} 57,51^{\prime}$ & $039^{\circ} 49,57^{\prime}$ & $19 / 06 / 2003$ & vertical & $100-550 m$ & cilíndrico-cônica & 500 & 1 \\
\hline
\end{tabular}

Referências: Houde, 1981; Houde, 1984; Matsuura et al., 1993; Namiki et al., 2006; Hare et al., 2006; Namiki et al., 2007a; Fahay, 2007. 


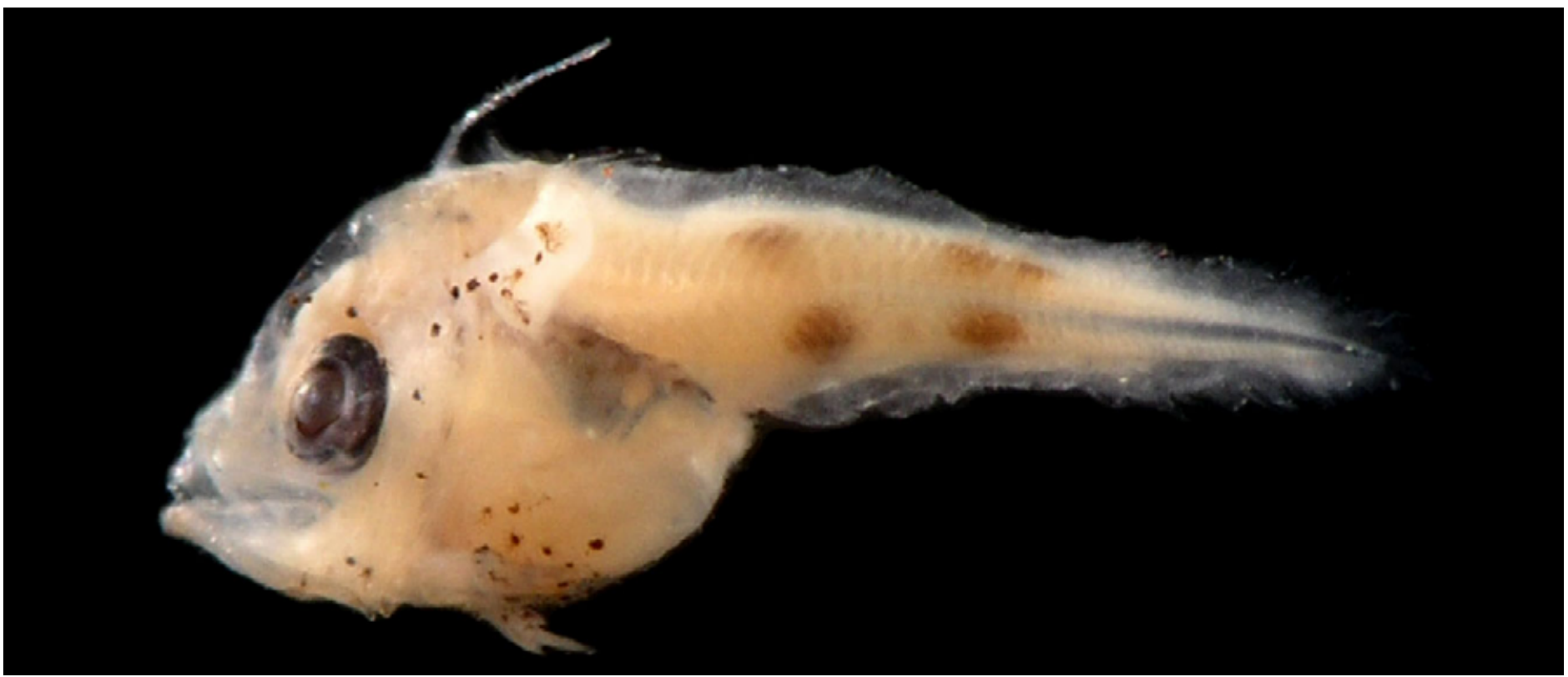

Figura 81: Bregmaceros nov sp. DZUFRJ 13487; Pré-flexão; CP 2,8 mm.

\section{Bregmaceros nov sp.}

Possui intestino curto e corpo alongado (52-59 miômeros) com menor número de pigmentos externos do que $B$. atlanticus. Nas larvas em pré-flexão (2,5-3,0 mm) os melanóforos da cabeça estão dispostos ao redor do raio occipital e apresentam três melanóforos sobre cada olho. Pigmentos no pedúnculo da nadadeira peitoral, sobre a massa visceral e no lado ventral do intestino. Possuem de dois a três melanóforos ventrais e dois dorsais opostos ao primeiro e terceiro pigmentos dorsais. A cabeça também apresenta menor número de melanóforos do que $B$. atlanticus. A primeira nadadeira dorsal é composta por um único raio prolongado localizado na região superior da cabeça, denominado raio occipital, que aparece no estágio de pré-flexão (antes da larva atingir 3,0 mm). Em exemplares maiores, o raio occipital alcança o meio da segunda nadadeira dorsal. A partir de 4,0 mm o corpo apresenta quatro melanóforos internos ventrais e quatro dorsais. Os pigmentos estão em menor número e distribuídos de maneira mais organizada que em $B$. atlanticus.

Tamanho: pré-flexão 2,8 mm.

Habitat: espécie marinha, epi-mesopelágica, ocorre em águas oceânicas. Anteriormente essa espécie era descrita como Bregmaceros mcclellandii Thompson,1840 que é endêmica do Oceano Índico.

\section{Georreferenciamento}

\begin{tabular}{|c|c|c|c|c|c|c|c|c|}
\hline DZUFRJ & Latitude (S) & Longitude (W) & Data & $\begin{array}{c}\text { Tipo de } \\
\text { arrasto }\end{array}$ & $\begin{array}{c}\text { Profundidade } \\
\text { de coleta }\end{array}$ & Rede & $\begin{array}{c}\text { Malha } \\
(\boldsymbol{\mu m})\end{array}$ & $\begin{array}{c}\mathbf{N}^{\circ} \text {. de } \\
\text { inds. }\end{array}$ \\
\hline 6226 & $22^{\circ} 34^{\prime} 05,0^{\prime \prime}$ & $040^{\circ} 19^{\prime} 40,0^{\prime \prime}$ & $17 / 05 / 2002$ & oblíquo & $600 \mathrm{~m}$ & cilíndrico-cônica & 500 & 1 \\
\hline
\end{tabular}

Referências: Houde, 1981; Houde, 1984; Matsuura et al., 1993; Harold \& Baltzegar, 2003; Namiki et al., 2006; Hare et al., 2006; Namiki et al., 2007a; Fahay, 2007. 


\section{Família Macrouridae}

A maioria das espécies da família Macrouridae é bentopelágica e vive em águas profundas. Ocorre desde o Ártico até a Antártica. Compreende quatro subfamílias e 27 gêneros com aproximadamente 350 espécies. Possuem o corpo alongado, cabeça grande e tronco curto terminando em uma cauda longa e com extremidade afilada. Não possuem nadadeira caudal. Podem apresentar uma nadadeira dorsal ou duas. No caso de duas nadadeiras dorsais, a primeira é curta e existe um espaço entre elas. As nadadeiras anal e dorsal são confluentes e a base da nadadeira anal é maior que da segunda nadadeira dorsal.

No Brasil já foram identificadas 30 espécies nas fases de larva e adulto. Nesse estudo é contemplada a espécie Coryphaenoides armatus. 


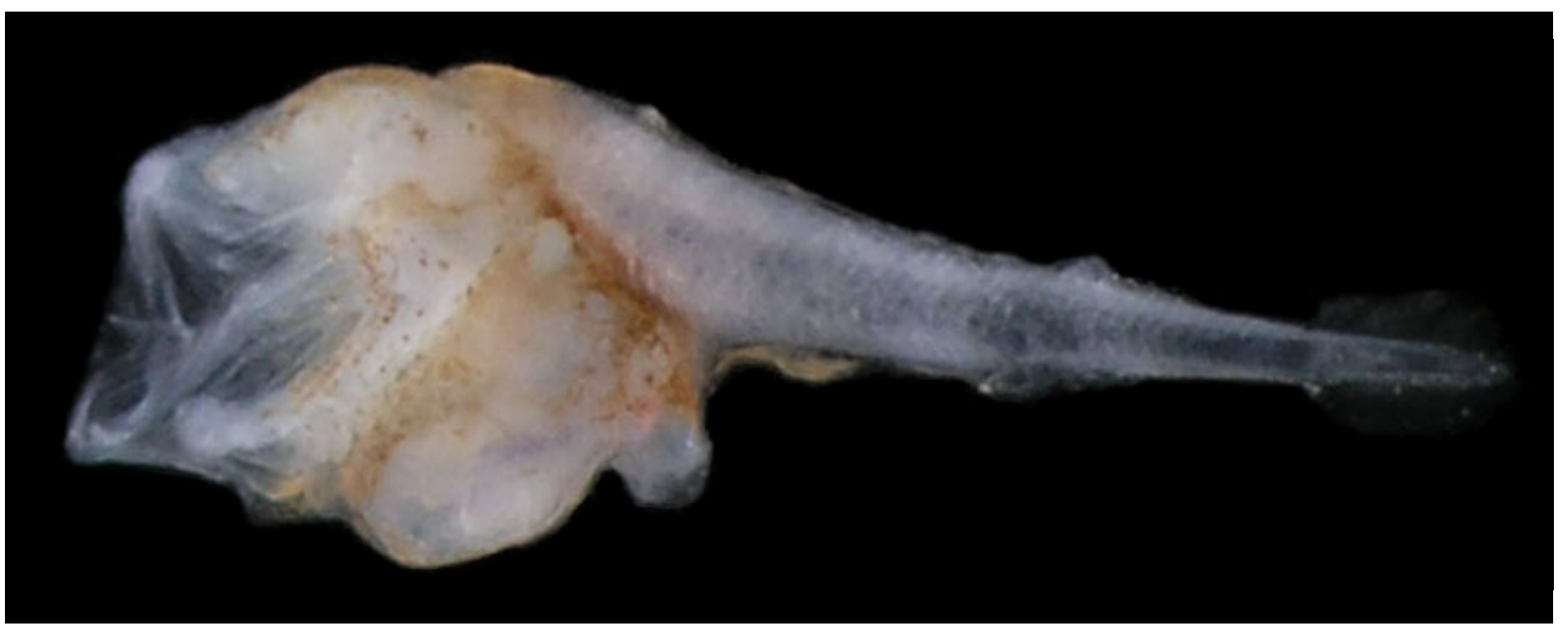

Figura 82: Coryphaenoides armatus. DZUFRJ 7514; CP 5,7 mm.

\section{Coryphaenoides armatus (Hector, 1875)}

Possui o corpo alto na região anterior terminando em uma cauda longa e fina. As bases das nadadeiras pélvica e peitoral são muito pedunculadas. Os raios da nadadeira anal são maiores que os da nadadeira dorsal. Possui um grande espaço entre as nadadeiras dorsais. A pigmentação se concentra na parte posterior da cabeça, na região peritoneal e na porção anterior do corpo. A cauda não possui pigmentação.

Tamanho: 5,7-18,0 mm.

Habitat: espécie marinha, bentopelágica, ocorre em águas tropicais e subpolares em profundidades entre 2.000 e $5.500 \mathrm{~m}$.

\section{Georreferencimento}

\begin{tabular}{|c|c|c|c|c|c|c|c|c|}
\hline DZUFR & Latitude (S) & Longitude (W) & Data & $\begin{array}{c}\text { Tipo de } \\
\text { arrasto }\end{array}$ & $\begin{array}{c}\text { Profundidade } \\
\text { de coleta }\end{array}$ & Rede & $\begin{array}{c}\text { Malha } \\
\text { ( } \boldsymbol{\mu m} \text { ) }\end{array}$ & $\begin{array}{c}\mathbf{N}^{\circ} \text {. de } \\
\text { inds. }\end{array}$ \\
\hline 7513 & $21^{\circ} 58^{\prime} 31,0^{\prime \prime}$ & $039^{\circ} 50^{\prime} 29,7^{\prime \prime}$ & $10 / 10 / 2001$ & oblíquo & $1.000 \mathrm{~m}$ & cilíndrico-cônica & 500 & 1 \\
\hline 7514 & $21^{\circ} 58^{\prime} 31,0^{\prime \prime}$ & $039^{\circ} 50^{\prime} 29,7^{\prime \prime}$ & $11 / 10 / 2001$ & oblíquo & $1.000 \mathrm{~m}$ & cilíndrico-cônica & 500 & 1 \\
\hline
\end{tabular}

Referências: Merrett, 2006; Fahay, 2007. 


\section{Família Phycidae}

A família Phycidae é marinha e ocorre no Atlântico, na África do Sul, Nova Zelândia e Japão. Compreende cinco gêneros com 25 espécies. Possuem cabeça e focinho arredondados. $O$ intestino é curto alcançando menos da metade do corpo. Presença de duas nadadeiras dorsais sem espinhos. A nadadeira pélvica tem três raios alongados.

No Brasil já foram identificadas três espécies nas fases de larva e adulto: Urophycis brasiliensis (Kaup, 1858); Urophycis cirrata (Goode \& Bean, 1896) e Urophycis mystacea Miranda Ribeiro, 1903. Nesse estudo é contemplada a espécie Urophycis cirrata. 


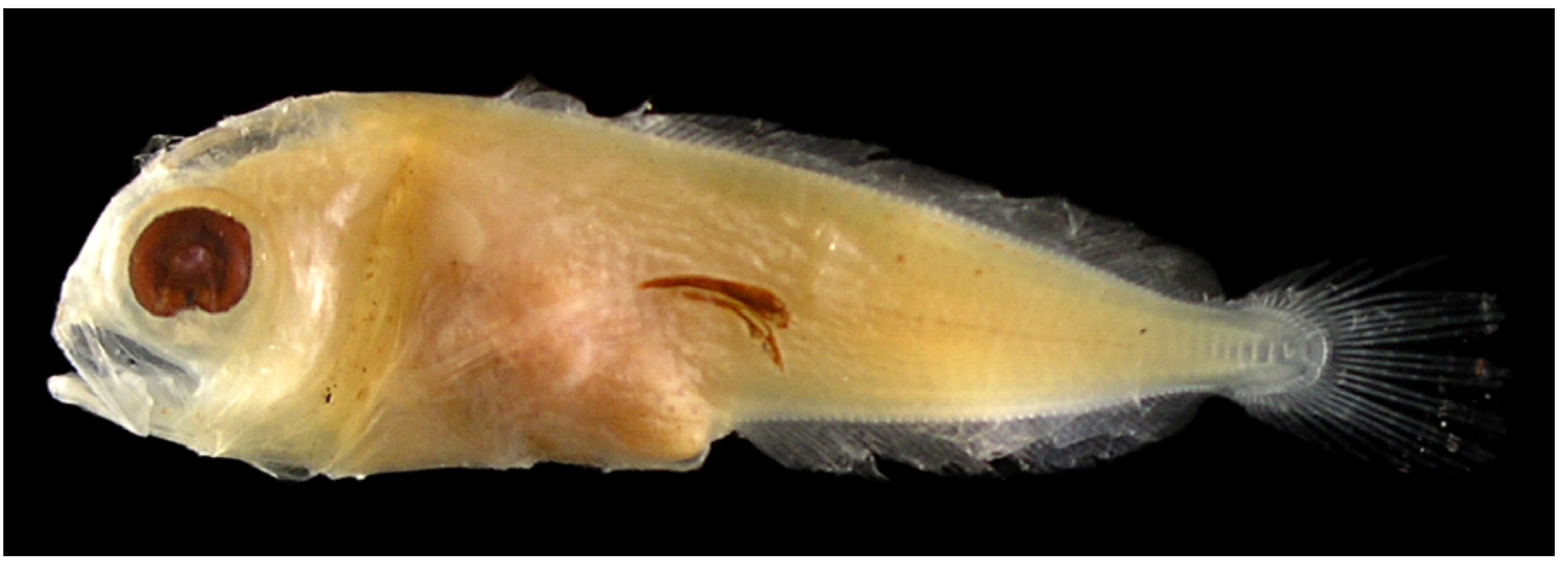

Figura 83: Urophycis cirrata. DZUFRJ 25290; Flexão; CP 10,5 mm.

\section{Urophycis cirrata (Goode \& Bean, 1896)}

Possui a cabeça e o focinho arredondados. A base da nadadeira peitoral é um pouco pedunculada. A nadadeira pélvica tem três raios longos com as extremidades pigmentadas. A distância pré-anal é curta representando menos da metade do corpo.

Tamanho: flexão 10,5 mm.

Habitat: espécie marinha, batidemersal, ocorre em águas tropicais em profundidades entre 360 e $470 \mathrm{~m}$.

Nome vulgar: Abrótea.

\section{Georreferencimento}

\begin{tabular}{|c|c|c|c|c|c|c|c|c|}
\hline DZUFRJ & Latitude (S) & Longitude (W) & Data & $\begin{array}{c}\text { Tipo de } \\
\text { arrasto }\end{array}$ & $\begin{array}{c}\text { Profundidade } \\
\text { de coleta }\end{array}$ & Rede & $\begin{array}{c}\text { Malha } \\
(\boldsymbol{\mu m})\end{array}$ & $\mathbf{N}^{\circ}$. de inds. \\
\hline 25290 & $22^{\circ} 28,5^{\prime}$ & $039^{\circ} 55,47^{\prime}$ & $16 / 06 / 2003$ & horizontal & superfície & nêuston & 500 & 1 \\
\hline
\end{tabular}

Referências: Comyns \& Bond, 2006; Fahay, 2007. 


\section{ORDEM OPHIDIIFORMES}

A ordem Ophidiiformes possui cinco famílias com aproximadamente 385 espécies. As nadadeiras pélvicas, quando presentes, estão inseridas ao nível do pré-opérculo ou muito antes, e a nadadeira caudal é confluente com as nadadeiras dorsal e anal.

Nesse estudo a ordem Ophidiiformes é representada pelas famílias Ophidiidae, Carapidae, e Aphyonidae. 


\section{Família Ophidiidae}

A família Ophidiidae é marinha e ocorre nos oceanos Atlântico, Índico e Pacífico. Compreende quatro subfamílias com 48 gêneros e aproximadamente 222 espécies. Os peixes desta família possuem a nadadeira dorsal igual ou mais longa que a nadadeira anal e as larvas não apresentam vexilo. Nesse estudo só foi registrada larva da subfamília Ophidiinae. Possuem corpo alongado e comprimento pré-anal relativamente curto. As nadadeiras dorsal e caudal são confluentes com a nadadeira caudal. O intestino forma uma volta na sua porção mediana ou final no início do desenvolvimento. As larvas mais desenvolvidas são lateralmente comprimidas. Os dois raios da nadadeira pélvica têm origem na região torácica e migram para a região posterior quando a larva assenta no fundo. Embora algumas espécies possam apresentar muitos pigmentos, as larvas da maioria das espécies são pouco pigmentadas.

No Brasil já foram identificadas 35 espécies nas fases de larva e adulto. Nesse estudo é contemplada a espécie Ophidion nocomis. 


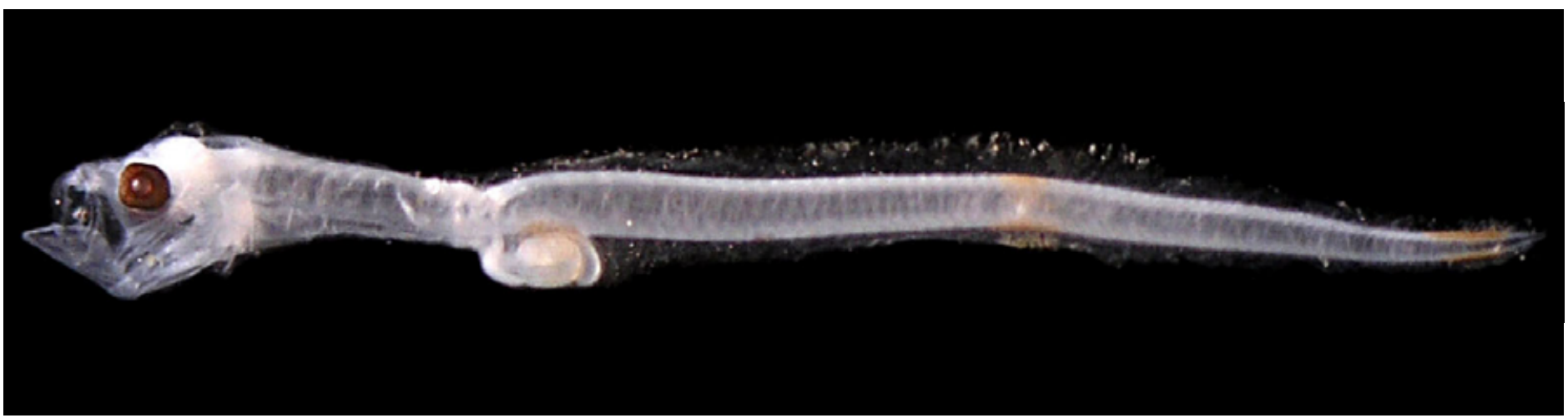

Figura 84: Ophidion nocomis. DZUFRJ 22406; Pré-flexão; CP 10,0 mm.

\section{Ophidion nocomis Robins \& Böhlke, 1959}

A cabeça e o corpo são extremamente delgados e o intestino forma uma volta próximo ao ânus. Esta região é muito pigmentada formando uma faixa. A região ventral do intestino não possui pigmentos. É observada uma faixa de pigmento no meio do corpo e outra na região do pedúnculo caudal. O número total de vértebras varia entre 84-87. Pode ser separada da espécie Ophidion selenops pelo padrão de pigmentação próximo ao ânus e na parte ventral do intestino que é mais intensa em 0 . nocomis.

Tamanho: pré-flexão 10,0 mm.

Habitat: espécie marinha, demersal, ocorre em águas tropicais até 17 $\mathrm{m}$ de profundidade.

\section{Georreferenciamento}

\begin{tabular}{|c|c|c|c|c|c|c|c|c|}
\hline DZUFRJ & Latitude (S) & Longitude (W) & Data & $\begin{array}{c}\text { Tipo de } \\
\text { arrasto }\end{array}$ & $\begin{array}{c}\text { Profundidade } \\
\text { de coleta }\end{array}$ & Rede & $\begin{array}{c}\text { Malha } \\
(\boldsymbol{\mu m})\end{array}$ & $\begin{array}{c}\mathbf{N}^{\circ} \text {. de } \\
\text { inds. }\end{array}$ \\
\hline 22406 & $22^{\circ} 399^{\prime} 68^{\prime}$ & $040^{\circ} 03,4^{\prime}$ & $13 / 06 / 2003$ & vertical & $0-60 \mathrm{~m}$ & cilíndrico-cônica & $500 \mu \mathrm{m}$ & 1 \\
\hline
\end{tabular}

Referências: Fahay \& Hare, 2006; Fahay, 2007. 


\section{Família Carapidae}

A família Carapidae é marinha e ocorre nos oceanos Atlântico, Índico e Pacífico. Compreende sete gêneros e 31 espécies. Algumas espécies são mesopelágicas e outras demersais vivendo como inquilinas nas cavidades de invertebrados, como bivalves, holotúrias e asteroides. Carapus bermudensis, vive em associação com pepinos do mar enquanto Echiodon dawsoni e Snyderidia canina são de vida livre. As larvas planctônicas possuem um filamento pré-dorsal longo e normalmente ornamentado, denominado vexilo. Esta estrutura aparentemente representa uma especialização das larvas desta família. O corpo é alongado e as nadadeiras dorsal e anal são longas.

No Brasil já foram identificadas quatro espécies nas fases de larva e adulto: Carapus bermudensis (Jones, 1874); Echiodon cryomargarites Markle, Williams \& Olney, 1983; Echiodon dawsoni Williams \& Shipp, 1982 e Snyderidia canina Gilbert, 1905. Nesse estudo são contempladas as espécies Echiodon dawsoni e Snyderidia canina. 


\section{Echiodon dawsoni} Williams \& Shipp, 1928

O corpo é alongado com cauda filamentosa. O número de vértebras pré-caudais varia entre 21-25. O vexilo está localizado na altura do miômero 11, posterior a origem da nadadeira anal, e apresenta poucas ornamentações. 0 primeiro raio da nadadeira dorsal se insere imediatamente após o vexilo. Possui entre nove e treze raios na nadadeira anal anteriores à origem da nadadeira dorsal. Ausência de nadadeiras pélvicas e as peitorais têm bases lobadas. A região peritoneal é muito pigmentada.

Tamanho: 3,0- > 75,0 mm.

Habitat: espécie marinha, demersal, ocorre águas tropicais em profundidades entre 75 e $175 \mathrm{~m}$.

\section{Georreferenciamento}

\begin{tabular}{|c|c|c|c|c|c|c|c|c|}
\hline DZUFRJ & Latitude (S) & Longitude (W) & Data & $\begin{array}{c}\text { Tipo de } \\
\text { arrasto }\end{array}$ & $\begin{array}{c}\text { Profundidade } \\
\text { de coleta }\end{array}$ & Rede & $\begin{array}{c}\text { Malha } \\
\mathbf{( \mu m )}\end{array}$ & $\begin{array}{c}\mathbf{N} \text {. de } \\
\text { inds. }\end{array}$ \\
\hline 520 & $22^{\circ} 34^{\prime} 05,0^{\prime \prime}$ & $040^{\circ} 19^{\prime} 40,0^{\prime \prime}$ & $17 / 05 / 2002$ & oblíquo & $600 \mathrm{~m}$ & cilíndrico-cônica & 500 & 3 \\
\hline 652 & $22^{\circ} 38^{\prime} 25,0^{\prime \prime}$ & $040^{\circ} 17^{\prime} 41,0^{\prime \prime}$ & $19 / 05 / 2002$ & oblíquo & $40 \mathrm{~m}$ & bongô & 330 & 1 \\
\hline 5422 & $22^{\circ} 31^{\prime} 58,9^{\prime \prime}$ & $040^{\circ} 02^{\prime} 53,4^{\prime \prime}$ & $07 / 11 / 2001$ & oblíquo & $1.000 \mathrm{~m}$ & cilíndrico-cônica & 500 & 1 \\
\hline 7526 & $21^{\circ} 58^{\prime} 31,0^{\prime \prime}$ & $039^{\circ} 50^{\prime} 29,7^{\prime \prime}$ & $10 / 10 / 2001$ & oblíquo & $1.000 \mathrm{~m}$ & cilíndrico-cônica & 500 & 1 \\
\hline 7527 & $21^{\circ} 54^{\prime} 36,5^{\prime \prime}$ & $039^{\circ} 45^{\prime} 20,0^{\prime \prime}$ & $10 / 10 / 2001$ & oblíquo & $1.000 \mathrm{~m}$ & cilíndrico-cônica & 500 & 1 \\
\hline
\end{tabular}

Referências: Markle \& Olney, 1990; Namiki \& Bonecker, 2006; Olney, 2006b; Namiki et al., 2007b; Fahay, 2007.

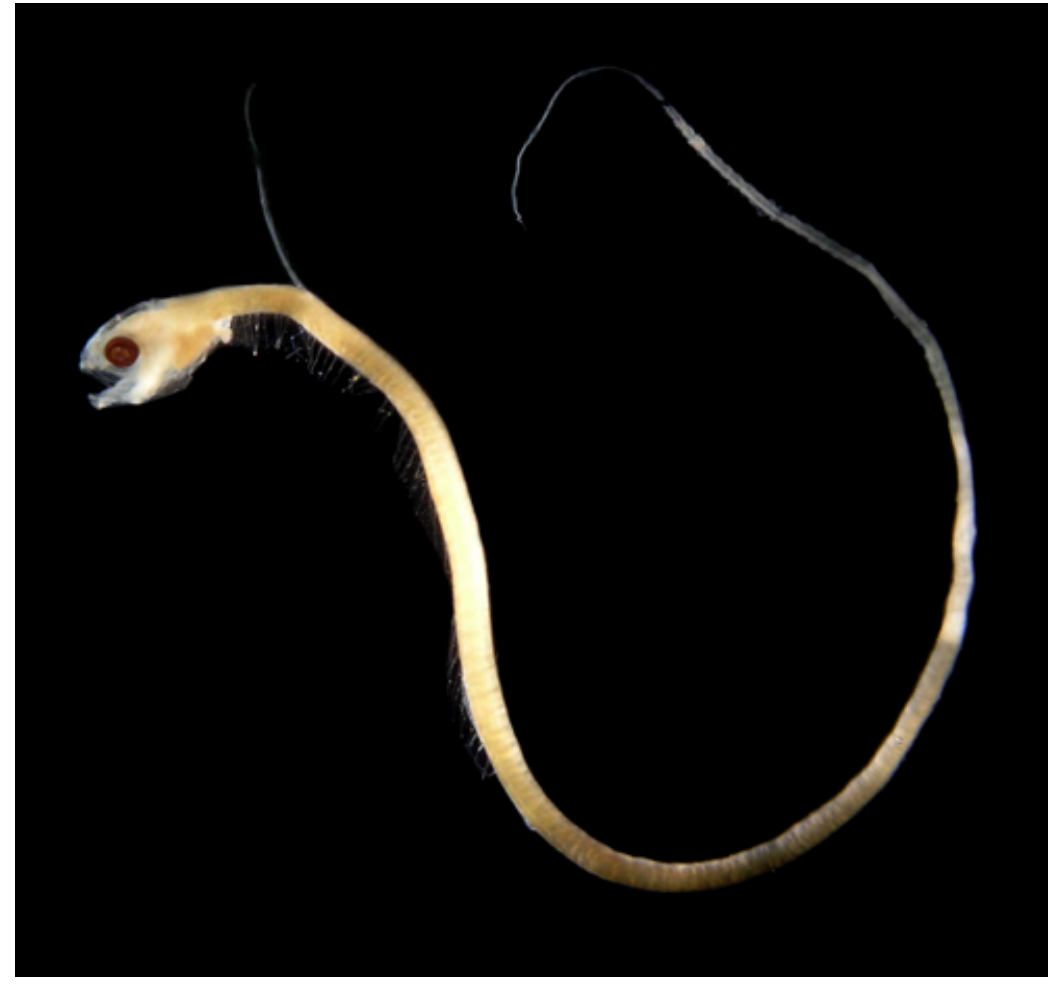

Figura 85 - A: Echiodon dawsoni. DZUFRJ 7526; CP >75,0 mm;

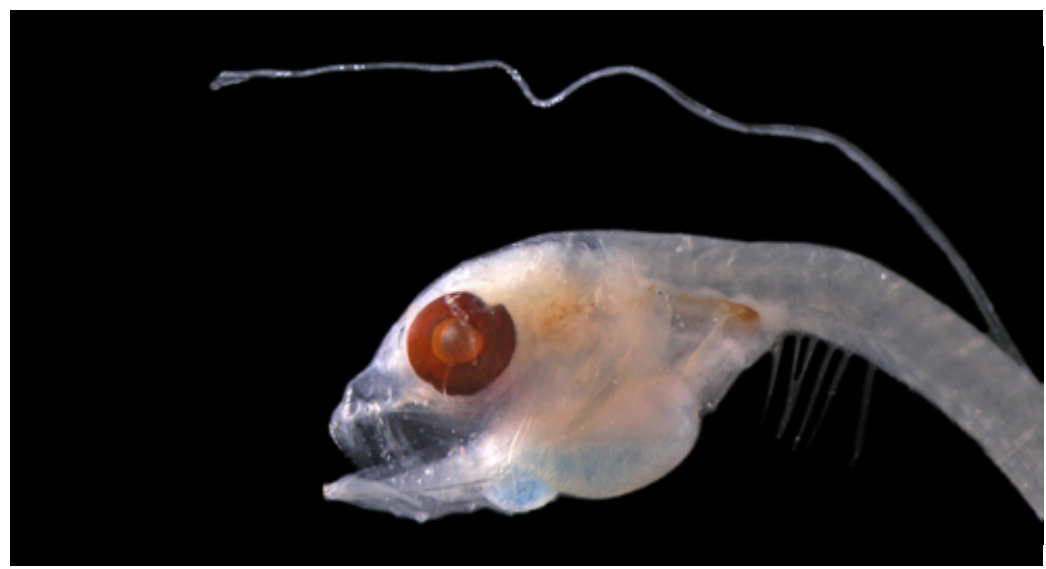

Figura 85 - B: Detalhe da cabeça. 


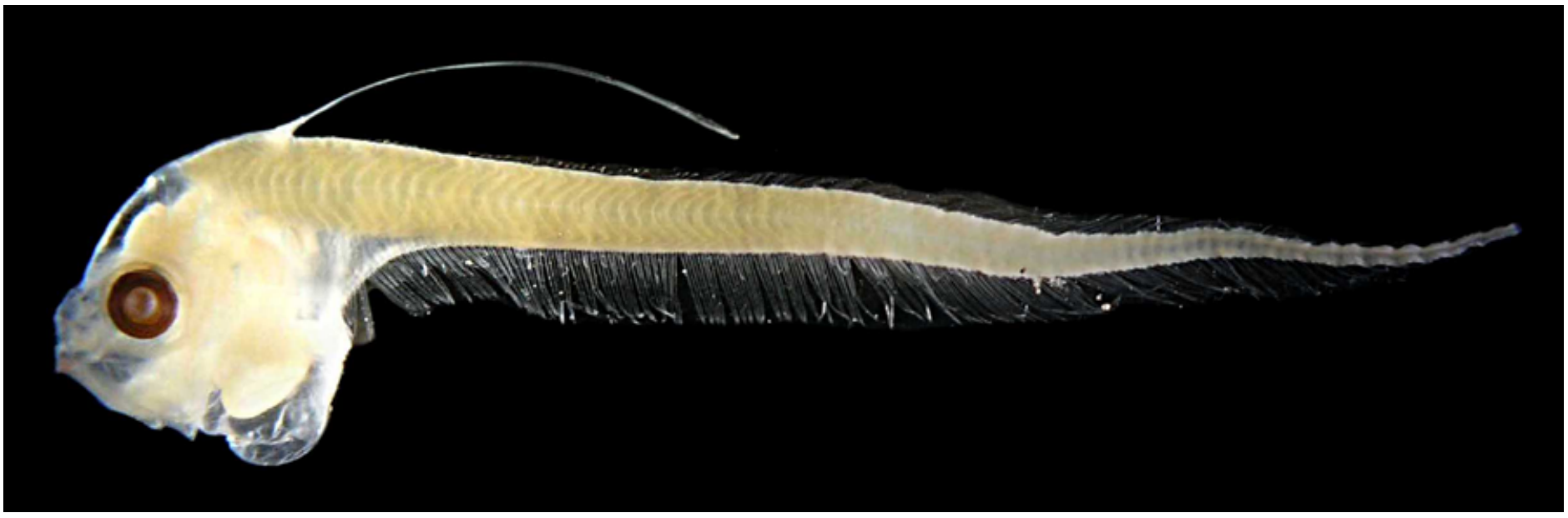

Figura 86: Snyderidia canina. DZUFRJ 5421; CP 26,5 mm.

\section{Snyderidia canina Gilbert, 1905}

O corpo não é tão alongado quando comparado com outras espécies de Carapidae. O número de vértebras pré-caudal varia entre 13-15. A cabeça é grande e o corpo é alto. O vexilo não possui ornamentação e é adjacente ao primeiro raio da nadadeira dorsal. Possui entre seis e nove raios dorsais anteriores à origem da nadadeira anal. Apresenta pigmentos na sínfise da maxila inferior e internamente na região da vesícula gasosa. Não possui dentes cardiformes nem nadadeira pélvica.

Tamanho: $26,5 \mathrm{~mm}$.

Habitat: espécie marinha, mesopelágica, ocorre em águas tropicais entre 110 e $1.500 \mathrm{~m}$ de profundidade.

\section{Georreferenciamento}

\begin{tabular}{|c|c|c|c|c|c|c|c|c|}
\hline DZUFRJ & Latitude (S) & Longitude (W) & Data & $\begin{array}{c}\text { Tipo de } \\
\text { arrasto }\end{array}$ & $\begin{array}{c}\text { Profundidade } \\
\text { de coleta }\end{array}$ & Rede & $\begin{array}{c}\text { Malha } \\
\text { ( } \boldsymbol{\mu m} \text { ) }\end{array}$ & $\begin{array}{c}\mathbf{N}^{\circ} \text {. de } \\
\text { inds. }\end{array}$ \\
\hline 5421 & $22^{\circ} 32^{\prime} 50,0^{\prime \prime}$ & $040^{\circ} 04^{\prime} 09,9^{\prime \prime}$ & $06 / 11 / 2001$ & oblíquo & $1.000 \mathrm{~m}$ & cilíndrico-cônica & 500 & 1 \\
\hline
\end{tabular}

Referências: Markle \& Olney, 1990; Olney, 2006b; Namiki et al., 2007b; Fahay, 2007. 


\section{Família Aphyonidae}

A família Aphyonidae é marinha e ocorre nos oceanos Atlântico, Índico e Pacífico. Compreende seis gêneros e 22 espécies. As larvas são raras e não há descrição para as larvas do Oceano Atlântico.

No Brasil já foram identificadas as espécies Aphyonus gelatinosus Günther, 1878 e Barathronus bicolor Goode \& Bean, 1886. Na área de estudo é contemplada o morfotipo Aphyonidae sp. 1. 


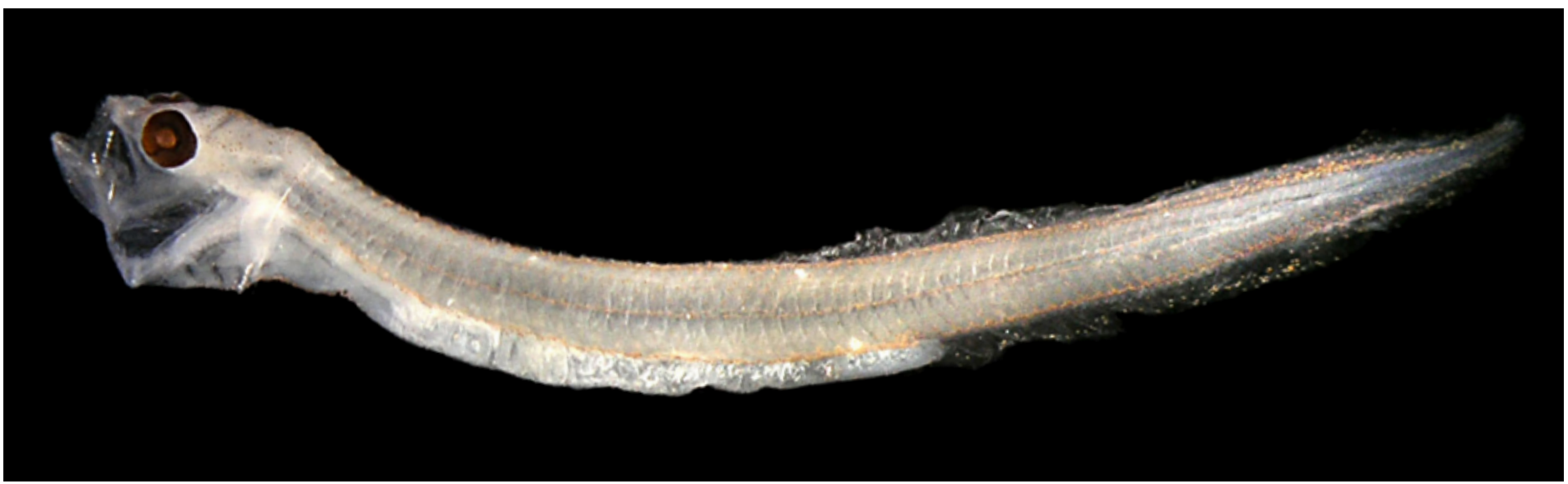

Figura 87: Aphyonidae sp. 1. DZUFRJ 22410; Flexão; CP 9,6 mm.

\section{Aphyonidae sp. 1}

Possui intestino longo e estreito. As nadadeiras dorsal e anal são confluentes. Os olhos são pouco desenvolvidos. O número de vértebras pré-caudais varia entre $26-48$ e o número total entre 68-86. O exemplar coletado na área de estudo apresenta a origem da nadadeira dorsal muito atrás da nadadeira peitoral.

Tamanho: pré-flexão 9,6 mm.

Habitat: todas as espécies são marinhas e podem ocorrer em profundidades superiores a $700 \mathrm{~m}$.

\section{Georreferenciamento}

\begin{tabular}{|c|c|c|c|c|c|c|c|c|}
\hline DZUFRJ & Latitude (S) & Longitude (W) & Data & $\begin{array}{c}\text { Tipo de } \\
\text { arrasto }\end{array}$ & $\begin{array}{c}\text { Profundidade } \\
\text { de coleta }\end{array}$ & Rede & $\begin{array}{c}\text { Malha } \\
(\boldsymbol{\mu m})\end{array}$ & $\begin{array}{c}\mathbf{N}^{\circ} \text {. de } \\
\text { inds. }\end{array}$ \\
\hline 22410 & $22^{\circ} 03^{\prime} 033^{\prime \prime}$ & $039^{\circ} 50^{\prime} 39,0^{\prime \prime}$ & $10 / 05 / 2002$ & horizontal & superfície & cilíndrico-cônica & 200 & 1 \\
\hline
\end{tabular}

Referências: Menezes et al., 2003; Fahay \& Hare, 2006; Nelson, 2006; Fahay, 2007; Franco et al., 2007; Mincarone et al., 2008; Froese \& Pauli, 2014. 


\section{ORDEM LOPHIIFORMES}

A ordem Lophiiformes é formada por 18 famílias com 313 espécies. São marinhas e a maioria ocorre em águas profundas. Possuem o corpo arredondado ou globular. Nos juvenis e adultos o primeiro espinho dorsal é transformado em um illicium.

Nesse estudo a ordem Lophiiformes é representada pelas famílias Antennariidae e Gigantactinidae. 


\section{Família Antennariidae}

A família Antennariidae é marinha e ocorre em todos os mares tropicais e subtropicais, exceto Mar Mediterrâneo. Compreende 12 gêneros com 42 espécies. Possui o corpo alto ou globoso, boca grande. Pode ser separada das demais famílias de Lophiiformes por possuírem três espinhos dorsais bem desenvolvidos. A nadadeira peitoral é pedunculada.

No Brasil já foram identificadas três espécies nas fases de larva e adulto: Antennarius multiocellatus (Valenciennes, 1837); Antennarius striatus (Shaw \& Nodder, 1794) e Histrio histrio (Linnaeus, 1758). Nesse estudo é contemplada a espécie Histrio histrio. 


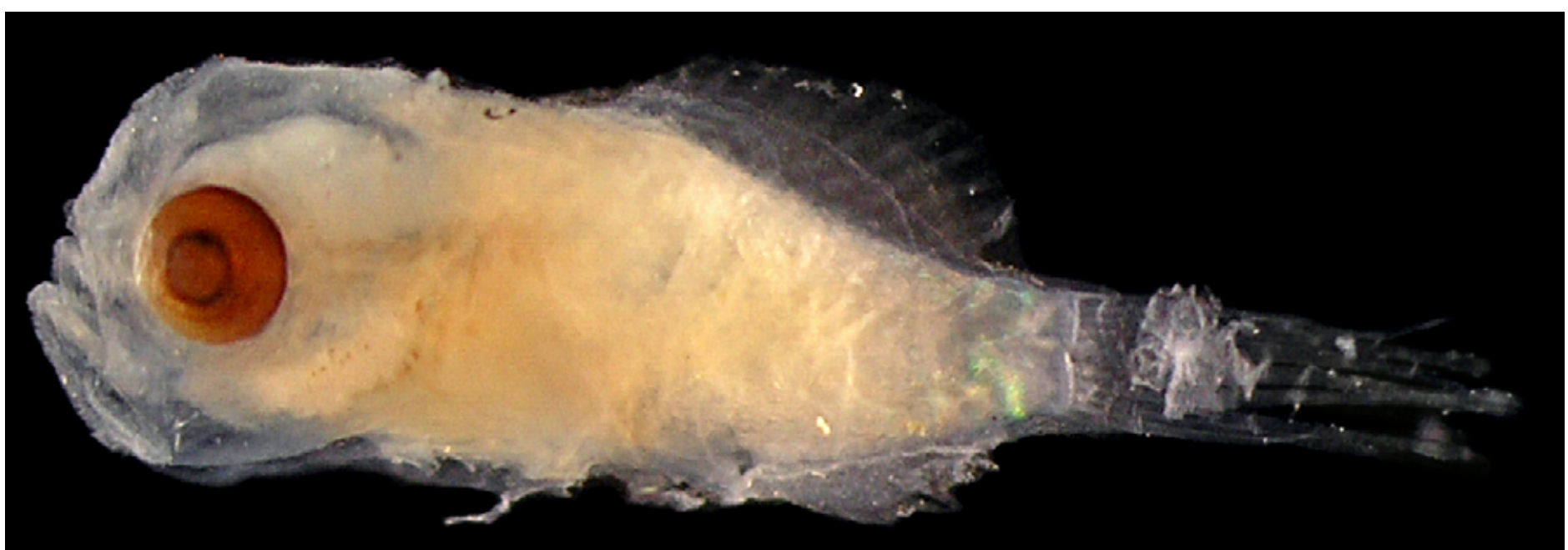

Figura 88: Histrio histrio. DZUFRJ 24179; Flexão; CP 2,7 mm.

\section{Histrio histrio (Linnaeus, 1758)}

A cabeça é grande compreendendo até $50 \%$ do corpo. As larvas menores em pré-flexão e flexão (até $5,0 \mathrm{~mm}$ ) estão envoltas em uma membrana. Pigmentos presentes na cabeça e na região do intestino. Nadadeira peitoral pedunculada. À medida que as larvas crescem a base da nadadeira pélvica cresce também. A nadadeira caudal é a primeira a ser formada, seguida pela dorsal e anal. A dorsal é formada por três espinhos e 11-13 raios e a anal por 6-8 raios. Possui aproximadamente 19 miômeros.

Tamanho: flexão 2,7-3,0 mm.

Habitat: espécie marinha, pelágica, associada a formações coralinas e a Sargassum. Ocorre em águas tropicais e subtropicais até $100 \mathrm{~m}$ de profundidade.

Nome vulgar: Peixe sargasso.

\section{Georreferenciamento}

\begin{tabular}{|c|c|c|c|c|c|c|c|c|}
\hline DZUFR & Latitude (S) & Longitude (W) & Data & $\begin{array}{c}\text { Tipo de } \\
\text { arrasto }\end{array}$ & $\begin{array}{c}\text { Profundidade } \\
\text { de coleta }\end{array}$ & Rede & $\begin{array}{c}\text { Malha } \\
\text { ( } \boldsymbol{\mu m} \text { ) }\end{array}$ & $\begin{array}{c}\mathbf{N}^{\circ} \text {. de } \\
\text { inds. }\end{array}$ \\
\hline 1173 & $22^{\circ} 02^{\prime} 30,3^{\prime \prime}$ & $039^{\circ} 50^{\prime} 41,3^{\prime \prime}$ & $10 / 05 / 2002$ & oblíquo & $1.000 \mathrm{~m}$ & cilíndrico-cônica & 500 & 1 \\
\hline 24179 & $22^{\circ} 31^{\prime} 58,9^{\prime \prime}$ & $040^{\circ} 02^{\prime} 53,4^{\prime \prime}$ & $07 / 11 / 2001$ & oblíquo & $1.000 \mathrm{~m}$ & cilíndrico-cônica & 500 & 1 \\
\hline
\end{tabular}

Referências: Jackson, 2006a; Fahay, 2007. 


\section{Família Gigantactinidae}

A família Gigantactinidae é marinha, mesopelágica e batipelágica. Ocorre nos oceanos Atlântico, Índico e Pacífico. Compreende dois gêneros com 22 espécies. A principal característica para separar essa família dos demais Lophiiformes é a presença de nadadeiras peitorais muito grandes, mesmo nos exemplares bem pequenos, chegando além das inserções das nadadeiras dorsal e anal. Não possuem nadadeiras pélvicas e têm entre 4-10 raios na nadadeira dorsal.

No Brasil já foi identificada uma espécie na fase de adulto: Gigantactis vanhoeffeni Brauer, 1902. Nesse estudo é contemplada a espécie Gigantactis sp. 


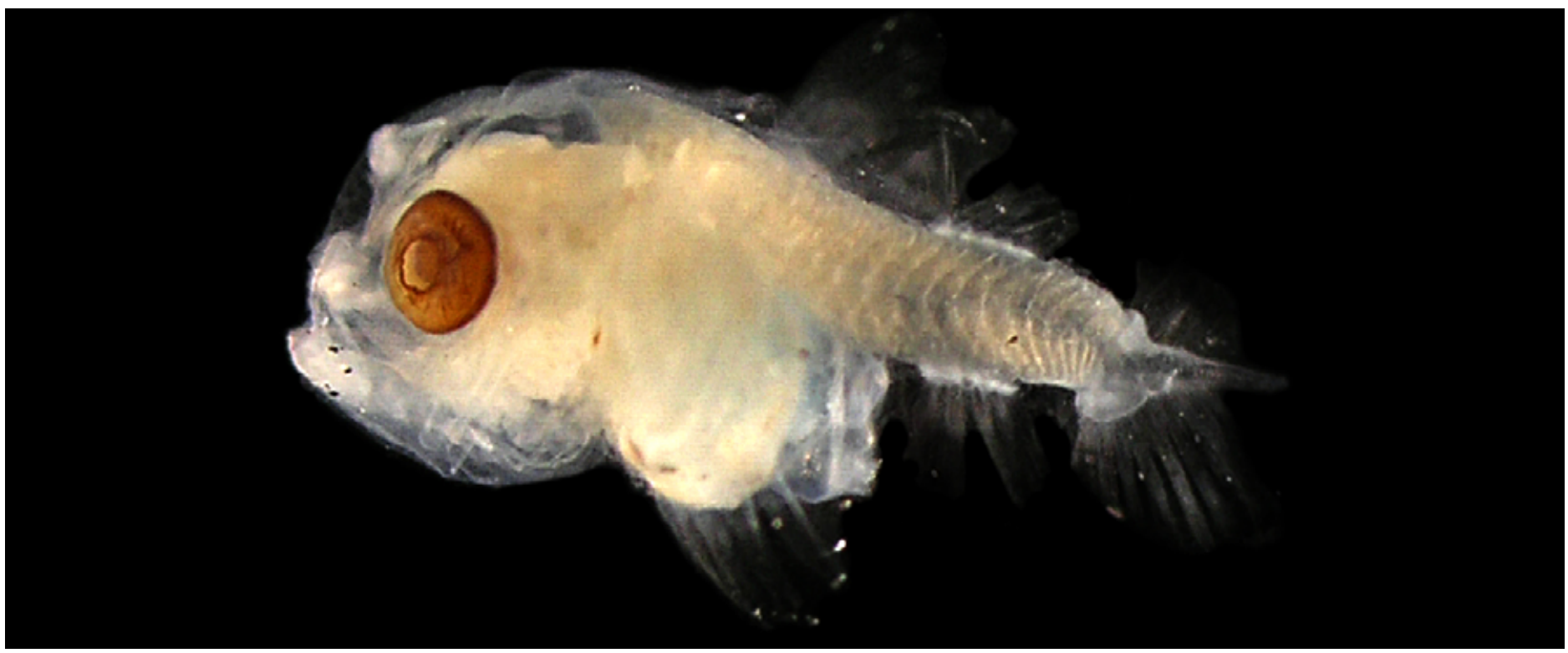

Figura 89: Gigantactis sp. DZUFRJ 1286; Flexão; CP 2,5 mm.

\section{Gigantactis sp.}

O corpo é pequeno (aproximadamente 22 miômeros), muito redondo e apresenta a membrana muito inflada. Nadadeira peitoral muito grande alcançando as bases das nadadeiras dorsal e anal. Não possuem nadadeiras pélvicas e não tem pigmentos no pedúnculo caudal.

Tamanho: flexão $2,5 \mathrm{~m}$.

Habitat: todas as espécies de Gigantactis são marinhas, mesopelágicas e batipelágicas. Ocorrem em águas tropicais e subtropicais e algumas espécies já foram registradas até $5.300 \mathrm{~m}$ de profundidade. Entretanto, a maioria ocorre entre 300 e $1.700 \mathrm{~m}$ de profundidade.

\section{Georreferenciamento}

\begin{tabular}{|c|c|c|c|c|c|c|c|c|}
\hline DZUFR & Latitude (S) & Longitude (W) & Data & $\begin{array}{c}\text { Tipo de } \\
\text { arrasto }\end{array}$ & $\begin{array}{c}\text { Profundida- } \\
\text { de de coleta }\end{array}$ & Rede & $\begin{array}{c}\text { Malha } \\
(\boldsymbol{\mu m})\end{array}$ & $\begin{array}{c}\mathbf{N}^{\circ} \text {. de } \\
\text { inds. }\end{array}$ \\
\hline 1286 & $22^{\circ} 06^{\prime} 52,3^{\prime \prime}$ & $039^{\circ} 48^{\prime} 46,2^{\prime \prime}$ & $11 / 05 / 2002$ & oblíquo & $\begin{array}{c}\text { até a } \\
\text { termoclina }\end{array}$ & bongô & 500 & 1 \\
\hline
\end{tabular}

Referências: Jackson, 2006a; Fahay, 2007. 


\section{Ordem Beloniformes}

A ordem Beloniformes é composta por cinco famílias e 227 espécies. Algumas espécies são restritas a ambientes de água doce e outras habitam estuários e regiões marinhas. Os representantes dessa ordem dominam a zona epipelágica nas regiões tropicais e subtropicais. As características comuns da ordem são: localização das nadadeiras dorsal e anal na parte posterior do corpo, nadadeira pélvica abdominal com seis raios e ausência de espinhos nas nadadeiras.

Nesse estudo a ordem Beloniformes é representada pelas famílias Scomberesocidae, Hemiramphidae e Exocoetidae. 


\section{Família Scomberesocidae}

A família Scomberesocidae é marinha e epipelágica. Ocorre nos mares tropicais e temperados. Compreende dois gêneros com duas espécies cada. A principal característica que separa essa família das demais da ordem Beloniformes é que a maxila superior é um pouco alongada.

No Brasil já foram identificadas três espécies nas fases de larva e adulto: Scomberesox saurus (Walbaum, 1792), Scomberesox scombroides (Richardson, 1843) e Scomberesox simulans (Hubbs \& Wisner, 1980). Nesse estudo é contemplada a espécie Scomberesox sp. 


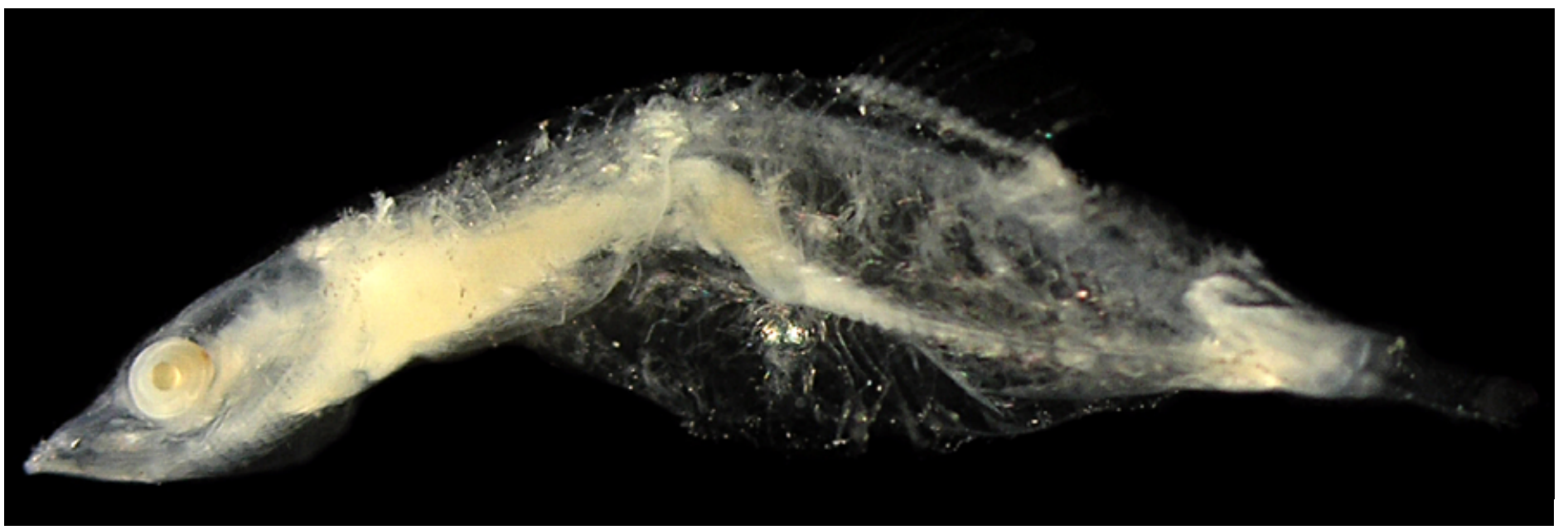

Figura 90: Scomberesox sp. DZUFRJ 20206; Flexão; CP 10,0 mm.

\section{Scomberesox sp.}

As larvas de Scomberesox possuem o corpo alongado (64 a 68 miômeros) e fino. O intestino é longo alcançando mais da metade do corpo. Possuem o corpo todo pigmentado. A nadadeira caudal é bem desenvolvida desde os estágios larvares iniciais.

Tamanho: flexão 10,0 mm.

Habitat: todas as espécies registradas na literatura são marinhas e epipelágicas. Ocorre em águas tropicais e temperadas, em regiões oceânicas.

\section{Georreferrenciamento}

\begin{tabular}{|c|c|c|c|c|c|c|c|c|}
\hline DZUFRJ & Latitude (S) & Longitude (W) & Data & $\begin{array}{c}\text { Tipo de } \\
\text { arrasto }\end{array}$ & $\begin{array}{c}\text { Profundidade } \\
\text { de coleta }\end{array}$ & Rede & $\begin{array}{c}\text { Malha } \\
\text { ( } \boldsymbol{\mu m} \text { ) }\end{array}$ & $\begin{array}{c}\mathbf{N}^{\circ} \text {. de } \\
\text { inds. }\end{array}$ \\
\hline 20206 & $22^{\circ} 08^{\prime} 01,8^{\prime \prime}$ & $039^{\circ} 37^{\prime} 30,8^{\prime \prime}$ & $03 / 12 / 2002$ & vertical & $50 \mathrm{~m}$ & cilíndrico-cônica & 500 & 1 \\
\hline
\end{tabular}

Referências: Hardy \& Collette, 2006; Fahay, 2007. 


\section{Família Hemiramphidae}

A família Hemiramphidae é marinha e epipelágica, também possui representantes de água doce. Ocorre nos oceanos Atlântico, Índico e Pacífico. Compreende duas subfamílias e 12 gêneros com aproximadamente 109 espécies. A principal característica que separa essa família das demais da ordem Beloniformes é que a maxila inferior é normalmente muito alongada e a maxila superior é muito curta e triangular.

No Brasil já foram identificadas sete espécies nas fases de larva e adulto. Nesse estudo são contempladas as espécies Euleptorhamphus velox e Hyporhamphus unifasciatus. 


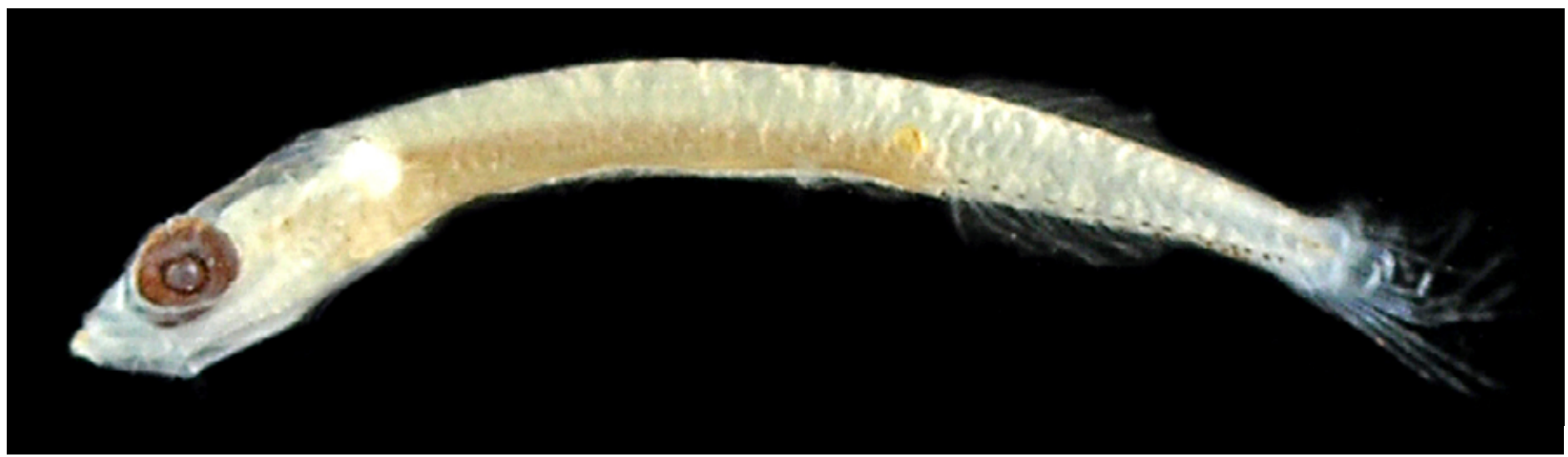

Figura 91: Euleptorhamphus velox. DZUFRJ 25291; Flexão; CP 7,3 mm.

\section{Euleptorhamphus velox Poey, 1868}

Possui o corpo muito alongado (aproximadamente 71-73 miômeros) e fino. 0 intestino é longo alcançando aproximadamente $70 \%$ do corpo. A maxila inferior é longa desde os estágios iniciais de desenvolvimento. As bases das nadadeiras dorsal e anal são grandes. Raios da dorsal: 21-24. Raios da anal: 20-24. Apresenta pigmentação na margem dorsal do intestino formando uma faixa atrás do olho. A margem dorsal do corpo também é muito pigmentada formando duas faixas contínuas (uma de cada lado do corpo) desde a cabeça até a cauda.

Tamanho: pré-flexão 1,5-2,0 mm; flexão 4,5-8,5 mm.

Habitat: espécie marinha e epipelágica. Ocorre em águas tropicais principalmente em regiões oceânicas ou próximas a ilhas.

Nome vulgar: Agulhinha.

\section{Georreferrenciamento}

\begin{tabular}{|c|c|c|c|c|c|c|c|c|}
\hline DZUFR & Latitude (S) & Longitude (W) & Data & $\begin{array}{c}\text { Tipo de } \\
\text { arrasto }\end{array}$ & $\begin{array}{c}\text { Profundidade } \\
\text { de coleta }\end{array}$ & Rede & $\begin{array}{c}\text { Malha } \\
(\boldsymbol{\mu m})\end{array}$ & $\begin{array}{c}\mathbf{N}^{\circ} \text {. de } \\
\text { inds. }\end{array}$ \\
\hline 360 & $22^{\circ} 38^{\prime} 25,0^{\prime \prime}$ & $040^{\circ} 17^{\prime} 41,0^{\prime \prime}$ & $19 / 05 / 2002$ & oblíquo & $40 \mathrm{~m}$ & bongô & 330 & 2 \\
\hline 371 & $22^{\circ} 33^{\prime} 37,0^{\prime \prime}$ & $040^{\circ} 19^{\prime} 10,0^{\prime \prime}$ & $17 / 05 / 2002$ & oblíquo & $50 \mathrm{~m}$ & bongô & 500 & 1 \\
\hline 450 & $22^{\circ} 42^{\prime} 06,0^{\prime \prime}$ & $040^{\circ} 14^{\prime} 26,0^{\prime \prime}$ & $19 / 05 / 2002$ & oblíquo & $50 \mathrm{~m}$ & bongô & 500 & 1 \\
\hline 1336 & $22^{\circ} 06^{\prime} 37,8^{\prime \prime}$ & $039^{\circ} 49^{\prime} 44,8^{\prime \prime}$ & $10 / 05 / 2002$ & oblíquo & até a termoclina & bongô & 330 & 1 \\
\hline 1382 & $22^{\circ} 08^{\prime} 149^{\prime \prime}$ & $039^{\circ} 46^{\prime} 34,6^{\prime \prime}$ & $11 / 05 / 2002$ & oblíquo & até a termoclina & bongô & 330 & 2 \\
\hline 25291 & $21^{\circ} 57,12^{\prime}$ & $039^{\circ} 37,32^{\prime}$ & $18 / 06 / 2003$ & horizontal & superfície & nêuston & 500 & 2 \\
\hline
\end{tabular}

Referências: Collette, 2006; Fahay, 2007. 


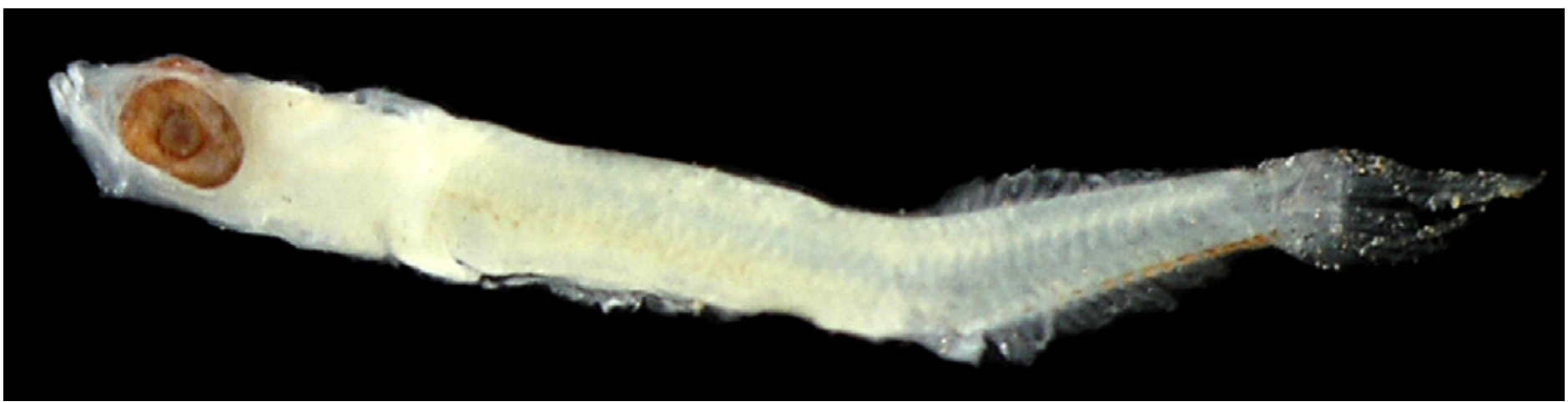

Figura 92 - A: Hyporhamphus unifasciatus. DZUFRJ 25293; Flexão; CP 4,5 mm.

\section{Hyporhamphus unifasciatus (Ranzani, 1841)}

Possui o corpo alongado e fino. $O$ número total de vértebras varia entre 50-54. O intestino é longo alcançando mais da metade do corpo. Raios da dorsal: 13-16. Raios da anal: 14-18. Possui pigmentação na região do intestino, nas extremidades das maxilas, na região inferior do opérculo. A margem dorsal do corpo possui blocos de pigmentos formando uma faixa descontínua desde a cabeça até a cauda. Em larvas maiores esses pigmentos formam uma linha pontilhada. Possui uma linha descontínua de pigmentos na linha lateral e um pigmento no meio do pedúnculo caudal.

Tamanho: flexão 4,5 mm; pós-flexão 13,5 mm.

Habitat: espécie marinha e epipelágica. Ocorre principalmente em regiões costeiras.

Nome vulgar: Agulha branca.

\section{Georreferrenciamento}

\begin{tabular}{|c|c|c|c|c|c|c|c|c|}
\hline DZUFRJ & Latitude (S) & Longitude (W) & Data & $\begin{array}{l}\text { Tipo de } \\
\text { arrasto }\end{array}$ & $\begin{array}{c}\text { Profundidade } \\
\text { de coleta }\end{array}$ & Rede & $\begin{array}{l}\text { Malha } \\
(\mu \mathrm{m})\end{array}$ & $\begin{array}{l}N^{\circ} \text {. de } \\
\text { inds. }\end{array}$ \\
\hline 1188 & $22^{\circ} 07^{\prime} 29,0^{\prime \prime}$ & $039^{\circ} 06^{\prime} 23,5^{\prime \prime}$ & $10 / 05 / 2002$ & oblíquo & $1.000 \mathrm{~m}$ & $\begin{array}{l}\text { cilíndrico- } \\
\text { cônica }\end{array}$ & 500 & 1 \\
\hline 1316 & $22^{\circ} 08^{\prime} 14,9^{\prime \prime}$ & $039^{\circ} 46^{\prime} 34,6^{\prime \prime}$ & $11 / 05 / 2002$ & oblíquo & até a termoclina & bongô & 500 & 2 \\
\hline 25292 & $22^{\circ} 02,27^{\prime}$ & $039^{\circ} 43,49^{\prime}$ & $18 / 06 / 2003$ & horizontal & superfície & nêuston & 500 & 1 \\
\hline 25293 & $22^{\circ} 28,52^{\prime}$ & $039^{\circ} 55,47^{\prime}$ & $16 / 06 / 2003$ & horizontal & superfície & nêuston & 500 & 1 \\
\hline
\end{tabular}

Referências: Collette, 2006.

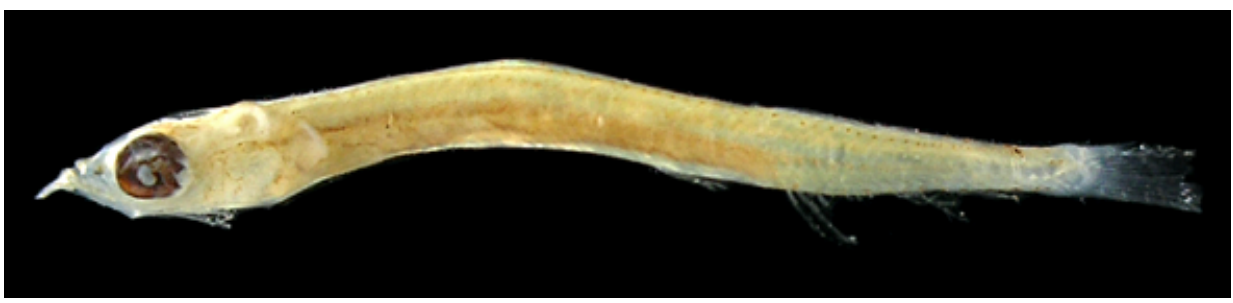

Figura 92 - B: DZUFRJ 25292; Pós-flexão; CP 13,5 mm. 


\section{Família Exocoetidae}

A família Exocoetidae é marinha e epipelágica. Ocorre nos oceanos Atlântico, Índico e Pacífico. Compreende cinco subfamílias e oito gêneros com aproximadamente 52 espécies. A principal característica que separa essa família das demais da ordem Beloniformes é que a maxila inferior é sempre reduzida nas larvas maiores. Algumas espécies possuem barbilhão e nadadeiras peitoral e pélvica muito desenvolvidas.

No Brasil já foram identificadas 12 espécies nas fases de larva e adulto. Nesse estudo é contemplada a espécie Hirundichthys rondeletti. 


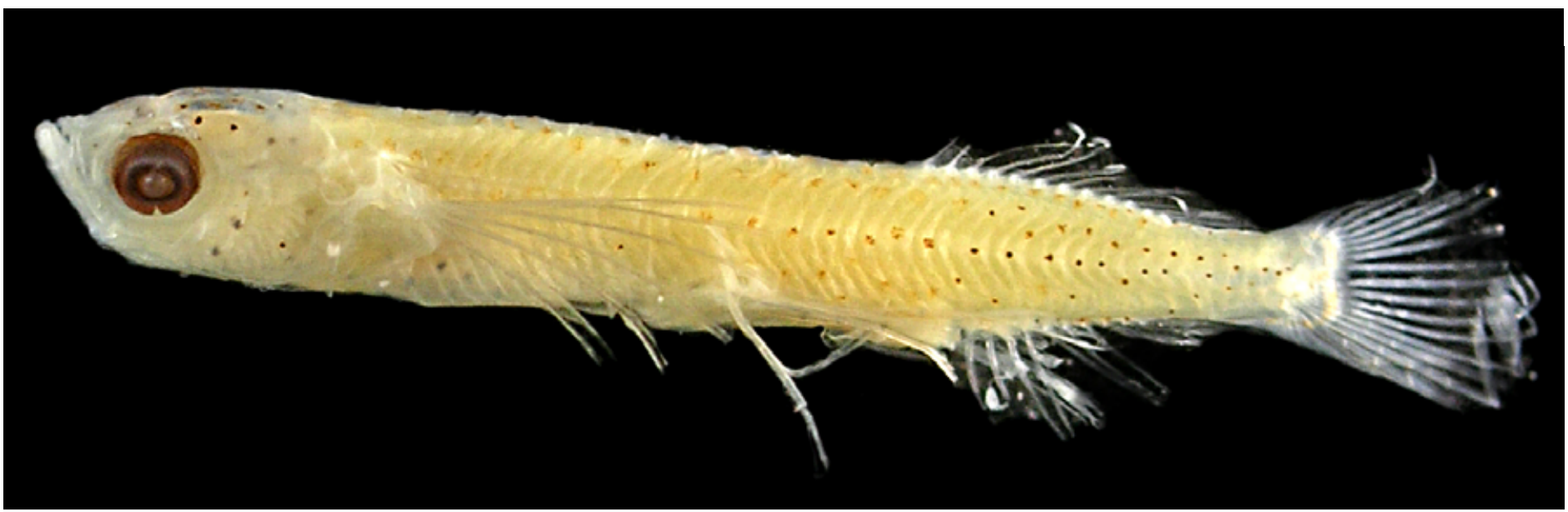

Figura 93: Hirundichthys rondeletti. DZUFRJ 26294; Pós-flexão; CP 13,5mm.

\section{Hirundichthys rondeletti (Valenciennes, 1847)}

As larvas de Hirundichthys podem ser separadas das demais espécies da família Exocoetidae pelo número de raios das nadadeiras dorsal e anal, pela posição dessas nadadeiras e pelo padrão de pigmentação. As larvas dessa espécie possuem 10-12 raios na nadadeira dorsal e 11-13 na anal. O corpo é todo pigmentado e os cromatóforos são grandes. O número de miômeros varia aproximadamente entre 45 e 46.

Tamanho: pós-flexão 13,5 mm.

Habitat: espécie marinha e epipelágica. Ocorre em águas subtropicais em regiões oceânicas.

Nome vulgar: Voador.

Georreferrenciamento

\begin{tabular}{|c|c|c|c|c|c|c|c|c|}
\hline DZUFRJ & Latitude (S) & Longitude (W) & Data & $\begin{array}{c}\text { Tipo de } \\
\text { arrasto }\end{array}$ & $\begin{array}{c}\text { Profundidade } \\
\text { de coleta }\end{array}$ & Rede & $\begin{array}{c}\text { Malha } \\
(\boldsymbol{\mu m})\end{array}$ & $\mathbf{N}^{\circ}$. de inds. \\
\hline 25294 & $22^{\circ} 28,5^{\prime}$ & $039^{\circ} 55,47^{\prime}$ & $16 / 06 / 2003$ & horizontal & superfície & nêuston & 500 & 1 \\
\hline
\end{tabular}

Referências: Cotton \& Comyns, 2006; Fahay, 2007. 


\section{Ordem Stephanoberyciformes}

A ordem Stephanoberyciformes é representada por nove famílias e 75 espécies exclusivamente marinhas. São peixes pequenos que vivem em regiões profundas. Algumas larvas são muito semelhantes aos adultos (Melamphaidae), enquanto outras se tornam muito diferentes.

Nesse estudo a ordem Stephanoberyciformes é representada pela família Melamphaidae. 


\section{Família Melamphaidae}

A família Melamphaidae é a maior e mais diversa da ordem Stephanoberyciformes, incluindo cinco gêneros com 36 espécies. São encontradas em regiões meso e batipelágicas, em zonas oceânicas de todo mundo. Podem possuir três padrões de pigmentação e diferentes tipos de ornamentação na cabeça (incluindo espinhos e cristas), que distinguem os gêneros.

No Brasil já foram identificadas sete espécies nas fases de larva e adulto. Nesse estudo são contempladas as espécies Poromitra capito e Melamphaes simus, ambas novas ocorrências para o Brasil. 


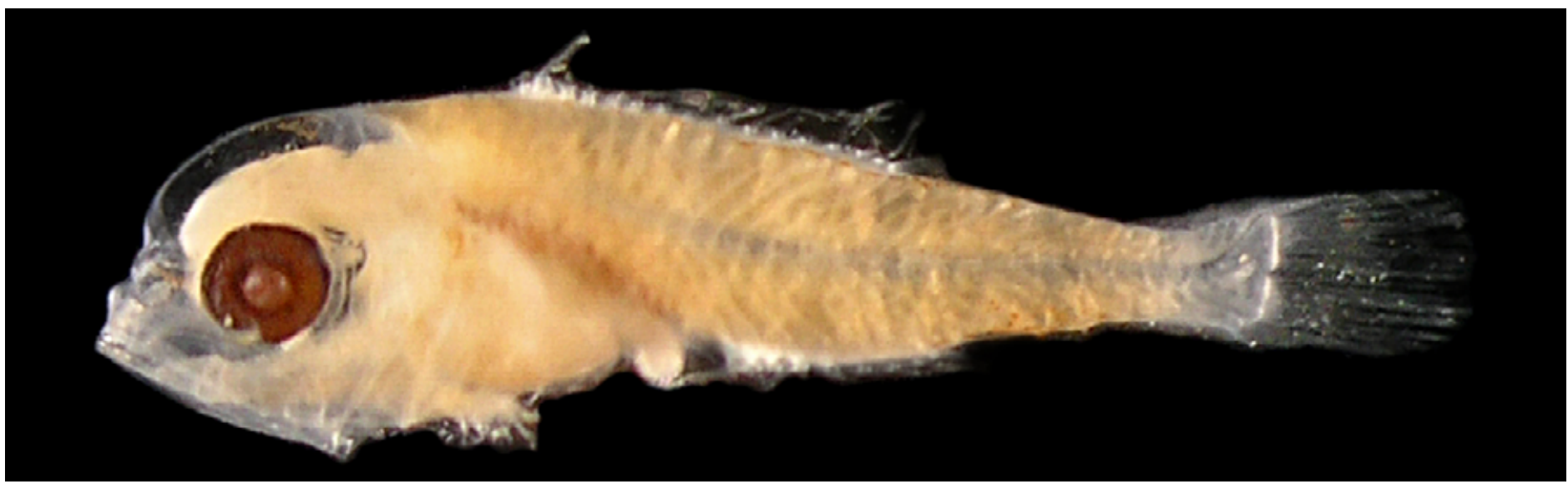

Figura 94 - A: Melamphaes simus. A. DZUFRJ 5501; Flexão; CP 5,4 mm.

\section{Melamphaes simus Ebeling, 1962}

Possui o corpo alongado (28-30 miômeros) durante todo desenvolvimento. A distância pré-anal aumenta de $29-35 \%$ CP durante a pré-flexão para 61-64\% CP em juvenis. Não possui espinhos na cabeça. A nadadeira pélvica começa abaixo ou um pouco depois da base da nadadeira peitoral. O padrão de pigmentação e o número de rastros presentes no primeiro arco branquial são as principais características que separam as espécies. No estágio de pré-flexão possui manchas de pigmentos dorsais e ventrais, presença de pigmentos peritoneais e internos sobre a cabeça. A partir da flexão há uma linha de melanóforos na margem dorsal do corpo e no pedúnculo caudal. Apresentam três espinhos e 15-16 raios na nadadeira dorsal e um espinho e oito a dez raios da nadadeira anal. Número de rastros: 4+11-12.

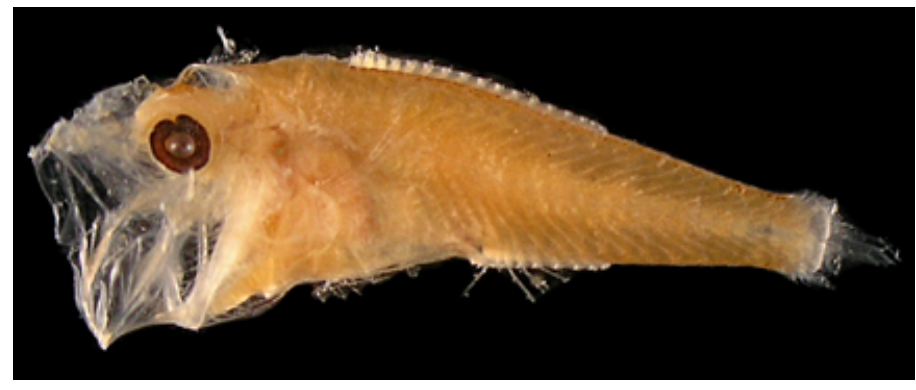

Figura 94 - B: DZUFRJ 119; Pós-flexão; CP 7,3 mm.

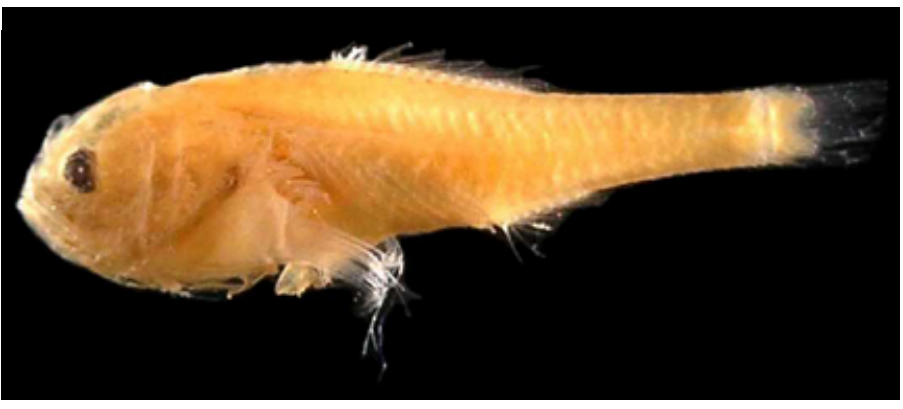

Figura 94 - C: DZUFRJ 5499; Transformação; CP 11,0 mm.

Tamanho: flexão 3,1-5,6 mm; pós-flexão 7,3 mm; transformação 11,0 mm.

Habitat: espécie marinha, mesopelágica e batipelágica, ocorre em regiões oceânicas entre 400 e $1.000 \mathrm{~m}$ de profundidade durante o dia. A noite ocorre desde a superfície até $600 \mathrm{~m}$ de profundidade.

\section{Georreferrenciamento}

\begin{tabular}{|c|c|c|c|c|c|c|c|c|}
\hline DZUFR & Latitude (S) & Longitude (W) & Data & $\begin{array}{c}\text { Tipo de } \\
\text { arrasto }\end{array}$ & $\begin{array}{c}\text { Profundidade } \\
\text { de coleta }\end{array}$ & Rede & $\begin{array}{c}\text { Malha } \\
\text { ( } \boldsymbol{\mu m})\end{array}$ & $\begin{array}{c}\mathbf{N}^{\circ} \text {. de } \\
\text { inds. }\end{array}$ \\
\hline 5499 & $22^{\circ} 32^{\prime} 49,0^{\prime \prime}$ & $040^{\circ} 04^{\prime} 20,9^{\prime \prime}$ & $07 / 11 / 2001$ & oblíquo & $1.000 \mathrm{~m}$ & cilíndrico-cônica & 500 & 4 \\
\hline 5500 & $22^{\circ} 31^{\prime} 40,9^{\prime \prime}$ & $040^{\circ} 02^{\prime} 39,6^{\prime \prime}$ & $07 / 11 / 2001$ & oblíquo & $1.000 \mathrm{~m}$ & cilíndrico-cônica & 500 & 1 \\
\hline 5501 & $22^{\circ} 32^{\prime} 50,0^{\prime \prime}$ & $040^{\circ} 04^{\prime} 09^{\prime \prime}$ & $06 / 11 / 2001$ & oblíquo & $1.000 \mathrm{~m}$ & cilíndrico-cônica & 500 & 4 \\
\hline 5502 & $22^{\circ} 32^{\prime} 50,0^{\prime \prime}$ & $040^{\circ} 04^{\prime} 09^{\prime \prime}$ & $06 / 11 / 2001$ & oblíquo & $1.000 \mathrm{~m}$ & cilíndrico-cônica & 500 & 8 \\
\hline
\end{tabular}

Referências: Sandknop \& Watson, 1996a; Garcia \& Morgan, 2002; Kotlyar, 2004; Frias-Torres, 2006a; Fahay, 2007; Campos et al., 2008; Froese \& Pauly, 2014. 


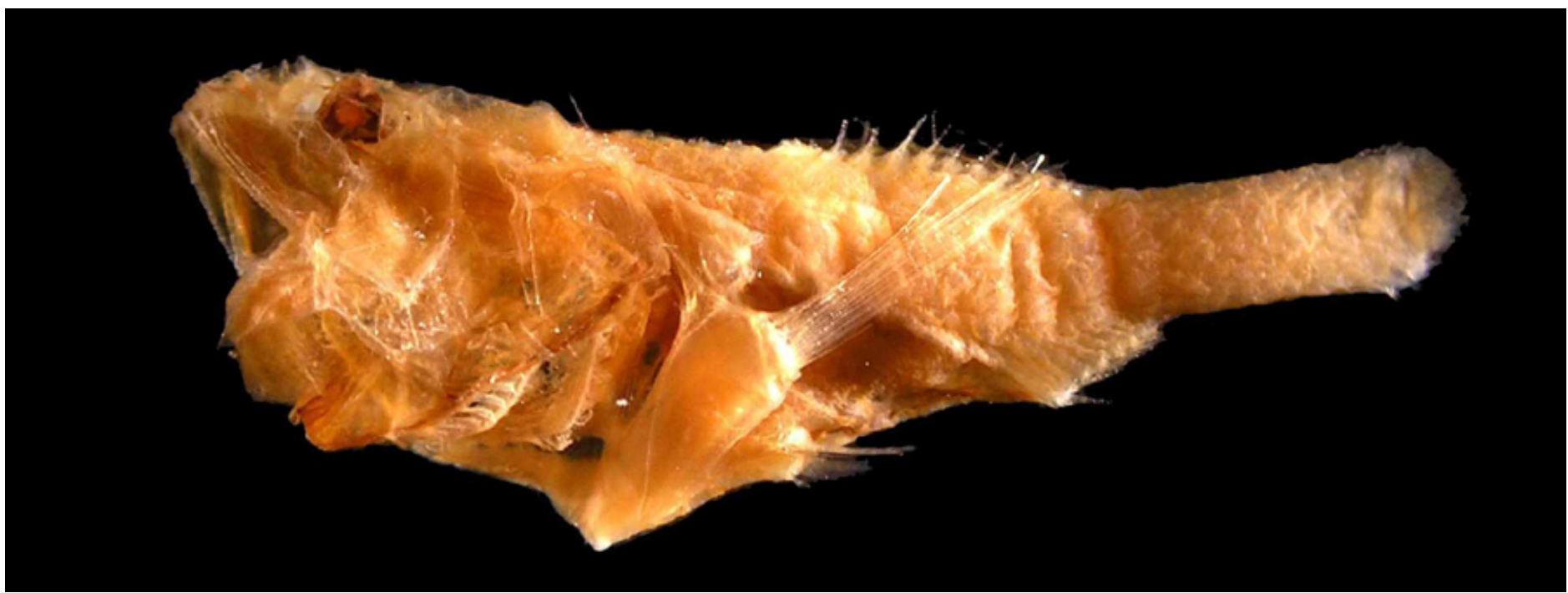

Figura 95: Poromitra capito. A. DZUFRJ 7512;Transformação; CP 20,8 mm.

\section{Poromitra capito Goode \& Bean, 1883}

O corpo é comprimido lateralmente, a cabeça é grande e os olhos são pequenos. O pedúnculo caudal é moderadamente alongado e o número de miômeros varia entre 25-26. A distância pré-anal é de aproximadamente $60 \%$ CP durante todo desenvolvimento. As larvas dessa espécie possuem várias cristas na região cefálica e muitos espinhos no pré-opérculo (3-4) e opérculo. A nadadeira dorsal é formada por três espinhos e 11 raios, enquanto a anal possui um espinho e oito raios. O número de rastros no primeiro arco branquial é fundamental para separação das espécies $(10+22)$. O número total de miômeros varia entre 25 e 26.

Tamanho: transformação 20,8 mm.

Habitat: espécie marinha, mesopelágica e batipelágica, ocorre em regiões oceânicas entre 750 e $1.550 \mathrm{~m}$ de profundidade durante o dia. A noite ocorre entre 100 e 750 m de profundidade.

\section{Georreferrenciamento}

\begin{tabular}{|c|c|c|c|c|c|c|c|c|}
\hline DZUFRJ & Latitude (S) & Longitude (W) & Data & $\begin{array}{c}\text { Tipo de } \\
\text { arrasto }\end{array}$ & $\begin{array}{c}\text { Profundidade } \\
\text { de coleta }\end{array}$ & Rede & $\begin{array}{c}\text { Malha } \\
\text { ( } \boldsymbol{\mu m})\end{array}$ & $\begin{array}{c}\mathbf{N}^{\circ} \text {. de } \\
\text { inds. }\end{array}$ \\
\hline 7512 & $21^{\circ} 54^{\prime} 36,5^{\prime \prime}$ & $039^{\circ} 4^{\prime} 20,0^{\prime \prime}$ & $10 / 10 / 2001$ & oblíquo & $1.000 \mathrm{~m}$ & cilíndrico-cônica & 500 & 1 \\
\hline
\end{tabular}

Referências: Sandknop \& Watson, 1996a; Garcia \& Morgan, 2002; Kotlyar, 2004; Frias-Torres, 2006a; Fahay, 2007; Campos et al., 2008; Froese \& Pauly, 2014. 


\section{ORDEM BERYCIFORMES}

A ordem Beryciformes é composta por sete famílias e 144 espécies. As espécies são caracterizadas pela presença do osso orbitoesfenoide e possuem mais de cinco raios nas nadadeiras pélvicas. As larvas assemelham-se as larvas da ordem Perciformes, com a cabeça proeminente e espinhos nas nadadeiras.

Nesse estudo a ordem Beryciformes é representada pela família Holocentridae. 


\section{Família Holocentridae}

A família Holocentridae é composta por oito gêneros com aproximadamente 78 espécies. Os representantes normalmente são associados a recifes. A maioria das espécies ocorre entre a linha da costa e a isóbata de $100 \mathrm{~m}$. Esta família está dividida em duas subfamílias Holocentrinae e Myripristinae. As larvas de Holocentrinae são caracterizadas por um espinho rostral simples e desenvolvimento tardio da nadadeira pélvica. As larvas de Myripristinae são caracterizadas por um espinho rostral bifurcado e desenvolvimento da nadadeira pélvica por volta dos $3,5 \mathrm{~mm}$. As famílias Peristidae e Triglidae também possuem espinhos no rostro, mas esses são normalmente bilaterais, o que as separa de Holocentridae. Os holocentrídeos apresentam uma forma de transição pelágica, um estágio de pré-assentamento denominado estágio rhynchichthys, onde os raios e espinhos das nadadeiras estão completamente formados, mas o espinho rostral permanece. Algumas espécies também possuem uma fase pré-juvenil denominada estágio meeki que permanece pelágica, mas já está pronta para assentar no fundo. Nesse estágio há perda dos espinhos da cabeça.

No Brasil já foram identificadas oito espécies nas fases de larva e adulto. Nesse estudo são contempladas as espécies Holocentrus sp. e Sargocentron bullisi. 


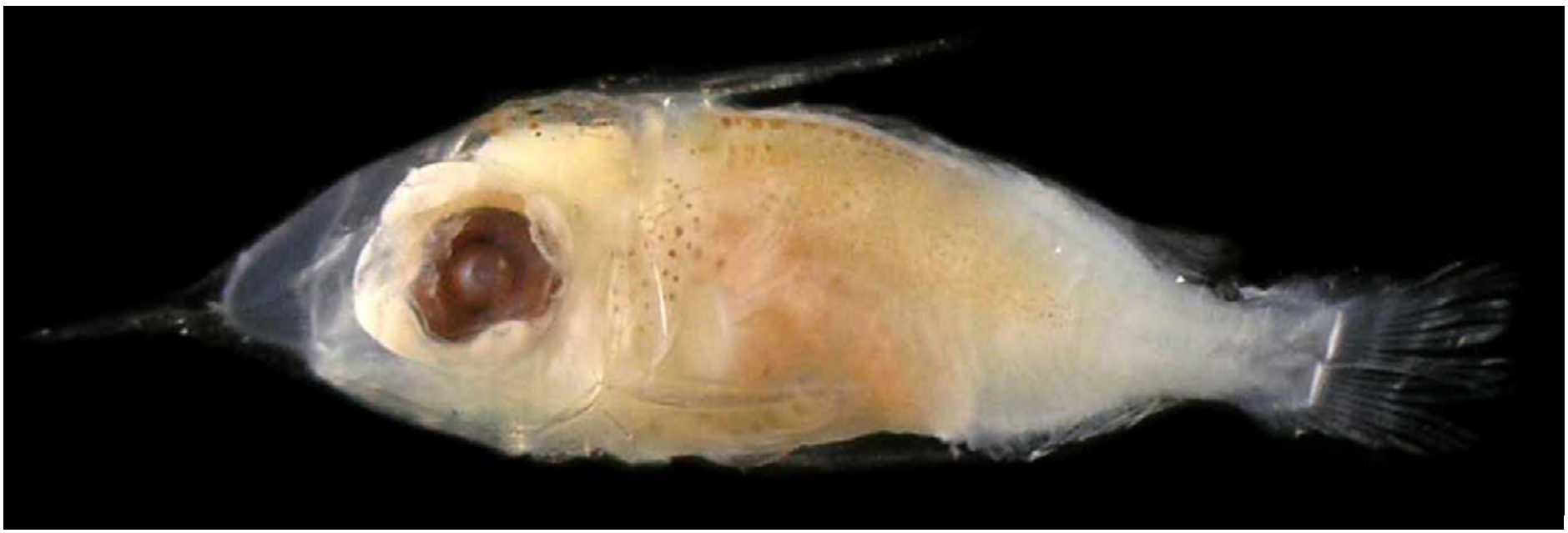

Figura 96: Holocentrus sp. DZUFRJ 1220; Flexão; CP 6,0 mm.

\section{Holocentrus sp.}

As larvas da família Holocentridae são separadas principalmente pela forma e pelo tamanho dos espinhos da cabeça, do pré-opérculo e do rostro. Os representantes do gênero Holocentrus possuem corpo e cabeça altos e pedúnculo caudal estreito. Apresentam pigmentação intensa no peritôneo. Os espinhos da cabeça, do pré-opérculo e do rostro possuem tamanho intermediário, entre as larvas de Sargocentron e Myripristinae. O espinho rostral é simples e os espinhos da cabeça e do pré-opéculo alcançam a metade do corpo. Nadadeira dorsal com 11 espinhos; nadadeira anal com 10 raios e nadadeira dorsal com 14-16 raios. O número total de miômeros varia entre 26 e 27. No Brasil foram registradas as espécies Holocentrus adscensionis (Osbeck, 1765) e Holocentrus rufus (Walbaum, 1792).

Tamanho: flexão 6,0-6,5 mm.

Habitat: todas as espécies de Holocentrus registradas na literatura são marinhas e vivem associadas a formações coralinas. São demersais e a maioria ocorre em águas rasas.

\section{Georreferencimento}

\begin{tabular}{|c|c|c|c|c|c|c|c|c|}
\hline DZUFR & Latitude (S) & Longitude (W) & Data & $\begin{array}{c}\text { Tipo de } \\
\text { arrasto }\end{array}$ & $\begin{array}{c}\text { Profundidade } \\
\text { de coleta }\end{array}$ & Rede & $\begin{array}{c}\text { Malha } \\
\text { ( } \boldsymbol{\mu m})\end{array}$ & $\begin{array}{c}\mathbf{N}^{\circ} \text {. de } \\
\text { inds. }\end{array}$ \\
\hline 1220 & $22^{\circ} 02^{\prime} 30,0^{\prime \prime}$ & $039^{\circ} 49^{\prime} 41,2^{\prime \prime}$ & $12 / 05 / 2002$ & oblíquo & $1.000 \mathrm{~m}$ & cilíndrico-cônica & 500 & 1 \\
\hline 7516 & $2^{\circ} 1^{\circ} 3^{\prime} 10,4^{\prime \prime}$ & $039^{\circ} 45^{\prime} 499^{\prime \prime}$ & $10 / 10 / 2001$ & oblíquo & $1.000 \mathrm{~m}$ & cilíndrico-cônica & 500 & 1 \\
\hline
\end{tabular}

Referências: Leis \& Rennis, 1983; Tyler et al., 1993; Lyczkowski-Shultz et al., 2000; Bonecker et al., 2006; Fahay, 2007. 


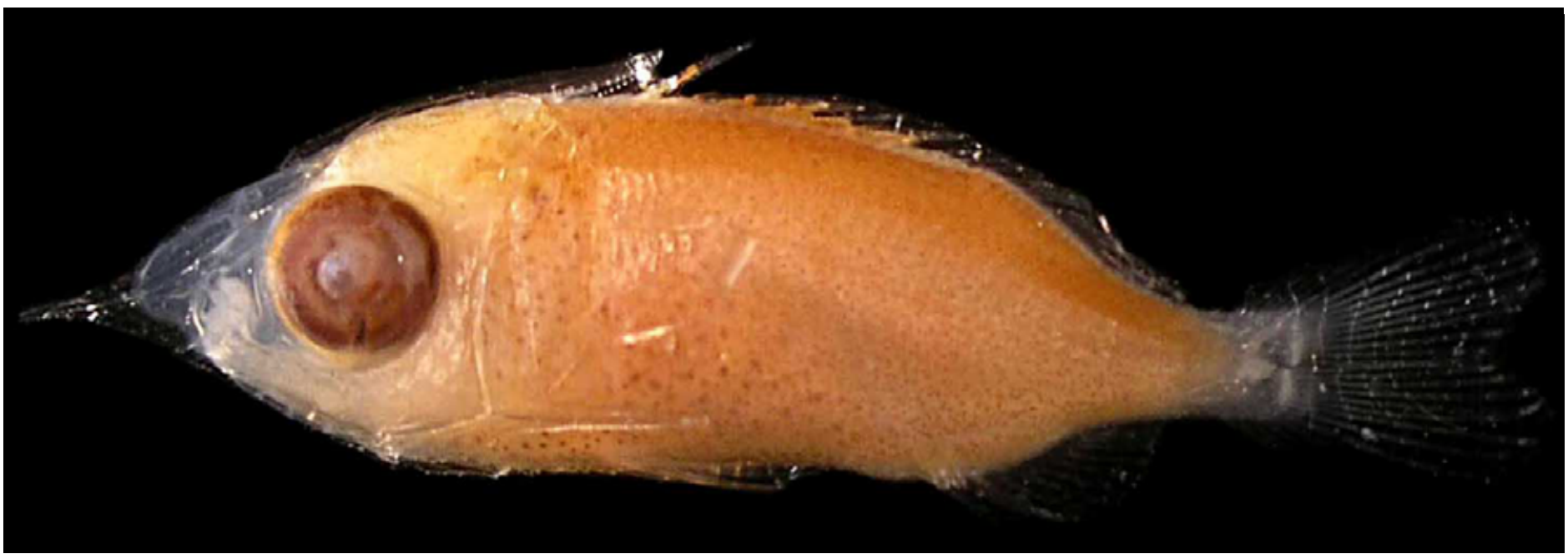

Figura 97: Sargocentron bullisi. DZUFRJ 7515; Pós-flexão; CP 11,0 mm.

\section{Sargocentron bullisi (Woods, 1955)}

Os espinhos da cabeça, do pré-opérculo e do rostro são longos. Os espinhos do pré-opérculo alcançam os últimos raios da nadadeira dorsal e anal. Apresenta pigmentação intensa no peritônio e alguns melanóforos no pedúnculo caudal e na cabeça. Nadadeira dorsal com 11 espinhos; nadadeira anal com oito raios e nadadeira dorsal com 11-12 raios. O número total de miômeros varia entre 26 e 27.

Tamanho: pós-flexão 11,0 mm.

Habitat: espécie associada a formações coralinas, ocorre entre 33 e 110 $\mathrm{m}$ de profundidade.

Nome vulgar: Jaguareçá listrado.

\section{Georreferencimento}

\begin{tabular}{|c|c|c|c|c|c|c|c|c|}
\hline DZUFRJ & Latitude (S) & Longitude (W) & Data & $\begin{array}{c}\text { Tipo de } \\
\text { arrasto }\end{array}$ & $\begin{array}{c}\text { Profundidade } \\
\text { de coleta }\end{array}$ & Rede & $\begin{array}{c}\text { Malha } \\
(\boldsymbol{\mu m})\end{array}$ & $\begin{array}{c}\mathbf{N}^{\circ} \text {. de } \\
\text { inds. }\end{array}$ \\
\hline 7515 & $21^{\circ} 54^{\prime} 36,5^{\prime \prime}$ & $039^{\circ} 45^{\prime} 20,0^{\prime \prime}$ & $09 / 10 / 2001$ & oblíquo & $1.000 \mathrm{~m}$ & cilíndrico-cônica & 500 & 1 \\
\hline
\end{tabular}

Referências: Leis \& Rennis, 1983; Lyczkowski-Shultz et al., 2000; Bonecker et al., 2006; Fahay, 2007. 


\section{ORDEM SYNGNATHIFORMES}

A ordem Syngnathiformes é formada por 11 famílias com 278 espécies. Possuem placas dérmicas que recobrem o corpo e a boca é normalmente pequena.

Nesse estudo a ordem Syngnathiformes é representada pelas famílias Fistulariidae e Syngnathidae. 


\section{Família Fistulariidae}

A família Fistulariidae é marinha e ocorre nos oceanos Atlântico, Índico e Pacífico. Compreende um gênero com quatro espécies. O corpo é muito alongado apresentando espinhos minúsculos e o focinho é longo e tubular. Nos exemplares maiores os dois raios centrais da nadadeira caudal formam um filamento longo. As nadadeiras dorsal e anal estão localizadas na parte posterior do corpo.

No Brasil já foram identificadas duas espécies nas fases de larva e adulto: Fistularia petimba Lacepède, 1803 e Fistularia tabacaria Linnaeus, 1758. Nesse estudo é contemplada a espécie Fistularia tabacaria. 


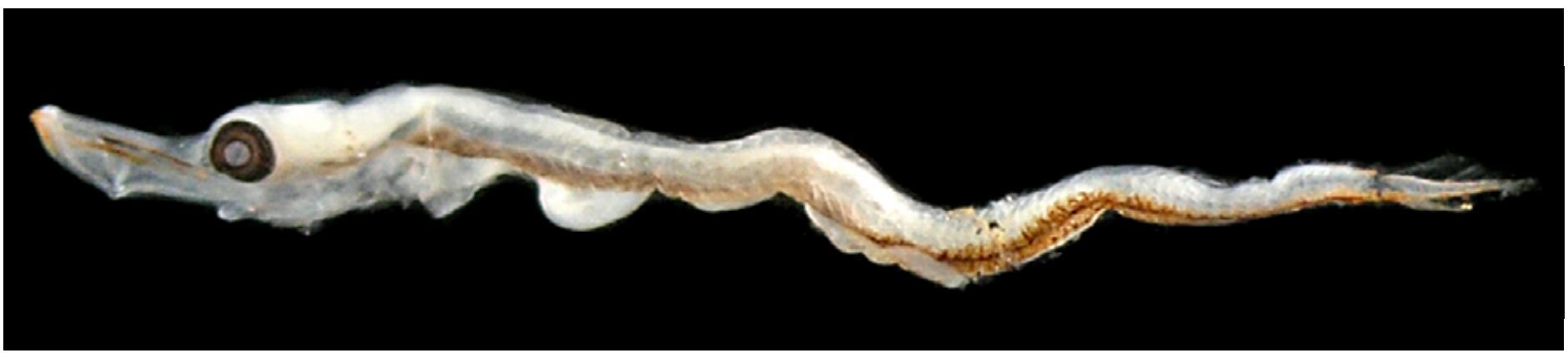

Figura 98: Fistularia tabacaria. DZUFRJ 25043; Pré-flexão; CP 7,2 mm.

\section{Fistularia tabacaria Linnaeus, 1758}

A principal característica para a identificação dessa espécie é o padrão de pigmentação, que acompanha toda a região ventral da larva e pode ser observado em vários estágios do desenvolvimento. Os exemplares menores possuem uma linha contínua de pigmento na região ventral desde a cabeça até a cauda. À medida que a larva cresce esses pigmentos formam uma linha pontilhada ao longo de toda a região ventral e no focinho. $O$ intestino termina na região mediana do corpo, antes da origem das nadadeiras dorsal e anal. O número de miômeros varia entre 75 e 88.

Tamanho: pré-flexão 5,5 mm.

Habitat: espécie de águas salobras e marinhas, demersal. Ocorre em áreas de formações coralinas sobre fundos duros e rochosos em 36 $\mathrm{m}$ de profundidade.

Nome vulgar: Cachimbau azul.

\section{Georreferencimento}

\begin{tabular}{|c|c|c|c|c|c|c|c|c|}
\hline DZUFRJ & Latitude (S) & Longitude (W) & Data & $\begin{array}{c}\text { Tipo de } \\
\text { arrasto }\end{array}$ & $\begin{array}{c}\text { Profundidade } \\
\text { de coleta }\end{array}$ & Rede & $\begin{array}{c}\text { Malha } \\
\text { ( } \boldsymbol{\mu m})\end{array}$ & $\begin{array}{c}\mathbf{N}^{\circ} \text {. de } \\
\text { inds. }\end{array}$ \\
\hline 458 & $22^{\circ} 38^{\prime} 25,0^{\prime \prime}$ & $040^{\circ} 17^{\prime} 41,0^{\prime \prime}$ & $19 / 05 / 2002$ & oblíquo & $40 \mathrm{~m}$ & bongô & 330 & 1 \\
\hline
\end{tabular}

Referências: Barros et al., 2006a; Ditty et al., 2006d; Barros et al., 2007; Fahay, 2007. 


\section{Família Syngnathidae}

A família Syngnathidae possui representantes marinhos, estuarinos e de água doce, incluindo 52 gêneros e aproximadamente 232 espécies. Ocorre nos oceanos Atlântico, Índico e Pacífico. Os adultos de Syngnathidae são pequenos e alcançam no máximo $65 \mathrm{~cm}$. O corpo é envolto por uma série de anéis ósseos articulados. Possuem uma nadadeira dorsal formada apenas por raios, nadadeira anal reduzida ou inexistente e nadadeira pélvica ausente. As aberturas branquiais são reduzidas.

Esta família é dividida em duas subfamílias: Syngnathinae (peixes-cachimbo) e Hippocampinae (cavalos-marinhos). Nesse estudo só foram registrados representantes da subfamília Syngnathinae. Nos peixes-cachimbo os eixos longitudinais da cabeça e do tronco são paralelos, a cauda é reta e não preênsil (com exceção do gênero Acentronura), nadadeira caudal presente.

No Brasil já foram identificadas 13 espécies nas fases de larva e adulto. Nesse estudo são contempladas as espécies Micrognathus crinitus e Micrognathus erugatus. 


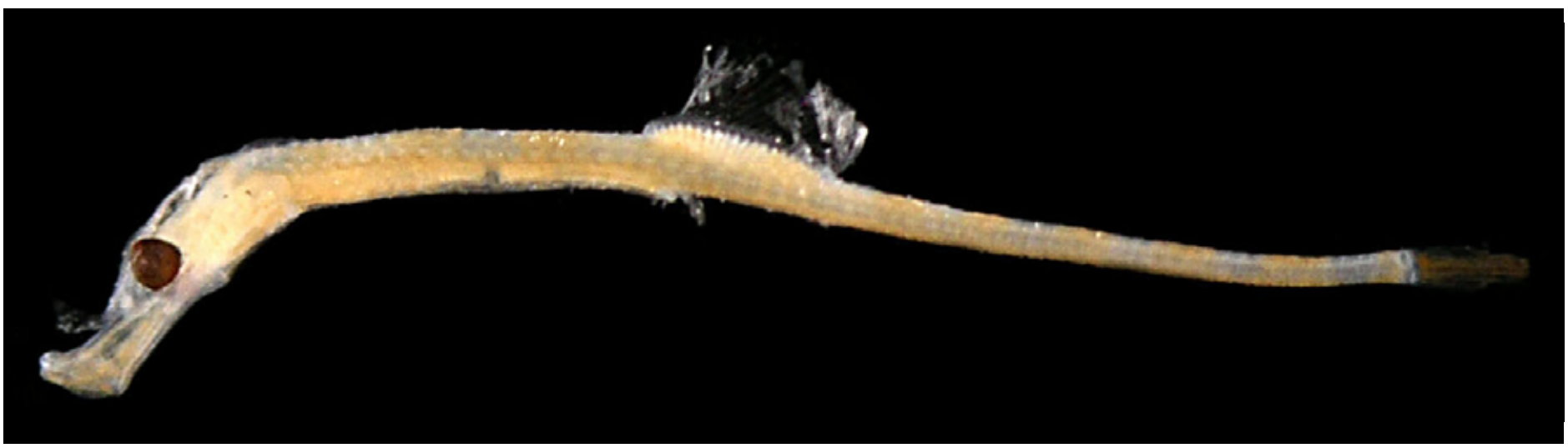

Figura 99: Micrognathus crinitus. A. DZUFRJ 374; CP 8,0 mm.

\section{Micrognathus crinitus (Jenyns, 1842)}

Possui focinho curto com crista mediana dorsal um pouco elevada. As cristas do tronco (dorsal) e da cauda são interrompidas próximo à parte posterior da nadadeira dorsal. A crista inferior do tronco termina no anel anal. As cristas são proeminentes e denticuladas. Possui nadadeira anal. A nadadeira caudal possui 10 raios, a nadadeira dorsal menos de 30 raios e as nadadeiras peitorais $12-14$ raios. Apresenta $17-18$ anéis no tronco; 32-35 anéis da cauda e o número total de anéis é 49-52. As duas espécies registradas são separadas pela diferença no número de anéis e pelas cristas que podem ser proeminentes e denticuladas ( $M$. crinitus) ou não (M. erugatus).

Habitat: espécie marinha, demersal, associada a formações coralinas, ocorre até $21 \mathrm{~m}$ de profundidade.

Tamanho: 8,0 mm.

Nome vulgar: Peixe cachimbo preto.

\section{Georreferencimento}

\begin{tabular}{|c|c|c|c|c|c|c|c|c|}
\hline DZUFRJ & Latitude (S) & Longitude (W) & Data & $\begin{array}{c}\text { Tipo de } \\
\text { arrasto }\end{array}$ & $\begin{array}{c}\text { Profundidade } \\
\text { de coleta }\end{array}$ & Rede & $\begin{array}{c}\text { Malha } \\
(\boldsymbol{\mu m})\end{array}$ & $\begin{array}{c}\mathbf{N}^{\circ} \text {. de } \\
\text { inds. }\end{array}$ \\
\hline 353 & $22^{\circ} 32^{\prime} 03,0^{\prime \prime}$ & $040^{\circ} 17^{\prime} 21,0^{\prime \prime}$ & $19 / 05 / 2002$ & oblíquo & $30 \mathrm{~m}$ & bongô & 330 & 1 \\
\hline 374 & $22^{\circ} 33^{\prime} 477^{\prime \prime}$ & $040^{\circ} 12^{\prime} 25^{\prime \prime}$ & $17 / 05 / 2002$ & oblíquo & $50 \mathrm{~m}$ & bongô & 330 & 1 \\
\hline 375 & $22^{\circ} 38^{\prime} 25,0^{\prime \prime}$ & $040^{\circ} 17^{\prime} 41,0^{\prime \prime}$ & $19 / 05 / 2002$ & oblíquo & $40 \mathrm{~m}$ & bongô & 500 & 2 \\
\hline 654 & $22^{\circ} 38^{\prime} 25,0^{\prime \prime}$ & $040^{\circ} 17^{\prime} 41,0^{\prime \prime}$ & $19 / 05 / 2002$ & oblíquo & $40 \mathrm{~m}$ & bongô & 330 & 1 \\
\hline
\end{tabular}

Referências: Dawson \& Vari, 1982; Barros et al., 2006a; Frias-Torres, 2006b. 


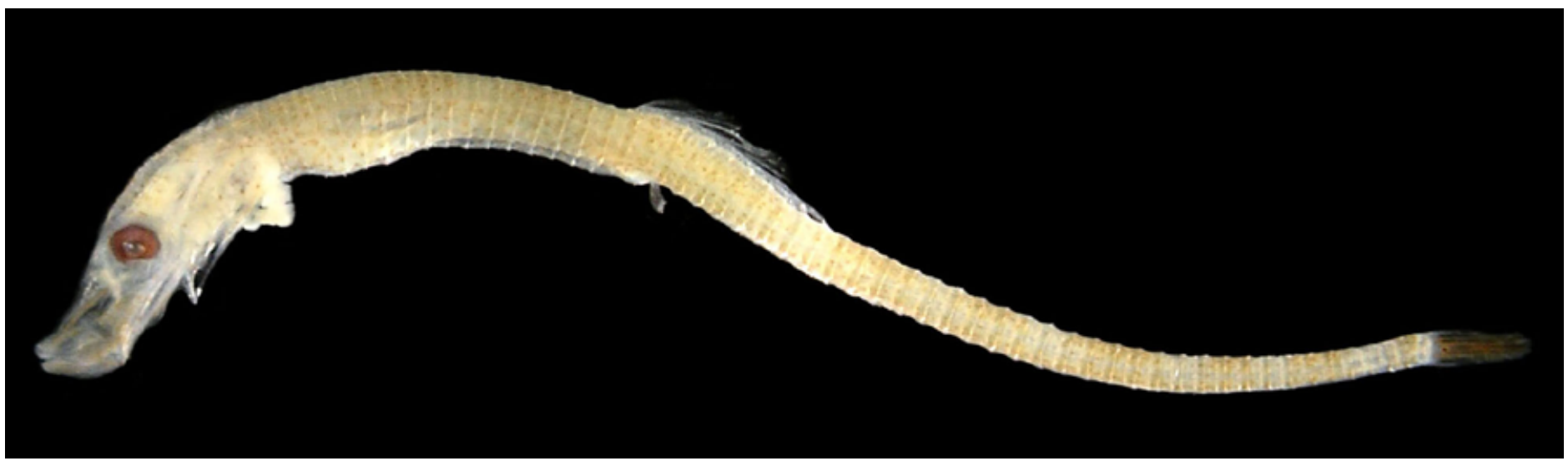

Figura 100: Micrognathus erugatus. A. DZUFRJ 446; CP 12,5 mm.

\section{Micrognathus erugatus Herald \& Dawson, 1974}

Possui focinho curto com quatro a cinco espinhos hialinos diminutos. As cristas do tronco (dorsal) e da cauda são interrompidas próximo à parte posterior da nadadeira dorsal. A crista inferior do tronco termina no anel anal. As cristas são indistinguíveis e essencialmente inteiras. Possui nadadeira anal. A nadadeira caudal possui 10 raios, a nadadeira dorsal menos de 30 raios e as nadadeiras peitorais 12-14 raios. Apresenta 20 anéis no tronco, 36 anéis na cauda e o número total de 56 anéis.

Tamanho: $12,5 \mathrm{~mm}$.

Habitat: espécie marinha e demersal.

Nome vulgar: Peixe cachimbo estrela.

\section{Georreferencimento}

\begin{tabular}{|c|c|c|c|c|c|c|c|c|}
\hline DZUFRJ & Latitude (S) & Longitude (W) & Data & $\begin{array}{c}\text { Tipo de } \\
\text { arrasto }\end{array}$ & $\begin{array}{c}\text { Profundidade } \\
\text { de coleta }\end{array}$ & Rede & $\begin{array}{c}\text { Malha } \\
\text { ( } \boldsymbol{\mu m} \text { ) }\end{array}$ & $\begin{array}{c}\mathbf{N}^{\circ} \text {. de } \\
\text { inds. }\end{array}$ \\
\hline 446 & $22^{\circ} 38^{\prime} 29,0^{\prime \prime}$ & $040^{\circ} 17^{\prime} 40,0^{\prime \prime}$ & $18 / 05 / 2002$ & oblíquo & $800 \mathrm{~m}$ & cilíndrico-cônica & 500 & 1 \\
\hline
\end{tabular}

Referências: Dawson \& Vari, 1982; Barros et al., 2006a; Frias-Torres, 2006b. 


\section{ORDEM SCORPAENIFORMES}

A ordem Scorpaeniformes é composta por 26 famílias com aproximadamente 1.477 espécies. São caracterizados por extensão do terceiro osso suborbital que vai desde o olho até o pré-opérculo. A cabeça é cheia de espinhos e placas ósseas.

Neste estudo a ordem Scorpaeniformes é representada pela família Scorpaenidae. 


\section{Família Scorpaenidae}

A família Scorpaenidae é marinha e ocorre em todos os mares tropicais e temperados. Compreende pelo menos 56 gêneros com aproximadamente 418 espécies. As larvas de Scorpaenidae possuem cabeça grande com muitos espinhos. Têm 1-2 espinhos operculares e 3-5 espinhos pré-operculares. São caracterizadas pela presença de um par de cristas parietais com margens serrilhadas, sustentadas por uma ou duas hastes na região terminal posterior. As larvas de Scorpaenidae podem ser separadas das larvas da família Triglidae pelas cristas parietais que nos triglídeos são sustentadas por várias hastes. A nadadeira dorsal é única, com 7-18 espinhos e 4-14 raios, e a nadadeira anal possui 2-4 espinhos e 5-14 raios.

No Brasil já foram identificadas 20 espécies nas fases de larva e adulto. Nesse estudo são contempladas as espécies Scorpaena sp. e Scorpaenodes sp. 


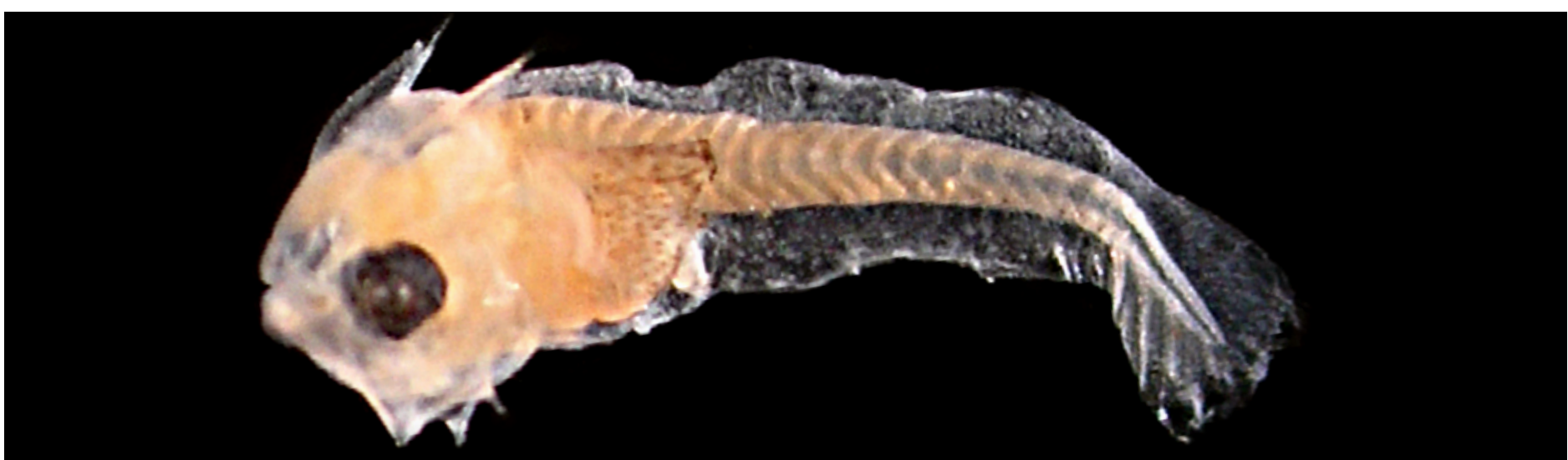

Figura 101 - A: Scorpaena sp. DZUFRJ 14030; Pré-flexão; CP 3,0 mm.

\section{Scorpaena sp.}

As larvas de Scorpaena na pré-flexão possuem uma faixa de melanóforos ao longo da linha média ventral da cauda e na superfície dorsolateral do intestino. Na flexão e pós-flexão desenvolvem um par moderadamente longo de espinhos parietais que alcançam seu maior comprimento relativo quando a formação da nadadeira caudal está completa. Presença de uma capa de melanina sobre a superfície dorso-lateral do intestino. As nadadeiras peitorais são muito pigmentadas desde a pré-flexão, moderadas em comprimento e em forma de leque, em oposição às extremamente longas em Scorpaenodes e em contraste com as aliformes de Pontinus. Possui um total de 24 miômeros. No Brasil já foram registradas onze espécies de Scorpaena.

Tamanho: pré-flexão 2,0-4,0 mm; flexão 4,5-5,5 mm; pós-flexão 6,8-8,0 mm.

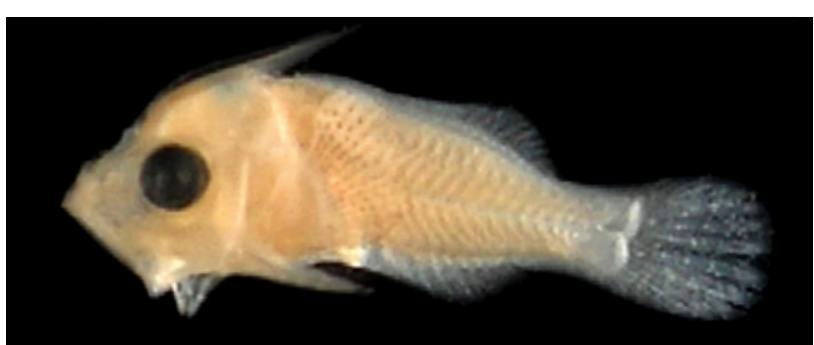

Figura 101 - B: DZUFRJ 13594; Flexão; CP 4,5 mm.

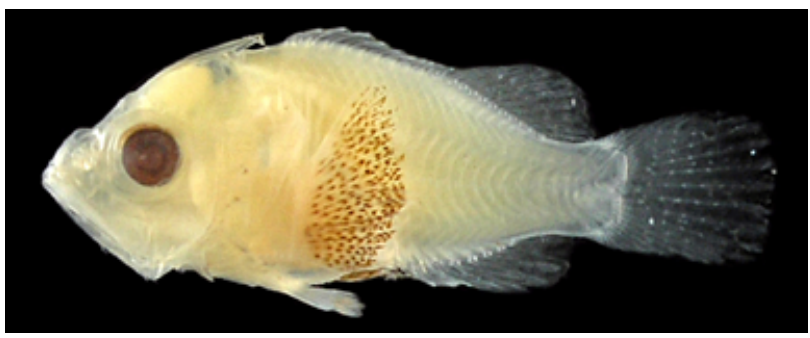

Figura 101 - C: DZUFRJ 5741; Pós-flexão; CP 6,8 mm.

Habitat: todas as espécies de Scorpaena registradas na literatura são marinhas e demersais.

\section{Georreferencimento}

\begin{tabular}{|c|c|c|c|c|c|c|c|c|}
\hline DZUFRJ & Latitude (S) & Longitude (W) & Data & $\begin{array}{l}\text { Tipo de } \\
\text { arrasto }\end{array}$ & $\begin{array}{c}\text { Profundidade } \\
\text { de coleta }\end{array}$ & Rede & $\begin{array}{l}\text { Malha } \\
(\mu \mathrm{m})\end{array}$ & $\begin{array}{l}N^{\circ} \text {. de } \\
\text { inds. }\end{array}$ \\
\hline 1371 & $22^{\circ} 08^{\prime} 52,5^{\prime \prime}$ & $039^{\circ} 46^{\prime} 27,9^{\prime \prime}$ & $12 / 05 / 2002$ & oblíquo & até a termoclina & bongô & 330 & 1 \\
\hline 1300 & $2^{\circ} 02^{\prime} 30,0^{\prime \prime}$ & $039^{\circ} 49^{\prime} 41,2^{\prime \prime}$ & $12 / 05 / 2002$ & oblíquo & até a termoclina & bongô & 500 & 1 \\
\hline 565 & $22^{\circ} 32^{\prime} 03,0^{\prime \prime}$ & $040^{\circ} 17^{\prime} 21,0^{\prime \prime}$ & $19 / 05 / 2002$ & oblíquo & $30 \mathrm{~m}$ & bongô & 330 & 1 \\
\hline 628 & $22^{\circ} 42^{\prime} 06,0^{\prime \prime}$ & $040^{\circ} 14^{\prime} 26,0^{\prime \prime}$ & $19 / 05 / 2002$ & oblíquo & $50 \mathrm{~m}$ & bongô & 330 & 3 \\
\hline 570 & $22^{\circ} 32^{\prime} 03,0^{\prime \prime}$ & $040^{\circ} 17^{\prime} 21,0^{\prime \prime}$ & $19 / 05 / 2002$ & oblíquo & $30 \mathrm{~m}$ & bongô & 500 & 1 \\
\hline 462 & $22^{\circ} 33^{\prime} 47,7^{\prime \prime}$ & $040^{\circ} 12^{\prime} 20,5^{\prime \prime}$ & $17 / 05 / 2002$ & oblíquo & $50 \mathrm{~m}$ & bongô & 500 & 2 \\
\hline 631 & $22^{\circ} 42^{\prime} 06,0^{\prime \prime}$ & $040^{\circ} 14^{\prime} 26,0^{\prime \prime}$ & $19 / 05 / 2002$ & oblíquo & $50 \mathrm{~m}$ & bongô & 500 & 2 \\
\hline 623 & $22^{\circ} 36^{\prime} 54,9^{\prime \prime}$ & $09 ' 19,4 "$ & $16 / 05 / 2002$ & oblíquo & 50 & bongô & 500 & 3 \\
\hline 22186 & $22^{\circ} 34^{\prime} 05,0^{\prime \prime}$ & 19'40,0" & $17 / 05 / 2002$ & oblíquo & $600 \mathrm{~m}$ & cilíndrico-cônica & 500 & 1 \\
\hline 692 & 7'35,5" & 9'32,8" & $16 / 05 / 2002$ & oblíquo & $1.000 \mathrm{~m}$ & cilíndrico-cônica & 500 & 1 \\
\hline 7503 & $21^{\circ} 58^{\prime} 31,0^{\prime \prime}$ & $039^{\circ} 50^{\prime 29,7 "}$ & $10 / 10 / 2001$ & oblíquo & $1.000 \mathrm{~m}$ & cilíndrico-cônica & 500 & 2 \\
\hline 22184 & $22^{\circ} 02^{\prime} 35,2^{\prime \prime}$ & $039^{\circ} 43^{\prime} 18,2^{\prime \prime}$ & $04 / 12 / 2002$ & vertical & $700-1.200 m$ & cilíndrico-cônica & 500 & 1 \\
\hline 22182 & $22^{\circ} 39,68^{\prime}$ & $040^{\circ} 03,24^{\prime}$ & $13 / 06 / 2003$ & vertical & $500-1.000 m$ & cilíndrico-cônica & 500 & 1 \\
\hline
\end{tabular}

Referências: Moser et al., 1977; Anderson, 2003; Anderson \& Springer, 2005; Hardy, $2006 a$. 


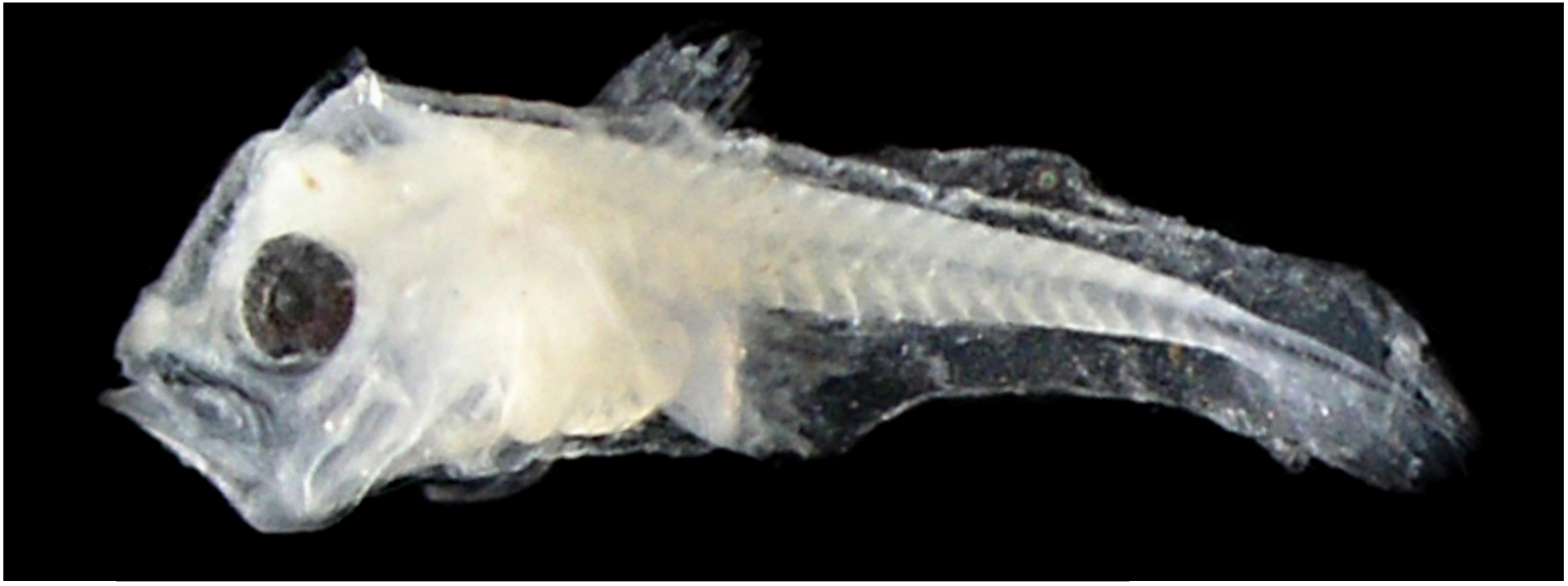

Figura 102 - A: Scorpaenodes sp. DZUFRJ 19364; Pré-flexão; CP 2,7 mm.

\section{Scorpaenodes sp.}

Em Scorpaenodes os espinhos da cabeça estão presentes em larvas em pré-flexão (<3,0 mm). As nadadeiras peitorais são grandes desde a pré-flexão e alcançam a metade das nadadeiras dorsal e anal. A pigmentação das nadadeiras peitorais é limitada à margem distal. Durante a pré-flexão, nas larvas recém eclodidas, há uma série de aproximadamente 12 melanóforos ao longo da linha média ventral da cauda. Estes se tornam internos e não são mais visíveis em larvas em flexão (> 4,0 mm). A flexão da notocorda ocorre entre 4,0 e 5,0 mm. Na pós-flexão possuem uma crista parietal bifurcada posteriormente, com um espinho nucal posterior grande. Não apresentam a capa de melanóforos que recobre a superfície dorso-lateral do intestino. Há uma mancha interna profunda na região dorso-posterior da base da nadadeira peitoral, que aumenta e cobre a superfície dorsal da vesícula gasosa. As larvas de Scorpaenodes diferem das demais, exceto Sebastobolus, por possuírem cristas

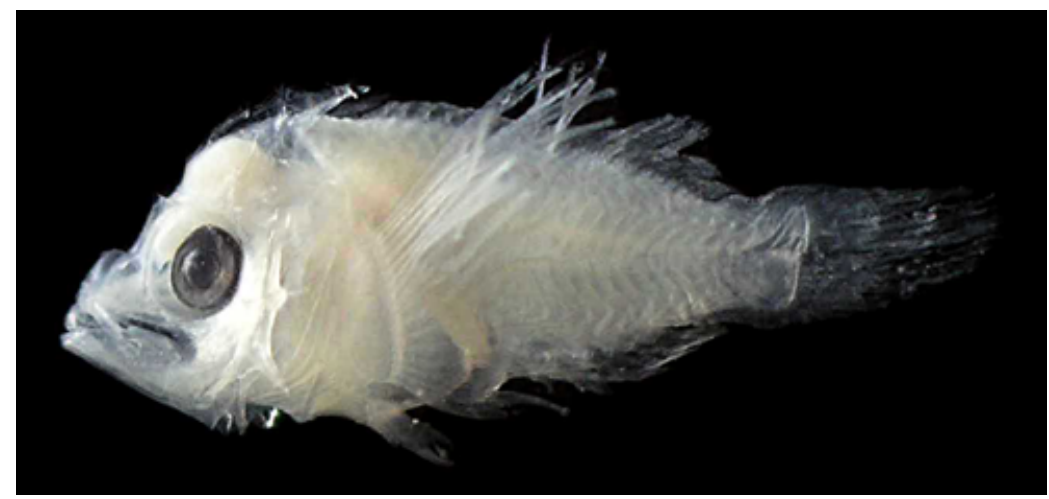

Figura 102 - B: DZUFRJ 11985; Flexão; CP 4,3 mm.

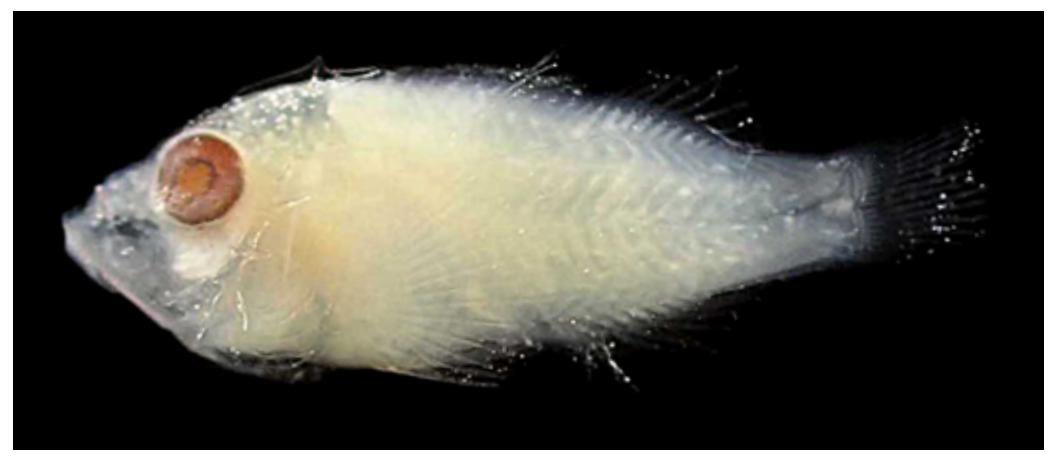

Figura 102 - C: DZUFRJ 19365; Pós-flexão; CP 9,0 mm. parietais proeminentes que terminam em espinhos duplos; o posterior (nucal) é mais proeminente do que o anterior (parietal). Os espinhos da cabeça e do corpo se desenvolvem em tamanhos menores em Scorpaenodes quando comparado a Sebastobolus. O número total de miômeros varia entre 24 e 25.

Tamanho: pré-flexão 2,7-3,0 mm; flexão 4,0-5,0 mm; pós-flexão 5,5-9,0 mm.

Habitat: todas as espécies de Scorpaenodes são marinhas e demersais. No Brasil já foram registradas as espécies Scorpaenodes caribbaeus Meek \& Hildebrand, 1928 e Scorpaenodes tredecimspinosus Metzelaar, 1919. 


\section{Georreferencimento}

\begin{tabular}{|c|c|c|c|c|c|c|c|c|}
\hline DZUFRJ & Latitude (S) & Longitude (W) & Data & $\begin{array}{l}\text { Tipo de } \\
\text { arrasto }\end{array}$ & $\begin{array}{c}\text { Profundidade } \\
\text { de coleta }\end{array}$ & Rede & $\begin{array}{l}\text { Malha } \\
(\mu \mathrm{m})\end{array}$ & $\begin{array}{l}N^{\circ} \text {. de } \\
\text { inds. }\end{array}$ \\
\hline 662 & $22^{\circ} 38^{\prime} 25,0^{\prime \prime}$ & $040^{\circ} 17^{\prime} 41^{\prime \prime}$ & $19 / 05 / 2002$ & oblíquo & $40 \mathrm{~m}$ & bongô & 330 & 1 \\
\hline 539 & $22^{\circ} 34^{\prime} 05,0^{\prime \prime}$ & 040¹9'40" & $17 / 05 / 2002$ & oblíquo & $600 \mathrm{~m}$ & cilíndrico-cônica & 500 & 2 \\
\hline 7525 & $21^{\circ} 57^{\prime} 10,5^{\prime \prime}$ & $039^{\circ} 43^{\prime} 33,3^{\prime \prime}$ & 09/10/2001 & oblíquo & $1.000 \mathrm{~m}$ & cilíndrico-cônica & 500 & 1 \\
\hline 7504 & $21^{\circ} 53^{\prime} 10,4^{\prime \prime}$ & $039^{\circ} 45^{\prime} 49,9^{\prime \prime}$ & $10 / 10 / 2001$ & oblíquo & $1.000 \mathrm{~m}$ & cilíndrico-cônica & 500 & 1 \\
\hline 7523 & $21^{\circ} 58^{\prime} 31,0^{\prime \prime}$ & $039^{\circ} 50^{\prime} 29,7^{\prime \prime}$ & $10 / 10 / 2001$ & oblíquo & $1.000 \mathrm{~m}$ & cilíndrico-cônica & 500 & 1 \\
\hline 7524 & $21^{\circ} 58 ' 31,0^{\prime \prime}$ & $039^{\circ} 50^{\prime} 29,7^{\prime \prime}$ & $10 / 10 / 2001$ & oblíquo & $1.000 \mathrm{~m}$ & cilíndrico-cônica & 500 & 1 \\
\hline 22183 & $22^{\circ} 32^{\prime} 50,0^{\prime \prime}$ & $040^{\circ} 04^{\prime} 09,9^{\prime \prime}$ & $06 / 11 / 2001$ & oblíquo & $1.000 \mathrm{~m}$ & cilíndrico-cônica & 500 & 1 \\
\hline 19365 & $22^{\circ} 31^{\prime} 58,9^{\prime \prime}$ & $040^{\circ} 02^{\prime} 53,4^{\prime \prime}$ & $07 / 11 / 2001$ & oblíquo & $1.000 \mathrm{~m}$ & cilíndrico-cônica & 500 & 1 \\
\hline
\end{tabular}

Referências: Moser et al., 1977; Hardy, $2006 a$. 


\section{ORDEM PERCIFORMES}

A ordem Perciformes é a mais diversa de todas as ordens de peixes e a maior ordem dos vertebrados. Contem 20 subordens, 160 famílias e mais de 10.000 espécies. As características que unem as famílias pertencentes a essa ordem são: presença de espinhos nas nadadeiras dorsal e anal; um espinho e cinco ou menos raios na nadadeira pélvica; ausência de nadadeira adiposa; presença de 17 ou menos raios principais na nadadeira caudal; e presença de quatro arcos branquiais.

Essa ordem é muito bem representada no litoral brasileiro e na área de estudo foi constituída por 26 famílias: Acropomatidae, Serranidae, Symphysanodontidae, Apogonidae, Pomatomidae, Carangidae, Coryphaenidae, Gerreidae, Mullidae, Chaetodontidae, Bramidae, Pomacanthidae, Cirrhitidae, Mugilidae, Pomacentridae, Labridae, Scaridae, Chiasmodontidae, Callionymidae, Gobiidae, Microdesmidae, Acanthuridae, Sphyraenidae, Gempylidae, Scombridae e Nomeidae. 


\section{Família Acropomatidae}

A família Acropomatidae é marinha, bentopelágica e ocorre nos oceanos Atlântico, Índico e Pacífico. Compreende oito gêneros com 31 espécies. Possuem nadadeira dorsal separada em duas partes. A primeira com VII-X espinhos; a segunda pode ter ou não espinho e tem 8-10 raios. A nadadeira anal tem II-III espinhos e 7-9 raios. Possuem 25 vértebras. A região da cabeça tem muitos espinhos bem desenvolvidos na região occipital, supra-ocular, frontal, opercular e pós-temporal. O tamanho dos espinhos da cabeça é uma característica diagnóstica das espécies, assim como o padrão de pigmentação na região dorsal, na base da nadadeira; podendo ou não haver melanóforos no pedúnculo caudal. A porção posterior da cabeça e o intestino possuem muitos pigmentos pequenos e aglomerados.

No Brasil já foram identificadas duas espécies nas fases de larva e adulto: Synagrops bellus (Goode \& Bean, 1896) e Synagrops spinosus Schultz, 1940. Nesse estudo é contemplada a espécie Synagrops spinosus. 


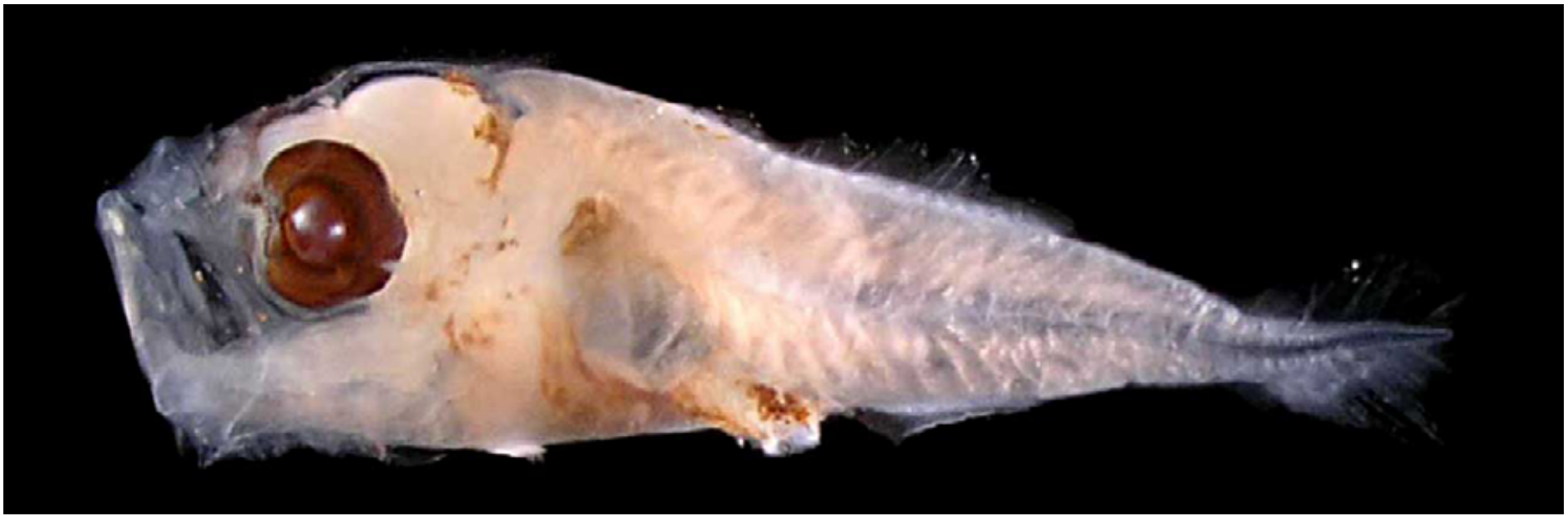

Figura 103 - A: Synagrops spinosus. DZUFRJ 22332; Pré-flexão; CP 4,5mm.

\section{Synagrops spinosus Schultz, 1940}

As larvas têm o corpo fusiforme e comprimido lateralmente. A boca é grande, quase vertical. Os espinhos da cabeça são bem desenvolvidos, principalmente na margem do pré-opérculo e opérculo, quando comparados aos demais representantes desse gênero. Possui crista su-

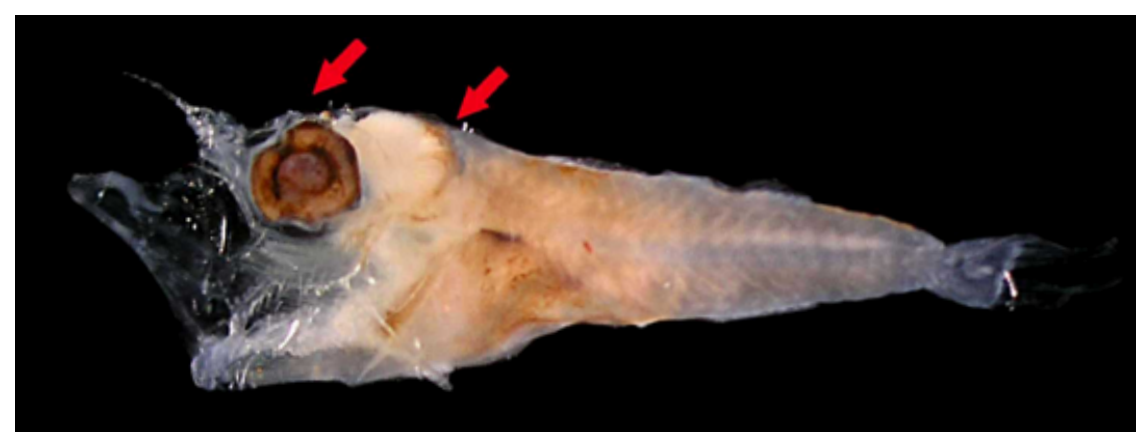

Figura 103 - B: DZUFRJ 22331; Flexão; CP 5,0 mm. praoccipital e frontal grande e serrilhada. Acima dos olhos a crista é menor e serrilhada. A margem do pré-opérculo possui espinhos bem desenvolvidos, serrilhados e com espículas. As larvas em pré-flexão não possuem pigmentos no pedúnculo caudal, mas já possuem muitos pigmentos difusos na parte posterior da cabeça, na região nucal. Após a flexão o pedúnculo caudal apresenta pigmentos cuja concentração aumenta com o desenvolvimento da larva. No corpo a pigmentação concentra-se na base das nadadeiras dorsal e anal. Número total de miômeros: 25.

Tamanho: pré-flexão 4,5 mm; flexão 5,0 mm.

Habitat: espécie marinha, bentopelágica. Ocorre em águas tropicais e subtropicais, na margem da plataforma continental e de ilhas, em profundidades entre 87 e $544 \mathrm{~m}$.

\section{Georreferencimento}

\begin{tabular}{|c|c|c|c|c|c|c|c|c|}
\hline DZUFR & Latitude (S) & Longitude (W) & Data & $\begin{array}{c}\text { Tipo de } \\
\text { arrasto }\end{array}$ & $\begin{array}{c}\text { Profundidade } \\
\text { de coleta }\end{array}$ & Rede & $\begin{array}{c}\text { Malha } \\
\text { ( } \boldsymbol{\mu m})\end{array}$ & $\begin{array}{c}\mathbf{N}^{\circ} \text {. de } \\
\text { inds. }\end{array}$ \\
\hline 22331 & $21^{\circ} 53^{\prime} 10,4^{\prime \prime}$ & $039^{\circ} 45^{\prime} 49,9^{\prime \prime}$ & $10 / 10 / 2001$ & oblíquo & $1.000 \mathrm{~m}$ & cilíndrico-cônica & 500 & 1 \\
\hline 22332 & $22^{\circ} 32^{\prime} 49,0^{\prime \prime}$ & $040^{\circ} 04^{\prime} 20,9^{\prime \prime}$ & $07 / 11 / 2001$ & oblíquo & $1.000 \mathrm{~m}$ & cilíndrico-cônica & 500 & 1 \\
\hline
\end{tabular}

Referências: Heemstra, 2002; Ruiz-Carus, 2006; Fahay, 2007. 


\section{Família Serranidae}

A família Serranidae compreende a maioria dos peixes marinhos de importância comercial e recreativa do mundo. É composta por aproximadamente 64 gêneros e 475 espécies. São os principais habitantes das águas costeiras tropicais, vivendo quase sempre sobre fundos rochosos e coralinos.

As características variam de acordo com a subfamília a que a larva pertence. O desenvolvimento ocorre relativamente rápido, o corpo é comprimido lateralmente, podendo ser moderadamente alongado até muito alto. Os espinhos das nadadeiras podem ser curtos e fracos, ou grandes e serrilhados. Os espinhos presentes no opérculo ou pré-opérculo podem ser reduzidos ou muito distintos e robustos. O padrão de pigmentação varia muito entre as espécies.

No Brasil já foram identificadas 50 espécies. Nesse estudo são contempladas as espécies Dules auriga, Liopropoma carmabi e Pseudogramma gregoryi. 


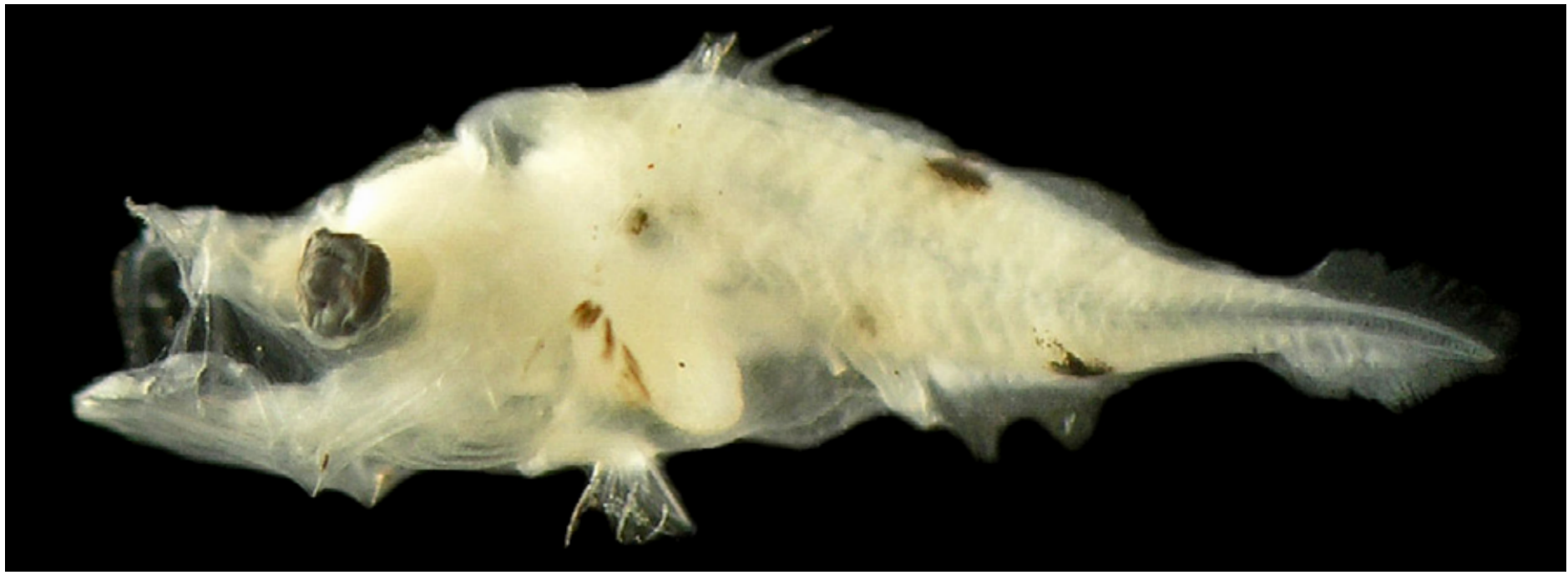

Figura 104 - A: Dules auriga. DZUFRJ 31258; Pré-flexão; CP 4,1mm.

\section{Dules auriga Cuvier, 1829}

As larvas possuem corpo fusiforme e pouco comprimido lateralmente. Existem poucos espinhos na cabeça e na região do opérculo. O terceiro espinho da nadadeira dorsal é longo, mas geralmente é quebrado durante a coleta. Desde a pré-flexão, possui duas grandes manchas de pigmentos dorsais (no final da primeira e da segunda nadadeira dorsal) e ventrais (na base e no fim da nadadeira anal), além de um pequeno pigmento no pedúnculo caudal. Essa pigmentação se torna mais evidente com o desenvolvimento da larva, permanecendo na mesma posição. Presença de pequenos pigmentos nos raios das nadadeiras peitorais, sobre o intestino, na região gular e na região anterior a base da nadadeira pélvica (istmo). Pode apresentar pigmentos na base da notocorda em larvas maiores do que $8,0 \mathrm{~mm}$. As manchas de pigmentos são intensas em algumas partes do corpo (cleitro, ânus, na base da nadadeira anal) e, em alguns casos, no pedúnculo caudal e base da nadadeira dorsal.

Tamanho: pré-flexão 2,0-4,5 mm; flexão 4,0-7,0 mm; pós-flexão 8,0-9,5 mm.

Habitat: espécie marinha e demersal.

Nome vulgar: Mariquita.

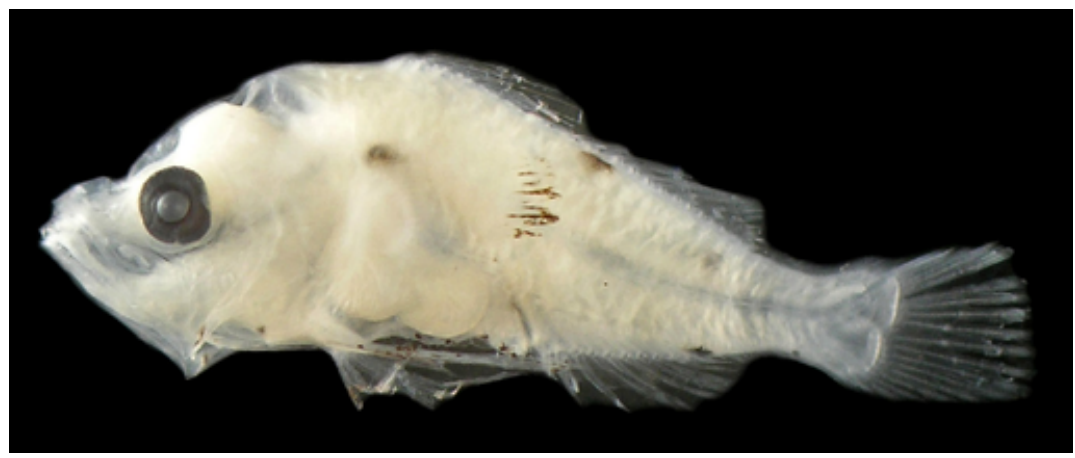

Figura 104 - B: DZUFRJ 31258; Flexão; CP 5,5 mm.

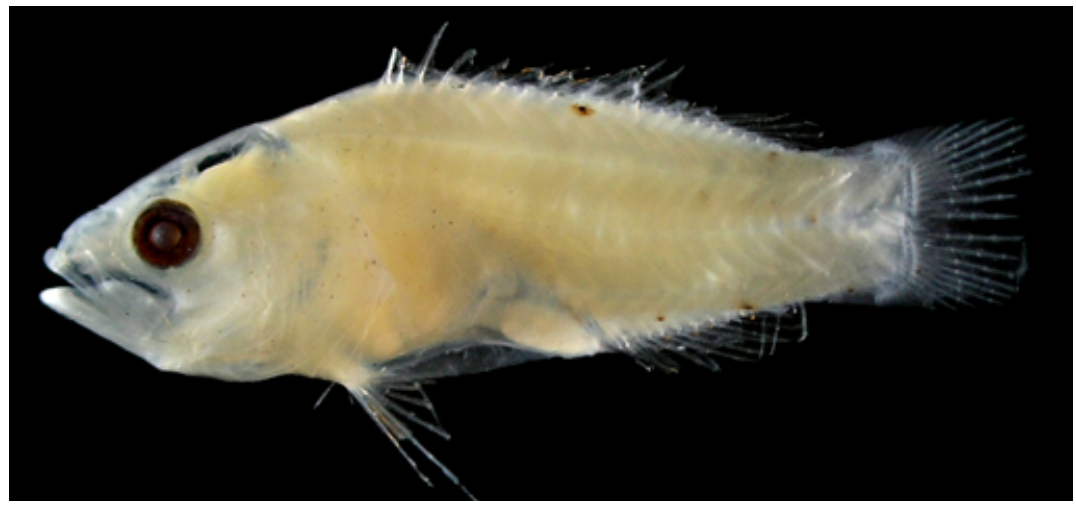

Figura 104 - C: DZUFRJ 586; Pós-flexão; CP 9,5 mm. 


\section{Georreferenciamento}

\begin{tabular}{|c|c|c|c|c|c|c|c|c|}
\hline DZUFRJ & Latitude (S) & Longitude (W) & Data & $\begin{array}{l}\text { Tipo de } \\
\text { arrasto }\end{array}$ & $\begin{array}{c}\text { Profundidade } \\
\text { de coleta }\end{array}$ & Rede & $\begin{array}{c}\text { Malha } \\
(\mu \mathrm{m})\end{array}$ & $\begin{array}{l}N^{\circ} \text {. de } \\
\text { inds. }\end{array}$ \\
\hline 449 & $22^{\circ} 33^{\prime} 47,7^{\prime \prime}$ & $040^{\circ} 12^{\prime} 20,5^{\prime \prime}$ & $17 / 05 / 2002$ & oblíquo & $50 \mathrm{~m}$ & bongô & 500 & 4 \\
\hline 455 & $22^{\circ} 33^{\prime} 37,0^{\prime \prime}$ & $040^{\circ} 19^{\prime} 10,0^{\prime \prime}$ & $17 / 05 / 2002$ & oblíquo & $50 \mathrm{~m}$ & bongô & 330 & 10 \\
\hline 456 & $22^{\circ} 33^{\prime} 45,8^{\prime \prime}$ & $040^{\circ} 13^{\prime} 22,9^{\prime \prime}$ & $17 / 05 / 2002$ & oblíquo & $800 \mathrm{~m}$ & cilíndrico-cônica & 500 & 1 \\
\hline 461 & $22^{\circ} 38^{\prime} 29,0^{\prime \prime}$ & $040^{\circ} 17^{\prime} 40,0^{\prime \prime}$ & $18 / 05 / 2002$ & oblíquo & $800 \mathrm{~m}$ & cilíndrico-cônica & 500 & 4 \\
\hline 518 & $22^{\circ} 34^{\prime} 05,0^{\prime \prime}$ & $040^{\circ} 19^{\prime} 40,0^{\prime \prime}$ & $17 / 05 / 2002$ & oblíquo & $600 \mathrm{~m}$ & cilíndrico-cônica & 500 & 24 \\
\hline 523 & $22^{\circ} 31^{\prime} 27,0^{\prime \prime}$ & $040^{\circ} 16^{\prime} 56,0^{\prime \prime}$ & $17 / 05 / 2002$ & oblíquo & $600 \mathrm{~m}$ & cilíndrico-cônica & 500 & 17 \\
\hline 538 & $22^{\circ} 42^{\prime} 06,0^{\prime \prime}$ & $040^{\circ} 14^{\prime} 26,0^{\prime \prime}$ & $19 / 05 / 2002$ & oblíquo & $50 \mathrm{~m}$ & bongô & 330 & 1 \\
\hline 564 & $22^{\circ} 32^{\prime} 03,0^{\prime \prime}$ & $040^{\circ} 17^{\prime} 21,0^{\prime \prime}$ & $19 / 05 / 2002$ & oblíquo & $30 \mathrm{~m}$ & bongô & 500 & 1 \\
\hline 586 & $22^{\circ} 33^{\prime} 47,7^{\prime \prime}$ & $040^{\circ} 12^{\prime} 20,5^{\prime \prime}$ & $17 / 05 / 2002$ & oblíquo & $50 \mathrm{~m}$ & bongô & 330 & 1 \\
\hline 630 & $22^{\circ} 36^{\prime} 54,9^{\prime \prime}$ & $040^{\circ} 09^{\prime} 19,4^{\prime \prime}$ & $16 / 05 / 2002$ & oblíquo & $50 \mathrm{~m}$ & bongô & 500 & 1 \\
\hline 636 & $22^{\circ} 36^{\prime} 54,9^{\prime \prime}$ & $040^{\circ} 09^{\prime} 19,4^{\prime \prime}$ & $16 / 05 / 2002$ & oblíquo & $50 \mathrm{~m}$ & bongô & 330 & 2 \\
\hline 644 & $22^{\circ} 38^{\prime} 25,0^{\prime \prime}$ & $040^{\circ} 17^{\prime} 41,0^{\prime \prime}$ & $19 / 05 / 2002$ & oblíquo & $40 \mathrm{~m}$ & bongô & 330 & 1 \\
\hline 673 & $22^{\circ} 41^{\prime} 54,7^{\prime \prime}$ & $040^{\circ} 14^{\prime} 04,5^{\prime \prime}$ & $16 / 05 / 2002$ & oblíquo & $1.000 \mathrm{~m}$ & cilíndrico-cônica & 500 & 3 \\
\hline 677 & $22^{\circ} 37^{\prime} 35,5^{\prime \prime}$ & $040^{\circ} 09^{\prime} 32,8^{\prime \prime}$ & $16 / 05 / 2002$ & oblíquo & $1.000 \mathrm{~m}$ & cilíndrico-cônica & 500 & 1 \\
\hline 1358 & $22^{\circ} 02^{\prime} 30,0^{\prime \prime}$ & 03949'41,2" & $12 / 05 / 2002$ & oblíquo & $\begin{array}{c}\text { até a } \\
\text { termoclina }\end{array}$ & bongô & 330 & 1 \\
\hline 19781 & $22^{\circ} 07^{\prime} 58,8^{\prime \prime}$ & $039^{\circ} 49^{\prime} 08,9^{\prime \prime}$ & $01 / 12 / 2002$ & vertical & $0-50 m$ & cilíndrico-cônica & 500 & 1 \\
\hline 22191 & $22^{\circ} 39,68^{\prime}$ & $040^{\circ} 03,24^{\prime}$ & $13 / 06 / 2003$ & vertical & $0-60 m$ & cilíndrico-cônica & 500 & 1 \\
\hline
\end{tabular}

Referências: Figueiredo \& Menezes, 1980; Watson, 1996c; Heemstra \& Randall, 2002; Richards et al., 2006; Fahay, 2007. 


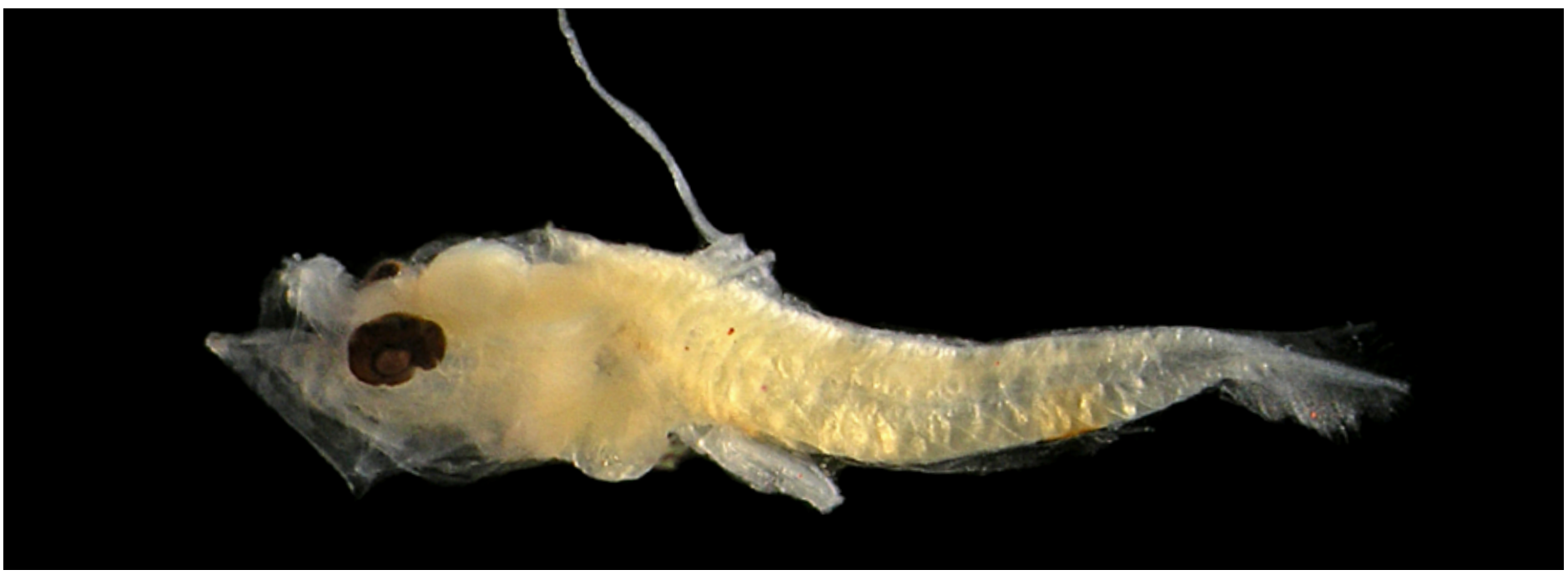

Figura 105 - A: Liopropoma carmabi. DZUFRJ 22488; Pré-flexão; CP 3,5 mm.

\section{Liopropoma carmabi (Randall, 1963)}

Possui nadadeira dorsal dupla, sendo a primeira com oito espinhos e a segunda dorsal 12-13 raios. O segundo e o terceiro espinhos dorsais são longos, com extremidades filamentosas, que se assemeIham a apêndices e normalmente são quebrados durante as coletas. A nadadeira anal tem três espinhos e oito raios. Os pigmentos são encontrados espalhados na cabeça e entre os apêndices da nadadeira dorsal. O pedúnculo caudal é alto.

Tamanho: pré-flexão 3,5 mm; transformação 20,5 $\mathrm{mm}$.

Habitat: espécie marinha, demersal, associada à regiões de recifes, ocorre entre 15 e $70 \mathrm{~m}$ de

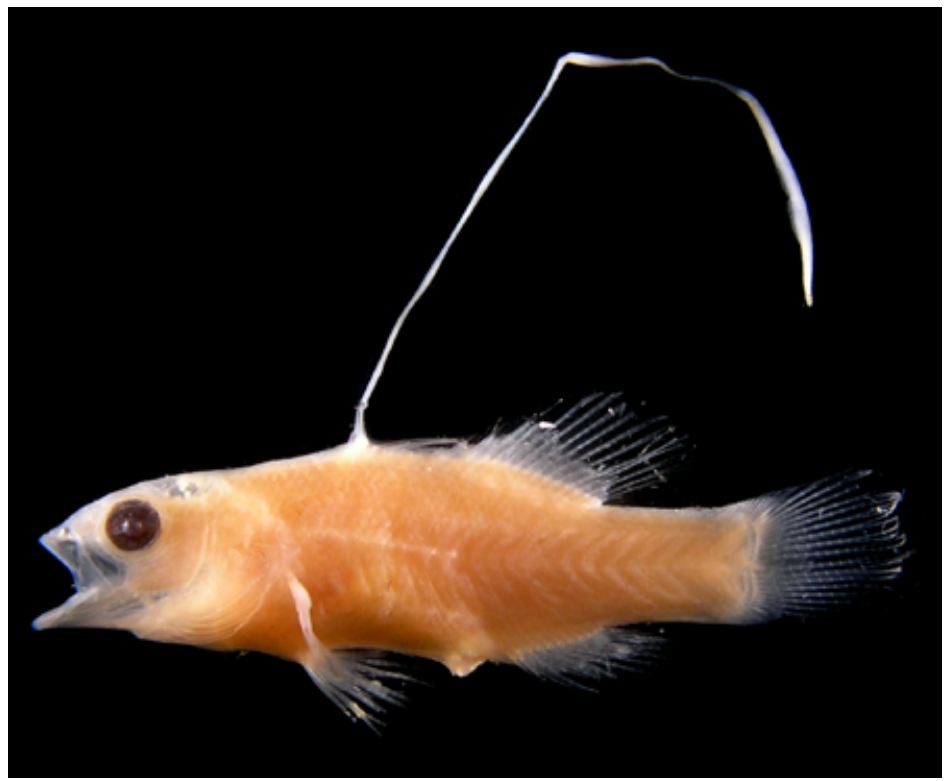

Figura 105 - B: DZUFRJ 5396; Transformação; CP 20,5 mm. profundidade.

Nome vulgar: Mariquita arlequim.

\section{Georreferenciamento}

\begin{tabular}{|c|c|c|c|c|c|c|c|c|}
\hline DZUFR & Latitude (S) & Longitude (W) & Data & $\begin{array}{c}\text { Tipo de } \\
\text { arrasto }\end{array}$ & $\begin{array}{c}\text { Profundidade } \\
\text { de coleta }\end{array}$ & Rede & $\begin{array}{c}\text { Malha } \\
\text { ( } \boldsymbol{\mu m}^{\prime}\end{array}$ & $\begin{array}{c}\mathbf{N}^{\circ} \text {. de } \\
\text { inds. }\end{array}$ \\
\hline 5396 & $22^{\circ} 32^{\prime} 50,0^{\prime \prime}$ & $040^{\circ} 04^{\prime} 09,9^{\prime \prime}$ & $06 / 11 / 2001$ & oblíquo & $1.000 \mathrm{~m}$ & cilíndrico-cônica & 500 & 1 \\
\hline 22488 & $22^{\circ} 42^{\prime} 06,0^{\prime \prime}$ & $040^{\circ} 14^{\prime} 26,0^{\prime \prime}$ & $19 / 05 / 2002$ & oblíquo & $50 \mathrm{~m}$ & bongô & 330 & 1 \\
\hline
\end{tabular}

Referências: Figueiredo \& Menezes, 1980; Watson, 1996c; Heemstra \& Randall, 2002; Richards et al., 2006; Fahay, 2007. 


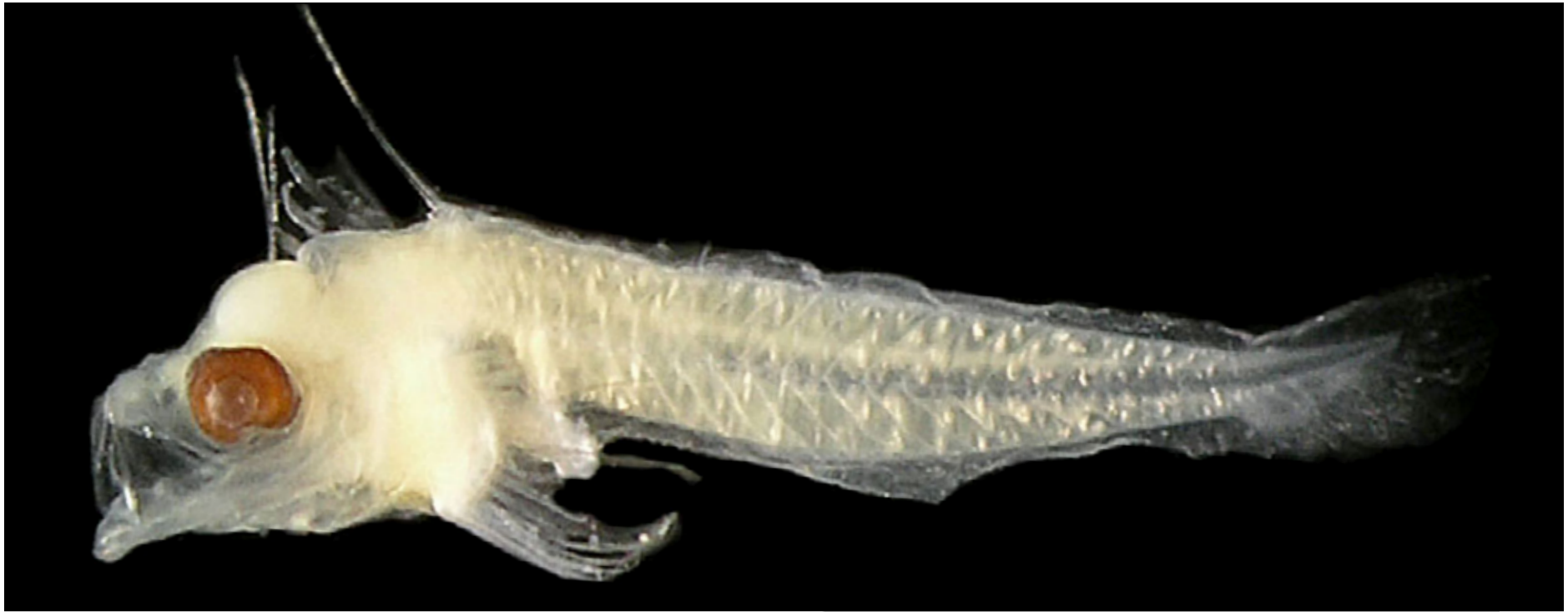

Figura 106 - A: Pseudogramma gregoryi. DZUFRJ 457; Pré-flexão; CP 3,2 mm.

\section{Pseudogramma gregoryi (Breder, 1927)}

Esta espécie é caracterizada por possuir corpo fusiforme e comprimido lateralmente nos estágios inicias de desenvolvimento, ficando mais robusto com o crescimento larval. A nadadeira peitoral tem desenvolvimento precoce, aparecendo desde a pré-flexão, e é bem desenvolvida. O intestino é curto correspondendo a cerca de $25 \%$ CP e a partir do estágio de flexão alcança quase a metade do corpo da larva. Possui VII espinhos na primeira nadadeira dorsal e 18-19 raios na segunda. Apenas o primeiro espinho da primeira dorsal é prolongado, e já está presente desde a pré-flexão. A nadadeira anal é composta por III espinhos e 14-16 raios. O pedúnculo caudal é alto nas larvas em estágio de pós-flexão. Não há pigmentação evidente espalhada pela cabeça ou corpo da larva em todos os estágios de desenvolvimento. Número total de vértebras: 26.

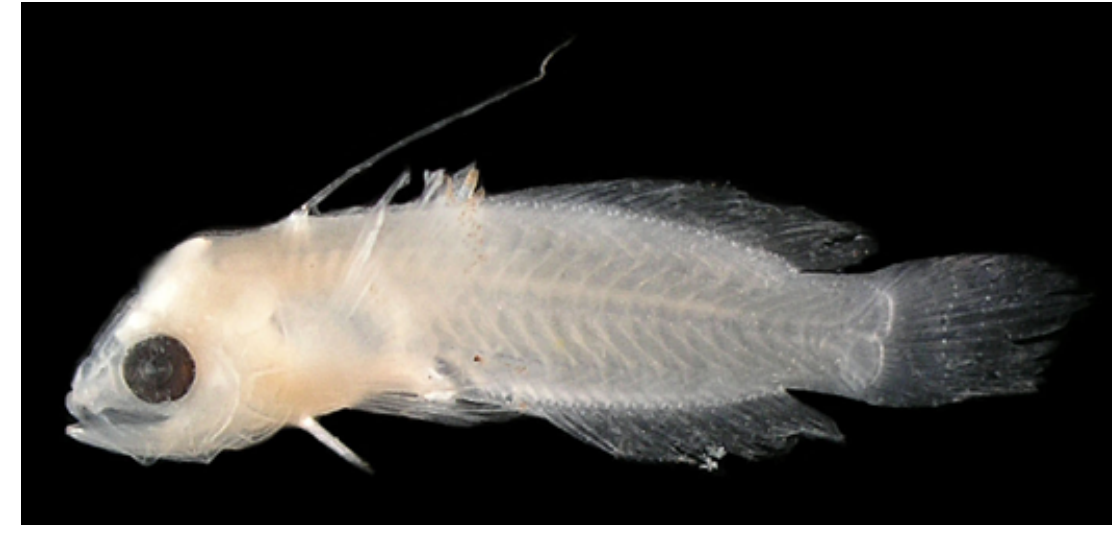

Figura 106 - B: DZUFRJ 7480; Flexão; CP 7,0 mm.

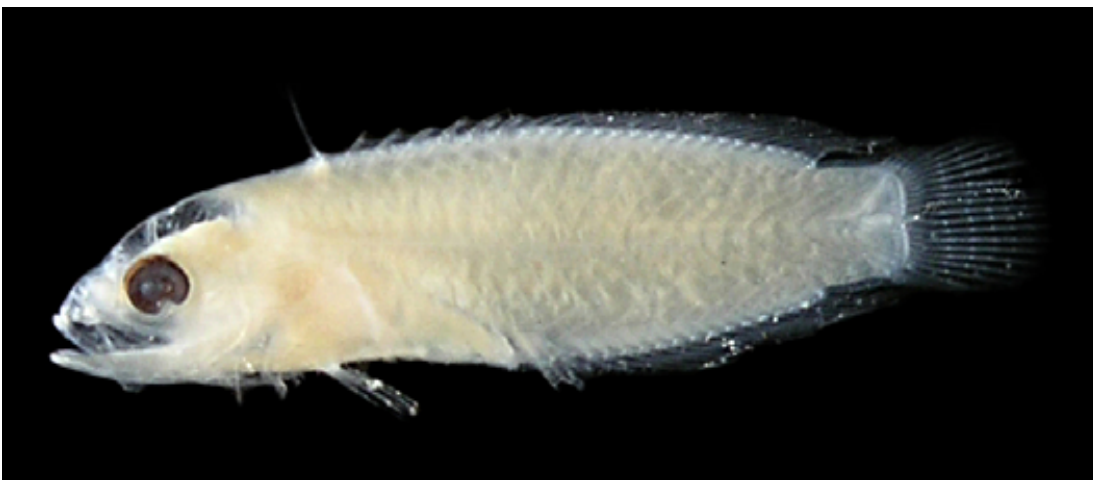

Figura 106 - C: DZUFRJ 22484; Pós-flexão; CP 9,2 mm.

Tamanho: pré-flexão 2,2-4,0 mm; flexão 4,5-7,0 mm; pós-flexão 8,5-9,2 mm.

Habitat: espécie marinha, demersal, associada a formações coralinas. Ocorre em águas tropicais até $61 \mathrm{~m}$ de profundidade.

Nome vulgar: Sabãozinho do alto. 


\section{Georreferenciamento}

\begin{tabular}{|c|c|c|c|c|c|c|c|c|}
\hline DZUFRJ & Latitude (S) & Longitude (W) & Data & $\begin{array}{l}\text { Tipo de } \\
\text { arrasto }\end{array}$ & $\begin{array}{c}\text { Profundidade } \\
\text { de coleta }\end{array}$ & Rede & $\begin{array}{c}\text { Malha } \\
(\mu \mathrm{m})\end{array}$ & $\begin{array}{l}N^{\circ} \text {. de } \\
\text { inds. }\end{array}$ \\
\hline 354 & $22^{\circ} 42^{\prime} 06,0^{\prime \prime}$ & $040^{\circ} 14^{\prime} 26,0^{\prime \prime}$ & $19 / 05 / 2002$ & oblíquo & $50 \mathrm{~m}$ & bongô & 330 & 1 \\
\hline 365 & $22^{\circ} 41^{\prime} 54,7^{\prime \prime}$ & $040^{\circ} 14^{\prime} 04,5^{\prime \prime}$ & $16 / 05 / 2002$ & oblíquo & $1.000 \mathrm{~m}$ & cilíndrico-cônica & 500 & 1 \\
\hline 457 & $22^{\circ} 33^{\prime} 37,0^{\prime \prime}$ & $040^{\circ} 19^{\prime} 10,0^{\prime \prime}$ & $17 / 05 / 2002$ & oblíquo & $50 \mathrm{~m}$ & bongô & 500 & 1 \\
\hline 1190 & $22^{\circ} 07^{\prime} 29,0^{\prime \prime}$ & $039^{\circ} 06^{\prime} 23,5^{\prime \prime}$ & $10 / 05 / 2002$ & oblíquo & $1.000 \mathrm{~m}$ & cilíndrico-cônica & 500 & 1 \\
\hline 5397 & $22^{\circ} 32^{\prime} 50,0^{\prime \prime}$ & $040^{\circ} 04^{\prime} 09,9^{\prime \prime}$ & $06 / 11 / 2001$ & oblíquo & $1.000 \mathrm{~m}$ & cilíndrico-cônica & 500 & 1 \\
\hline 5398 & $22^{\circ} 32^{\prime} 50,0^{\prime \prime}$ & $040^{\circ} 04^{\prime} 09,9^{\prime \prime}$ & $06 / 11 / 2001$ & oblíquo & $1.000 \mathrm{~m}$ & cilíndrico-cônica & 500 & 1 \\
\hline 7482 & $21^{\circ} 54^{\prime} 36,5^{\prime \prime}$ & $039^{\circ} 45^{\prime} 20,0^{\prime \prime}$ & $10 / 10 / 2001$ & oblíquo & $1.000 \mathrm{~m}$ & cilíndrico-cônica & 500 & 1 \\
\hline 7485 & $21^{\circ} 54^{\prime} 36,5^{\prime \prime}$ & $039^{\circ} 45^{\prime} 20,0^{\prime \prime}$ & $10 / 10 / 2001$ & oblíquo & $1.000 \mathrm{~m}$ & cilíndrico-cônica & 500 & 1 \\
\hline 7484 & $21^{\circ} 53^{\prime} 10,4^{\prime \prime}$ & $039^{\circ} 45^{\prime} 49,9^{\prime \prime}$ & 10/10/2001 & oblíquo & $1.000 \mathrm{~m}$ & cilíndrico-cônica & 500 & 1 \\
\hline 7481 & $21^{\circ} 53^{\prime} 10,4^{\prime \prime}$ & $039^{\circ} 45^{\prime} 49,9^{\prime \prime}$ & $10 / 10 / 2001$ & oblíquo & $1.000 \mathrm{~m}$ & cilíndrico-cônica & 500 & 1 \\
\hline 7480 & $21^{\circ} 53^{\prime} 10,4^{\prime \prime}$ & $039^{\circ} 45^{\prime} 49,9^{\prime \prime}$ & $10 / 10 / 2001$ & oblíquo & $1.000 \mathrm{~m}$ & cilíndrico-cônica & 500 & 1 \\
\hline 7486 & $21^{\circ} 58 ' 31,0^{\prime \prime}$ & 039०50'29,7" & $10 / 10 / 2001$ & oblíquo & $1.000 \mathrm{~m}$ & cilíndrico-cônica & 500 & 1 \\
\hline 7483 & $21^{\circ} 58^{\prime} 31,0^{\prime \prime}$ & $039^{\circ} 50^{\prime} 29,7^{\prime \prime}$ & $10 / 10 / 2001$ & oblíquo & $1.000 \mathrm{~m}$ & cilíndrico-cônica & 500 & 2 \\
\hline 22188 & $22^{\circ} 37^{\prime} 21,9^{\prime \prime}$ & $040^{\circ} 02^{\prime} 42,5^{\prime \prime}$ & $08 / 12 / 2002$ & vertical & $0-50 m$ & cilíndrico-cônica & 200 & 1 \\
\hline 22485 & $22^{\circ} 43^{\prime} 50,4^{\prime \prime}$ & $040^{\circ} 02^{\prime} 42,5^{\prime \prime}$ & $07 / 12 / 2002$ & vertical & $0-50 m$ & cilíndrico-cônica & 200 & 1 \\
\hline
\end{tabular}

Referências: Figueiredo \& Menezes, 1980; Watson, 1996c; Heemstra \& Randall, 2002; Richards et al., 2006; Fahay, 2007. 


\section{Família Symphysanodontidae}

A família Symphysanodontidae é marinha e ocorre nos oceanos Atlântico, Índico e Pacífico. Compreende um gênero com seis espécies. Os adultos são pequenos, podendo ocorrer desde 80 a $700 \mathrm{~m}$ de profundidade.

O gênero Symphysanodon foi considerado por vários autores como membro das famílias Acropomatidae, Lutjanidae ou Serranidae devido a presença de espinhos muito desenvolvidos na cabeça, porém não apresentava características específicas dessas famílias. Os representantes desse gênero possuem o corpo lateralmente comprimido, cabeça grande e larga e olhos redondos. O intestino alcança mais de $50 \%$ do comprimento padrão da larva. As espécies podem ser separadas pelo padrão dos espinhos cefálicos, pela pigmentação e, principalmente, pelas características merísticas dos elementos das nadadeiras.

No Brasil essa família nunca tinha sido registrada, sendo uma nova ocorrência. Nesse estudo é contemplada a espécie Symphysanodon sp. 


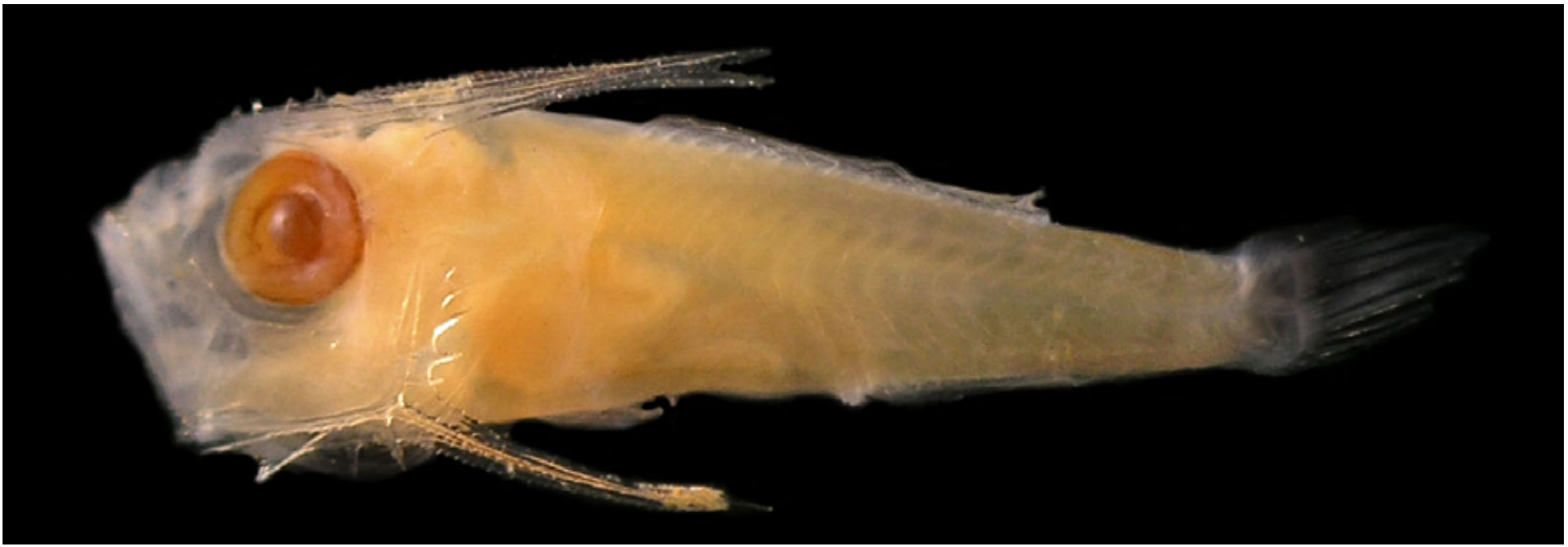

Figura 107 - A: Symphysanodon sp. DZUFRJ 21382; Pós-flexão; CP 7,8 mm.

\section{Symphysanodon sp.}

As larvas de Symphysanodon possuem o corpo lateralmente comprimido, cabeça grande e larga, e olhos redondos. São caracterizadas pelos grandes pares de espinhos serriIhados frontais na cabeça e espinhos menores na região do pré-opérculo. No estágio de pós-flexão, o intestino alcança mais de $50 \%$ do comprimento padrão da larva. Nadadeira dorsal: VIII,11; nadadeira anal: III,7. As larvas encontradas nesse estudo estavam com pigmentação pouco preservada, mas foi possível visualizar alguns melanóforos nas bases das nadadeiras dorsal e anal, além do

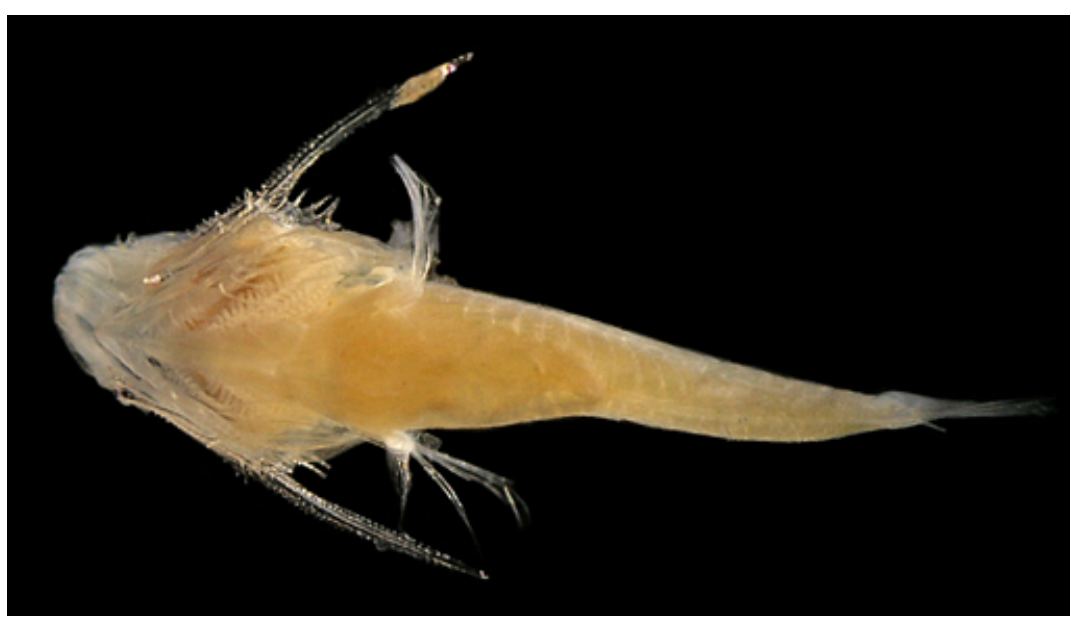

Figura 107 - B: Vista ventral dos espinhos da cabeça. pedúnculo caudal (dorsal e ventralmente). Número total de miômeros: 25.

Tamanho: pós-flexão 7,6-8,8 mm.

Habitat: vive associada ao fundo e é encontrada ao longo da plataforma continental e talude continental superior ou ainda ao redor de ilhas.

\section{Georreferenciamento}

\begin{tabular}{|c|c|c|c|c|c|c|c|c|}
\hline DZUFRJ & Latitude (S) & Longitude (W) & Data & $\begin{array}{c}\text { Tipo de } \\
\text { arrasto }\end{array}$ & $\begin{array}{c}\text { Profundidade } \\
\text { de coleta }\end{array}$ & Rede & $\begin{array}{c}\text { Malha } \\
\text { ( } \boldsymbol{\mu m})\end{array}$ & $\begin{array}{c}\text { No. de } \\
\text { inds. }\end{array}$ \\
\hline 21382 & $22^{\circ} 32^{\prime} 50,0^{\prime \prime}$ & $040^{\circ} 04^{\prime} 09,9^{\prime \prime}$ & $06 / 11 / 2001$ & oblíquo & $1.000 \mathrm{~m}$ & cilíndrico-cônica & 500 & 2 \\
\hline
\end{tabular}

Referências: Leis \& Trnski, 2000; Menezes et al., 2003; Anderson, 2003; Anderson \& Springer, 2005; Hardy, 2006b; Fahay, 2007; Froese \& Pauly, 2014. 


\section{Família Apogonidae}

A família Apogonidae ocorre nos oceanos Atlântico, Índico e Pacífico. Compreende aproximadamente 23 gêneros e 273 espécies. Os membros da família Apogonidae vivem associados a formações coralinas e ocorrem em mares tropicais e subtropicais, sendo que algumas espécies vivem em água doce e salobra. Possuem as nadadeiras dorsais separadas, corpo alto na porção anterior e o pedúnculo caudal é longo e estreito. A identificação das espécies se baseia principalmente no número de rastros branquiais, número de raios da nadadeira peitoral e no padrão de pigmentação.

No Brasil já foram identificadas oito espécies nas fases de larva e adulto. Nesse estudo são contempladas as espécies Apogon sp. e Astrapogon sp. 


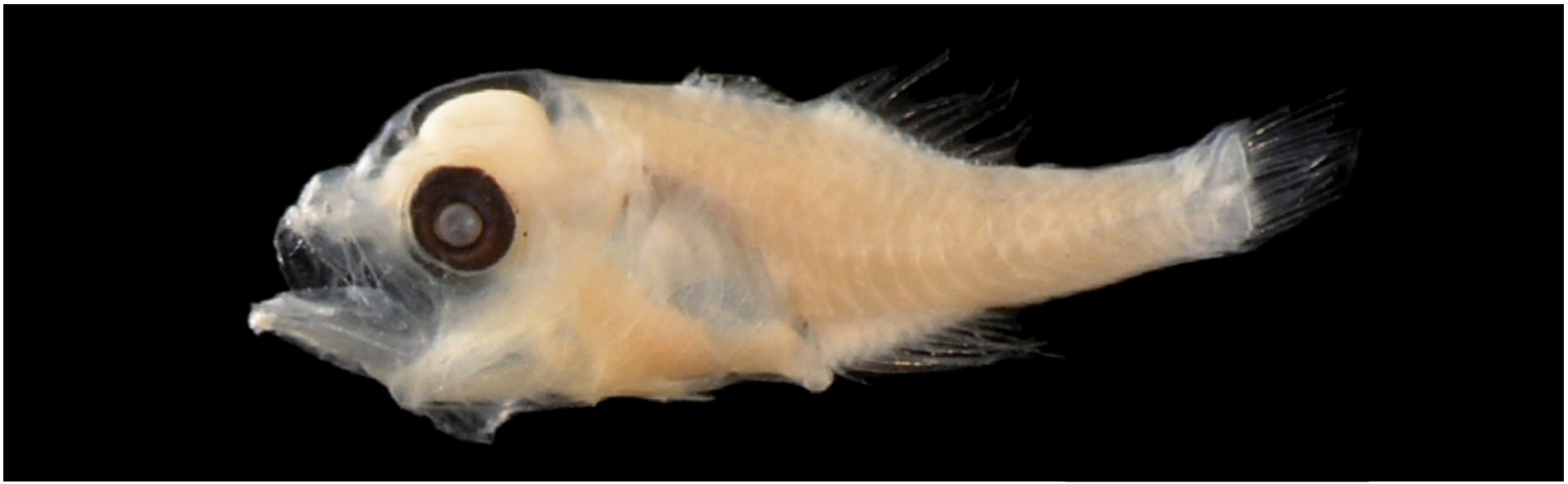

Figura 108 - A: Apogon sp. A. DZUFRJ 13958; Flexão; CP 3,5 mm.

\section{Apogon sp.}

As larvas de Apogon possuem a margem do pré-opérculo pouco serrilhada. Têm nadadeiras dorsais espaçadas, pouca pigmentação espalhada pelo corpo e nos raios das nadadeiras, principalmente na pélvica. A pigmentação se concentra na cabeça e próximo aos olhos e opérculo, além de pequenas manchas na base das

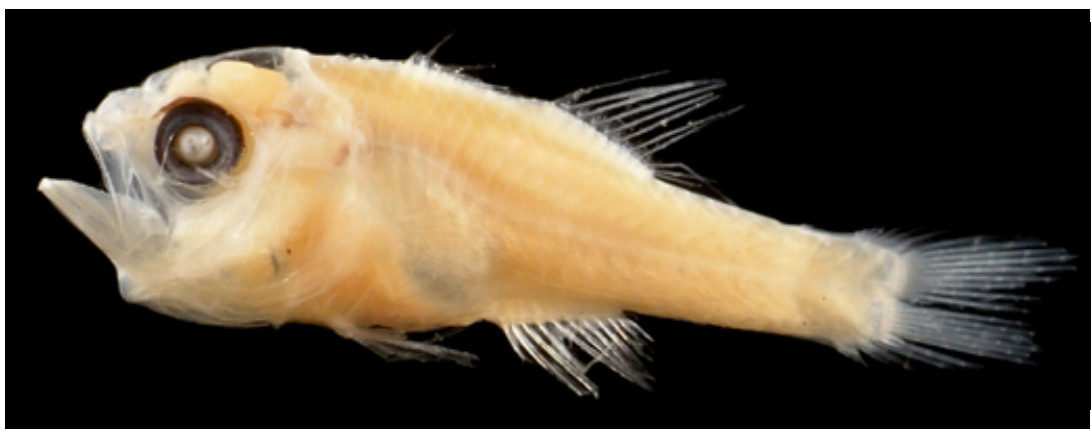

Figura 108 - B: DZUFRJ 14132; Pós-flexão; CP 6,2 mm. nadadeiras dorsal e caudal. Esse padrão de pigmentação e a contagem dos rastros branquiais possibilitam a identificação das espécies. A pigmentação das larvas utilizadas nesse estudo estava pouco preservada, o que impossibilitou a identificação até espécie. Número total de miômeros: 24 . No Brasil, foram registradas as espécies: Apogon americanus Castelnau, 1855; Apogon planifrons Longley \& Hildebrand, 1940; Apogon pseudomaculatus Longley, 1932 e Apogon quadrisquamatus Longley, 1934.

Tamanho: flexão 3,5 mm; pós-flexão 6,0-6,5 mm.

Habitat: todas as espécies de Apogon são demersais, com hábitos noturnos. São tipicamente associadas a formações coralinas e cavernas.

\section{Georreferenciamento}

\begin{tabular}{|c|c|c|c|c|c|c|c|c|}
\hline DZUFRJ & Latitude (S) & Longitude (W) & Data & $\begin{array}{c}\text { Tipo de } \\
\text { arrasto }\end{array}$ & $\begin{array}{c}\text { Profundidade } \\
\text { de coleta }\end{array}$ & Rede & $\begin{array}{c}\text { Malha } \\
\text { ( } \boldsymbol{\mu m})\end{array}$ & $\begin{array}{c}\mathbf{N}^{\circ} \text {. de } \\
\text { inds. }\end{array}$ \\
\hline 378 & $22^{\circ} 33^{\prime} 45,8^{\prime \prime}$ & $040^{\circ} 13^{\prime} 22,9^{\prime \prime}$ & $17 / 05 / 2002$ & oblíquo & $800 \mathrm{~m}$ & cilíndrico-cônica & 500 & 1 \\
\hline 389 & $22^{\circ} 37^{\prime} 35,5^{\prime \prime}$ & $040^{\circ} 09^{\prime} 32,8^{\prime \prime}$ & $16 / 05 / 2002$ & oblíquo & $1.000 \mathrm{~m}$ & cilíndrico-cônica & 500 & 1 \\
\hline 400 & $22^{\circ} 31^{\prime} 27,0^{\prime \prime}$ & $040^{\circ} 16^{\prime} 56,0^{\prime \prime}$ & $17 / 05 / 2002$ & oblíquo & $600 \mathrm{~m}$ & cilíndrico-cônica & 500 & 1 \\
\hline 401 & $22^{\circ} 41^{\prime} 54,7^{\prime \prime}$ & $040^{\circ} 14^{\prime} 04,5^{\prime \prime}$ & $16 / 05 / 2002$ & oblíquo & $1.000 \mathrm{~m}$ & cilíndrico-cônica & 500 & 1 \\
\hline 404 & $22^{\circ} 33^{\prime} 47,7^{\prime \prime}$ & $040^{\circ} 12^{\prime} 20,5^{\prime \prime}$ & $17 / 05 / 2002$ & oblíquo & $50 \mathrm{~m}$ & bongô & 330 & 2 \\
\hline
\end{tabular}

Referências: Figueiredo \& Menezes, 1980; Lara, 2006a; Fahay, 2007. 


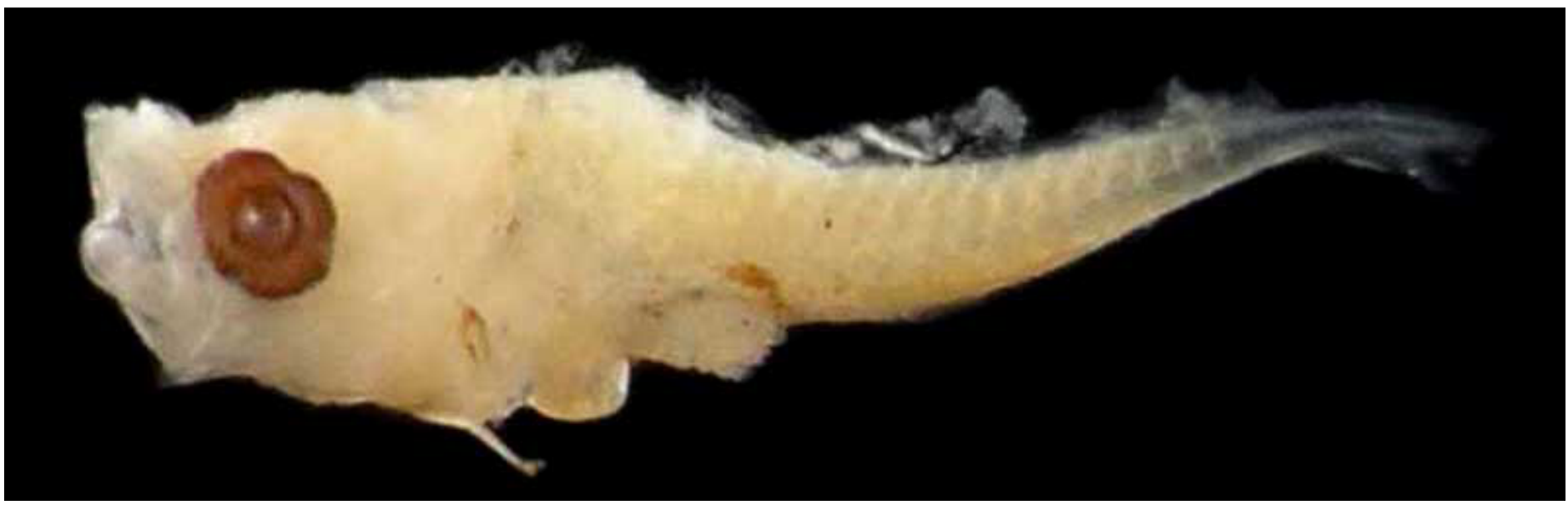

Figura 109 - A: Astrapogon sp. DZUFRJ 403; Pré-flexão; CP 2,4 mm.

\section{Astrapogon sp.}

As larvas deste gênero tem a margem do pré-opérculo lisa. A partir da flexão as larvas de Astrapogon possuem melanóforos grandes e estrelados na cabeça e espalhados pelo corpo, diferente do observado em Apogon. A membrana entre os espinhos das nadadeiras dorsal e pélvica é pigmentada. Com o desenvolvimento larval, os melanóforos tendem a se espalhar por todo corpo, tornando-se mais intensos. A pigmentação das lar-

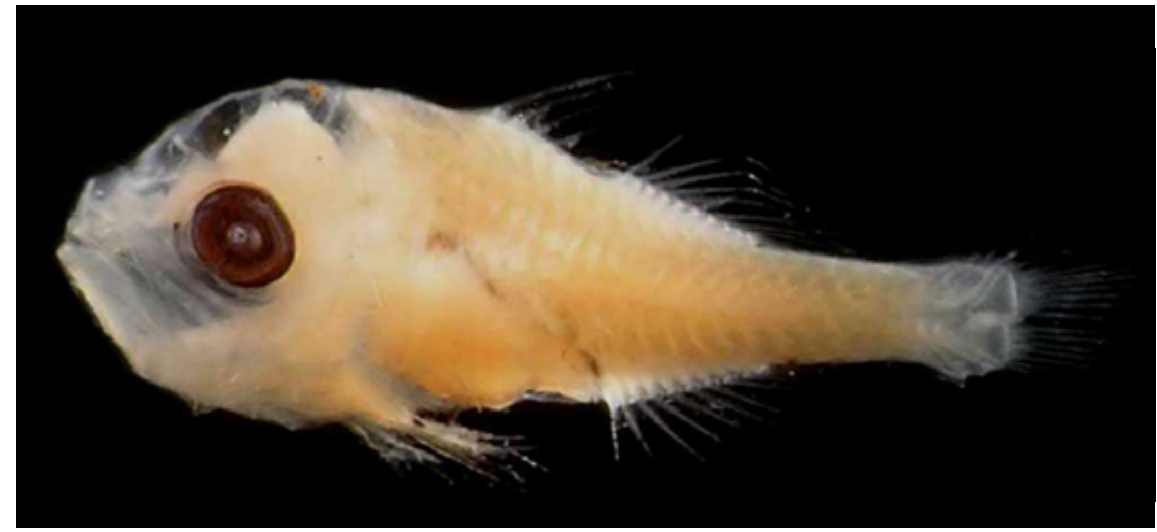

Figura 109 - B: DZUFRJ 1696; Flexão; CP 4,0 mm. vas em pré-flexão e flexão não estava bem preservada, o que impossibilitou a identificação até espécie. Número total de miômeros: 24.

Tamanho: pré-flexão 2,4-3,0 mm; flexão 4,0-5,5 mm.

Habitat: todas as espécies de Astapogon são demersais e tipicamente associadas a formações coralinas e cavernas.

Nome vulgar: Totó pintadinho.

\section{Georreferenciamento}

\begin{tabular}{|c|c|c|c|c|c|c|c|c|}
\hline DZUFR & Latitude (S) & Longitude (W) & Data & $\begin{array}{c}\text { Tipo de } \\
\text { arrasto }\end{array}$ & $\begin{array}{c}\text { Profundidade } \\
\text { de coleta }\end{array}$ & Rede & $\begin{array}{c}\text { Malha } \\
\text { ( } \boldsymbol{\mu m})\end{array}$ & $\begin{array}{c}\mathbf{N}^{\circ} \text {. de } \\
\text { inds. }\end{array}$ \\
\hline 386 & $22^{\circ} 33^{\prime} 37,0^{\prime \prime}$ & $040^{\circ} 19^{\prime} 10,0^{\prime \prime}$ & $17 / 05 / 2002$ & oblíquo & $50 \mathrm{~m}$ & bongô & 500 & 2 \\
\hline 402 & $22^{\circ} 33^{\prime} 47,7^{\prime \prime}$ & $040^{\circ} 12^{\prime} 20,5^{\prime \prime}$ & $17 / 05 / 2002$ & oblíquo & $50 \mathrm{~m}$ & bongô & 500 & 2 \\
\hline 403 & $22^{\circ} 34^{\prime} 05,0^{\prime \prime}$ & $040^{\circ} 19^{\prime} 40,0^{\prime \prime}$ & $17 / 05 / 2002$ & oblíquo & $600 \mathrm{~m}$ & cilíndrico-cônica & 500 & 3 \\
\hline 1230 & $22^{\circ} 02^{\prime} 30,0^{\prime \prime}$ & $039^{\circ} 49^{\prime} 41,2^{\prime \prime}$ & $12 / 05 / 2002$ & oblíquo & $1.000 \mathrm{~m}$ & cilíndrico-cônica & 500 & 1 \\
\hline 1345 & $22^{\circ} 06^{\prime} 52,3^{\prime \prime}$ & $039^{\circ} 48^{\prime} 46,2^{\prime \prime}$ & $11 / 05 / 2002$ & oblíquo & até a termoclina & bongô & 330 & 1 \\
\hline
\end{tabular}

Referências: Figueiredo \& Menezes, 1980; Lara, 2006a; Fahay, 2007. 


\section{Família Pomatomidae}

A família Pomatomidae é mono-específica representada por Pomatomus saltatrix. Essa espécie é pelágica, encontrada em diversas áreas do mundo, exceto no Pacífico leste. Utiliza águas costeiras e regiões estuarinas para reprodução. 


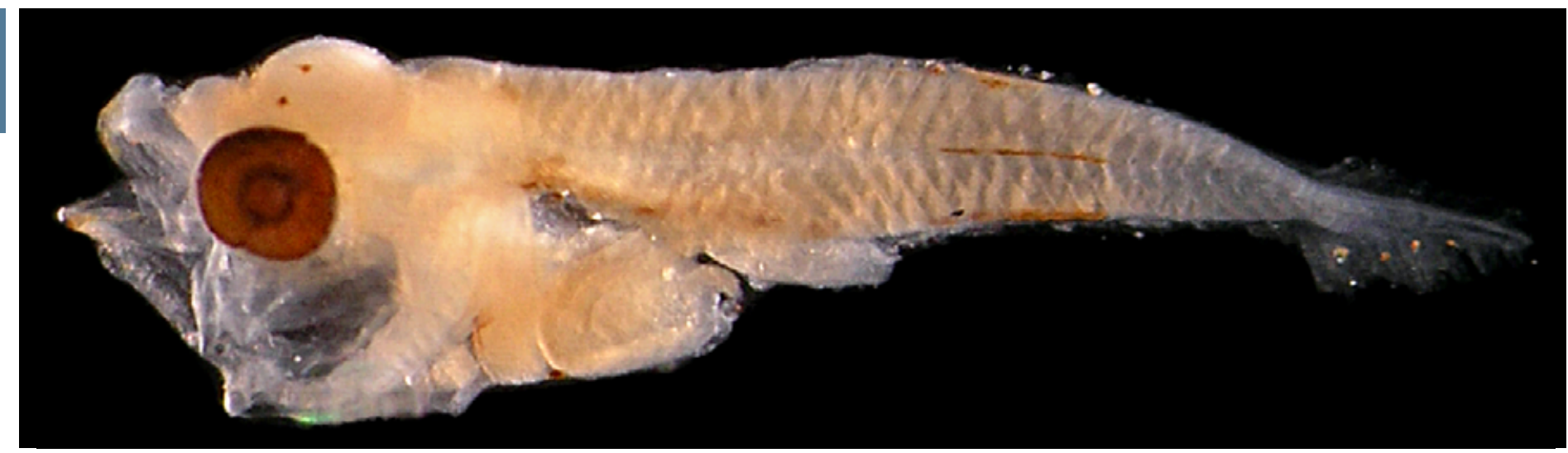

Figura 110 - A: Pomatomus saltatrix. DZUFRJ 5498; Pré-flexão; CP 3,4 mm.

\section{Pomatomus saltatrix (Linnaeus, 1766)}

As larvas possuem o corpo fusiforme (26 miômeros). O intestino é curto, alcançando aproximadamente $50 \%$ do comprimento padrão. Pequenos espinhos são encontrados na margem posterior do pré-opérculo. Essa espécie é caracterizada pelos melanóforos presentes

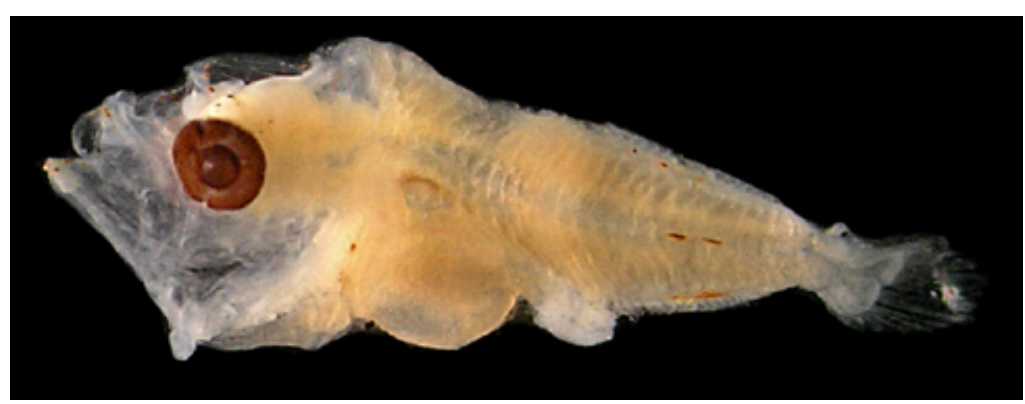

Figura 110 - B: DZUFRJ 7146; Flexão; CP 4,1 mm. na cabeça, nas regiões dorsal, ventral e na linha lateral do corpo, desde a pré-flexão até a pós-flexão. Há pigmentos também sobre a massa visceral, logo abaixo da base da nadadeira peitoral, que ficam menos intensos com o desenvolvimento larval. As duas nadadeiras dorsais são separadas, com VII-VIII, 23-28. A nadadeira anal é formada por II-III, 23-27.

Tamanho: pré-flexão 2,2-4,0 mm; flexão 4,1-4,2 mm.

Habitat: espécie costeira, pelágica, podendo ser encontrada em águas da plataforma continental, em profundidades de até 200 m, além de baías e estuários.

Nome vulgar: Enchova.

\section{Georreferenciamento}

\begin{tabular}{|c|c|c|c|c|c|c|c|c|}
\hline DZUFRJ & Latitude (S) & Longitude (W) & Data & $\begin{array}{l}\text { Tipo de } \\
\text { arrasto }\end{array}$ & $\begin{array}{l}\text { Profundidade } \\
\text { de coleta }\end{array}$ & Rede & $\begin{array}{l}\text { Malha } \\
\text { ( } \mu \mathrm{m})\end{array}$ & $\begin{array}{l}N^{\circ} \text {. de } \\
\text { inds. }\end{array}$ \\
\hline 5495 & $22^{\circ} 32^{\prime} 49,0^{\prime \prime}$ & $040^{\circ} 04^{\prime} 20,9^{\prime \prime}$ & $07 / 11 / 2001$ & oblíquo & $1.000 \mathrm{~m}$ & cilíndrico-cônica & 500 & 1 \\
\hline 5496 & $22^{\circ} 31^{\prime} 40,9^{\prime \prime}$ & $040^{\circ} 02^{\prime} 39,6^{\prime \prime}$ & $07 / 11 / 2001$ & oblíquo & $1.000 \mathrm{~m}$ & cilíndrico-cônica & 500 & 10 \\
\hline 5497 & $22^{\circ} 32^{\prime} 50,0^{\prime \prime}$ & $040^{\circ} 04^{\prime} 09,9^{\prime \prime}$ & $06 / 11 / 2001$ & oblíquo & $1.000 \mathrm{~m}$ & cilíndrico-cônica & 500 & 2 \\
\hline 5498 & $22^{\circ} 31^{\prime} 40,9^{\prime \prime}$ & $040^{\circ} 02^{\prime} 39,6^{\prime \prime}$ & $07 / 11 / 2001$ & oblíquo & $1.000 \mathrm{~m}$ & cilíndrico-cônica & 500 & 3 \\
\hline 5538 & $22^{\circ} 31^{\prime} 58,9^{\prime \prime}$ & $040^{\circ} 02^{\prime} 53,4^{\prime \prime}$ & $07 / 11 / 2001$ & oblíquo & $1.000 \mathrm{~m}$ & cilíndrico-cônica & 500 & 1 \\
\hline 5543 & $22^{\circ} 32^{\prime} 49,0^{\prime \prime}$ & $040^{\circ} 04^{\prime} 20,9^{\prime \prime}$ & $07 / 11 / 2001$ & oblíquo & $1.000 \mathrm{~m}$ & cilíndrico-cônica & 500 & 3 \\
\hline 5548 & $22^{\circ} 31^{\prime} 58,9^{\prime \prime}$ & $040^{\circ} 02^{\prime} 53,4^{\prime \prime}$ & $07 / 11 / 2001$ & oblíquo & $1.000 \mathrm{~m}$ & cilíndrico-cônica & 500 & 1 \\
\hline 7374 & 215'10,4" & $039^{\circ} 45^{\prime} 49,9^{\prime \prime}$ & 10/10/2001 & oblíquo & $1.000 \mathrm{~m}$ & cilíndrico-cônica & 500 & 1 \\
\hline 7375 & 2158'31,0" & $039^{\circ} 50^{\prime} 29,7^{\prime \prime}$ & 10/10/2001 & oblíquo & $1.000 \mathrm{~m}$ & cilíndrico-cônica & 500 & 2 \\
\hline 7376 & $21^{\circ} 54 ' 36,5^{\prime \prime}$ & $039^{\circ} 45^{\prime} 20,0^{\prime \prime}$ & 10/10/2001 & oblíquo & $1.000 \mathrm{~m}$ & cilíndrico-cônica & 500 & 1 \\
\hline 7377 & $21^{\circ} 54^{\prime} 36,5^{\prime \prime}$ & $039^{\circ} 45^{\prime} 20,0^{\prime \prime}$ & $10 / 10 / 2001$ & oblíquo & $1.000 \mathrm{~m}$ & cilíndrico-cônica & 500 & 1 \\
\hline 7378 & $21^{\circ} 53^{\prime} 10,4^{\prime \prime}$ & $039^{\circ} 45^{\prime} 49,9^{\prime \prime}$ & $10 / 10 / 2001$ & oblíquo & $1.000 \mathrm{~m}$ & cilíndrico-cônica & 500 & 1 \\
\hline
\end{tabular}

Referências: Collette, 2002a; Ditty, 2006d; Fahay, 2007. 


\section{Família Carangidae}

A família Carangidae é tipicamente marinha e ocorre nos oceanos Atlântico, Índico e Pacífico. Compreende aproximadamente 32 gêneros com 140 espécies. As espécies podem ser pelágicas ou demersais e muitas possuem importância comercial.

As larvas dessa família têm o formato do corpo variando desde fusiforme a alto e discoide. Apresentam três espinhos na nadadeira anal, sendo dois destacados. Possuem muitos espinhos no pré-opérculo, crista supraoccipital mediana desenvolvida e cristas supraoculares. A combinação dos caracteres merísticos e o padrão de pigmentação das larvas são importantes para a identificação das espécies.

No Brasil já foram identificadas 35 espécies nas fases de larva e adulto. Nesse estudo são contempladas as espécies Caranx sp., Decapterus punctatus, Selar crumenophthalmus, Seriola dumerili e Trachurus lathami. 


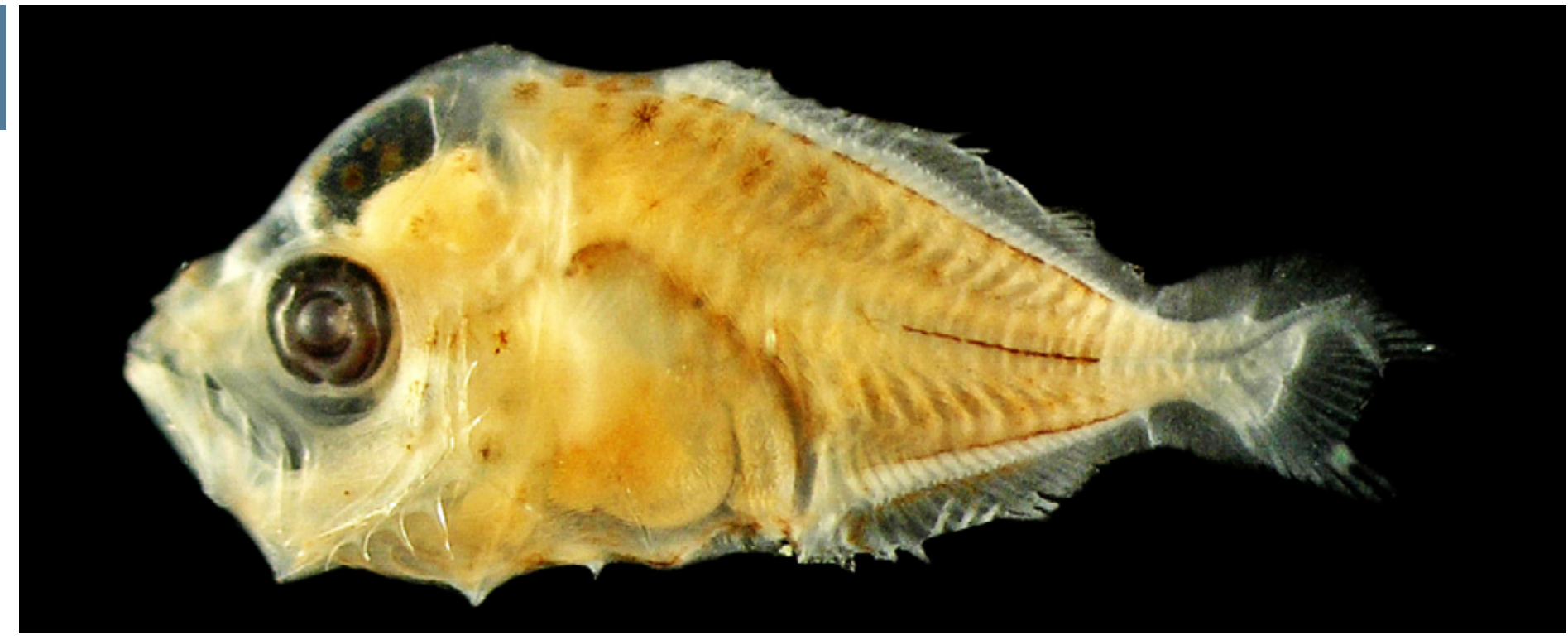

Figura 111: Caranx sp. DZUFRJ 30830; Flexão; CP 4,7 mm.

\section{Caranx sp.}

A identificação das larvas do gênero Caranx ainda é um pouco incerta. As espécies podem ser diferenciadas pelo padrão de pigmentação do corpo e da cabeça. As larvas em pré-flexão são dificilmente identificadas além de gênero, pois ainda não possuem as características necessárias para a identificação desenvolvidas. As larvas em flexão possuem crista supraoccipital, espinho pré-opercular simples, corpo mais alto, forte pigmentação dorso e ventro-lateral, sendo que a linha dorsal estende-se até a nuca. As larvas de Caranx não possuem elementos das nadadeiras alongados. Na área de estudo não estava com a pigmentação preservada, nem os raios das nadadeiras estavam formados, dificultando a identificação até espécie. Número total de miômeros: 24. No Brasil já foram registradas as espécies Caranx crysos (Mitchill, 1815), Caranx hippos (Linnaeus, 1766), Caranx latus Agassiz, 1831 e Caranx lugubris Poey, 1860.

Tamanho: flexão 4,0 mm.

Habitat: todas as espécies de Caranx são pelágicas e ocorrem em regiões costeiras ou oceânicas. Os adultos são encontrados em áreas além da quebra da plataforma ou associados a formações coralinas ou ilhas.

\section{Georreferenciamento}

\begin{tabular}{|c|c|c|c|c|c|c|c|c|}
\hline DZUFR & Latitude (S) & Longitude (W) & Data & $\begin{array}{c}\text { Tipo de } \\
\text { arrasto }\end{array}$ & $\begin{array}{c}\text { Profundidade } \\
\text { de coleta }\end{array}$ & Rede & Malha ( $\boldsymbol{\mu m})$ & $\mathbf{N}^{\circ}$. de inds. \\
\hline 1225 & $22^{\circ} 28,58^{\prime}$ & $039^{\circ} 55,72^{\prime}$ & $16 / 06 / 2003$ horizontal & superfície & nêuston & 500 & 1 \\
\hline
\end{tabular}

Referências: Menezes \& Figueiredo, 1980; Watson et al., 1996; Smith-Vaniz, 2002; Ditty et al., 2004; Laroche et al., 2006; Fahay, 2007. 


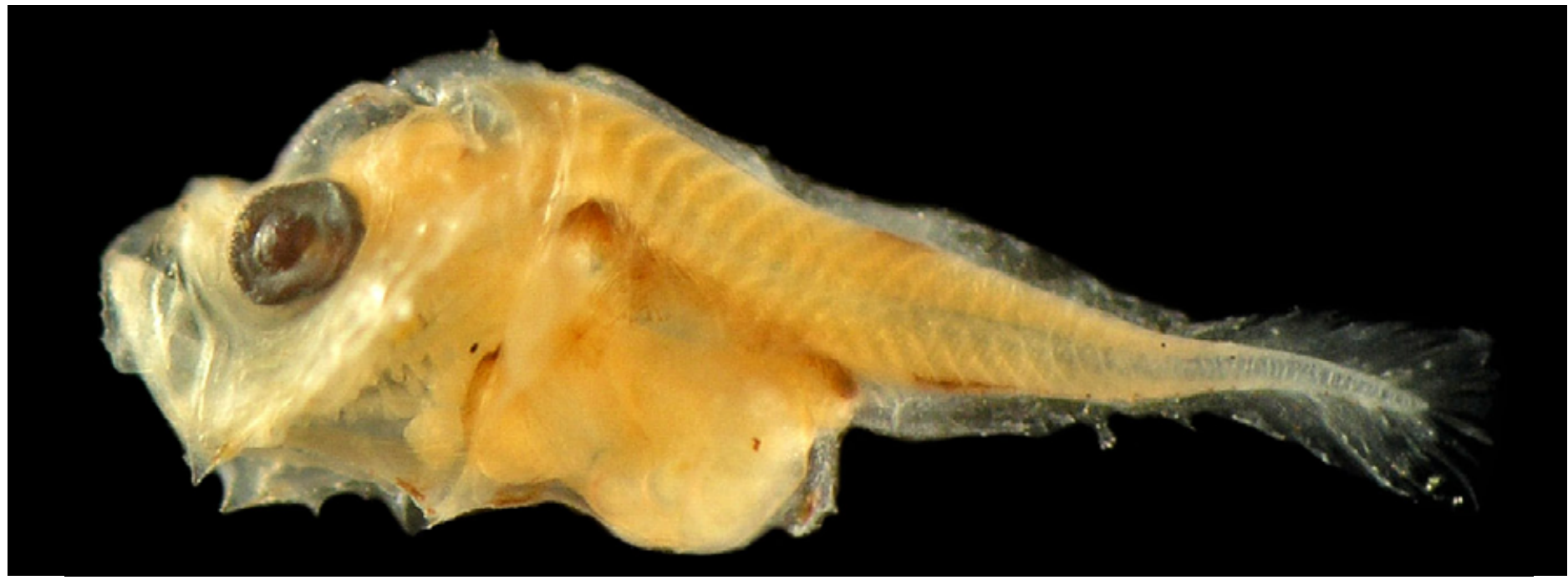

Figura 112 - A: Decapterus punctatus. DZUFRJ 24979; Pré-flexão; CP 2,9mm.

\section{Decapterus punctatus (Cuvier, 1829)}

As larvas pertencentes a essa espécie possuem o corpo moderadamente alto, com cabeça de tamanho moderado a grande e focinho côncavo. A crista supraoccipital é bem desenvolvida e irregular. Em pré-flexão, a pigmentação dorsal é pouco intensa e concentrada na porção posterior do corpo, a partir da base do segundo espinho da nadadeira dorsal. Na cabeça, as larvas possuem melanóforos dispersos na porção posterior do encéfalo, próximo aos olhos e na ponta da mandíbula. Diferem-se pela pouca quantidade de pigmentos abaixo da massa visceral. Em flexão, a pigmentação torna-se mais intensa e se espalha pelas bases dos espinhos e raios das nadadeiras dorsal e anal, além da linha lateral. Na cabeça a pigmentação se espalha para a porção anterior do encéfalo, no

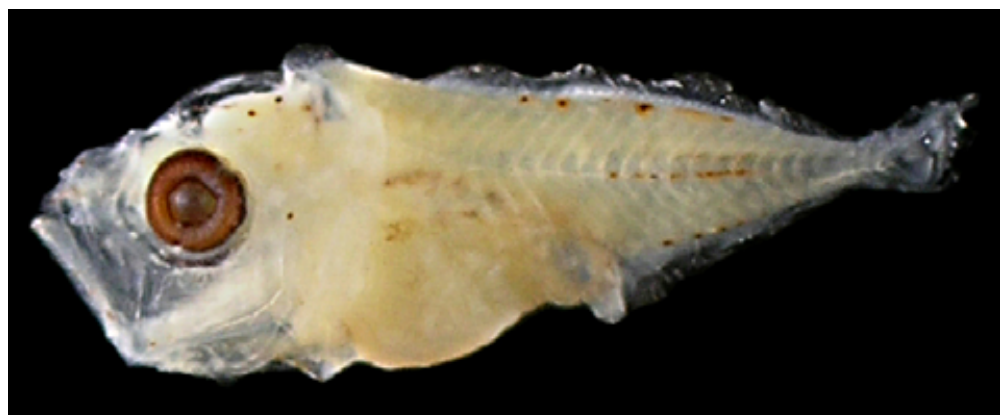

Figura 112 - B: DZUFRJ 366; Flexão; CP 4,8 mm.

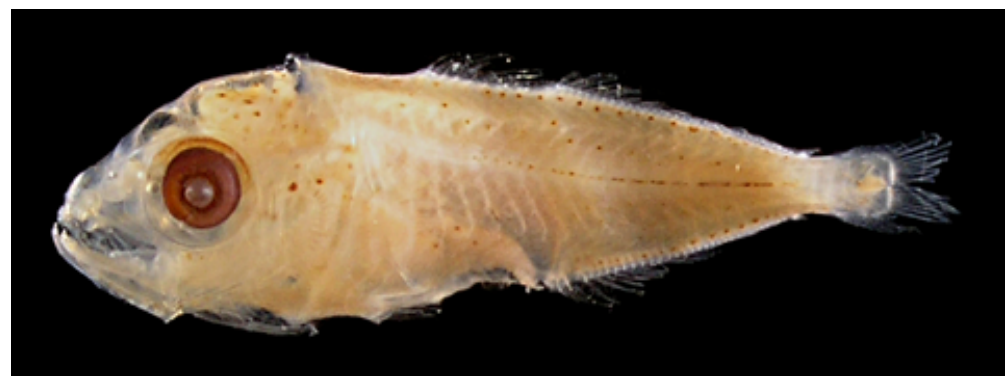

Figura 112 - C: DZUFRJ 7493; Pós-flexão; CP 9,8 mm. cleitro e permanece na mandíbula. No estágio de pós-flexão a crista é reduzida, tendendo a desaparecer com o crescimento e ocorre o isolamento do último raio da nadadeira dorsal. A pigmentação na cabeça concentra-se no encéfalo, próximo aos olhos e no cleitro. No abdome, vários melanóforos aparecem na parede da vesícula gasosa, peritôneo e intestino. Os pigmentos espalham-se ao longo do corpo e entre as linhas mediano-dorsal, ventral e lateral. Essa espécie é muito semelhante a Trachurus lathami, podendo ser separada pela quantidade e posição dos pigmentos na região dorsal do corpo. Número total de miômeros: 25.

Tamanho: pré-flexão 2,3-3,8 mm; flexão 4,5-4,8 mm; pós-flexão 9,8 mm.

Habitat: espécie marinha, pelágica, ocorre em águas subtropicais entre 9 e 90 m de profundidade. Durante o dia os juvenis ocorrem próximo à superfície, descendo para o fundo a noite.

Nome vulgar: Chicharro pintado. 


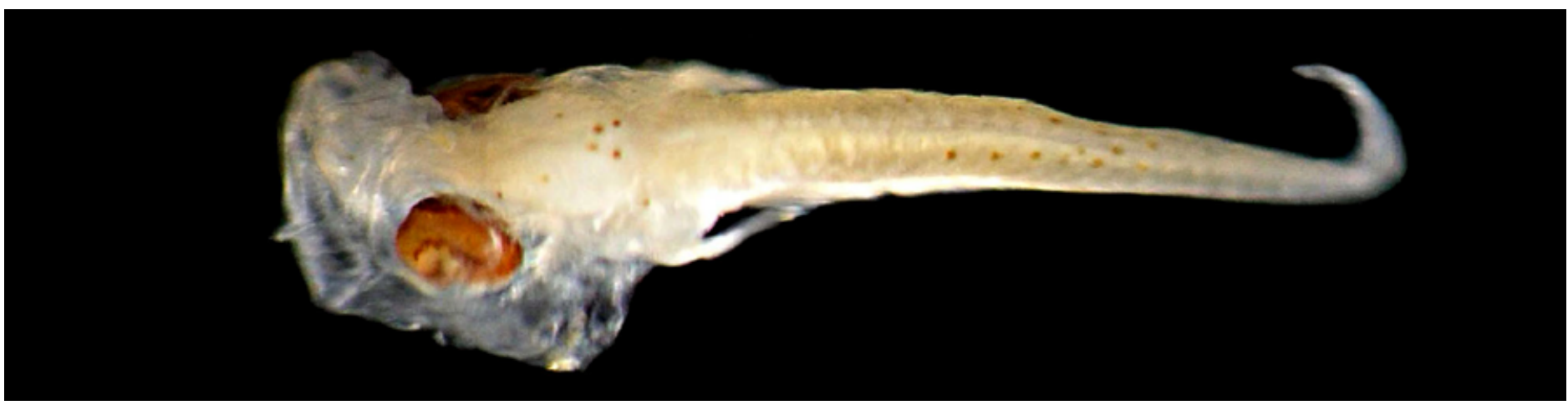

Figura 112 - D: Detalhe da cabeça na pré-flexão.

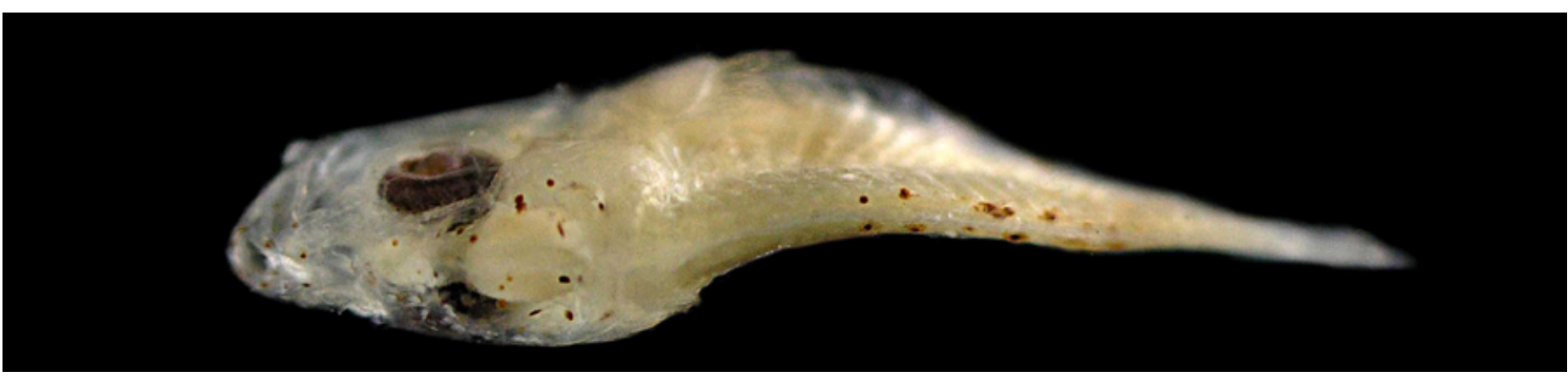

Figura 112 - E: Detalhe da cabeça na flexão.

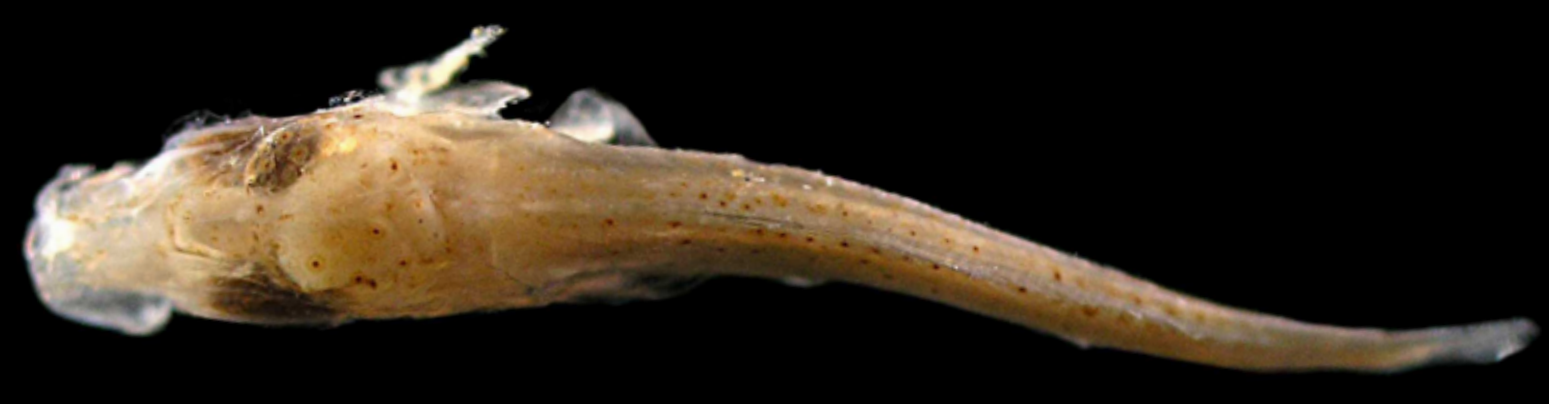

Figura 112 - F: Detalhe da cabeça na pós-flexão.

\section{Georreferenciamento}

\begin{tabular}{|c|c|c|c|c|c|c|c|c|}
\hline DZUFR & Latitude (S) & Longitude (W) & Data & $\begin{array}{c}\text { Tipo de } \\
\text { arrasto }\end{array}$ & $\begin{array}{c}\text { Profundidade } \\
\text { de coleta }\end{array}$ & Rede & $\begin{array}{c}\text { Malha } \\
\text { ( } \boldsymbol{\mu m} \text { ) }\end{array}$ & $\begin{array}{c}\mathbf{N}^{\circ} \text {. de } \\
\text { inds. }\end{array}$ \\
\hline 366 & $22^{\circ} 34^{\prime} 05,0^{\prime \prime}$ & $040^{\circ} 19^{\prime} 40,0^{\prime \prime}$ & $17 / 05 / 2002$ & oblíquo & $600 \mathrm{~m}$ & cilíndrico-cônica & 500 & 3 \\
\hline 2618 & $22^{\circ} 35^{\prime} 66,4^{\prime \prime}$ & $039^{\circ} 46^{\prime} 40,6^{\prime \prime}$ & $06 / 12 / 2002$ & horizontal & superfície & nêuston & 500 & 2 \\
\hline 2623 & $22^{\circ} 35^{\prime} 66,4^{\prime \prime}$ & $039^{\circ} 46^{\prime} 40,6^{\prime \prime}$ & $06 / 12 / 2002$ & horizontal & superfície & nêuston & 500 & 3 \\
\hline 7491 & $21^{\circ} 54^{\prime} 36,5^{\prime \prime}$ & $039^{\circ} 45^{\prime} 20,0^{\prime \prime}$ & $10 / 10 / 2001$ & oblíquo & $1.000 \mathrm{~m}$ & cilíndrico-cônica & 500 & 1 \\
\hline 7493 & $21^{\circ} 58^{\prime} 31,0^{\prime \prime}$ & $039^{\circ} 50^{\prime} 29,7^{\prime \prime}$ & $10 / 11 / 2001$ & oblíquo & $1.000 \mathrm{~m}$ & cilíndrico-cônica & 500 & 1 \\
\hline 7494 & $2^{\circ} 57^{\prime} 10,5^{\prime \prime}$ & $039^{\circ} 43^{\prime} 33,3^{\prime \prime}$ & $09 / 10 / 2001$ & oblíquo & $1.000 \mathrm{~m}$ & cilíndrico-cônica & 500 & 1 \\
\hline
\end{tabular}

Referências: Menezes \& Figueiredo, 1980; Katsuragawa \& Matsuura, 1992; Watson et al., 1996; Smith-Vaniz, 2002; Laroche et al., 2006; Fahay, 2007 


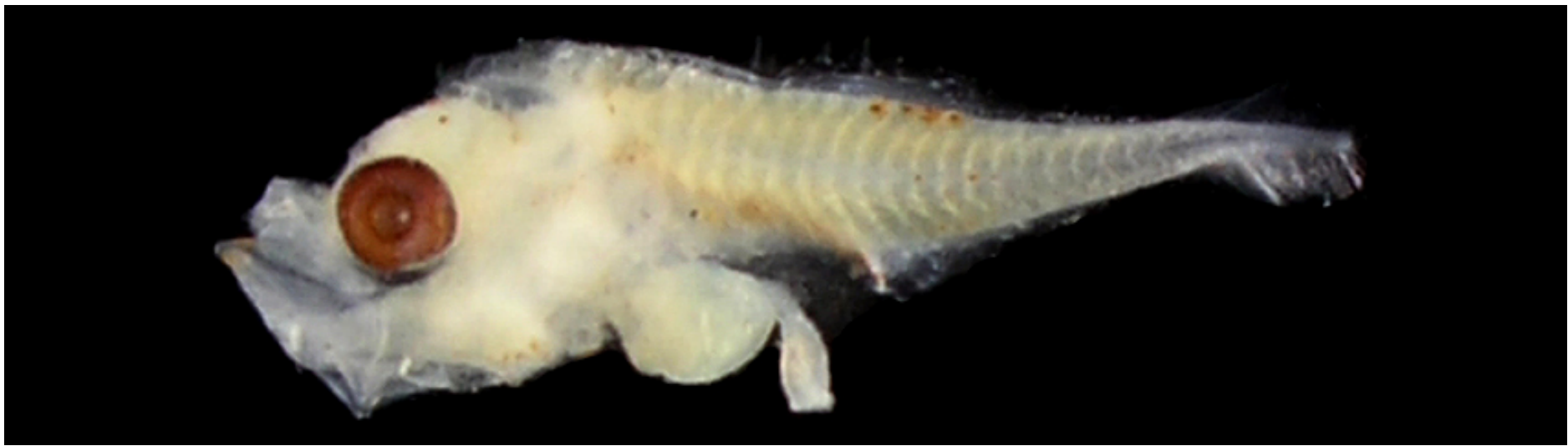

Figura 113 - A: Selar crumenophthalmus. DZUFRJ 476; Pré-flexão; CP 2,3 mm.

\section{Selar}

\section{crumenophthalmus (Bloch, 1793)}

Os representantes dessa espécie são caracterizados pela presença de crista supraoccipital desenvolvida, melanóforos alinhados na região inferior da cauda, no miossepto e pelo pouco número de raios

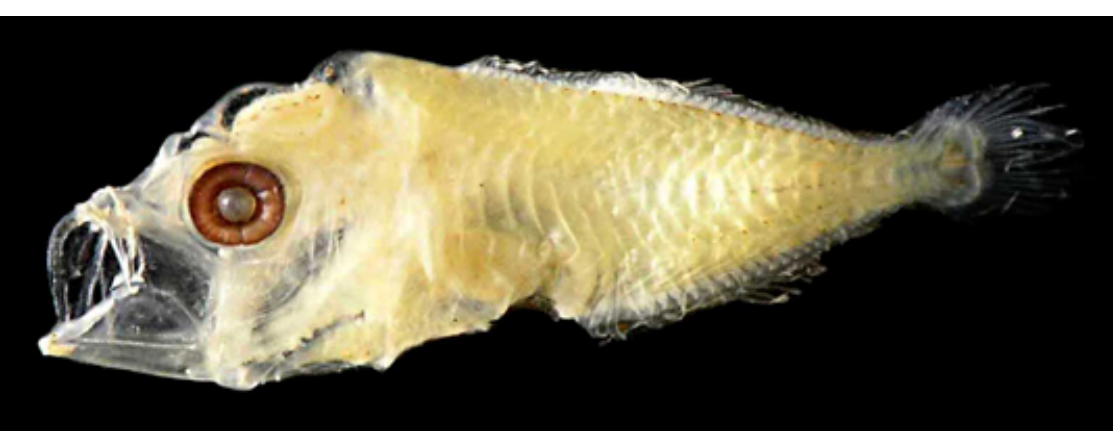

Figura 113 - B: DZUFRJ 477; Flexão; CP 5,0 mm. nas nadadeiras dorsal (VIII-IX, 25-26) e anal (II-III, 21-23). Nos estágios de pré-flexão e flexão, há a presença de poucos melanóforos na cabeça, mandíbula, superfície dorsal da vesícula gasosa e massa visceral. Pigmentos na base da nadadeira pélvica, na margem dorsal (formando uma fileira bilateral) e ventral no corpo, além de pigmentos destacados ao longo da linha lateral e base da notocorda. Número total de miômeros: 24.

Tamanho: pré-flexão 2,3-3,7 mm; flexão 3,8-6,4 mm.

Habitat: espécie marinha, pelágica que vive em grupos muito próximos à costa ou sobre formações coralinas rasas. Ocorre em águas tropicais e subtropicais, até $170 \mathrm{~m}$ de profundidade.

Nome vulgar: Chicharro olho grande.

\section{Georreferenciamento}

\begin{tabular}{|c|c|c|c|c|c|c|c|c|}
\hline DZUFRJ & Latitude (S) & Longitude (W) & Data & $\begin{array}{c}\text { Tipo de } \\
\text { arrasto }\end{array}$ & $\begin{array}{c}\text { Profundidade } \\
\text { de coleta }\end{array}$ & Rede & $\begin{array}{c}\text { Malha } \\
(\boldsymbol{\mu m})\end{array}$ & $\begin{array}{c}\mathbf{N}^{\circ} \text {. de } \\
\text { inds. }\end{array}$ \\
\hline 356 & $22^{\circ} 31^{\prime} 27,0^{\prime \prime}$ & $040^{\circ} 16^{\prime} 56,0^{\prime \prime}$ & $17 / 05 / 2002$ & oblíquo & $600 \mathrm{~m}$ & cilíndrico-cônica & 500 & 1 \\
\hline 363 & $22^{\circ} 38^{\prime} 25,0^{\prime \prime}$ & $040^{\circ} 17^{\prime} 41,0^{\prime \prime}$ & $19 / 05 / 2002$ & oblíquo & $40 \mathrm{~m}$ & bongô & 500 & 3 \\
\hline 364 & $22^{\circ} 33^{\prime} 47,7^{\prime \prime}$ & $040^{\circ} 12^{\prime} 20,5^{\prime \prime}$ & $17 / 05 / 2002$ & oblíquo & $50 \mathrm{~m}$ & bongô & 500 & 4 \\
\hline 476 & $22^{\circ} 37^{\prime} 355^{\prime \prime}$ & $040^{\circ} 09^{\prime} 32,8^{\prime \prime}$ & $16 / 05 / 2002$ & oblíquo & $1.000 \mathrm{~m}$ & cilíndrico-cônica & 500 & 4 \\
\hline 477 & $22^{\circ} 41^{\prime} 547^{\prime \prime}$ & $040^{\circ} 14^{\prime} 04,5^{\prime \prime}$ & $16 / 05 / 2002$ & oblíquo & $1.000 \mathrm{~m}$ & cilíndrico-cônica & 500 & 2 \\
\hline 483 & $22^{\circ} 33^{\prime} 37,0^{\prime \prime}$ & $040^{\circ} 19^{\prime} 10,0^{\prime \prime}$ & $17 / 05 / 2002$ & oblíquo & $50 \mathrm{~m}$ & bongô & 500 & 2 \\
\hline 6951 & $22^{\circ} 35^{\prime} 08,5^{\prime \prime}$ & $039^{\circ} 46^{\prime} 22,3^{\prime \prime}$ & $06 / 12 / 2002$ & vertical & $0-50 \mathrm{~m}$ & cilíndrico-cônica & 200 & 1 \\
\hline
\end{tabular}

Referências: Menezes \& Figueiredo, 1980; Watson et al., 1996; Smith-Vaniz, 2002; Ditty et al., 2004; Laroche et al., 2006; Fahay, 2007. 


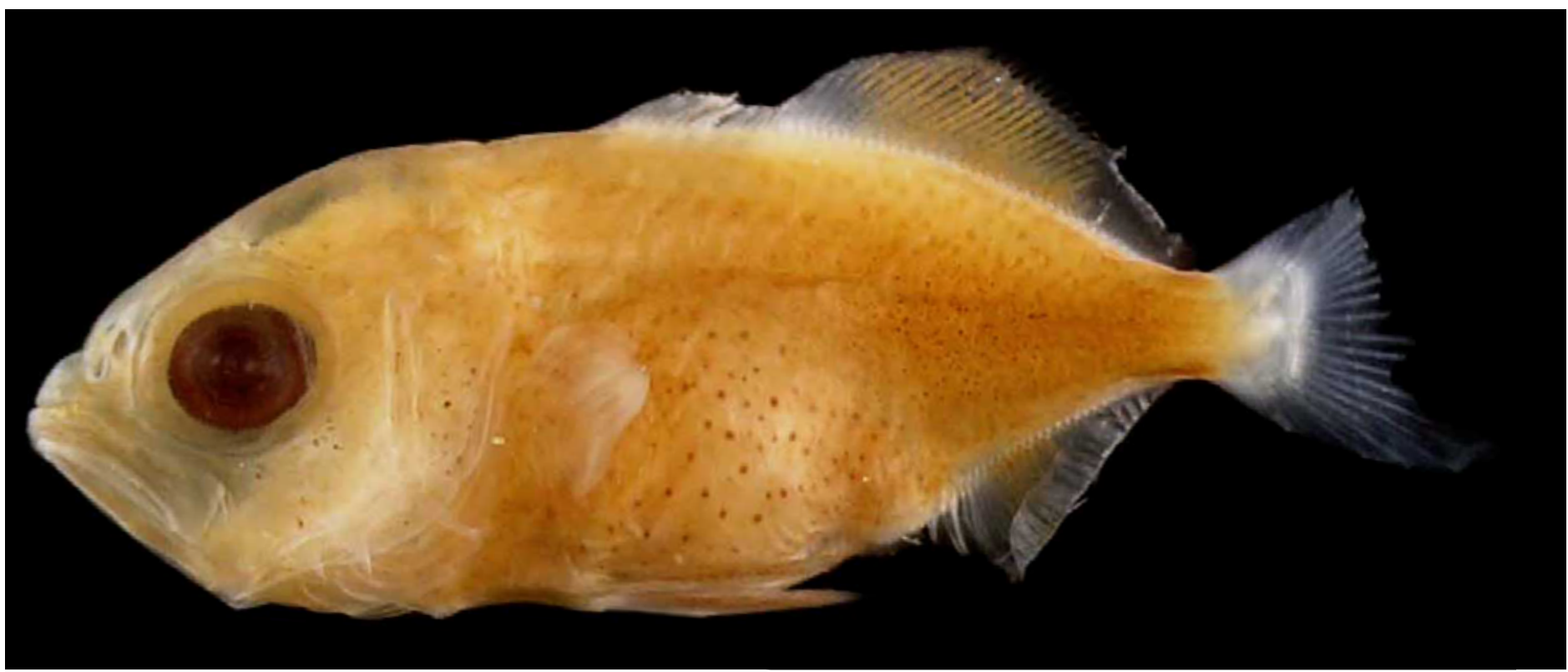

Figura 114 - Seriola dumerili. DZUFRJ 21384; Pós-flexão; CP 8,6 mm.

\section{Seriola dumerili (Risso, 1810)}

As larvas dessa espécie não apresentam crista supraoccipital, durante todos os estágios de desenvolvimento. Possui espinhos simples e proeminentes no pré-opérculo e na região pós-temporal. Apresenta pigmentos no dorso da cabeça, na mandíbula, região dorsal da vesícula gasosa, massa visceral e intestino. Pigmentos presentes também na linha lateral, regiões dorsal e ventral do corpo, extremidade da notocorda e membranas das nadadeiras. Em pós-flexão a pigmentação aumenta na cabeça e no corpo, concentrando-se nas margens dorsal, ventral e na linha lateral. As nadadeiras dorsal, anal, pélvica e caudal são pigmentadas. O pedúnculo caudal não tem pigmentação até a transformação. Número total de miômeros: 24.

Tamanho: pós-flexão 8,6 mm.

Habitat: espécie marinha, pelágica, ocorre em mar aberto em águas tropicais e subtropicais até $450 \mathrm{~m}$ de profundidade.

Nome vulgar: Olho de boi.

Georreferenciamento

\begin{tabular}{|c|c|c|c|c|c|c|c|c|}
\hline DZUFRJ & Latitude (S) & Longitude (W) & Data & $\begin{array}{c}\text { Tipo de } \\
\text { arrasto }\end{array}$ & $\begin{array}{c}\text { Profundidade } \\
\text { de coleta }\end{array}$ & Rede & $\begin{array}{c}\text { Malha } \\
(\boldsymbol{\mu m})\end{array}$ & $\begin{array}{c}\mathbf{N}^{\circ} \text {. de } \\
\text { inds. }\end{array}$ \\
\hline 21384 & $22^{\circ} 285^{\prime} 8^{\prime}$ & $039^{\circ} 55,72^{\prime}$ & $16 / 06 / 2003$ & horizontal & superfície & nêuston & 500 & 1 \\
\hline
\end{tabular}

Referências: Menezes \& Figueiredo, 1980; Watson et al., 1996; Smith-Vaniz, 2002; Ditty et al., 2004; Laroche et al., 2006; Fahay, 2007. 


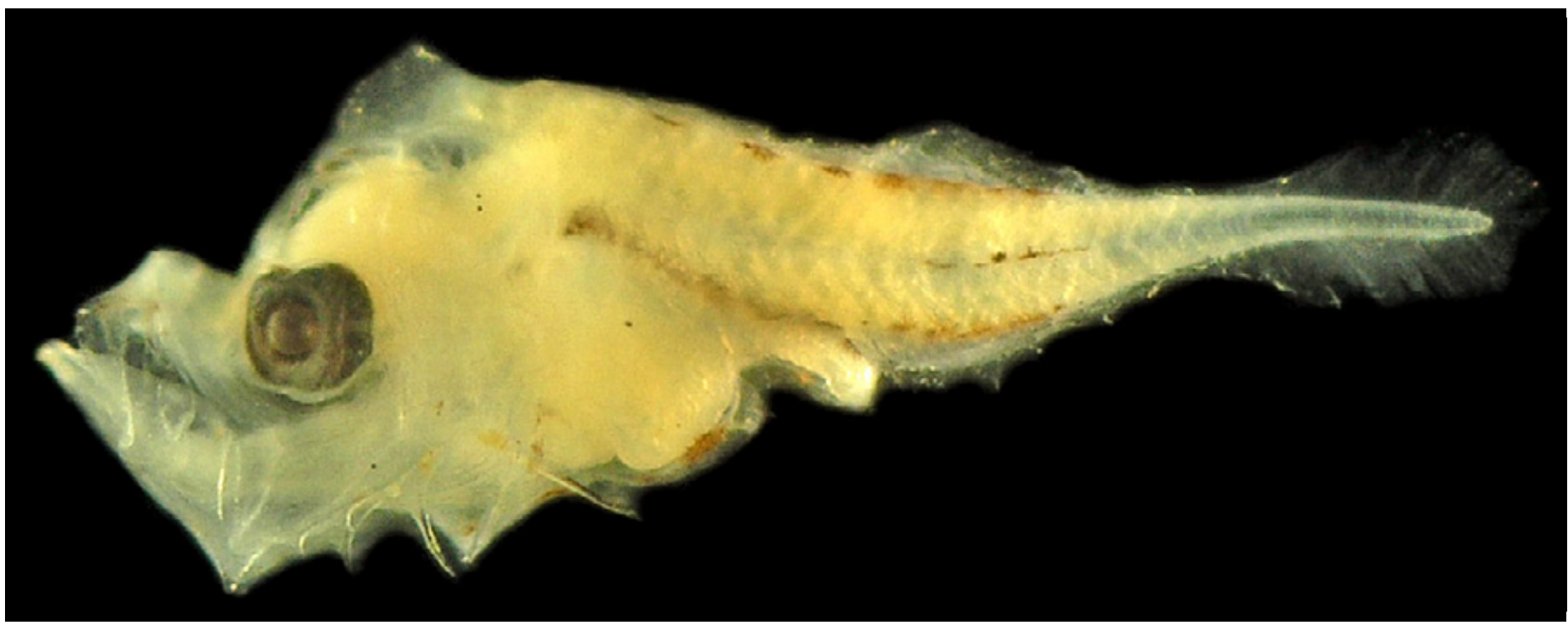

Figura 115 - Trachurus lathami. DZUFRJ 27391; Pré-flexão; CP 2,9 mm.

\section{Trachurus lathami Nichols, 1920}

A crista supraoccipital está presente até o estágio de transformação. As larvas em pré-flexão, apresentam pigmentos na mandíbula (ângulo inferior e extremidade), abaixo da massa visceral, base da nadadeira peitoral, dorso da cabeça, nuca, superfície dorsal da vesícula gasosa e massa visceral. Os pigmentos dorsais aparecem espaçados e há uma fileira de pigmentos na linha mediana do corpo. Em flexão, forma-se uma série pontual de pigmentos, ventralmente, na massa visceral, região posterior do intestino e ao longo da margem ventral do corpo e da cauda. Em pós-flexão a pigmentação prolifera-se sobre o dorso da cabeça, acima e abaixo da massa visceral, na porção final do intestino e na linha lateral do corpo. O número de raios das nadadeiras dorsal (VIII+I, 30-32) e anal (II+I, 27-28) também separa essa espécie dos demais carangídeos. Número total de miômeros: 24.

Tamanho: pré-flexão 2,7 mm.

Habitat: espécie marinha, pelágica ocorre em águas subtropicais entre 50 e $90 \mathrm{~m}$ de profundidade. Vive próximo ao fundo e às vezes na superfície; não é comum próximo à costa.

Nome vulgar: Chicharro lombo preto.

\section{Georreferenciamento}

\begin{tabular}{|c|c|c|c|c|c|c|c|c|}
\hline DZUFRJ & Latitude (S) & Longitude (W) & Data & $\begin{array}{c}\text { Tipo de } \\
\text { arrasto }\end{array}$ & $\begin{array}{c}\text { Profundidade } \\
\text { de coleta }\end{array}$ & Rede & $\begin{array}{c}\text { Malha } \\
(\boldsymbol{\mu m})\end{array}$ & $\begin{array}{c}\mathbf{N}^{\circ} \text {. de } \\
\text { inds. }\end{array}$ \\
\hline 970 & $22^{\circ} 43^{\prime} 50,4^{\prime \prime}$ & $040^{\circ} 02^{\prime} 425^{\prime \prime}$ & $07 / 12 / 2002$ & vertical & $0-50 \mathrm{~m}$ & cilíndrico-cônica & 200 & 1 \\
\hline
\end{tabular}

Referências: Menezes \& Figueiredo, 1980; Katsuragawa \& Matsuura, 1992; Watson et al., 1996; Smith-Vaniz, 2002; Ditty et al., 2004; Laroche et al., 2006; Fahay, 2007. 


\section{Família Coryphaenidae}

A família Coryphaenidae é marinha e ocorre nos oceanos Atlântico, Índico e Pacífico. Compreende um gênero e duas espécies. São peixes epipelágicos, encontrados em áreas costeiras e oceânicas, que vivem associados a objetos à deriva no mar. Tem grande importância comercial no litoral brasileiro. Os representantes dessa família possuem o corpo alongado e comprimido, com nadadeiras dorsal e anal muito longas e ausência de espinhos nas mesmas. O padrão de pigmentação do corpo durante todo desenvolvimento larval é importante para a identificação das duas espécies.

No Brasil já foram identificadas duas espécies nas fases de larva e adulto: Coryphaena equiselis Linnaeus, 1758 e Coryphaena hippurus Linnaeus, 1758. Nesse estudo é contemplada a espécie Coryphaena hippurus. 


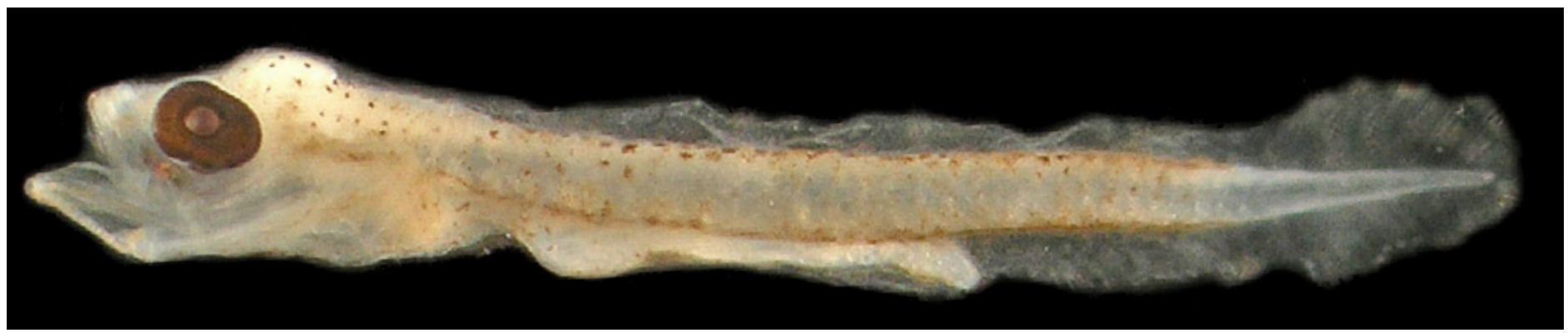

Figura 116 - A: Coryphaena hippurus. DZUFRJ 31422; Pré-flexão; CP 4,7 mm.

\section{Coryphaena hippurus Linnaeus, 1758}

Possui o corpo alongado, cabeça bem desenvolvida, intestino longo e uma única nadadeira dorsal longa e sem espinhos. Tem grandes espinhos na margem posterior do pré-opérculo e espinhos menores lateralmente. Essa espécie pode ser separada de Coryphaena equiselis principalmente, pelo padrão de pigmentação do corpo. No estágio de pré-flexão possuem o corpo todo pigmentado com exceção do pedúnculo caudal. Nos estágios de flexão e pós-flexão, começam a formar barras verticais de pigmento que se estendem até as nadadeiras dorsal e anal.

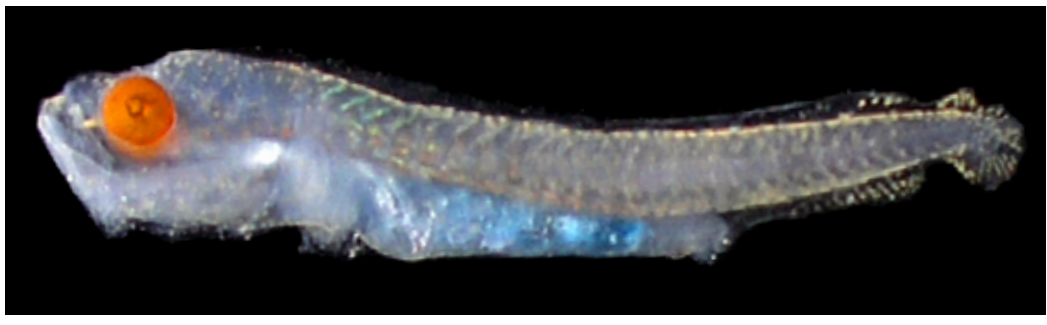

Figura 116 - B: DZUFRJ 1327; Flexão; CP 7,2 mm.

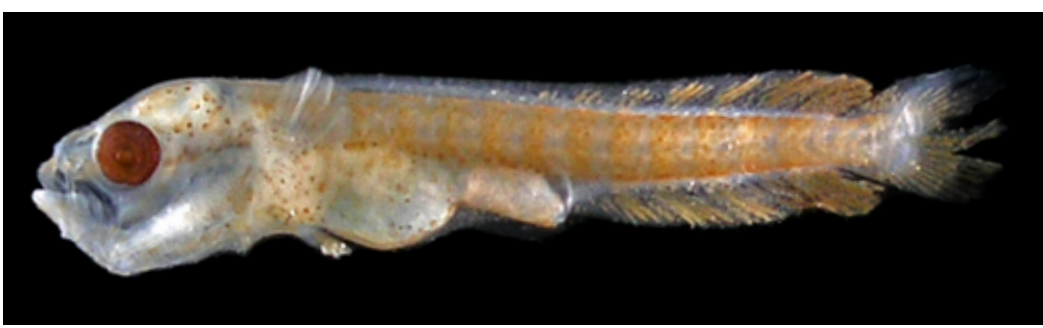

Figura 116 - C: DZUFRJ 2701; Pós-flexão; CP 10,5 mm. Há melanóforos na membrana entre os raios de todas as nadadeiras. O número total de miômeros varia entre 30 e 31.

Tamanho: pré-flexão 4,0-5,0 mm; flexão 6,6-7,5 mm; pós-flexão 10,5 mm.

Habitat: espécie marinha, epipelágica, ocorre em águas tropicais e subtropicais em áreas costeiras e oceânicas.

Nome vulgar: Dourado.

\section{Georreferenciamento}

\begin{tabular}{|c|c|c|c|c|c|c|c|c|}
\hline DZUFRJ & Latitude (S) & Longitude (W) & Data & $\begin{array}{c}\text { Tipo de } \\
\text { arrasto }\end{array}$ & $\begin{array}{c}\text { Profundidade } \\
\text { de coleta }\end{array}$ & Rede & $\begin{array}{c}\text { Malha } \\
\text { ( } \boldsymbol{\mu m} \text { ) }\end{array}$ & $\begin{array}{c}\mathbf{N}^{\circ} \text {. de } \\
\text { inds. }\end{array}$ \\
\hline 645 & $22^{\circ} 38^{\prime} 25,0^{\prime \prime}$ & $040^{\circ} 17^{\prime} 41,0^{\prime \prime}$ & $19 / 05 / 2002$ & oblíquo & $40 \mathrm{~m}$ & bongô & 330 & 1 \\
\hline 663 & $22^{\circ} 33^{\prime} 47,7^{\prime \prime}$ & $040^{\circ} 12^{\prime} 20,5^{\prime \prime}$ & $17 / 05 / 2002$ & oblíquo & $50 \mathrm{~m}$ & bongô & 500 & 1 \\
\hline 1285 & $22^{\circ} 06^{\prime} 52,3^{\prime \prime}$ & $039^{\circ} 48^{\prime} 46,2^{\prime \prime}$ & $11 / 05 / 2002$ & oblíquo & até a termoclina & bongô & 500 & 1 \\
\hline 1327 & $22^{\circ} 03^{\prime} 03,3^{\prime \prime}$ & $039^{\circ} 50^{\prime} 39,0^{\prime \prime}$ & $10 / 05 / 2002$ & oblíquo & até a termoclina & bongô & 330 & 1 \\
\hline 1337 & $22^{\circ} 06^{\prime} 37,8^{\prime \prime}$ & $039^{\circ} 49^{\prime} 44,8^{\prime \prime}$ & $10 / 05 / 2002$ & oblíquo & até a termoclina & bongô & 330 & 1 \\
\hline 1341 & $22^{\circ} 06^{\prime} 52,3^{\prime \prime}$ & $039^{\circ} 48^{\prime} 46,2^{\prime \prime}$ & $11 / 05 / 2002$ & oblíquo & até a termoclina & bongô & 330 & 1 \\
\hline 1381 & $22^{\circ} 08^{\prime} 14,9^{\prime \prime}$ & $039^{\circ} 46^{\prime} 34,6^{\prime \prime}$ & $11 / 05 / 2002$ & oblíquo & até a termoclina & bongô & 330 & 1 \\
\hline 22508 & $22^{\circ} 31^{\prime} 58,9^{\prime \prime}$ & $040^{\circ} 02^{\prime} 53,4^{\prime \prime}$ & $07 / 11 / 2001$ & oblíquo & $1.000 \mathrm{~m}$ & cilíndrico-cônica & 500 & 2 \\
\hline 23210 & $22^{\circ} 28,58^{\prime}$ & $039^{\circ} 55,72^{\prime}$ & $16 / 06 / 2003$ & horizontal & superfície & nêuston & 500 & 1 \\
\hline
\end{tabular}

Referências: Ambrose, 1996c; Ditty, 2006d; Fahay, 2007. 


\section{Família Bramidae}

A família Bramidae é marinha e ocorre nos oceanos Atlântico, Índico e Pacífico. Vive em regiões oceânicas e tem distribuição circumglobal. Compreende sete gêneros com aproximadamente 22 espécies. Os adultos são pelágicos e os estágios mais jovens podem ser capturados em regiões mais afastadas da costa. As larvas são caracterizadas pelo grande número de miômeros e nadadeiras bem desenvolvidas. A região ao redor da cabeça e do intestino possui muitos pigmentos. A cauda é longa com poucos pigmentos, que se distribuem pelas margens dorsal e ventral do corpo até a notocorda.

No Brasil já foram identificadas seis espécies nas fases de larva e adulto. Nesse estudo é contemplada a espécie Brama dussumieri. 


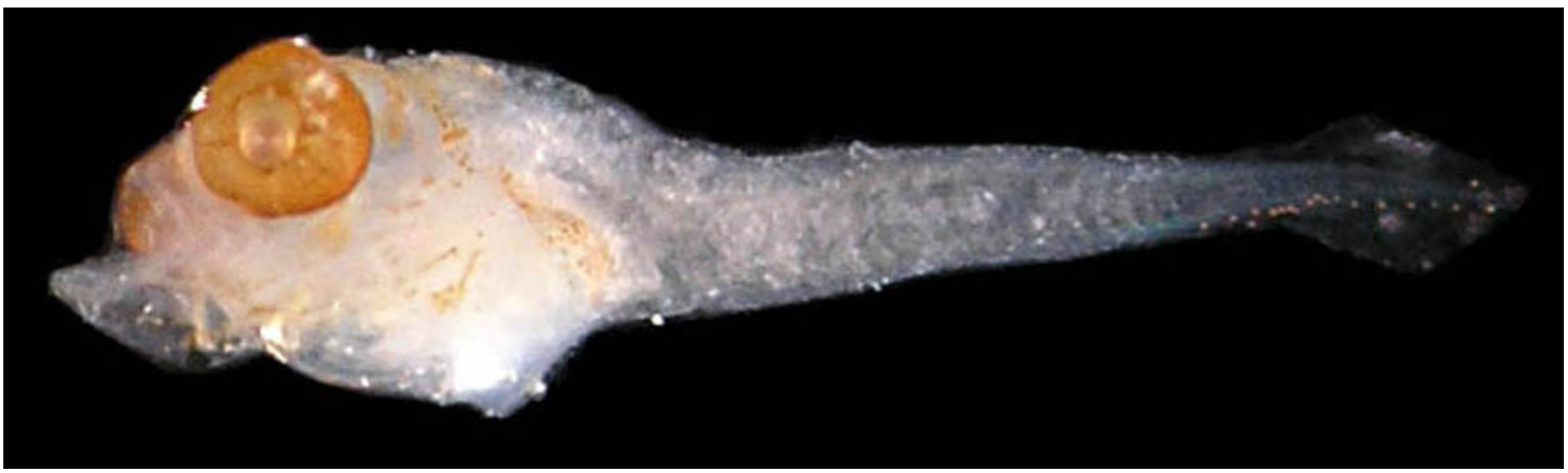

Figura 117: Brama dussumieri. DZUFRJ 20076; Pré-flexão; CP 4,4 mm.

\section{Brama dussumieri Cuvier, 1831}

As larvas dessa espécie possuem entre 40-43 miômeros e apresentam corpo mais alto anteriormente, com cabeça e focinho arredondados. Desde o estágio de pré-flexão, possuem melanóforos que cobrem toda a cabeça e a região do trato digestório, além de alguns melanóforos próximos ao fim da notocorda. Com o decorrer do desenvolvimento larval, na região anterior da nadadeira dorsal existem melanóforos que se desenvolvem e se espalham até a cauda. Além do padrão de pigmentação, o número de raios das nadadeiras (dorsal 33-35; anal 27-29 e peitoral 19-21) são importantes na identificação das larvas dessa espécie.

Tamanho: pré-flexão 3,2-4,5 mm.

Habitat: espécie marinha, epi-mesopelágica, ocorre em águas tropicais até $300 \mathrm{~m}$ de profundidade.

Nome vulgar: Palombeta.

\section{Georreferenciamento}

\begin{tabular}{|c|c|c|c|c|c|c|c|c|}
\hline DZUFRJ & Latitude (S) & Longitude (W) & Data & $\begin{array}{c}\text { Tipo de } \\
\text { arrasto }\end{array}$ & $\begin{array}{c}\text { Profundidade } \\
\text { de coleta }\end{array}$ & Rede & $\begin{array}{c}\text { Malha } \\
\text { ( } \boldsymbol{\mu m})\end{array}$ & $\begin{array}{c}\text { No. de } \\
\text { inds. }\end{array}$ \\
\hline 1228 & $22^{\circ} 02^{\prime} 30,0^{\prime \prime}$ & $039^{\circ} 49^{\prime} 41,2^{\prime \prime}$ & $12 / 05 / 2002$ & oblíquo & $1.000 \mathrm{~m}$ & cilíndrico-cônica & 500 & 1 \\
\hline 1287 & $22^{\circ} 06^{\prime} 52,3^{\prime \prime}$ & $039^{\circ} 48^{\prime} 46,2^{\prime \prime}$ & $11 / 05 / 2002$ & oblíquo & até a termoclina & bongô & 500 & 1 \\
\hline 7507 & $21^{\circ} 58^{\prime} 31,0^{\prime \prime}$ & $039^{\circ} 50^{\prime} 29,7^{\prime \prime}$ & $11 / 10 / 2001$ & oblíquo & $1.000 \mathrm{~m}$ & cilíndrico-cônica & 500 & 1 \\
\hline 20076 & $22^{\circ} 32^{\prime} 50,0^{\prime \prime}$ & $040^{\circ} 04^{\prime} 09^{\prime \prime}$ & $06 / 11 / 2001$ & oblíquo & $1.000 \mathrm{~m}$ & cilíndrico-cônica & 500 & 1 \\
\hline
\end{tabular}

Referências: Menezes \& Figueiredo, 1980; Moser \& Mundy, 1996; Richards., 2006h; Fahay, 2007. 


\section{Família Lutjanidae}

A família Lutjanidae é representada por peixes marinhos, que raramente são encontrados em estuários e na água doce, principalmente quando juvenis. Vivem em regiões tropicais e subtropicais dos oceanos Atlântico, Índico e Pacífico. É uma das famílias de maior importância econômica para o litoral brasileiro. Compreende 17 gêneros com aproximadamente 105 espécies.

Apresentam corpo alongado até a flexão da notocorda, quando começa a ficar mais alto à medida que a larva cresce. São caracterizados por uma grande boca terminal e a margem do pré-opérculo constituída por muitos espinhos. A nadadeira dorsal é contínua formada por IX-XII espinhos, sendo o primeiro curto e os demais extremamente a moderadamente longos, e 9-18 raios. Nadadeira anal: III, 7-9. Presença de grande espinho pélvico, frequentemente serrilhado. 0 padrão de pigmentação varia muito de acordo com a espécie.

No Brasil já foram identificadas 16 espécies nas fases de larva e adulto. Nesse estudo é contemplada a espécie Lutjanus sp. 


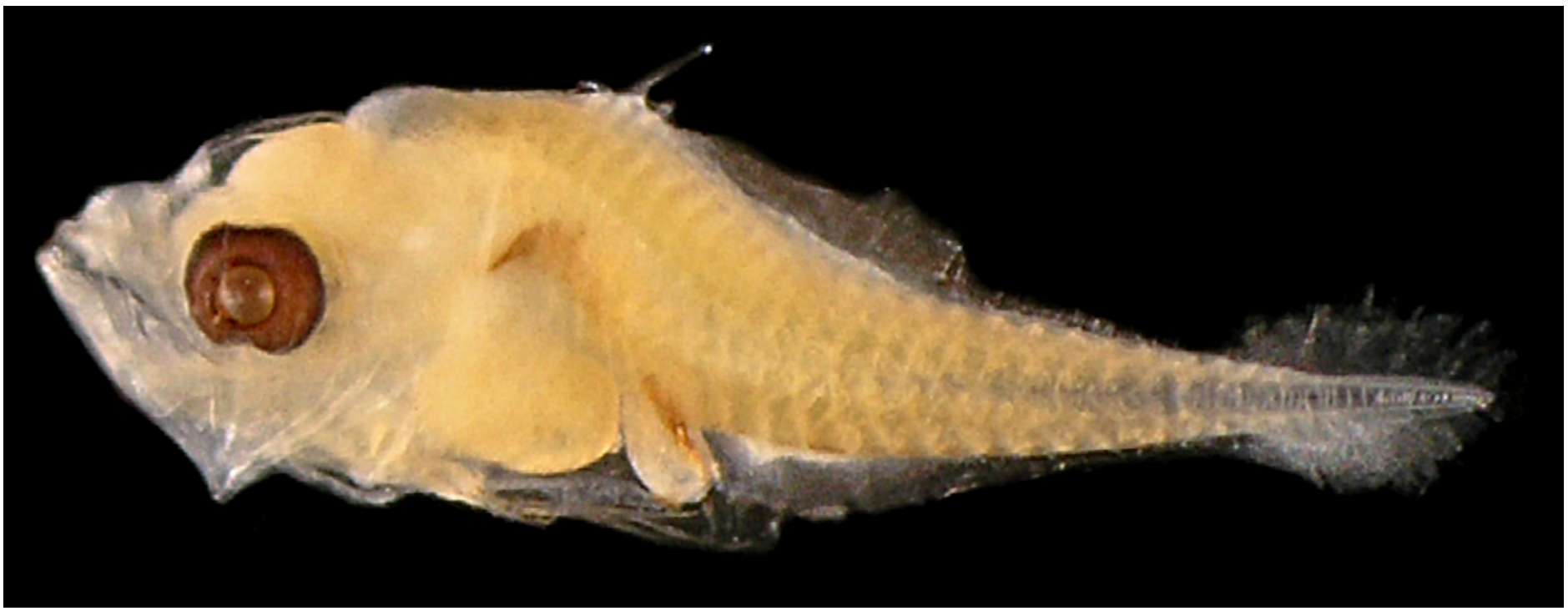

Figura 118: Lutjanus sp. DZUFRJ 15647; Pré-flexão; CP 3,0 mm.

\section{Lutjanus sp.}

Apresentam o corpo alongado no início do desenvolvimento, tornando-se mais alto, de acordo com o crescimento. Possuem uma grande boca terminal e vários espinhos não serrilhados na região do pré-opérculo. O padrão de pigmentação é importante para separar as espécies de Lutjanus. Nesse estudo a pigmentação das larvas não estava muito preservada impossibilitando a identificação até espécie. Número de miômeros: 24.

Tamanho: pré-flexão 3,0-4,0 mm.

Habitat: as espécies de Lutjanus são marinhas e demersais. No Brasil já foram registradas nove espécies de Lutjanus.

\section{Georreferenciamento}

\begin{tabular}{|c|c|c|c|c|c|c|c|c|}
\hline DZUFRJ & Latitude (S) & Longitude (W) & Data & $\begin{array}{l}\text { Tipo de } \\
\text { arrasto }\end{array}$ & $\begin{array}{c}\text { Profundidade } \\
\text { de coleta }\end{array}$ & Rede & $\begin{array}{l}\text { Malha } \\
(\mu \mathrm{m})\end{array}$ & $\begin{array}{l}\text { No. de } \\
\text { inds. }\end{array}$ \\
\hline 463 & & & $17 / 05 / 2002$ & oblíquo & $50 \mathrm{~m}$ & & 500 & 1 \\
\hline 522 & 22031'27,0" & 040o16'56,0" & $17 / 05 / 2002$ & oblíquo & $600 \mathrm{~m}$ & cilíndrico-cônica & 500 & 2 \\
\hline
\end{tabular}

Referências: Menezes \& Figueiredo, 1980; Lindeman et al., 2006; Fahay, 2007; Froese \& Pauly, 2014. 


\section{Família Gerreidae}

A família Gerreidae é marinha e ocasionalmente ocorre em águas salobras. Os representantes dessa família vivem em águas costeiras e estuarinas, principalmente, próximas ao fundo. Compreende oito gêneros com aproximadamente 44 espécies.

As larvas dessa família possuem olhos grandes e focinho pontudo, com a boca pequena e geralmente protrátil. Apresentam de dois a três espinhos e de 7-10 raios na nadadeira anal. Os espinhos da cabeça são pequenos e restritos a região do pré-opérculo. Possuem pigmentação limitada à superfície dorsal da cabeça, na vesícula gasosa e intestino. O número de melanóforos aumenta nas margens dorsal e ventral do corpo, no decorrer do desenvolvimento larval.

No Brasil já foram identificadas 11 espécies nas fases de larva e adulto. Nesse estudo é contemplada a espécie Eucinostomus sp. 


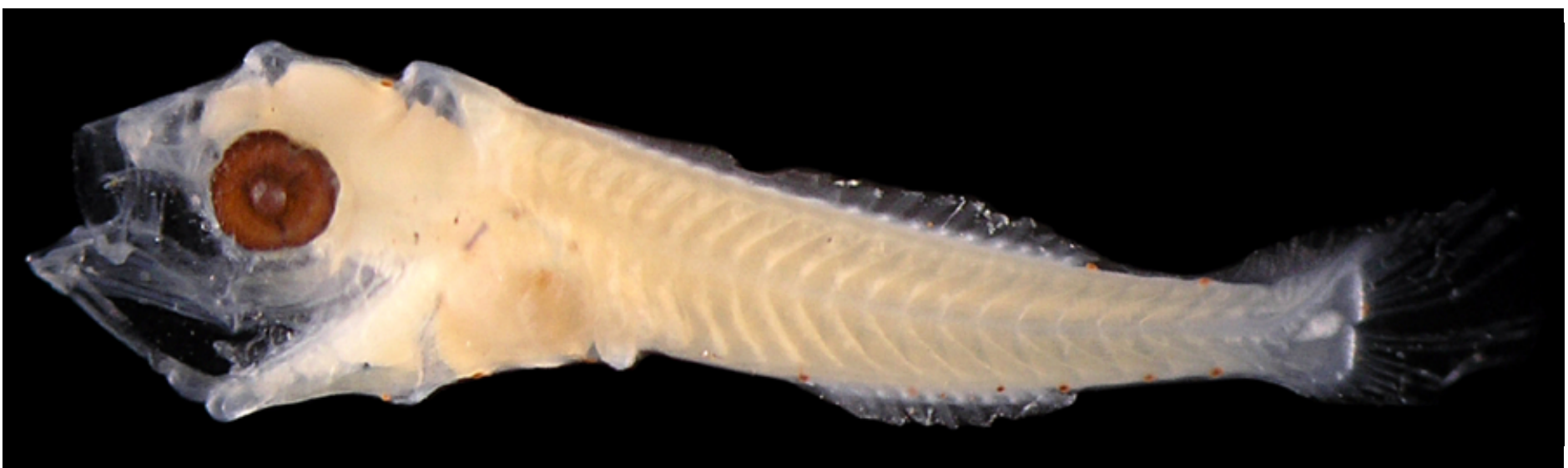

Figura 119- A: Eucinostomus sp. DZUFRJ 509; Flexão; CP 4,5 mm.

\section{Eucinostomus sp.}

As larvas de Eucinostomus apresentam pigmentação característica na cabeça. Melanóforos estrelados pareados começam a se formar na base do encéfalo e, à medida que a larva cresce,

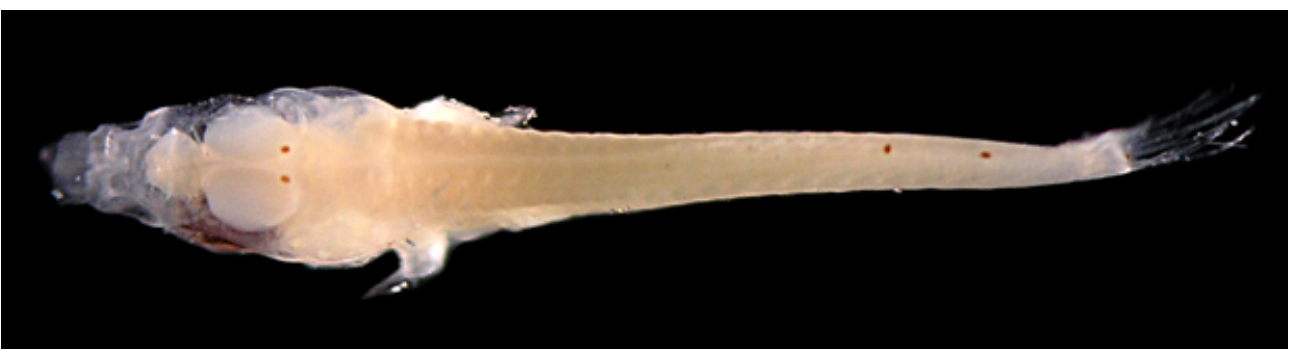

Figura 119 - B: Melanóforos pareados na base do encéfalo e dois pigmentos pós-dorsais. outros melanóforos aparecem, originando o formato da letra " $U$ ". Presença de pequenos melanóforos atrás dos olhos e um antes do intestino e de pigmentos internos na base da nadadeira peitoral. Apresentam um a três pigmentos na base da nadadeira dorsal (após a formação da mesma) e mais dois pós-dorsais. Na margem ventral, presença de três a oito pigmentos na base da nadadeira anal e três a seis pós-anais. A região do pré-opérculo possui poucos espinhos. Número total de miômeros: 24. No Brasil já foram registradas oito espécies de Eucinostomus.

Tamanho: flexão 4,3-4,5 mm.

Habitat: as espécies de Eucinostomus são demersais e ocorrem em águas tropicais costeiras. São marinhas, mas algumas vivem em águas salobras ou água doce.

\section{Georreferenciamento}

\begin{tabular}{|c|c|c|c|c|c|c|c|c|}
\hline DZUFRJ & Latitude (S) & Longitude (W) & Data & $\begin{array}{c}\text { Tipo de } \\
\text { arrasto }\end{array}$ & $\begin{array}{c}\text { Profundidade } \\
\text { de coleta }\end{array}$ & Rede & $\begin{array}{c}\text { Malha } \\
(\boldsymbol{\mu m})\end{array}$ & $\begin{array}{c}\mathbf{N}^{\circ} \text {. de } \\
\text { inds. }\end{array}$ \\
\hline 509 & $22^{\circ} 31^{\prime} 27,0^{\prime \prime}$ & $040^{\circ} 16^{\prime} 56,0^{\prime \prime}$ & $17 / 05 / 2002$ & oblíquo & $600 \mathrm{~m}$ & cilíndrico-cônica & 500 & 2 \\
\hline
\end{tabular}

Referências: Menezes \& Figueiredo, 1980; Watson, 1996d; Araújo \& Santos, 1999; Gilmore Jr \& Greenfield, 2002; Jimenez-Rosenberg et al., 2006; Powell \& Greene, 2006a; Fahay, 2007 


\section{Família Mullidae}

Os peixes pertencentes à família Mullidae são pequenos e possuem corpo alongado (24 miômeros). Geralmente, são encontrados em águas costeiras na plataforma, próximo ao fundo.

Os membros dessa família possuem as nadadeiras dorsais bem separadas. A nadadeira pélvica está inserida logo anteriormente ou abaixo da primeira nadadeira dorsal. A origem da nadadeira anal está localizada atrás da origem da segunda nadadeira dorsal. Difere de outras famílias pelas seguintes características: na pré-flexão o intestino é curto e compacto, geralmente, $35 \%$ do CP, alcançando 50-60\% CP após a flexão da notocorda; espaço entre o ânus e a nadadeira anal grande que vai diminuindo com o crescimento do intestino; poucos ou nenhum espinho no pré-opérculo; nadadeiras dorsais separadas; poucos raios nas nadadeiras dorsal e anal.

No Brasil já foram identificadas quatro espécies nas fases de larva e adulto: Mulloidichthys martinicus (Cuvier, 1829); Mullus argentinae Hubbs \& Marini, 1933; Pseudupeneus maculatus (Bloch, 1793) e Upeneus parvus Poey, 1852. Nesse estudo é contemplada a espécie Upeneus parvus. 


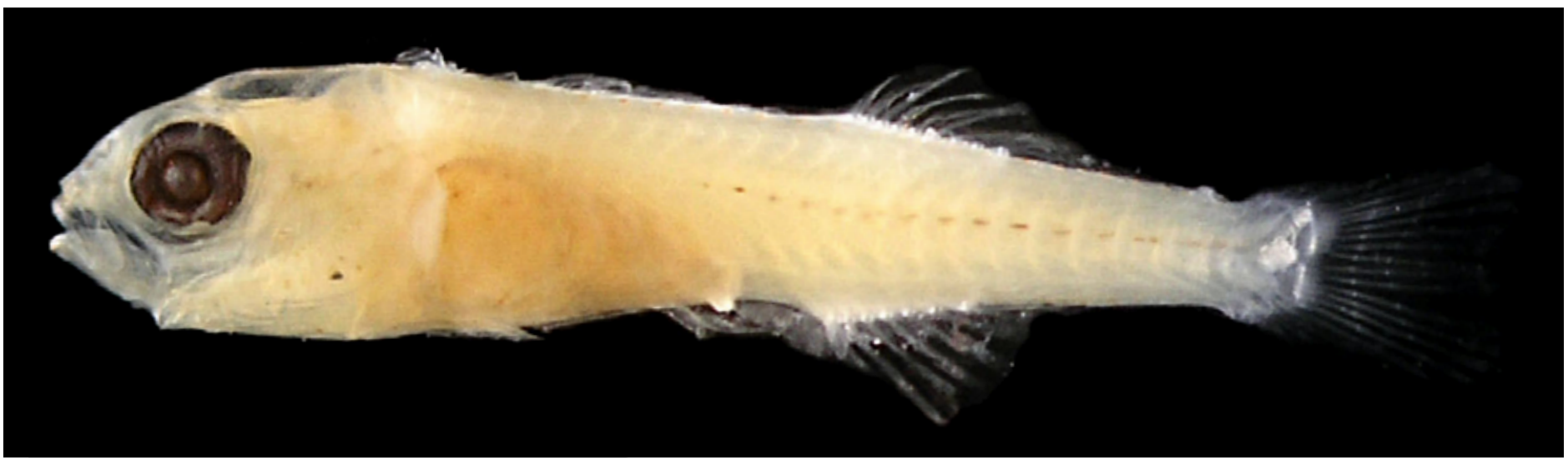

Figura 120 - A: Upeneus parvus. DZUFRJ 2700; Flexão; CP 7,0 mm.

\section{Upeneus parvus Poey, 1852}

Possui o corpo alongado (24 miômeros), comprimido lateralmente, cabeça de tamanho moderado, arredondada dorsalmente. Não tem espinhos cefálicos. As nadadeiras dorsais são bem separadas, com VII espinhos igualmente espaçados na primeira dorsal, sendo o primeiro e o segundo de comprimentos semelhantes. As bases da segunda dorsal e da nadadeira anal são curtas, com oito raios cada. As larvas em flexão já apresentam grandes melanóforos estrelados na porção posterior do encéfalo, formando um triângulo, que segue pela margem dorsal do corpo como uma dupla fileira

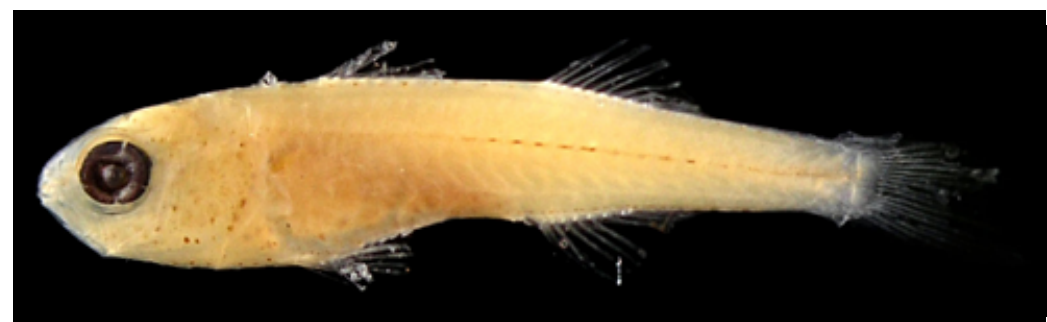

Figura 120 - B: DZUFRJ 2700; Pós-flexão; CP 10,5 mm.

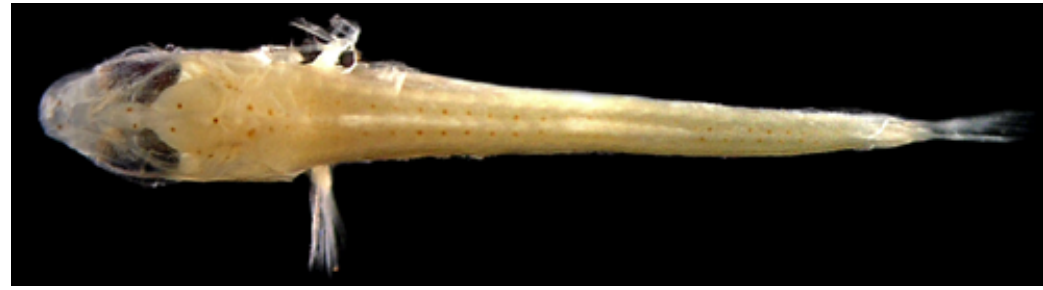

Figura 120 - C: Detalhe da pigmentação da região dorsal durante a pós-flexão.

de pigmentos, até o pedúnculo caudal. A cabeça possui pigmentação característica, com um par de melanóforos na extremidade da maxila superior e entre os olhos, na região anterior do encéfalo. A linha lateral também é muito pigmentada, acompanhada de pequenos melanóforos internos.

Tamanho: flexão 5,0-8,5 mm; pós-flexão 10,2-10,5 mm.

Habitat: espécie marinha, demersal, ocorre em águas tropicais até $100 \mathrm{~m}$ de profundidade.

Nome vulgar: Trilha anã.

\section{Georreferenciamento}

\begin{tabular}{|c|c|c|c|c|c|c|c|c|}
\hline DZUFRJ & Latitude (S) & Longitude (W) & Data & $\begin{array}{l}\text { Tipo de } \\
\text { arrasto }\end{array}$ & $\begin{array}{c}\text { Profundidade } \\
\text { de coleta }\end{array}$ & Rede & $\begin{array}{l}\text { Malha } \\
(\mu \mathrm{m})\end{array}$ & $\begin{array}{l}N^{\circ} \text {. de } \\
\text { inds. }\end{array}$ \\
\hline 466 & $22^{\circ} 33^{\prime} 37,0^{\prime \prime}$ & $040^{\circ} 19^{\prime} 10,0^{\prime \prime}$ & $17 / 05 / 2002$ & oblíquo & $50 \mathrm{~m}$ & bongô & 500 & 2 \\
\hline 2692 & $21^{\circ} 57,51^{\prime}$ & $039^{\circ} 49,57^{\prime}$ & 19/06/2003 & horizontal & superfície & nêuston & 500 & 1 \\
\hline 2700 & $22^{\circ} 28,58^{\prime}$ & $039^{\circ} 55,72^{\prime}$ & $16 / 06 / 2003$ & horizontal & superfície & nêuston & 500 & 3 \\
\hline 2709 & $22^{\circ} 39,68^{\prime}$ & $040^{\circ} 03,24^{\prime}$ & $14 / 06 / 2003$ & horizontal & superfície & nêuston & 500 & 1 \\
\hline 22383 & $22^{\circ} 07^{\prime} 58,8^{\prime \prime}$ & $039^{\circ} 49^{\prime} 08,9^{\prime \prime}$ & $01 / 12 / 2002$ & vertical & $0-50 m$ & cilíndrico-cônica & 500 & 1 \\
\hline
\end{tabular}

Referências: Menezes \& Figueiredo, 1985; Randall, 2002a; Watson, 1996e; Ditty et al., 2006b; Fahay, 2007. 


\section{Família Chaetodontidae}

A família Chaetodontidae é marinha e ocorre nos oceanos Atlântico, Índico e Pacífico. É tipicamente encontrada em regiões tropicais e subtropicais, porém poucas larvas são coletadas em amostragem de ictioplâncton. Compreende 11 gêneros com aproximadamente 122 espécies. Os representantes dessa família são caracterizados pelo corpo lateralmente comprimido e com formato ovalado. No entanto, durante o período larval o corpo pode apresentar-se mais delgado com focinho arredondado e curto. Possui forte pigmentação nas regiões dorsal e ventral do corpo, cabeça e intestino.

No Brasil já foram identificadas seis espécies nas fases de larva e adulto. Nesse estudo é contemplada a espécie Chaetodon sedentarius. 


\section{Chaetodon} sedentarius

\section{Poey, 1860}

A identificação das larvas do gênero Chaetodon baseia-se, principalmente, na contagem dos elementos das nadadeiras, permitindo apenas a identificação no estágio de pós-flexão. Nadadeira dorsal: VIII, 20-24; nadadeira anal: III,17-20 e nadadeira peitoral: I, 13-14. A pigmentação concentra-se na região da cabeça e na porção dorsal do corpo. Alguns melanóforos também são encontrados espalhados na margem ventral do corpo e acompanhando a linha lateral. Presença de pigmentos na membrana entre os espinhos da

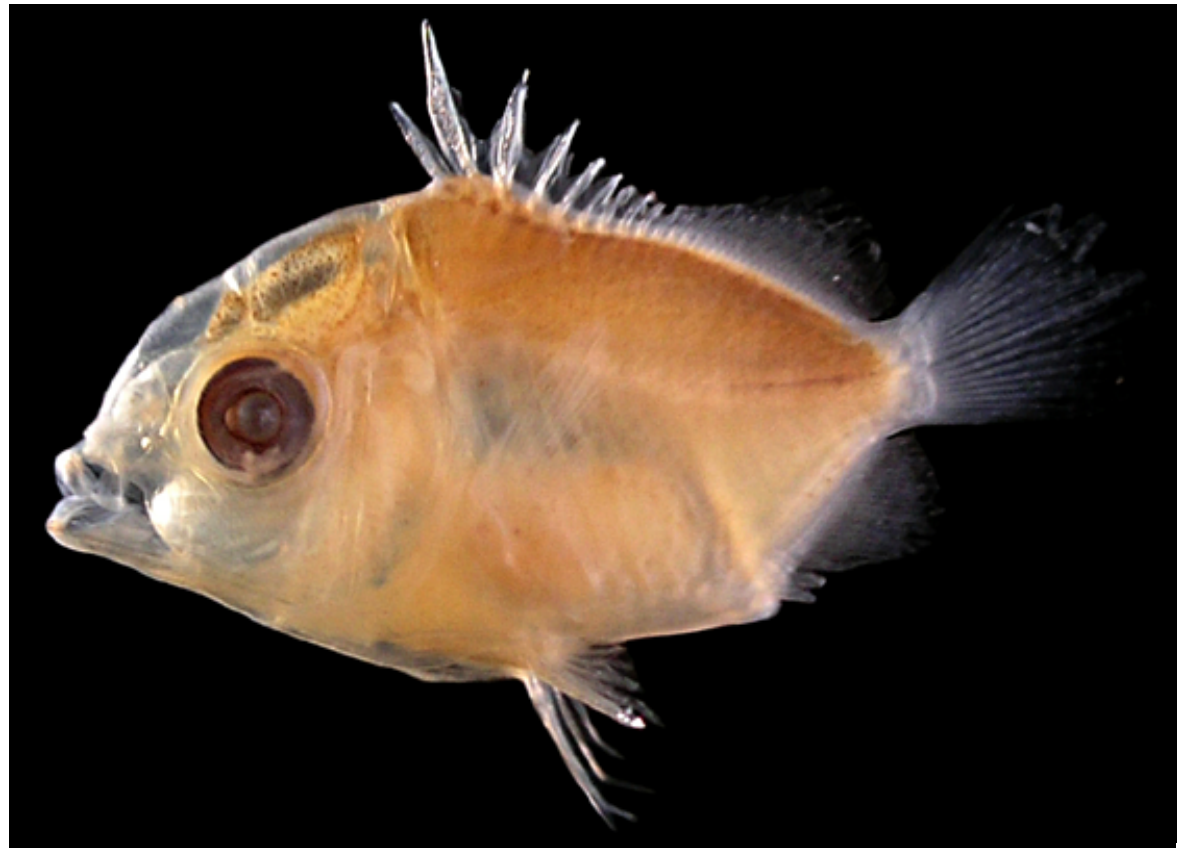

Figura 121: Chaetodon sedentarius. DZUFRJ 7510; Pós-flexão; CP 11,0 mm. primeira nadadeira dorsal. Número total de miômeros: 24.

Tamanho: pós-flexão 11,0 mm.

Habitat: espécie marinha, pelágica, associada a formações coralinas, rochas e substratos. Ocorre em águas subtropicais entre 5 e $92 \mathrm{~m}$ de profundidade.

Nome vulgar: Borboleta namorada.

\section{Georreferenciamento}

\begin{tabular}{|c|c|c|c|c|c|c|c|c|}
\hline DZUFRJ & Latitude (S) & $\begin{array}{c}\text { Longitude } \\
\mathbf{( W )}\end{array}$ & Data & $\begin{array}{c}\text { Tipo de } \\
\text { arrasto }\end{array}$ & $\begin{array}{c}\text { Profundidade } \\
\text { de coleta }\end{array}$ & Rede & $\begin{array}{c}\text { Malha } \\
(\boldsymbol{\mu m})\end{array}$ & $\begin{array}{c}\text { No. de } \\
\text { inds. }\end{array}$ \\
\hline 7510 & $21^{\circ} 54^{\prime} 365^{\prime \prime}$ & $039^{\circ} 45^{\prime} 20,0^{\prime \prime}$ & $10 / 10 / 2001$ & oblíquo & $1.000 \mathrm{~m}$ & cilíndrico-cônica & 500 & 1 \\
\hline
\end{tabular}

Referências: Menezes \& Figueiredo, 1985; Burgess, 2002a; Kelly, $2006 a$. 


\section{Família Pomacanthidae}

A família Pomacanthidae é marinha e ocorre nos oceanos Atlântico, Índico e Pacífico. Vive em águas rasas próximo a formações coralinas e pedras, em grupos ou isoladamente. Compreende oito gêneros com aproximadamente 82 espécies.

O corpo é ovalado e muito comprimido lateralmente. É caracterizada pela presença de um forte espinho no ângulo do pré-opérculo. A boca é pequena e protrátil e o focinho um pouco saliente. Dados merísticos podem ajudar na separação dos gêneros, usando a combinação de dois ou mais elementos. A nadadeira dorsal é contínua: IX-XV, 15-37. Nadadeira anal: III, 14-25.

No Brasil já foram identificadas cinco espécies nas fases de larva e adulto: Centropyge aurantonotus Burgess, 1974; Holacanthus ciliaris (Linnaeus, 1758) e Holacanthus tricolor (Bloch, 1795); Pomacanthus arcuatus (Linnaeus, 1758); Pomacanthus paru (Bloch, 1787). Nesse estudo é contemplada a espécie Centropyge aurantonotus. 


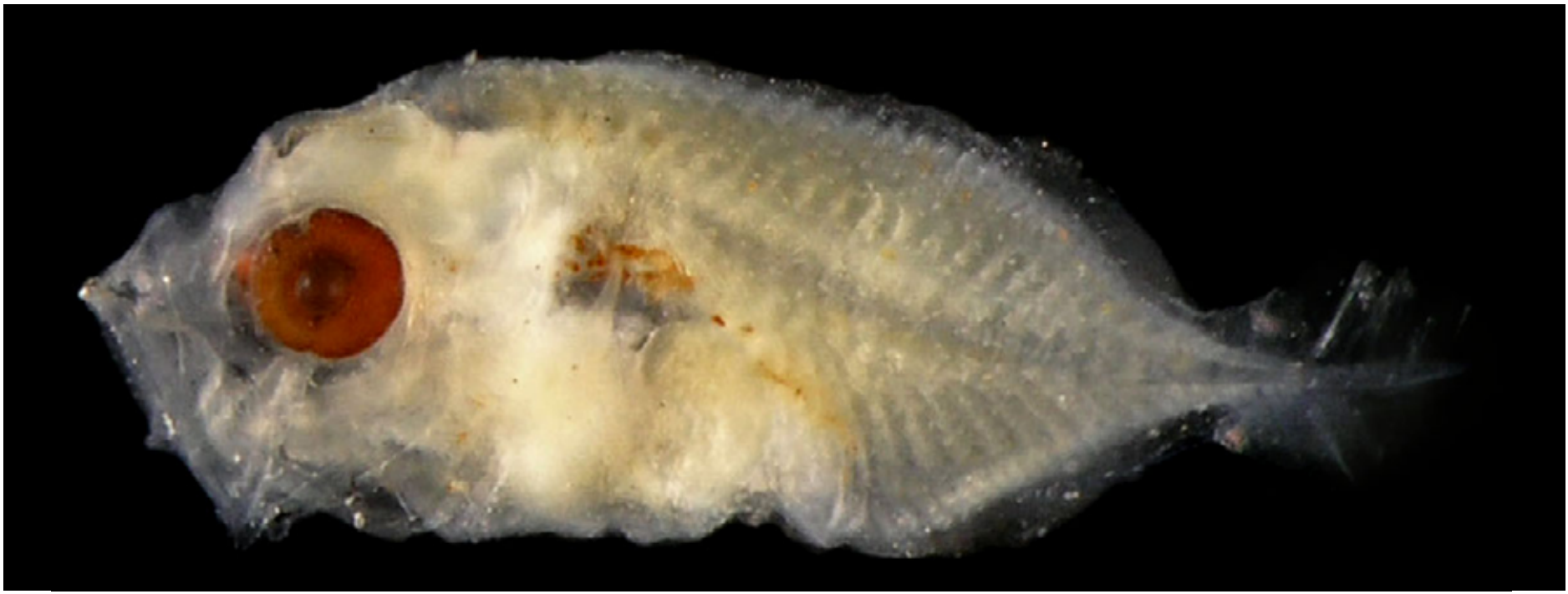

Figura 122 - A: Centropyge aurantonotus. DZUFRJ 352; Pré-flexão; CP 3,0 mm.

\section{Centropyge \\ aurantonotus Burgess, 1974}

A principal característica dessa espécie é o terceiro espinho dorsal mais alongado que os demais, a partir de larvas com 3,4 mm, ficando mais longo em larvas com $4,3 \mathrm{~mm}$ CP de comprimento. No estágio de pré-flexão possui corpo alto e pouco comprimido lateralmente, tornando-se discoide e muito comprimido lateralmente em pós-flexão. Durante a pré-flexão a concentração de pigmentos na cabeça e na região interna acima

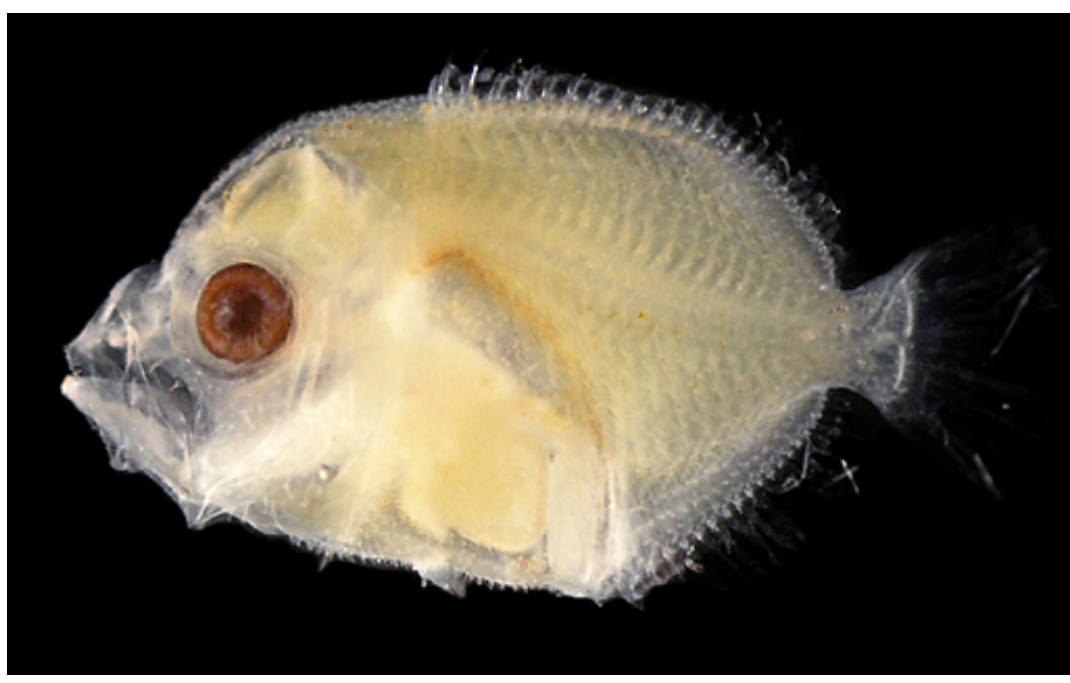

Figura 122 - B: DZUFRJ 352; Flexão; CP 4,8 mm. da vesícula gasosa e do intestino são bem visíveis. Ao longo do desenvolvimento, pequenos espinhos se desenvolvem na cabeça e no corpo. Apresentam melanóforos na cabeça dispersos anterior e posteriormente. A margem da mandíbula é pigmentada. Na margem dorsal do corpo há uma linha simples de melanóforos, começando no terceiro ou quarto miômero, estendendo-se até o $15^{\circ}$. Ao longo da linha lateral, melanóforos estão presentes entre o oitavo e o $15^{\circ}$ miômero. As nadadeiras dorsal e anal apresentam pigmentação acima e abaixo dos miômeros 14 e 15 e melanóforos espalhados na membrana entre os espinhos da nadadeira dorsal. Possui 24 miômeros. Nadadeira dorsal: XIV-XV, 15-17. Nadadeira anal: III, 17.

Tamanho: pré-flexão 3,0 mm; flexão 4,0-5,0 mm; pós-flexão 8,0-8,2 mm; transformação 10,5 mm.

Habitat: espécie marinha, demersal, associada a formações coralinas, ocorre em águas tropicais até $200 \mathrm{~m}$ de profundidade.

Nome vulgar: Anjo dorso de fogo. 


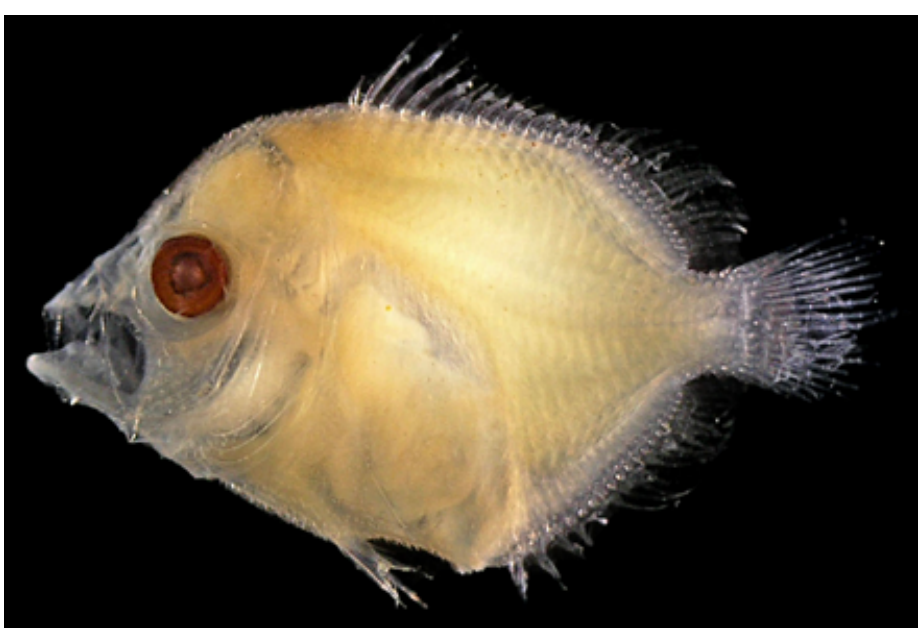

Figura 122 - C: DZUFRJ 1171; Pós-flexão; CP 8,2 mm.

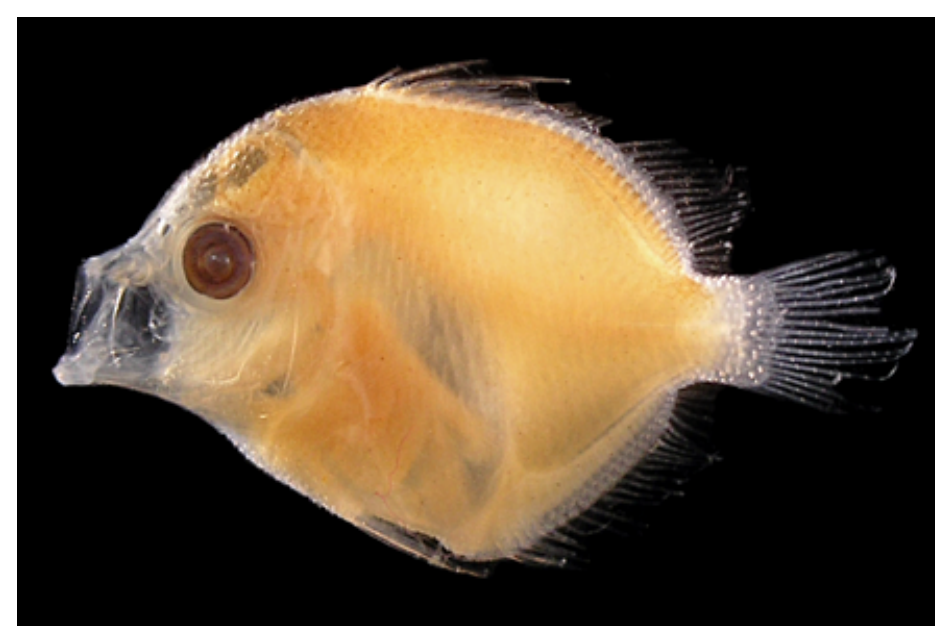

Figura 122 - D: DZUFRJ 7509; Transformação; CP 10,5 mm.

\section{Georreferenciamento}

\begin{tabular}{|c|c|c|c|c|c|c|c|c|}
\hline DZUFRJ & Latitude (S) & Longitude (W) & Data & $\begin{array}{l}\text { Tipo de } \\
\text { arrasto }\end{array}$ & $\begin{array}{c}\text { Profundidade } \\
\text { de coleta }\end{array}$ & Rede & $\begin{array}{l}\text { Malha } \\
(\mu \mathrm{m})\end{array}$ & $\begin{array}{l}N^{\circ} \text {. de } \\
\text { inds. }\end{array}$ \\
\hline 352 & $22^{\circ} 42^{\prime} 06,0^{\prime \prime}$ & $040^{\circ} 14^{\prime} 26,0^{\prime \prime}$ & $19 / 05 / 2002$ & oblíquo & $50 \mathrm{~m}$ & & 330 & 2 \\
\hline 357 & $2 \circ 33 ' 47,7 "$ & (II" & $17 / 05 / 2002$ & oblíquo & $50 \mathrm{~m}$ & & & 1 \\
\hline 1171 & & & $10 / 05 / 2002$ & & & cilíndrico-cônica & & 1 \\
\hline 1226 & $22^{\circ} 02^{\prime} 30,0^{\prime \prime}$ & 39०49'41,2" & $12 / 05 / 2002$ & oblíquo & $1.000 \mathrm{~m}$ & cilíndrico-cônica & 500 & 1 \\
\hline 7509 & $21^{\circ} 54^{\prime} 36,5^{\prime \prime}$ & $39^{\circ} 45^{\prime} 20,0^{\prime \prime}$ & $10 / 10 / 2001$ & oblíquo & $1.000 \mathrm{~m}$ & cilíndrico-cônica & 500 & 1 \\
\hline 22406 & $22^{\circ} 08^{\prime} 01,8^{\prime \prime}$ & $039^{\circ} 37^{\prime} 30,8^{\prime \prime}$ & $03 / 12 / 2002$ & vertical & $200-500 m$ & cilíndrico-cônica & 500 & 1 \\
\hline
\end{tabular}

Referências: Menezes \& Figueiredo, 1985; Burgess, 2002b; Kelly, 2006b; Fahay, 2007. 


\section{Família Cirrhitidae}

A família Cirrhitidae é marinha e ocorre nos oceanos Atlântico tropical, Índico e Pacífico. A maioria das espécies ocorre no Indo-Pacífico. São encontradas em águas tropicais e costeiras e os adultos vivem associados a rochas e corais. Compreende 12 gêneros com aproximadamente 33 espécies.

São caracterizadas pelo corpo alongado, com focinho pontudo e um barbilhão na extremidade da maxila inferior. Essa característica é diagnóstica da família e o barbilhão aumenta de tamanho com o decorrer do desenvolvimento da larva.

No Brasil já foi identificada uma espécie nas fases de larva e adulto: Amblycirrhitus pinos (Mowbray, 1927). Nesse estudo é contemplada a espécie Amblycirrhitus pinos. 


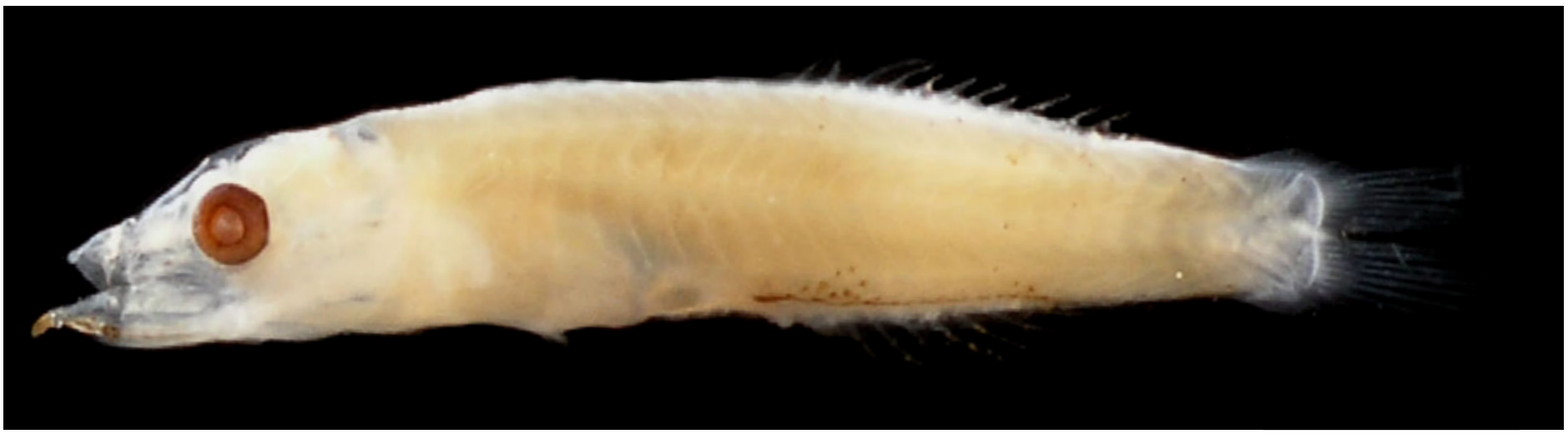

Figura 123 - A: Amblycirrhitus pinos. DZUFRJ 16055; Flexão; CP 4,9 mm.

\section{Amblycirrhitus pinos (Mowbray, 1927)}

O corpo é inicialmente alongado (26 miômeros) e lateralmente comprimido. Com o crescimento o corpo e o pedúnculo caudal tornam-se mais altos. A cabeça possui tamanho moderado e o focinho é pontudo. A

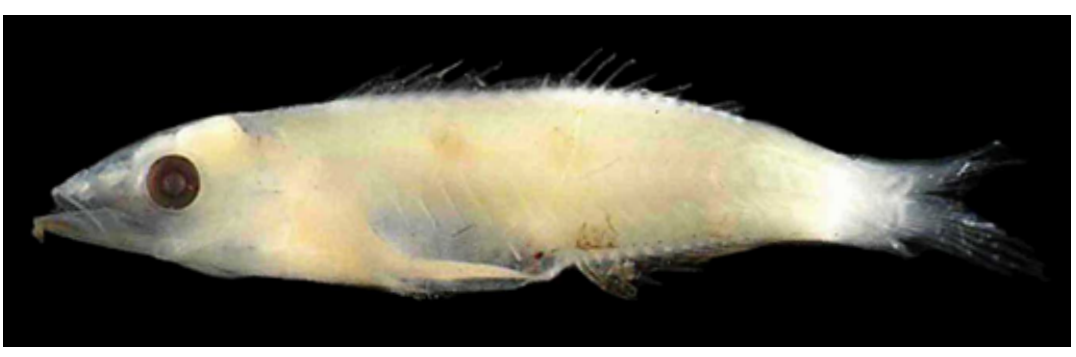

Figura 123 - B: DZUFRJ 341; Pós-flexão; CP 10,0 mm.

boca é terminal e na maxila inferior encontra-se um barbilhão pigmentado que se desenvolve a medida que a larva cresce. O intestino é longo e estreito. A origem da nadadeira pélvica é bem posterior à origem da nadadeira peitoral. No estágio de flexão existem poucos pigmentos espaIhados na margem ventral do corpo, começando a organizar-se em blocos. No estágio de pós-flexão formam-se várias bandas de pigmento no corpo, sempre associadas aos ângulos superior e inferior dos miosseptos. Outros melanóforos estão presentes no dorso da cabeça e focinho. As membranas que cobrem os espinhos e raios das nadadeiras dorsal e anal são pigmentadas.

Tamanho: flexão 4,9-7,5 mm; pós-flexão 8,0-10,0 mm.

Habitat: espécie marinha, demersal, ocorre em águas tropicais próximo a rochas e a formações coralinas até $46 \mathrm{~m}$ de profundidade.

Nome vulgar: Pinos.

\section{Georreferenciamento}

\begin{tabular}{|c|c|c|c|c|c|c|c|c|}
\hline DZUFRJ & Latitude (S) & Longitude (W) & Data & $\begin{array}{c}\text { Tipo de } \\
\text { arrasto }\end{array}$ & $\begin{array}{c}\text { Profundidade } \\
\text { de coleta }\end{array}$ & Rede & $\begin{array}{c}\text { Malha } \\
(\boldsymbol{\mu m})\end{array}$ & $\begin{array}{c}\mathbf{N}^{\circ} \text {. de } \\
\text { inds. }\end{array}$ \\
\hline 635 & $22^{\circ} 36^{\prime} 54,9^{\prime \prime}$ & $040^{\circ} 09^{\prime} 19,4^{\prime \prime}$ & $16 / 05 / 2002$ & oblíquo & $50 \mathrm{~m}$ & bongô & 330 & 1 \\
\hline 698 & $22^{\circ} 37^{\prime} 355^{\prime \prime}$ & $040^{\circ} 09^{\prime} 32,8^{\prime \prime}$ & $16 / 05 / 2002$ & oblíquo & $1.000 \mathrm{~m}$ & cilíndrico-cônica & 500 & 1 \\
\hline 1224 & $22^{\circ} 02^{\prime} 30,0^{\prime \prime}$ & $039^{\circ} 49^{\prime} 41,2^{\prime \prime}$ & $12 / 05 / 2002$ & oblíquo & $1.000 \mathrm{~m}$ & cilíndrico-cônica & 500 & 1 \\
\hline 1233 & $22^{\circ} 03^{\prime} 21,7^{\prime \prime}$ & $039^{\circ} 45^{\prime} 11,9^{\prime \prime}$ & $12 / 05 / 2002$ & oblíquo & $1.000 \mathrm{~m}$ & cilíndrico-cônica & 500 & 1 \\
\hline 1275 & $22^{\circ} 06^{\prime} 37,8^{\prime \prime}$ & $039^{\circ} 49^{\prime} 44,8^{\prime \prime}$ & $10 / 05 / 2002$ & oblíquo & até a termoclina & bongô & 500 & 1 \\
\hline 1297 & $22^{\circ} 02^{\prime} 30,0^{\prime \prime}$ & $039^{\circ} 49^{\prime} 41,2^{\prime \prime}$ & $12 / 05 / 2002$ & oblíquo & até a termoclina & bongô & 500 & 2 \\
\hline 1315 & $22^{\circ} 08^{\prime} 14,9^{\prime \prime}$ & $039^{\circ} 46^{\prime} 34,6^{\prime \prime}$ & $11 / 05 / 2002$ & oblíquo & até a termoclina & bongô & 500 & 3 \\
\hline 1361 & $22^{\circ} 02^{\prime} 30,0^{\prime \prime}$ & $039^{\circ} 49^{\prime} 41,2^{\prime \prime}$ & $12 / 05 / 2002$ & oblíquo & até a termoclina & bongô & 330 & 1 \\
\hline 1384 & $22^{\circ} 08^{\prime} 14,9^{\prime \prime}$ & $039^{\circ} 46^{\prime} 34,6^{\prime \prime}$ & $11 / 05 / 2002$ & oblíquo & até a termoclina & bongô & 330 & 1 \\
\hline
\end{tabular}

Referências: Watson, 1996f; Randall, 2002b; Criales, 2006; Fahay, 2007. 


\section{Família Mugilidae}

A família Mugilidae é marinha e costeira ou estuarina e migra além da plataforma continental para reprodução. É representada por 17 gêneros, com aproximadamente 72 espécies. Possui nadadeira dorsal separada, com IV espinhos e 8-10 raios. A anal é formada por II - III espinhos e 7-11 raios. É caracterizada pela nadadeira pélvica subabdominal.

No Brasil já foram identificadas dez espécies nas fases de larva e adulto. Nesse estudo é contemplada a espécie Mugil curema. 


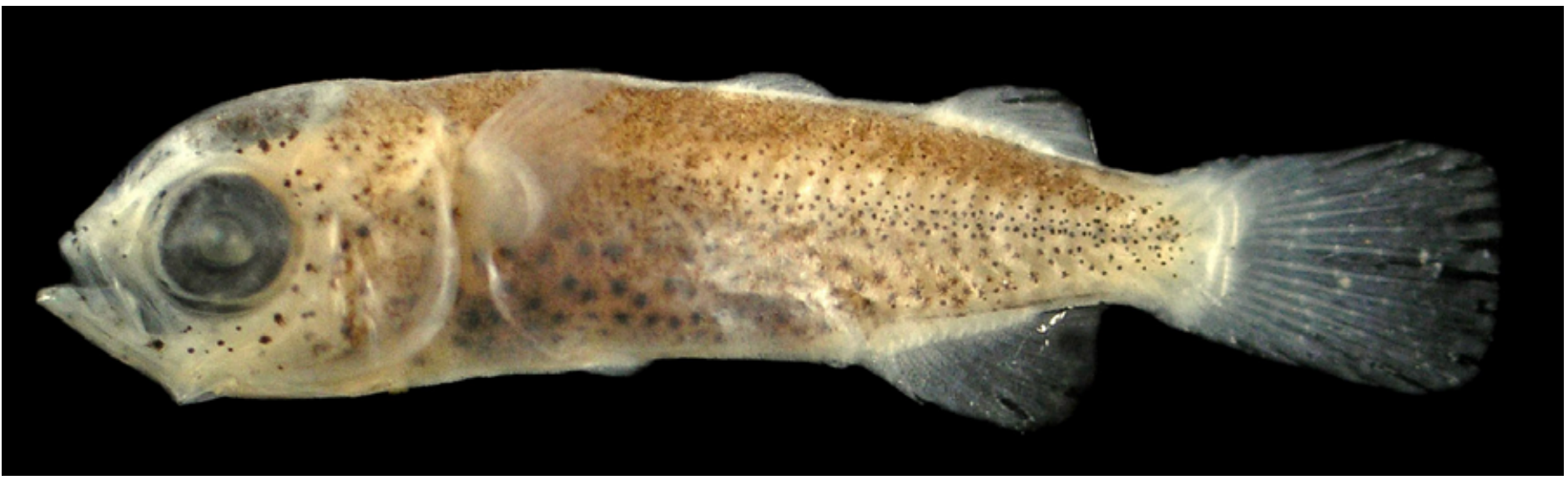

Figura 124 - A: Mugil curema. A. DZUFRJ 33543; Pós-flexão; CP 6,0 mm.

\section{Mugil curema Valenciennes, 1836}

O corpo é relativamente estreito e robusto, o intestino é grande e volumoso e corresponde até $70 \%$ do CP. É caracterizada por duas nadadeiras dorsais com base curta (quatro espinhos e oito raios). A nadadeira anal é formada por três espinhos e nove

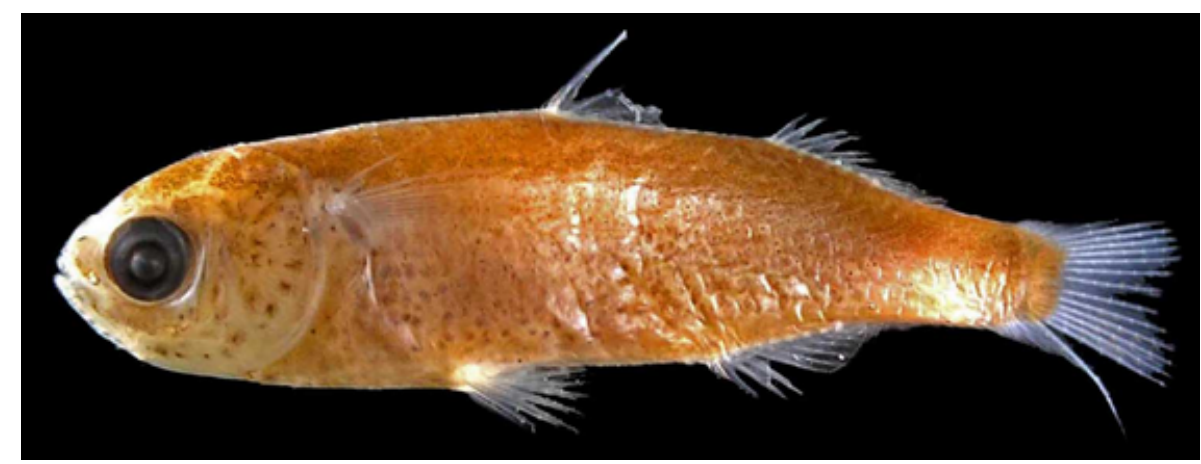

Figura 124 - B: DZUFRJ 24896; Transformação; CP 16,2 mm. raios, o que a separa das espécies Mugil cephalus, Mugil curvidens, Mugil liza, Mugil trichodon. Pode ser separada de Mugil incilis pela posição da origem da segunda nadadeira dorsal ao longo da base da anal. A pigmentação é muito evidente na região dorsal da cabeça, seguindo até a base da segunda nadadeira dorsal. A região dorsal do intestino e a margem ventral do corpo (entre o ânus e a base da nadadeira caudal) são muito pigmentadas. Em pós-flexão e transformação a larva é muito escura na maior parte do corpo. Número total de miômeros: 24.

Tamanho: pós-flexão 6,0-8,0 mm; transformação 16,2 mm.

Habitat: espécie marinha, pelágica, ocorre em águas subtropicais. Vivem em regiões costeiras ou estuarinas até $15 \mathrm{~m}$ de profundidade.

Nome vulgar: Tainha pratiqueira.

Georreferenciamento

\begin{tabular}{|c|c|c|c|c|c|c|c|c|}
\hline DZUFRJ & Latitude (S) & Longitude (W) & Data & $\begin{array}{l}\text { Tipo de } \\
\text { arrasto }\end{array}$ & $\begin{array}{c}\text { Profundidade } \\
\text { de coleta }\end{array}$ & Rede & $\begin{array}{l}\text { Malha } \\
(\mu \mathrm{m})\end{array}$ & $\begin{array}{l}\mathrm{N}^{\circ} \text {. de } \\
\text { inds. }\end{array}$ \\
\hline 24895 & $22^{\circ} 28,52^{\prime}$ & $039^{\circ} 55,47^{\prime}$ & $16 / 06 / 2003$ & horizontal & superfície & nêuston & 500 & 2 \\
\hline 24896 & $22^{\circ} 36,08^{\prime}$ & $039^{\circ} 54,39^{\prime}$ & $15 / 06 / 2003$ & horizontal & superfície & nêuston & 500 & 1 \\
\hline
\end{tabular}

Referências: Monteiro_Ribas \& Bonecker, 2001; Ditty et al., 2006c; Fahay, 2007. 


\section{Família Pomacentridae}

A família Pomacentridae é marinha e ocorre em todos os mares tropicais. Compreende 28 gêneros com aproximadamente 348 espécies. Algumas espécies são encontradas também em regiões temperadas e muito poucas podem viver em águas salobras e doces. Ocorre em águas costeiras, de baixa profundidade, associada a rochas ou formações coralinas. As larvas são alongadas até a flexão da notocorda. A medida que a larva cresce o corpo torna-se alto. O intestino enrola-se adquirindo um formato triangular e curto, muito pigmentado. Uma pequena vesícula gasosa está localizada anteriormente a massa visceral. Apresenta poucos espinhos na cabeça (com exceção da subfamília Chrominae), região suborbital serrilhada, presença de um pequeno espinho opercular e alguns pequenos espinhos pré-operculares e supracleitral. Possui boca pequena e linha lateral incompleta. Nadadeira anal: II, 9-15. Nadadeira dorsal contínua: XII-XIII, 11-17.

No Brasil já foram identificadas 16 espécies nas fases de larva e adulto. Nesse estudo são contempladas as espécies Abudefduf saxatilis, Stegastes leucostictus e Microspathodon chrysurus. 


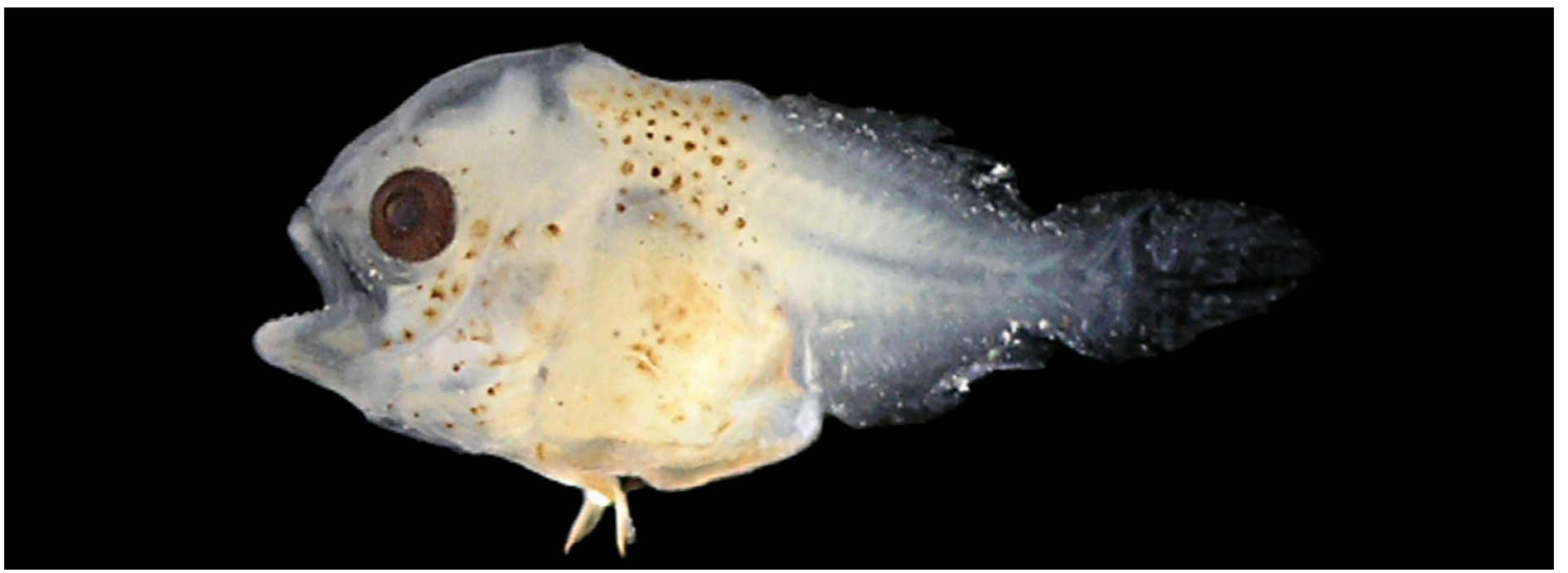

Figura 125 - Abudefduf saxatilis. DZUFRJ 388; Flexão; CP 3,5 mm.

\section{Abudefduf saxatilis (Linnaeus, 1758)}

O corpo é inicialmente alongado (26 miômeros) e lateralmente comprimido, tornando-se alto após a flexão. A cabeça também é alta e o focinho é arredondado. O intestino enrola-se adquirindo um formato triangular e curto, muito pigmentado. Possui melanóforos na porção ventral da massa visceral, o que separa essa espécie das demais. No estágio de flexão, a porção anterior do corpo é muito pigmentada, concentrando-se na área do opérculo, cabeça e sobre o intestino. O pedúnculo caudal não tem pigmentos. Nadadeira dorsal: XIII, 12-13. Nadadeira anal: II, 12-13.

Tamanho: flexão 3,5 mm.

Habitat: espécie marinha, demersal, ocorre em águas subtropicais até $15 \mathrm{~m}$ de profundidade. Vive associada a formações coralinas e rochas.

Nome vulgar: Sargento.

\section{Georreferenciamento}

\begin{tabular}{|c|c|c|c|c|c|c|c|c|}
\hline DZUFRJ & Latitude (S) & Longitude (W) & Data & $\begin{array}{c}\text { Tipo de } \\
\text { arrasto }\end{array}$ & $\begin{array}{c}\text { Profundidade } \\
\text { de coleta }\end{array}$ & Rede & $\begin{array}{c}\text { Malha } \\
\left.\text { ( } \boldsymbol{\mu m}^{2}\right)\end{array}$ & $\begin{array}{c}\mathbf{N}^{\circ} \text {. de } \\
\text { inds. }\end{array}$ \\
\hline 388 & $22^{\circ} 31^{\prime} 27,0^{\prime \prime}$ & $040^{\circ} 16^{\prime} 56,0^{\prime \prime}$ & $17 / 05 / 2002$ & oblíquo & $600 \mathrm{~m}$ & cilíndrico-cônica & 500 & 1 \\
\hline
\end{tabular}

Referências: Menezes \& Figueiredo, 1985; Watson, 1996g; Carter, 2002; Fahay, 2007. 


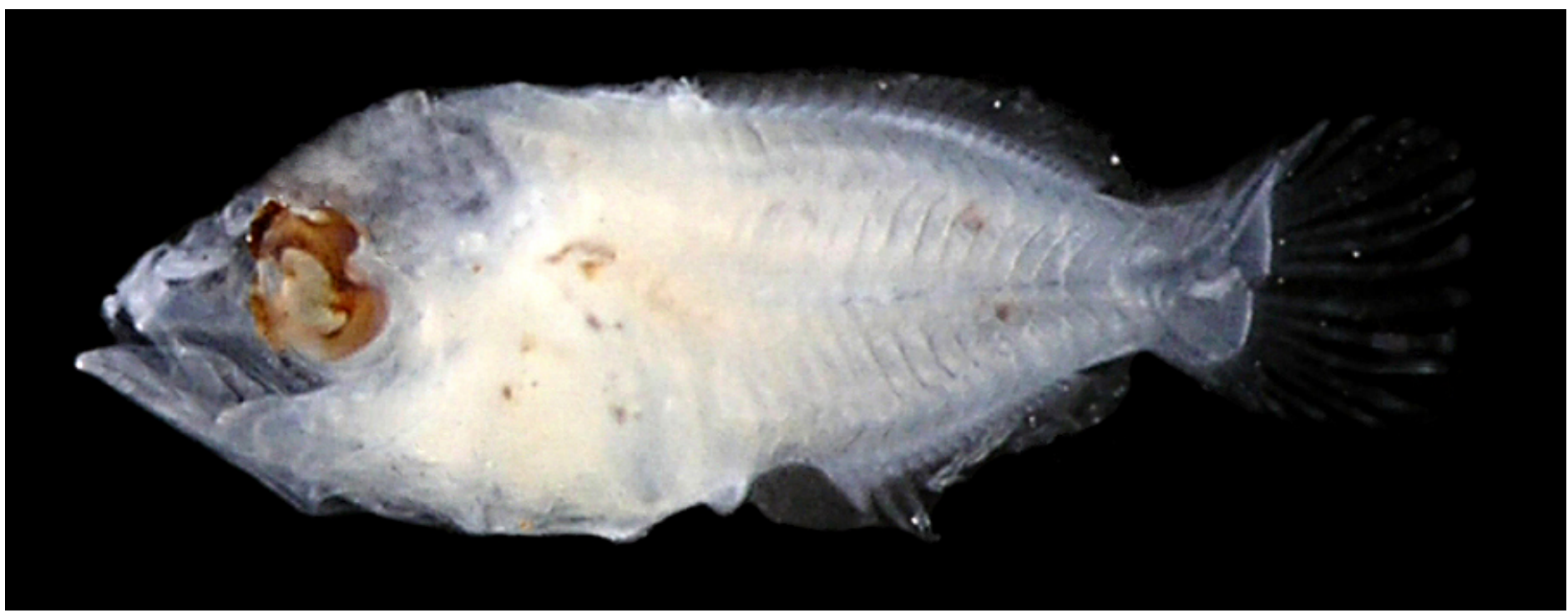

Figura 126: Microspathodon chrysurus. DZUFRJ 22408; Flexão; CP 3,8 mm.

\section{Microspathodon chrysurus (Cuvier, 1830)}

Desde a pré-flexão possui pigmentos espalhados pela membrana entre os raios da nadadeira peitoral. Forte pigmentação na metade da cabeça e na nuca. Tem melanóforos distribuídos na porção anterior da massa visceral e no cleitro. Possui manchas internas de melanóforos na porção mediano-dorsal e mediano-ventral. A nadadeira pélvica apresenta pigmentos nos raios antes da flexão da notocorda. Número total de miômeros: 26.

Tamanho: flexão 3,8-4,6 mm.

Habitat: espécie marinha, demersal, ocorre em águas subtropicais até $120 \mathrm{~m}$ de profundidade, mas normalmente é encontrada a $10 \mathrm{~m}$. Vive próximo ao topo ou exterior de cavernas e frestas, sendo abundante em regiões de formações coralinas.

Nome vulgar: Donzela azul.

Georreferenciamento

\begin{tabular}{|c|c|c|c|c|c|c|c|c|}
\hline DZUFR & Latitude (S) & Longitude (W) & Data & $\begin{array}{c}\text { Tipo de } \\
\text { arrasto }\end{array}$ & $\begin{array}{c}\text { Profundidade } \\
\text { de coleta }\end{array}$ & Rede & $\begin{array}{c}\text { Malha } \\
\text { ( } \boldsymbol{\mu m} \text { ) }\end{array}$ & $\begin{array}{c}\text { No. de } \\
\text { inds. }\end{array}$ \\
\hline 492 & $22^{\circ} 33^{\prime} 45,8^{\prime \prime}$ & $040^{\circ} 13^{\prime} 22,9^{\prime \prime}$ & $17 / 05 / 2002$ & oblíquo & $800 \mathrm{~m}$ & cilíndrico-cônica & 500 & 1 \\
\hline 22408 & $22^{\circ} 07^{\prime} 58,8^{\prime \prime}$ & $039^{\circ} 49^{\prime} 08,9^{\prime \prime}$ & $01 / 12 / 2002$ & vertical & $0-50 \mathrm{~m}$ & cilíndrico-cônica & 500 & 1 \\
\hline
\end{tabular}

Referências: Menezes \& Figueiredo, 1985; Watson, 1996g; Carter, 2002; Fahay, 2007. 


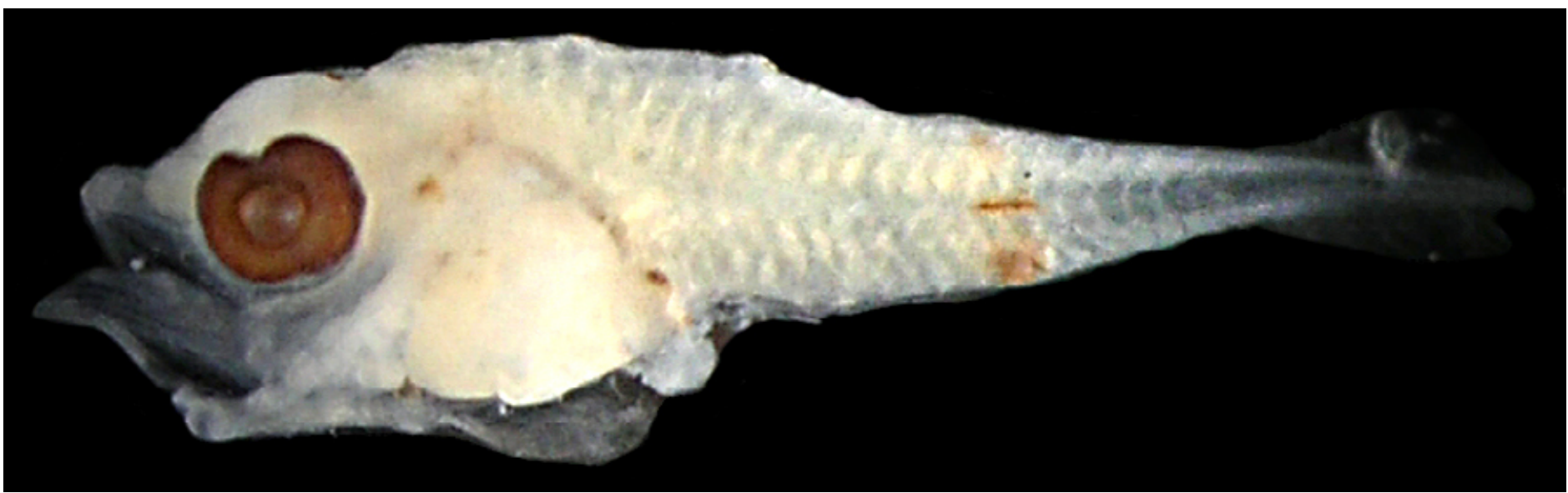

Figura 127 - A: Stegastes leucostictus. DZUFRJ 383; Pré-flexão; CP 2,5 mm.

\section{Stegastes leucostictus (Müller \& Troschel, 1848)}

Essa espécie se difere de outros pomacentrídeos pela combinação de características merísticas e pelo padrão de pigmentação. As larvas em pré-flexão apresentam poucos melanóforos na porção posterior da cabeça, uma linha ventral de pigmentos no corpo e na base da notocorda. Em flexão, possuem pigmentos na linha lateral com poucas manchas mediano-dorsais claras, além de forte pigmentação na margem dorsal da massa visceral. No estágio de pós-flexão a primeira nadadeira dorsal e a peitoral são pigmentadas, enquanto a segunda dorsal e a anal não possuem pigmentos. Em todos os estágios não há pigmentação no pedúnculo caudal e nem no focinho. Número total de miômeros: 26.

Tamanho: pré-flexão 2,1-2,8 mm; flexão 4,6-4,8 mm; pós-flexão 5,0 mm.

Habitat: espécie marinha, demersal, ocorre em águas

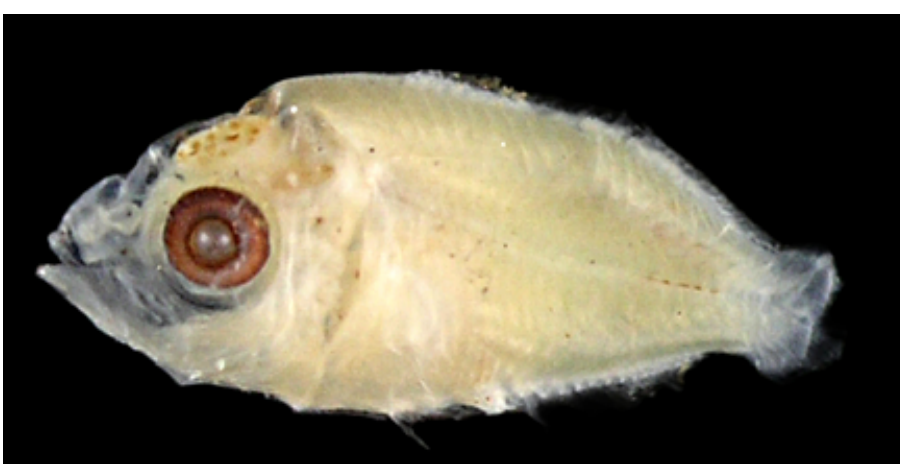

Figura 127 - B: DZUFRJ 392; Flexão; CP 4,8 mm.

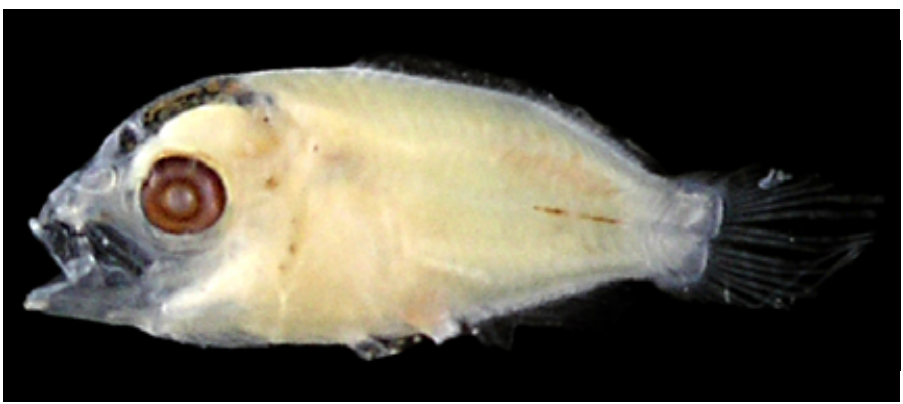

Figura 127 - C: DZUFRJ 5027; Pós-flexão; CP 5,0 mm. tropicais até $10 \mathrm{~m}$ de profundidade. Vive próximo a gramas marinhas, formações coralinas e rochas, podendo ser encontrada também em áreas de mangue.

\section{Georreferenciamento}

\begin{tabular}{|c|c|c|c|c|c|c|c|c|}
\hline DZUFR & Latitude (S) & Longitude (W) & Data & $\begin{array}{c}\text { Tipo de } \\
\text { arrasto }\end{array}$ & $\begin{array}{c}\text { Profundidade } \\
\text { de coleta }\end{array}$ & Rede & $\begin{array}{c}\text { Malha } \\
\text { ( } \boldsymbol{\mu m} \text { ) }\end{array}$ & $\begin{array}{c}\text { No. de } \\
\text { inds. }\end{array}$ \\
\hline 383 & $22^{\circ} 31^{\prime} 27,0^{\prime \prime}$ & $040^{\circ} 16^{\prime} 56,0^{\prime \prime}$ & $17 / 05 / 2002$ & oblíquo & $600 \mathrm{~m}$ & cilíndrico-cônica & 500 & 3 \\
\hline 387 & $22^{\circ} 36^{\prime} 54,9^{\prime \prime}$ & $040^{\circ} 09^{\prime} 19,4^{\prime \prime}$ & $16 / 05 / 2002$ & oblíquo & $50 \mathrm{~m}$ & bongô & 500 & 1 \\
\hline 391 & $22^{\circ} 32^{\prime} 03,0^{\prime \prime}$ & $040^{\circ} 17^{\prime} 21,0^{\prime \prime}$ & $19 / 05 / 2002$ & oblíquo & $30 \mathrm{~m}$ & bongô & 330 & 1 \\
\hline 392 & $22^{\circ} 41^{\prime} 544^{\prime \prime}$ & $040^{\circ} 14^{\prime} 04,5^{\prime \prime}$ & $16 / 05 / 2002$ & oblíquo & $1.000 \mathrm{~m}$ & cilíndrico-cônica & 500 & 1 \\
\hline 22198 & $22^{\circ} 33^{\prime} 477^{\prime \prime}$ & $040^{\circ} 12^{\prime} 20,5^{\prime \prime}$ & $17 / 05 / 2002$ & oblíquo & $50 \mathrm{~m}$ & bongô & 330 & 1 \\
\hline
\end{tabular}

Referências: Menezes \& Figueiredo, 1985; Watson, 1996g; Carter, 2002; Fahay, 2007. 


\section{Família Labridae}

A família Labridae é marinha e ocorre nos oceanos Atlântico, Índico e Pacífico. Compreende aproximadamente 68 gêneros e 453 espécies. É dominante na ictiofauna que vive associada à corais e comunidades de gramas marinhas, em regiões tropicais. Vive em todos os ambientes tropicais do mundo e é uma das famílias mais diversificadas, em relação à coloração, ao formato e tamanho do corpo.

As larvas de Labridae são tipicamente alongadas, comprimidas lateralmente e possuem uma única nadadeira dorsal que se origina sobre a base da peitoral ou atrás da cabeça. O pedúnculo caudal é alto e o intestino é rugoso estendendo-se até metade do corpo. Não apresenta espinho na cabeça. O formato dos olhos é variável e pode ter uma massa ventral de tecido coroide despigmentado. As larvas no estágio de pré-flexão frequentemente possuem melanóforos na membrana embrionária, enquanto que a maioria das larvas em pós-flexão tem pouca ou nenhuma pigmentação.

No Brasil já foram identificadas 18 espécies nas fases de larva e adulto. Nesse estudo são contempladas as espécies Halichoeres maculipina e Thalassoma noronhanum. 


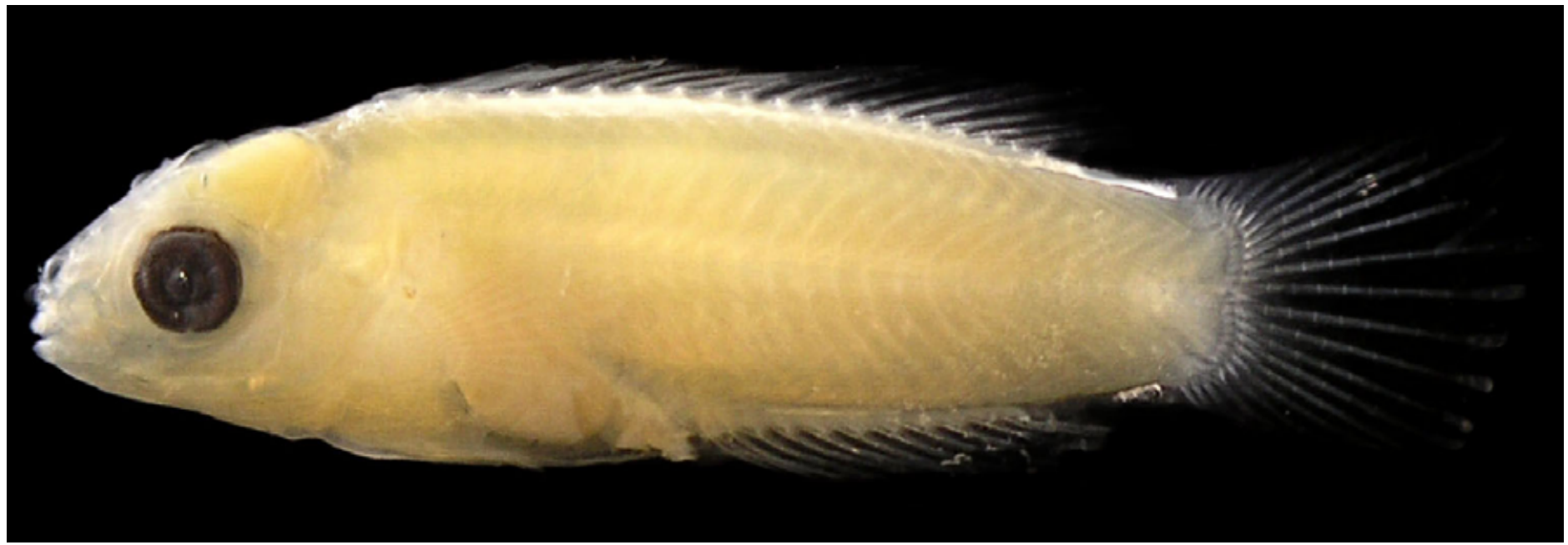

Figura 128: Halichoeres maculipinna. DZUFRJ 11898; Pós-flexão; CP 8,9mm.

\section{Halichoeres maculipinna (Müller \& Troschel, 1848)}

O corpo é alongado (25 miômeros), comprimido lateralmente e mais alto na região peitoral; o pedúnculo caudal é alto. A cabeça é pequena com um focinho pontudo, olho arredondado e boca mediana. Nadadeira dorsal: IX, 11. Nadadeira anal: III, 11. A nadadeira peitoral é formada por 14 raios. A ausência de pigmentos pelo corpo é característica da espécie. A pigmentação se restringe a uma mancha de melanóforos sobre o intestino (próximo ao ânus) e alguns pigmentos associados a porção posterior dos raios das nadadeiras dorsal e anal.

Tamanho: pós-flexão 7,0-9,5 mm.

Habitat: espécie marinha, demersal, ocorre em águas tropicais até $24 \mathrm{~m}$ de profundidade. Vive associada a formações coralinas, algas e áreas rochosas.

Nome vulgar: Budião palhaço.

\section{Georreferenciamento}

\begin{tabular}{|c|c|c|c|c|c|c|c|c|}
\hline DZUFRJ & Latitude (S) & Longitude (W) & Data & $\begin{array}{l}\text { Tipo de } \\
\text { arrasto }\end{array}$ & $\begin{array}{c}\text { Profundidade } \\
\text { de coleta }\end{array}$ & Rede & $\begin{array}{l}\text { Malha } \\
(\mu \mathrm{m})\end{array}$ & $\begin{array}{l}N^{\circ} \text {. de } \\
\text { inds. }\end{array}$ \\
\hline 499 & $22^{\circ} 38^{\prime} 25,0^{\prime \prime}$ & $040^{\circ} 17^{\prime} 41,0^{\prime \prime}$ & 19/05/2002 & oblíquo & $40 \mathrm{~m}$ & bongô & 500 & 1 \\
\hline 508 & $22^{\circ} 31^{\prime} 27,0^{\prime \prime}$ & $040^{\circ} 16^{\prime} 56,0^{\prime \prime}$ & $17 / 05 / 2002$ & oblíquo & $600 \mathrm{~m}$ & cilíndrico-cônica & 500 & 1 \\
\hline 537 & $22^{\circ} 33^{\prime} 47,7^{\prime \prime}$ & $040^{\circ} 12^{\prime} 20,5^{\prime \prime}$ & $17 / 05 / 2002$ & oblíquo & $50 \mathrm{~m}$ & bongô & 330 & 1 \\
\hline
\end{tabular}

Referências: Menezes \& Figueiredo, 1985; Watson, 1996h; Westneat, 2002a; Jones et al., 2006a; Fahay, 2007. 


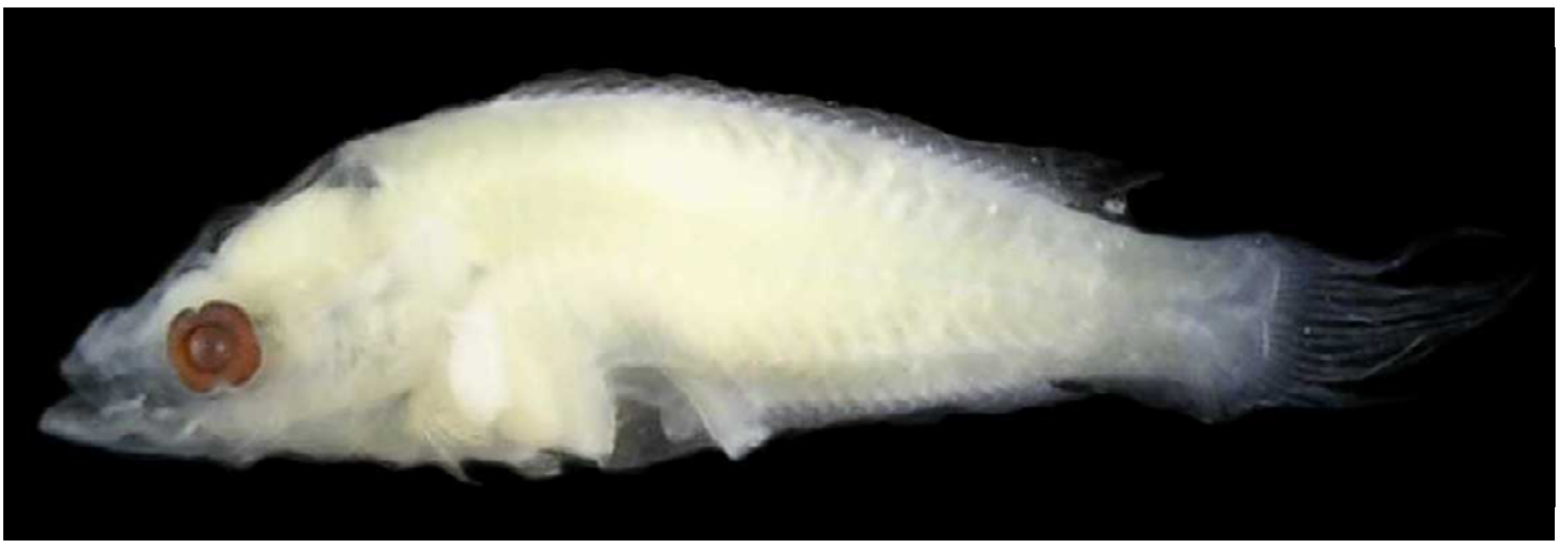

Figura 129: Thalassoma noronhanum. DZUFRJ 12057; Flexão; CP 4,8 mm.

\section{Thalassoma noronhanum (Boulenger, 1890)}

O corpo é alongado (25 miômeros), comprimido lateralmente, sendo mais alto na região peitoral; o pedúnculo caudal é alto. A cabeça é proporcionalmente grande em relação a outras espécies dessa família. A boca é muito pequena e o olho é arredondado.

Tamanho: flexão 4,8-6,5 mm.

Habitat: espécie marinha, demersal, ocorre em águas tropicais até $60 \mathrm{~m}$ de profundidade, mas normalmente é encontrada entre 2 e $5 \mathrm{~m}$. Vive associada a formações coralinas, esponjas ou conchas vazias.

Nome vulgar: Budião de Noronha.

\section{Georreferenciamento}

\begin{tabular}{|c|c|c|c|c|c|c|c|c|}
\hline DZUFR J & Latitude (S) & Longitude (W) & Data & $\begin{array}{c}\text { Tipo de } \\
\text { arrasto }\end{array}$ & $\begin{array}{c}\text { Profundidade } \\
\text { de coleta }\end{array}$ & Rede & $\begin{array}{c}\text { Malha } \\
\text { ( } \boldsymbol{\mu m} \text { ) }\end{array}$ & $\begin{array}{c}\mathbf{N}^{\circ} \text {. de } \\
\text { inds. }\end{array}$ \\
\hline 368 & $22^{\circ} 38^{\prime} 25,0^{\prime \prime}$ & $040^{\circ} 17^{\prime} 41,0^{\prime \prime}$ & $19 / 05 / 2002$ & oblíquo & $40 \mathrm{~m}$ & bongô & 500 & 1 \\
\hline 372 & $22^{\circ} 33^{\prime} 477^{\prime \prime}$ & $040^{\circ} 12^{\prime} 20,5^{\prime \prime}$ & $17 / 05 / 2002$ & oblíquo & $50 \mathrm{~m}$ & bongô & 500 & 1 \\
\hline
\end{tabular}

Referências: Menezes \& Figueiredo, 1985; Westneat, 2002a; Jones et al., 2006a; Fahay, 2007. Thalassoma noronhanum. DZUFRJ 12057; Flexão; CP 4,8 mm. 


\section{Família Scaridae}

A família Scaridae é marinha e ocorre principalmente nas regiões tropicais. Vive em áreas de formações coralinas. Apresenta distribuição circumtropical, estando presente nos oceanos Atlântico, Pacífico e Índico. Compreende dez gêneros com 88 espécies.

A separação das espécies é difícil e ocorre, principalmente, quando adultos, devido à coloração específica. As larvas são alongadas, possuem corpo comprimido lateralmente e olhos elípticos nas fases inicias de desenvolvimento. Tem apenas uma nadadeira dorsal. O intestino é rugoso e estreito e se estende até metade do corpo. Não possui nenhum espinho na cabeça e a boca é pequena e sem dentes. A nadadeira dorsal é formada por IX espinhos flexíveis e 10 raios; a anal tem III-9. As larvas dos gêneros Cryptotomus, Scarus e Sparisoma podem ser separadas pelo padrão de pigmentação presente desde a pré-flexão. Nos três gêneros há melanóforos na região dorso-lateral do ânus e uma série de grandes melanóforos na região ventral do corpo.

No Brasil já foram identificadas 18 espécies nas fases de larva e adulto. Nesse estudo são contempladas as espécies Cryptotomus roseus, Scarus sp., Sparisoma sp. 


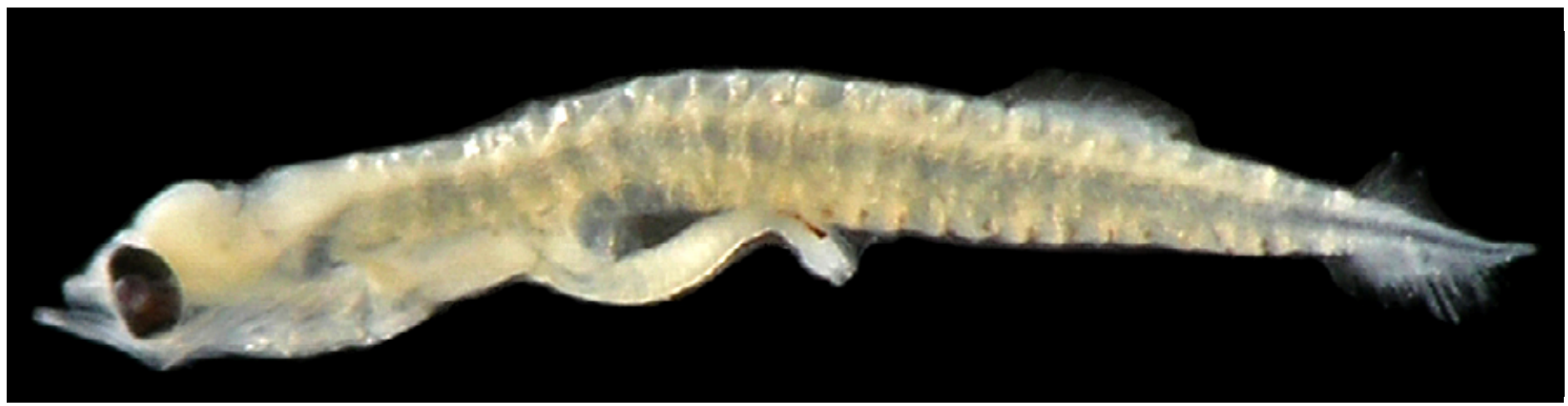

Figura 130 - A: Cryptotomus roseus. DZUFRJ 20050; Pré-flexão; CP 3,2 mm.

\section{Cryptotomus roseus \\ Cope, 1871}

A pigmentação está limitada a uma mancha na região dorso-lateral do ânus e a uma série de melanóforos ao longo da margem ventral da cauda, presentes desde o estágio de pré-flexão. A principal característica dessa espécie é a ausência de outros pigmentos no restante do corpo. Número total de miômeros: 25.

Tamanho: pré-flexão 2,5-3,2 mm; flexão 3,8-7,5 mm; pós-flexão 7,6-

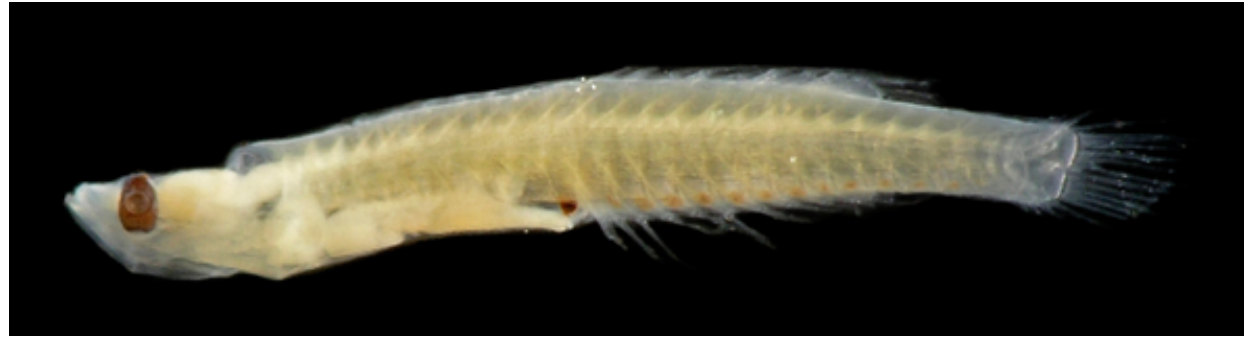

Figura 130 - B: DZUFRJ 17474; Flexão; CP 7,0 mm.

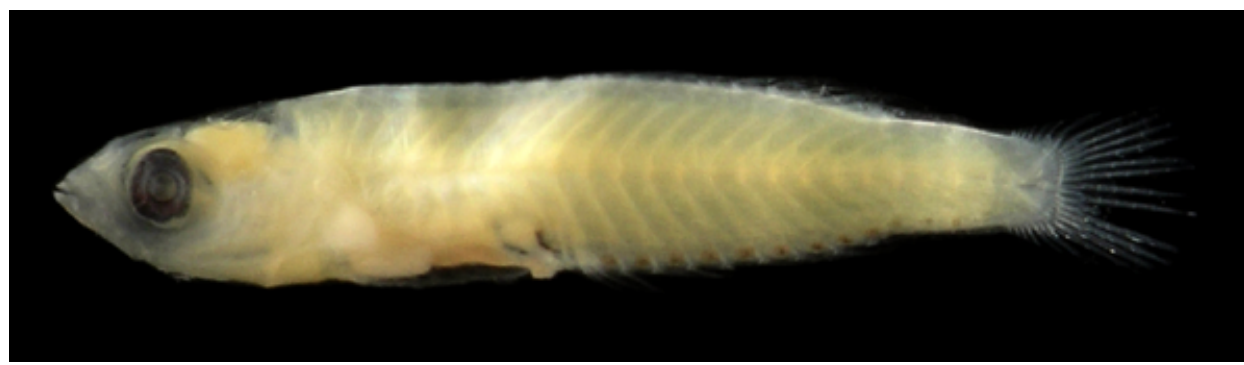

Figura 130 - C: DZUFRJ 17476; Pós-flexão; CP 8,2 mm. $10,0 \mathrm{~mm}$.

Habitat: espécie marinha, demersal, ocorre em águas tropicais até $60 \mathrm{~m}$ de profundidade. Vive em áreas de formações coralinas, associada à algas, gramas marinhas e substratos rochosos.

Nome vulgar: Periquito.

\section{Georreferenciamento}

\begin{tabular}{|c|c|c|c|c|c|c|c|c|}
\hline DZUFRJ & Latitude (S) & Longitude (W) & Data & $\begin{array}{l}\text { Tipo de } \\
\text { arrasto }\end{array}$ & $\begin{array}{l}\text { Profundidade } \\
\text { de coleta }\end{array}$ & Rede & $\begin{array}{c}\text { Malha } \\
(\mu \mathrm{m})\end{array}$ & $\begin{array}{l}N^{\circ} \text {. de } \\
\text { inds. }\end{array}$ \\
\hline 519 & $22^{\circ} 34^{\prime} 05,0^{\prime \prime}$ & $040^{\circ} 19^{\prime} 40,0^{\prime \prime}$ & $17 / 05 / 2002$ & oblíquo & $600 \mathrm{~m}$ & cilíndrico-cônica & 500 & 2 \\
\hline 7616 & $21^{\circ} 53^{\prime} 10,4^{\prime \prime}$ & $039^{\circ} 45^{\prime} 49,9^{\prime \prime}$ & $10 / 10 / 2001$ & oblíquo & $1.000 \mathrm{~m}$ & cilíndrico-cônica & 500 & 2 \\
\hline 17474 & $22^{\circ} 07^{\prime} 29,0^{\prime \prime}$ & $039^{\circ} 06^{\prime} 23,5^{\prime \prime}$ & $10 / 05 / 2002$ & oblíquo & $1.000 \mathrm{~m}$ & cilíndrico-cônica & 500 & 4 \\
\hline 17476 & $22^{\circ} 06^{\prime} 37,8^{\prime \prime}$ & $039^{\circ} 49^{\prime} 44,8^{\prime \prime}$ & $10 / 05 / 2002$ & oblíquo & até a termoclina & bongô & 500 & 3 \\
\hline 17486 & $22^{\circ} 32^{\prime} 49,0^{\prime \prime}$ & $040^{\circ} 04^{\prime} 20,9^{\prime \prime}$ & $07 / 11 / 2001$ & oblíquo & $1.000 \mathrm{~m}$ & cilíndrico-cônica & 500 & 1 \\
\hline 17487 & $22^{\circ} 32^{\prime} 49,0^{\prime \prime}$ & $040^{\circ} 04^{\prime} 20,9^{\prime \prime}$ & $07 / 11 / 2001$ & oblíquo & $1.000 \mathrm{~m}$ & cilíndrico-cônica & 500 & 7 \\
\hline 17495 & $22^{\circ} 32^{\prime} 49,0^{\prime \prime}$ & $040^{\circ} 04^{\prime} 20,9^{\prime \prime}$ & $07 / 11 / 2001$ & oblíquo & $1.000 \mathrm{~m}$ & cilíndrico-cônica & 500 & 1 \\
\hline 17498 & $22^{\circ} 32^{\prime} 50,0^{\prime \prime}$ & $040^{\circ} 04^{\prime} 09,9^{\prime \prime}$ & $06 / 11 / 2001$ & oblíquo & $1.000 \mathrm{~m}$ & cilíndrico-cônica & 500 & 1 \\
\hline 20043 & $21^{\circ} 54^{\prime} 36,5^{\prime \prime}$ & $039^{\circ} 45^{\prime} 20,0^{\prime \prime}$ & 09/10/2001 & oblíquo & $1.000 \mathrm{~m}$ & cilíndrico-cônica & 500 & 2 \\
\hline
\end{tabular}




\begin{tabular}{|c|c|c|c|c|c|c|c|c|}
\hline DZUFRJ & Latitude (S) & Longitude (W) & Data & $\begin{array}{c}\text { Tipo de } \\
\text { arrasto }\end{array}$ & $\begin{array}{c}\text { Profundidade } \\
\text { de coleta }\end{array}$ & Rede & $\begin{array}{c}\text { Malha } \\
\text { ( } \boldsymbol{\mu m})\end{array}$ & $\begin{array}{c}\mathbf{N}^{\circ} \text {. de } \\
\text { inds. }\end{array}$ \\
\hline 20050 & $22^{\circ} 33^{\prime} 45,8^{\prime \prime}$ & $040^{\circ} 13^{\prime} 22,9^{\prime \prime}$ & $17 / 05 / 2002$ & oblíquo & $800 \mathrm{~m}$ & cilíndrico-cônica & 500 & 4 \\
\hline 20052 & $21^{\circ} 53^{\prime} 10,4^{\prime \prime}$ & $039^{\circ} 45^{\prime} 49,9^{\prime \prime}$ & $10 / 10 / 2001$ & oblíquo & $1.000 \mathrm{~m}$ & cilíndrico-cônica & 500 & 1 \\
\hline 20054 & $22^{\circ} 33^{\prime} 37,0^{\prime \prime}$ & $040^{\circ} 19^{\prime} 10,0^{\prime \prime}$ & $17 / 05 / 2002$ & oblíquo & $50 \mathrm{~m}$ & bongô & 500 & 8 \\
\hline 20057 & $2^{\circ} 58^{\prime} 31,0^{\prime \prime}$ & $039^{\circ} 50^{\prime} 29,7^{\prime \prime}$ & $10 / 10 / 2001$ & oblíquo & $1.000 \mathrm{~m}$ & cilíndrico-cônica & 500 & 4 \\
\hline 20058 & $2^{\circ} 58^{\prime} 31,0^{\prime \prime}$ & $039^{\circ} 50^{\prime} 29,7^{\prime \prime}$ & $10 / 11 / 2001$ & oblíquo & $1.000 \mathrm{~m}$ & cilíndrico-cônica & 500 & 1 \\
\hline 20061 & $21^{\circ} 58^{\prime} 31,0^{\prime \prime}$ & $039^{\circ} 50^{\prime} 29,7^{\prime \prime}$ & $10 / 10 / 2001$ & oblíquo & $1.000 \mathrm{~m}$ & cilíndrico-cônica & 500 & 2 \\
\hline 20062 & $2^{\circ} 54^{\prime} 36,5^{\prime \prime}$ & $039^{\circ} 45^{\prime} 20,0^{\prime \prime}$ & $10 / 10 / 2001$ & oblíquo & $1.000 \mathrm{~m}$ & cilíndrico-cônica & 500 & 2 \\
\hline 20065 & $21^{\circ} 54^{\prime} 36,5^{\prime \prime}$ & $039^{\circ} 45^{\prime} 20,0^{\prime \prime}$ & $10 / 10 / 2001$ & oblíquo & $1.000 \mathrm{~m}$ & cilíndrico-cônica & 500 & 2 \\
\hline 20069 & $21^{\circ} 57^{\prime} 10,5^{\prime \prime}$ & $039^{\circ} 43^{\prime} 33,3^{\prime \prime}$ & $09 / 10 / 2001$ & oblíquo & $1.000 \mathrm{~m}$ & cilíndrico-cônica & 500 & 1 \\
\hline
\end{tabular}

Referências: Menezes \& Figueiredo, 1985; Watson, 1996i; Westneat, 2002b; Jones et al., 2006b; Fahay, 2007. 


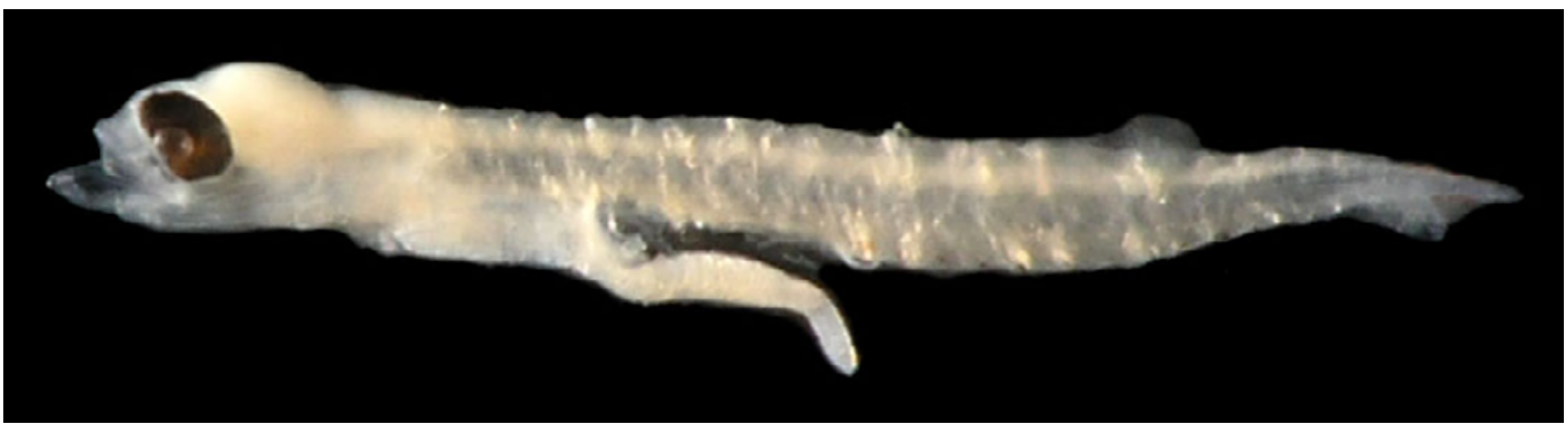

Figura 131 - A: Scarus sp. DZUFRJ 514; Pré-flexão; CP 3,2 mm.

\section{Scarus sp.}

A principal característica que permite a separação desse gênero, desde o estágio de pré-flexão, é a presença de pigmentos na margem dorsal do pedúnculo caudal formando uma linha. Possui melanóforos na região dorso-lateral

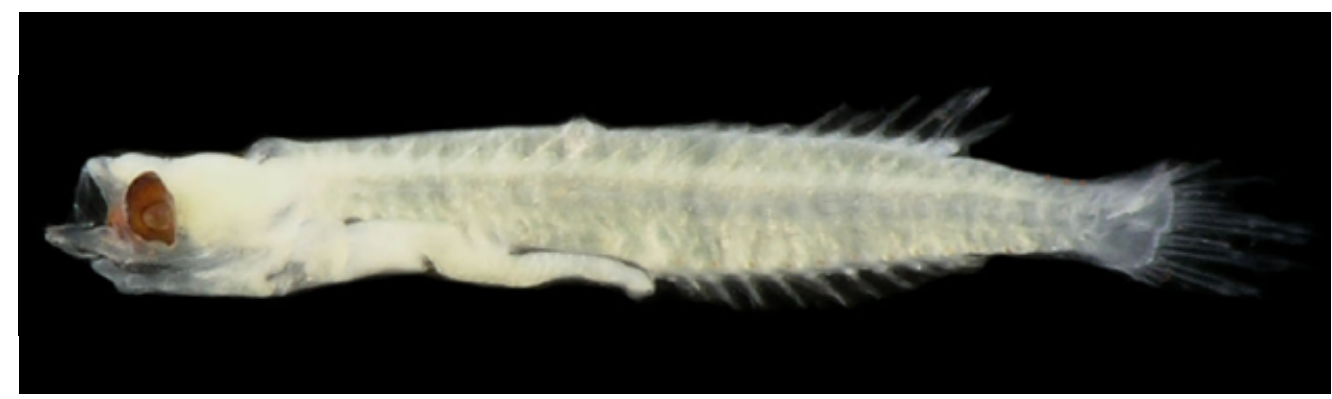

Figura 131 - B: DZUFRJ 20070; Flexão; CP 4,0 mm. do ânus e uma série ao longo da margem ventral da cauda. Número total de miômeros: 25.

Tamanho: pré-flexão 2,6-3,5 mm; flexão 3,5-5,0 mm.

Habitat: as espécies de Scarus são marinhas e demersais. Vivem em áreas de formações coralinas, associadas a algas, gramas marinhas e substratos rochosos. No Brasil já foram registradas seis espécies de Scarus.

\section{Georreferenciamento}

\begin{tabular}{|c|c|c|c|c|c|c|c|c|}
\hline DZUFRJ & Latitude (S) & Longitude (W) & Data & $\begin{array}{c}\text { Tipo de } \\
\text { arrasto }\end{array}$ & $\begin{array}{c}\text { Profundidade } \\
\text { de coleta }\end{array}$ & Rede & $\begin{array}{c}\text { Malha } \\
\text { ( } \boldsymbol{\mu m} \text { ) }\end{array}$ & $\begin{array}{c}\text { No. de } \\
\text { inds. }\end{array}$ \\
\hline 514 & $22^{\circ} 31^{\prime} 27,0^{\prime \prime}$ & $040^{\circ} 16^{\prime} 56,0^{\prime \prime}$ & $17 / 05 / 2002$ & oblíquo & $600 \mathrm{~m}$ & cilíndrico-cônica & 500 & 21 \\
\hline 648 & $22^{\circ} 38^{\prime} 25,0^{\prime \prime}$ & $040^{\circ} 17^{\prime} 41,0^{\prime \prime}$ & $19 / 05 / 2002$ & oblíquo & $40 \mathrm{~m}$ & bongô & 330 & 2 \\
\hline 693 & $22^{\circ} 41^{\prime} 54,7^{\prime \prime}$ & $040^{\circ} 14^{\prime} 04,5^{\prime \prime}$ & $16 / 05 / 2002$ & oblíquo & $1.000 \mathrm{~m}$ & cilíndrico-cônica & 500 & 13 \\
\hline 17468 & $22^{\circ} 35^{\prime} 08^{\prime \prime}$ & $039^{\circ} 46^{\prime} 22,3^{\prime \prime}$ & $06 / 12 / 2002$ & vertical & $0-50 \mathrm{~m}$ & cilíndrico-cônica & 200 & 2 \\
\hline 20044 & $22^{\circ} 33^{\prime} 477^{\prime \prime}$ & $040^{\circ} 12^{\prime} 20,5^{\prime \prime}$ & $17 / 05 / 2002$ & oblíquo & $50 \mathrm{~m}$ & bongô & 500 & 4 \\
\hline 20045 & $22^{\circ} 38^{\prime} 29,0^{\prime \prime}$ & $040^{\circ} 17^{\prime} 40,0^{\prime \prime}$ & $18 / 05 / 2002$ & oblíquo & $800 \mathrm{~m}$ & cilíndrico-cônica & 500 & 2 \\
\hline 20048 & $22^{\circ} 33^{\prime} 477^{\prime \prime}$ & $040^{\circ} 12^{\prime} 20,5^{\prime \prime}$ & $17 / 05 / 2002$ & oblíquo & $50 \mathrm{~m}$ & bongô & 330 & 3 \\
\hline 20055 & $22^{\circ} 38^{\prime} 25,0^{\prime \prime}$ & $040^{\circ} 17^{\prime} 41,0^{\prime \prime}$ & $19 / 05 / 2002$ & oblíquo & $40 \mathrm{~m}$ & bongô & 500 & 1 \\
\hline 20059 & $22^{\circ} 36^{\prime} 54,9^{\prime \prime}$ & $040^{\circ} 09^{\prime} 19,4^{\prime \prime}$ & $16 / 05 / 2002$ & oblíquo & $50 \mathrm{~m}$ & bongô & 330 & 15 \\
\hline 20067 & $22^{\circ} 33^{\prime} 37,0^{\prime \prime}$ & $040^{\circ} 19^{\prime} 10,0^{\prime \prime}$ & $17 / 05 / 2002$ & oblíquo & $50 \mathrm{~m}$ & bongô & 500 & 15 \\
\hline 20070 & $22^{\circ} 34^{\prime} 05,0^{\prime \prime}$ & $040^{\circ} 19^{\prime} 40,0^{\prime \prime}$ & $17 / 05 / 2002$ & oblíquo & $600 \mathrm{~m}$ & cilíndrico-cônica & 500 & 13 \\
\hline
\end{tabular}

Referências: Menezes \& Figueiredo, 1985; Watson, 1996i; Westneat, 2002b; Jones et al., 2006b; Fahay, 2007. 


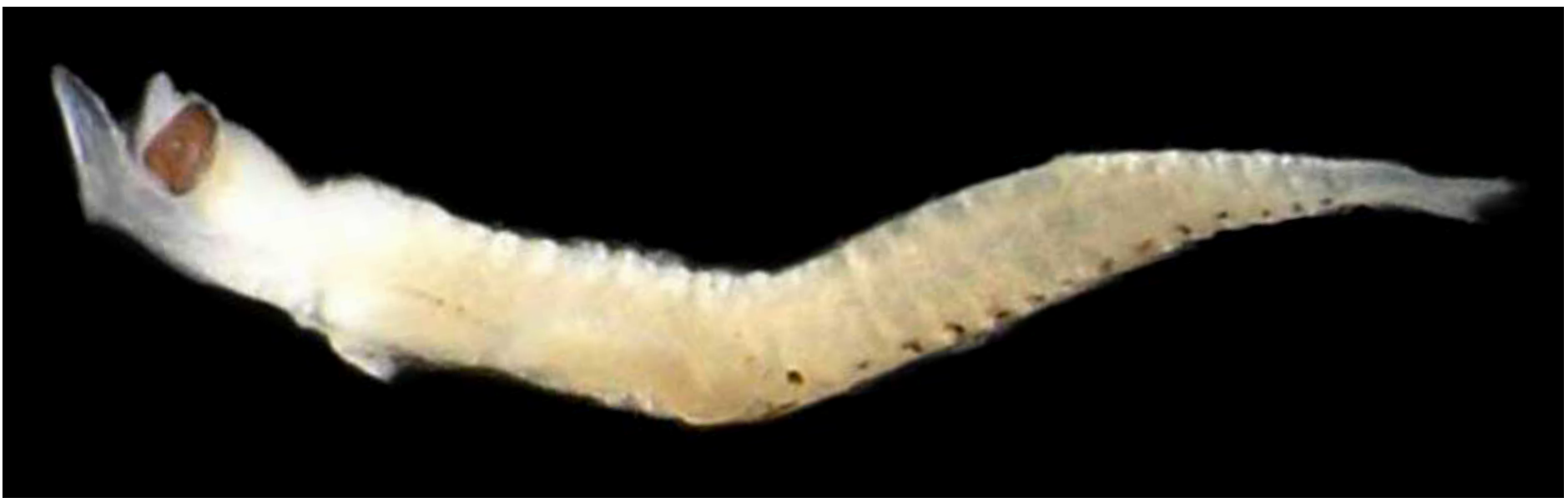

Figura 132 - A: Sparisoma sp. DZUFRJ 500; Pré-flexão; CP 3,0 mm.

\section{Sparisoma sp.}

A principal característica que permite a separação desse gênero é a presença de um grande melanóforo atrás da base da nadadeira peitoral, na região cardíaca, desde a pré-flexão até os últimos estágios de desenvolvimento. Possui melanóforos na região dorso-lateral do ânus e uma série ao longo da margem ventral da cauda. Número total de miômeros 25. No Brasil já foram registradas dez espécies de Sparisoma.

Tamanho: pré-flexão 2,3-3,5 mm; flexão 3,6-7,6 mm; pós-flexão 7,8$11,0 \mathrm{~mm}$.

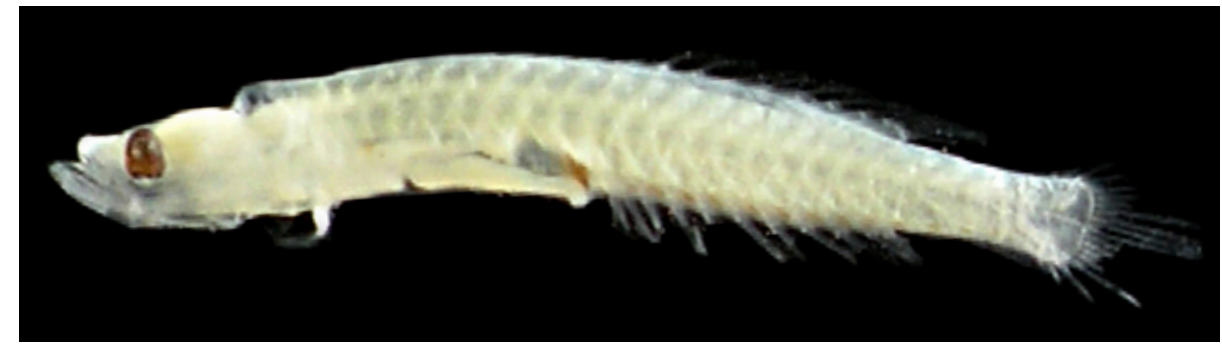

Figura 132 - B: DZUFRJ 1355; Flexão; CP 4,5 mm.

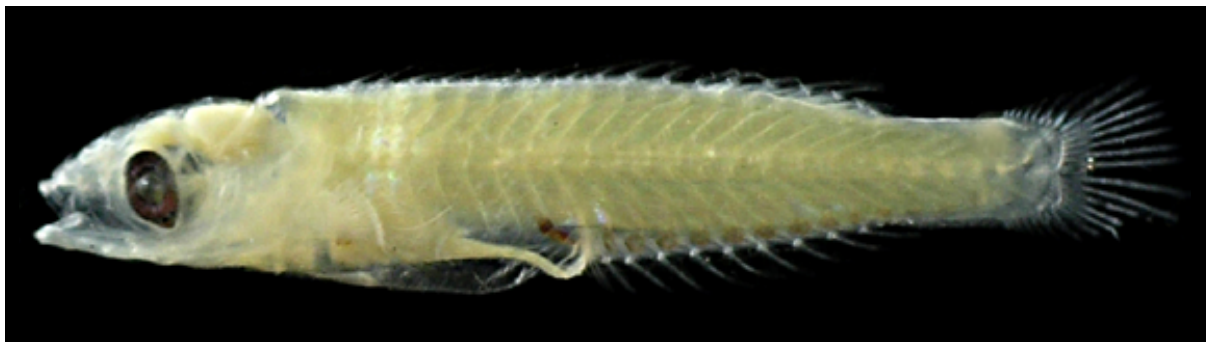

Figura 132 - C: DZUFRJ 1217; Pós-flexão; CP 8,0 mm.

Habitat: as espécies de Sparisoma são marinhas e demersais. Vivem em áreas de formações coralinas, associadas a algas, gramas marinhas e substratos rochosos.

\section{Georreferenciamento}

\begin{tabular}{|c|c|c|c|c|c|c|c|c|}
\hline DZUFR J & Latitude (S) & Longitude (W) & Data & $\begin{array}{c}\text { Tipo de } \\
\text { arrasto }\end{array}$ & $\begin{array}{c}\text { Profundidade } \\
\text { de coleta }\end{array}$ & Rede & $\begin{array}{c}\text { Malha } \\
\text { ( } \boldsymbol{\mu m} \text { ) }\end{array}$ & $\begin{array}{c}\text { No. de } \\
\text { inds. }\end{array}$ \\
\hline 485 & $22^{\circ} 33^{\prime} 37,0^{\prime \prime}$ & $040^{\circ} 19^{\prime} 10,0^{\prime \prime}$ & $17 / 05 / 2002$ & oblíquo & $50 \mathrm{~m}$ & bongô & 500 & 7 \\
\hline 500 & $22^{\circ} 38^{\prime} 25,0^{\prime \prime}$ & $040^{\circ} 17^{\prime} 41,0^{\prime \prime}$ & $19 / 05 / 2002$ & oblíquo & $40 \mathrm{~m}$ & bongô & 500 & 2 \\
\hline 554 & $22^{\circ} 32^{\prime} 03,0^{\prime \prime}$ & $040^{\circ} 17^{\prime} 21,0^{\prime \prime}$ & $19 / 05 / 2002$ & oblíquo & $30 \mathrm{~m}$ & bongô & 330 & 2 \\
\hline 561 & $22^{\circ} 32^{\prime} 03,0^{\prime \prime}$ & $040^{\circ} 17^{\prime} 21,0^{\prime \prime}$ & $19 / 05 / 2002$ & oblíquo & $30 \mathrm{~m}$ & bongô & 500 & 3 \\
\hline 578 & $22^{\circ} 33^{\prime} 37,0^{\prime \prime}$ & $040^{\circ} 19^{\prime} 10,0^{\prime \prime}$ & $17 / 05 / 2002$ & oblíquo & $50 \mathrm{~m}$ & bongô & 330 & 22 \\
\hline 585 & $22^{\circ} 33^{\prime} 45,8^{\prime \prime}$ & $040^{\circ} 13^{\prime} 22,9^{\prime \prime}$ & $17 / 05 / 2002$ & oblíquo & $800 \mathrm{~m}$ & cilíndrico-cônica & 500 & 8 \\
\hline 596 & $22^{\circ} 33^{\prime} 47,7^{\prime \prime}$ & $040^{\circ} 12^{\prime} 20,5^{\prime \prime}$ & $17 / 05 / 2002$ & oblíquo & $50 \mathrm{~m}$ & bongô & 330 & 15 \\
\hline 611 & $22^{\circ} 42^{\prime} 06,0^{\prime \prime}$ & $040^{\circ} 14^{\prime} 26,0^{\prime \prime}$ & $19 / 05 / 2002$ & oblíquo & $50 \mathrm{~m}$ & bongô & 330 & 12 \\
\hline 617 & $22^{\circ} 42^{\prime} 06,0^{\prime \prime}$ & $040^{\circ} 14^{\prime} 26,0^{\prime \prime}$ & $19 / 05 / 2002$ & oblíquo & $50 \mathrm{~m}$ & bongô & 500 & 13 \\
\hline 637 & $22^{\circ} 36^{\prime} 54,9^{\prime \prime}$ & $040^{\circ} 09^{\prime} 19,4^{\prime \prime}$ & $16 / 05 / 2002$ & oblíquo & $50 \mathrm{~m}$ & bongô & 500 & 20 \\
\hline
\end{tabular}




\begin{tabular}{|c|c|c|c|c|c|c|c|c|}
\hline DZUFRJ & Latitude (S) & Longitude (W) & Data & $\begin{array}{l}\text { Tipo de } \\
\text { arrasto }\end{array}$ & $\begin{array}{c}\text { Profundidade } \\
\text { de coleta }\end{array}$ & Rede & $\begin{array}{c}\text { Malha } \\
(\mu \mathrm{m})\end{array}$ & $\begin{array}{l}N^{\circ} \text {. de } \\
\text { inds. }\end{array}$ \\
\hline 669 & $22^{\circ} 33^{\prime} 47,7^{\prime \prime}$ & $040^{\circ} 12^{\prime} 20,5^{\prime \prime}$ & $17 / 05 / 2002$ & oblíquo & $50 \mathrm{~m}$ & bongô & 500 & 5 \\
\hline 1168 & $22^{\circ} 02^{\prime} 30,3^{\prime \prime}$ & $039^{\circ} 50^{\prime} 41,3^{\prime \prime}$ & $10 / 05 / 2002$ & oblíquo & $1.000 \mathrm{~m}$ & cilíndrico-cônica & 500 & 1 \\
\hline 1180 & $22^{\circ} 07^{\prime} 29,0^{\prime \prime}$ & $039^{\circ} 06^{\prime} 23,5^{\prime \prime}$ & $10 / 05 / 2002$ & oblíquo & $1.000 \mathrm{~m}$ & cilíndrico-cônica & 500 & 78 \\
\hline 1195 & $22^{\circ} 03^{\prime} 03,3^{\prime \prime}$ & $039^{\circ} 50^{\prime} 39,0^{\prime \prime}$ & $10 / 05 / 2002$ & oblíquo & até a termoclina & bongô & 500 & 1 \\
\hline 1202 & $22^{\circ} 06^{\prime} 52,3^{\prime \prime}$ & $039^{\circ} 48^{\prime} 46,2^{\prime \prime}$ & $11 / 05 / 2002$ & oblíquo & $1.000 \mathrm{~m}$ & cilíndrico-cônica & 500 & 5 \\
\hline 1217 & $22^{\circ} 02^{\prime} 30,0^{\prime \prime}$ & $039^{\circ} 49^{\prime} 41,2^{\prime \prime}$ & $12 / 05 / 2002$ & oblíquo & $1.000 \mathrm{~m}$ & cilíndrico-cônica & 500 & 6 \\
\hline 1247 & $22^{\circ} 08^{\prime} 17,5^{\prime \prime}$ & $039^{\circ} 46^{\prime} 28,5^{\prime \prime}$ & $11 / 05 / 2002$ & oblíquo & $1.000 \mathrm{~m}$ & cilíndrico-cônica & 500 & 22 \\
\hline 1274 & $22^{\circ} 06^{\prime} 37,8^{\prime \prime}$ & $039^{\circ} 49^{\prime} 44,8^{\prime \prime}$ & $10 / 05 / 2002$ & oblíquo & até a termoclina & bongô & 500 & 41 \\
\hline 1294 & $22^{\circ} 02^{\prime} 30,0^{\prime \prime}$ & $039^{\circ} 49^{\prime} 41,2^{\prime \prime}$ & $12 / 05 / 2002$ & oblíquo & até a termoclina & bongô & 500 & 17 \\
\hline 1305 & $22^{\circ} 08^{\prime} 52,5^{\prime \prime}$ & $039^{\circ} 46^{\prime} 27,9^{\prime \prime}$ & $12 / 05 / 2002$ & oblíquo & até a termoclina & bongô & 500 & 1 \\
\hline 1313 & $22^{\circ} 08^{\prime} 14,9^{\prime \prime}$ & $039^{\circ} 46^{\prime} 34,6^{\prime \prime}$ & $11 / 05 / 2002$ & oblíquo & até a termoclina & bongô & 500 & 14 \\
\hline 1322 & $22^{\circ} 03^{\prime} 03,3^{\prime \prime}$ & $039^{\circ} 50^{\prime} 39,0^{\prime \prime}$ & $10 / 05 / 2002$ & oblíquo & até a termoclina & bongô & 330 & 2 \\
\hline 1332 & $22^{\circ} 06^{\prime} 37,8^{\prime \prime}$ & $039^{\circ} 49^{\prime} 44,8^{\prime \prime}$ & $10 / 05 / 2002$ & oblíquo & até a termoclina & bongô & 330 & 26 \\
\hline 1344 & $22^{\circ} 06^{\prime} 52,3^{\prime \prime}$ & $039^{\circ} 48^{\prime} 46,2^{\prime \prime}$ & $11 / 05 / 2002$ & oblíquo & até a termoclina & bongô & 330 & 2 \\
\hline 1355 & $22^{\circ} 02^{\prime} 30,0^{\prime \prime}$ & $039^{\circ} 49^{\prime} 41,2^{\prime \prime}$ & $12 / 05 / 2002$ & oblíquo & até a termoclina & bongô & 330 & 19 \\
\hline 7608 & $21^{\circ} 57^{\prime} 10,5^{\prime \prime}$ & $039^{\circ} 43^{\prime} 33,3^{\prime \prime}$ & $09 / 10 / 2001$ & oblíquo & $1.000 \mathrm{~m}$ & cilíndrico-cônica & 500 & 2 \\
\hline 7611 & $21^{\circ} 58^{\prime} 31,0^{\prime \prime}$ & $039^{\circ} 50^{\prime} 29,7^{\prime \prime}$ & $10 / 10 / 2001$ & oblíquo & $1.000 \mathrm{~m}$ & cilíndrico-cônica & 500 & 4 \\
\hline 7613 & $21^{\circ} 54 ' 36,5^{\prime \prime}$ & $039^{\circ} 45^{\prime} 20,0^{\prime \prime}$ & $10 / 10 / 2001$ & oblíquo & 1.0 & cilíndrico-cônica & 500 & 4 \\
\hline 7614 & $21^{\circ} 57^{\prime} 10,5^{\prime \prime}$ & $039^{\circ} 43^{\prime} 33,3^{\prime \prime}$ & $09 / 10 / 2001$ & oblíquo & $1.000 \mathrm{~m}$ & cilíndrico-cônica & 500 & 2 \\
\hline 7615 & $21^{\circ} 54 ' 36,5^{\prime \prime}$ & $039^{\circ} 45^{\prime} 20,0^{\prime \prime}$ & $10 / 10 / 2001$ & oblíquo & $1.000 \mathrm{~m}$ & cilíndrico-cônica & 500 & 12 \\
\hline 7617 & $21^{\circ} 58^{\prime} 31,0^{\prime \prime}$ & $039^{\circ} 50^{\prime} 29,7^{\prime \prime}$ & $10 / 11 / 2001$ & oblíquo & $1.000 \mathrm{~m}$ & cilíndrico-cônica & 500 & 3 \\
\hline 7618 & $21^{\circ} 54 ' 36,5^{\prime \prime}$ & $039^{\circ} 45^{\prime} 20,0^{\prime \prime}$ & $09 / 10 / 2001$ & oblíquo & $1.000 \mathrm{~m}$ & cilíndrico-cônica & 500 & 12 \\
\hline 17467 & $22^{\circ} 07^{\prime} 58,8^{\prime \prime}$ & $039^{\circ} 49^{\prime} 08,9^{\prime \prime}$ & $01 / 12 / 2002$ & vertical & $0-50 m$ & cilíndrico-cônica & 500 & 1 \\
\hline 17478 & $22^{\circ} 02,27^{\prime}$ & $039^{\circ} 43,49^{\prime}$ & $18 / 06 / 2003$ & vertical & $0-90 m$ & cilíndrico-cônica & 500 & 3 \\
\hline 17479 & $22^{\circ} 39,68^{\prime}$ & $040^{\circ} 03,24^{\prime}$ & $13 / 06 / 2003$ & vertical & $0-60 m$ & cilíndrico-cônica & 500 & 2 \\
\hline 17480 & $22^{\circ} 35,12^{\prime}$ & $39^{\circ} 46,24^{\prime}$ & $15 / 06 / 2003$ & vertical & $0-80 \mathrm{~m}$ & cilíndrico-cônica & 500 & 1 \\
\hline 17481 & $22^{\circ} 43,56^{\prime}$ & $039^{\circ} 53,25^{\prime}$ & $14 / 06 / 2003$ & vertical & $1.000-2.000 \mathrm{~m}$ & cilíndrico-cônica & 500 & 2 \\
\hline 17488 & $22^{\circ} 32^{\prime} 49,0^{\prime \prime}$ & & $07 / 11 / 2001$ & oblíquo & $1.000 \mathrm{~m}$ & cilíndrico-cônica & 500 & 17 \\
\hline 17489 & $22^{\circ} 32^{\prime} 50,0^{\prime \prime}$ & $040^{\circ} 04^{\prime} 09,9^{\prime \prime}$ & $06 / 11 / 2001$ & oblíquo & $1.000 \mathrm{~m}$ & cilíndrico-cônica & 500 & 1 \\
\hline 17490 & $22^{\circ} 31^{\prime} 40,9^{\prime \prime}$ & $040^{\circ} 02^{\prime} 39,6^{\prime \prime}$ & $07 / 11 / 2001$ & oblíquo & $1.000 \mathrm{~m}$ & cilíndrico-cônica & 500 & 10 \\
\hline 17491 & $22^{\circ} 31^{\prime} 40,9^{\prime \prime}$ & $040^{\circ} 02^{\prime} 39,6^{\prime \prime}$ & $07 / 11 / 2001$ & oblíquo & & cilíndrico-cônica & 500 & 7 \\
\hline 17492 & $22^{\circ} 32^{\prime} 49,0^{\prime \prime}$ & $040^{\circ} 04^{\prime} 20,9^{\prime \prime}$ & $07 / 11 / 2001$ & oblíquo & $1.000 \mathrm{~m}$ & cilíndrico-cônica & 500 & 15 \\
\hline 17493 & $22^{\circ} 32^{\prime} 50,0^{\prime \prime}$ & $040^{\circ} 04^{\prime} 09,9^{\prime \prime}$ & $06 / 11 / 2001$ & oblíquo & $1.000 \mathrm{~m}$ & cilíndrico-cônica & 500 & 1 \\
\hline 17494 & $22^{\circ} 31^{\prime} 40,9^{\prime \prime}$ & $040^{\circ} 02^{\prime} 39,6^{\prime \prime}$ & $07 / 11 / 2001$ & oblíquo & $1.000 \mathrm{~m}$ & cilíndrico-cônica & 500 & 11 \\
\hline 17496 & $22^{\circ} 31^{\prime} 58,9^{\prime \prime}$ & $040^{\circ} 02^{\prime} 53,4^{\prime \prime}$ & $07 / 11 / 2001$ & oblíquo & $1.000 \mathrm{~m}$ & cilíndrico-cônica & 500 & 1 \\
\hline 17497 & $22^{\circ} 32^{\prime} 49,0^{\prime \prime}$ & $040^{\circ} 04^{\prime} 20,9^{\prime \prime}$ & $07 / 11 / 2001$ & oblíquo & $1.000 \mathrm{~m}$ & cilíndrico-cônica & 500 & 20 \\
\hline 20041 & $21^{\circ} 58^{\prime} 31,0^{\prime \prime}$ & $039^{\circ} 50^{\prime} 29,7^{\prime \prime}$ & $10 / 10 / 2001$ & oblíquo & $1.000 \mathrm{~m}$ & cilíndrico-cônica & 500 & 3 \\
\hline 20049 & $22^{\circ} 34^{\prime} 05,0^{\prime \prime}$ & $040^{\circ} 19^{\prime} 40,0^{\prime \prime}$ & $17 / 05 / 2002$ & oblíquo & $600 \mathrm{~m}$ & cilíndrico-cônica & 500 & 6 \\
\hline 20051 & $22^{\circ} 41^{\prime} 54,7^{\prime \prime}$ & $040^{\circ} 14^{\prime} 04,5^{\prime \prime}$ & $16 / 05 / 2002$ & oblíquo & $1.000 \mathrm{~m}$ & cilíndrico-cônica & 500 & 2 \\
\hline 20060 & $22^{\circ} 38^{\prime} 25,0^{\prime \prime}$ & $040^{\circ} 17^{\prime} 41,0^{\prime \prime}$ & 19/05/2002 & oblíquo & $40 \mathrm{~m}$ & bongô & 330 & 2 \\
\hline 20072 & $22^{\circ} 37^{\prime} 35,5^{\prime \prime}$ & $040^{\circ} 09^{\prime} 32,8^{\prime \prime}$ & $16 / 05 / 2002$ & oblíquo & $1.000 \mathrm{~m}$ & cilíndrico-cônica & 500 & 18 \\
\hline 20073 & $22^{\circ} 36^{\prime} 54,9^{\prime \prime}$ & $040^{\circ} 09^{\prime} 19,4^{\prime \prime}$ & $16 / 05 / 2002$ & oblíquo & $50 \mathrm{~m}$ & bongô & 330 & 55 \\
\hline 20074 & $21^{\circ} 53^{\prime} 10,4^{\prime \prime}$ & $039^{\circ} 45^{\prime} 49,9^{\prime \prime}$ & $10 / 10 / 2001$ & oblíquo & $1.000 \mathrm{~m}$ & cilíndrico-cônica & 500 & 2 \\
\hline
\end{tabular}

Referências: Menezes \& Figueiredo, 1985; Watson, 1996i; Westneat, 2002b; Jones et al., 2006b; Fahay, 2007. 


\section{Família Chiasmodontidae}

A família Chiasmodontidae é tipicamente mesopelágica e batipelágica e algumas espécies podem ser encontradas em até $2.740 \mathrm{~m}$ de profundidade. A maioria das espécies vive em áreas tropicais e temperadas, nos oceanos Atlântico e Pacífico. Compreende quatro gêneros com aproximadamente 15 espécies.

Apresenta o corpo estreito e cabeça proporcionalmente pequena. Pode ser separada dos demais Perciformes pelo pré-maxilar e mandíbula longas e finas, intestino dilatado, nadadeiras dorsais separadas, 33 a 48 vértebras. Os representantes dos gêneros Chiasmodon e Pseudoscopelus possuem muitos espinhos espalhados pelo corpo, estando ausentes no gênero Kali. Nesse gênero as nadadeiras peitoral e ventral são extremamente alongadas, a cabeça é achatada e os olhos ficam localizados próximos ao final da mandíbula.

No Brasil já foram identificadas as espécies Chiasmodon niger Johnson, 1864; Kali normani (Parr, 1931); Pseudoscopelus altipinnis Parr, 1933 e Pseudoscopelus scutatus Krefft, 1971. Nesse estudo é contemplada a espécie Chiasmodon niger. 


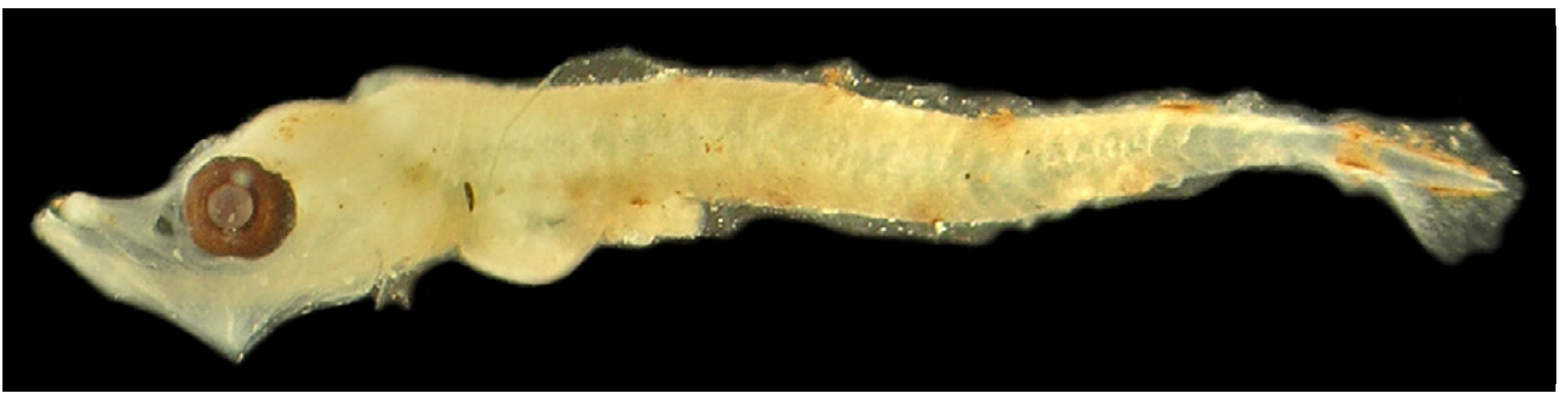

Figura 133 - A: Chiasmodon niger. DZUFRJ 12183; Pré-flexão; CP 4,2 mm.

\section{Chiasmodon}

\section{niger Johnson, 1864}

As larvas possuem o corpo alongado (42 a 44 miômeros), com cabeça pequena e focinho pontudo.

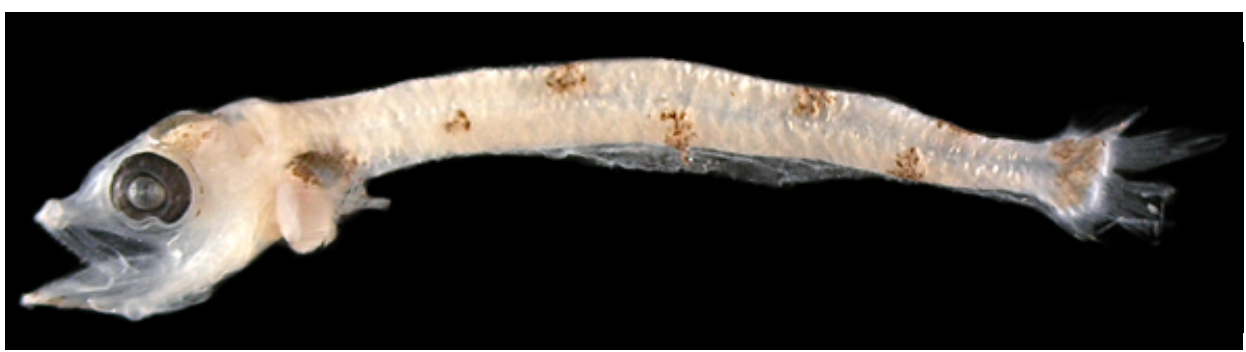

Figura 133 - B: DZUFRJ 22506; Flexão; CP 8,4 mm.

Os olhos são ovais nas larvas em pré-flexão e arredondados durante a flexão. Presença de poucos espinhos na cabeça, no entanto o corpo é coberto com espículas, que começam a se formar a partir de duas fileiras nas superfícies dorso e ventro-laterais, para depois cobrir todo o corpo. Em pré-flexão, as larvas apresentam três manchas de pigmentos apenas na margem ventral do corpo. Com o crescimento, duas manchas de pigmentos dorsais alternam com as ventrais. Presença de cromatóforos próximos à extremidade da notocorda e aumento da quantidade de pigmentos na cabeça. As larvas em flexão seguem o mesmo padrão dos estágios iniciais, porém com pigmentação mais intensa.

Tamanho: pré-flexão 3,5-4,8 mm; flexão 7,0-8,4 mm.

Habitat: espécie marinha, mesopelágica e batipelágica, ocorre em águas tropicais e subtropicais em profundidades maiores que $750 \mathrm{~m}$.

\section{Georreferenciamento}

\begin{tabular}{|c|c|c|c|c|c|c|c|c|}
\hline DZUFR & Latitude (S) & Longitude (W) & Data & $\begin{array}{c}\text { Tipo de } \\
\text { arrasto }\end{array}$ & $\begin{array}{c}\text { Profundidade } \\
\text { de coleta }\end{array}$ & Rede & $\begin{array}{c}\text { Malha } \\
(\boldsymbol{\mu m})\end{array}$ & $\begin{array}{c}\mathbf{N}^{\circ} \text {. de } \\
\text { inds. }\end{array}$ \\
\hline 1204 & $22^{\circ} 06^{\prime} 52,3^{\prime \prime}$ & $039^{\circ} 48^{\prime} 46,2^{\prime \prime}$ & $11 / 05 / 2002$ & oblíquo & $1.000 \mathrm{~m}$ & cilíndrico-cônica & 500 & 2 \\
\hline 1242 & $22^{\circ} 03^{\prime} 21,7^{\prime \prime}$ & $039^{\circ} 45^{\prime} 11,9^{\prime \prime}$ & $12 / 05 / 2002$ & oblíquo & $1.000 \mathrm{~m}$ & cilíndrico-cônica & 500 & 1 \\
\hline 1389 & $22^{\circ} 08^{\prime} 149^{\prime \prime}$ & $039^{\circ} 46^{\prime} 34,6^{\prime \prime}$ & $11 / 05 / 2002$ & oblíquo & até a termoclina & bongô & 330 & 1 \\
\hline 22506 & $22^{\circ} 32^{\prime} 50,0^{\prime \prime}$ & $040^{\circ} 04^{\prime} 09^{\prime \prime}$ & $06 / 11 / 2001$ & oblíquo & $1.000 \mathrm{~m}$ & cilíndrico-cônica & 500 & 2 \\
\hline 22507 & $21^{\circ} 53^{\prime} 10,4^{\prime \prime}$ & $039^{\circ} 45^{\prime} 49,9^{\prime \prime}$ & $10 / 10 / 2001$ & oblíquo & $1.000 \mathrm{~m}$ & cilíndrico-cônica & 500 & 1 \\
\hline
\end{tabular}

Referências: Watson \& Sandknop, 1996; McEachran; 2002; Hardy, 2006c; Fahay, 2007. 


\section{Família Callionymidae}

A família Callionymidae é marinha, com duas espécies que entram em rios, ocorrendo em todos os mares temperados. São pequenos e demersais, vivendo em regiões tropicais e subtropicais, até $650 \mathrm{~m}$ de profundidade. As espécies dessa família ocupam os mais diferentes tipos de habitat. Compreende dez gêneros com aproximadamente 182 espécies.

As larvas de Callionymidae são diferenciadas das demais famílias devido ao padrão característico de pigmentação lateral, a presença de espinhos no pré-opérculo, a morfologia do corpo, ao baixo número de miômeros e por possuir a extremidade da notocorda alongada. As larvas são robustas anteriormente, mas a região posterior do corpo é caracterizada por uma notocorda longa e fina. A pigmentação do corpo é constituída por uma série de melanóforos que se desenvolve durante a pré-flexão e permanece por todo período larval.

No Brasil já foram identificadas três espécies nas fases de larva e adulto: Foetorepus agassizii (Goode \& Bean, 1888); Foetorepus dagmarae (Fricke, 1985) e Callionymus bairdi Jordan, 1888. Nesse estudo é contemplada a espécie Callionymus bairdi. 


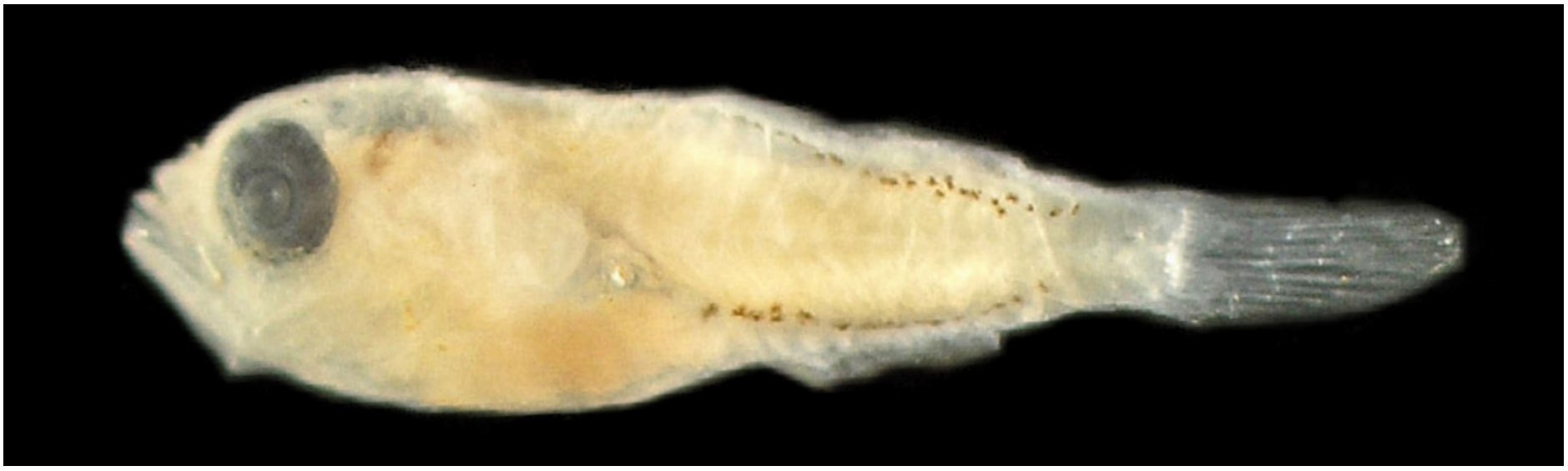

Figura 134 - A: Callionymus bairdi. DZUFRJ 33540; Flexão; CP 3,3 mm.

\section{Callionymus bairdi Jordan, 1888}

As larvas dessa espécie possuem a extremidade da notocorda longa e entre 21 e 22 miômeros. A flexão ocorre em larvas com menos de 2,0 mm de comprimento. Nesse estágio, caracterizam-se pela presença de um semicírculo pigmentado na região mediana e posterior

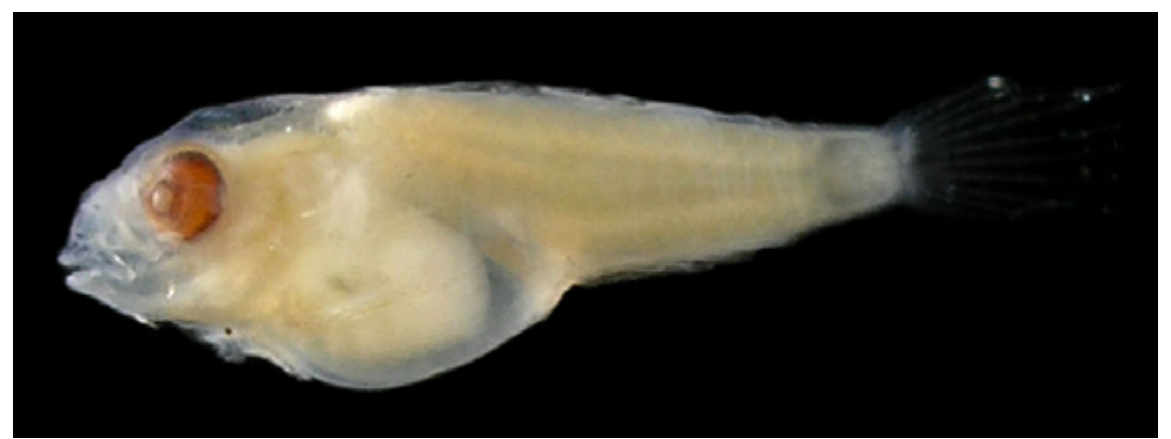

Figura 134 - B: DZUFRJ 20063; Pós-flexão; CP 6,0 mm.

da cabeça. Tem pigmentos ventrais na porção anterior do intestino e na linha dorsal, formando duas fileiras distintas. Esse padrão de pigmentação espalha-se pelo corpo com o desenvolvimento da larva. Há pigmentos também entre os raios das nadadeiras pélvicas. Nadadeira dorsal: IV, 9 (8-10); nadadeira anal: 8 (6-9); nadadeira peitoral: 19-20.

Tamanho: flexão 3,3-4,5 mm; pós-flexão 6,0 mm.

Habitat: espécie marinha, demersal, ocorre em águas tropicais até $91 \mathrm{~m}$ de profundidade.

Nome vulgar: Dragãozinho.

\section{Georreferenciamento}

\begin{tabular}{|c|c|c|c|c|c|c|c|c|}
\hline DZUFRJ & Latitude (S) & Longitude (W) & Data & $\begin{array}{c}\text { Tipo de } \\
\text { arrasto }\end{array}$ & $\begin{array}{c}\text { Profundidade } \\
\text { de coleta }\end{array}$ & Rede & $\begin{array}{c}\text { Malha } \\
\text { ( } \begin{array}{c}\boldsymbol{N} \text { m }) \\
\text { inds. de }\end{array}\end{array}$ \\
\hline 1172 & $22^{\circ} 02^{\prime} 30,3^{\prime \prime}$ & $039^{\circ} 50^{\prime} 41,3^{\prime \prime}$ & $10 / 05 / 2002$ & oblíquo & $1.000 \mathrm{~m}$ & cilíndrico-cônica & 500 & 1 \\
\hline 7487 & $21^{\circ} 58^{\prime} 31,0^{\prime \prime}$ & $039^{\circ} 50^{\prime} 29,7^{\prime \prime}$ & $11 / 10 / 2001$ & oblíquo & $1.000 \mathrm{~m}$ & cilíndrico-cônica & 500 & 1 \\
\hline 7489 & $21^{\circ} 54^{\prime} 36,5^{\prime \prime}$ & $039^{\circ} 45^{\prime} 20,0^{\prime \prime}$ & $09 / 10 / 2001$ & oblíquo & $1.000 \mathrm{~m}$ & cilíndrico-cônica & 500 & 1 \\
\hline 20063 & $22^{\circ} 31^{\prime} 58,9^{\prime \prime}$ & $040^{\circ} 02^{\prime} 53,4^{\prime \prime}$ & $07 / 11 / 2001$ & oblíquo & $1.000 \mathrm{~m}$ & cilíndrico-cônica & 500 & 1 \\
\hline
\end{tabular}

Referências: Menezes \& Figueiredo, 1985; Watson, 1996j; Fricke; 2002; Powell \& Greene, 2006b; Fahay, 2007. 


\section{Família Gobiidae}

A família Gobiidae ocorre em ambientes marinhos, salobros e ocasionalmente de água doce, na maioria das áreas tropicais e subtropicais. Grande parte das espécies é marinha vivendo associada a formações coralinas ou ainda podem estar presentes em regiões costeiras, associados à baixa salinidade, próximo ao fundo. Compreende aproximadamente 210 gêneros com no mínimo 1.950 espécies. É a família marinha com o maior número de espécies e a sua sistemática está sendo revista.

As características usadas na separação das larvas de Gobiidae são: forma do corpo, tamanho dos olhos, número de raios das nadadeiras e padrão de pigmentação. Na maioria das espécies as nadadeiras dorsais são separadas e as bases das dorsais e da anal são curtas. A cabeça e os olhos são proporcionalmente de tamanho moderado, com pigmentos na área dos olhos. O corpo é alongado, quase sem diferenciação de espessura entre a cabeça e a cauda. Possuem um longo pedúnculo caudal. O intestino é reto ou um pouco curvado para baixo da vesícula gasosa e se estende até aproximadamente metade do corpo. Possui vesícula gasosa grande que se torna proeminente nas larvas maiores que $10 \mathrm{~mm}$ de comprimento, com pigmentação típica nas superfícies dorsal e posterior. Ausência de espinhos na cabeça.

Presença de um ou muitos melanóforos, simples ou pareados, uniformemente espaçados, na linha ventral da cauda. Pigmentos são frequentemente encontrados na região ventral do intestino e na base do istmo e da nadadeira pélvica.

No Brasil já foram identificadas 40 espécies nas fases de larva e adulto. Nesse estudo são contempladas as espécies Bathygobius soporator, Ctenogobius sp., Gnatholepis thompsoni, Gobionellus sp. 1, Gobionellus sp. 2 e o morfotipo Gobiidae sp. 1. 


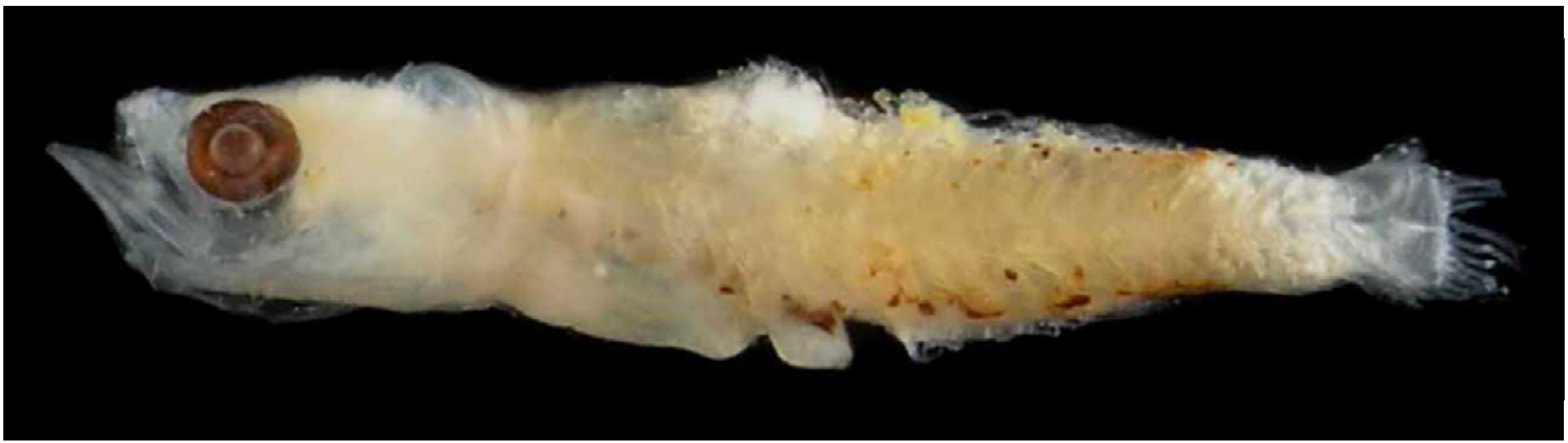

Figura 135: Bathygobius soporator. DZUFRJ 22243; Flexão; CP 4,0 mm.

\section{Bathygobius soporator (Valenciennes, 1837)}

As larvas dessa espécie são caracterizadas por serem muito pigmentadas e por terem o corpo mais alto que os demais gobiídeos. Nadadeira dorsal: VI, 10-11. Nadadeira anal: 8-9. Possui pigmentos internos na parte dorsal da cavidade abdominal. Tem densos melanóforos ao longo da linha ventral, formando uma fileira simples; e da linha dorsal, a partir da base da segunda nadadeira. Presença de melanóforos ao longo da maxila inferior e próximo aos olhos; melanóforos alongados na linha ventral do istmo, anteriormente ao grande melanóforo estrelado na base da nadadeira pélvica. Fileira de três manchas na linha ventral do abdome, atrás da nadadeira pélvica. Ausência de pigmentos na primeira nadadeira dorsal, na peitoral e na pélvica. Presença de pigmentos anteriormente a segunda nadadeira dorsal e melanóforos na base ventral da nadadeira caudal. Número total de miômeros: 27.

Tamanho: flexão 4,0 mm.

Habitat: espécie marinha, demersal, que pode habitar água doce e salobra. Ocorre em águas tropicais costeiras até $16 \mathrm{~m}$ de profundidade.

Nome vulgar: Amoré de buzo.

Georreferenciamento

\begin{tabular}{|c|c|c|c|c|c|c|c|c|}
\hline DZUFR & Latitude (S) & Longitude (W) & Data & Tipo de arrasto & $\begin{array}{c}\text { Profundidade } \\
\text { de coleta }\end{array}$ & Rede & $\begin{array}{c}\text { Malha } \\
\text { ( } \boldsymbol{\mu m} \text { ) }\end{array}$ & $\begin{array}{c}\text { No. de } \\
\text { inds. }\end{array}$ \\
\hline 22243 & $22^{\circ} 42^{\prime} 06,0^{\prime \prime}$ & $040^{\circ} 14^{\prime} 26,0^{\prime \prime}$ & $19 / 05 / 2002$ & oblíquo & $50 \mathrm{~m}$ & bongô & 500 & 1 \\
\hline
\end{tabular}

Referências: Figueiredo \& Menezes, 2000; Watson, 1996k; Baldwin \& Smith; 2003; Yeung \& Ruple, 2006; Fahay, 2007. 


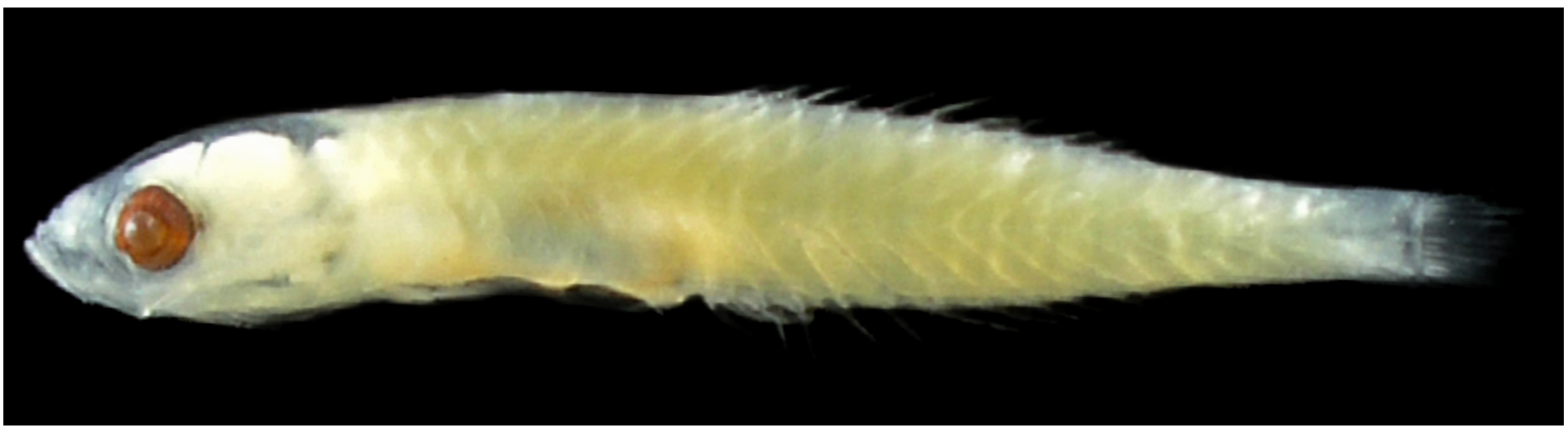

Figura 136 - A: Ctenogobius sp. DZUFRJ 5463; Flexão; CP 8,0 mm.

\section{Ctenogobius sp.}

Os representantes desse gênero possuem o corpo alongado (26 miômeros) e a cabeça proporcionalmente arredondada. São caracteri-

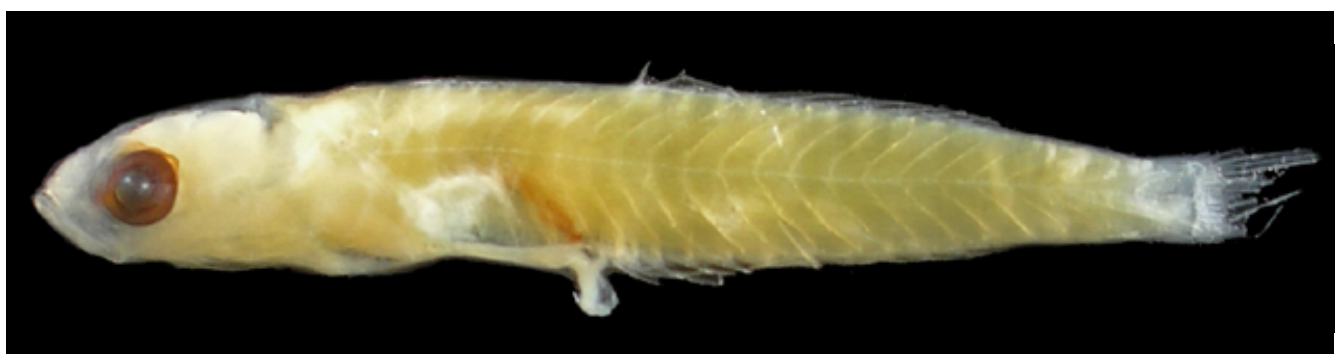

Figura 137 - B: DZUFRJ 5463; Pós-flexão; CP 11,0 mm. zados pela presença de pigmentos na região dorsal e posterior da vesícula gasosa. As nadadeiras dorsais são separadas: VI, 11-12. Nadadeira anal: I, 11.

Tamanho: flexão 4,8-8,0 mm; pós-flexão 8,5-11,0 mm.

Habitat: as espécies de Ctenogobius são marinhas, demersais, ocorrem em águas costeiras e estuarinas. No Brasil já foram registradas seis espécies de Ctenogobius.

\section{Georreferenciamento}

\begin{tabular}{|c|c|c|c|c|c|c|c|c|}
\hline DZUFRJ & Latitude (S) & Longitude (W) & Data & $\begin{array}{l}\text { Tipo de } \\
\text { arrasto }\end{array}$ & $\begin{array}{c}\text { Profundidade } \\
\text { de coleta }\end{array}$ & Rede & $\begin{array}{c}\text { Malha } \\
(\mu \mathrm{m})\end{array}$ & $\begin{array}{l}N^{\circ} \text {. de } \\
\text { inds. }\end{array}$ \\
\hline 1191 & $22^{\circ} 07^{\prime} 29,0^{\prime \prime}$ & $039^{\circ} 06^{\prime} 23,5^{\prime \prime}$ & $10 / 05 / 2002$ & oblíquo & $1.000 \mathrm{~m}$ & cilíndrico-cônica & 500 & 1 \\
\hline 1201 & $22^{\circ} 06^{\prime} 52,3^{\prime \prime}$ & $039^{\circ} 48^{\prime} 46,2^{\prime \prime}$ & $11 / 05 / 2002$ & oblíquo & $1.000 \mathrm{~m}$ & cilíndrico-cônica & 500 & 3 \\
\hline 1250 & $22^{\circ} 08^{\prime} 17,5^{\prime \prime}$ & $039^{\circ} 46^{\prime} 28,5^{\prime \prime}$ & $11 / 05 / 2002$ & oblíquo & $1.000 \mathrm{~m}$ & cilíndrico-cônica & 500 & 1 \\
\hline 1369 & $22^{\circ} 08^{\prime} 52,5^{\prime \prime}$ & $039^{\circ} 46^{\prime} 27,9^{\prime \prime}$ & $12 / 05 / 2002$ & oblíquo & até a termoclina & bongô & 330 & 1 \\
\hline 5463 & $22^{\circ} 32^{\prime} 49,0^{\prime \prime}$ & $040^{\circ} 04^{\prime} 20,9^{\prime \prime}$ & 07/11/2001 & oblíquo & $1.000 \mathrm{~m}$ & cilíndrico-cônica & 500 & 5 \\
\hline 5464 & $22^{\circ} 31^{\prime} 40,9^{\prime \prime}$ & $040^{\circ} 02^{\prime} 39,6^{\prime \prime}$ & 07/11/2001 & oblíquo & $1.000 \mathrm{~m}$ & cilíndrico-cônica & 500 & 1 \\
\hline 5467 & $22^{\circ} 31^{\prime} 58,9^{\prime \prime}$ & $040^{\circ} 02^{\prime} 53,4^{\prime \prime}$ & $07 / 11 / 2001$ & oblíquo & $1.000 \mathrm{~m}$ & cilíndrico-cônica & 500 & 1 \\
\hline 5469 & $22^{\circ} 32^{\prime} 49,0^{\prime \prime}$ & $040^{\circ} 04^{\prime} 20,9^{\prime \prime}$ & $07 / 11 / 2001$ & oblíquo & $1.000 \mathrm{~m}$ & cilíndrico-cônica & 500 & 3 \\
\hline 5470 & $22^{\circ} 32^{\prime} 50,0^{\prime \prime}$ & $040^{\circ} 04^{\prime} 09,9^{\prime \prime}$ & $06 / 11 / 2001$ & oblíquo & $1.000 \mathrm{~m}$ & cilíndrico-cônica & 500 & 5 \\
\hline 7415 & $21^{\circ} 57^{\prime} 10,5^{\prime \prime}$ & $039^{\circ} 43^{\prime} 33,3^{\prime \prime}$ & 09/10/2001 & oblíquo & $1.000 \mathrm{~m}$ & cilíndrico-cônica & 500 & 1 \\
\hline 7418 & $21^{\circ} 57^{\prime} 10,5^{\prime \prime}$ & $039^{\circ} 43^{\prime} 33,3^{\prime \prime}$ & 09/10/2001 & oblíquo & $1.000 \mathrm{~m}$ & cilíndrico-cônica & 500 & 1 \\
\hline
\end{tabular}

Referências: Figueiredo \& Menezes, 2000; Watson, 1996l; Baldwin \& Smith; 2003; Yeung \&; Ruple, 2006b; Fahay, 2007. 


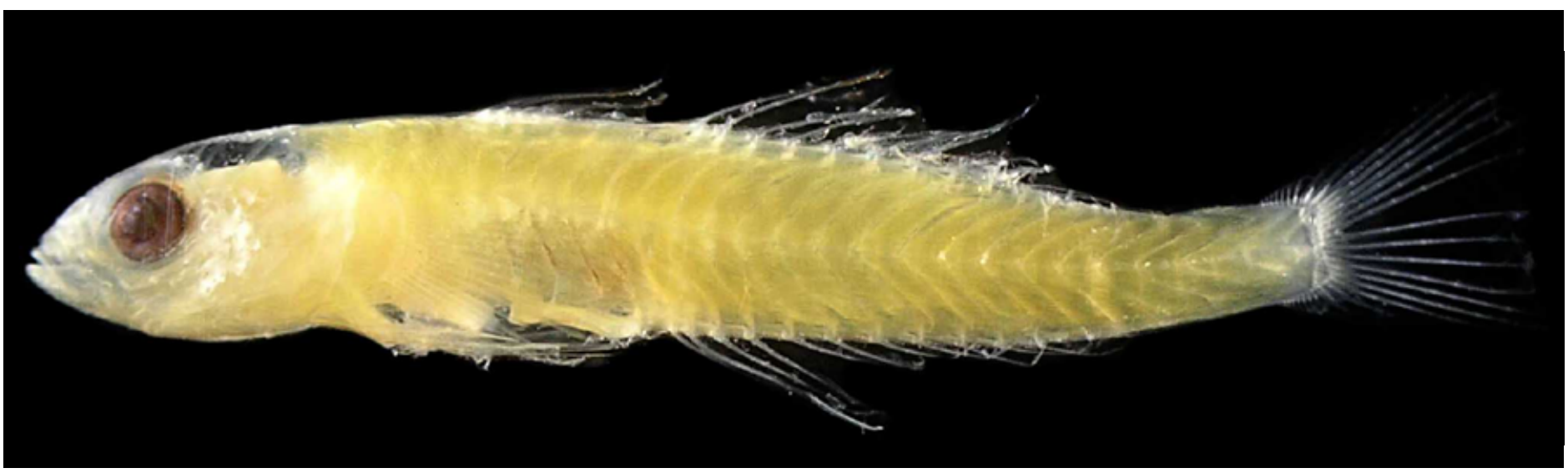

Figura 137: Gnatholepis thompsoni. DZUFRJ 22242; Pós-flexão; CP 10,5 mm.

\section{Gnatholepis thompsoni Jordan, 1904}

As larvas apresentam corpo alongado (26 miômeros), com olhos relativamente grandes e arredondados. As bases das nadadeiras dorsal e anal são moderadamente longas e de comprimento semelhante (11 raios na dorsal e 12 raios na anal). A base da nadadeira pélvica é parcialmente unida na porção ventral do corpo. Nadadeira peitoral com 16-17 raios. A vesícula gasosa possui pigmentos na porção dorsal e posterior. A principal característica é a presença de melanóforos associados aos espinhos e raios anteriores da nadadeira dorsal. Distingue-se também pela ausência de melanóforos na linha ventral. Possui uma faixa de pigmentos abaixo e acima dos olhos; no opérculo; na região frontal e na base da dorsal.

Tamanho: pós-flexão 10,5 mm.

Habitat: espécie marinha, demersal, ocorre em águas tropicais até 30 $\mathrm{m}$ de profundidade. Vive próximo ao substrato e rochas da plataforma continental.

Nome vulgar: Amoré de mancha dourada.

\section{Georreferenciamento}

\begin{tabular}{|c|c|c|c|c|c|c|c|c|}
\hline DZUFRJ & Latitude (S) & Longitude (W) & Data & $\begin{array}{c}\text { Tipo de } \\
\text { arrasto }\end{array}$ & $\begin{array}{c}\text { Profundidade } \\
\text { de coleta }\end{array}$ & Rede & $\begin{array}{c}\text { Malha } \\
\text { ( } \boldsymbol{\mu m})\end{array}$ & $\begin{array}{c}\mathbf{N}^{\circ} \text {. de } \\
\text { inds. }\end{array}$ \\
\hline 22242 & $22^{\circ} 32^{\prime} 03,0^{\prime \prime}$ & $040^{\circ} 17^{\prime} 21,0^{\prime \prime}$ & $19 / 05 / 2002$ & oblíquo & $30 \mathrm{~m}$ & bongô & 330 & 1 \\
\hline
\end{tabular}

Referências: Figueiredo \& Menezes, 2000; Watson, 1996l; Baldwin \& Smith; 2003; Yeung \&; Ruple, 2006b; Fahay, 2007. 


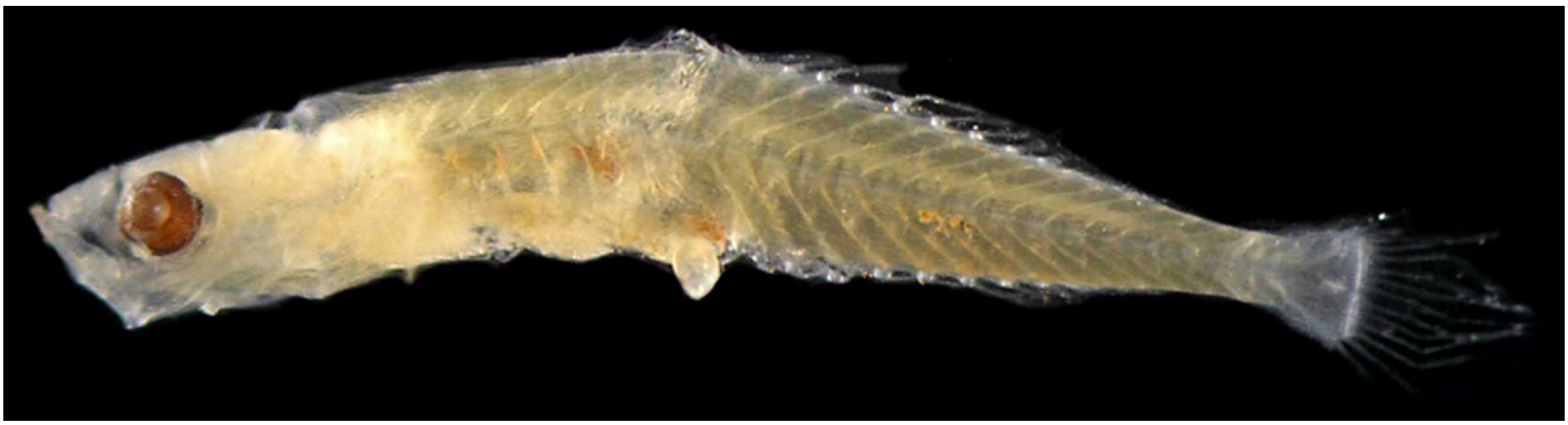

Figura 138 - A: Gobiidae sp. 1. DZUFRJ 22241; Flexão; CP 3,0 mm.

\section{Gobiidae sp. 1}

Os exemplares que foram tipados nesse grupo são caracterizados pela presença de pigmentos entre os miômeros em flexão e pós-flexão. Presença de pigmentação na porção dorsal e posterior da vesícula gasosa, na extremidade da maxila

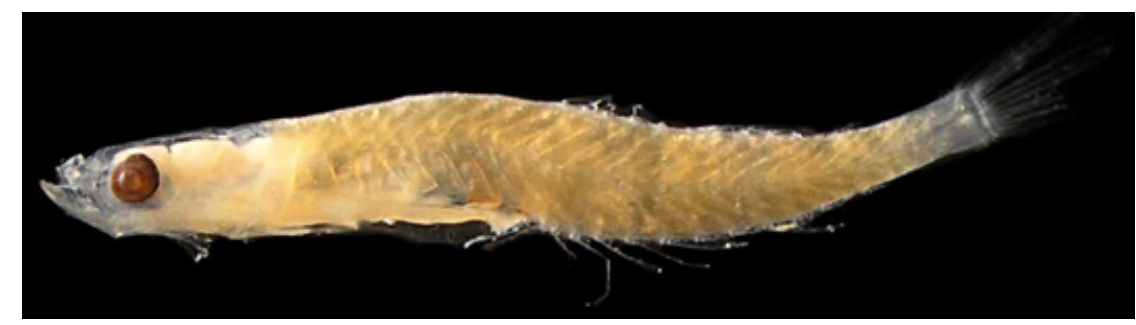

Figura 138 - B: DZUFRJ 22244; Pós-flexão; CP 6,5 mm. inferior. Na base da nadadeira anal há quatro manchas ventrais. A nadadeira dorsal é separada e a segunda possui 10 raios; nadadeira anal formada por 11-12 raios.

Tamanho: flexão 2,6-5,5 mm; pós-flexão 5,6-6,5 mm.

Habitat: as espécies de Gobiidae são costeiras e estuarinas, mas algumas podem ocorrer em águas oceânicas.

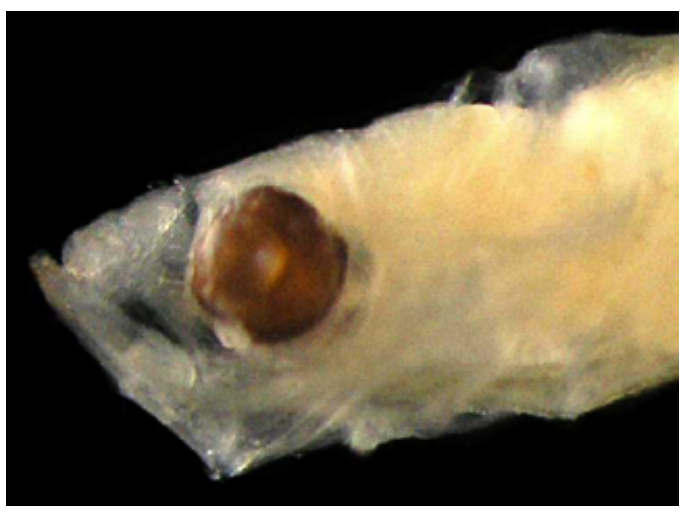

Figura 138 - C: Pigmentação na extremidade da maxila inferior.

\section{Georreferenciamento}

\begin{tabular}{|c|c|c|c|c|c|c|c|c|}
\hline DZUFRJ & Latitude (S) & Longitude (W) & Data & $\begin{array}{l}\text { Tipo de } \\
\text { arrasto }\end{array}$ & $\begin{array}{l}\text { Profundidade } \\
\text { de coleta }\end{array}$ & Rede & $\begin{array}{c}\text { Malha } \\
(\mu \mathrm{m})\end{array}$ & $\begin{array}{l}\text { No. de } \\
\text { inds. }\end{array}$ \\
\hline 604 & $22^{\circ} 38^{\prime} 29,0^{\prime \prime}$ & $040^{\circ} 17^{\prime} 40,0^{\prime \prime}$ & $18 / 05 / 2002$ & oblíquo & $800 \mathrm{~m}$ & cilíndrico-cônica & 500 & 3 \\
\hline 624 & $22^{\circ} 42^{\prime} 06,0^{\prime \prime}$ & $040^{\circ} 14^{\prime} 26,0^{\prime \prime}$ & $19 / 05 / 2002$ & oblíquo & $50 \mathrm{~m}$ & bongô & 500 & 4 \\
\hline 22241 & $22^{\circ} 33^{\prime} 47,7^{\prime \prime}$ & $040^{\circ} 12^{\prime} 20,5^{\prime \prime}$ & $17 / 05 / 2002$ & oblíquo & $50 \mathrm{~m}$ & bongô & 330 & 3 \\
\hline 22244 & $21^{\circ} 53^{\prime} 10,4^{\prime \prime}$ & $039^{\circ} 45^{\prime} 49,9^{\prime \prime}$ & $10 / 10 / 2001$ & oblíquo & $1.000 \mathrm{~m}$ & cilíndrico-cônica & 500 & 1 \\
\hline 22259 & $22^{\circ} 38^{\prime} 25,0^{\prime \prime}$ & $040^{\circ} 17^{\prime} 41,0^{\prime \prime}$ & 19/05/2002 & oblíquo & $40 \mathrm{~m}$ & bongô & 330 & 2 \\
\hline 22260 & $22^{\circ} 36^{\prime} 54,9^{\prime \prime}$ & $040^{\circ} 09^{\prime} 19,4^{\prime \prime}$ & $16 / 05 / 2002$ & oblíquo & $50 \mathrm{~m}$ & bongô & 330 & 27 \\
\hline 22261 & $22^{\circ} 33^{\prime} 37,0^{\prime \prime}$ & $040^{\circ} 19^{\prime} 10,0^{\prime \prime}$ & $17 / 05 / 2002$ & oblíquo & $50 \mathrm{~m}$ & bongô & 500 & 3 \\
\hline 22262 & $22^{\circ} 38^{\prime} 25,0^{\prime \prime}$ & $040^{\circ} 17^{\prime} 41,0^{\prime \prime}$ & 19/05/2002 & oblíquo & $40 \mathrm{~m}$ & bongô & 500 & 1 \\
\hline 22263 & $22^{\circ} 36^{\prime} 54,9^{\prime \prime}$ & $040^{\circ} 09^{\prime} 19,4^{\prime \prime}$ & $16 / 05 / 2002$ & oblíquo & $50 \mathrm{~m}$ & bongô & 500 & 3 \\
\hline 22264 & $22^{\circ} 34^{\prime} 05,0^{\prime \prime}$ & $040^{\circ} 19^{\prime} 40,0^{\prime \prime}$ & $17 / 05 / 2002$ & oblíquo & $600 \mathrm{~m}$ & cilíndrico-cônica & 500 & 4 \\
\hline 22265 & $22^{\circ} 41^{\prime} 54,7^{\prime \prime}$ & $040^{\circ} 14^{\prime} 04,5^{\prime \prime}$ & $16 / 05 / 2002$ & oblíquo & $1.000 \mathrm{~m}$ & cilíndrico-cônica & 500 & 4 \\
\hline
\end{tabular}

Referências: Figueiredo \& Menezes, 2000; Watson, 1996l; Baldwin \& Smith; 2003; Yeung \&; Ruple, 2006b; Fahay, 2007. 


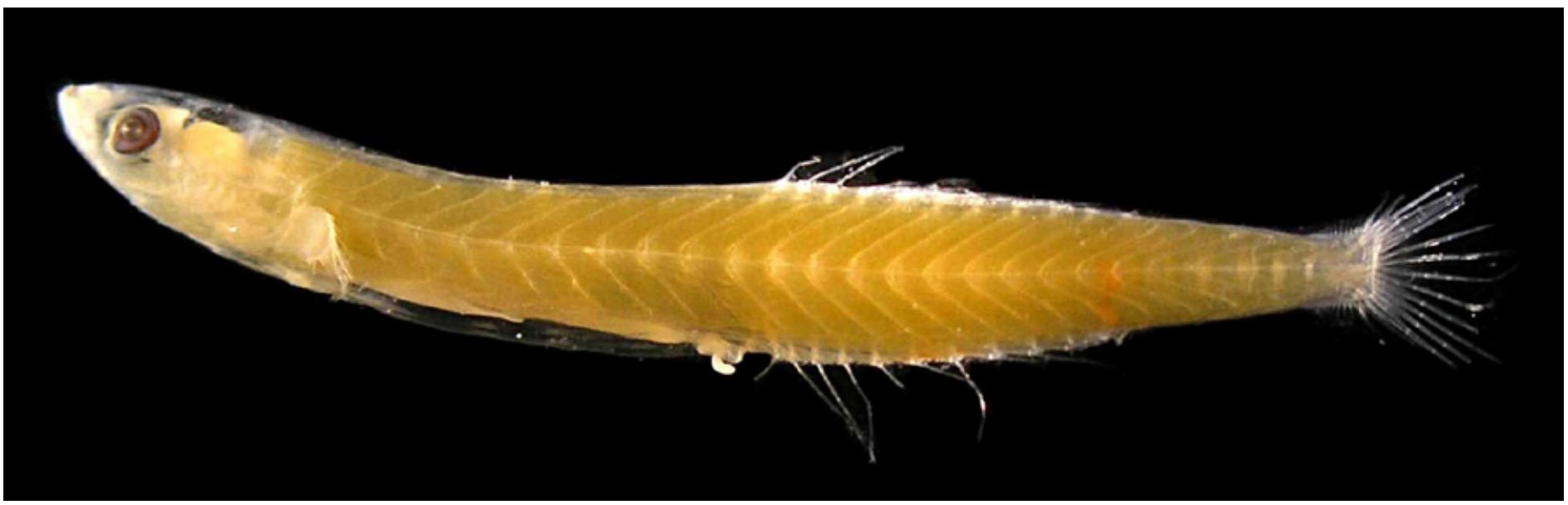

Figura 139: Gobionellus sp. 1. DZUFRJ 22285; Pós-flexão; CP 13,5 mm.

\section{Gobionellus sp. 1}

Possuem o corpo muito alongado (26 miômeros) e a cabeça afilada com pigmentação na extremidade da mandíbula. Presença de 11 raios na segunda nadadeira dorsal e 12 raios na nadadeira anal. Pigmentação presente na porção posterior da vesícula gasosa. Apresentam uma mancha de pigmentos na base da nadadeira anal, entre o sexto e o oitavo raios. Na região do pedúnculo caudal, há um pigmento ventral (interno e superficial), com origem no último raio da nadadeira anal, que se estende acima da linha lateral. No Brasil já foram registradas as espécies Gobionellus oceanicus (Pallas, 1770), Gobionellus stomatus Starks, 1913 e Gobionellus thoropsis Pezold \& Gilbert, 1987.

Tamanho: pós-flexão 13,5-14,5 mm.

Habitat: as espécies de Gobionellus vivem em regiões costeiras, com ampla variação de salinidade.

\section{Georreferenciamento}

\begin{tabular}{|c|c|c|c|c|c|c|c|c|}
\hline DZUFRJ & Latitude (S) & Longitude (W) & Data & $\begin{array}{c}\text { Tipo de } \\
\text { arrasto }\end{array}$ & $\begin{array}{c}\text { Profundidade } \\
\text { de coleta }\end{array}$ & Rede & $\begin{array}{c}\text { Malha } \\
(\boldsymbol{\mu m})\end{array}$ & $\begin{array}{c}\mathbf{N}^{\circ} \text {. de } \\
\text { inds. }\end{array}$ \\
\hline 22285 & $22^{\circ} 02^{\prime} 30,0^{\prime \prime}$ & $039^{\circ} 49^{\prime} 41,2^{\prime \prime}$ & $12 / 05 / 2002$ & oblíquo & $1.000 \mathrm{~m}$ & cilíndrico-cônica & 500 & 2 \\
\hline
\end{tabular}

Referências: Figueiredo \& Menezes, 2000; Watson, 1996l; Baldwin \& Smith; 2003; Yeung \&; Ruple, 2006b; Fahay, 2007. 


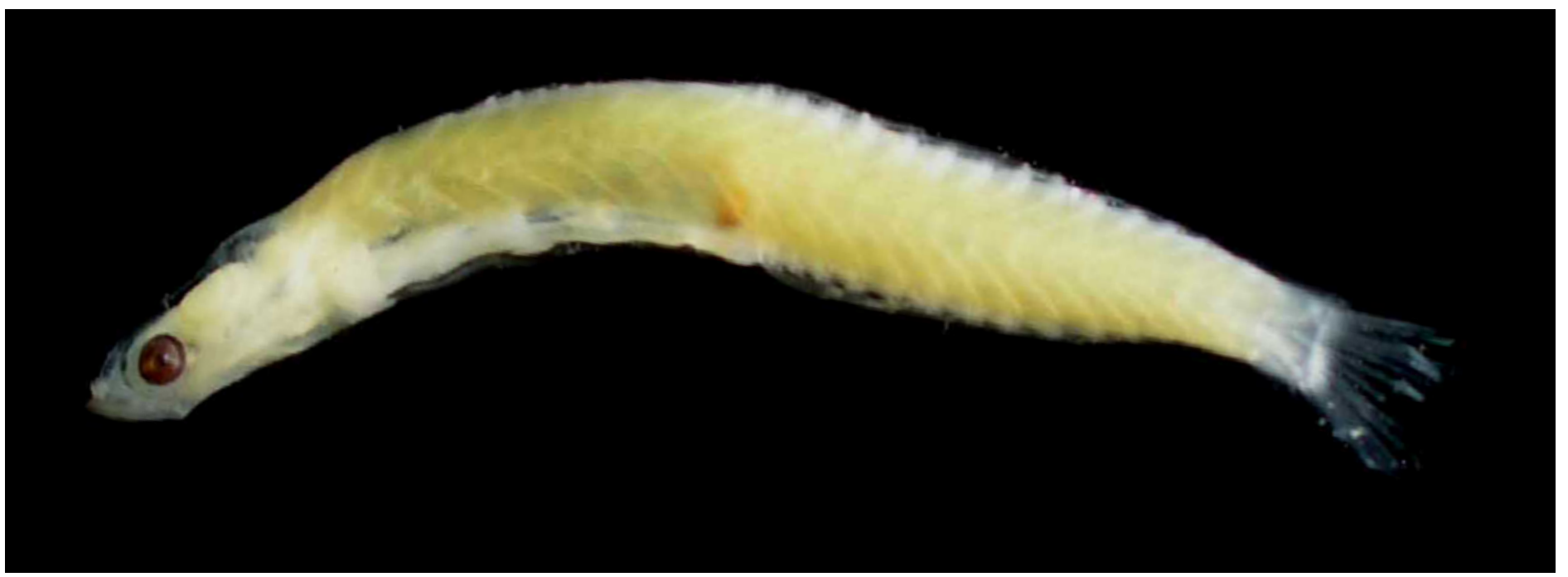

Figura 140: Gobionellus sp. 2. DZUFRJ 22286; Pós-flexão; CP 9,0 mm.

\section{Gobionellus sp. 2}

Possuem o corpo muito alongado (26 miômeros) e a cabeça afilada, com pigmentação na extremidade das maxilas. Presença de 13 raios na segunda nadadeira dorsal e na nadadeira anal. A vesícula gasosa possui pigmentação apenas na porção posterior.

Tamanho: pós-flexão 9,0 mm.

Habitat: as espécies de Gobionellus vivem em regiões costeiras, com ampla variação de salinidade. No Brasil já foram registradas as espécies Gobionellus oceanicus (Pallas, 1770), Gobionellus stomatus Starks, 1913, Gobionellus thoropsis Pezold \& Gilbert, 1987.

\section{Georreferenciamento}

\begin{tabular}{|c|c|c|c|c|c|c|c|c|}
\hline DZUFRJ & Latitude (S) & Longitude (W) & Data & $\begin{array}{c}\text { Tipo de } \\
\text { arrasto }\end{array}$ & $\begin{array}{c}\text { Profundidade } \\
\text { de coleta }\end{array}$ & Rede & $\begin{array}{c}\text { Malha } \\
\text { ( } \boldsymbol{\mu m})\end{array}$ & $\begin{array}{c}\mathbf{N}^{\circ} \text {. de } \\
\text { inds. }\end{array}$ \\
\hline 22286 & $22^{\circ} 08^{\prime} 175^{\prime \prime}$ & $039^{\circ} 46^{\prime} 28,5^{\prime \prime}$ & $11 / 05 / 2002$ & oblíquo & $1.000 \mathrm{~m}$ & cilíndrico-cônica & 500 & 1 \\
\hline
\end{tabular}

Referências: Figueiredo \& Menezes, 2000; Watson, 1996l; Baldwin \& Smith; 2003; Yeung \&; Ruple, 2006b; Fahay, 2007. 


\section{Família Microdesmidae}

É formada por peixes marinhos, raramente de água doce e salobra, que ocorrem em regiões tropicais e subtropicais. Compreende 10 gêneros com aproximadamente 66 espécies. A primeira nadadeira dorsal possui X - XXVIII espinhos e a segunda tem 23 a 61 raios. O corpo é relativamente longo e o pedúnculo caudal é curto. A pigmentação na vesícula gasosa se restringe à superfície dorsal.

No Brasil já foram identificadas quatro espécies nas fases de larva e adulto: Cerdale fasciata Dawson, 1974; Microdesmus bahianus Dawson, 1973; Microdesmus longipinnis (Weymouth, 1910) e Ptereleotris randalli Gasparini, Rocha \& Floeter, 2001. Nesse estudo é contemplada a espécie Ptereleotris randalli Gasparini, Rocha \& Floeter, 2001. Essa espécie fazia parte da família Ptereleotridae que passou a ser reconhecida como subfamília (Ptereleotrinae) de Microdesmidae. 


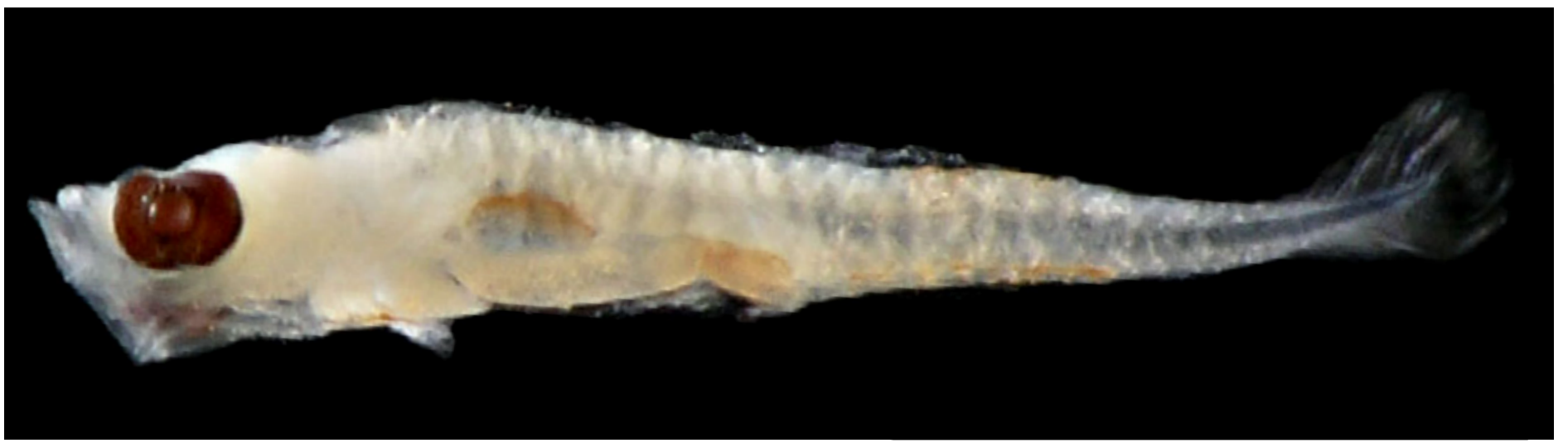

Figura 141 - A: Ptereleotris randalli. DZUFRJ 535; Pré-flexão; CP 3,0 mm.

\section{Ptereleotris} randalli

\section{Gasparini, Rocha \& Floeter, 2001}

Possui o corpo alongado (26 miômeros) e a região do pedúnculo caudal muito curta. É caracterizada pelo grande comprimento da base da segunda nadadeira dorsal, com 26-28 raios. Na pré-flexão possui manchas estreladas na porção posterior da cabeça, pigmentos sobre a vesícula gasosa e porção final do intestino, e uma fileira única de pigmentos na região dorsal no terço final da larva. A partir da flexão $(3,5 \mathrm{~mm})$ a fileira de pigmentos na região dorsal já é dupla. Essa dupla fileira começa no $2^{\circ}$ raio da $2^{a}$ nadadeira dorsal e torna-se mais unida em direção à nadadeira caudal. Na margem ventral do corpo também são encontrados pigmentos que ficam mais espaçados durante os estágios de flexão e de pós-flexão.

Tamanho: pré-flexão 2,5-3,0 mm; flexão 3,57,5 mm; pós-flexão 11,7 mm.

Habitat: espécie marinha, demersal, ocorre em águas tropicais entre 8 e $60 \mathrm{~m}$ de profundidade.

Nome vulgar: Linha azul.

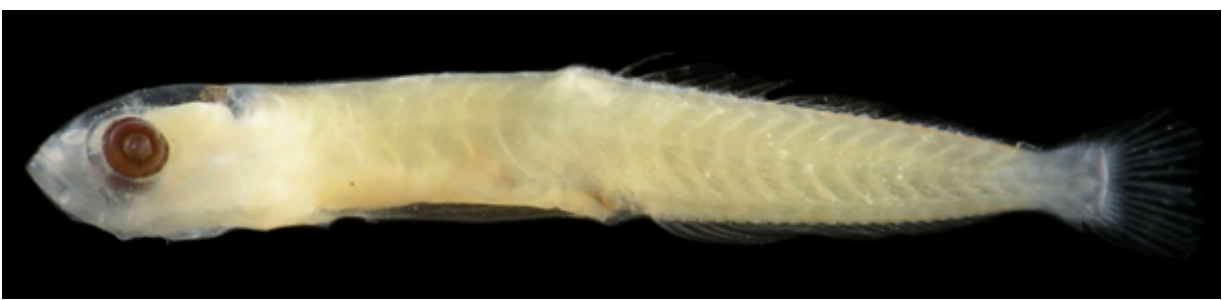

Figura 141 - B: DZUFRJ 646; Flexão; CP 7,0 mm.

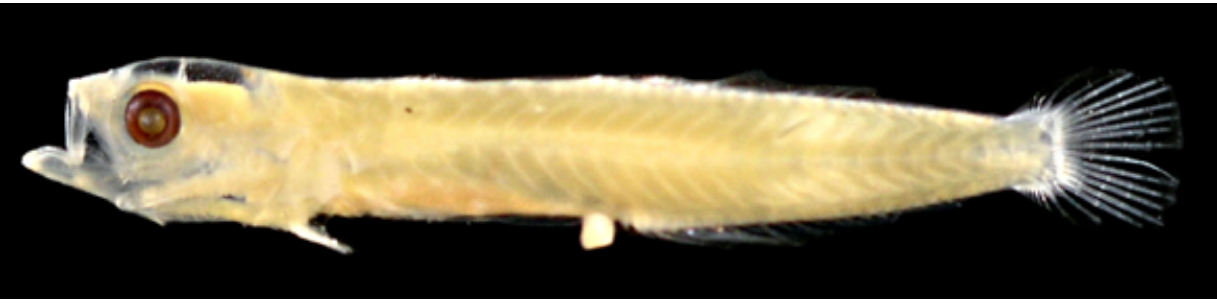

Figura 141 - C: DZUFRJ 1221; Pós-flexão; CP 11,7 mm.

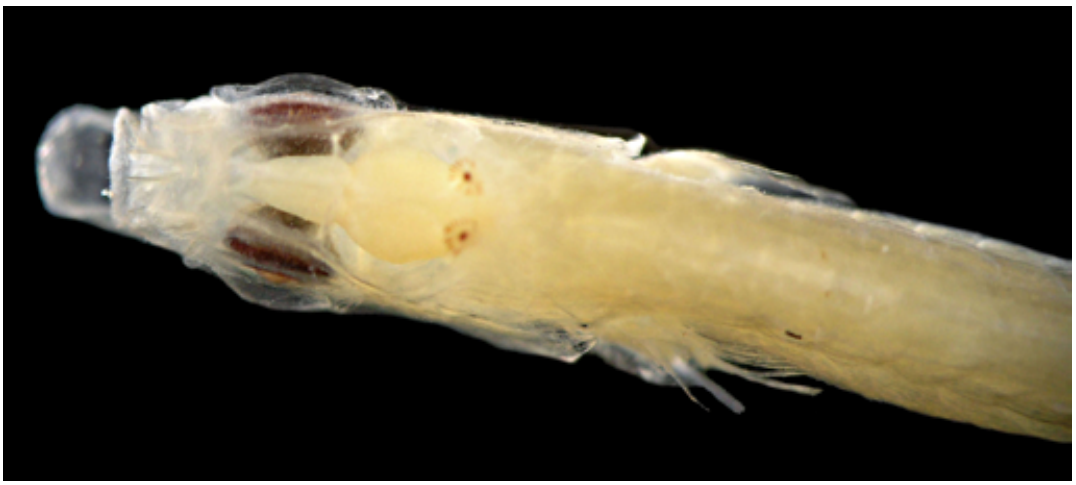

Figura 141 - D: Manchas estreladas na porção posterior da cabeça.

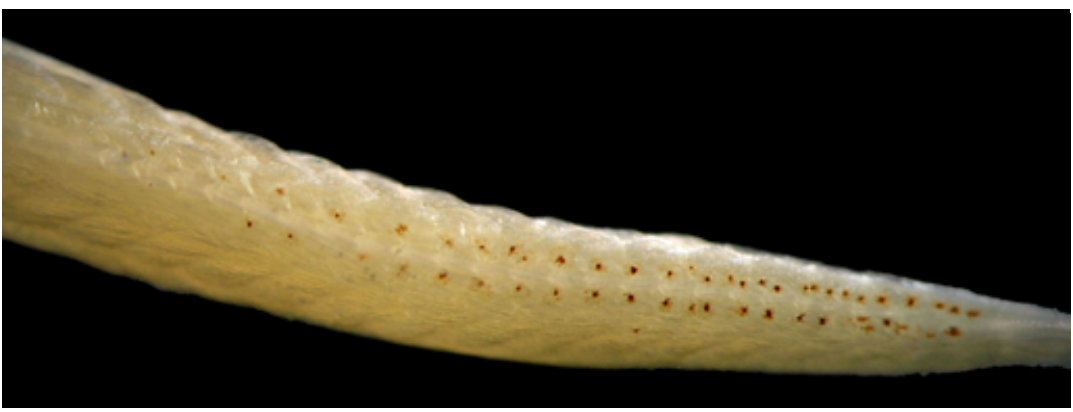

Figura 141 - E: Fileira dupla de melanóforos na região dorsal. 


\section{Georreferenciamento}

\begin{tabular}{|c|c|c|c|c|c|c|c|c|}
\hline DZUFR & Latitude (S) & Longitude (W) & Data & $\begin{array}{c}\text { Tipo de } \\
\text { arrasto }\end{array}$ & $\begin{array}{c}\text { Profundidade } \\
\text { de coleta }\end{array}$ & Rede & $\begin{array}{c}\text { Malha } \\
\text { ( } \boldsymbol{\mu m} \text { ) }\end{array}$ & $\begin{array}{c}\text { No. de } \\
\text { inds. }\end{array}$ \\
\hline 488 & $22^{\circ} 33^{\prime} 37,0^{\prime \prime}$ & $040^{\circ} 19^{\prime} 10,0^{\prime \prime}$ & $17 / 05 / 2002$ & oblíquo & $50 \mathrm{~m}$ & bongô & 500 & 30 \\
\hline 512 & $22^{\circ} 31^{\prime} 27,0^{\prime \prime}$ & $040^{\circ} 16^{\prime} 56,0^{\prime \prime}$ & $17 / 05 / 2002$ & oblíquo & $600 \mathrm{~m}$ & cilíndrico-cônica & 500 & 37 \\
\hline 529 & $22^{\circ} 34^{\prime} 05,0^{\prime \prime}$ & $040^{\circ} 19^{\prime} 40,0^{\prime \prime}$ & $17 / 05 / 2002$ & oblíquo & $600 \mathrm{~m}$ & cilíndrico-cônica & 500 & 48 \\
\hline 575 & $22^{\circ} 33^{\prime} 477^{\prime \prime}$ & $040^{\circ} 12^{\prime} 20,5^{\prime \prime}$ & $17 / 05 / 2002$ & oblíquo & $50 \mathrm{~m}$ & bongô & 330 & 2 \\
\hline 591 & $22^{\circ} 33^{\prime} 45,8^{\prime \prime}$ & $040^{\circ} 13^{\prime} 22,9^{\prime \prime}$ & $17 / 05 / 2002$ & oblíquo & $800 \mathrm{~m}$ & cilíndrico-cônica & 500 & 5 \\
\hline 646 & $22^{\circ} 38^{\prime} 25,0^{\prime \prime}$ & $040^{\circ} 17^{\prime} 41,0^{\prime \prime}$ & $19 / 05 / 2002$ & oblíquo & $40 \mathrm{~m}$ & bongô & 330 & 34 \\
\hline 1221 & $22^{\circ} 02^{\prime} 30,0^{\prime \prime}$ & $039^{\circ} 49^{\prime} 41,2^{\prime \prime}$ & $12 / 05 / 2002$ & oblíquo & $1.000 \mathrm{~m}$ & cilíndrico-cônica & 500 & 1 \\
\hline 1357 & $22^{\circ} 02^{\prime} 30,0^{\prime \prime}$ & $039^{\circ} 49^{\prime} 41,2^{\prime \prime}$ & $12 / 05 / 2002$ & oblíquo & até a termoclina & bongô & 330 & 2 \\
\hline
\end{tabular}

Referências: Gasparini et al., 2001; Baldwin \& Smith; 2003; Watson \& Walker, 2006; Fahay, 2007; Gomes \& Bonecker, 2014. 


\section{Família Acanthuridae}

Os membros da família Acanthuridae são encontrados em águas tropicais, subtropicais e, algumas vezes, temperadas dos oceanos Atlântico e Pacífico. Compreende seis gêneros com aproximadamente 80 espécies. Os adultos liberam larvas planctônicas que vivem 45-70 dias em águas pelágicas. Os representantes desta família têm um estágio pós-larval especializado, conhecido como acronurus. Esse estágio é caracterizado pela forma arredondada e quase total transparência do corpo, exceto em relação aos pigmentos internos no intestino e na cabeça.

No Brasil, já foram identificadas quatro espécies nas fases de larva e adulto: Acanthurus bahianus Castelnau, 1855; Acanthurus chirurgus (Bloch, 1787); Acanthurus coerulus Bloch \& Schneider, 1801 e Acanthurus monroviae Steindachner, 1876. Nesse estudo é contemplada a espécie Acanthurus sp. 


\section{Acanthurus sp.}

As larvas de Acanthurus possuem o corpo com formato discoide, comprimido lateralmente e boca pequena. Desenvolvem espinhos na cabeça, mas não há espinhos no opérculo. A principal característica é a presença de um pequeno espinho retroarticular, localizado em ambos os lados do pedúnculo caudal. A separação das espécies é baseada nos dados merísticos. As larvas utilizadas nesse estudo estavam no estágio de pré-flexão e os raios não estavam formados, o que impossibilitou a identificação até espécie. Número total de miômeros: 22.

Tamanho: pré-flexão 2,6-3,2 mm.

Habitat: as espécies de Acanthurus são marinhas, pelágicas, vivem associadas a formações coralinas e rochas, misturadas ao fundo arenoso.

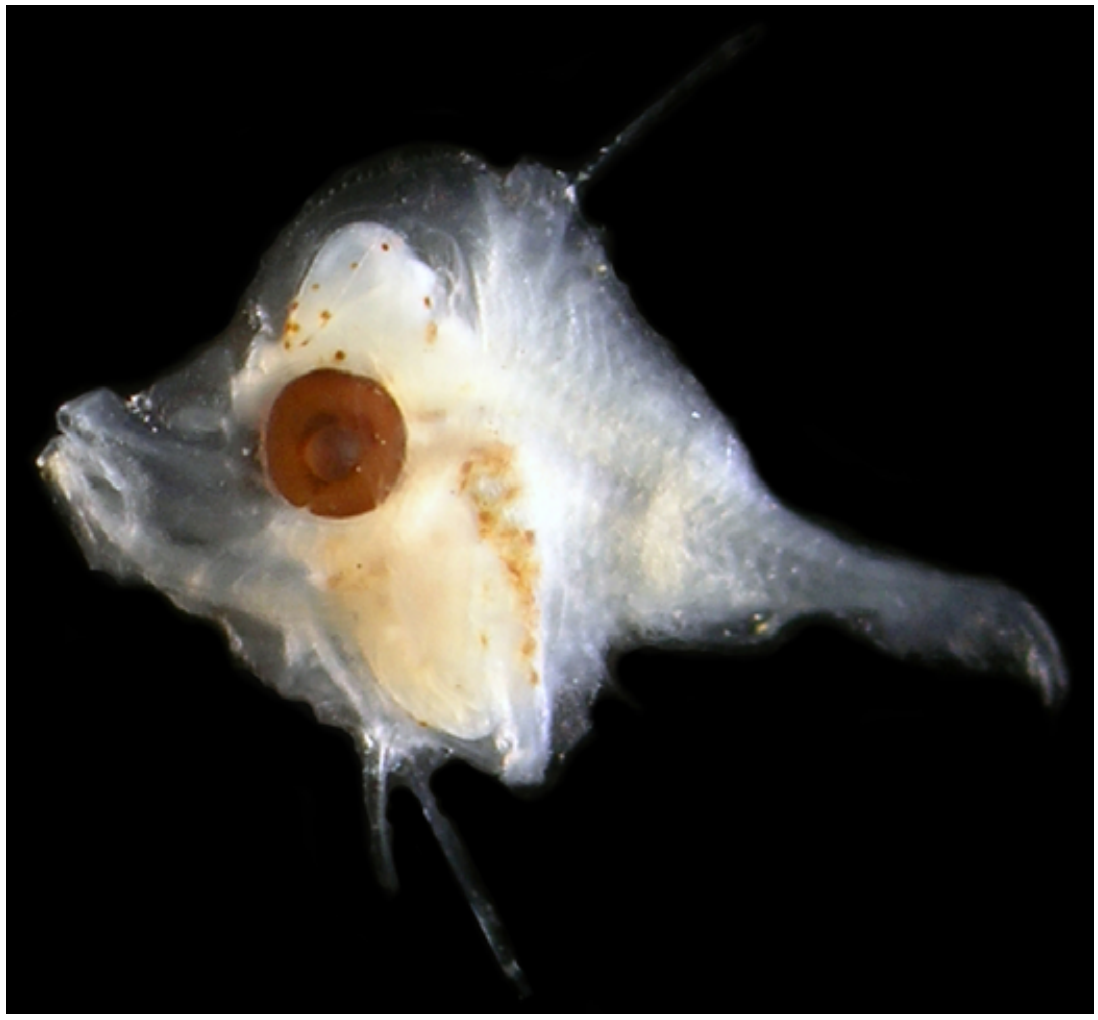

Figura 142: Acanthurus sp. DZUFRJ 464; Pré-flexão; CP 3,2 mm.

\section{Georreferenciamento}

\begin{tabular}{|c|c|c|c|c|c|c|c|c|}
\hline DZUFRJ & Latitude (S) & Longitude (W) & Data & $\begin{array}{c}\text { Tipo de } \\
\text { arrasto }\end{array}$ & $\begin{array}{c}\text { Profundidade } \\
\text { de coleta }\end{array}$ & Rede & $\begin{array}{c}\text { Malha } \\
\text { ( } \boldsymbol{\mu m})\end{array}$ & $\begin{array}{c}\mathbf{N}^{\circ} \text {. de } \\
\text { inds. }\end{array}$ \\
\hline 464 & $22^{\circ} 33^{\prime} 477^{\prime \prime}$ & $040^{\circ} 12^{\prime} 20,5^{\prime \prime}$ & $17 / 05 / 2002$ & oblíquo & $50 \mathrm{~m}$ & bongô & $330 \mu \mathrm{m}$ & 1 \\
\hline 671 & $22^{\circ} 41^{\prime} 54,7^{\prime \prime}$ & $040^{\circ} 14^{\prime} 04,5^{\prime \prime}$ & $16 / 05 / 2002$ & oblíquo & $1000 \mathrm{~m}$ & cilíndrico-cônica & $500 \mu \mathrm{m}$ & 1 \\
\hline
\end{tabular}

Referências: Leis \& Richards, 1984; Rocha et al., 2002; Luiz-Júnior et al., 2004; Jackson, 2006b; Fahay, 2007. 


\section{Família Sphyraenidae}

Os representantes da família Sphyraenidae são encontradas em regiões temperadas e tropicais em todo mundo. São pelágicos e ocorrem, principalmente, em águas próximas a plataforma e em regiões de fundo rígido. A família compreende um gênero e aproximadamente 21 espécies.

As larvas são caracterizadas pela presença da nadadeira pélvica na região abdominal. As nadadeiras dorsais são bem separadas, sendo a primeira com $V$ espinhos e a segunda I, 8-10. A anal é formada por um a três espinhos e sete a nove raios. O corpo (24 miômeros) e o focinho são moderadamente alongados. A maxila superior não é protrátil, enquanto a inferior se projeta além da superior. As larvas e os adultos são separados pelo padrão de pigmentação, presença ou ausência de uma protuberância da maxila inferior, comprimento da nadadeira peitoral e a posição da primeira dorsal, em relação a origem das nadadeiras anal e pélvica.

No Brasil, já foram identificadas quatro espécies nas fases de larva e adulto: Sphyraena barracuda (Walbaum, 1792); Sphyraena guachancho Cuvier, 1829; Sphyraena sphyraena (Linnaeus, 1758) e Sphyraena tome Fowler, 1903. Nesse estudo é contemplada a espécie Sphyraena guachancho. 


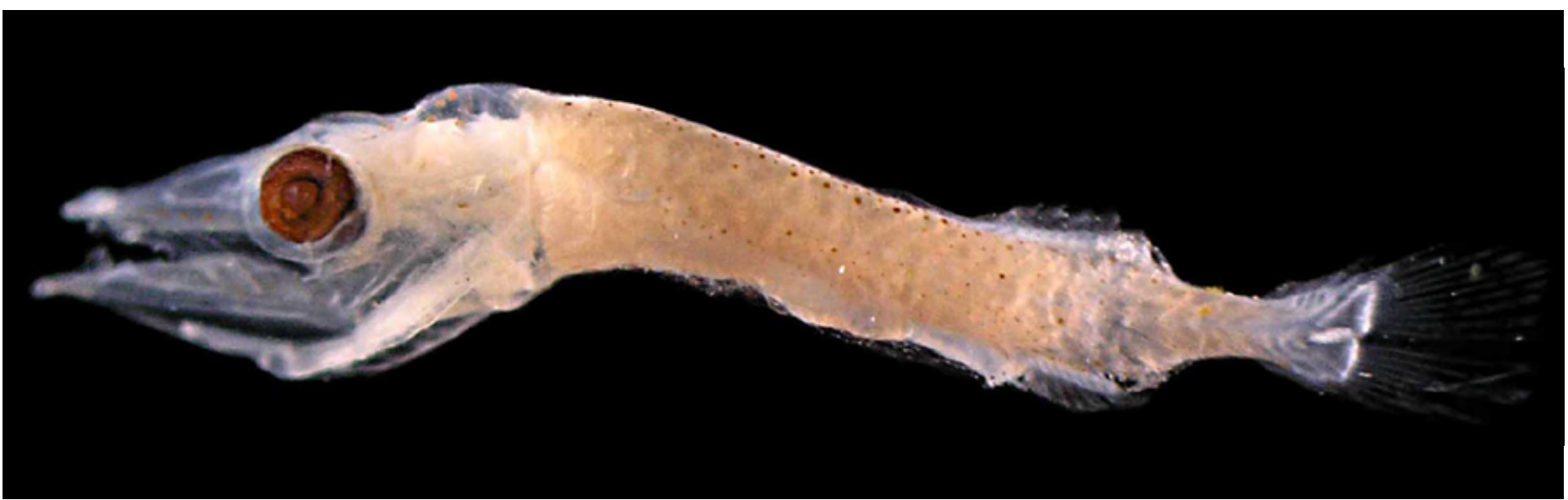

Figura 143: Sphyraena guachancho. DZUFRJ 351; Flexão; CP 5,4 mm.

\section{Sphyraena guachancho Cuvier, 1829}

As larvas apresentam o corpo moderadamente alongado (24 miômeros). O intestino é comprido chegando a $65 \%$ do CP, aumentando até $70 \%$ do CP com o crescimento. A cabeça também aumenta de comprimento de acordo com o crescimento da larva, passando de $27 \%$ para $38 \%$ do CP. O focinho é muito pontudo, sendo que a maxila inferior estende-se além da inferior. Os pigmentos estão presentes na maxila inferior, no focinho, na margem ventral do intestino e nas linhas dorsal, ventral e lateral do corpo. Os melanóforos são mais densos nas margens dorsal e ventral do corpo e da cauda, sendo a região do intestino pouco pigmentada. A pigmentação da cabeça é ausente em estágios menores, aparecendo fracamente nos estágios mais desenvolvidos.

Tamanho: flexão 5,4 mm.

Habitat: espécie marinha, pelágica, ocorre em águas subtropicais desde próximo à superfície até $100 \mathrm{~m}$ de profundidade. Vive em águas costeiras, com alta turbidez, podendo ocorrer também em regiões estuarinas.

Nome vulgar: Bicuda branca.

Georreferenciamento

\begin{tabular}{|c|c|c|c|c|c|c|c|c|}
\hline DZUFRJ & Latitude (S) & Longitude (W) & Data & $\begin{array}{c}\text { Tipo de } \\
\text { arrasto }\end{array}$ & $\begin{array}{c}\text { Profundidade } \\
\text { de coleta }\end{array}$ & Rede & $\begin{array}{c}\text { Malha } \\
(\boldsymbol{\mu m})\end{array}$ & $\begin{array}{c}\mathbf{N}^{\circ} \text {. de } \\
\text { inds. }\end{array}$ \\
\hline 351 & $22^{\circ} 31^{\prime} 27,0^{\prime \prime}$ & $040^{\circ} 16^{\prime} 56,0^{\prime \prime}$ & $17 / 05 / 2002$ & oblíquo & $600 \mathrm{~m}$ & cilíndrico-cônica & 500 & 1 \\
\hline
\end{tabular}

Referências: Menezes \& Figueiredo, 1985; Sandknop \& Watson, 1996b; Matsuura \& Suzuki, 1997; Russell, 2002; Ditty et al., 2006; Fahay, 2007. 


\section{Família Gempylidae}

As larvas pertencentes a família Gempylidae vivem em zonas pelágicas de regiões tropicais e temperadas, em todo mundo. Quando adultos, apresentam ampla distribuição geográfica, vivendo em zonas mesopelágicas. A família compreende 16 gêneros e aproximadamente 24 espécies.

As larvas têm espinhos proeminentes e a contagem dos elementos das nadadeiras é importante para a separação das espécies. O formato do corpo é variado, desde muito alongado até fusiforme. Há dois orifícios nasais de cada lado do focinho. A primeira nadadeira dorsal é muito desenvolvida, sendo maior que a segunda. A nadadeira caudal é furcada e a pélvica é pouco desenvolvida, podendo estar ausente nos adultos de algumas espécies.

No Brasil, já foram identificadas dez espécies nas fases de larva e adulto. Nesse estudo são contempladas as espécies Diplospinus multistriatus, Gempylus serpens, Lepidocybium flavobrunneum e Nesiarchus nasutus. 


\section{Diplospinus multistriatus Maul, 1948}

Nadadeira dorsal: XXX-XXXVI+I, 35-41. Nadadeira anal: II, 29-35. O corpo é mais alto na região peitoral e fino na região do pedúnculo caudal. O número de miômeros varia entre 58-61. O focinho é alongado e pontudo. Presença de espinhos na cabeça que são característicos dessa espécie. 0 espinho da nadadeira pélvica é muito longo e serrilhado. As lar-

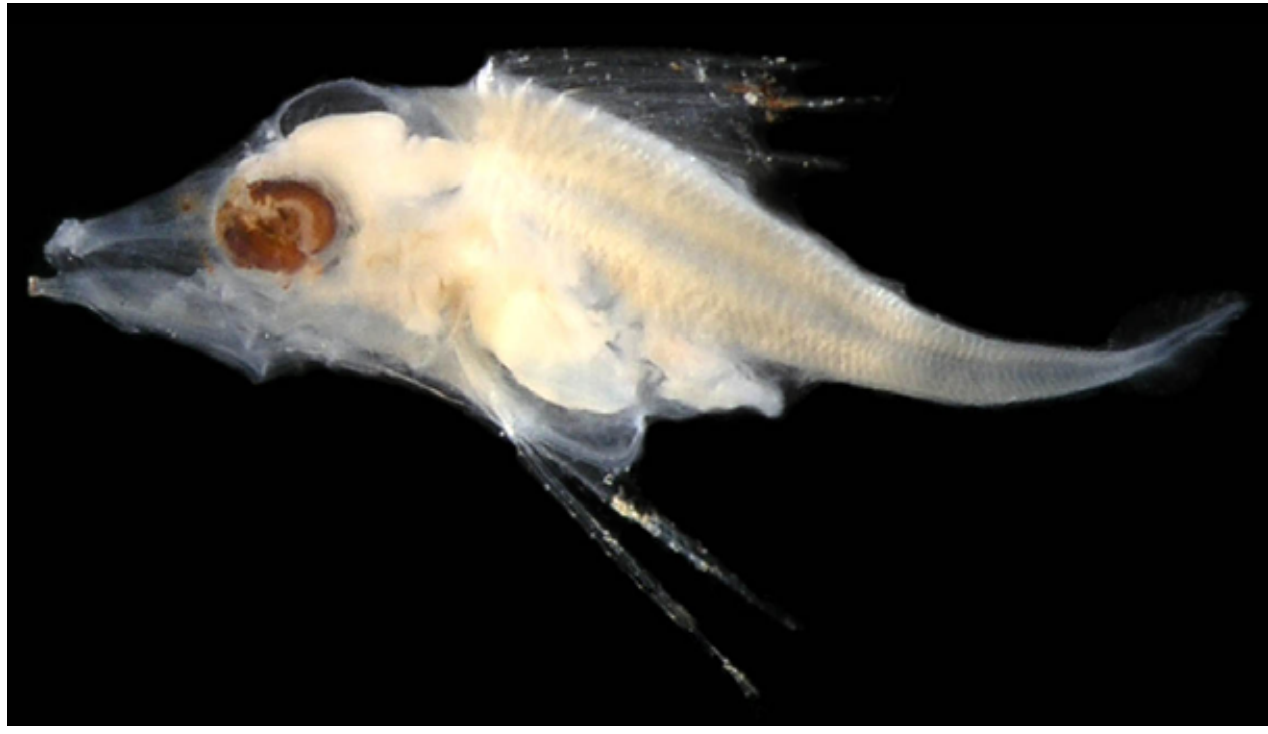

Figura 144 A: Diplospinus multistriatus. DZUFRJ 19772; Pré-flexão; CP 5,7 mm. vas apresentam pigmentos na região mediana e posterior da cabeça, sobre o intestino, na extremidade da maxila inferior e atrás dos olhos. Diferenciam-se pela pigmentação presente na membrana entre os espinhos da primeira nadadeira dorsal e na margem dorsal do corpo.

Tamanho: pré-flexão 4,2-8,5 mm; flexão 9,1 mm.

Habitat: espécie marinha, mesopelágica, ocorre até $1.000 \mathrm{~m}$ de profundidade.

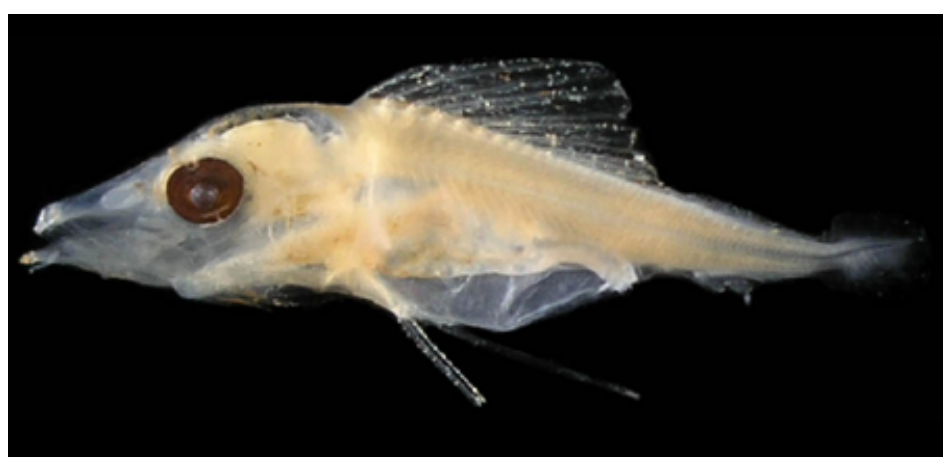

Figura 144 B: DZUFRJ 7430; Flexão; CP 9,1 mm.

\section{Georreferenciamento}

\begin{tabular}{|c|c|c|c|c|c|c|c|c|}
\hline DZUFRJ & Latitude (S) & Longitude (W) & Data & $\begin{array}{c}\text { Tipo de } \\
\text { arrasto }\end{array}$ & $\begin{array}{c}\text { Profundidade } \\
\text { de coleta }\end{array}$ & Rede & $\begin{array}{c}\text { Malha } \\
(\boldsymbol{\mu m})\end{array}$ & $\begin{array}{c}\text { No. de } \\
\text { inds. }\end{array}$ \\
\hline 5492 & $22^{\circ} 32^{\prime} 50,0^{\prime \prime}$ & $040^{\circ} 04^{\prime} 099^{\prime \prime}$ & $06 / 11 / 2001$ & oblíquo & $1.000 \mathrm{~m}$ & cilíndrico-cônica & 500 & 1 \\
\hline 7427 & $21^{\circ} 54^{\prime} 36,5^{\prime \prime}$ & $039^{\circ} 45^{\prime} 20,0^{\prime \prime}$ & $09 / 10 / 2001$ & oblíquo & $1.000 \mathrm{~m}$ & cilíndrico-cônica & 500 & 2 \\
\hline 7430 & $21^{\circ} 53^{\prime} 10,4^{\prime \prime}$ & $039^{\circ} 45^{\prime} 49,9^{\prime \prime}$ & $10 / 10 / 2001$ & oblíquo & $1.000 \mathrm{~m}$ & cilíndrico-cônica & 500 & 2 \\
\hline 19772 & $22^{\circ} 32^{\prime} 50,0^{\prime \prime}$ & $040^{\circ} 04^{\prime} 09^{\prime \prime}$ & $06 / 11 / 2001$ & oblíquo & $1.000 \mathrm{~m}$ & cilíndrico-cônica & 500 & 2 \\
\hline
\end{tabular}

Referências: Ambrose, 1996d; Figueiredo \& Menezes, 2000; Richards, 2006i; Fahay, 2007. 


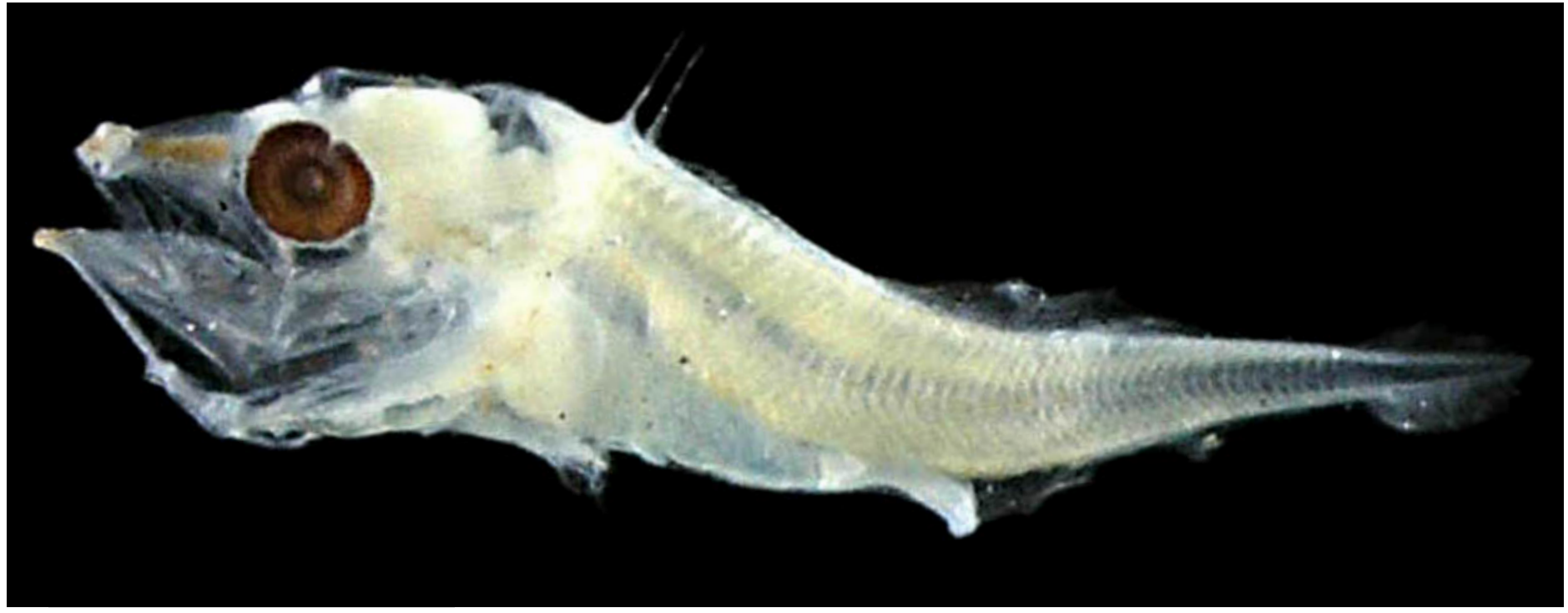

Figura 145 - A: Gempylus serpens. DZUFRJ 1295; Pré-flexão; CP 3,5 mm.

\section{Gempylus serpens Cuvier, 1829}

É a única espécie de Gempylidae que possui pigmentos ao longo da linha lateral do corpo durante todo desenvolvimento. O número de miômeros varia entre 51-55. Tem pigmentos nas regiões mediana e posterior da cabeça, sobre o intestino, no orifício nasal, na extremidade da mandíbula, nas margens ventral e dorsal da cauda, na primeira nadadeira dorsal e atrás dos olhos, desde a pré-flexão. A pigmentação sobre o dorso, nadadeira dorsal e intestino intensificam-se ao longo do desenvolvimento. Após a formação das nadadeiras, a presença de XXVVI-XXXII espinhos na primeira dorsal e I-Il espinhos e 10-14 raios na segunda dorsal são características diagnósticas dessa espécie.

Tamanho: pré-flexão 2,5-6,2 mm; flexão 6,7-9,0 mm; pós-flexão 10,5 mm.

Habitat: espécie marinha, epi-mesopelágica, ocorre em águas tropicais e subtropicais em profundidades superiores a $200 \mathrm{~m}$.

Nome vulgar: Lanceta.

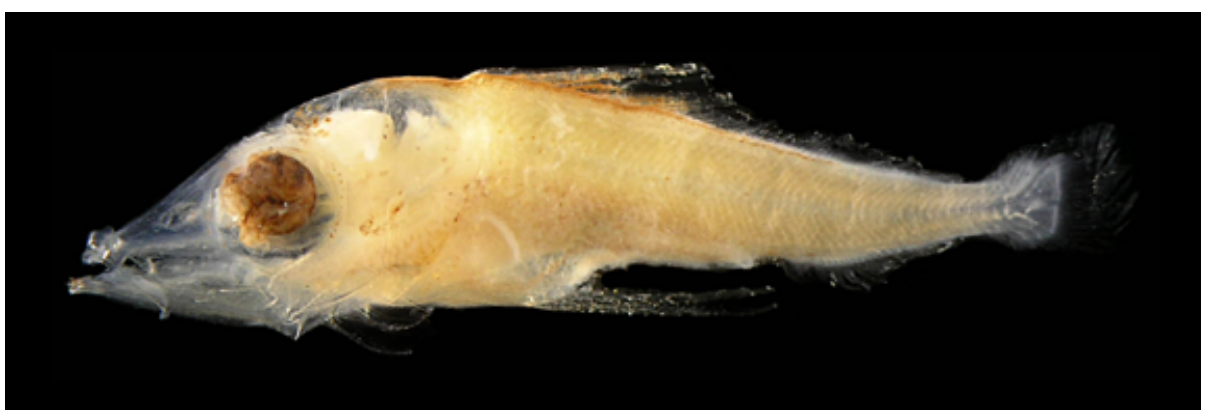

Figura 145 - B: DZUFRJ 7424; Flexão; CP 8,2 mm.

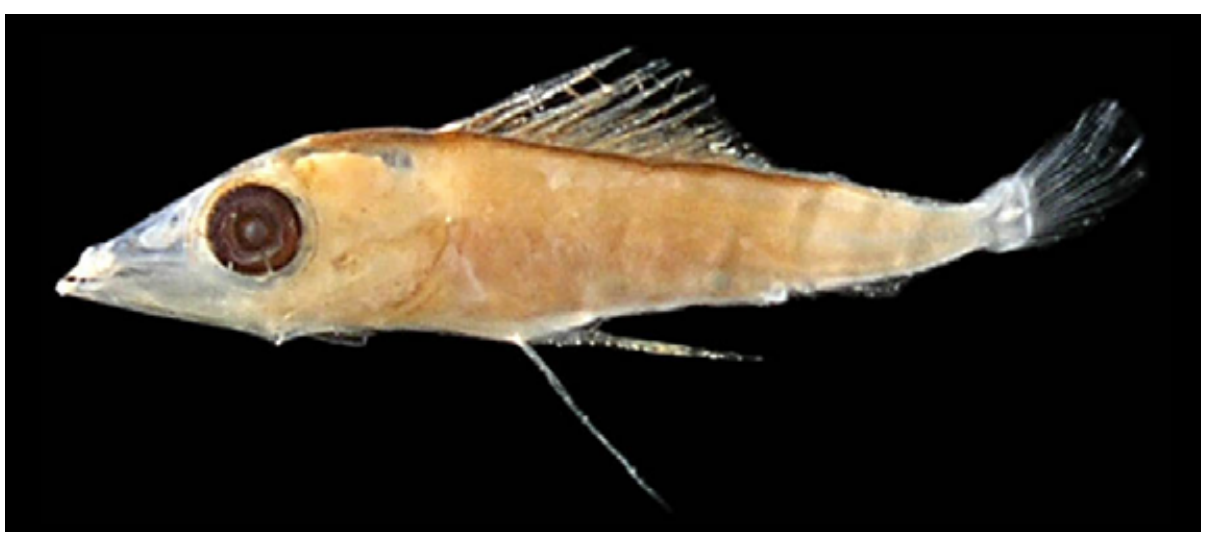

Figura 145 - C: DZUFRJ 7426; Pós-flexão; CP 10,5 mm. 


\section{Georreferenciamento}

\begin{tabular}{|c|c|c|c|c|c|c|c|c|}
\hline DZUFRJ & Latitude (S) & Longitude (W) & Data & $\begin{array}{l}\text { Tipo de } \\
\text { arrasto }\end{array}$ & $\begin{array}{c}\text { Profundidade } \\
\text { de coleta }\end{array}$ & Rede & $\begin{array}{c}\text { Malha } \\
(\mu \mathrm{m})\end{array}$ & $\begin{array}{l}N^{\circ} \text {. de } \\
\text { inds. }\end{array}$ \\
\hline 531 & $22^{\circ} 36^{\prime} 54,9^{\prime \prime}$ & $040^{\circ} 09^{\prime} 19,4^{\prime \prime}$ & $16 / 05 / 2002$ & oblíquo & $50 \mathrm{~m}$ & bongô & 330 & 1 \\
\hline 676 & $22^{\circ} 42^{\prime} 06,0^{\prime \prime}$ & $040^{\circ} 14^{\prime} 26,0^{\prime \prime}$ & $19 / 05 / 2002$ & oblíquo & $50 \mathrm{~m}$ & bongô & 330 & 2 \\
\hline 1187 & $22^{\circ} 07^{\prime} 29,0^{\prime \prime}$ & $039^{\circ} 06^{\prime} 23,5^{\prime \prime}$ & $10 / 05 / 2002$ & oblíquo & $1.000 \mathrm{~m}$ & cilíndrico-cônica & 500 & 2 \\
\hline 1277 & $22^{\circ} 06^{\prime} 37,8^{\prime \prime}$ & $039^{\circ} 49^{\prime} 44,8^{\prime \prime}$ & $10 / 05 / 2002$ & oblíquo & até a termoclina & bongô & 500 & 2 \\
\hline 1284 & $22^{\circ} 06^{\prime} 52,3^{\prime \prime}$ & $039^{\circ} 48^{\prime} 46,2^{\prime \prime}$ & $11 / 05 / 2002$ & oblíquo & até a termoclina & bongô & 500 & 3 \\
\hline 1295 & $22^{\circ} 02^{\prime} 30,0^{\prime \prime}$ & $039^{\circ} 49^{\prime} 41,2^{\prime \prime}$ & $12 / 05 / 2002$ & oblíquo & até a termoclina & bongô & 500 & 2 \\
\hline 1328 & $22^{\circ} 03^{\prime} 03,3^{\prime \prime}$ & $039^{\circ} 50^{\prime} 39,0^{\prime \prime}$ & $10 / 05 / 2002$ & oblíquo & até a termoclina & bongô & 330 & 2 \\
\hline 1346 & $22^{\circ} 06^{\prime} 52,3^{\prime \prime}$ & $039^{\circ} 48^{\prime} 46,2^{\prime \prime}$ & $11 / 05 / 2002$ & oblíquo & até a termoclina & bongô & 330 & 9 \\
\hline 1387 & $22^{\circ} 08^{\prime} 14,9^{\prime \prime}$ & $039^{\circ} 46^{\prime} 34,6^{\prime \prime}$ & $11 / 05 / 2002$ & oblíquo & até a termoclina & bongô & 330 & 1 \\
\hline 5438 & $22^{\circ} 31^{\prime} 58,9^{\prime \prime}$ & $040^{\circ} 02^{\prime} 53,4^{\prime \prime}$ & $07 / 11 / 2001$ & oblíquo & $1.000 \mathrm{~m}$ & cilíndrico-cônica & 500 & 5 \\
\hline 5440 & $22^{\circ} 31^{\prime} 58,9^{\prime \prime}$ & $040^{\circ} 02^{\prime} 53,4^{\prime \prime}$ & $07 / 11 / 2001$ & oblíquo & $1.000 \mathrm{~m}$ & cilíndrico-cônica & 500 & 3 \\
\hline 5493 & $22^{\circ} 32^{\prime} 50,0^{\prime \prime}$ & $040^{\circ} 04^{\prime} 09,9^{\prime \prime}$ & $06 / 11 / 2001$ & oblíquo & $1.000 \mathrm{~m}$ & cilíndrico-cônica & 500 & 2 \\
\hline 5490 & $22^{\circ} 31^{\prime} 58,9^{\prime \prime}$ & $040^{\circ} 02^{\prime} 53,4^{\prime \prime}$ & $07 / 11 / 2001$ & oblíquo & $1.000 \mathrm{~m}$ & cilíndrico-cônica & 500 & 1 \\
\hline 5494 & $22^{\circ} 31^{\prime} 40,9^{\prime \prime}$ & $040^{\circ} 02^{\prime} 39,6^{\prime \prime}$ & $07 / 11 / 2001$ & oblíquo & $1.000 \mathrm{~m}$ & cilíndrico-cônica & 500 & 2 \\
\hline 7424 & $21^{\circ} 54^{\prime} 36,5^{\prime \prime}$ & $039^{\circ} 45^{\prime} 20,0^{\prime \prime}$ & $10 / 10 / 2001$ & oblíquo & $1.000 \mathrm{~m}$ & cilíndrico-cônica & 500 & 1 \\
\hline 7426 & $21^{\circ} 53^{\prime} 10,4^{\prime \prime}$ & $039^{\circ} 45^{\prime} 49,9^{\prime \prime}$ & 10/10/2001 & oblíquo & $1.000 \mathrm{~m}$ & cilíndrico-cônica & 500 & 2 \\
\hline 19776 & $22^{\circ} 03^{\prime} 03,3^{\prime \prime}$ & 03950'39,0" & $10 / 05 / 2002$ & oblíquo & até a termoclina & bongô & 500 & 1 \\
\hline
\end{tabular}

Referências: Ambrose, 1996d; Figueiredo \& Menezes, 2000; Richards, 2006i; Fahay, 2007. 


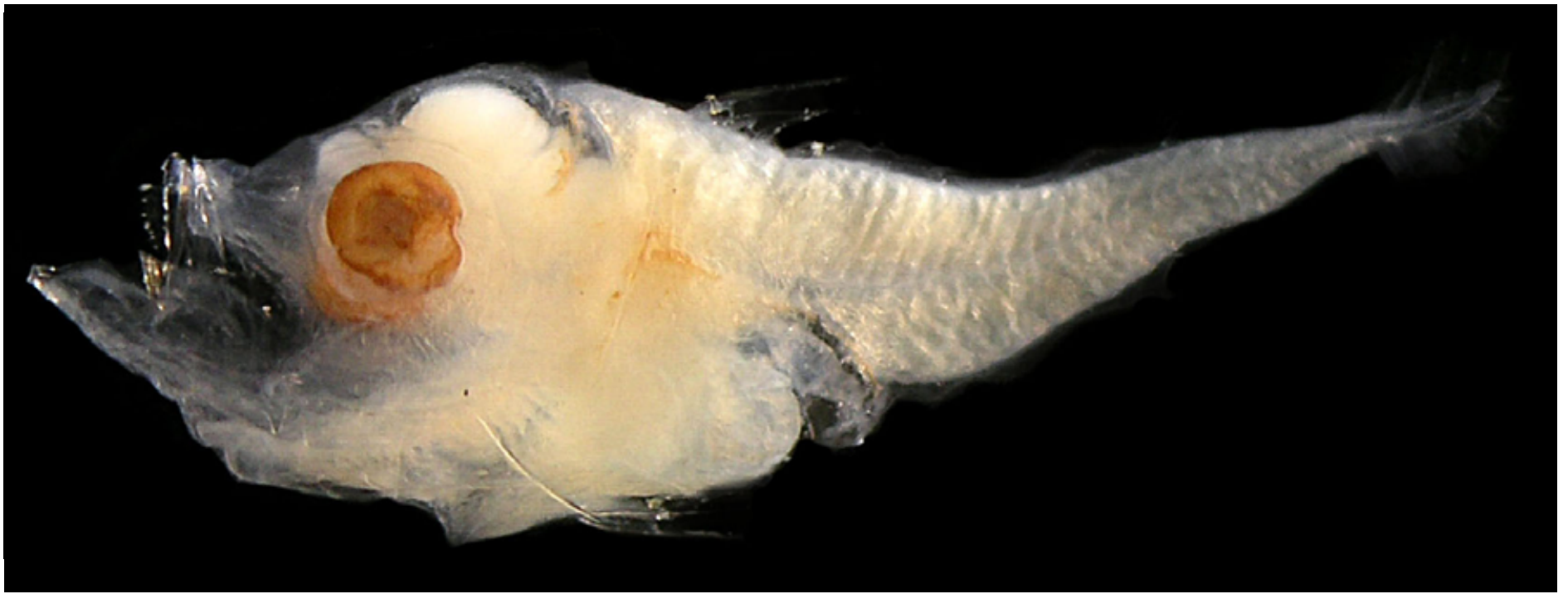

Figura 146 - A: Lepidocybium flavobrunneum. DZUFRJ 7425; Pré-flexão; CP 5,5 mm.

\section{Lepidocybium flavobrunneum (Smith, 1843)}

O corpo é alto e curto (31 miômeros) e o focinho é pontudo e curto. Desde o estágio de pré-flexão possui vários espinhos na cabeça, principalmente na região occipital, e pigmentos nas regiões mediana e posterior da cabeça, sobre o intestino, na membrana e na base da primeira nadadeira dorsal. Nadadeira dorsal: VIII-XXII, 16-18. Nadadeira anal: II, 10-14.

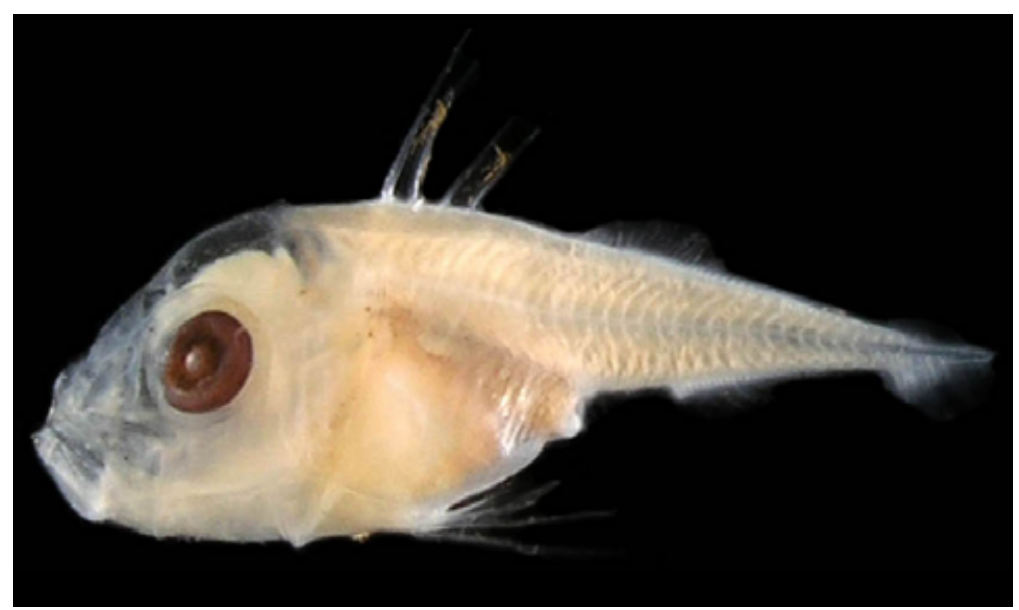

Figura 146 - B: DZUFRJ 5491; Flexão; CP 7,0 mm.

Tamanho: pré-flexão 4,0-5,5 mm; flexão 7,0 mm.

Habitat: espécie marinha, mesopelágica, ocorre em águas tropicais e subtropicais em profundidades superiores a $200 \mathrm{~m}$.

\section{Georreferenciamento}

\begin{tabular}{|c|c|c|c|c|c|c|c|c|}
\hline DZUFRJ & Latitude (S) & Longitude (W) & Data & $\begin{array}{c}\text { Tipo de } \\
\text { arrasto }\end{array}$ & $\begin{array}{c}\text { Profundidade } \\
\text { de coleta }\end{array}$ & Rede & $\begin{array}{c}\text { Malha } \\
(\boldsymbol{\mu m})\end{array}$ & $\begin{array}{c}\mathbf{N}^{\circ} \text {. de } \\
\text { inds. }\end{array}$ \\
\hline 5491 & $22^{\circ} 32^{\prime} 50,0^{\prime \prime}$ & $040^{\circ} 04^{\prime} 09,9^{\prime \prime}$ & $06 / 11 / 2001$ & oblíquo & $1.000 \mathrm{~m}$ & cilíndrico-cônica & 500 & 2 \\
\hline 7425 & $21^{\circ} 58^{\prime} 31,0^{\prime \prime}$ & $039^{\circ} 50^{\prime} 29,7^{\prime \prime}$ & $10 / 10 / 2001$ & oblíquo & $1.000 \mathrm{~m}$ & cilíndrico-cônica & 500 & 1 \\
\hline 22195 & $21^{\circ} 58^{\prime} 31,0^{\prime \prime}$ & $0^{\circ} 9^{\circ} 50^{\prime} 29,7^{\prime \prime}$ & $10 / 10 / 2001$ & oblíquo & $1.000 \mathrm{~m}$ & cilíndrico-cônica & 500 & 1 \\
\hline
\end{tabular}

Referências: Ambrose, 1996d; Figueiredo \& Menezes, 2000; Richards, 2006i; Fahay, 2007. 


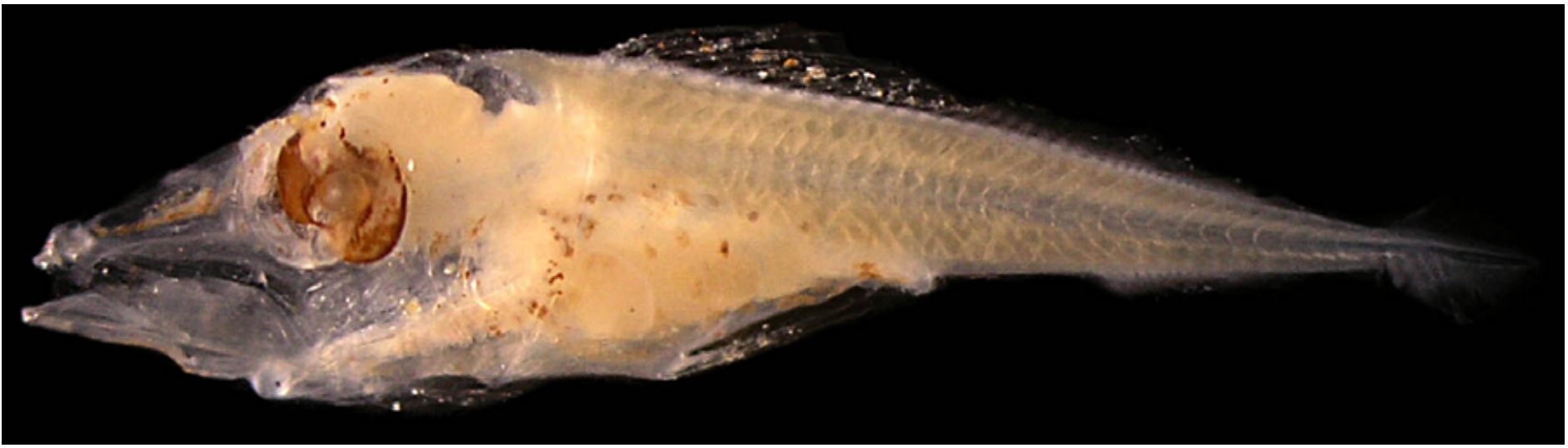

Figura 147 - A: Nesiarchus nasutus. DZUFRJ 7428; Pré-flexão; CP 6,8 mm.

\section{Nesiarchus}

\section{nasutus}

\section{Johnson, 1862}

Nadadeira dorsal: XIX-XXII+I, 19-22. Nadadeira anal: II-III, 15-17. O corpo (33-37 miômeros) e o focinho são alongados. A boca é grande e alguns dentes projetam-se na maxila inferior. Presença de uma linha de pigmentos na região nasal e gular. Possui pigmentação distribuída nas porções mediana e posterior da cabeça, sobre o intestino, na extremidade da mandíbula, entre os espinhos e na base da primeira nadadeira dorsal, e atrás dos olhos. Tem um grupo de pigmentos na base da notocorda.

Tamanho: pré-flexão 3,5-6,8 mm; flexão 7,1 mm.

Habitat: espécie marinha, mesopelágica e bentopelágica, ocorre em águas tropicais e subtropicais em profundidades entre 200 e $1.200 \mathrm{~m}$.

\section{Georreferenciamento}

\begin{tabular}{|c|c|c|c|c|c|c|c|c|}
\hline DZUFR & Latitude (S) & Longitude (W) & Data & $\begin{array}{c}\text { Tipo de } \\
\text { arrasto }\end{array}$ & $\begin{array}{c}\text { Profundidade } \\
\text { de coleta }\end{array}$ & Rede & $\begin{array}{c}\text { Malha } \\
\text { ( } \boldsymbol{\mu m})\end{array}$ & $\begin{array}{c}\text { No. de } \\
\text { inds. }\end{array}$ \\
\hline 1254 & $22^{\circ} 08^{\prime} 175^{\prime \prime}$ & $039^{\circ} 46^{\prime} 28,5^{\prime \prime}$ & $11 / 05 / 2002$ & oblíquo & $1.000 \mathrm{~m}$ & cilíndrico-cônica & 500 & 1 \\
\hline 7428 & $21^{\circ} 58^{\prime} 31,0^{\prime \prime}$ & $039^{\circ} 50^{\prime} 29,7^{\prime \prime}$ & $11 / 10 / 2001$ & oblíquo & $1.000 \mathrm{~m}$ & cilíndrico-cônica & 500 & 1 \\
\hline 19773 & $22^{\circ} 02^{\prime} 30,0^{\prime \prime}$ & $039^{\circ} 49^{\prime} 41,2^{\prime \prime}$ & $12 / 05 / 2002$ & oblíquo & até a termoclina & bongô & 500 & 1 \\
\hline 19775 & $22^{\circ} 06^{\prime} 522^{\prime \prime}$ & $039^{\circ} 48^{\prime} 46,2^{\prime \prime}$ & $11 / 05 / 2002$ & oblíquo & até a termoclina & bongô & 330 & 1 \\
\hline 22193 & $22^{\circ} 32^{\prime} 49 \mathbf{1}^{\prime \prime}$ & $040^{\circ} 04^{\prime} 20,9^{\prime \prime}$ & $07 / 11 / 2001$ & oblíquo & $1.000 \mathrm{~m}$ & cilíndrico-cônica & 500 & 1 \\
\hline
\end{tabular}

Referências: Ambrose, 1996d; Figueiredo \& Menezes, 2000; Richards, 2006i; Fahay, 2007.

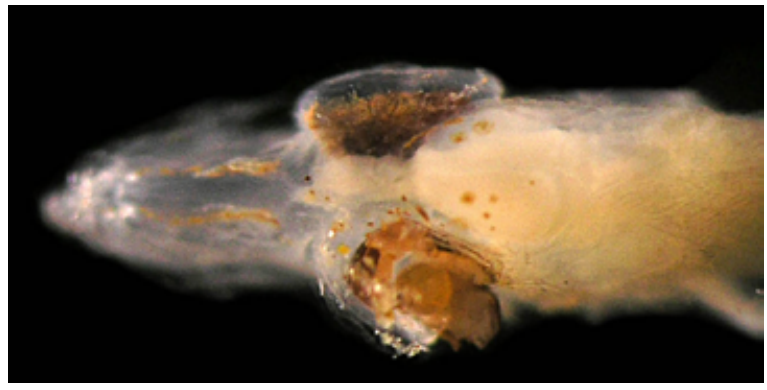

Figura 147 - C: Pigmentos na região nasal.

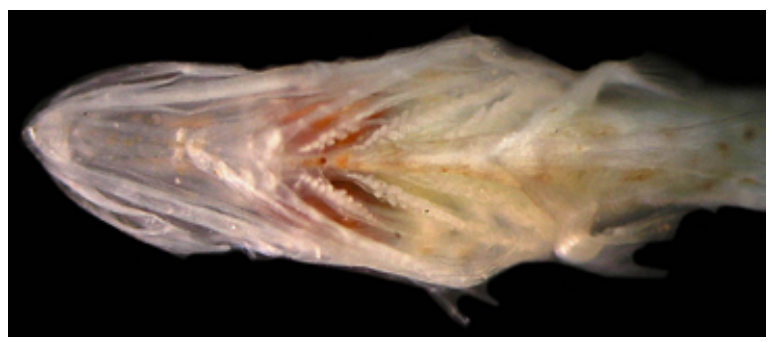

Figura 147 - D: Pigmentos na região gular.

Figura 147 - B: DZUFRJ 1254; Flexão; CP 7,1 mm.

西

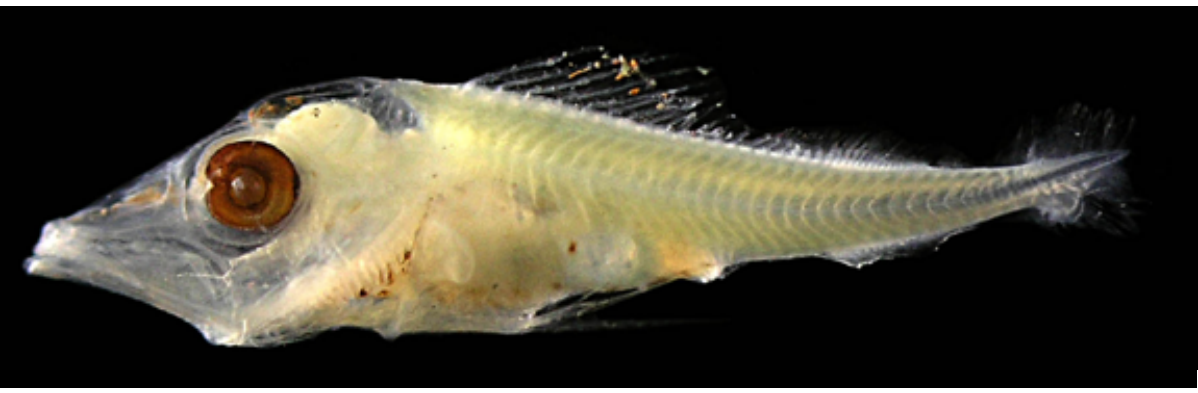




\section{Família Scombridae}

Devido a grande importância econômica dessa família, as espécies são muito estudadas e conhecidas pelo mundo. Compreende espécies marinhas, raramente, vivendo em água doce. Ocorrem em áreas tropicais e subtropicais. Abrange 15 gêneros com 51 espécies.

O formato do corpo, número de miômeros e a pigmentação são usados na identificação. O corpo é geralmente fusiforme (31 a 66 miômeros) e, em alguns casos, comprimido lateralmente. A cabeça é grande e o focinho pontudo, sendo a mandíbula muito desenvolvida. Possuem um espaço entre o ânus e o início da nadadeira anal cujo tamanho varia de acordo com a espécie. A pigmentação varia muito, estando sempre presente na cabeça, podendo ou não ocorrer próximo aos olhos e na margem ventral da cauda.

No Brasil, já foram identificadas 19 espécies nas fases de larva e adulto. Nesse estudo são contempladas as espécies Auxis thazard, Euthynnus alletteratus e Scomber colias. 


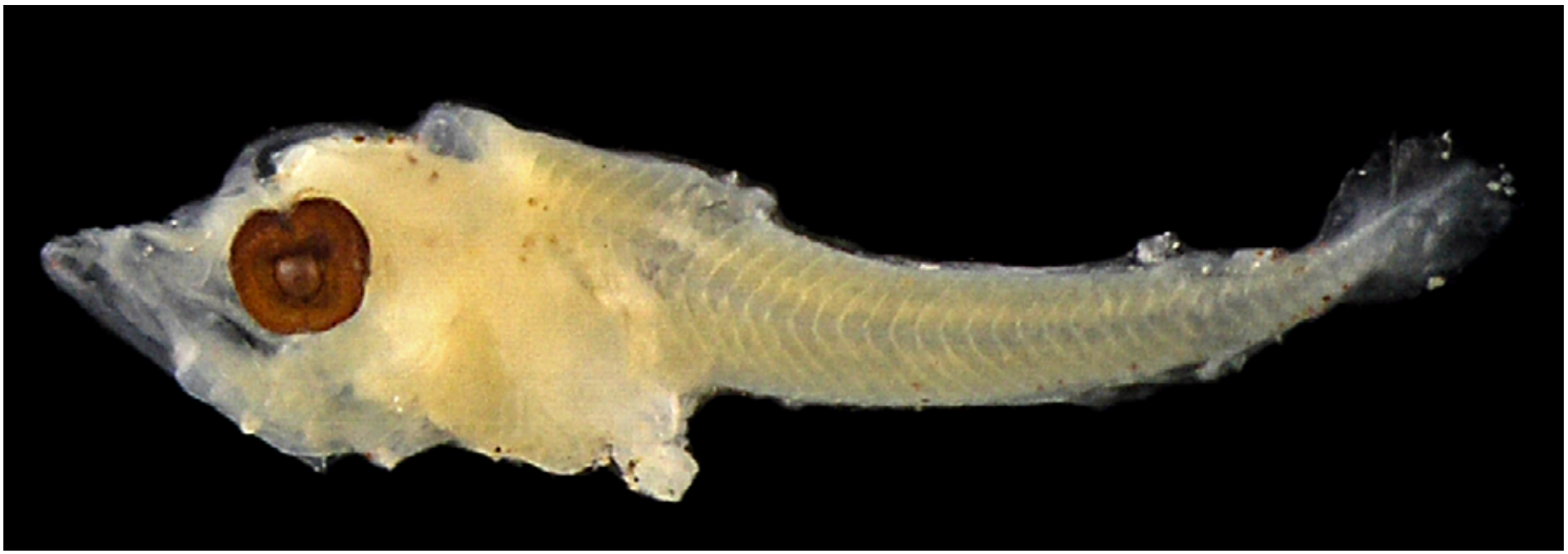

Figura 148: Auxis thazard. DZUFRJ 503; Flexão; CP 5,5 mm.

\section{Auxis thazard (Lacepède, 1800)}

O corpo é pouco alongado (39 miômeros), a cabeça é grande e a mandíbula é curta. O intestino é curto e em formato triangular. Presença de espinhos na cabeça e margem do opérculo e pré-opérculo. Pigmentos presentes na região mediana e posterior da cabeça, no cleitro e nas margens ventral e dorsal do corpo, incluindo o pedúnculo caudal. Uma fileira de pigmentos é encontrada na linha lateral, na porção posterior da cauda. Nadadeira dorsal: XX-XXII, 10-12; nadadeira anal: 11-14.

Tamanho: flexão 4,5-5,5 mm.

Habitat: espécie marinha, epipelágica, ocorre em águas quentes costeiras, oceânicas e próximo a ilhas.

Nome vulgar: Bonito cachorro.

\section{Georreferenciamento}

\begin{tabular}{|c|c|c|c|c|c|c|c|c|}
\hline DZUFR & Latitude (S) & Longitude (W) & Data & $\begin{array}{c}\text { Tipo de } \\
\text { arrasto }\end{array}$ & $\begin{array}{c}\text { Profundidade } \\
\text { de coleta }\end{array}$ & Rede & $\begin{array}{c}\text { Malha } \\
\text { ( } \boldsymbol{\mu m} \text { ) }\end{array}$ & $\begin{array}{c}\mathbf{N}^{\circ} \text {. de } \\
\text { inds. }\end{array}$ \\
\hline 407 & $22^{\circ} 31^{\prime} 27,0^{\prime \prime}$ & $040^{\circ} 16^{\prime} 56,0^{\prime \prime}$ & $17 / 05 / 2002$ & oblíquo & $600 \mathrm{~m}$ & cilíndrico-cônica & 500 & 2 \\
\hline 503 & $22^{\circ} 33^{\prime} 37,0^{\prime \prime}$ & $040^{\circ} 19^{\prime} 10,0^{\prime \prime}$ & $17 / 05 / 2002$ & oblíquo & $50 \mathrm{~m}$ & bongô & 500 & 1 \\
\hline
\end{tabular}

Referências: Ambrose, 1996e; Figueiredo \& Menezes, 2000; Collette, 2002b; Richards, 2006j; Fahay, 2007. Auxis thazard. DZUFRJ 503; Flexão; CP 5,5 mm. 


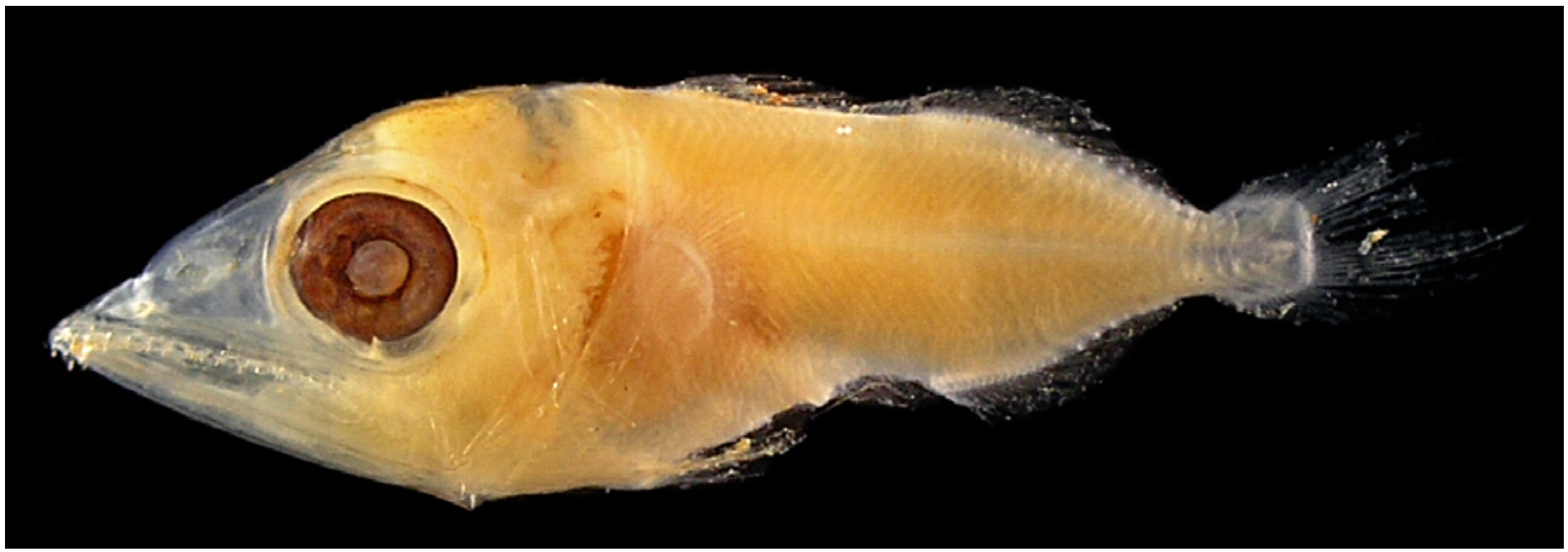

Figura 149 - Euthynnus alletteratus. DZUFRJ 7409; Flexão; CP 8,7 mm.

\section{Euthynnus alletteratus (Rafinesque, 1810)}

O corpo é pouco alongado (39 miômeros), a cabeça é grande, com focinho e mandíbula bem desenvolvida. O intestino é compacto e em formato triangular. Os espinhos da cabeça são moderadamente desenvolvidos, estando presentes também na margem do opérculo e pré-opérculo. Presença de pigmentos na região anterior e posterior da cabeça, na extremidade da mandíbula, formando uma fileira na maxila inferior, no cleitro e na margem ventral da cauda. Há pigmentos bem desenvolvidos na membrana entre os raios da primeira nadadeira dorsal. Nadadeira dorsal: XIII-XVII, 11-13; nadadeira anal: 11-15.

Tamanho: flexão 6,5-8,7 mm.

Habitat: espécie marinha, epipelágica, ocorre em águas tropicais e subtropicais em regiões neríticas, sobre a plataforma continental.

Nome vulgar: Bonito pintado.

\section{Georreferenciamento}

\begin{tabular}{|c|c|c|c|c|c|c|c|c|}
\hline DZUFRJ & Latitude (S) & Longitude (W) & Data & $\begin{array}{l}\text { Tipo de } \\
\text { arrasto }\end{array}$ & $\begin{array}{c}\text { Profundidade } \\
\text { de coleta }\end{array}$ & Rede & $\begin{array}{c}\text { Malha } \\
(\mu \mathrm{m})\end{array}$ & $\begin{array}{l}N^{\circ} \text {. de } \\
\text { inds. }\end{array}$ \\
\hline 7407 & $21^{\circ} 58^{\prime} 31,0^{\prime \prime}$ & $039^{\circ} 50^{\prime 29,7 " '}$ & $11 / 10 / 2001$ & oblíquo & $1.000 \mathrm{~m}$ & cilíndrico-cônica & 500 & 1 \\
\hline 7408 & $21^{\circ} 54^{\prime} 36,5^{\prime \prime}$ & $039^{\circ} 45^{\prime} 20,0^{\prime \prime}$ & $10 / 10 / 2001$ & oblíquo & $1.000 \mathrm{~m}$ & cilíndrico-cônica & 500 & 2 \\
\hline 7409 & $21^{\circ} 54^{\prime} 36,5^{\prime \prime}$ & $039^{\circ} 45^{\prime} 20,0^{\prime \prime}$ & $10 / 10 / 2001$ & oblíquo & $1.000 \mathrm{~m}$ & cilíndrico-cônica & 500 & 1 \\
\hline 7412 & $21^{\circ} 58^{\prime} 31,0^{\prime \prime}$ & 039०50'29,7"' & 10/10/2001 & oblíquo & $1.000 \mathrm{~m}$ & cilíndrico-cônica & 500 & 1 \\
\hline
\end{tabular}

Referências: Ambrose, 1996e; Figueiredo \& Menezes, 2000; Collette, 2002b; Richards, 2006j; Fahay, 2007. 


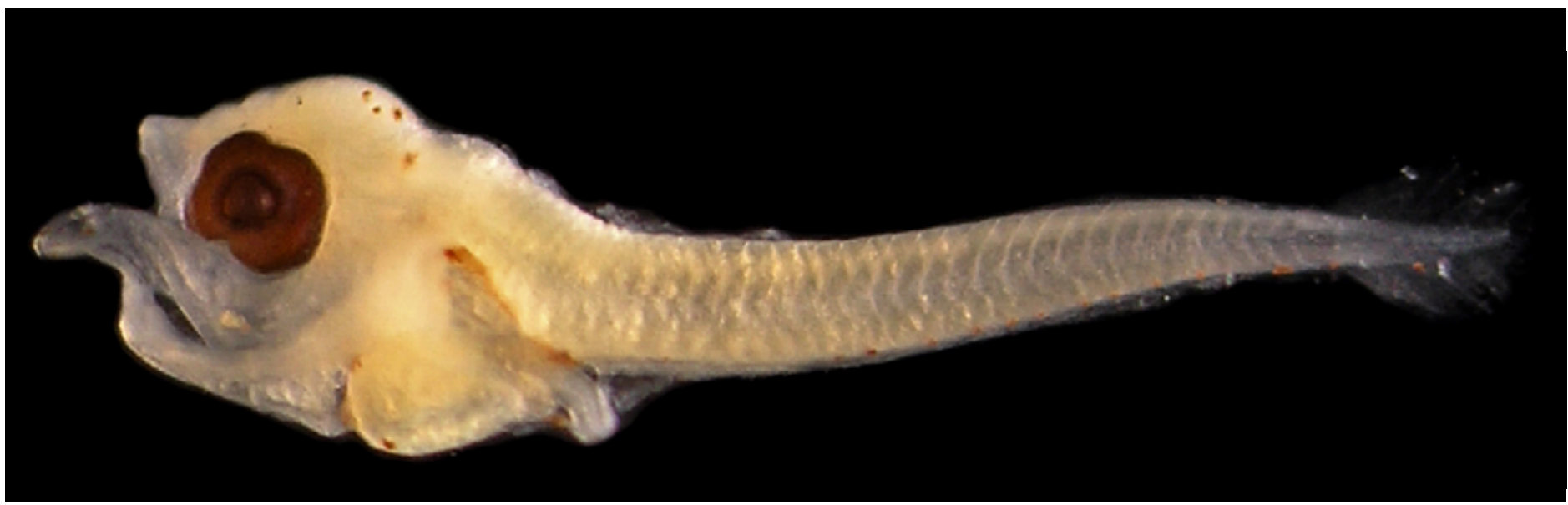

Figura 150: Scomber colias. DZUFRJ 361; Pré-flexão; CP 3,0 mm.

\section{Scomber colias Gmelin, 1789}

Possui poucos miômeros (31) e a primeira nadadeira dorsal tem desenvolvimento tardio. A cabeça é de tamanho mediano, com focinho arredondado e mandíbula pequena. $O$ intestino é compacto e em formato triangular. Não possui espinhos na cabeça. Tem pigmentos nas regiões anterior e posterior da cabeça, sobre o intestino e na margem ventral da cauda. Nadadeira dorsal: IX-XIII, 11-12; nadadeira anal: I, 11-14.

Tamanho: pré-flexão 3,0 mm.

Habitat: espécie marinha, epipelágica, ocorre em águas tropicais e temperadas, normalmente próximo à costa.

Nome vulgar: Cavala sardinheira.

\section{Georreferenciamento}

\begin{tabular}{|c|c|c|c|c|c|c|c|c|}
\hline DZUFRJ & Latitude (S) & Longitude (W) & Data & $\begin{array}{c}\text { Tipo de } \\
\text { arrasto }\end{array}$ & $\begin{array}{c}\text { Profundidade } \\
\text { de coleta }\end{array}$ & Rede & $\begin{array}{c}\text { Malha } \\
\text { ( } \boldsymbol{\mu m} \text { ) }\end{array}$ & $\begin{array}{c}\mathbf{N}^{\circ} \text {. de } \\
\text { inds. }\end{array}$ \\
\hline 361 & $22^{\circ} 38^{\prime} 25,0^{\prime \prime}$ & $040^{\circ} 17^{\prime} 41,0^{\prime \prime}$ & $19 / 05 / 2002$ & oblíquo & $40 \mathrm{~m}$ & bongô & 330 & 1 \\
\hline
\end{tabular}

Referências: Ambrose, 1996e; Figueiredo \& Menezes, 2000; Collette, 2002b; Richards, 2006j; Fahay, 2007. 


\section{Família Nomeidae}

Os representantes da família Nomeidae são pelágicos, com exceção da espécie Nomeus gronovii, cujos adultos são demersais. Compreende três gêneros com aproximadamente 16 espécies.

As larvas e juvenis possuem o corpo afilado ou alto com 30-40 miômeros. As nadadeiras dorsal e anal são semelhantes em tamanho e posicionamento. Apesar da sobreposição, algumas espécies podem ser separadas pelas características merísticas. A linha lateral acompanha o perfil dorsal do corpo, não se estendendo até o curto pedúnculo caudal.

No Brasil, já foram identificadas sete espécies nas fases de larva e adulto. Nesse estudo é contemplada a espécie Psenes cyanophrys. 


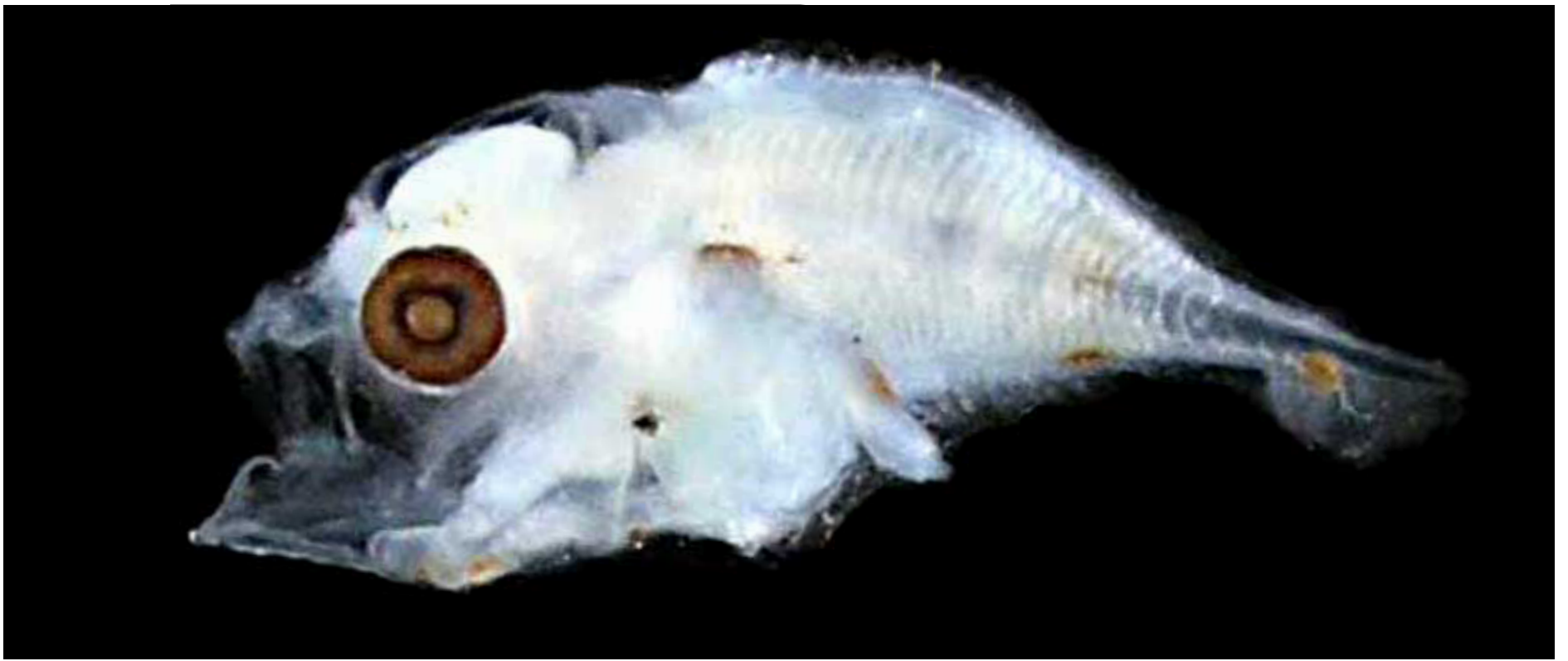

Figura 151 - A: Psenes cyanophrys. DZUFRJ 2624; Pré-flexão; CP 4,0 mm.

\section{Psenes cyanophrys Valenciennes, 1833}

Possui o corpo curto (31 miômeros) e alto. Os espinhos do opérculo e pré-opérculo são fracos. Durante o estágio de pré-flexão, a nadadeira pélvica já está formada e bem desenvolvida. No estágio de pré-flexão a pigmentação concentra-se na porção posterior do corpo entre a linha lateral e as margens dorsal e anal e na base da notocorda. Durante a flexão, formam-se manchas no topo da cabeça e há uma concentração de pigmentos nos raios da nadadeira pélvica. Presença de pigmentos peritoneais na margem dorsal do intestino e de uma mancha próxima ao ânus. No estágio de pós-flexão, formam-se bandas de pigmentos pelo corpo, entre os miômeros 20 e 23. Uma única mancha concentra-se na base da notocorda. Em juvenis, formam-se 4-5 barras atravessando o corpo, da parte posterior da cabeça até o pedúnculo caudal.

Tamanho: pré-flexão 4,0 mm; flexão 4,3-4,5 mm; pós-flexão 7,2 mm; transformação 31,0 mm.

Habitat: espécie marinha, epipelágica e mesopelágica, ocorre em águas tropicais e subtropicais em áreas oceânicas.

Nome vulgar: Rombudo.

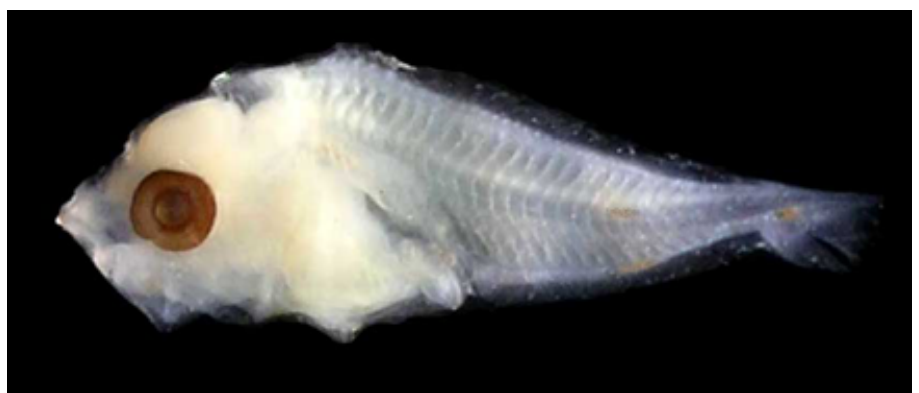

Figura 151 - B: DZUFRJ 22386; Flexão; CP 4,5 mm.

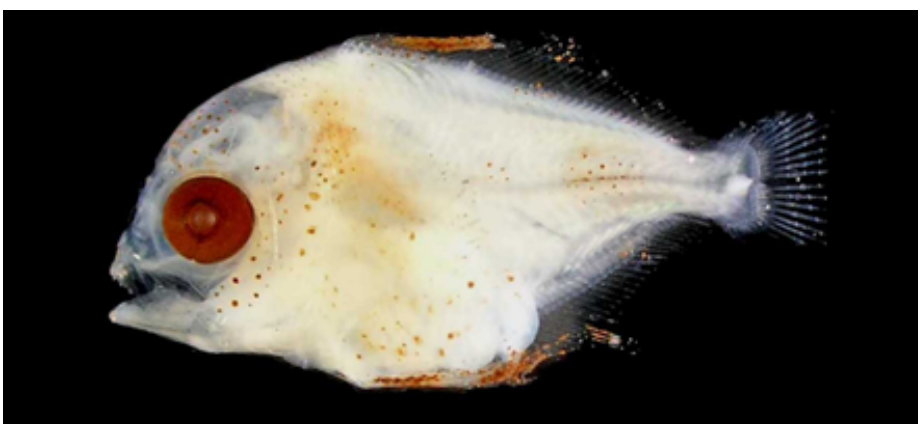

Figura 151 - C: DZUFRJ 21383; Pós-flexão; CP 7,2 mm.

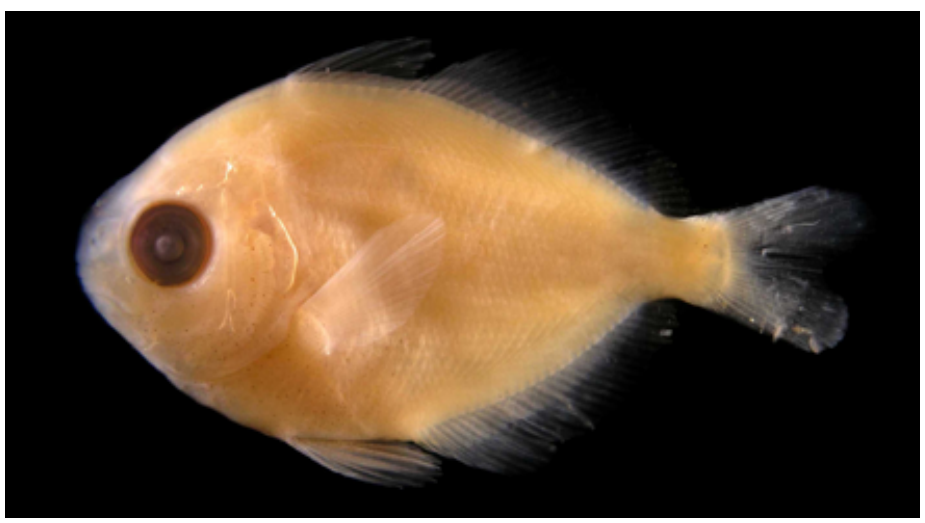

Figura 151 - D: DZUFRJ 22385; Transformação; CP 31,0 mm. 


\section{Georreferenciamento}

\begin{tabular}{|c|c|c|c|c|c|c|c|c|}
\hline DZUFRJ & Latitude (S) & Longitude (W) & Data & $\begin{array}{c}\text { Tipo de } \\
\text { arrasto }\end{array}$ & $\begin{array}{c}\text { Profundidade } \\
\text { de coleta }\end{array}$ & Rede & $\begin{array}{c}\text { Malha } \\
\text { ( } \boldsymbol{\mu m})\end{array}$ & $\begin{array}{c}\mathbf{N}^{\circ} \text {. de } \\
\text { inds. }\end{array}$ \\
\hline 2624 & $22^{\circ} 35^{\prime} 08,5^{\prime \prime}$ & $039^{\circ} 46^{\prime} 22,3^{\prime \prime}$ & $06 / 12 / 2002$ & horizontal & superfície & nêuston & 500 & 1 \\
\hline 2684 & $22^{\circ} 43^{\prime} 50,4^{\prime \prime}$ & $039^{\circ} 53^{\prime} 20,5^{\prime \prime}$ & $07 / 12 / 2002$ & horizontal & superfície & nêuston & 500 & 1 \\
\hline 21383 & $22^{\circ} 02^{\prime} 35,2^{\prime \prime}$ & $039^{\circ} 43^{\prime} 18,2^{\prime \prime}$ & $04 / 12 / 2002$ & vertical & $700-1.200 \mathrm{~m}$ & cilíndrico-cônica & 200 & 1 \\
\hline 22385 & $21^{\circ} 57^{\prime} 114^{\prime \prime}$ & $039^{\circ} 37^{\prime} 27,9^{\prime \prime}$ & $05 / 12 / 2002$ & vertical & $0-40 \mathrm{~m}$ & cilíndrico-cônica & 200 & 1 \\
\hline 22386 & $22^{\circ} 35^{\prime} 08^{\prime \prime} 5^{\prime \prime}$ & $039^{\circ} 46^{\prime} 22,3^{\prime \prime}$ & $06 / 12 / 2002$ & vertical & $0-50 \mathrm{~m}$ & cilíndrico-cônica & 200 & 1 \\
\hline
\end{tabular}

Referências: Watson, 1996l; Figueiredo \& Menezes, 2000; Last, 2002; Lamkin, 2006; Fahay, 2007. 


\section{ORDEM PLEURONECTIFORMES}

A ordem Pleuronectiformes é composta por 14 famílias com aproximadamente 678 espécies. A maioria é marinha, mas existem cerca de dez espécies que ocorrem apenas em ambientes de água doce. Algumas espécies originalmente de água doce podem entrar eventualmente em regiões estuarinas e marinhas, enquanto outras espécies marinhas ocasionalmente ocorrem na água doce.

As larvas são bilateralmente simétricas e entre 10 e $25 \mathrm{~mm}$ sofrem a metamorfose, quando um dos olhos migra para um dos lados do corpo. A partir dessa fase, ocorre uma assimetria, e há um aumento do pigmento no lado onde o olho está localizado. Nesse estudo a ordem Pleuronectiformes é representada pelas famílias Paralichthyidae, Bothidae e Cynoglossidae. 


\section{Família Paralichthyidae}

A família Paralichthyidae é marinha, raramente registrada em água doce, e ocorre nos oceanos Atlântico, Índico e Pacífico. Compreende 16 gêneros com 105 espécies. Os olhos após a metamorfose estão posicionados do lado esquerdo da cabeça na maioria das espécies. As nadadeiras dorsal e anal não são confluentes com a nadadeira caudal. As nadadeiras pélvica e peitoral estão presentes.

No Brasil já foram identificadas 19 espécies nas fases de larva e adulto. Nesse estudo são contempladas as espécies Citharichthys sp. e Syacium papillosum. 


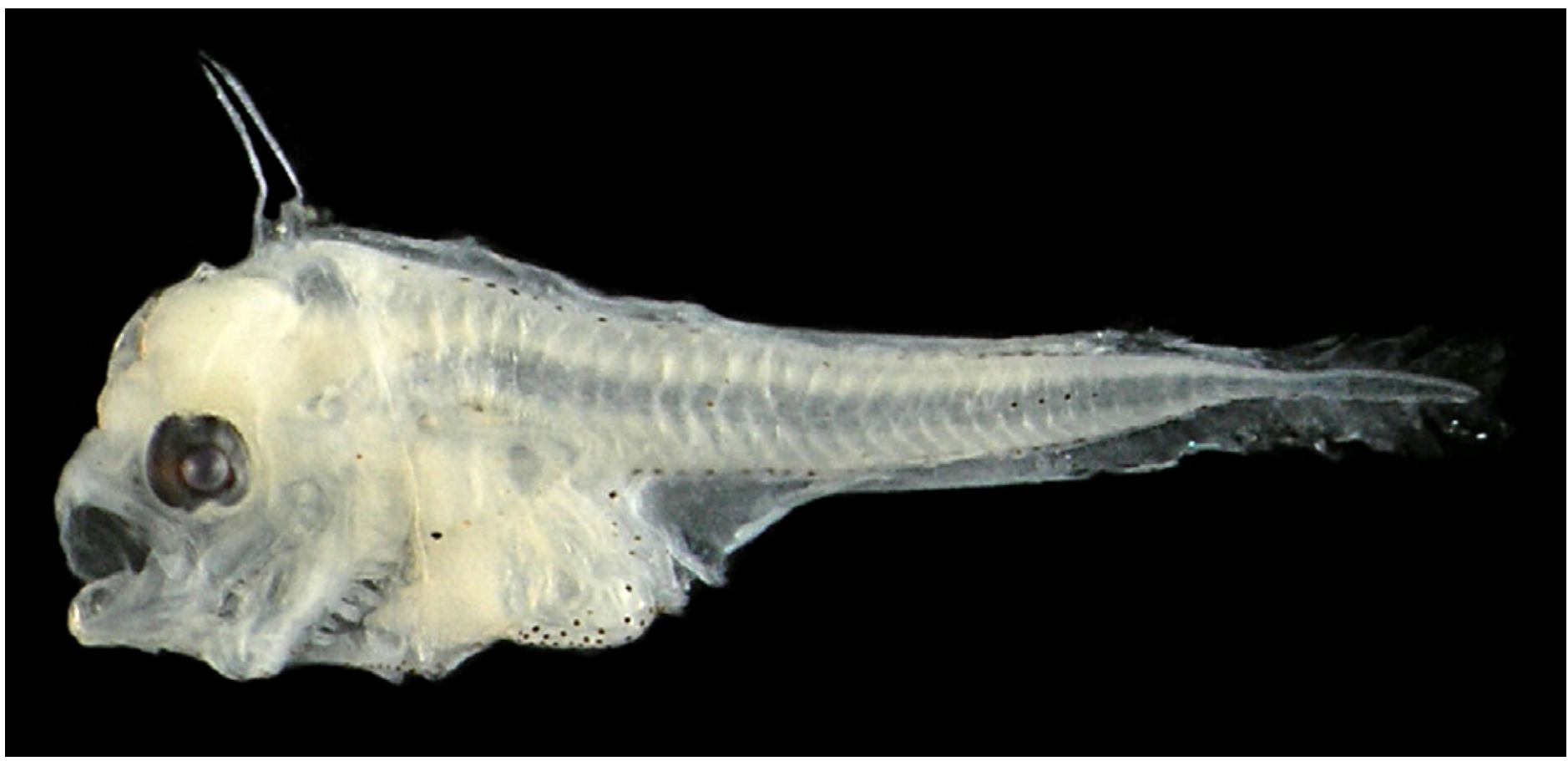

Figura 152: Citharichthys sp. DZUFRJ 20989; Pré-flexão; CP 3,5 mm.

\section{Citharichthys sp.}

As larvas de Citharichthys são caracterizadas desde o estágio de pré-flexão por apresentarem pigmentos na região da cauda, na altura da linha lateral, podendo em algumas espécies formar uma barra. Blocos de pigmentos estão presentes nas margens dorsal e ventral do corpo. Dependendo da espécie pode ter dois ou três primeiros raios da nadadeira dorsal alongados e um raio longo na nadadeira pélvica. Algumas espécies possuem espinhos no pré-opérculo. O número de miômeros varia aproximadamente entre 33 e 37. No Brasil já foram registradas as espécies Citharichthys arenaceus Evermann \& Marsh, 1900; Citharichthys cornutus (Günther, 1880); Citharichthys dinoceros Goode \& Bean, 1886; Citharichthys macrops Dresel, 1885 e Citharichthys spilopterus Günther, 1862.

Tamanho: pré-flexão 3,2 mm.

Habitat: a maioria das espécies de Citharichthys registradas na literatura é marinha e demersal, com algumas ocorrendo em águas salobra e doce. A profundidade de ocorrência varia muito entre as espécies chegando a $1.800 \mathrm{~m}$.

\section{Georreferenciamento}

\begin{tabular}{|c|c|c|c|c|c|c|c|c|}
\hline DZUFRJ & Latitude (S) & Longitude (W) & Data & $\begin{array}{c}\text { Tipo de } \\
\text { arrasto }\end{array}$ & $\begin{array}{c}\text { Profundidade } \\
\text { de coleta }\end{array}$ & Rede & $\begin{array}{c}\text { Malha } \\
\text { ( } \boldsymbol{\mu m}_{\mathbf{m}}\end{array}$ & $\begin{array}{c}\text { No. de } \\
\text { inds. }\end{array}$ \\
\hline 675 & $22^{\circ} 33^{\prime} 477^{\prime \prime}$ & $040^{\circ} 12^{\prime} 20,5^{\prime \prime}$ & $17 / 05 / 2002$ & oblíquo & $50 \mathrm{~m}$ & bongô & 500 & 1 \\
\hline
\end{tabular}

Referências: Fahay, 1983; Lyczkowski-Shultz \& Bond, 2006; Macedo \& Monteiro-Ribas, 2006. 


\section{Syacium}

papillosum

\section{(Linnaeus, 1758)}

A principal característica das larvas dessa espécie é a presença de dois espinhos na região do crânio (um de cada lado), mesmo em larvas muito pequenas, no estágio de pré-flexão. Possui entre quatro e sete espinhos pré-operculares. A partir de 3,0 mm de comprimento tem entre cinco e oito raios anteriores da nadadeira dorsal alongados. Possui cinco grupos de pigmentos na região dorsal do corpo, três a quatro na região ventral, dois na linha lateral na região da cauda. O número de miômeros varia entre 33 e 36.

Tamanho: pré-flexão 3,2-5,0 mm; flexão $6,5 \mathrm{~mm}$.

Habitat: espécie marinha, demersal, associada a formações coralinas, ocorre entre 9 e 140 m de profundidade, normalmente em profundidades inferiores a $90 \mathrm{~m}$.

Nome vulgar: Linguado do olho riscado.

\section{Georreferenciamento}

\begin{tabular}{|c|c|c|c|c|c|c|c|c|}
\hline DZUFR & Latitude (S) & Longitude (W) & Data & $\begin{array}{c}\text { Tipo de } \\
\text { arrasto }\end{array}$ & $\begin{array}{c}\text { Profundidade } \\
\text { de coleta }\end{array}$ & Rede & $\begin{array}{c}\text { Malha } \\
\text { ( } \boldsymbol{\mu m} \text { ) }\end{array}$ & $\begin{array}{c}\text { No. de } \\
\text { inds. }\end{array}$ \\
\hline 487 & $22^{\circ} 33^{\prime} 37,0^{\prime \prime}$ & $040^{\circ} 19^{\prime} 10,0^{\prime \prime}$ & $17 / 05 / 2002$ & oblíquo & $50 \mathrm{~m}$ & bongô & 500 & 5 \\
\hline 506 & $22^{\circ} 31^{\prime} 27,0^{\prime \prime}$ & $040^{\circ} 16^{\prime} 56,0^{\prime \prime}$ & $17 / 05 / 2002$ & oblíquo & $600 \mathrm{~m}$ & cilíndrico-cônica & 500 & 3 \\
\hline 527 & $22^{\circ} 34^{\prime} 05,0^{\prime \prime}$ & $040^{\circ} 19^{\prime} 40,0^{\prime \prime}$ & $17 / 05 / 2002$ & oblíquo & $600 \mathrm{~m}$ & cilíndrico-cônica & 500 & 14 \\
\hline 542 & $22^{\circ} 32^{\prime} 03,0^{\prime \prime}$ & $040^{\circ} 17^{\prime} 21,0^{\prime \prime}$ & $19 / 05 / 2002$ & oblíquo & $30 \mathrm{~m}$ & bongô & 330 & 4 \\
\hline 571 & $22^{\circ} 32^{\prime} 03,0^{\prime \prime}$ & $040^{\circ} 17^{\prime} 21,0^{\prime \prime}$ & $19 / 05 / 2002$ & oblíquo & $30 \mathrm{~m}$ & bongô & 500 & 1 \\
\hline 581 & $22^{\circ} 33^{\prime} 37,0^{\prime \prime}$ & $040^{\circ} 19^{\prime} 10^{\prime \prime} 0^{\prime \prime}$ & $17 / 05 / 2002$ & oblíquo & $50 \mathrm{~m}$ & bongô & 330 & 3 \\
\hline 618 & $22^{\circ} 36^{\prime} 54,9^{\prime \prime}$ & $040^{\circ} 09^{\prime} 19,4^{\prime \prime}$ & $16 / 05 / 2002$ & oblíquo & $50 \mathrm{~m}$ & bongô & 500 & 2 \\
\hline 694 & $22^{\circ} 33^{\prime} 477^{\prime \prime}$ & $040^{\circ} 12^{\prime} 20,5^{\prime \prime}$ & $17 / 05 / 2002$ & oblíquo & $50 \mathrm{~m}$ & bongô & 500 & 3 \\
\hline
\end{tabular}

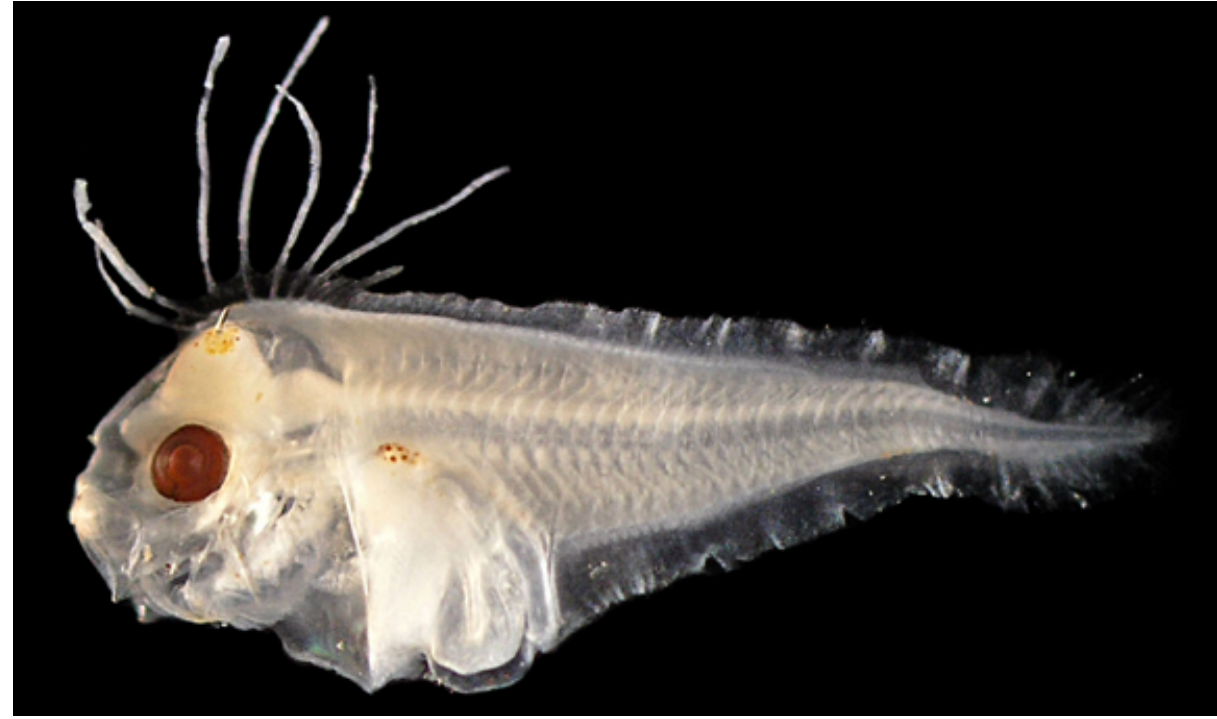

Figura 153 - A: Syacium papillosum. DZUFRJ 13431; Pré-flexão; CP 5,0 mm.

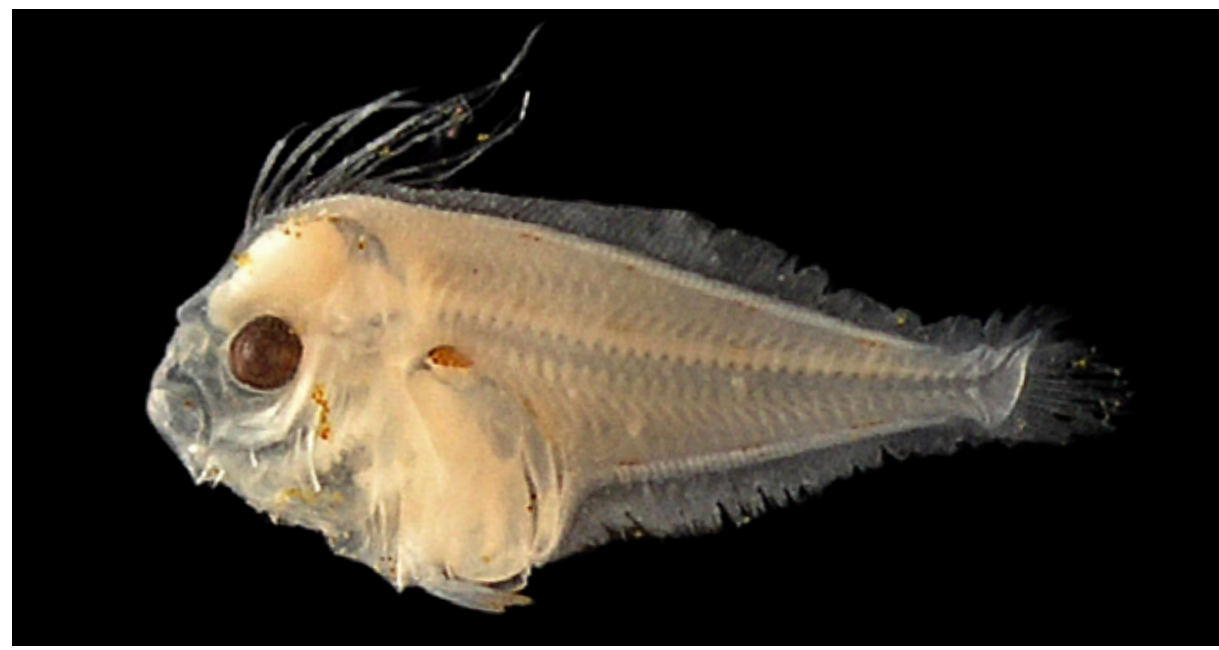

Figura 153 - B: DZUFRJ 13662; Flexão; CP 6,5 mm. 


\section{Família Bothidae}

A família Bothidae é marinha e ocorre nos oceanos Atlântico, Índico e Pacífico. Compreende 20 gêneros com aproximadamente 140 espécies. As larvas são bilateralmente simétricas e o corpo é alto e lateralmente comprimido. O primeiro ou segundo raio da nadadeira dorsal é alongado. Antes da metamorfose as larvas perdem o raio alongado. As nadadeiras dorsal e anal são longas e contínuas com a base da nadadeira caudal fazendo com que o pedúnculo seja muito pequeno ou ausente. Os olhos após a metamorfose estão posicionados do lado esquerdo da cabeça.

No Brasil já foram identificadas 12 espécies nas fases de larva e adulto. Nesse estudo são contempladas as espécies Bothus ocellatus e Chascanopsetta lugubris. 


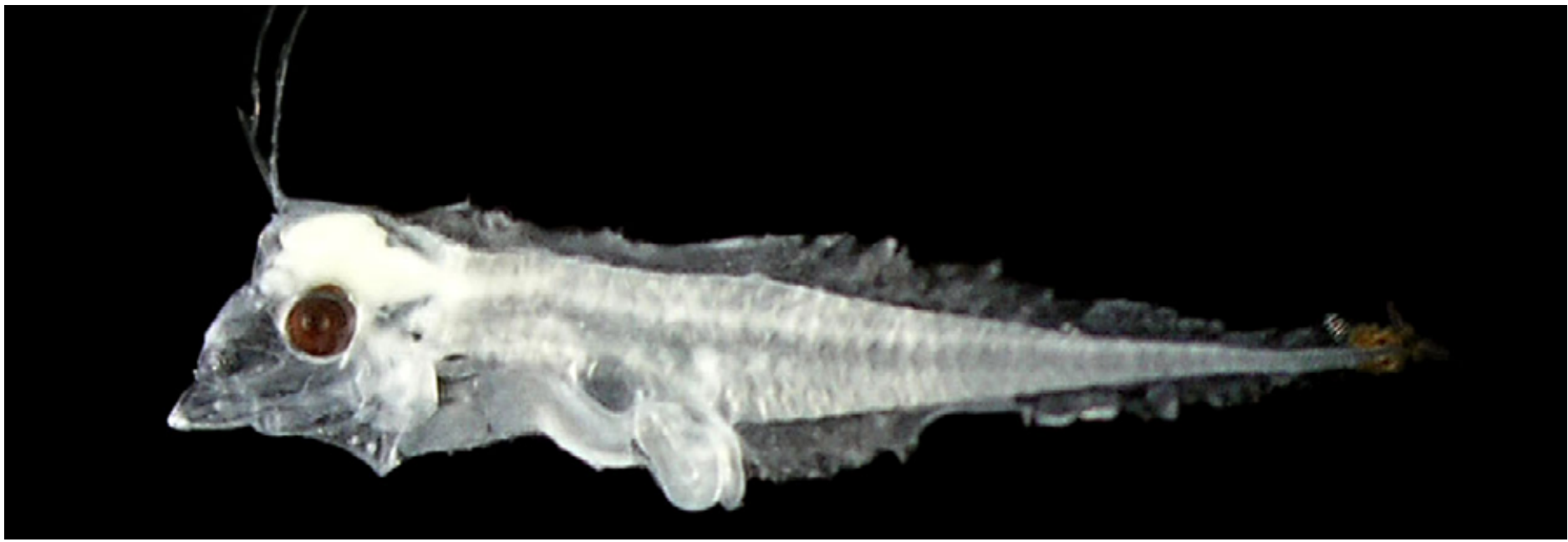

Figura 154 - A: Bothus ocellatus. DZUFRJ 25137 Pré-flexão; CP 4,1mm.

\section{Bothus ocellatus (Agassiz, 1831)}

As larvas em estágio de pré-flexão possuem o corpo alongado, muito comprimido, e o intestino faz uma volta. Tem pequenos melanóforos na extremidade da cauda. Durante os estágios de flexão e pós-flexão as larvas possuem o corpo mais robusto. O primeiro raio da nadadeira dorsal é alongado em todos os estágios de desenvolvimento e começa a diminuir durante a transformação. Em larvas maiores que 10 mm não tem nenhuma pigmentação. Raios da nadadeira dorsal: 76-91; raios da nadadeira anal: 58-69. O número de miômeros varia entre 35 e 37.

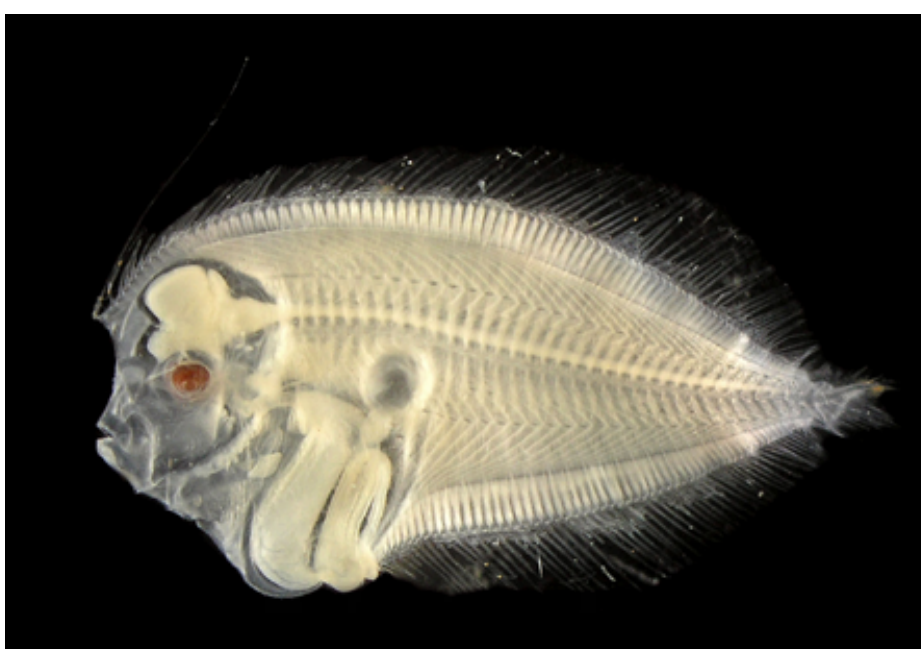

Figura 154 - B: DZUFRJ; 13165 Flexão; CP 7,5 mm.

Tamanho: pré-flexão 4,0-5,2 mm; flexão 7,3-7,6 mm; pós-flexão 11,5 mm; transformação 20,8 mm.

Habitat: espécie marinha, demersal, associada a formações coralinas, ocorre até $110 \mathrm{~m}$ de profundidade.

Nome vulgar: Linguado arco íris.

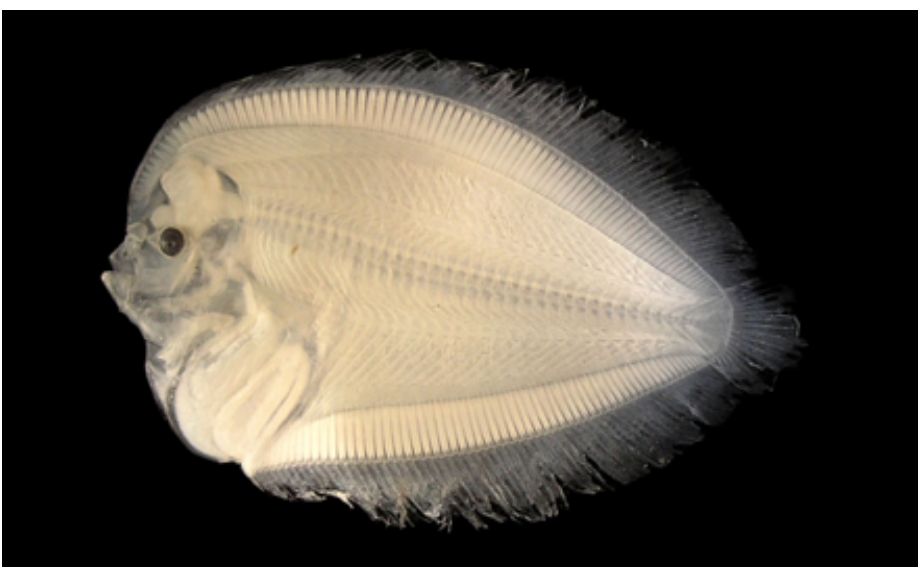

Figura 154 - C: DZUFRJ 11910; Pós-flexão; CP 12,0 mm.

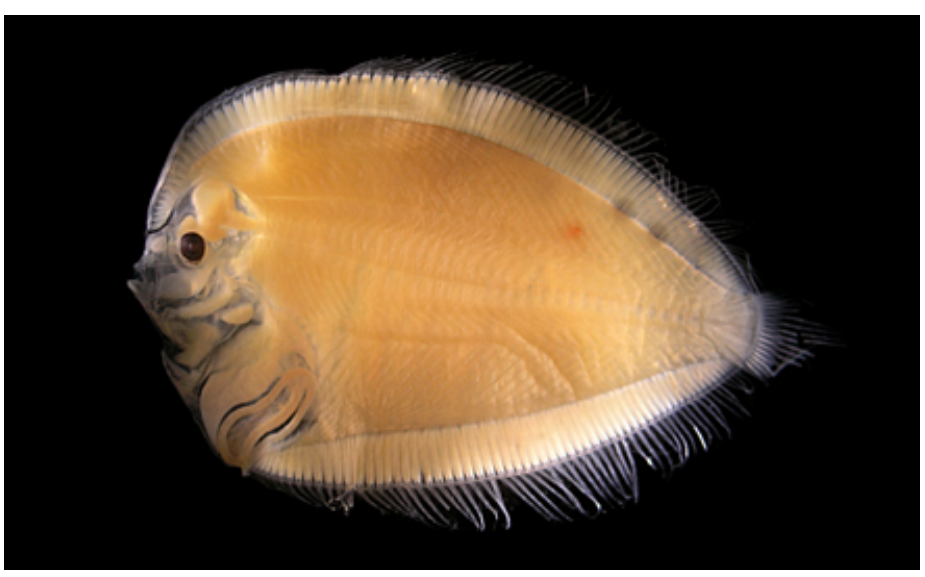

Figura 154 - D: DZUFRJ 19901; Transformação; CP 20,8 mm. 


\section{Georreferenciamento}

\begin{tabular}{|c|c|c|c|c|c|c|c|c|}
\hline DZUFRJ & Latitude (S) & Longitude (W) & Data & $\begin{array}{l}\text { Tipo de } \\
\text { arrasto }\end{array}$ & $\begin{array}{c}\text { Profundidade } \\
\text { de coleta }\end{array}$ & Rede & $\begin{array}{c}\text { Malha } \\
(\mu \mathrm{m})\end{array}$ & $\begin{array}{l}N^{\circ} \text {. de } \\
\text { inds. }\end{array}$ \\
\hline 481 & $22^{\circ} 33^{\prime} 37,0^{\prime \prime}$ & $040^{\circ} 19^{\prime} 10,0^{\prime \prime}$ & $17 / 05 / 2002$ & oblíquo & $50 \mathrm{~m}$ & bongô & 500 & 1 \\
\hline 510 & $22^{\circ} 38^{\prime} 25,0^{\prime \prime}$ & $040^{\circ} 17^{\prime} 41,0^{\prime \prime}$ & $19 / 05 / 2002$ & oblíquo & $40 \mathrm{~m}$ & bongô & 500 & 2 \\
\hline 550 & $22^{\circ} 34^{\prime} 05,0^{\prime \prime}$ & $040^{\circ} 19^{\prime} 40,0^{\prime \prime}$ & $17 / 05 / 2002$ & oblíquo & $600 \mathrm{~m}$ & cilíndrico-cônica & 500 & 2 \\
\hline 567 & $22^{\circ} 33^{\prime} 37,0^{\prime \prime}$ & $040^{\circ} 19^{\prime} 10,0^{\prime \prime}$ & $17 / 05 / 2002$ & oblíquo & $50 \mathrm{~m}$ & bongô & 330 & 1 \\
\hline 573 & $22^{\circ} 32^{\prime} 03,0^{\prime \prime}$ & $040^{\circ} 17^{\prime} 21,0^{\prime \prime}$ & $19 / 05 / 200$ & oblíquo & $30 \mathrm{~m}$ & bongô & 500 & 2 \\
\hline 607 & $22^{\circ} 38^{\prime} 29,0^{\prime \prime}$ & $040^{\circ} 17^{\prime} 40,0^{\prime \prime}$ & $18 / 05 / 2002$ & oblíquo & $800 \mathrm{~m}$ & cilíndrico-cônica & 500 & 1 \\
\hline 614 & $22^{\circ} 36^{\prime} 54,9 "$ & $040^{\circ} 09^{\prime} 19,4^{\prime \prime}$ & $16 / 05 / 2002$ & oblíquo & $50 \mathrm{~m}$ & bongô & 500 & 3 \\
\hline 625 & $22^{\circ} 36^{\prime} 54,9^{\prime \prime}$ & $040^{\circ} 09^{\prime} 19,4^{\prime \prime}$ & $16 / 05 / 2002$ & oblíquo & $50 \mathrm{~m}$ & bongô & 330 & 7 \\
\hline 658 & $22^{\circ} 33^{\prime} 47,7^{\prime \prime}$ & $040^{\circ} 12^{\prime} 20,5^{\prime \prime}$ & $17 / 05 / 2002$ & oblíquo & $50 \mathrm{~m}$ & bongô & 500 & 1 \\
\hline 687 & $22^{\circ} 41^{\prime} 54,7^{\prime \prime}$ & $040^{\circ} 14^{\prime} 04,5^{\prime \prime}$ & $16 / 05 / 2002$ & oblíquo & $1.000 \mathrm{~m}$ & cilíndrico-cônica & 500 & 6 \\
\hline 697 & $22^{\circ} 37^{\prime} 35,5^{\prime \prime}$ & $040^{\circ} 09^{\prime} 32,8^{\prime \prime}$ & $16 / 05 / 2002$ & oblíquo & $1.000 \mathrm{~m}$ & cilíndrico-cônica & 500 & 2 \\
\hline 1333 & $22^{\circ} 06^{\prime} 37,8^{\prime \prime}$ & $039^{\circ} 49^{\prime} 44,8^{\prime \prime}$ & $10 / 05 / 2002$ & oblíquo & até a termoclina & bongô & 330 & 1 \\
\hline 2621 & $22^{\circ} 35^{\prime} 08,5^{\prime \prime}$ & $039^{\circ} 46^{\prime} 22,3^{\prime \prime}$ & $07 / 12 / 2002$ & horizontal & superfície & nêuston & 500 & 1 \\
\hline 16287 & $22^{\circ} 08^{\prime} 14,9^{\prime \prime}$ & $039^{\circ} 46^{\prime} 34,6^{\prime \prime}$ & $11 / 05 / 2002$ & oblíquo & até a termoclina & bongô & 330 & 2 \\
\hline 19901 & $22^{\circ} 31^{\prime} 40,9^{\prime \prime}$ & $040^{\circ} 02^{\prime} 39,6^{\prime \prime}$ & $07 / 11 / 2001$ & oblíquo & $1.000 \mathrm{~m}$ & cilíndrico-cônica & 500 & 1 \\
\hline 19902 & $22^{\circ} 02^{\prime} 35,2^{\prime \prime}$ & $039^{\circ} 43^{\prime} 18,2^{\prime \prime}$ & $04 / 12 / 2002$ & vertical & $700-1.200 m$ & cilíndrico-cônica & 200 & 2 \\
\hline 19904 & $22^{\circ} 35^{\prime} 08,5^{\prime \prime}$ & $039^{\circ} 46^{\prime} 22,3^{\prime \prime}$ & $07 / 12 / 2002$ & vertical & $200-500 m$ & cilíndrico-cônica & 200 & 1 \\
\hline 19905 & $22^{\circ} 02^{\prime} 35,2^{\prime \prime}$ & $039^{\circ} 43^{\prime} 18,2^{\prime \prime}$ & $04 / 12 / 2002$ & vertical & $700-1.200 m$ & cilíndrico-cônica & 500 & 3 \\
\hline
\end{tabular}

Referências: Lara, 2006b; Macedo \& Monteiro-Ribas, 2006; Fahay, 2007. 


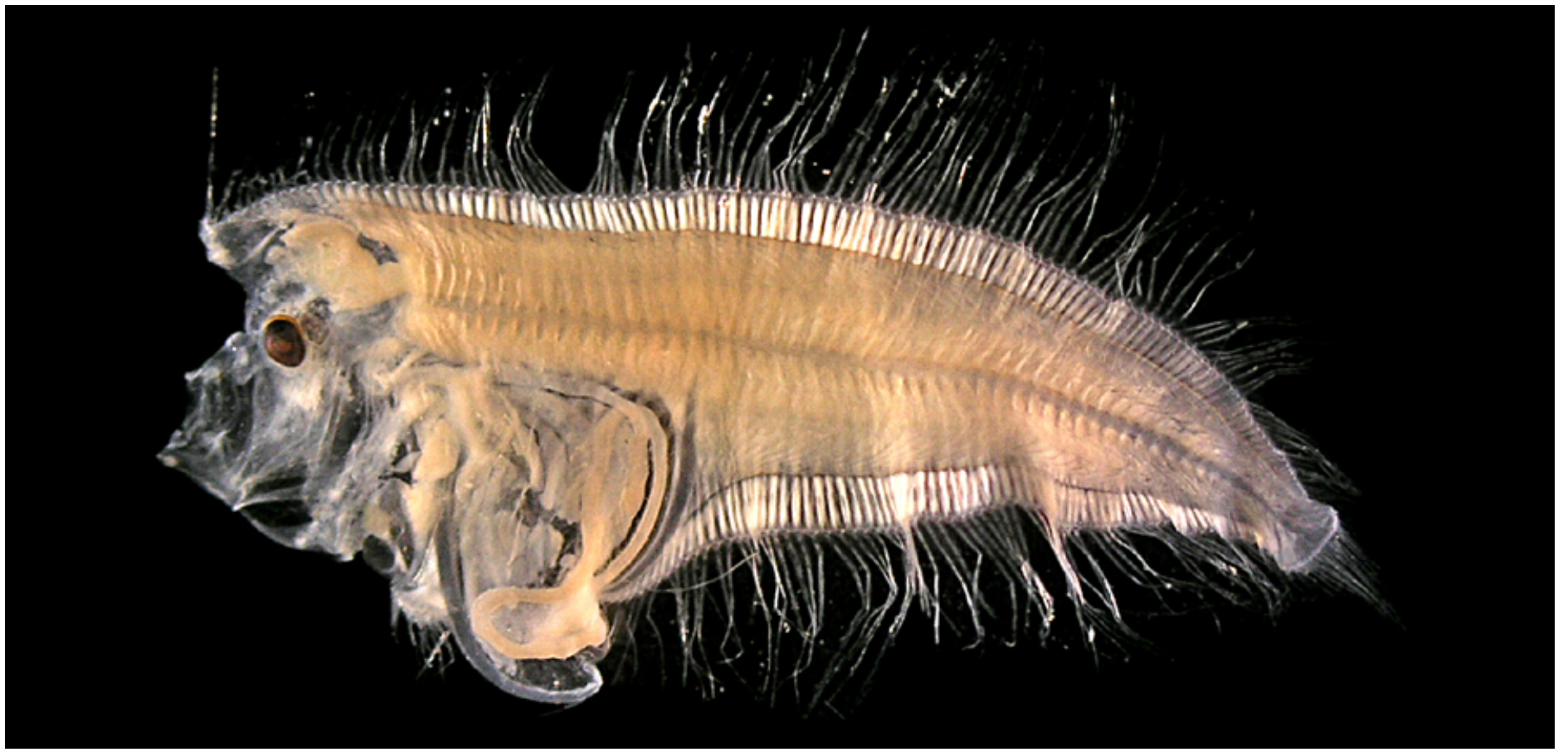

Figura 155: Chascanopsetta lugubris. DZUFRJ 7499; Pós-flexão; CP 16,5mm.

\section{Chascanopsetta lugubris Alcock, 1894}

As larvas em estágio de pós-flexão têm o corpo mais alto que alongado. Possui o segundo raio da nadadeira dorsal alongado e o intestino é expandido, passando da margem ventral do corpo. Raios da nadadeira dorsal: 111-122; raios da nadadeira anal: 76-85. Possui um total de 55 miômeros.

Tamanho: pós-flexão 16,5 mm.

Habitat: espécie marinha, batidemersal, ocorre entre 60 e 977 m de profundidade.

Nome vulgar: Linguado.

\section{Georreferenciamento}

\begin{tabular}{|c|c|c|c|c|c|c|c|c|}
\hline DZUFRJ & Latitude (S) & Longitude (W) & Data & $\begin{array}{c}\text { Tipo de } \\
\text { arrasto }\end{array}$ & $\begin{array}{c}\text { Profundidade } \\
\text { de coleta }\end{array}$ & Rede & $\begin{array}{c}\text { Malha } \\
\text { ( } \boldsymbol{\mu m})\end{array}$ & $\begin{array}{c}\mathbf{N}^{\circ} \text {. de } \\
\text { inds. }\end{array}$ \\
\hline 7499 & $21^{\circ} 58^{\prime} 31,0^{\prime \prime}$ & $039^{\circ} 50^{\prime} 29,7^{\prime \prime}$ & $10 / 10 / 2001$ & oblíquo & $1.000 \mathrm{~m}$ & cilíndrico-cônica & 500 & 1 \\
\hline
\end{tabular}

Referências: Lara, 2006b; Fahay, 2007. 


\section{Família Cynoglossidae}

A família Cynoglossidae é marinha, mas algumas espécies entram em ambientes de água doce. Ocorre nos mares tropicais e subtropicais. Compreende três gêneros com 127 espécies. As larvas possuem o corpo alongado e lateralmente comprimido. O intestino forma uma alça e é projetado para a região ventral do corpo. O número de raios alongados da nadadeira dorsal, o padrão de pigmentação nas margens dorsal e ventral do corpo e a presença ou ausência de um apêndice cônico na região ventral do abdome são características importantes para a identificação das espécies.

No Brasil já foram identificadas 12 espécies nas fases de larva e adulto. Nesse estudo é contemplada a espécie Symphurus kyaropterygium. 


\section{Symphurus}

kyaropterygium

Menezes \&

\section{Benvegnú, 1976}

Tem o primeiro raio da nadadeira dorsal curto, seguido de quatro raios longos. Possui quatro blocos de pequenos melanóforos nas regiões dorsal e ventral do corpo. Tem pequenos melanóforos na região do trato digestório.

Tamanho: flexão 6,6-7,5 mm.

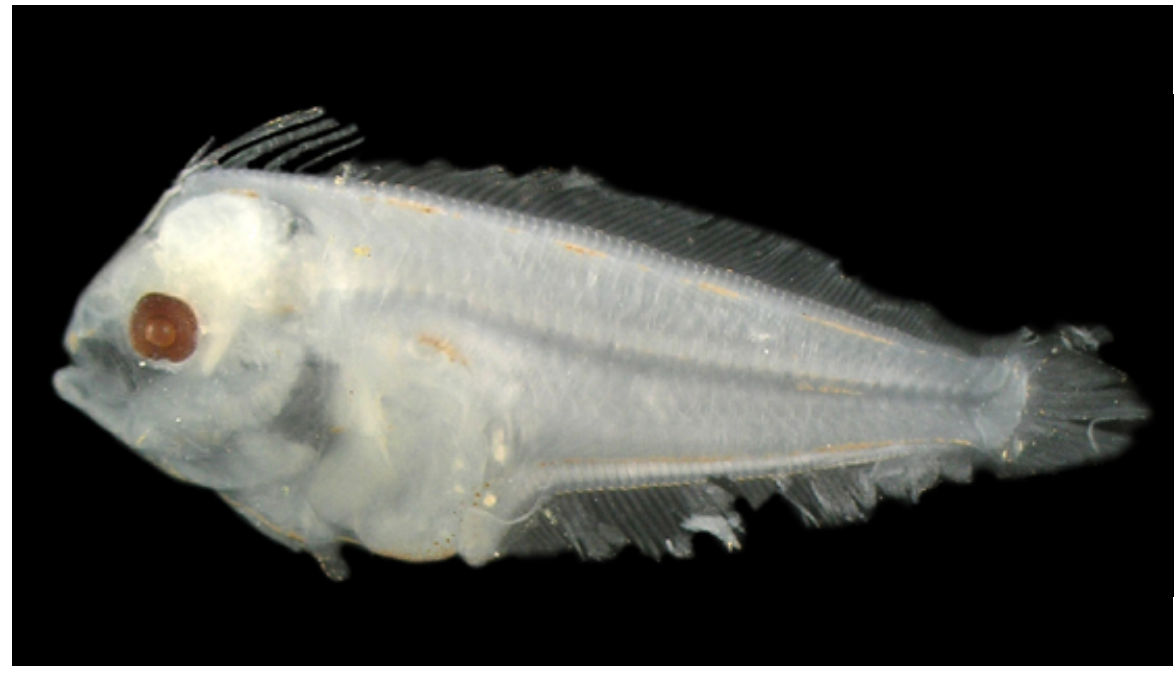

Figura 156 - Symphurus kyaropterygium. DZUFRJ 1063; Flexão; CP 6,6 mm.

Habitat: espécie marinha, demersal, ocorre entre 36 e $69 \mathrm{~m}$ de profundidade.

Nome vulgar: Língua de vaca.

\section{Georreferenciamento}

\begin{tabular}{|c|c|c|c|c|c|c|c|c|}
\hline DZUFR & Latitude (S) & Longitude (W) & Data & $\begin{array}{c}\text { Tipo de } \\
\text { arrasto }\end{array}$ & $\begin{array}{c}\text { Profundidade } \\
\text { de coleta }\end{array}$ & Rede & $\begin{array}{c}\text { Malha } \\
\text { ( } \boldsymbol{\mu m})\end{array}$ & $\begin{array}{c}\text { No. de } \\
\text { inds. }\end{array}$ \\
\hline 7500 & $21^{\circ} 54^{\prime} 36,5^{\prime \prime}$ & $039^{\circ} 45^{\prime} 20,0^{\prime \prime}$ & $10 / 10 / 2001$ & oblíquo & $1.000 \mathrm{~m}$ & cilíndrico-cônica & 500 & 1 \\
\hline 19900 & $22^{\circ} 32^{\prime} 50,0^{\prime \prime}$ & $040^{\circ} 04^{\prime} 09,9^{\prime \prime}$ & $06 / 11 / 2001$ & oblíquo & $1.000 \mathrm{~m}$ & cilíndrico-cônica & 500 & 1 \\
\hline
\end{tabular}

Referências: Kurtz \& Matsuura, 1994; Macedo \& Monteiro-Ribas, 2006. 


\section{ORDEM TETRAODONTIFORMES}

A ordem Tetraodontiformes é composta por nove famílias e 357 espécies. O corpo pode ser arredondado ou moderadamente alongado. As larvas possuem um saco dermal ou epiderme inflada, grupo de espinhos no opérculo e espinhos ou placas dérmicas na superfície do corpo. As nadadeiras dorsal e anal estão situadas na porção posterior do corpo com exceção da família Monacanthidae.

Nesse estudo a ordem Tetraodontiformes é representada pelas famílias Monacanthidae, Ostraciidae e Tetraodontidae. 


\section{Família Monacanthidae}

A família Monacanthidae é marinha e ocorre nos oceanos Atlântico, Índico e Pacífico. Compreende 32 gêneros com 102 espécies. As larvas possuem o corpo alto ou alongado em algumas espécies. O corpo é muito comprimido com espinhos minúsculos e as nadadeiras pélvicas são ausentes. Possuem grupos de espinhos no pré-opérculo, pequenos espinhos dermais na área interorbital, melanóforos na cabeça e uma série de melanóforos na região ventral ao longo da cauda. O primeiro espinho dorsal é alongado com projeções dos dois lados, o segundo é muito menor e pode estar ausente.

No Brasil já foram identificadas nove espécies nas fases de larva e adulto. Nesse estudo é contemplada a espécie Monacanthus ciliatus. 


\section{Monacanthus ciliatus (Mitchill, 1818)}

As larvas no estágio de pré-flexão possuem o corpo alto e muito comprimido e focinho relativamente curto, que fica projetado, mas não muito alongado nos estágios de desenvolvimento seguintes. Possui um total de 19 miômeros. Tem dois espinhos dorsais, sendo que o primeiro se origina na parte posterior do olho. O espinho pélvico é bem desenvolvido, com denticulações curtas. Tem espinhos pequenos ao longo do corpo. O padrão de pigmentação é bem característico. Nas larvas em pré-flexão os melanóforos estão espalhados pela cabeça, sobre todo o cérebro alcançando a região ocular, no peritônio, sobre a vesícula gasosa e trato digestório. A partir da flexão surgem melanóforos no primeiro

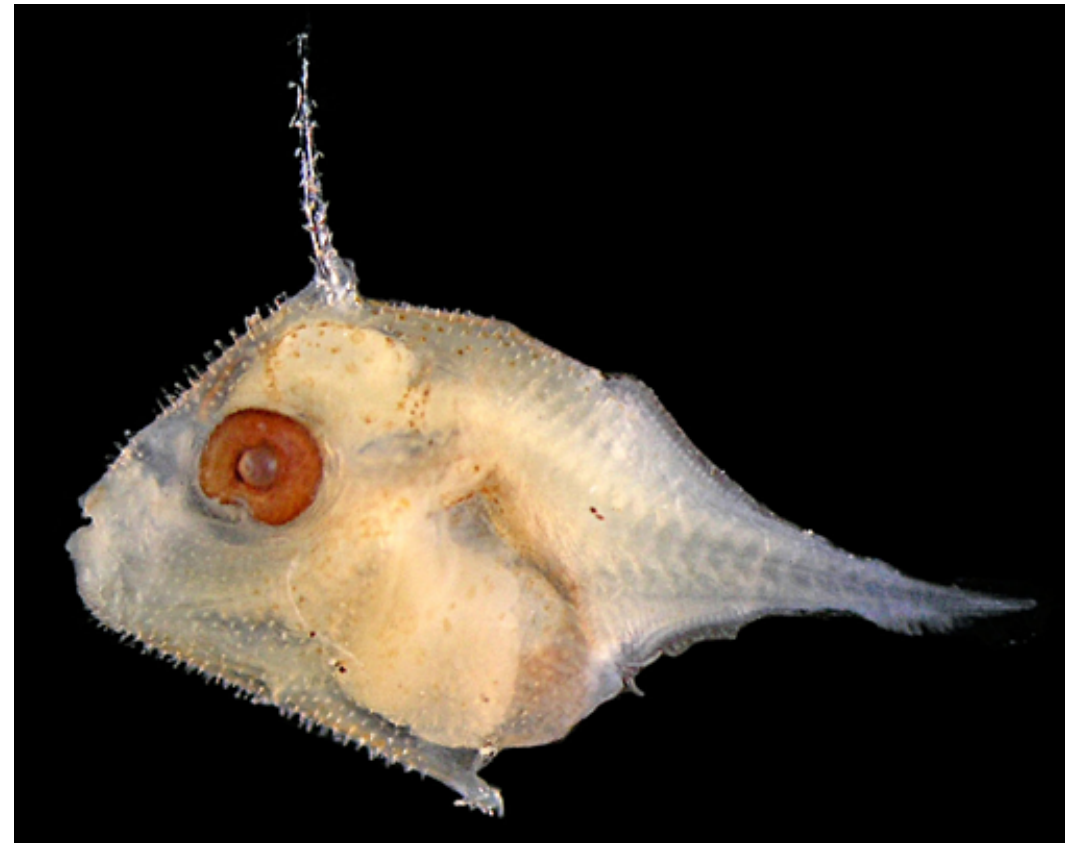

Figura 157-A: Monacanthus ciliatus. DZUFRJ 472; Pré-flexão; CP 4,1 mm. espinho dorsal e a pigmentação da cabeça e do corpo se intensificam. A linha de pigmentos sobre a linha lateral, na região posterior do corpo, se expande em direção a região anterior. Nadadeira dorsal: II + 29-37; nadadeira anal: 28-36.

Tamanho: pré-flexão 2,44,1 mm; flexão 4,5-5,2 mm; transformação $12,0 \mathrm{~mm}$.

Habitat: espécie marinha, demersal, associada a formações coralinas, ocorre até $50 \mathrm{~m}$ de profundidade.

Nome vulgar: Porquinho de franja.

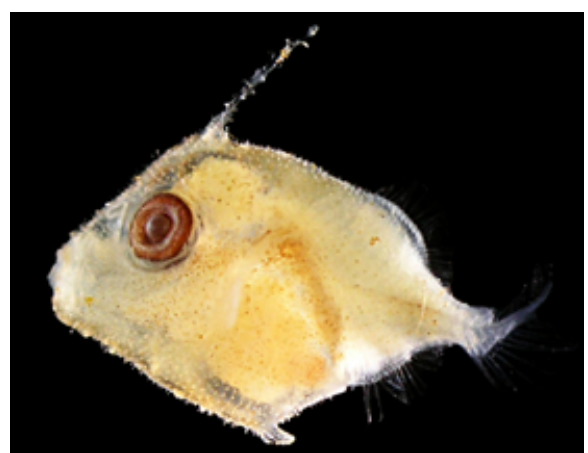

Figura 157 - B: DZUFRJ 472; Flexão; CP 5,0 mm.

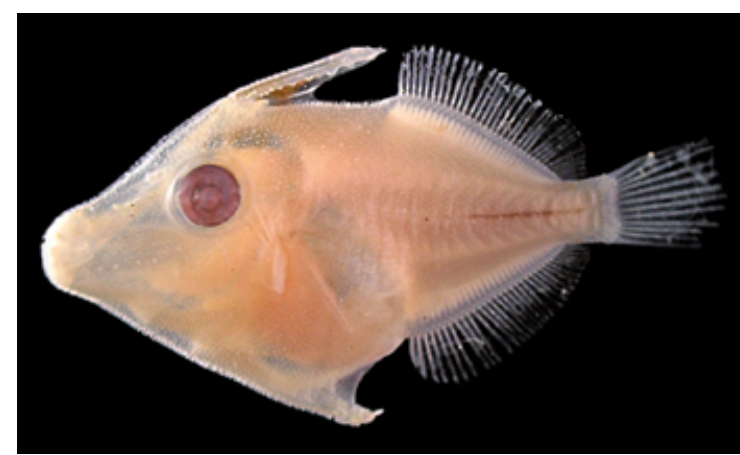

Figura 157 - C: DZUFRJ 19890; Transformação; CP 12,0 mm.

\section{Georreferenciamento}

\begin{tabular}{|c|c|c|c|c|c|c|c|c|}
\hline DZUFRJ & Latitude (S) & Longitude (W) & Data & $\begin{array}{l}\text { Tipo de } \\
\text { arrasto }\end{array}$ & $\begin{array}{c}\text { Profundidade } \\
\text { de coleta }\end{array}$ & Rede & $\begin{array}{l}\text { Malha } \\
(\mu \mathrm{m})\end{array}$ & $\begin{array}{l}N^{\circ} \text {. de } \\
\text { inds. }\end{array}$ \\
\hline 465 & $22^{\circ} 36^{\prime} 54,9^{\prime \prime}$ & $040^{\circ} 09^{\prime} 19,4^{\prime \prime}$ & $16 / 05 / 2002$ & oblíquo & $50 \mathrm{~m}$ & bongô & 500 & 1 \\
\hline 469 & $22^{\circ} 37^{\prime} 35,5^{\prime \prime}$ & $040^{\circ} 09^{\prime} 32,8^{\prime \prime}$ & $16 / 05 / 2002$ & oblíquo & $1.000 \mathrm{~m}$ & cilíndrico-cônica & 500 & 1 \\
\hline 472 & $22^{\circ} 36^{\prime} 54,9^{\prime \prime}$ & $040^{\circ} 09^{\prime} 19,4^{\prime \prime}$ & $16 / 05 / 2002$ & oblíquo & $50 \mathrm{~m}$ & bongô & 330 & 5 \\
\hline 473 & $22^{\circ} 42^{\prime} 06,0^{\prime \prime}$ & $040^{\circ} 14^{\prime} 26,0^{\prime \prime}$ & $19 / 05 / 2002$ & oblíquo & $50 \mathrm{~m}$ & bongô & 330 & 1 \\
\hline 478 & $22^{\circ} 33^{\prime} 37,0^{\prime \prime}$ & $040^{\circ} 19^{\prime} 10,0^{\prime \prime}$ & $17 / 05 / 2002$ & oblíquo & $50 \mathrm{~m}$ & bongô & 500 & 2 \\
\hline 19889 & $21^{\circ} 53^{\prime} 10,4^{\prime \prime}$ & $039^{\circ} 45^{\prime} 49,9^{\prime \prime}$ & $10 / 10 / 2001$ & oblíquo & $1.000 \mathrm{~m}$ & cilíndrico-cônica & 500 & 1 \\
\hline 19890 & $22^{\circ} 32^{\prime} 50,0^{\prime \prime}$ & $040^{\circ} 04^{\prime} 09,9^{\prime \prime}$ & $06 / 11 / 2001$ & oblíquo & $1.000 \mathrm{~m}$ & cilíndrico-cônica & 500 & 1 \\
\hline 19891 & $22^{\circ} 35^{\prime} 08,5^{\prime \prime}$ & $039^{\circ} 46^{\prime} 22,3^{\prime \prime}$ & $06 / 12 / 2002$ & vertical & $50 \mathrm{~m}$ & cilíndrico-cônica & 200 & 1 \\
\hline 19910 & $22^{\circ} 02^{\prime} 35,2^{\prime \prime}$ & $039^{\circ} 43^{\prime} 18,2^{\prime \prime}$ & $04 / 12 / 2002$ & vertical & $700-1.200 m$ & cilíndrico-cônica & 500 & 2 \\
\hline
\end{tabular}

Referências: Watson, 1996m; Barros et al., 2006b; Zapfe \& Lyczkowski-Shultz, 2006; Fahay, 2007. 


\section{Família Ostraciidae}

A família Ostraciidae é marinha e ocorre nos oceanos Atlântico, Índico e Pacífico. Compreende 14 gêneros com 33 espécies. As larvas possuem o corpo muito arredondado coberto por uma carapaça óssea desde os estágios iniciais de desenvolvimento. As nadadeiras dorsal e anal são curtas (9-13 raios) e estão posicionadas na região posterior do corpo.

No Brasil já foram identificadas cinco espécies nas fases de larva e adulto: Acanthostracion polygonius Poey, 1876; Acanthostracion quadricornis (Linnaeus, 1758); Lactophrys bicaudalis (Linnaeus, 1758); Lactophrys trigonus (Linnaeus, 1758) e Lactophrys triqueter (Linnaeus, 1758). Nesse estudo é contemplada a espécie Acanthostracion sp. 


\section{Acanthostracion sp.}

As larvas de Acanthostracion possuem a parte anterior do corpo arredondada e a parte posterior mais fina. Uma carapaça cobre a parte anterior do corpo e está completamente formada até o final da flexão. Distância pré-anal aproximadamente $65 \%$ do corpo. A pigmentação é intensa na parte anterior do corpo e ausente na cauda. As nadadeiras dorsal e anal são pequenas e estão situadas na parte posterior do corpo, na mesma direção. Raios da nadadeira dorsal: 10; raios da nadadeira anal: 10.

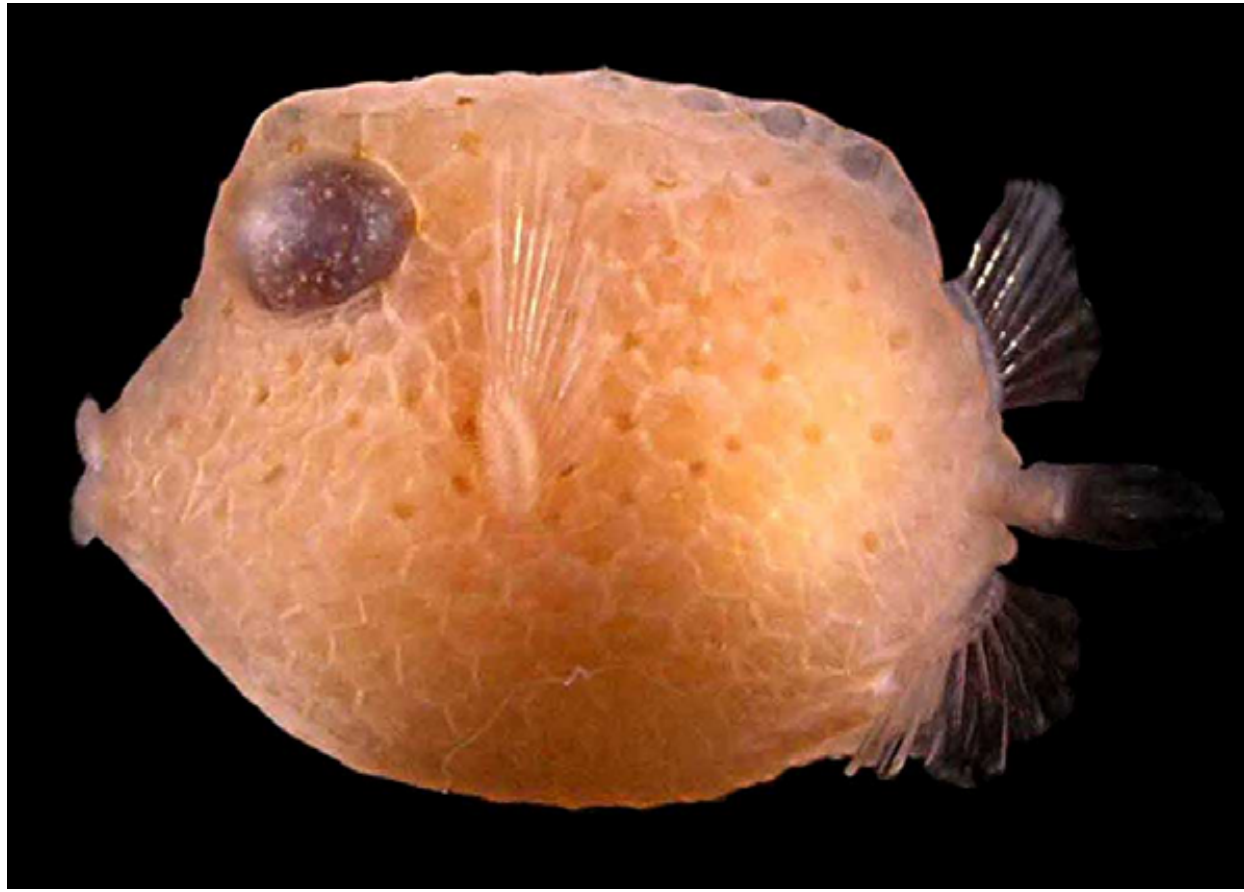

Figura 158 - Acanthostracion sp. DZUFRJ 5506; Transformação; CP 10,0 mm.

Tamanho: transformação 10,0 mm.

Habitat: todas as espécies são marinhas e demersais, associadas a formações coralinas, ocorrem até $200 \mathrm{~m}$ de profundidade.

No Brasil já foram registradas as espécies Acanthostracion polygonius Poey, 1876 e Acanthostracion quadricornis (Linnaeus, 1758).

\section{Georreferenciamento}

\begin{tabular}{|c|c|c|c|c|c|c|c|c|}
\hline DZUFRJ & Latitude (S) & Longitude (W) & Data & $\begin{array}{c}\text { Tipo de } \\
\text { arrasto }\end{array}$ & $\begin{array}{c}\text { Profundidade } \\
\text { de coleta }\end{array}$ & Rede & $\begin{array}{c}\text { Malha } \\
(\mu \mathrm{\mu m})\end{array}$ & $\begin{array}{c}\mathbf{N}^{\circ} \text {. de } \\
\text { inds. }\end{array}$ \\
\hline 5506 & $22^{\circ} 32^{\prime} 499^{\prime \prime}$ & $040^{\circ} 04^{\prime} 20,9^{\prime \prime}$ & $07 / 11 / 2001$ & oblíquo & $1.000 \mathrm{~m}$ & cilíndrico-cônica & 500 & 1 \\
\hline
\end{tabular}

Referências: Barros et al., 2006b; Lyczkowski-Shultz et al., 2006, Fahay, 2007. 


\section{Família Tetraodontidae}

A família Tetraodontidae é marinha, com algumas espécies habitantes de formações coralinas e várias espécies vivem em água salobra e doce. Ocorre nas regiões tropicais e subtropicais, nos oceanos Atlântico, Índico e Pacífico. Compreende 19 gêneros e aproximadamente 130 espécies.

Os representantes dessa família são caracterizados pelo formato do corpo e pela capacidade de inflá-lo, engolindo água ou ar. A maioria das espécies possui o corpo oval com espinhos cobrindo a porção ventral do corpo. Não possuem nadadeira pélvica e as nadadeiras dorsal e anal são curtas e opostas. A pigmentação do corpo varia muito de acordo com as espécies, estando presente na margem dorsal do intestino, cabeça e tronco e aumentando com o desenvolvimento da larva.

No Brasil já foram identificadas 13 espécies. Nesse estudo são contempladas as espécies Canthigaster rostrata e Lagocephalus lagocephalus. 


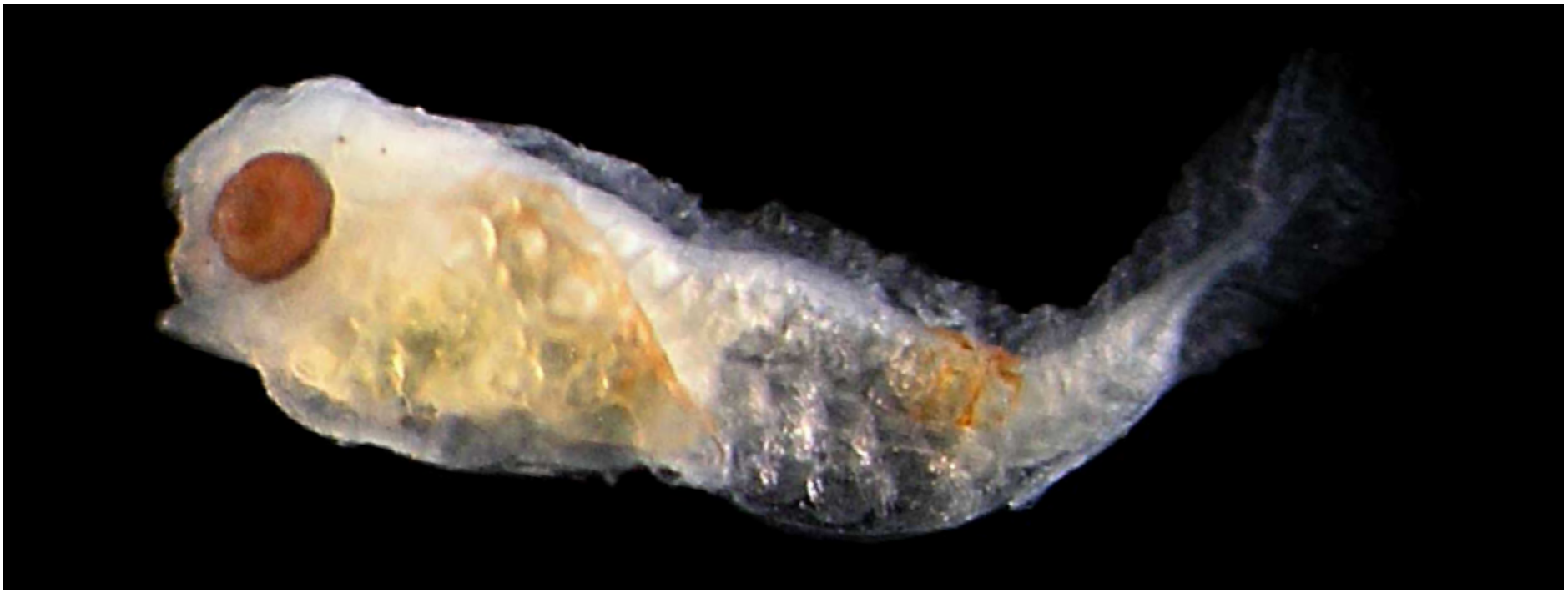

Figura 159 - A: Canthigaster rostrata. A. DZUFRJ 22509; Pré-flexão; 2,0 mm.

\section{Canthigaster rostrata (Bloch, 1786)}

O corpo é arredondado e pouco comprimido lateralmente. As larvas no estágio de pré-flexão já possuem espinhos distribuídos por todo corpo. As espécies podem ser separadas pelo número de raios nas nadadeiras. A dorsal é formada por dez raios e a anal por nove raios. Desde a pré-flexão apresenta uma faixa vertical de pigmentos, entre os miômeros 12 e 15. Com o desenvolvimento, uma banda horizontal se forma no corpo, desde a margem ventral da nadadeira caudal até a base da nadadeira anal. Possui um total de 17 vértebras.

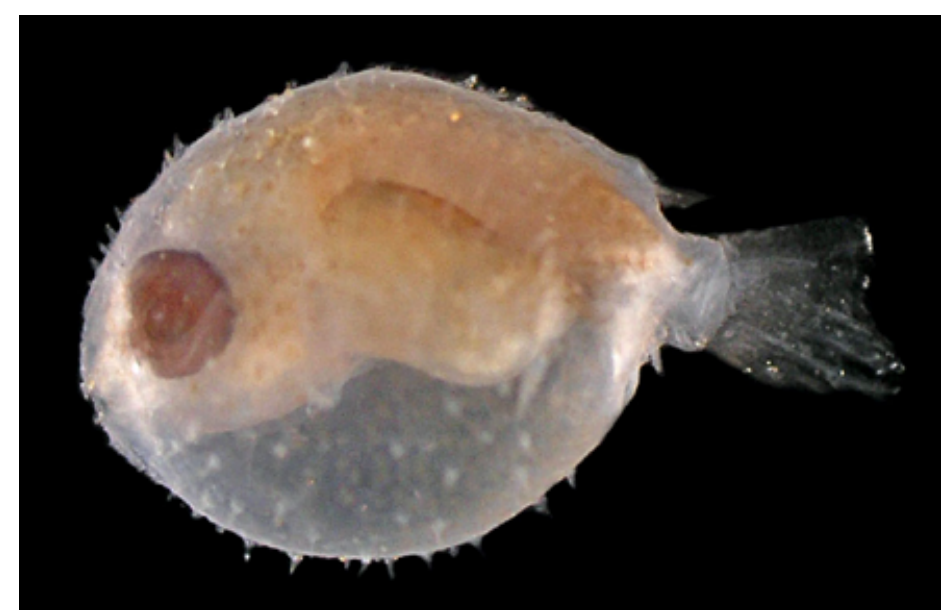

Figura 159 - B: DZUFRJ 5504; Flexão; CP 7,0 mm.

Tamanho: pré-flexão 2,0 mm; flexão 7,0 mm.

Habitat: espécie marinha, demersal, associada a formações coralinas, ocorre até $40 \mathrm{~m}$ de profundidade.

Nome vulgar: Baiacu.

\section{Georreferenciamento}

\begin{tabular}{|c|c|c|c|c|c|c|c|c|}
\hline DZUFRJ & Latitude (S) & Longitude (W) & Data & $\begin{array}{c}\text { Tipo de } \\
\text { arrasto }\end{array}$ & $\begin{array}{c}\text { Profundidade } \\
\text { de coleta }\end{array}$ & Rede & $\begin{array}{c}\text { Malha } \\
\text { ( } \boldsymbol{\mu m})\end{array}$ & $\begin{array}{c}\mathbf{N}^{\circ} \text {. de } \\
\text { inds. }\end{array}$ \\
\hline 5503 & $22^{\circ} 31^{\prime} 40,9^{\prime \prime}$ & $040^{\circ} 02^{\prime} 39,6^{\prime \prime}$ & $07 / 11 / 2001$ & oblíquo & $1.000 \mathrm{~m}$ & cilíndrico-cônica & 500 & 1 \\
\hline 5504 & $22^{\circ} 32^{\prime} 50,0^{\prime \prime}$ & $040^{\circ} 04^{\prime} 09,9^{\prime \prime}$ & $06 / 11 / 2001$ & oblíquo & $1.000 \mathrm{~m}$ & cilíndrico-cônica & 500 & 1 \\
\hline 22509 & $22^{\circ} 32^{\prime} 03,0^{\prime \prime}$ & $040^{\circ} 17^{\prime} 21,0^{\prime \prime}$ & $19 / 05 / 2002$ & oblíquo & $30 \mathrm{~m}$ & bongô & 330 & 2 \\
\hline
\end{tabular}

Referências: Figueiredo \& Menezes, 2000; Moura \& Castro, 2002; Shipp, 2002; Barros et al., 2006b; Lyczkowski-Shultz, 2006; Froese \& Pauly, 2014. 


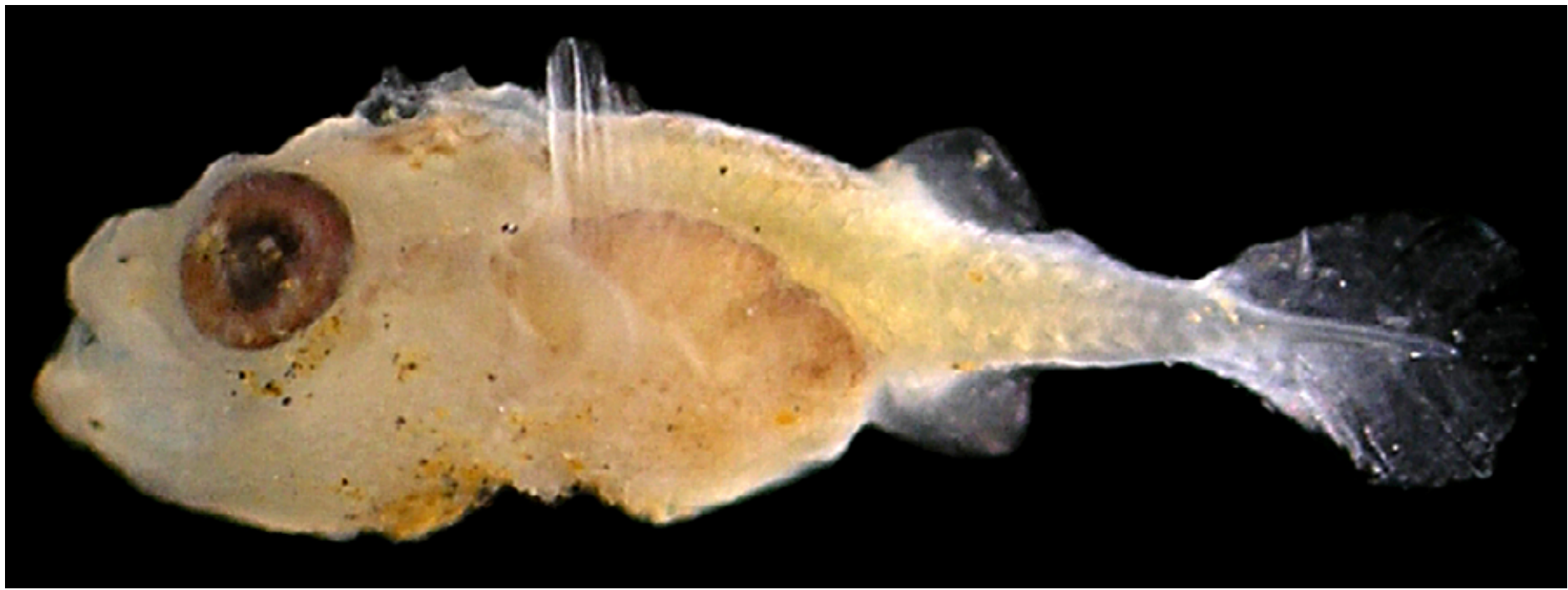

Figura 160 - A: Lagocephalus lagocephalus. DZUFRJ 430; Pré-flexão; CP 3,2 mm.

\section{Lagocephalus lagocephalus (Linnaeus, 1758)}

O corpo é arredondado e possui espinhos por toda região ventral. As nadadeiras dorsal e anal estão situadas na região posterior do corpo. Possui melanóforos espalhados pela região dorso-lateral do corpo e do trato digestório desde o estágio de pré-flexão.

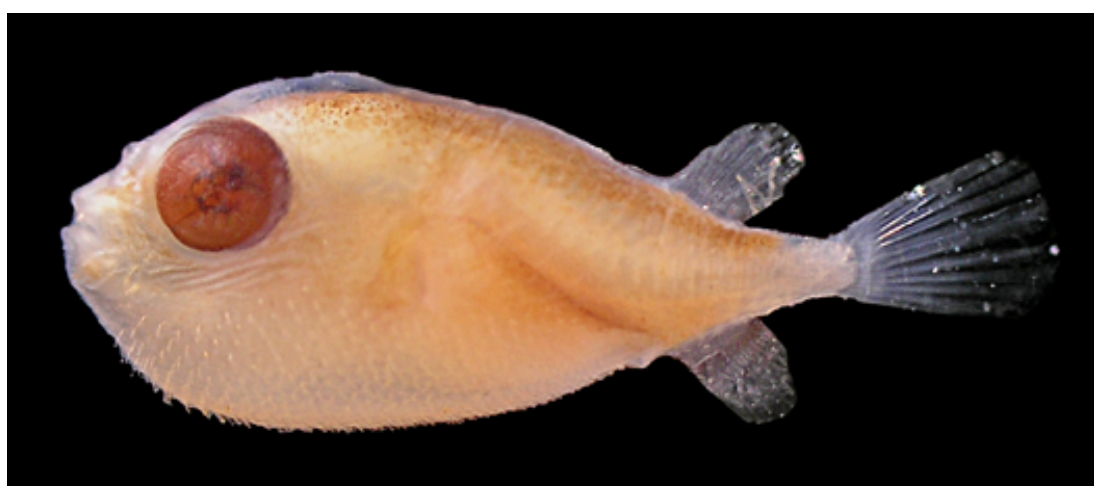

Figura 160 - B: DZUFRJ 7505; Flexão; CP 7,0 mm.

A pigmentação dorso-lateral se intensifica ao longo do desenvolvimento. Nadadeira dorsal: 13-16 raios; nadadeira caudal: 12-13 raios; nadadeira peitoral: 14-16 raios. Possui um total de 18 vértebras.

Tamanho: pré-flexão 1,8-3,2 mm; flexão 7,0-8,0 mm.

Habitat: espécie marinha, demersal, ocorre entre 10 e 476 m de profundidade.

Nome vulgar: Baiacu.

\section{Georreferenciamento}

\begin{tabular}{|c|c|c|c|c|c|c|c|c|}
\hline DZUFRJ & Latitude (S) & Longitude (W) & Data & $\begin{array}{c}\text { Tipo de } \\
\text { arrasto }\end{array}$ & $\begin{array}{c}\text { Profundidade } \\
\text { de coleta }\end{array}$ & Rede & $\begin{array}{c}\text { Malha } \\
\text { ( } \boldsymbol{\mu m})\end{array}$ & $\begin{array}{c}\mathbf{N}^{\circ} \text {. de } \\
\text { inds. }\end{array}$ \\
\hline 429 & $22^{\circ} 32^{\prime} 03,0^{\prime \prime}$ & $040^{\circ} 17^{\prime} 21,0^{\prime \prime}$ & $19 / 05 / 2002$ & oblíquo & $30 \mathrm{~m}$ & bongô & 330 & 2 \\
\hline 426 & $22^{\circ} 38^{\prime} 29,0^{\prime \prime}$ & $040^{\circ} 17^{\prime} 40,0^{\prime \prime}$ & $18 / 05 / 2002$ & oblíquo & $800 \mathrm{~m}$ & cilíndrico-cônica & 500 & 1 \\
\hline 427 & $22^{\circ} 31^{\prime} 27,0^{\prime \prime}$ & $040^{\circ} 16^{\prime} 56,0^{\prime \prime}$ & $17 / 05 / 2002$ & oblíquo & $600 \mathrm{~m}$ & cilíndrico-cônica & 500 & 1 \\
\hline 428 & $22^{\circ} 34^{\prime} 05,0^{\prime \prime}$ & $040^{\circ} 19^{\prime} 40,0^{\prime \prime}$ & $17 / 05 / 2002$ & oblíquo & $600 \mathrm{~m}$ & cilíndrico-cônica & 500 & 2 \\
\hline 430 & $22^{\circ} 33^{\prime} 37,0^{\prime \prime}$ & $040^{\circ} 19^{\prime} 10,0^{\prime \prime}$ & $17 / 05 / 2002$ & oblíquo & $50 \mathrm{~m}$ & bongô & 330 & 2 \\
\hline 5505 & $22^{\circ} 32^{\prime} 50,0^{\prime \prime}$ & $040^{\circ} 04^{\prime} 09,9^{\prime \prime}$ & $06 / 11 / 2001$ & oblíquo & $1.000 \mathrm{~m}$ & cilíndrico-cônica & 500 & 1 \\
\hline 7505 & $21^{\circ} 54^{\prime} 36,5^{\prime \prime}$ & $039^{\circ} 45^{\prime} 20,0^{\prime \prime}$ & $09 / 10 / 2001$ & oblíquo & $1.000 \mathrm{~m}$ & cilíndrico-cônica & 500 & 1 \\
\hline
\end{tabular}

Referências: Figueiredo \& Menezes, 2000; Shipp, 2002; Barros et al., 2006b; Lyczkowski-Shultz, 2006; Froese \& Pauly, 2009. 


\section{AGRADECIMENTOS}

À Ana Paula Falcão do Centro de Pesquisas e Desenvolvimento Leopoldo Américo Miguez de Mello (Cenpes/Petrobras) que nos convidou para participar do Projeto de Caracterização Ambiental de Águas Profundas da Bacia de Campos. Ao Dr. Willian D. Anderson Jr. pela confirmação da identificação das larvas de Symphysanodontidae. Ao biólogo Pedro de Freitas Carvalho pelas fotografias das larvas de peixes. Aos técnicos Cláudio de Souza Ressur e José Ribamar Santos Silva pelo auxílio na triagem do material ictioplanctônico. Ao MSc. Eduardo Gomes pelo auxílio na identificação das larvas de Gobiidae e Microdesmidae. Ao Dr. Sérgio Bonecker pelo apoio e incentivo. Gostaríamos de fazer um agradecimento especial a toda equipe do Laboratório Integrado de Zooplâncton e Ictioplâncton (LIZI) do Departamento de Zoologia do Instituto de Biologia da Universidade Federal do Rio de Janeiro pela amizade. 


\section{Glossário}

B

Barbilhão - projeção sensorial estreita que se origina na maxila inferior.

\section{C}

$\boldsymbol{c} \boldsymbol{a}$ - aproximadamente, cerca de.

Cleitro - osso alongado verticalmente localizado na junção da cabeça com o tronco do peixe.

Comprimento padrão - distância da extremidade do focinho até a margem vertical posterior da placa hipural.

Crista parietal - Crista localizada na cabeça na região parietal. Os ossos parietais são um par de ossos que formam a parede lateral e superior do crânio. É uma das principais características para identificação da família Scorpaenidae.

Crista supraoccipital - Crista óssea localizada posteriormente no topo da cabeça.

Crista supraopercular - crista óssea localizada sobre o opérculo (ex. Família Syngnathidae).

\section{D}

Distância pré-anal - distância da extremidade do focinho até a margem posterior do ânus.

$\mathbf{F}$

Fotóforo - pequenos órgãos que produzem luz localizados na cabeça e no corpo de alguns grupos de peixes (ex. Família Myctophidae).

\section{I}

Illicium - espinho da nadadeira dorsal, semelhante a um tentáculo, localizado no focinho da maioria dos peixes da ordem Lophiiformes.

Istmo - região ventral da cabeça, abaixo das brânquias, conectando as regiões abaixo da maxila inferior e cleitral.

\section{M}

Maxila - ossos que formam a boca do peixe, formado pela maxila superior ou somente maxila e pela maxila inferior ou mandíbula.

Melanóforo - célula que contém pigmento de melanina marrom ou preto.

Membrana embrionária - membrana que envolve o corpo da larva durante os estágios iniciais de desenvolvimento e na qual as nadadeiras dorsal, anal e caudal se desenvolvem.

Meninge - membrana que cobre a região do cérebro.

Miômero - segmentos de músculos do corpo que ocorrem em série, aproximadamente em mesmo número que as vértebras nos indivíduos adultos.

Miossepto - tecido conectivo entre os miômeros adjacentes.

$\mathbf{N}$

Nefro - rim. O local onde o nefro termina (miômero nefrítico) é uma característica importante na identificação das leptocephali.

Notocorda - estrutura cartilaginosa longitudinal que suporta o eixo do corpo.
0

Ossos hipurais - uma série de ossos derivados dos ossos dos espinhos hemais (espinhos medianos na superfície central do corpo da vértebra) da última vértebra que suporta os principais raios da nadadeira caudal.

$\mathbf{P}$

Palato - região superior interna da boca.

Pigmentos peritoneais - pigmentos localizados na região do corpo associada ao intestino ou a membrana do peritôneo.

Pré-opérculo - osso anterior mais superior da cobertura das brânquias, frequentemente com uma série de espinhos.

Pterigióforos - elementos cartilaginosos ou ósseos que formam a base da nadadeira e sustentam os raios de um peixe.

$\mathbf{R}$

Raio occipital - raio (suporte segmentado da nadadeira) localizado sobre o topo da cabeça (ex. Família Bregmacerotidae).

Região gular - região ventral da cabeça, anterior ao istmo e abaixo da maxila inferior. cinho.

Rostro - prolongamento do focinho, extremidade do fo-

\section{$S$}

Sínfise da maxila - junção ventral das maxilas.

\section{$\mathbf{T}$}

Tecido coroide - massa de tecido vascular primordial que apresenta várias formas e está localizado abaixo do olho. Normalmente está presente em olhos elípticos e apresenta pigmentação (ex. Myctophidae).

V

Vesícula gasosa - saco cheio de gás localizado abaixo da coluna, na região abdominal.

Vexilo - raio dorsal anterior alongado modificado em larvas da família Carapidae. 


\section{REFERÊNCIAS}

ALMEIDA, E.M., 2001. Estrutura da população, crescimento e reprodução de Maurolicus stehmanni Parin \& Kobyliansky, 1993 (Teleostei: Sternoptychidae) na Zona Econômica Exclusiva do Sul e Sudeste do Brasil. Dissertação de Mestrado. Universidade de São Paulo. 115 p.

AMBROSE, D.A., 1996a. Paralepididae: Barracudinas. In: MOSER, H.G. (Ed.). The Early Stages of Fishes in the California Current Region. La Jolla, Calcofi, Atlas n 33, p. 352-367.

AMBROSE, D.A., 1996b. Anotopteridae: Daggertooth. In: MOSER, H.G. (Ed.). The Early Stages of Fishes in the California Current Region. La Jolla, Calcofi, Atlas n 33, p. 369-371.

AMBROSE, D.A., 1996c. Coryphaenidae: Dolphinfishes. In: MOSER, H.G. (Ed.). The Early Stages of Fishes in the California Current Region. La Jolla, Calcofi. Atlas n³3, p. 959-963.

AMBROSE, D.A., 1996d. Gempylidae: Snake Mackerels. In: MOSER, H.G. (Ed.). The Early Stages of Fishes in the California Current Region. La Jolla, Calcofi. Atlas n 33, p. 1258-1269.

AMBROSE, D.A., 1996e. Scombridae: Mackerels \& Tunas. In: MOSER, H.G. (Ed.). The Early Stages of Fishes in the California Current Region. La Jolla, Calcofi. Atlas n 33, p. 1270-1285.

ANDERSON, W.D. Jr., 2003. Symphysanodontidae. In: CARPENTER, K.E. (Ed.). The Living Marine Resources of the Western Central Atlantic. Bony Fishes Part 1 (Acipenseridae to Grammatidae). FAO, p. 1304-1307.

ANDERSON, W.D. Jr.; SPRINGER, V.G., 2005. Review of the perciform fish genus Symphysanodon Bleeker (Symphysanodontidae), with descriptions of three new species, S. mona, S. parini, and S. rhax. Zootaxa v. 996, p. 1-44.

ARAÚJO, F.G.; SANTOS, A.C. de A., 1999. Distribution and recruitment of Mojarras (Perciformes, Gerreidae) in the continental margin of Sepetiba Bay, Brazil. Bulletin of Marine Science, n. 2, p. 431-439.

BADCOCK, J.; BAIRD, R.C., 1980. Remarks on systematics, development, and distribution of the hatchetfish genus Sternoptyx (Pisces, Stomiatoidei). Fishery Bulletin, v. 77, n. 4, p. 803-820.

BALDWIN, C.C.; SMITH, D.G., 2003. Larval Gobiidae (Teleostei: Perciformes) of Carrie Bow Cay, Belize, Central America. Bulletin of Marine Science, v. 72, p. 639-674.

BARROS, F.B.A.G.; CASTRO, M.S.; BONECKER, A.C.T., 2006a. Syngnathiformes. In: BONECKER, A.C.T.; CASTRO, M.S. (Eds) Atlas de larvas de peixes da região central da Zona Econômica Exclusiva brasileira. p. 167-175.

BARROS, F.B.A.G.; CASTRO, M.S.; BONECKER, A.C.T., 2007. Description and distribution of the larvae of two species of Fistulariidae (Teleostei, Syngnathiformes) in the southeastern Brazil. Biota neotropica, v.7, n. 1, p. 105-108.

BARROS, F.B.A.G.; NAMIKI, C.A.; CASTRO, M.S., 2006b. Tetraodontiformes. In: BONECKER, A.C.T.; CASTRO, M.S. (Eds.) Atlas de larvas de peixes da região central da Zona Econômica Exclusiva brasileira. Museu Nacional. p. 191-202.

BERTELSEN, E.; KREFFT, G.; MARSHALL, N. B., 1976. The fishes of the family Notosudidae. Dana-Report Carlsberg Foundation. v. 86, p. 1-114.

BOND, G.W. Jr.; TIGHE, K.A., 1974. A diagnostic character for rapid identification of lightly pigmented species of the genus Cyclothone (Gonostomatidae) in the North Atlantic. Copeia, v. 1974, n.1, p. 272-275.

BONECKER, A.C.T.; BONECKER, F.T.; BARROS, F.B.A.G., 2006. Beryciformes. In: BONECKER, A.C.T.; CASTRO, M.S. (Eds.) Atlas de larvas de peixes da região central da Zona Econômica Exclusiva brasileira. Museu Nacional. p. 161-165.

BONECKER, A.C.T.; CASTRO, M.S. (Eds.), 2006. Atlas de larvas de peixes da região central da Zona Econômica Exclusiva brasileira. Museu Nacional. 214 p.

BONECKER, A.C.T.; KATSURAGAWA, M.; CASTRO, M.S.; GOMES, E.A.P.; NAMIKI, C.A.P.; ZANI-TEIXEIRA, M.L., 2013. Larval fish of the Campos Basin, southeastern Brazil. Check List. V. 8, n. 6, p. 1280-1292. 
BONECKER, F.T.; BONECKER, A.C.T.; CASTRO, M.S.; NAMIKI, C.A.; BARROS, F.B.A.G., 2006a. Stomiiformes. In: BONECKER, A.C.T.; CASTRO, M.S. (Eds.) Atlas de larvas de peixes da região central da Zona Econômica Exclusiva brasileira. Museu Nacional. p. 75-98.

BONECKER, F.T.; NAMIKI, C.A.; CASTRO, M.S.; 2006b. Aulopiformes. In: BONECKER, A.C.T.; CASTRO, M.S. (Eds.) Atlas de larvas de peixes da região central da Zona Econômica Exclusiva brasileira. Museu Nacional. p. 99-121.

BURGESS, W.E., 2002a. Perciformes: Percoidei: Chaetodontidae: Butterflyfishes. In: CARPENTER, K.E. (Ed.). The living marine resources of the Western Central Atlantic. Rome: FAO. p. 1663-1672.

BURGESS, W.E., 2002b. Perciformes: Percoidei: Pomacanthidae: Angelfishes. In: CARPENTER, K.E. (Ed.). The living marine resources of the Western Central Atlantic. Rome: FAO. p. 1673-1678.

CAMPOS, P.N.; BONECKER, A.C.T.; de CASTRO, M.S., 2008. Pisces, Melamphaidae, Poromitra capito Goode \& Bean, 1883 and Melamphaes simus Ebeling, 1962: Distribution extension to the western South Atlantic Ocean. Check List, v. 4, n. 3, p. $275-278$.

CARTER, J.A., 2002. Perciformes: Labroidei: Pomacentridae: Damselfishes. In: CARPENTER, K.E. (Ed.). The living marine resources of the Western Central Atlantic. Rome: FAO. p. 1694-1700.

CASTRO, M.S.; BONECKER, A.C.T., 2005. Leptocephali collected off the eastern coast of Brazil (12 S-23오. Zootaxa 935, p. 1-28.

CASTRO, M.S.; BONECKER, A.C.T., 2006a. Anguilliformes. In: Bonecker, A.C.T.; Castro, M.S. (Eds.) Atlas de larvas de peixes da região central da Zona Econômica Exclusiva brasileira. Museu Nacional. p. 39-74.

CASTRO, M.S.; BONECKER, A.C.T., 2006b. Distribution of larval Stomiidae of the Brazilian central coast, southwest Atlantic Ocean $\left(12^{\circ} \mathrm{S}-22^{\circ} \mathrm{S}\right)$. Zootaxa 1236, p. 23-36.

CASTRO, M.S.; BONECKER, A.C.T., 2006c. Myctophiformes. In: Bonecker, A.C.T.; Castro, M.S. (Eds.) Atlas de larvas de peixes da região central da Zona Econômica Exclusiva brasileira. Museu Nacional. p. 123-152.

CIECHOMSKI, J.D., 1965. Observaciones sobre la reproducción, desarrollo embrionário y larval de la anchoíta argentina (Engraulis anchoita). Boletin del Instituto de Biologia Marina, n. 9, p. 1-29.

COLLETTE, B.B., 2002a. Perciformes: Percoidei: Pomatomidae: Bluefishes. In: CARPENTER, K.E. (Ed.). The living marine resources of the Western Central Atlantic. Rome: FAO. p. 1412-1413.

COLLETTE, B.B., 2002b. Perciformes: Scombroidei: Scombridae: Mackerels and tunas. In: CARPENTER, K.E. (Ed.). The living marine resources of the Western Central Atlantic. Rome: FAO. p. 1836-1848.

COLLETTE, B.B., 2006. Hemiramphidae: Halfbeaks. In: RICHARDS, W.J. (Ed.). Early Stages of Atlantic Fishes: An Identification Guide for the Western Central North Atlantic. Taylor \& Francis Group. p. 933-954.

COMYNS, B.H.; BOND, P.J., 2006. Phycidae: Phycid hakes. In: RICHARDS, W.J. (Ed.). Early Stages of Atlantic Fishes: An Identification Guide for the Western Central North Atlantic. Taylor \& Francis Group. p. 639-656.

COTTON, N.; COMYNS, B.H., 2006. Exocoetidae: Flyingfishes. In: RICHARDS, W.J. (Ed.). Early Stages of Atlantic Fishes: An Identification Guide for the Western Central North Atlantic. Taylor \& Francis Group. p. 955-990.

CRIALES, M.M., 2006. Cirrhitidae: Hawkfishes. In: RICHARDS, W.J. (Ed.). Early Stages of Atlantic Fishes: An Identification Guide for the Western Central North Atlantic. Taylor \& Francis Group. p. 1823-1826.

DAWSON, C.E.; VARI, R.P., 1982. Order Gasterosteiformes, Suborder Syngnathoidei. Syngnathidae (Doryrhamphinae, Synganthinae, Hippocampinae). In: BÖHLKE, J.E.; COHEN, D.M.; COLLETE, B.B.; ESCHMEYER, W.N.; GIBBS Jr., R.H.; PIETSCH, T.W.; RICHARDS, W.J.; SMITH, C.L.; THOMSON, K.S. (Eds.). Fishes of the Western North Atlantic. Memoir Sears Foundation for Marine Research. n.1 pt. 8, 198 p.

DITTY, J.G., 2006a. Scopelarchidae: Pearleyesfishes. In: RICHARDS, W.J. (Ed.) Early Stages of Atlantic Fishes: An Identification Guide for the Western Central North Atlantic. Taylor \& Francis Group. p. 429-442.

DITTY, J.G., 2006b. Paralepididae. In: RICHARDS, W.J. (Ed.). Early Stages of Atlantic Fishes: An Identification Guide for the Western Central North Atlantic. Taylor \& Francis Group. p. 385-428. 
DITTY, J.G., 2006c. Evermannellidae. In: RICHARDS, W.J. (Ed.). Early Stages of Atlantic Fishes: An Identification Guide for the Western Central North Atlantic. Taylor \& Francis Group. p. 375-384.

DITTY, J.G., 2006d. Coryphaenidae: Dolphinfishes. In: RICHARDS, W.J. (Ed.). Early Stages of Atlantic Fishes: An Identification Guide for the Western Central North Atlantic. Taylor \& Francis Group. p. 1511-1516.

DITTY, J.G., 2006e. Pomatomidae: Bluefishes. In: RICHARDS, W.J. (Ed.). Early Stages of Atlantic Fishes: An Identification Guide for the Western Central North Atlantic. Taylor \& Francis Group. p. 1425-1428.

DITTY, J.G.; FAROOQI, T.; SHAW, R.F., 2006a. Order Aulopiformes: Aulopidae \& Synodontidae (Suborder Synodontoidei). In: RICHARDS, W.J. (Ed.). Early Stages of Atlantic Fishes: An Identification Guide for the Western Central North Atlantic. Taylor \& Francis Group. p. 301-324.

DITTY, J.G.; FAROOQI, T.; SHAW, R.F., 2006b Mullidae: Goatfishes. In: RICHARDS, W.J. (Ed.). Early Stages of Atlantic Fishes: An Identification Guide for the Western Central North Atlantic. Taylor \& Francis Group. p. 1731-1744.

DITTY, J.G.; FAROOQI, T.; SHAW, R.F., 2006c Mugilidae: Mullets. In: RICHARDS, W.J. (Ed.). Early Stages of Atlantic Fishes: An Identification Guide for the Western Central North Atlantic. Taylor \& Francis Group. p. 891-900.

DITTY, J.G.; KILFOYLE, K.; FAROOQI, T.; SHAW, R.F., 2006d. Order Syngnathiformes: Families Aulostomidae, Centriscidae, Fistulariidae. In: RICHARDS, W.J. (Ed.). Early Stages of Atlantic Fishes: An Identification Guide for the Western Central North Atlantic. Taylor \& Francis Group. p. 1121-1123.

DITTY, J.G.; SHAW, R.F.; COPE, J.S., 2004. Distribution of carangid larvae (Teleostei: Carangidae) and concentrations of zooplankton in the northern Gulf of Mexico, with illustrations of early Hemicaranx amblyrhynchus and Caranx spp. Larvae. Marine Biology v.145, p. 1001-1014.

DITTY, J.G.; SHAW, R.F.; FAROOQI, T.W., 2006. Sphyraenidae: Barracudas. In: RICHARDS, W.J. (Ed.). Early Stages of Atlantic Fishes: An Identification Guide for the Western Central North Atlantic. Taylor \& Francis Group. p. 2135-2148.

ESCHMEYER, W.N. Catalog of Fishes. Disponível em http://www.calacademy.org/research/ichthyology/catalog/. Acesso em $24 / 01 / 2014$.

FAHAY, M.P., 1983. Guide to the Early Stages of Marine Fishes Occurring in the Western North Atlantic Ocean, Cape Hatteras to the Southern Scotian Shelf. Journal of Northwest Atlantic Fishery Science, v. 4, p. 1-423.

FAHAY, M.P., 2007. Early Stages of Fishes in the Western North Atlantic Ocean (Davis Strait, Southern Greenland and Flemish Cap to Cape Hatteras). Northwest Atlantic Fisheries Organization. 1696 p.

FAHAY, M.P.; HARE, J.A., 2006. Order Ophidiiformes, Aphyonidae, Bythitidae, Ophidiidae. In: RICHARDS, W.J. (Ed.). Early Stages of Atlantic Fishes: An Identification Guide for the Western Central North Atlantic. Taylor \& Francis Group, v.1, p. $661-748$.

FIGUEIREDO, J.L.; MENEZES, N.A., 1980. Manual de Peixes Marinhos do Sudeste do Brasil. III. Teleostei (2). Museu de Zoologia da Universidade de São Paulo, São Paulo. 90 p.

FIGUEIREDO, J.L.; MENEZES, N.A., 2000. Manual de Peixes Marinhos do Sudeste do Brasil. VI. Teleostei (5). Museu de Zoologia da Universidade de São Paulo, São Paulo. 116 p.

FRANCO, M.A.L.; COSTA, P.A.S.; BRAGA, A.C. 2007. New records of Aphyonidae (Teleostei: Ophidiiformes) from the south-western Atlantic. Journal of Fish Biology, v. 71, p. 908-912.

FREIRE, K.M.F.; CARVALHO-FILHO, A. 2009. Richness of common names of Brazilian reef fishes. Pan-American Journal of Aquatic Sciences v. 4, p. 96-145.

FRIAS-TORRES, S., 2006a. Melamphaidae: Bigscale fishes or ridgeheads. In: RICHARDS, W.J. (Ed.). Early Stages of Atlantic Fishes: An Identification Guide for the Western Central North Atlantic. Taylor \& Francis Group. p. 1067-1074.

FRIAS-TORRES, S., 2006b. Syngnathidae: Seahorses \& pipefishes In: RICHARDS, W.J. (Ed.) Early Stages of Atlantic Fishes: An Identification Guide for the Western Central North Atlantic. Taylor \& Francis Group. p. 1133-1138.

FRICKE, R., 2002. Perciformes: Perciformes: Callionymoidei: Callionymidae Dragonets. In: CARPENTER, K.E. (Ed.). The living marine resources of the Western Central Atlantic. Rome: FAO. p. 3549-3566. 
FROESE, R.; PAULY, D. (Eds.), 2014. Disponível em FishBase (World Wide Web electronic publication). www.fishbase.org, version. Acesso em 23/01/2014.

GARCIA, M.L.; C.C. MORGAN., 2002. Poromitra crassiceps (Teleostei, Melamphaidae) associated with the 500 fathoms fauna off Argentina. Journal of Applied Ichthyology v. 18, p. 216-218.

GASPARINI, J.L.; ROCHA, L.A.; FLOETER, S.R., 2001. Ptereleotris randali n. sp., a new dartfish (Gobioidei, Microdesmidae) from the Brazilian Coast. Journal of Ichthyology and Aquatic Biology, v. 4, n. 3, p. 109-114.

GILMORE JR., R.G.; GREENFIELD, D.W., 2002. Perciformes: Percoidei: Gerreidae: Mojarras. In: CARPENTER, K.E. (Ed.). The living marine resources of the Western Central Atlantic. Rome: FAO. p. 1506-1513.

GOMES, E.A.P.; BONECKER, A.C.T., 2014. Larval Description of Ptereleotris randalli Gasparini, Rocha \& Floeter, 2001 (Teleostei, Perciformes: Ptereleotridae) from the Western South Atlantic Ocean. Zootaxa. In press.

GREY, M., 1964. Family Gonostomatidae. In: BIGELOW, H.B.; BREDER, C.M.; COHEN, D.M.; MEAD, G.W.; MERRIMAN, D.; OLSEN, Y.H.; SCHROEDER, W.C.; SCHULTZ, L.P.; TEE-VAN, J. (Eds.). Fishes of the Western North Atlantic. Memoir Sears Foundation for Marine Research, $\mathrm{n}^{\circ} 1$ Pt. 4. p. 79-240.

HARDY, J.D., 2006a. Scorpaenidae: Scorpionfishes. In: RICHARDS, W.J. (Ed.) Early Stages of Atlantic Fishes: An Identification Guide for the Western Central North Atlantic. Taylor \& Francis Group. p. 1141-1179.

HARDY, J.D., 2006b. Symphysanodontidae: Bunguelovelies, wampeejawedfishes, shelf beauties, slopefishes. In: RICHARDS, W.J. (Ed.). Early Stages of Atlantic Fishes: An Identification Guide for the Western Central North Atlantic. Taylor \& Francis Group. p. $1337-1340$.

HARDY, J.D., 2006c. Chiasmodontidae: Swallowers. In: RICHARDS, W.J. (Ed.). Early Stages of Atlantic Fishes: An Identification Guide for the Western Central North Atlantic. Taylor \& Francis Group. p. 1901-1916.

HARDY, J.D; COLLETTE, B.B., 2006. Scomberesocidae: Sauries. In: RICHARDS, W.J. (Ed.). Early Stages of Atlantic Fishes: An Identification Guide for the Western Central North Atlantic. Taylor \& Francis Group. p. 905-908.

HARE, J.A.; MARANCIK, K.E.; GREENE, M.D., 2006. Bregmacerotidae: Codlets, Unicorn cods. In: RICHARDS, W.J. (Ed.) Early Stages of Atlantic Fishes: An Identification Guide for the Western Central North Atlantic. Taylor \& Francis Group. p. 583-594.

HAROLD, N.A.S.; BALTZEGAR, D.A., 2003. A new widely distributed species of Bregmaceros (Teleostei: Bregmacerotidae) from the Atlantic Ocean. 2003 Joint Meeting of Icthyologists and Herpetologists, de 26/06 a 01/07/2003, Manaus (Brasil). (Em resumo).

HEEMSTRA, P.C., 2002. Perciformes: Percoidei: Acropomatidae Temperate ocean-basses. In: CARPENTER, K.E. (Ed.). The living marine resources of the Western Central Atlantic. Rome: FAO. p. 1299-1303.

HEEMSTRA, P.C.; RANDALL, J.E., 2002. Perciformes: Percoidei: Serranidae: Groupers and sea basses (also, soapfishes, anthiines, etc.). In: CARPENTER, K.E. (Ed.). The living marine resources of the Western Central Atlantic. Rome: FAO. p. $2442-2473$.

HOUDE, E.D., 1981. Distribution and abundance of four types of codlet (Pisces: Bregmacerotidae) larvae from the Eastern Gulf of Mexico. Biological Oceanography, v. 1, n. 1, p. 81-104.

HOUDE E.D., 1984. Bregmacerotidae: Development and relationships. In: MOSER, H.G.; RICHARDS, W.J.; COHEN, D.M.; FAHAY, M.P.; KENDALL Jr., A.W.; RICHARDSON, S.L. (Ed.). Ontogeny and Systematics of Fishes. American Society Ichthyologists and Herpetologists, Special Publication. v. 2, p. 300-308.

JACKSON, T.L., 2006a. Antennariidae: Anglerfishes, frogfishes. In: RICHARDS, W.J. (Ed.). Early Stages of Atlantic Fishes: An Identification Guide for the Western Central North Atlantic. Taylor \& Francis Group. p. 783-790.

JACKSON, T.L., 2006b. Acanthuridae: Surgeonfish, doctor fish, tang. In: RICHARDS, W.J. (Ed.). Early Stages of Atlantic Fishes: An Identification Guide for the Western Central North Atlantic. Taylor \& Francis Group. p. 2119-2132.

JIMENEZ-ROSENBERG, S.P.A.; GONZALEZ-NAVARRO, E.A.; SALDIERNA-MARTINEZ, R.J., 2006. Larval, prejuvenile and juvenile development of Eucinostomus currani. Journal of Fish Biology, n. 69, p. 28-37.

JOHNSON, R.K., 1974. A Revision of the Alepsauroid Family Scopelarchidae (Pisces: Myctophiformes). Fieldiana. Zoology. Museum of Natural History, v. 66, p. 1-249. 
JONES, D.L.; LARA, M.R.; W.J. RICHARDS., 2006a. Labridae: Wrasses. In: RICHARDS, W.J. (Ed.). Early Stages of Atlantic Fishes: An Identification Guide for the Western Central North Atlantic. Taylor \& Francis Group. p. 1835-1872.

JONES, D.L.; LARA, M.R.; RICHARDS, W.J., 2006b. Scaridae: Parrotfishes. In: RICHARDS, W.J. (Ed.). Early Stages of Atlantic Fishes: An Identification Guide for the Western Central North Atlantic. Taylor \& Francis Group. p.1873-1892.

KATSURAGAWA, M.; MATSUURA, Y., 1992. Distribution and Abundance of carangid larvae in the southeastern Brazilian Bight during 1975-1981. Boletim do Instituto Oceanográfico, São Paulo, v.40, n.1, p. 155-78.

KELLY, S., 2006a. Chaetodontidae: Butterflyfishes. In: RICHARDS, W.J. (Ed.). Early Stages of Atlantic Fishes: An Identification Guide for the Western Central North Atlantic. Taylor \& Francis Group. p. 1763-1766.

KELLY, S., 2006b. Pomacanthidae. In: RICHARDS, W.J. (Ed.). Early Stages of Atlantic Fishes: An Identification Guide for the Western Central North Atlantic. Taylor \& Francis Group. p. 1767-1786.

KENDALL, A.W.; AHLSTROM, E.H.; MOSER, H.G., 1984, Early Life History Stages of Fish and their Characters. In: MOSER, H.G.; RICHARDS, W.J.; COHEN, D.M.; FAHAY, M.P.; KENDALL Jr., A.W.; RICHARDSON, S.L. (Eds.). Ontogeny and Systematics of Fishes. American Society of Ichthyologists and Herpetologists, Special Publication n० 1. p. 11-22.

KOTLYAR, A.N., 2004. Family Melamphaidae Gill 1893 - bigscales. Bulletin of the Southern California Academy of Sciences. Annotated Checklists of Fishes. $n^{\circ} 29$.

KURTZ, F.W.; MATSUURA, Y., 1994. Early Development of Four Tonguefishes of the Genus Symphurus (Osteichthyes: Cynoglossidae) from the Southern Brazil. Japanese Journal of Ichthyology, v. 41 n. 2, p. 141-148.

LAMKIN, J.T., 2006. Nomeidae. In: RICHARDS, W.J. (Ed.). Early Stages of Atlantic Fishes: An Identification Guide for the Western Central North Atlantic. Taylor \& Francis Group. p. 2255-2272.

LARA, M.R., 2006a. Apogonidae: Cardinalfishes. In: RICHARDS, W.J. (Ed.). Early Stages of Atlantic Fishes: An Identification Guide for the Western Central North Atlantic. Taylor \& Francis Group. p. 1363-1400.

LARA, M.R., 2006b. Bothidae: Lefteye flounders. In: RICHARDS, W.J. (Ed). Early Stages of Atlantic Fishes: An Identification Guide for the Western Central North Atlantic. Taylor \& Francis Group. p. 2327-2344.

LAROCHE, W.A.; DITTY, J.G.; LAMKIN, J.T.; WHITCRAFT, S.R., 2006. Carangidae: Jacks. In: RICHARDS, W.J. (Ed.). Early Stages of Atlantic Fishes: An Identification Guide for the Western Central North Atlantic. Taylor \& Francis Group. p. 1439-1510.

LAST, P.R., 2002. Perciformes: Stromateoidei: Nomeidae: Driftfishes (cigarfishes). In: CARPENTER, K.E. (Ed.). The living marine resources of the Western Central Atlantic. Rome: FAO. p. 3771-3779.

LEIBY, M.M., 1989. Family Ophichthidae: Leptocephali. In: BÖHLKE, E.B. (Ed.). Fishes of the Western North Atlantic. Memoir Sears Foundation for Marine Research, n¹, Pt. 9: v. 2, p. 764-897.

LEIS, J.M.; RENNIS, D.S., 1983. The Larvae of Indo-Pacific Coral Reef Fishes. New South Wales University Press. Sidney, 269 p.

LEIS, J.M.; RICHARDS, W.J., 1984. Acanthuroidei: development and relationships. In: MOSER, H.G.; RICHARDS, W.J.; COHEN, D.M.; FAHAY, M.P.; KENDALL, A.W. Jr.; RICHARDSON, S.L. (Eds.) Ontogeny and systematics of fishes. American Society of Ichthyologists and Herpetologists., Special Publication n¹, p. 547-551.

LEIS, J.M.; TRNSKI, T., 2000. Symphysanodontidae. In: LEIS, J.M.; CARSON-EWART, B. M. (Eds.). The Larvae of Indo-Pacific Coastal Fishes: An Identification Guide to Marine Fish Larvae, Brill, Leiden, p. 394-398.

LIMA, A.T., 2005. Os peixes da família Sternoptychidae (Teleostei, Stomiiformes) do talude e plataforma continental brasileira entre $11^{\circ} \mathrm{S}$ e $23^{\circ} \mathrm{S}$. Dissertação de Mestrado. Universidade Federal do Rio de Janeiro. $85 \mathrm{p}$.

LINDEMAN, K.C.; RICHARDS, W.J.; LYCZKOWSKI-SHULTZ, J.; DRASS, D. M.; PARIS, C.B.; LEIS, J.M.; LARA, M.; COMYNS B.H., 2006. Lutjanidae: Snappers. In: RICHARDS, W.J. (Ed.). Early Stages of Atlantic Fishes: An Identification Guide for the Western Central North Atlantic. Taylor \& Francis Group. p. 1225-1334.

LUIZ-JÚNIOR, O.J.; FLOETER, S.R.; GASPARINI, J.L.; FERREIRA, C.E.L.; WIRTZ, P., 2004. The occurrence of Acanthurus monroviae (Perciformes: Acanthuridae) in the south-western Atlantic, with comments on other eastern Atlantic reef fishes occurring in Brazil. Journal of Fish Biology n. 65, p.1173-1179. 
LYCZKOWSKI-SHULTZ, J. 2006. Tetraodontidae: Puffers. In: RICHARDS, W. J. (Ed.). Early Stages of Atlantic Fishes: An Identification Guide for the Western Central North Atlantic. CRC Press, Boca Raton, Florida. v. 2, p. 2439-2448.

LYCZKOWSKI-SHULTZ, J.; BOND, P.J., 2006. Paralichthyidae: Sand flounders. In: RICHARDS, W.J. (Ed.). Early Stages of Atlantic Fishes: An Identification Guide for the Western Central North Atlantic. Taylor \& Francis Group. p. 2291-2336.

LYCZKOWSKI-SHULTZ, J.; KONIECZNA, M.; RICHARDS, W.J., 2000. Occurrence of the larvae of Beryciform fishes in the Gulf of México. Bulletin of the Sea Fisheries Institute. v. 151, n. 3, p. 55-65.

MACEDO, A.P.S.; MONTEIRO-RIBAS, W.M., 2006. Pleuronectiformes. In: BONECKER, A.C.T.; CASTRO, M.S. (Eds.) Atlas de larvas de peixes da região central da Zona Econômica Exclusiva brasileira. p. 176-190.

MARKLE, C.F.; OLNEY, J.E., 1990. Systematics of the Pearlfishes (Pisces, Carapidae). Bulletin of Marine Science, v. 47, n. 2, p. $269-410$.

MATSUURA, Y.; de SILVA, G.A.C., KATSURAGAWA, M.; SUZUKI K., 1993. Distribuition and abundance of two species of codlet (Teleostei, Bregmacerotidea) larvae from the South-Eastern of Brazilian Bight. Fisheries Oceanography, v. 2, n. 2, p. 82-90.

MATSUURA, Y.; SUZUKI, K. 1997. Larval development of two species of barracuda, Sphyraena guachancho and S. tome (Teleostei: Sphyraenidae), from the southeastern Brazil. Ichthyological Research, v.44, n. 4, p. 369-378.

McEACHRAN, J.D., 2002. Perciformes: Trachinoidei: Chiasmodontidae: Swallowers. In: CARPENTER, K.E. (Ed.). The living marine resources of the Western Central Atlantic. Rome: FAO. p.1742-1743.

MENEZES, N.A.; FIGUEIREDO, J.L., 1980. Manual de Peixes Marinhos do Sudeste do Brasil. IV. Teleostei (3). Museu de Zoologia, Universidade de São Paulo. 96 p.

MENEZES, N.A.; FIGUEIREDO, J.L., 1985. Manual de Peixes Marinhos do Sudeste do Brasil. V. Teleostei (4). Museu de Zoologia da Universidade de São Paulo, São Paulo. 106 p.

MENEZES, N. A.; BUCKUP, P. A.; FIGUEIREDO, J.L.; MOURA, R.L. 2003. Catálogo das espécies de peixes marinhos do Brasil. Museu de Zoologia da Universidade de São Paulo, São Paulo. 160 p.

MERRETT, N.R., 2006. Bathygadidae \& Macrouridae: Grenadiers. In: RICHARDS, W.J. (Ed.). Early Stages of Atlantic Fishes: An Identification Guide for the Western Central North Atlantic. Taylor \& Francis Group. p. 595-616.

MINCARONE, M.M.; NIELSEN, J.G.; COSTA, P.A.S. 2008. Deep-sea ophidiiform fishes collected on the Brazilian continental slope, between $11^{\circ}$ and $23^{\circ}$ S. Zootaxa, v. 1770, p. 41-64.

MIYA, M., 1994. Cyclothone kobayashii, a new gonostomatid fish (Teleostei: Stomiiformes) from the Southern Ocean, with notes on its ecology. Copeia. v. 1994, n.1, p. 191-204.

MONTEIRO-RIBAS, W.M.; BONECKER, A.C.T., 2001. Artificial fertilization and development in laboratory of Mugil liza (Valenciennes,1836) (Osteichthyes, Mugilidae). Bulletin of Marine Science, v. 68, n. 3, p. 427-433.

MORROW Jr., J.E., 1964a. Family Chauliodontidae. In: BIGELOW, H.B.; BREDER, C.M.; COHEN, D.M.; MEAD, G.W.; MERRIMAN, D.; OLSEN, Y.H.; SCHROEDER, W.C.; SCHULTZ, L.P.; TEE-VAN, J. (Eds.). Fishes of the Western North Atlantic. Memoir Sears Foundation for Marine Research, $n^{\circ} 1$, Pt. 4. p. 274-289.

MORROW Jr., J.E., 1964b. Family Stomiatidae. In: BIGELOW, H.B.; BREDER, C.M.; COHEN, D.M.; MEAD, G.W.; MERRIMAN, D.; OLSEN, Y.H.; SCHROEDER, W.C.; SCHULTZ, L.P.; TEE-VAN, J. (Eds.). Fishes of the Western North Atlantic. Memoir Sears Foundation for Marine Research, $\mathrm{n}^{\circ} 1$, Pt. 4, p. 290-310.

MOSER, H.G., 1996. Stomiidae: Scaly dragonfishes. In: MOSER, H.G. (Ed.). The Early Stages of Fishes in the California Current Region. La Jolla, Calcofi. Atlas n³3, p. 301-303.

MOSER, H.G.; AHLSTROM, E.H.; SANDKNOP, E.M., 1977. Guide to the identification of Scorpionfish larvae (Family Scorpaenidae) in the Eastern Pacific with comparative notes on species of Sebastes and Helicolenus from other oceans. NOAA Technical Report NMFS Circular 402. $71 \mathrm{p}$.

MOSER, H.G.; AHLSTROM, E.H., 1996. Myctophidae: Lanternfishes. In: MOSER. H.G. (Ed.) The early stages of fishes in the California Current Region. La Jolla, Calcofi, Atlas n³3, p. 387-475. 
MOSER, H.G.; MUNDY, B.C., 1996. Bramidae: Pomfrets. In: MOSER, H. G. (Ed.). The Early Stages of Fishes in the California Current Region.La Jolla, Calcofi. Atlas n³3, p. 964-971.

MOSER, H.G.; WATSON, W., 2006. Myctophidae. In: RICHARDS, W.J. (Ed.). Early Stages of Atlantic Fishes: An Identification Guide for the Western Central North Atlantic. Taylor \& Francis Group. p. 473-580.

MOURA, R.L.; CASTRO, R.M.C. 2002. Revision of Atlantic sharpnose pufferfishes (Tetraodontiformes: Tetraodontidae: Canthigaster), with description of three new species. Proceedings of the biological society of Washington, v. 115, n. 1, p. 32-50.

NAFPAKTITIS, B.G.; BACKUS, R.H.; CRADDOCK, J.E.; HAEDRICH, R.L.; ROBINSON, B.H.; KARNELLA, C., 1977. Family Myctophidae. In: GIBBS Jr., R.H. (Ed.). Fishes of the Western North Atlantic. Memoir Sears Foundation for Marine Research, n¹, Pt. 7, p. 13-287.

NAMIKI, C.A.P.; BONECKER, A.C.T., 2006. Ophidiiformes. In: BONECKER, A.C.T.; CASTRO, M.S. (Eds.) Atlas de larvas de peixes da região central da Zona Econômica Exclusiva brasileira. Museu Nacional. p. 153-155.

NAMIKI, C.; BONECKER, A.C.T.; CASTRO, M.S., 2007a. Occurrence and abundance of three larval codlet species (Bregmacerotidae, Teleostei) in the Southwest Atlantic Ocean (12-22 ${ }^{\circ}$ S). Journal of Applied Ichthyology, v. 23, p. 136-141.

NAMIKI, C.; BONECKER, A.C.T.; CASTRO, M.S., 2007b. Carapidae larvae (Acanthomorpha, Paracanthopterygii, Ophidiiformes) from the oceanic region of the southwest Atlantic Ocean off Brazil (12-22 S). Deep-Sea Research I, v. 54, p. $292-295$.

NAMIKI, C.A.P.; BONECKER, A.C.T.; MONTEIRO-RIBAS, W.M., 2006. Gadiformes. In: BONECKER, A.C.T.; CASTRO, M.S. (Eds.) Atlas de larvas de peixes da região central da Zona Econômica Exclusiva brasileira. Museu Nacional. p. 157-60.

NELSON, J.R. 2006. Fishes of the World. John Wiley \& Sons. $4^{\text {a }}$ edição. 601 p.

OLIVAR, M.P.; FORTUÑO, J.M., 1991. Guide to Ichthyoplankton of the Southeast Atlantic (Benguela Current Region). Science Marine, v. 55, n. 1, p. 1-383.

OLNEY, J.E., 2006a. Trachipteridae: Dealfishes, Ribbonfishes. In: RICHARDS, W.J. (Ed.) Early Stages of Atlantic Fishes: An Identification Guide for the Western Central North Atlantic. Taylor \& Francis Group. p. 1019-1026

OLNEY, J.E., 2006b. Carapidae: Pearlfishes. In: RICHARDS, W.J. (Ed.) Early Stages of Atlantic Fishes: An Identification Guide for the Western Central North Atlantic. Taylor \& Francis Group. p. 749-757.

OZAWA, T. 1986. Scopelarchid Fish Larvae in the Ocean off Southern Japan. In: OZAWA, T. (Ed.) Studies on the Oceanic Ichthyoplankton in the Western North Pacific. Kyushu University Press. Fukuoka. p. 212-222.

PARIN, N.V.; KOBYLIANSKY, S.G., 1996. Diagnoses and Distribution of Fifteen Species Recognized in Genus Maurolicus Cocco (Sternoptychidae, Stomiiformes) with a Key to their Identification. Cybium, v. 20, n. 2, p. 185-195.

PHONLOR, G., 1984. Morfologia e biologia de larvas de Engraulis anchoita (Hubbs \& Marini), (Osteichthyes, Engraulidae). Atlântica, Rio Grande, v. 7, p. 85-98.

POWELL, A.B.; GREENE, M.D., 2006a. Gerreidae: Mojarras. In: RICHARDS, W.J. (Ed.). Early Stages of Atlantic Fishes: An Identification Guide for the Western Central North Atlantic. Taylor \& Francis Group. p. 1591-1596.

POWELL, A.B.; GREENE, M.D., 2006b. Callionymidae: Dragonets. In: RICHARDS, W.J. (Ed.). Early Stages of Atlantic Fishes: An Identification Guide for the Western Central North Atlantic. Taylor \& Francis Group. p. 2015-2022.

RANDALL, J.E., 2002a. Perciformes: Percoidei: Mullidae: Goatfishes. In: CARPENTER, K.E. (Ed.). The living marine resources of the Western Central Atlantic. Rome: FAO. p. 1654-1659.

RANDALL, J.E., 2002b. Perciformes: Percoidei: Cirrhitidae: Swallowers. In: CARPENTER, K.E. (Ed.). The living marine resources of the Western Central Atlantic. Rome: FAO. p. 3321-3328.

RICHARDS, W.J. (Ed), 2006. Early Stages of Atlantic Fishes: An Identification Guide for the Western Central North Atlantic. Taylor \& Francis Group. v. I e v. II, 2.640 p.

RICHARDS, W.J., 2006a. Gonostomatidae: Bristlemouths. In: RICHARDS, W.J. (Ed). Early Stages of Atlantic Fishes: An Identification Guide for the Western Central North Atlantic. Taylor \& Francis Group. p. 183-216. 
RICHARDS, W.J., 2006b. Sternoptychidae: Marine Hatchetfishes \& Relatives. In: RICHARDS, W.J. (Ed). Early Stages of Atlantic Fishes: An Identification Guide for the Western Central North Atlantic. Taylor \& Francis Group. p. 217-246.

RICHARDS, W.J., 2006c. Phosichthyidae: Lightfishes. In: RICHARDS, W.J. (Ed). Early Stages of Atlantic Fishes: An Identification Guide for the Western Central North Atlantic. Taylor \& Francis Group. p. 247-266.

RICHARDS, W.J., 2006d. Chauliodontidae: Viperfishes. In: RICHARDS, W.J. (Ed.). Early Stages of Atlantic Fishes: An Identification Guide for the Western Central North Atlantic. Taylor \& Francis Group. p. 271-274.

RICHARDS, W.J., 2006e. Melanostomiidae: Scaleless dragonfishes. In: RICHARDS, W.J. (Ed.). Early Stages of Atlantic Fishes: An Identification Guide for the Western Central North Atlantic. Taylor \& Francis Group. p. 283-288.

RICHARDS, W.J., 2006f. Stomiidae: Scaly dragonfishes. In: RICHARDS, W.J. (Ed.). Early Stages of Atlantic Fishes: An Identification Guide for the Western Central North Atlantic. Taylor \& Francis Group. p. 275-278.

RICHARDS, W.J., 2006g. Notosudidae: Paperbones.In: RICHARDS, W.J. (Ed.) Early Stages of Atlantic Fishes: An Identification Guide for the Western Central North Atlantic. Taylor \& Francis Group. p. 347-358.

RICHARDS, W.J., 2006h. Bramidae: Pomfrets. In: RICHARDS, W.J. (Ed.). Early Stages of Atlantic Fishes: An Identification Guide for the Western Central North Atlantic. Taylor \& Francis Group. p. 1517-1538.

RICHARDS, W.J., 2006i. Gempylidae: Snake Mackerels. In: RICHARDS, W.J. (Ed.). Early Stages of Atlantic Fishes: An Identification Guide for the Western Central North Atlantic. Taylor \& Francis Group. p. 2155-2176.

RICHARDS, W.J., 2006j. Scombridae: Mackerels \& Tunas. In: RICHARDS, W.J. (Ed.). Early Stages of Atlantic Fishes: An Identification Guide for the Western Central North Atlantic. Taylor \& Francis Group. p. 2187-2228.

RICHARDS, W.J.; BALDWIN, C.C.; RÖPKE, A., 2006. Serranidae: Sea basses. In: RICHARDS, W.J. (Ed.). Early Stages of Atlantic Fishes: An Identification Guide for the Western Central North Atlantic. CRC Press,Taylor \& Francis Group. p. 1225-1335.

ROCHA, L.A.; BASS, A.L.; ROBERTSON, D.R. BOWEN, B.W., 2002. Adult habitat preferences, larval dispersal, and the comparative phylogeography of three Atlantic surgeonfishes (Teleostei: Acanthuridae). Molecular Ecology n.11, p. $243-252$.

ROFEN, R.R., 1966a. Family Paralepididae. Barracudinas. In: MEAD, G.W. (Ed.). Fishes of the Western North Atlantic. Memoir Sears Foundation for Marine Research, n¹, Pt. 5. p. 205-510.

ROFEN, R.R., 1966b. Families Anotopteridae, Evermannellidae and Scopelarchidae. In: MEAD, G.W. (Ed.). Fishes of the Western North Atlantic. Memoir Sears Foundation for Marine Research, n¹, Pt. 5. p. 511-602.

RUIZ-CARUS, R., 2006. Acropomatidae: Oceanic basses. In: RICHARDS, W.J. (Ed.). Early Stages of Atlantic Fishes: An Identification Guide for the Western Central North Atlantic. Taylor \& Francis Group. p. 1207-1216.

RUSSELL, B.C., 2002. Perciformes: Scombroidei: Sphyraenidae: Barracudas. In: CARPENTER, K.E. (Ed.). The living marine resources of the Western Central Atlantic. Rome: FAO. p. 1807-1811.

SANDKNOP, E.M.; WATSON, W., 1996a. Melamphaidae: Bigscales. In: MOSER, H. G. (Ed.). The Early Stages of Fishes in the California Current Region. La Jolla, Calcofi. Atlas n³3, p. 692-712.

SANDKNOP, E.M.; WATSON, W., 1996b. Sphyraenidae: Barracudas. In: MOSER, H.G. (Ed.). The Early Stages of Fishes in the California Current Region. La Jolla, Calcofi. Atlas n.33, p. 1250-1256.

SANTOS, A.P. dos; FIGUEIREDO, J.L. de., 2008. Guia de identificação dos peixes da família Myctophidae do Brasil. EDUSP. São Paulo. $176 \mathrm{p}$.

SHIPP, R.L. 2002. Tetraodontiformes: Tetraodontidae. In: CARPENTER, K. E. The living marine resources of the Western Central Atlantic. Rome: FAO. p. 1988-1998.

SMITH, D.G., 1989a. Family Chlopsidae: Leptocephali. In: BÖHLKE, E.B. (Ed.). Fishes of the Western North Atlantic. Memoir Sears Foundation for Marine Research, n¹, Pt. 9, v. 2, p. 933-942.

SMITH, D.G., 1989b. Family Muraenidae: Leptocephali. In: BÖHLKE, E.B. (Ed.). Fishes of the Western North Atlantic. Memoir Sears Foundation for Marine Research. $\mathrm{n}^{\circ 1}$, Pt. 9, v. 2, p. 900-916 
SMITH, D.G., 1989c. Family Congridae: Leptocephali. In: BÖHLKE, E.B. (Ed.). Fishes of the Western North Atlantic. Memoir Sears Foundation for Marine Research, n¹, Pt. 9, v. 2, p. 723-763.

SMITH, D.G. 1989d. Family Nemichthyidae: Leptocephali. In: BÖHLKE, E.B. (Ed.). Fishes of the Western North Atlantic. Memoir Sears Foundation for Marine Research, n¹, Pt. 9, v. 2, p. 925-932.

SMITH, D.G., 1989e. Family Nettastomatidae: Leptocephali. In: BÖHLKE, E.B. (Ed.). Fishes of the Western North Atlantic. Memoir Sears Foundation for Marine Research, n¹, Pt. 9, v. 2, p. 704-722.

SMITH, D.G.; CASTLE, P.H.J., 1982. Larvae of the Nettastomatid eels: systematics and distribution. The Carlsberg Foundation's oceanographical expeditions round the world 1928-30 and previous "DANA"- expeditions. DANA-Report N90. Scandinavian Science Press Ltda. Copenhagen. 44 p.

SMITH-VANIZ, W.F., 2002. Perciformes: Percoidei: Carangidae: Jacks and scads (bumpers, pompanos, leatherjacks, amberjacks, pilotfishes, rudderfishes). In: CARPENTER, K.E. (Ed.). The living marine resources of the Western Central Atlantic. Rome: FAO. p. 1426-1468.

SZPILMAN, M. 2000. Peixes marinhos do Brasil: guia prático de identificação. Rio de Janeiro. Instituto Ecológico Aqualung. 288 p.

TYLER, J.C.; JOHNSON, G.D.; BROTHERS, E.B.; TYLER, D.M.; SMITH, C.L., 1993. Comparative early life histories of Western Atlantic Squirrelfishes (Holocentridae): age and settlement of rhynchichthys, meeki, and juvenile stages. Bulletin of Marine Science, v. 53, n. 3, p. 1126-1150.

WATSON, W., 1996a. Gonostomatidae: Bristlemouths. In: MOSER, H.G. (Ed.). The Early Stages of Fishes in the California Current Region. La Jolla, Calcofi. Atlas n³3, p. 247-267.

WATSON, W., 1996b. Phosichthyidae: Lightfishes. In: MOSER, H.G. (Ed.). The Early Stages of Fishes in the California Current Region. La Jolla, Calcofi. Atlas n³3, p. 284-293.

WATSON, W., 1996c. Serranidae: Sea basses. In: MOSER, H.G. (Ed.). The Early Stages of Fishes in the California Current Region. La Jolla, Calcofi. Atlas n³3, p. 876-899.

WATSON, W., 1996d. Gerreidae: Mojarras. In: MOSER, H.G. (Ed.). The Early Stages of Fishes in the California Current Region. La Jolla, Calcofi. Atlas n³3, p. 998-1001.]

WATSON, W., 1996e. Mullidae: Goatfishes. In: MOSER, H. G. (Ed.). The Early Stages of Fishes in the California Current Region. La Jolla, Calcofi. Atlas n³3, p. 1034-1037.

WATSON, W., 1996f. Cirrhitidae: Hawkfishes. In: MOSER, H.G. (Ed.). The Early Stages of Fishes in the California Current Region. La Jolla, Calcofi. Atlas n³3, p. 1064-1067.

WATSON, W., 1996g. Pomacentridae: Damselfishes. In: MOSER, H.G. (Ed.). The Early Stages of Fishes in the California Current Region. La Jolla, Calcofi. Atlas n³3, p. 1054-1063.

WATSON, W., 1996h. Labridae: Wrasses. In: MOSER, H.G. (Ed.). The Early Stages of Fishes in the California Current Region. La Jolla, Calcofi. Atlas n³3, p. 1088-1103.

WATSON, W., 1996i. Scaridae: Parrotfishes. In: MOSER, H.G. (Ed.). The Early Stages of Fishes in the California Current Region. La Jolla, Calcofi. Atlas n³3, p. 1104-1109.

WATSON, W., 1996j. Callionymidae: Dragonets. In: MOSER, H.G. The Early Stages of Fishes in the California Current Region. La Jolla, Calcofi. Atlas n³3, p. 1205-1207.

WATSON, W., 1996k. Gobiidae: Gobies. In: MOSER, H.G. (Ed.). The Early Stages of Fishes in the California Current Region. La Jolla, Calcofi. Atlas n³3, p. 1214-1245.

WATSON, W., 1996I. Nomeidae: Driftfishes. In: MOSER, H.G. (Ed.). The Early Stages of Fishes in the California Current Region. La Jolla, Calcofi. Atlas n³3, p. 1300-1311.

WATSON, W., 1996m. Monacanthidae: Filefishes. In: MOSER, H.G. (Ed.). The Early Stages of Fishes in the California Current Region. La Jolla, Calcofi. Atlas n³3, p. 1422-1423. 
WATSON, W.; CHARTER, S.R.; MOSER, H.G.; AMBROSE, D.A.; SANDKNOP, E.M., 1996. Carangidae: Jacks. In: MOSER, H. G. (Ed.). The Early Stages of Fishes in the California Current Region. La Jolla, Calcofi. Atlas n 33, p. 914-953.

WATSON, W.; SANDKNOP, E.M., 1996. Chiasmodontidae: Swallowers. In: MOSER, H.G. (Ed.). The Early Stages of Fishes in the California Current Region. La Jolla, Calcofi. Atlas n³ 33, p. 1131-1137.

WATSON, W.; WALKER, JR. H.J., 2006. Ptereleotridae: Dartfishes. In: RICHARDS, W.J. (Ed.). Early Stages of Atlantic Fishes: An Identification Guide for the Western Central North Atlantic. Taylor \& Francis Group. p. 2105-2108.

WESTNEAT, M.W., 2002a. Perciformes: Labroidei: Labridae: Wrasses. In: CARPENTER, K.E. (Ed.). The living marine resources of the Western Central Atlantic. Rome: FAO. p. 1701-1709.

WESTNEAT, M.W., 2002b. Perciformes: Labroidei: Scaridae: Parrotfishes. In: CARPENTER, K.E. (Ed.). The living marine resources of the Western Central Atlantic. Rome: FAO. p. 1723-1732.

YEUNG, C.; RUPLE, D., 2006. Gobiidae: Gobies. In: RICHARDS, W.J. (Ed.). Early Stages of Atlantic Fishes: An Identification Guide for the Western Central North Atlantic. Taylor \& Francis Group. p. 2029-2078.

ZAPFE, G.A.; LYCZKOWSKI-SHULTZ, J., 2006. Monacanthidae: Filefishes. In: RICHARDS, W.J. (Ed.). Early Stages of Atlantic Fishes: An Identification Guide for the Western Central North Atlantic. Taylor \& Francis Group. p. 2399-2428. 
Curitiba, 2014 